1989

\title{
Joseph E Johnston and the defense of Richmond
}

Steven H. Newton

College of William \& Mary - Arts \& Sciences

Follow this and additional works at: https://scholarworks.wm.edu/etd

Part of the United States History Commons

\section{Recommended Citation}

Newton, Steven H., "Joseph E Johnston and the defense of Richmond" (1989). Dissertations, Theses, and Masters Projects. Paper 1539623789.

https://dx.doi.org/doi:10.21220/s2-rab2-9m87

This Dissertation is brought to you for free and open access by the Theses, Dissertations, \& Master Projects at W\&M ScholarWorks. It has been accepted for inclusion in Dissertations, Theses, and Masters Projects by an authorized administrator of W\&M ScholarWorks. For more information, please contact scholarworks@wm.edu. 


\section{INFORMATION TO USERS}

The most advanced technology has been used to photograph and reproduce this manuscript from the microfilm master. UMI films the text directly from the original or copy submitted. Thus, some thesis and dissertation copies are in typewriter face, while others may be from any type of computer printer.

The quality of this reproduction is dependent upon the quality of the copy submitted. Broken or indistinct print, colored or poor quality illustrations and photographs, print bleedthrough, substandard margins, and improper alignment can adversely affect reproduction.

In the unlikely event that the author did not send UMI a complete manuscript and there are missing pages, these will be noted. Also, if unauthorized copyright material had to be removed, a note will indicate the deletion.

Oversize materials (e.g., maps, drawings, charts) are reproduced by sectioning the original, beginning at the upper left-hand corner and continuing from left to right in equal sections with small overlaps. Eacn original is also photographed in one exposure and is included in reduced form at the back of the book.

Photographs included in the original manuscript have been reproduced xerographically in this copy. Higher quality $6 "$ " 9 " black and white photographic prints are available for any photographs or illustrations appearing in this copy for an additional charge. Contact UMI directly to order.

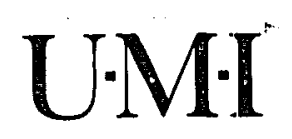

University Microfilms International

A Bell \& Howell Information Company

300 North Zeeb Road. Ann Arbor, Ml 48106-1346 USA

$313 / 761-4700 \quad 800 / 521-0600$ 
Order Number 9102176

Joseph E. Johnston and the defense of Richmond

Newton, Steven Harvey, Ph.D.

The College of William and Mary, 1989

Copyright C1991 by Newton, Steven Harvey. All rights reBerved.

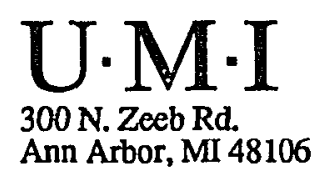

Reproduced with permission of the copyright owner. Further reproduction prohibited without permission. 


\section{A Dissertation}

$$
\text { Presented to }
$$

The Faculty of the Department of History The College of William and Mary in Virginia

In Partial Fulfillment of the Requirements for the Degree of Doctor of Philosophy

by

Steven Harvey Newton

1989 
This dissertation is submitted in partial fulfillment of the requirements for the degree of

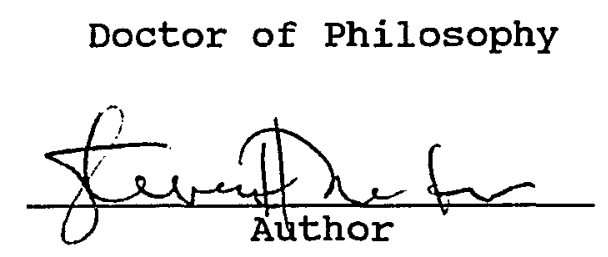

Approved, August 1989

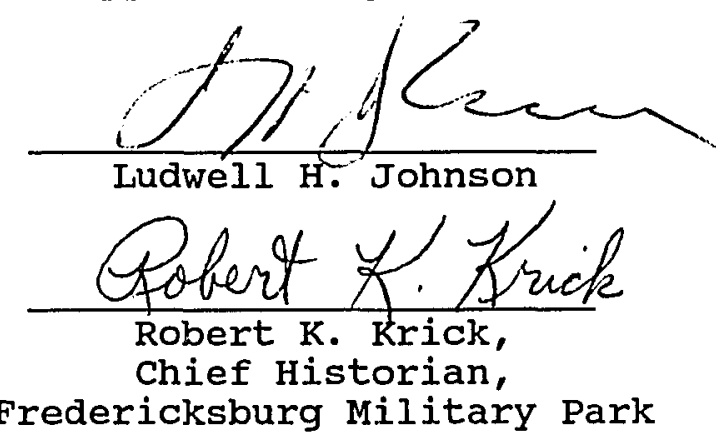

Fredericksburg Military Park

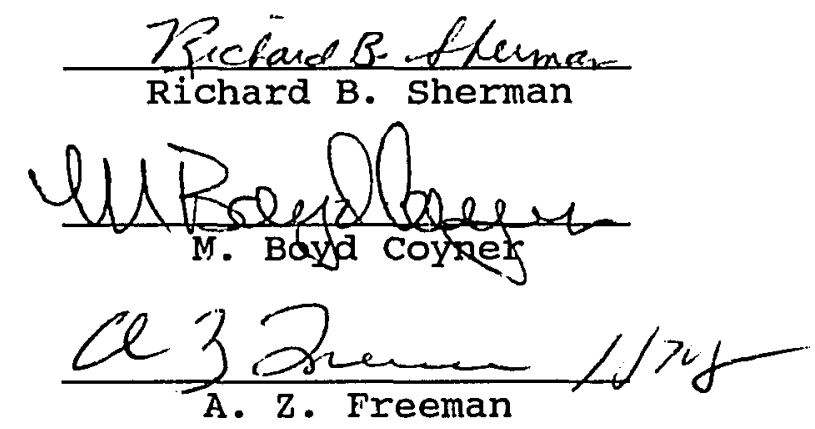


"bald, quiet Joe Johnston,

The little precise Scotch-dominie of a general,

Stubborn as flint, in advance not always so lucky,

In retreat more dangerous than a running wolf--

Slant shadow, sniffing the traps and the poisoned meat, And going on to pause and slash at the first

Unwary dogs before the hunters came up.

Grant said of him once,

I was always anxious with Joe Johnston in front of me, I was never half so anxious in front of Lee.'

He kissed his friends in the Nelson-way we 've forgotten,

He could make men cheer him after six-weeks retreating.

Another man said of him, after the war was done,

Still with that puzzled comparison we find

When Lee, the reticent sword, comes into question,

'Yes, Lee was a great general, a good man;

But I never wanted to put my arms around his neck

As I used to want to with Johnston.

The two sayings

Make a good epitaph for so Scotch a ghost, or would if they were all.

They were not quite all,

He had to write his reminiscences, too,

And tell what he would have done if it had not been

For Davis and chance and a dozen turns of the wheel.

That was the thistle in him--the other strain--

But he was older then.

I'd like to have seen him

That day as he galloped along beside Beauregard."

--Stephen Vincent Benet, John Brown's Body

To the memory of Carlton Smith, scholar and friend--the

rarest of men, a teacher who could make history live, breathe, laugh, and cry. Without him, many things, including this dissertation, would not have happened.

ii i 
TABLE OF CONTENTS

Page PREFACE • . . . . . . . . . . . . . . . . . . . V

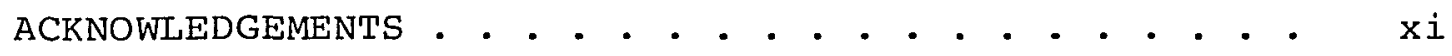
LIST OF MAPS . . . . . . . . . . . . . . . . . . xii ABSTRACT - . . . . . . . . . . . . . . . . xiii CHAPTER I. THE GENERAL . . . . . . . . . . . . . . . 1 CHAPTER II. THE DEPARTMENT OF NORTHERN VIRGINIA . . . 24 CHAPTER III. DECISION IN RICHMOND . • . . . . . . . 63 CHAPTER IV. WITHDRAWAL FROM THE FRONTIER . . . . . . . 102 Chapter V. ENTER LEE . . . . . . . . . . . . . . 156 CHAPTER VI. SHOULD YORKTOWN BE DEFENDED? . . . . . . . 193 CHAPTER VII. DECISION IN RICHMOND (II) . . • . . . . . 234 CHAPTER VIII. ISOLATED ON THE PENINSULA . . . . . . . 279 CHAPTER IX. RETREAT FROM YORKTOWN • • . • • . • . • . 326 CHAPTER X. DEFENDING RICHMOND . . . . . . . . . 385 CHAPTER XI. SEVEN PINES . . . . . . . . . . . . . . 430 CHAPTER XII. JOHNSTON'S CAMPAIGN : AN ASSESSMENT . • 495 APPENDICES • . . . . . . . . . . . . . . . . . 519 BIBLIOGRAPHY . . • . . . . . . . . . . . . . 546

iv 
PREFACE

One of the more curious gaps in Confederate historiography is the lack of a modern study of the Department of Northern Virginia under the leadership of General Joseph E. Johnston. Certainly the earlier stages of the Peninsula Campaign did not lack drama: Johnston's repeated confrontations with Jefferson Davis and Robert $\mathrm{E}$. Lee, the sorties of the ironclad Virginia, the siege of Yorktown, the rear guard action at Williamsburg, the Valley sideshow, and the final confused fight at seven Pines all contain the elements necessary for an interesting narrative. Nor did these operations lack significance. Had the Confederates lost Richmond in the early summer of 1862, that defeat, combined with the Federal capture of Memphis, Nashville, New Orleans, and Norfolk, would very probably have ended the war with George Brinton McClellan elevated to the status of savior of the Union. Instead, following Johnston's wounds at Seven Pines, Lee took over the Army of Northern Virginia and drove the Yankees away from Richmond in short order, not only saving the capital for the moment but also beginning a period of Confederate resurgence in Virginia that kept the Union Army reeling for nearly three years.

Only two book-length treatments, written from a Confederate perspective, have covered the Peninsula Campaign: 
volume one of Douglas Southall Freeman's Lee Lieutenants and Clifford Dowdey's The Seven Days, the Emergence of Robert $E$. Lee. Robert G. Tanner's Stonewall in the Valley covers the Valley Campaign and its relationship to events on the Peninsula. This is a surprisingly thin bookshelf for such a critical campaign.

To make matters worse, all three books contain serious flaws. Tanner, while he deserves considerable praise for unearthing new material on the Shenandoah Valley, based his whole presentation of Johnston's and Lee's relations with Thomas J. "Stonewall" Jackson on the interpretation originated by Freeman and extended by Dowdey. As a result he failed to examine their basic assumptions, many of which turn out upon close analysis to be ac best on shaky ground and at worst totally unfounded.

Dowdey's work has always been questionable in terms of evidentiary foundation, for while he wrote quite well he eschewed footnotes. Though quite often the text made Dowdey's sources apparent, there were many occasions when his strongest contentions (or in Johnston's case accusations) were erected entirely upon assertion rather than documentation. This rather cavalier approach to scholarship was combined with outright hero-worship of Lee, whom Dowdey continually elevated through the literary device of contrasting his virtues with Johnston's supposed shortcomings. The theme of Dowdey's book can be summarized in a single 
sentence: Johnston's generalship was so inept that only the caution of McClellan, the Machiavellian maneuvers of Lee behind the scenes, and the fact that Johnston was wounded too badly to resume command of the army after seven Pines allowed the Confederates to avoid the loss of Richmond.

Dowdey derived much of his interpretation from Freeman, though he extended it to the point of caricature. Freeman, though consistently judicious and measured in his evaluations, also viewed Johnston through the prism of Lee. In $\underline{R}$. E. Lee he made a point of trying to prove just how lax Johnston's administration of the army had been before seven Pines, and he repeated the performance at greater length in Lee's Lieutenant's. With prose more subtle and analysis much more penetrating than Dowdey's, Freeman nonetheless pursued the idea that the proper study of the Army of Northern Virginia always begins and ends with Robert $\mathrm{E}$. Lee. Johnston, to Freeman, was a gallant man and a good soldier, but only an adequate general at best. As Lee stepped upon the stage as commander of the army in either of Freeman's works the reader can almost feel the author's relief: the prologue is over, time for the main act.

And that is the problem. As long as the campaign leading up to seven Pines is considered as merely a prologue and not as a separate entity, Johnston's operations remain hopelessly obscured in the long, very deep shadow of Lee. The only way, I have come to believe, to understand the confed-

\section{vii}


erate army in Virginia before Lee assumed command of the Army of Northern Virginia, is to limit the scope of inquiry to the tenure of Johnston's command. Thus this narrative, which commences after a short chapter to introduce Joseph Johnston, begins with President Jefferson Davis's midFebruary summons of Johnston to Richmond to discuss withdrawing his army from the Potomac line, and ends when the General topples off his horse on the evening of May 31 , 1862. It is an unorthodox treatment for a military history, for none of the battles are decisive, more attention is paid to conferences in Richmond than any single combat action, and when the study ends Mcclellan is still only a few miles outside Richmond and the fate of the city is very much in doubt.

Yet focusing on the period between mid-February and late May allows time to deal with several key issues in far greater detail than did Freeman or Dowdey. The conference in Richmond which decided that the army would pull back to the Rappahannock received a line from Dowdey and two pages from Freeman; here it merits a chapter to explain it completely. The question of Johnston's administrative competence--often raised by his enemies and given great play by historians--is thoroughly investigated, as are his own strategic views, which turn out to have been much more complex and comprehensive than heretofore suspected. This study also takes pains to relate the war in Virviii 
ginia to operations in the western Confederacy. How did the fall of Fort Donelson lead not only to Shiloh but also to the withdrawal from the Potomac? How did Beauregard's defeat at Shiloh affect Davis's state of mind in the April 14 conference to determine whether or not Yorktown should be held? By restricting the focus to Johnston's portion of the Peninsula Campaign, these issues and others can be addressed in depth.

Johnston as the commander of the Department of Northern Virginia is, of course, the main subject of this work, but time has been taken to present Davis, Lee, Gustavus Smith, James Longstreet, and others in sufficient detail to allow the reader to understand the motives behind their actions, the feelings that led them sometimes to irrational or emotional decisions. How much of Johnston's decision to entrust the attack at Seven Pines to Longstreet and not Smith can be traced to his irritation at Smith falling asleep in the April 14 conference? In the same meeting: can the refusal of both Johnston and Lee to consider strategic compromise with the other's view be attributed in part to the competitive nature of their friendship?

The study that resulted from this approach is one that concentrates on Johnston's role as army commander but hopefully without slighting either the men who fought the battles or the larger issues of Confederate policy-making. While it will quickly become obvious that I believe that

$$
\text { ix }
$$


Johnston's performance was far better than has usually been credited, I have not attempted to gloss over his failures or his shortcomings as a commander. I have tried to present his case with a fair amount of objectivity and without recourse to special pleading. It is my belief that such is all that the General would have wanted. 


\section{ACKNOWLEDGEMENTS}

The writer wishes to express his appreciation to Professor Ludwell H. Johnston, for patience, guidance, friendship, and the strength of will to remain "above party" even when bad things were said of Robert $E$. Lee and Jefferson Davis. The author is also indebted to the following:

Robert K. Krick, Chief Historian, Fredericksburg Military Park.

Richard Sherman, Boyd Coyner, and A. Z. Freeman, Professors of History of the College of William and Mary.

Michael Musick, Old Army Branch, National Archives.

Margaret Cook, Special Collections Librarian, the College of William and Mary.

Ellen Emser, Special Collections Librarian, Old Dominion Library.

Richard Sommers, Chief Historian, Carlisle Barracks.

Cynthia Cossitor, formerly interlibrary-loan technician, Patch Barracks Library. .

Vicky King, formerly Reference Librarian, Augusta County Library.

Gordon Miller, Reference Librarian, James Madison University. Georgia.

Leslie Jill Gordon, graduate student, University of

Donna P. Freeman, typist extraordinaire.

The following people have provided patience, inspiration, and prodding in equal measure: Hank Foresman, Dana Sadarananda, Lee Smith, Steve Guerrier, Cathy Boyd, Louise Loe, and Mark Six (plus several persons too shy to be named).

And finally, this study belongs in truth to my parents, Kenneth and Marion Newton, and my brother, David, without whom it would never have been written.

$x i$ 


\section{LIST OF MAPS}

Map

Page

1. Department of Northern Virginia, March, 1862 . . 32

2. Confederate Defenses at Yorktown, April, 1862 . 223

3. Battle of Williamsburg, May 5, 1862 . . . . . 347

4. Strategic Options, Shenandoah Valley \& Central Virginia, mid-May, 1862... . . . . . . 409

5. Johnston's Plan of Attack at Seven Pines, May 31,1862 .............. . 440 


\section{ABSTRACT}

This study examines confederate military operations in Virginia from February 17 - May 31, 1862, focusing specifically on the role of Joseph $E$. Johnston as commander of the Department of Northern Virginia. It includes a detailed consideration of Confederate grand strategy, Johnston's withdrawal from the Potomac River, the redeployment of the army to Yorktown, the siege of Yorktown, and the Battles of Williamsburg and seven Pines.

In February, 1862, following the surrender of Fort Donelson, President Jefferson Davis reoriented strategy in Virginia from a defense of the frontiers to a closer defense of Richmond; he also recalled General Robert E. Lee from South Carolina to coordinate that defense. But the strategic concepts of Davis, Lee, and Joseph Johnston (the senior field commander in Virginial often differed a great deal, leading to confrontation and discord.

This study concentrates on following Johnston's point of view during the campaign, especially on his role as a field army commander. The conclusion suggests that Johnston was a superior strategist, administrator, and operational commander, but suffered from serious deficiencies as in tactical supervision of his own subordinates and an inability to deal tactfully with his superiors. 
Chapter one

The General

The chance musket shot and the ricocheting shell fragment which wounded General Joseph Eggleston Johnston in the early evening of May 31, 1862, effectively ended the Battle of Seven Pines. While worried aides dragged their commander to safety, the fighting, which had raged between Richmond and the Chickahominy River for several hours, degenerated into sporadic sniping. Rebels and Yankees alike collapsed in exhaustion. The conflict resumed in a desultory fashion the next morning; but neither the confederate divisions defending the capital, nor Major-General George B. Mcclellan's Federal Army of the Potomac could muster the energy to strike a decisive blow. Each army had suffered about 5,000 casualties in a bloody stalemate. Later, the battle appeared significant more because Johnston's wound resulted in the appointment of Robert $E$. Lee as his successor than for any other reason.

Joseph Johnston always believed that his troops had been on the verge of victory when those unlucky shots knocked him off his horse and out of the battle. His attack had caught two corps of McClellan's army isolated from the main body by the rain-swollen Chickahominy. The right wing, under Major-General James Longstreet, had driven the enemy 
in disarray from three successive lines. The left, commanded by Major-General Gustavus W. Smith, was advancing under Johnston's eye to deliver the coup de grace. "Darkness only," Johnston insisted, prevented the complete defeat of the Federals that night. Likewise, on the following morning, he maintained it was simply the inaction of Smith, temporarily in command, that saved several Union divisions from destruction. Such an accomplishment would have silenced those who had begun to say that Johnston's only skill as a general lay in his ability to retreat. For the rest of his life, Johnston remained convinced that it had been his wounds which had prevented him from conclusively vindicating the strategy by which he had conducted the defense of Richmond. I

In retrospect, Johnston's tactical assessment was far too optimistic. Unknown to him, by the time he was struck, the entire senior command structure of his army had ceased to function. Smith had collapsed from a nervous ailment. 2 Smith's deputy, Brigadier-General W. H. C. Whiting, was struggling vainly to coordinate the movements of five

$1_{\text {Joseph E. Johnston, Narrative of Military Operations }}$ Directed During the Late war Between the states (Blooming ton, IN: Indiana University Press, 1959), pp. 139-143; Joseph E. Johnston, "Manassas to Seven Pines," in Robert $U$. Johnson and Clarence C. Buel, ed., Battles and Leaders of the Civil War (Secaucus, NJ: Castle, 1980, reprint of 1887 edition), II: p. 215 (cited hereafter as B\&L).

2Benjamin Stoddert Ewell to Joseph E. Johnston, May 4, 1885, in Robert Morton Hughes Collection, old Dominion University, Norfolk, Virginia (cited hereafter as RMH). 
brigades which were in varying states of disorganization, across a field where undergrowth often limited vision to less than ten paces. 3 Far to the right, Longstreet's failure to follow the correct road, and a quarrel over seniority with Major-General Benjamin Huger, helped immobilize their troops most of the day. Those who did engage fought under Major-General Daniel Harvey Hill, the most junior division commander involved in the attack. By dusk, Hill's men had fought themselves out, and the General himself had become thoroughly disgusted with superiors who seemed content to sacrifice his soldiers while they bickered.4 In short, though Johnston's plan had been sound enough, botched execution produced a fiasco which resulted in a drawn battle, only because conditions on Mcclellan's side of the line were equally confused.

Later, Johnston's detractors argued that a mismanaged battle was the appropriate punctuation to conclude a mismanaged campaign. Since March, his only major movements had been a pair of retreats which exposed to the enemy all

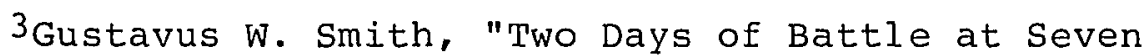
Pines," in B\&L, II: p.227.

${ }^{4}$ D. H. Hill to Gustavus W. Smith, May 22, 1885, in Gustavus W. Smith, The Battle of Seven Pines (New York: $C$. C. Crawford, 1895), p. 66. See also "Report of Maj.-Gen. D. H. Hill, C. S. Army, commanding division [at Seven Pines]," -- -, 1862, in United States War Department, The War of the Rebellion: A Compilation of the official Records of the Union and Confederate Armies (Washington, DC: Government Printing office, 1880-1901), Series 1, XI (part 1): pp. 943-946 (cited hereafter as $O R$; all references are to series 1 unless otherwise indicated). 
of Virginia north of the Rappahannock River and east of Richmond. Fredericksburg, Yorktown, and Norfolk had fallen into Federal hands, as the Army of the Potomac marched within five miles of Richmond. His most severe critics suggested that the General had originally intended to surrender the Confederate capital without a fight. 5

Such an appraisal is grossly unfair to Johnston. It ignores the fact that one of his retreats was ordered by President Jefferson Davis, and that the other was rendered necessary because Johnston was directed to place himself in a strategic cul de sac at Yorktown. Nor did Johnston exercise undisputed control over his own department throughout most of the campaign. For long periods, General Lee, commanding in Richmond, directed the operations of four of his eight divisions, usually without Johnston's knowledge, always without his consent, and often in a pattern completely at odds with Johnston's own intentions. Between March and June, 1862, Joseph Johnston spent almost as much of his time reacting to the actions of his own superiors as he did those of his opponent.

Nonetheless, Johnston's campaign in defense of Richmond must be rated as a strategic victory for the Confederacy. First and foremost, it kept his army in being. Given the

5 Jefferson Davis, Rise and Fall of the Confederate Government (New York: Thomas Yoseloff, 1958, reprint of 1881 edition), II: p. 120; John Bell Hood, Advance and Retreat (Secaucus, NJ: Blue and Grey, 1985, $\frac{\text { reprint of } 1880}{2}$ edition), pp. 153-155. 
odds with which he had to contend, this was no mean feat. His withdrawal from Yorktown successfully extricated the Confederacy's only major eastern field army from a carefully crafted double envelopment. Opposed by any commander less skillful than Johnston, McClellan might well have captured the entire force. This accomplishment stands out as even more remarkable in light of the convulsions which racked the army as a result of the first conscription act; Johnston held his army together as a coherent fighting force despite the demoralizing and potentially destructive regimental elections.

His operations also bought time, a commodity infinitely more valuable to the confederacy than the territory for which he traded it. In the months Johnston delayed McClel1 an's advance, the arms production centers he defended stamped out thousands of new rifles and cast hundreds of cannon. 6 Additional ordnance supplies filtered into. Southern ports through the Federal blockade. 7 At the same

6 Tredegar Iron Works cast 164 pieces of field artillery and thirty-nine heavy guns between January and June, 1862 . During the same period, the Richmond arsenal produced at 1 east 6,000 new muskets. See Charles B. Dew, Ironmaker to the Confederacy, Joseph R. Anderson and the Tredegar Iron Works (Wilmington, NC: Broadfoot, 1987, reprint of 1966 edition), p. Ill; Richard D. Goff, Confederate Supply (Durham, NC: Duke University Press, 1969), p. 31; Larry J. Daniel, "Manufacturing Cannon in the Confederacy," Civil War

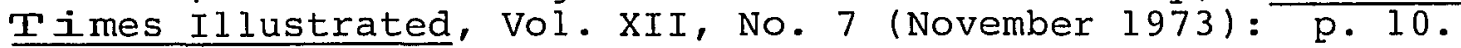

7 Between April 27, 1862 and August 16, 1862, more than 48,000 small arms slipped through the blockade to arrive at Wilmington, Charleston, or Savannah. This was more than three times the total number of such weapons imported 
time, a combination of Johnston's administrative efficiency, Lee's juggling of garrisons along the Atlantic Coast, and Rebel operations in the Shenandoah Valley and central Virginia allowed the South to neutralize the overwhelming numerical superiority with which McClellan opened his campaign. Three weeks after Johnston fell, Lee opened the Battle of Mechanicsville with the largest Confederate army ever sent into combat, and met McClellan with virtual numerical parity. 8 Johnston's defense of Richmond was the first and most critical Confederate success in 1862 .

Certainly no one had expected anything less than success from Joseph Johnston when the war began. Resigning his commission as Brigadier-General and QuartermasterGeneral of the United States Army upon Virginia's secession in April, 1861, the fifty-four-year-old Virginian seemed inevitably bound for glory. His military career had already spanned more than three decades, including command or staff service in every branch of the army. Nine wounds and four brevet promotions for gallantry attested to his coolness

between September, 1861 and February, 1862. See Frank Vandiver, ed., Confederate Blockade Running Through Bermuda, 1861-1865, Letters and Cargo Manifests (Austin, TX: University of Texas, 1947), pp. xviii, xxiv; stephen $\mathrm{R}$. Wise, Lifeline of the Confederacy, Blockade Running During the Civil War (Columbia, SC: University of South Carolina Press, 1988), pp. 55-73.

8 Thomas L. Livermore, Numbers and Losses in the Civil War in America, $1861-1865$ (Dayton, OH: Morningside, 1986, reprint of 1900 edition), p. 86 . 
under fire. 9 He was one of the most widely read soldiers in the army, an acknowledged scholar and expert in military history. Winfield scott, the greatest American soldier between the Revolutionary and Civil Wars, had been his mentor. 10 His closest contemporaries-at once both friends and rivals--were Albert Sidney Johnston and Robert E. Lee. II "Johnston," concludes historian Jay Luvaas, "was one of the best prepared professional soldiers to enter Confederate service." 12

Not a large man--"rather below middle height" according to British Colonel Arthur Fremantle--Johnston stood about five feet eight inches and weighed less than 140 pounds.13 Yet there was something in the way he moved that made him seem taller. A reporter for the Southern Literary Messenger overestimated his height by two inches, and added that "he

${ }^{9} \mathrm{Gilbert} \mathrm{E}$. Govan and James W. Livingood, A Different Valor, The Story of General Joseph E. Johnston, C. S. A. (New York: Bobbs-Merril1, 1956), pp. 11-28.

10 Edward Johnston to John Warfield Johnston, January 2, 1848, in RMH; Winfield Scott, Memoirs of Lieut.-General Scott, LL. D., Written By Himself (New York: Sheldon and Co., 1864), II: p. 517; Govan and Livingood, Different Valor, p. 20; Dabney H. Maury, "Interesting Reminiscences of General Johnston," Southern Historical Society Papers, Vol. XVIII (1890): pp. 178-179 (hereafter cited as SHSP).

$1 l_{\text {Govan }}$ and Livingood, Different Valor, pp. 14, 21, 25.

12 Jay Luvaas, "An Appraisal of Joseph E. Johnston," Civil War Times Illustrated, Vol. IV, No. 9 (January 1966): p. 7 .

13 Walter Lord, ed., The Fremantle Diary (Boston: Little, Brown, \& Co., 1954), p. 93 . 
looks taller on account of his erect carriage."14 There was a quality about him that demanded attention, but also defied definition. It was more than the piercing gray eyes, the long straight nose, or the grizzled--though neatly trimmed-side-whiskers, mustache, and goatee. This was something more than the sum of his individual parts: a sense of presence.

He simply looked like a soldier. "Soldier-like," recorded Fremantle.15 "Every inch a soldier," said Henry Kyd Douglas.16 "The beau ideal of a soldier," recalled Richard Taylor.17 And Benjamin Stoddert Ewell, who served under the General for three years and knew him as well as any, told a group of veterans that Johnston "had more the appearance of a soldier than anyone $I$ ever met in the Confederate, or subsequently in the Union Army."l8 Some of this martial quality still emanates from war-time photographs of Johnston. In them, he is always posed in a

$14 \mathrm{P}$. W. Alexander, "Confederate Chieftains," Southern Literary Messenger, Vol. XXXV, No. 1 (January 1863 ): p. 35 .

15Lord, Fremantle, p. 93.

16 Henry Kyd Douglas, I Rode with Stonewall (Chapel Hill, NC: University of North Carolina Press, 1940), p. 234.

17Richard Taylor, Destruction and Reconstruction (New York: Longman's, Green \& Co., 1955, reprint of 1889 edition), p. 42 .

18Undated notes for a talk by Benjamin $S$. Ewell before the Magruder-Ewell 1 Camp, United Confederate Veterans, Benjamin Stoddert Ewell papers, Swem Library, College of William and Mary, Williamsburg, Virginia. 
position of not-quite-rigid attention, viewing the camera inquisitively, even suspiciously, as if it were a courier entering his headquarters in the middle of a battle, bearing what might be unpleasant news.

His personality ranged from bursts of spontaneous affection to guarded reserve. Major Robert Stiles remembered that he liked to greet his close friends with a hug and a kiss.19 "He loved good cheer," recalled staff officer Archer Anderson, "he enjoyed a glass of wine, and his conversation at a dinner-table with congenial companions was often fascinating and memorable."20 Yet there was the colder side of Johnston's character; Brigadier-General Bradley T. Johnson admitted him to be "quick-tempered and imperious."21 "Genial and confiding as he was to the friends he knew and trusted, he was reticent and ever aversive to those whom he did not like," observed MajorGeneral Dabney Maury. Maury also remembered that Johnston "was quick to resent any freedom or liberty from those he did not like or know."22 "To me he was extremely affable," confided Fremantle to his diary, "but he certainly possesses

19 Robert Stiles, Four Years Under Marse Robert (Washington, DC: n. p., 1903), p. 90 .

20 Quoted in Bradley T. Johnson, A Memoir of the Life and Public Service of General Johnston (Baltimore: R. H. Woodward \& Co., 1891), p. 313.

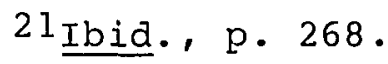

22 Quoted in Ibid., pp. 301-302. 
the power of keeping people at a distance when he chooses. . . $" 23$

Colonel Fremantle also noted that Johnston's "officers stand in great awe of him. . . Many of the officers told me that they did not consider him inferior as a general to Lee or anyone else."24 A considerable number of officers who served under both Johnston and Lee held the opinion that "old Joe" was, at the very least, the equal of "Marse Robert." Lieutenant-General James Longstreet eulogized him as "skilled in the art and science of war, [and] gifted in his quick, penetrating mind. . . " After the war, Longstreet characterized Johnston rather than Lee as "the most accomplished and capable" of Confederate generals.25 He was praised by Lieutenant-General Richard Taylor for "great coolness, tact, and judgment," while Lieutenant-General Wade Hampton regarded him as a commander "in whose skill and generalship I have always entertained implicit confidence. - . "26 Junior officers were, if anything, more effusive

23 Lord, Fremantle, p. 93.

24 Ibia.

25 James Longstreet, From Manassas to Appomattox (Secaucus, NJ: Blue and Grey, 1984, reprint of 1896 edition, p. 100; Donald B. Sanger and Thomas Robson Hay, James Longstreet (Baton Rouge, LA: Louisiana State University Press, 1952), p. 426; H. J. Eckenrode and Bryan Conrad, James Longstreet, Lee's War Horse (Chapel Hill, NC: University of North Carolina Press, 1936), pp. 326-327.

26 Taylor, Destruction, p. 28; Wade Hampton, The Battle of Bentonville," B\&L, IV: p. 703; Manly Wade Wellman, Giant in Gray, A Biography of wade Hampton of South Carolina 
in their praise of Johnston. Though he entitled his memoirs Four Years Under Marse Robert, Major Robert Stiles opined of Johnston that "as a trained, professional soldier, I do not believe he had his superior, if indeed his equal, on this continent. . . ."27 Likewise, in I Rode With Stonewall, Major Henry Kyd Douglas concluded that "for clear military judgment and capacity to comprehend and take advantage of what is loosely termed 'the situation,' General Johnston was not surpassed by any general in either army."28

During the summer of 1861, he seemed more than to fulfill the promise of his earlier career. In late July, he slipped away from the Federal force assigned to pin him in the Shenandoah Valley, and rushed his small army to reinforce Brigadier-General P. G. T. Beauregard at Manassas. Neither he nor anyone else had reason to suspect that July 21, 1861, represented the pinnacle of his career, the last moment in the war before his reputation would be unstained by controversy or recriminations. All that was visible at the time was the victorious general, the assured soldier. With a perspective that the participants lacked on that hot, dusty afternoon, Stephen Vincent Benet wrote wistfully of

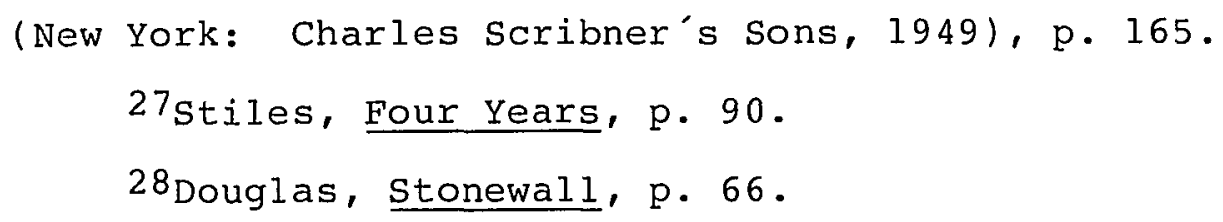


Johnston, "I'd like to have seem him that day. . . "29

Superficially, Johnston's career continued in an upward spiral. He remained at Manassas after the battle and, ranking Beauregard, took permanent command of their combined armies. During October, the War Department expanded his authority over what was styled the "Department of Northern Virginia," extending his control over all Confederate forces in northwestern Virginia, the lower Shenandoah Valley, around Fredericksburg, and down the south bank of the Rappahannock to Urbana. When 1862 arrived, Johnston commanded the largest, best-equipped Confederate army in the entire South. 30

But below the surface, all was not well. In August, Johnston was stung by newspaper assertions that Beauregard,

${ }^{29}$ Stephen Vincent Benet, John Brown's Body (New York: Book of the Month Club, 1980, reprint of 1927 edition), p. 93.

30 Johnston's Department of Northern Virginia contained 62,112 "effectives" on December 31, 1861, compared to 54,004 "present for duty" in Albert Sidney Johnston's Western Department, the Confederacy's next largest army, on about the same date. But the difference between the equipment and organization of the two armies was considerable; as Richard McMurry has recently observed: "The Army of Tennessee was to suffer greatly because it was built on a foundation of sand; the Army of Northern Virginia rested by comparison, on a rock." See "General Orders No. 15, Adjutant and Inspector-General's office, October 22, 1861," and "Abstract from return of the Department of Northern Virginia, commanded by General Joseph E. Johnston, C. S. Army, for the month of December, 1861, in OR, V: pp. 913-914, 1015; "Abstract from return of Western Department, General A. S. Johnston, commanding (Date about December 31, 1861)," in OR, VII: p. 813; Richard M. McMurry, Two Great Rebel Armies, An Essay in Confederate Military History (Chapel Hill, NC: University of North Carolina Press, 1989), pp. 74-86. 
not he, had been primarily responsible for winning the Battle of Manassas.31 Questions arose about the army's failure to follow up the victory with an invasion across the Potomac. Ludicrous as the idea appeared to anyone privy to the actual strength of the army or the woeful inadequacy of its supplies, it nonetheless circulated quite freely throughout the Confederacy. Johnston could not respond to insinuations of inactivity without revealing his weakness and, therefore, had to suffer suspicions about his lack of offensive intentions in silence. 32

In September, he quarreled with President Davis over his rank. Historians have often cited this as the main factor contributing to later discord between Johnston and Davis. The incident, asserted Douglas Southall Freeman, "aroused in Johnston a resentment that colored his views throughout the war."33 An examination of the evidence, however, suggests that the disagreement over rank may not have been the primary cause of the General and the President becoming "perfectly and entirely estranged and separated." 34

The squabble began with a misreading by Johnston of Confederate military law. On August 31, President Davis had

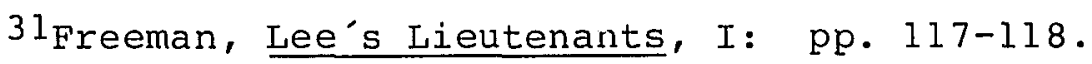

32 Johnston, Narrative, pp. 59-63.

${ }^{3}$ Douglas Southall Freeman, R. E. Lee, A Biography (New York: Charles Scribner's Sons, 1935), I: p. 559.

34 Johnson, Johnston, p. 251. 
submitted his list of nominations to the rank of "general" to Congress, which immediately confirmed them. The dates of the commissions read: Samuel Cooper, May 16, 1861; Albert Sidney Johnston, May 28, 1861; Robert E. Lee, June 14, 1861; Joseph E. Johnston, July 4, 1861; and P. G. T. Beauregard, July $21,1861.35$ Johnston read the 1 ist with "surprise and mortification" about two weeks later. His understanding of the appropriate statutes had lead him to believe that he should have ranked first instead of fourth. Since he could not conceive of Davis, a former secretary of War, U. S. Senator, and the preeminent constitutional lawyer alive, misreading the law, he presumed that his reduction was an intentional slight. He had to complain, "lest my silence be significant of acquiesence. . . ."36

In such temper, when he sat down to pen his letter, Johnston thought that events called for strong language. He baldly stated his belief that "this is a blow aimed at me alone," which resulted in "the benefit of persons neither of whom has yet struck a blow for the confederacy." 37 Contrary to what he later asserted, however, Johnston consulted with

35 Jefferson Davis to Howell Cobb, August 31,1861 , in James D. Richardson, ed., The Messages and Papers of Jefferson Davis and the Confederacy, Including Diplomatic Correspondence, 1861-1865, 2 volumes (New York: R. R. Bowker, 1966), I: p. 129; Joseph E. Johnston to Jefferson Davis, september 12, 1861, in OR, Series 4, I: p. 605.

36 Joseph E. Johnston to Jefferson Davis, September 12 , 1861, in OR, Series 4, I: pp. 607-608.

37 Ibia. , p. 609 . 
his brother Beverly on the phrasing of the letter, and deleted 350 words so heated that, even when infuriated, he realized he could not send to the President. 38

Stripped of invective, Johnston's argument seemed logical. Five brigadier-generals had been created by the acts of March 6 and March 14, 1861. Section five of the second act provided

That in all cases of officers who have resigned, or who may within six months tender their resignations from the Army of the United States, and who may be appointed to original vacancies in the Army of the Confederate states, the commissions issued shall bear one and the same date, so that the relative rank of officers of each grade shall be determined by their former commissions in the $U$. S. Army, held anterior to the secession of these Confederate States from the United States.39

An amendatory act on May 16 allowed for the conversion of the title of "brigadier-general" to "general," a change which, Johnston contended, could not affect the relative seniority of the office-holders. The determination of seniority would then be according to the precedence of prewar commissions. "The order of rank established by law," as

38 An incomplete draft of the letter, in the handwriting of Beverly Johnston, is in RMH. Aside from the deleted paragraph, marked out with a large " $X$ " (see Appendix-A), the differences between the draft and the published copy are mostly differences of syntax. Johnston, Narrative, pp. 7273; Joseph E. Johnston to Jefferson Davis, September 12 , 1861, in OR, Series 4, I: pp. 607-608.

39"An Act Amendatory of an Act for the Organization of the staff Departments of the Army and an Act for the Establishment and Organization of the Army of the Confederate States of America," March 14, 1861, in OR, Series 4, I: p. 164 . 
Johnston saw it, "was--first, J. E. Johnston (brigadiergeneral U. S. A.); second, S. Cooper (colonel U. S. A.); third, A. S. Johnston (colonel U. S. A.); fourth, R. E. Lee (lieutenant-colonel U. S. A.)."40

Johnston was correct in assuming that the confederate Congress guaranteed resigning officers of the United States Army the same relative rank they had enjoyed before the war. What he missed was the fact that the act of March 6, 1861, changed the manner in which that rank was calculated. Section twenty-nine wiped out any practical use for brevet rank beyond courts martial and boards of inquiry. It also specified that an officer's seniority, for purposes of command, would be determined from his highest commission in the corps or arm in which he currently served.41

This provision accounted, quite legally, for Johnston's drop in the rankings. Samuel Cooper held a staff colonelcy

\section{Johnston, Narrative, p. 72.}

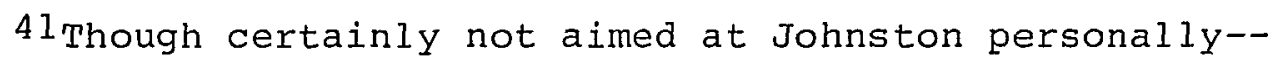
the law had been passed before he resigned from the U. S. Army--this provision was probably included at Davis's instigation. He was a long-time opponent of brevet rank, and did not believe that staff officers should be entitled to exercise command. "An Act for the Establishment and Organization of the Army of the Confederate states of America," March 6, 1861, in OR, Series 4, I: p. 131. For Davis's opinion on brevet rank, see Robert M. Utley, Frontiersmen in Blue, The United States Army and the Indian, 1848-1865 (Lincoln, NE: University of Nebraska Press, 1967), p. 33; his view on staff officers in command positions is found in Jefferson Davis to James Lyons, August 30 , 1878, in Dunbar Rowland, Jefferson Davis, Constitutionalist, His Letters, Papers, and Speeches (Jackson, MS: n. p., 1923), VIII: p. 257 . 
as the United States Army Adjutant General. He was assigned the same post in the Confederacy--with a specific prohibition against ever commanding troops--so his staff commission counted toward his seniority as a general.42 Johnston, on the other hand, had been transferred out of the Quartermaster's Department and back to the line of the army. By Confederate law, he then could only claim his highest line commission--lieutenant colonel of cavalry--in figuring seniority relative to Albert Sidney Johnston and Robert $\mathrm{E}$. Lee. In those terms, he was junior to both. 43 The procedure Davis followed in arriving at the rank order of his senior generals was consistent with the letter of the law. Davis was ill when he received Johnston's letter of protest, and he had reason to believe that the General knew

42 In contrast to U. S. Army regulations, Confederate law specifically prohibited staff officers from assuming command. The U. S. Army operated on the principle that rank "shall always confer the right to command, whether the same be by ordinary commission, by brevet commission, or by staff commission. . . " The Confederates provided that staff officers, "though eligible to command, according to the rank they hold in the Army of the Confederate States of America, shall not assume command of troops unless put on duty under orders which specially so direct by authority of the president." "Report of Board of officers, November, 1850; Opinion of Secretary of War Charles M. Conrad, 1851; both in Letters and Telegrams Received, Secretary of War, Main Series, 1801-1870, National Archives, M-567, Reel 192; "An Act for the Establishment and Organization of a General Staff for the Army of the Confederate States of America," February 26, 1861, in OR series 4, I: p. 115.

43 see the Official Army Register for August 1, 1855 (Washington, DC: Adjutant General's Office, 1855), p. 9, for the relative ranks of the two Johnstons and Lee when the 1st and 2nd Cavalry Regiments were organized. 
that when he sent it. 44 His state of health may have contributed to the terseness of this reply. Had Johnston written a more diplomatic letter, the president might have explained his reasoning, no matter how sick. Stung by the attack, Davis fired back his famous bullet: "I have just received and read your letter of the 12 th instant. Its language is, as you say, unusual; its arguments and statements utterly one-sided, and its insinuations as unfounded as they are unbecoming." 45

Despite the heat of their rhetoric, however, both men acted in such a way as to bury the conflict rather than escalate it. Davis did not retain Johnston's letter in the official files. 46 Johnston neither threatened to resign nor intimated--then, or in the future--that he would not accept orders from any of the three generals senior to him. Both men refrained from speaking of the issue to anyone besides their closest friends, and the conflict did not surface

${ }^{44}$ Davis had mentioned his illness repeatedly in letters to Johnston throughout early September. See Jefferson Davis to Joseph E. Johnston, September 5, 1861, and Jefferson Davis to Joseph E. Johnston, September 8,1861 , both in OR, V: pp. 829-830, 833-834; Rembert W. Patrick, Jefferson Davis and His Cabinet (Baton Rouge, LA: Louisiana State University Press, 1944), p. 36 .

45 Jefferson Davis to Joseph E. Johnston, September 14, 1861, in OR, Series 4, I: p. 611 .

$46_{\mathrm{He}}$ gave the letter to Assistant Secretary of War Albert Bledsoe with instructions not to file it. See Joseph E. Johnston, "Responsibilities of the First Bull Run," B\&L, II: p. $240 \mathrm{n}$. 
publicly until much later.47 In fact, all that either man actually seems to have done was to write one intemperate letter and then return to this duties.

Admittedly, their correspondence became more formal and less frequent. "My Dear General" and "Your Friend" disappeared from the headings and closings of their letters. 48 The reduction in the number of letters was not, however, the result of personal disharmony. The exchange had coincided closely with the appointment of Judah P. Benjamin as Secretary of War. Because he trusted the former Louisiana

47 Stephen Mallory was the only cabinet member who mentioned the incident at the time, though Judah Benjamin must certainly have been aware of it. Likewise, in Johnston's entourage, only the sometimes overzealous $A$. H. Cole commented on the issue at the time, in an October letter to Brigadier-General Roswell S. Ripley in Charleston. Mary Chesnut, as close as she and her husband were to both the Davis and Johnston families, apparertly caught no hint of the feud; editor $C$. Vann Woodward dismissed the entry in the first publication of her diary as an afterthought, probably inserted in the 1880's. Entry for September 18, 1861, Stephen Mallory diary, Southern Historical Collection, University of North Carolina, Chapel Hill, NC; C. Vann Woodward, ed., Mary Chesnut's Civil War (New Haven, CT: Yale University Press, 1981), p. 136n; Extract from A. H. Cole to Roswell S. Ripley, October 10, 1861, in Ellsworth Elliot, West Point in the Confederacy (New York: G. A. Baker and Co., 1914), pp. 84-86.

48 For examples of correspondence which predates the rank controversy, see Joseph E. Johnston to Jefferson Davis, August 19, 1861; Jefferson Davis to Joseph E. Johnston, September 5, 1861; Jefferson Davis to Joseph E. Johnston, September 8, 1861; Jefferson Davis to Joseph E. Johnston, September 13, 1861. The cooler attitude between the two is in evidence in Jefferson Davis to Joseph E. Johnston, September 18, 1861; Joseph E. Johnston to Jefferson Davis, September 22, 1861; Jefferson Davis to Joseph E. Johnston, November 10,1861 , all in $\mathrm{OR}, \mathrm{V}: \mathrm{pp} .797-798,829-830,833-$ $834,850-851,857,872,945-947$. 
Senator so completely, Davis delegated nearly all of the routine details of the War Department to him, and the President's personal correspondence with all his generals diminished during the fall of 1861.49

Johnston and Davis kept working together in harness, and only someone privy to their earlier letters would have detected the shift away from their previous informality. In November when Davis needed support for his contention that he had not prevented a pursuit of the defeated Federals after Manassas, Johnston promptly and unequivocally provided it. 50 Johnston wrote flatteringly of Davis's personal popularity in February, 1862: "Your presence here now or soon would secure to us thousands of excellent troops. - ."5l This obviously pleased Davis, who replied, "I will visit the Army - . as soon as other engagements will

49 The correspondence between Davis and his two other senior generals, Lee and Albert Sidney Johnston, can be cited as examples of the lessening of direct presidential correspondence. Between November 8, 1861 and March 3, 1862 , the oR shows only a single entry as correspondence between Lee and Davis, against fifteen between Lee and the War Department; see OR, VI: pp. 928-929. Between November 20, 1861 and March 4, 1862, the number of entries for correspondence between $A$. S. Johnston and Jefferson Davis is three, against thirty-one between Johnston and the War Department. See OR, VII: p. 980; see also Patrick, Jefferson Davis and His Cabinet, pp. 164-165.

50 Jefferson Davis to Joseph E. Johnston, November 3, 1861, in OR, II: pp. 511-512; Joseph E. Johnston to Jefferson Davis, November 10, 1861, in OR, LI (part 2): $p$. 374 .

$5 l_{J o s e p h}$ E. Johnston to Jefferson Davis, February 5, 1862 , in OR, V: p. 1062 . 
permit, although I cannot realize your complimentary assurance that great good to the army will result from it. - ."52 Davis even essentially defended Johnston's actions in March, 1862, in a letter to W. M. Brooks of Alabama: "though General Johnston was offended because of his relative rank, he certainly never thought of resigning. . . . 153

The issue, as far as the public was concerned, stayed buried. No controversial articles appeared in the Richmond newspapers, as they did when Davis and Beauregard conflicted over that general's report of the Battle of Manassas. 54 Surprisingly, the ranks of the senior generals were not common knowledge. In January, 1862, the Richmond Enquirer reprinted from the Charleston Courier what purported to be a definitive listing of the relative ranks of Confederate generals. It is significant because it was inaccurate, citing the top four generals in order as samuel Cooper, Albert Sidney Johnston, Joseph E. Johnston, and Robert E. Lee.55 No protests or correction of the list ever ran, which probably would have been the case had the rank controversy still been boiling. Five months later, the same

52 Jefferson Davis to Joseph E. Johnston, February 14, 1862 , in OR, V: p. 1072 .

53 Jefferson Davis to W. M. Brooks, March 15, 1862, in OR, Series 4, I: p. 999.

${ }^{54}$ Freeman, Lee's Lieutenants, I: pp. 102-106.

55 Richmond Enquirer, January 10, 1862, p. 3. 
newspaper editorialized positively on the lack of any friction between Johnston and Lee: "with neither of the distinguished Generals, is there any mawkish punctilio about rank."56 While relations between the two were considerably more strained at seven Pines than this account suggested, it was, nonetheless, an indicator that the question of seniority had not become fuel for public debate.

Yet throughout the campaign in defense of Richmond there was a noticeable and increasing tension between Joseph Johnston and Jefferson Davis. If this developing rift was not directly attributable to Johnston's disaffection over his rank, then what caused it? Johnston became more contentious with the President because he believed that Davis had allowed Benjamin and the rest of the military bureaucracy in Richmond to begin meddling in his legitimate prexogatives of command. Davis, at the same time, was receiving reports from the War Department that Johnston could not be depended upon to carry out legitimate administrative directives. Under the tremendous pressure of completely redirecting confederate strategy in the wake of the Fort Donelson disaster, the President failed to investigate these contradictory allegations as thoroughly as he should have. Instead, he believed the accusations of Benjamin and mildly rebuked Johnston for non-cooperation. Compared to the other decisions Jefferson Davis faced

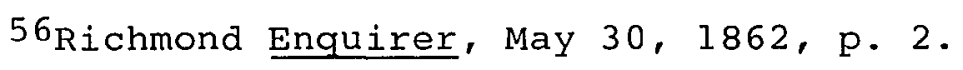


in February, 1862, it seemed a trivial matter. Yet, it came near the beginning of the critical period in which the fate of Richmond would be decided, a time at which trust between the General and the President was becoming especially important. Unfortunately, it turned out to be a time when trust was increasingly being replaced by suspicion. 


\section{Chapter Two}

The Department of Northern Virginia

Centreville, in northern Virginia, is eighty-five miles distant from Richmond. On February 13, 1862, when Jefferson Davis folded and sealed the letter he had just written to Joseph Johnston, he knew that the envelope would not reach the General for at least two, probably three, and possibly as many as five days. A clerk would collect it from his office and bundle it with the daily correspondence from the Secretary of War and the Adjutant and Inspector-General which was also addressed to the headquarters of the Department of Northern Virginia. Sometime later, the postman would toss that bundle into his sack and carry it several hundred yards to the Virginia Central railroad Depot on Broad street. In all probability, the presence of official. mail in the bag did not weigh heavily on his mind or speed his steps; the mail train to Centreville only departed once a day, early in the morning. 1 Besides, if the President or the Secretary of War or the Adjutant General had themselves felt any particular urgency about their correspondence, they could have sent a telegram.

Isee the train schedules published daily in the Richmond newspapers, for example, Richmond Examiner, February 13, 1862, p. 1 . 
When the train pulled out of Richmond in the morning, two to three hours late--often as not--and crowded with soldiers returning from furlough or a stay in the hospital, the locomotive struggled to keep up enough steam to maintain a speed of just under ten miles per hour. In 1860 , the run would have been faster, but by the second year of the American Civil War, the lack of spare parts produced in Northern factories was already being felt on Virginia railroads. Couplings and bearings had to be used long after they should have been replaced because there were not, and would never be, enough replacements while the war dragged on. The engineers knew this, and babied their machines, despite all the fuming of generals and politicians. ${ }^{2}$

If the route was slow, it was also circuitous. First, the Virginia Central swung northeast in a shallow arc that eventually curved back west to intersect the Richmond, Fredericksburg, and Potomac at Hanover Junction. The junction stood twelve miles north of the city, but the train

2 The general condition of prewar railroads in Virginia, while among the best in the South, was hardly that good in the best of times. The rails were made of soft iron, not steel, were usually shaped in a weak "T"-rail configuration, but often still included older wooden "stringers" along many stretches. Robert C. Black, The Railroads of the Confederacy (Chapel Hill, NC: University of North Carolina Press, 1952, pp. 12-14, 31-32; John F. Stover, Iron Road to the West, American Railroads in the $1850^{\prime} \mathrm{s}$ (New York: Columbia University Press, 1987), pp. 65, 203; see also Angus J. Johnston II, Virginia Railroads in the Civil War (Chapel Hill, NC: University of North Carolina Press, 1961), pp. 917; Charles W. Turner, "The Virginia Central Railroad at War, 1861-1865," Journal of Southern History, Vol. XII, No. 4 (November 1946): pp. 510-533. 
meandered more than twice that distance before arriving there. 3 Following a brief stop, the train headed forty miles northwest, more nearly in a straight line, to Gordonsville.

At Gordonsville some baggage handler or detailed soldier plucked the mailbag off the train and carried it across to the freight ramp serving the Orange and Alexandria. In theory, the train from Richmond should have made a fairly close connection every afternoon with the one travelling north from Charlottesville to Manassas; but that was only theory. Most days the schedule ran so far out of kilter that the mail could sit there for nearly twenty-four hours.4 Once tossed aboard a northbound car, however, the process moved more quickly: eight miles to orange court House, sixteen more to culpeper, and a further thirty-nine to Manassas Junction, most of it straight and well-graded. Manassas was only about six and one-half miles from Centreville.

Those six and one-half miles were, however, among the most difficult in the state. Winter storms had turned the

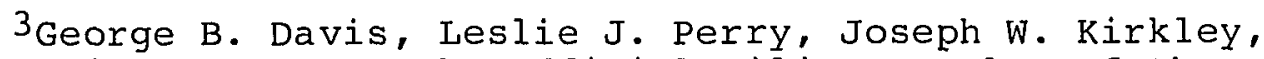
and Calvin D. Cowles, The Official Military Atlas of the Civil War (New York: Arno Press, 1978, reprint of 1891-1895 editions), Plate CXXXVII (hereafter cited as OR Atlas).

${ }^{4}$ Schedules for the Orange and Alexandria were also printed in the Richmond newspapers on a daily basis, as well as persistent stories of delays in those schedules and missed connections. See Richmond Examiner, February 10, p. 1; February 13, p. 1; February 19, p. 1. 
roads of northern Virginia into muddy troughs that seemed to have no bottoms. A rider on a strong horse could only manage two miles an hour, and few of the horses hauling supplies--or mail--from the depot to Johnston's headquarters were strong or well fed. 5 overworked and undernourished, horses and even mules simply fell down in the mud and died by the hundreds. Teamsters pushed their carcasses to the side of the road, where they stiffened and rotted, raising "a putrifaction that makes it quite unpleasant to go along there." 6

Johnston, in a desperate attempt to improve the flow of supplies to his army, had decided in December to extend a railroad spur from Manassas to Centreville. He was able to procure the track from Major-General Thomas J. "Stonewall" Jackson who had made off with nearly a dozen miles of Yankee rails in a raid a few months earlier on the Baltimore and

\footnotetext{
5Joseph E. Johnston to Jefferson Davis, January 14, 1862, Joseph E. Johnston to Jefferson Davis, February 23, 1862 , in OR, V: pp. 1028, 1079; Joseph E. Johnston to Abraham C. Myers, January 14, 1862, in Letters and Telegrams Received, Adjutant and Inspector General's Office, Confederate States of America, National Archives, M-474, Reel 27 (hereafter cited as LR-AIGO); Mary Conner Moffett, ed., Letters of General James Conner, C. S. A. (Columbia, SC: R. L. Bryan, 1950), p. 60 .

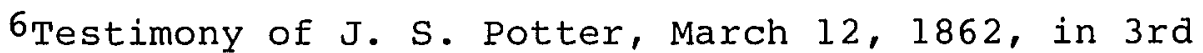
Congress, 3 rd Session, Report of the Joint Committee on the Conduct of the War (Washington, DC: Government Printing Office, 1863), I: p. 244 (hereafter cited as JCCW; all citations are from Volume I unless otherwise indicated); see also Augustus P. Dickert, History of Kershaw's Brigade (Newberry, SC: Elber H. Aull, 1899), p. 89 .
} 
Ohio. 7 Tredegar Iron Works in Richmond produced the spikes and nails to tie them together, while local landowners, albeit under duress, provided their slaves to grade the roadbed and lay the track. 8 He found a former railroad engineer, Captain Stephen W. Presstman, serving in the 17 th Virginia, and detached him to supervise their labor. 9 Johnston's railroad had just gone into bareboned service when Davis's letter arrived at Manassas Depot. Only one dilapidated locomotive, impressed from the Orange and Alexandria, plied the line. The lack of a turnaround at the end forced the engineer to back cautiously over the bumpy road and across the shaky bridge spanning Bull Run in order to make his return trip. 10 No fueling stations existed

7Joseph Miles Hanson, Bull Run Remembers... The History, Traditions, and Landmarks of the Manassas (Bul1 Run) Campaigns Before Washington, 1861-1862 (Manassas, VA: National Capitol Publishers, 1953), pp. 40-41.

8Dew, Ironmaker, p. 128; Joseph E. Johnston to A. W. Barbour, February 12, 1862, in Joseph E. Johnston papers, Swem Library, College of William and Mary, Williamsburg, Virginia (hereafter cited as (JJWM).

${ }^{9}$ Assistant Adjutant General to Stephen W. Presstman, January 9, 1862, in Letters and Telegrams Sent, Army of Northern Virginia, January 1862-March 1863, National Archives (Hereafter cited as LTS-ANVA); Secretary of the Congress to Jefferson Davis, February 17,1862 , in LR-AIGo, M-474, Reel 11; James L. Nichols, Confederate Engineers (Tuscaloosa, AL: Confederate Publishing Co., 1957), p. 97 ; George Wise, History of the Seventeenth Virginia Infantry, C. S. A. (Baltimore: Kelly, Piet, \& Co., 1870), p. 18 .

10 Though there are very few written sources on the railroad itself, it shows up surprisingly in maps made by Federal topographical engineers after the second Manassas campaign, as well as in photographs taken either upon Mcclellan's occupation of the Centreville position in March, 
along the route, so that if the train ran out of wood, the crew had to get off and cut down the nearest trees.11 Freight, baggage, soldiers, and official mail were all unloaded unceremoniously into a muddy field near centreville, and left there for the army's staff to sort out as best they could. 12

Eventually, when one aide or a nother recognized the mail sack among the flotsam, he would have taken it to Major Thomas G. Rhett, Assistant Adjutant-General, and Johnston's de facto Chief of staff. Rhett sorted the mail, every day sifting through hundreds of reports; requests for furlough, appointment, or discharge; recruiting notices; and miscellaneous trivia for official letters directed to his commander. When he was satisfied that he had found them all, he took them the final few feet to the next room: General Johnston's office.

A letter from the president demanded, of course, immediate attention. Unfortunately, Davis's February 13 letter to his general does not seem to have survived, and

1862, or during Major-General Irwin McDowell's operations during the summer. See Hanson, Bull Run, pp. 40-4l; OR Atlas, Plates XXII (3), (4), (6), (7), XXIII (1); William C. Davis, ed., The Image of War, 1861-1865 (Garden City, NY: Doubleday, 1982), II: pp. 406, 407 .

${ }^{11}$ Abraham C. Myers to Joseph E. Johnston, January 20, 1862, in Letters and Telegrams Sent, Quartermaster-General, Confederate States of America, National Archives, T-13I, Reel 8 (hereafter cited as LS-QMG).

12 Hanson, Bull Run, pp. 40-41. 
only Johnston's indirect paraphrase years later, combined with the inferences which can be drawn from a telegram and letter he dispatched in response, suggest the content of the letter that set in motion Johnston's campaign to defend Richmond. "I was summoned to Richmond by the President," he recalled, "who wished to confer with me on a subject in which secrecy was so important that he could not venture, he said, to commit it to paper, and the mail."13

Despite the leisurely pace at which it was delivered, the summons must have contained some element of immediacy. At once, Johnston felt compelled to dash off a telegraphic answer, which requested a delay of one or two days while his second-in-command, Major-General Gustavus Woodson Smith, recovered from his most recent bout with a chronic nervous ailment.14 It must also have suggested to the General, despite his later recollection, the subject to be considered. Both men had been concerned for some time with the exposed state of Johnston's army, strung out along the Potomac frontier. The paragraph in Johnston's letter to Davis the same day, concerning the possible withdrawal of his forces deeper into Virginia, appears almost unmistakably to be the answer to a direct question, a question not

\footnotetext{
13 Johnston, Narrative, p. 96.

14 Joseph E. Johnston to Jefferson Davis, February 16 , 1862 , in JJWM).
} 
contained in any of Davis's earlier letters. 15

Johnston certainly had good reason to be worried about the vulnerable disposition of his troops. The Department of Northern Virginia controlled the operations of all Confederate forces north of the Rappahannock River and in the Shenandoah Valley. To cover his front with even a thin crust of pickets and detached garrisons required Johnston to disperse his 47,617 effectives in a dangerous manner (see Map No. 1).16

Nearly half his strength was deployed in semi-independent columns, most of which were too far divided to march rapidly to reinforce each other in case of an attack. Jackson had 5,394 men in the Valley, isolated by a march of several days from Johnston's main position at Centreville. Brigadier-General Daniel Harvey Hill held an exposed outpost at Leesburg with just 2,460 soldiers; his correspondence throughout the winter revealed his sensitivity to the possibility of being cut off by a quick Federal thrust across the Potomac. Along the Potomac south of Washington D. C., Brigadier-General William Henry Chase Whiting's command of 7,596 protected ten miles of Johnston's exposed right flank from a surprise amphibious landing, but it was

15Joseph E. Johnston to Jefferson Davis, February 16, 1862 , in OR, V: p. 1074.

16 "Abstract from Return of the Department of Northern Virginia, General Joseph E. Johnston, C. S. Army, commanding, for the month of February, 1862," in OR, V: p. 1086. 


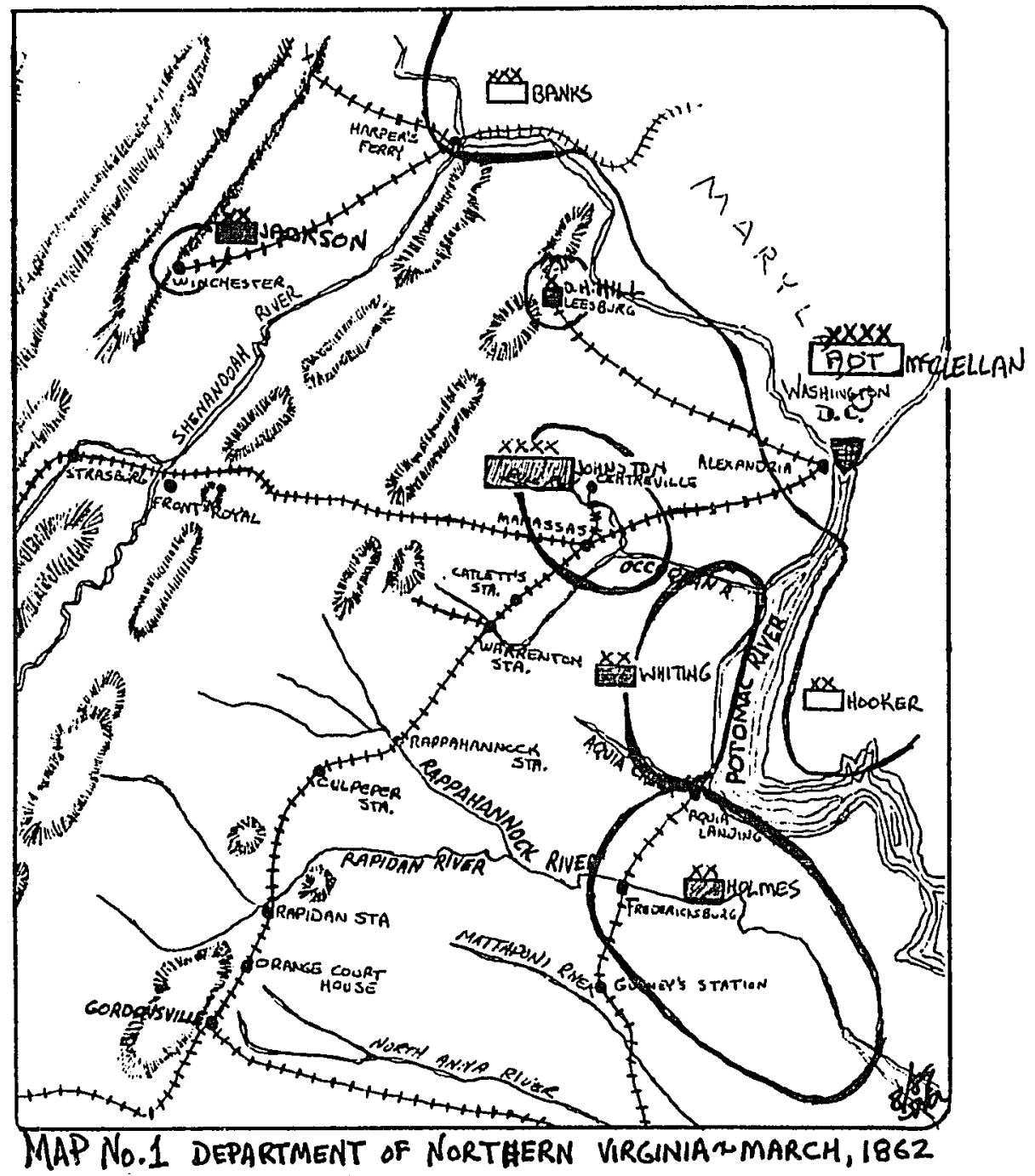


spread so thin that Whiting also lived in a continual state of anxiety about the security of his position. Likewise, Major-General Theophilus Holmes' 5,956 troops could only maintain a fragile screen of pickets from Aquia Creek down to Urbana on the Rappahannock. This left General Johnston at centreville with a field army that, even if he counted his reserve artillery park, all his cavalry, and the permanent garrison at Manassas, numbered only 26,211 men.17 North of the river, in an arc that paralleled Johnston's line from Harper's Ferry to the Eastern Shore, Mcclellan's Army of the Potomac reported 185,420 "present for duty"--almost four Yankees to each Rebel.18 Not only numbers, but disparity of equipment, favored the Federals; everything Johnston's troops lacked--rifles, cannon, horses,

17The breakdown of strength is drawn from Ibid.; for D. H. Hill's concerns about his position's vulnerability, see D. H. Hill to Judah P. Benjamin, February 7, 1862, in oR, LI (Part 2): p. 465; D. H. Hill to Samuel Cooper, February 7, 1862, D. H. Hill to Judah P. Benjamin, February 22, 1862, in LR-AIGO, M-474, Reel 23; Thomas J. Jackson to D. H. Hill, February 20, 1862, Thomas J. Jackson to D. H. Hill, February 22, 1862, in D. H. Hil1, "The Haversack," Land We Love, Vol. I, No. 2 (June 1866): p. 116. On the vulnerability of Whiting's line, see Joseph E. Johnston to Judah P. Benjamin, January 3, 1862, in Letters and Telegrams Received, Secretary of War, Confederate States of America, National Archives, M-618, Reel 8 (hereafter cited as LR-SW); Joseph E. Johnston to W. H. C. Whiting, December $5, \overline{1861}$, Joseph E. Johnston to W. H. C. Whiting, December 6, 1861, Wade Hampton to Joseph E. Johnston, December 8, 1861, in $\underline{\mathrm{R}}, \mathrm{V}$ : pp. 985987 .

18 "Extract, embracing the 'First Period,' from Maj. Gen. George B. McClellan's report of the operations of the Army of the Potomac from July 27, 1861, to November 9, 1862 ," in OR, V: p. 12 (hereafter cited as "McClellan's Report (I)"). 
wagons, medicines, or rations--was available in abundance on the other side of the Potomac. A French observer with the Union army commented that "the volunteer is provided with everything, and is supplied so liberally with rations that he daily throws away a part of them," adding dryly that "one may imagine what such an army must cost."19 Even McClellan's most strident critics accredited him as the master organizer. Journalist and historian William Swinton wrote that "if other generals, the successors of Mcclellan, were able to achieve more decisive results than he, it was, again, in no small degree, because they had the perfect instrument he had fashioned to work withal."20

Despite the immensely greater handicaps under which he labored, neither his contemporaries nor historians have tended to award similar accolades to Joseph Johnston. Brigadier-General Robert Toombs complained in September, 1861 that "I never knew as incompetent [an] executive officer."21 Secretary of war Benjamin regularly accused Johnston of every administrative shortcoming from failure to

19The Prince de Joinville, The Army of the Potomac: Its Organization, Its Commander, and Its Campaign (New York: Anson D. F. Randolph, 1862), p. 13 .

20 William swinton, Campaigns of the Army of the Potomac, A Critical History of Operations in Virginia, Maryland, and Pennsylvania from the Commencement to the close of the War, 1861-1865, revised edition (New York: University Publishing Company, [1881]), p. 67.

$2 l_{U}$. B. Phillips, ed., The Correspondence of Robert Toombs, Alexander $\mathrm{H}$. Stephens, and Howell Cobb (Washington, DC: n. p., 1913), p. 557 . 
file reports to neglecting to provide winter quarters for his troops.22 "Discipline had been lax under Johnston; drunkenness had been frequent; many things were at loose ends," concluded Douglas Southall Freeman, who took meticulous pains to praise Lee, not Johnston, for nearly every positive step toward the organization of the Army of Northern Virginia.23 Clifford Dowdey characterized Joseph Johnston as lacking energy, and contended that "while social life at headquarters was genial and relaxed, Johnston was a slovenly administrator and careless about details. He liked to be 1 iked." 24

Johnston's performance as an administrator that winter deserves more credit than he has been allowed. Few, if any, Confederate commanders ever organized an army facing such a disparity of numbers, had to contend with more serious shortages of munitions, or had to deal with such a high degree of bureaucratic interference from Richmond. If he was not always completely successful in his efforts, and if he sometimes became less than tactful in his communications, the difficulty of his circumstances has to be pleaded in

22 For representative examples, see Judah $\mathrm{P}$. Benjamin to Joseph E. Johnston, September 29, 1861, Judah P. Benjamin to Joseph E. Johnston, January 25, 1862, Jefferson Davis to Joseph E. Johnston, March 1, 1862, in OR, V: pp. 883, 1045$1046,1089$.

23 Freeman, R. E. Lee, II: p. 87.

$24 \mathrm{Cl}$ ifford Dowdey, The Seven Days, The Emergence of Robert E. Lee (Boston: Little, Brown, \& Co., 1964), p. 36 . 
extenuation.

Johnston's rebel soldiers were not merely outnumbered, but man for man they were badly outgunned. The scarcity of firearms which plagued the confederacy in the first year of the war was so severe in the Department of Northern Virginia that the weapons of soldiers in the hospital had to be consolidated to drill recruits in unarmed regiments. 25 Those rifles and muskets actually on hand were a baffling mix of calibers, brands, and qualities. The best of them were issued to the infantry, while much of Brigadier-General J. E. B. Stuart's cavalry made due with sabers, pistols, and shotguns. 26

The state of Johnston's artillery was even more dismal than that of the infantry. The fact that the army contained several men who would become the premier cannoneers of the war could not outweigh the scarcity of guns or the insufficiency of powder. Though the precise number is elusive, Johnston's entire department probably did not contain more than 175 pieces of field artillery, while Mcclellan could

$25_{G}$. W. Smith, "Council of war at Centreville, October 1, 1861, P. G. T. Beauregard to Samuel Cooper, October 25, 1861, Joseph E. Johnston to W. H. C. Whiting, November 16 , 1861, Joseph E. Johnston to S. Bassett French, January 29, 1862, in OR, $V:$ pp. 886, 921, 958, 1051-1052; Judah P.

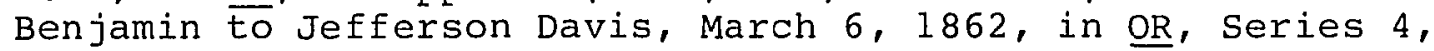
I : p. 971 .

26 Stephen $z$. Starr, The Union Cavalry in the Civil War (Baton Rouge, LA: Louisiana State University Press, 1979, 1985), I: pp. 218-221. 
deploy 465.27 Many of the cannon Johnston did possess were six-pounders, which had too small a caliber to be effective on the Civil war battlefield.28

The nationwide shortage of gunpowder prevented the batteries he did possess from conducting enough live-fire training to assure their efficiency in combat. When the gunners did get to practice, the results were often demoralizing. In order to stretch its meager supply of powder, the Ordnance Department mixed in a proportion of less potent blasting powder. Brigadier-General Samuel French, commanding the Confederate artillery--both light and heavy--with which Whiting was attempting to blockade the lower Potomac, remembered that his ammunition "was very indifferent." "Sometimes," he recalled, "the Armstrong gun, at the same elevation, would not throw a shell more than halfway across

27 This figure may actually be on the high side for the field artillery of the Department of Northern Virginia, because the count may have included thirty-five to forty heavy guns on the lower Potomac. Jennings $C$. Wise, The Long Arm of Lee, The History of the Artillery of the Army of Northern Virginia, one-volume edition (New York: Oxford University Press, 1959, reprint of 1915 edition), p. 143; J. Thomas Scharf, History of the Confederate States Navy From Its Organization to the Surrender of Its Last Vessel (New York: Rogers \& Sherwood, 1887), pp. 95-99.

28 Johnston believed six-pounders to be less than half as effective on the battlefield as twelve-pounders, and recommended decreasing them as a proportion of his artillery. See Joseph E. Johnston to Jefferson Davis, August 10 , 1861, Jefferson Davis to Joseph E. Johnston, August 13, 1861 , in OR, $\mathrm{V}$ : pp. 777, 784; Wise, Long Arm, pp. 67, 7172, 79, 110, 136, 145; Daniel, "Manuf acturing Cannon," p. 40; Jack Coggins, Arms and Equipment of the Civil War (Garden City, NY: Doubleday, 1962), pp. 63-64, 66. 
the river; then again far over the river."29 Such unpredictable differences in performance hardly instilled confidence in Johnston's cannoneers.

Aside from being outnumbered and inadequately armed, Johnston's troops also suffered from a high rate of sickness. Throughout the fall and winter, the number of soldiers confined to the hospitals, either near Centreville or further back in Richmond or Charlottesville, varied between 13,000 and $16,000--t h e$ equivalent of two ful1strength divisions! Hundreds died each month, and hundreds more were discharged by surgeons who pronounced them permanently unfit for military duty. 30

Four circumstances beyond his control accounted for the high incidence of disease in Johnston's department. First, a significant proportion of his regiments had come straight to his army upon organization, instead of remaining in camps of instruction for the first few weeks following their induction. Consequently, they experienced the normal run of "camp diseases" prevalent among new soldiers in both armies

29 Samuel G. French, Two Wars: An Autobiography of Gen. Samuel G. French (Nashville: Confederate Veteran, 1901), p. 143; see also Samuel French to Samuel Cooper, February 12, 1862, Samuel French to Samuel Cooper, February 14, 1862, in LR-AIGO, M-474, Reel 18; J. B. Walton to Samuel Cooper, January 17, 1862, in LR-AIGO, M-474, Reel 52; Wise, Long Arm, p. 144 .

30 This information cannot be derived from the "extracts" of monthly departmental returns in OR, but shows up in the originals. The originals of the monthly returns for the Department of Northern Virginia for October, November, and December, 1861 are in JJWM. 
--mini-epidemics of everything from typhus to influenza--in the field.31 This condition was exacerbated by the severity of winter in northern Virginia which, to unprepared troops from the deep South, must have seemed nearly indistinguishable from the blizzards of the Arctic. Exposure to cold, wind, rain, and snow, combined with the inadequate shelters that the army could provide ("negro cabins," Toombs called them), increased the vulnerability of green troops to disease to such an extent that several whole regiments had to be witharawn to Richmond because they were totally incapacitated. 32 Medical care at the front ran from rudimentary to nonexistent, simply because there were neither enough doctors nor enough medicine. Many of the physicians available were apparently incompetent; D. H. Hill

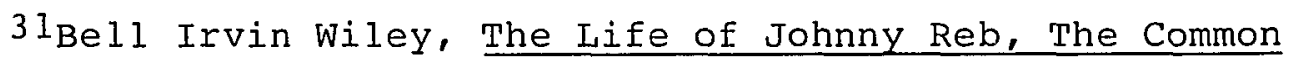
Soldier of the Confederacy (Baton Rouge, LA: Louisiana State University Press, 1978, reprint of 1943 edition), pp. $251-254$.

32 Two examples of regiments from the deep South which suffered heavily were the 35 th Georgia and the 14 th Alabama. Disease in the 14 th Alabama was so prevalent that Secretary Benjamin had to order it to Richmond in December, 1862 in order for it to recover. Judah P. Benjamin to Theophilus Holmes, January 5, 1862, in OR, V: p. 1020; Phillips, Correspondence, pp. 575, 578; Wiley, Johnny Reb, p. 59; Joseph E. Johnston to Samuel Cooper, October 7, 1861, Theophilus Holmes to Samuel Cooper, October 9, 1861, Judah P. Benjamin to Joseph E. Johnston, October 13, 1861, Joseph E. Johnston to Samuel Cooper, November 2, 1861, Judah P. Benjamin to Joseph E. Johnston, November 7, 1861, Joseph E. Johnston to W. H. C. Whiting, November 11, 1861, Joseph E. Johnston to Judah P. Benjamin, November 13, 1861, Judah P. Benjamin to Joseph E. Johnston, November 17, 1861, C. W. C. Dunnington to R. M. Smith, December 16,1861 , in OR, V: pp. $891,893,896-897,934,941-942,948-949,951,962,998-999$. 
suggested that the health of the army would be vastly improved if "one half of our surgeons were hung."33 And finally, the diet of the soldiers was chronically low in vegetables and anti-scorbutics, while high in half-baked bread and sinewy pork and beef of questionable quality. 34

Even if more plentiful supplies of weapons, ammunition, accoutrement, medicines, and rations had existed, it is doubtful that the logistical situation of the Department of Northern Virginia that winter could have been significantly improved. The supply lines leading from Richmond to Manassas, as has already been seen, consisted of rickety, single-track railroads served by deteriorating equipment, and administered so poorly that the government, the army, and the railroad companies sometimes lost sight of dozens of loaded freight cars for months at a time. 35 Distribution at the receiving end was no more efficient due to the inade-

33 Quoted in Jeffrey Wert, "I Am So Unlike Other Folks," Civil War Time Illustrated, Vol. XXVIII, No. 2 (April 1989): p. 16; see also extract from the Journal of the Provisional Congress, reporting on the Quartermaster's Commissary, and Medical Departments, January 29, 1862, in OR, Series 4, I: pp. 887-890.

${ }^{34}$ Extract from the Journal of the Provisional Congress, reporting on the Quartermaster's Commissary, and Medical Departments, January 29, 1862, in OR, Series 4, I: pp. 887.

35Jefferson Davis to Joseph E. Johnston, September 18 , 1861, Judah P. Benjamin to Joseph E. Johnston, September 19, 1861, Joseph E. Johnston to Judah P. Benjamin, September 20, 1861 , W. L. Powell to Jefferson Davis, September 20, 1861, Abraham C. Myers to Judah P. Benjamin, September 21, 1861, Joseph E. Johnston to Jefferson Davis, September 22, 1861, in $\underline{O R}, \mathrm{~V}: \mathrm{pp} .857,867,871-873$. 
quate number of horses and mules which attempted to haul supplies over the muddy roads. Whiting's command on the Potomac provided a telling example of the consequences: though none of his troops were stationed farther than thirty miles from the railhead at Manassas Junction--and some as close as sixteen miles--he had to put his division on half rations several times during the winter. 36 There were rations in the depots but his dilapidated wagon trains could not bring them up fast enough to keep pace with daily consumption, let alone quickly enough to build up his own reserve stock.

The inevitable repercussion was a gradual erosion in the morale of Johnston's soldiers. Men who had sustained themselves through the fall on the flush of victory generated at the Battle of Manassas slowly found their will to continue eaten away by months of inactivity and intolerable Iiving conditions, neither of which showed any immediate prospect of improving. Regiments from Tennessee and Alabama petitioned the government to send them home. 37 Hundreds of

\footnotetext{
$36 \mathrm{~W}$. H. C. Whiting to Theophilus Holmes, March 21 , 1862, Joseph E. Johnston to Judah P. Benjamin, January 14, 1862 , in OR, V: pP. 529, 1028 .

37The 1st (Provisional), 7th, and 14th Tennessee, as well as the 4th Alabama petitioned the government to be sent home during the winter. Robert E. Lee to Edmund Kirby Smith, April 7, 1862, in OR, X (part 2): p. 397; George Maney to otho R. Singleton, February 23, 1862, in OR, VII: pp. 901-903; Judah P. Benjamin to Joseph E. Johnston, February 12, 1862, in Letters and Telegrams Sent, Secretary of War, Confederate states of America, National Archives, $M-$ 522, Reel 3 (hereafter cited as LS-WD).
} 
soldiers illegally extended their furloughs by skulking about Richmond instead of returning promptly to the army. 38 Alcohol abuse, up to and including blatant drunkenness on duty by company and regimental officers, soared. 39 The recruiters swarming over his camps Eound Johnston's men quite willing to sign up for almost any unit of any kind which could guarantee them that they would serve out their terms almost anywhere else.40 As the months of March, April, and May approached, when the enlistments of more than half the department's soldiers would expire, everyone from Jefferson Davis and the Confederate Congress down to Joseph Johnston and his subordinates feared the worst: the army threatened to simply melt away without ever fighting another battle. 41

38 Entries for January 23, 1862, January 28-29, 1862, February 10-12, 1862, Thomas Bragg diary, typescript, Southern Historical Collection, University of North Carolina, Chapel Hill, NC, pp. 123, 127, 141-144.

${ }^{39} \mathrm{Phillips,}$ Correspondence, p. 592; Entry for January 8, 1862, Bragg diary, p. 104; W. D. Camp to Samuel Cooper, February 13, 1862, in LR-AIGO, M-474, Ree1 11; Joseph E. Johnston to Samuel Cooper, January 10, 1862, in LR-AIGO, M474 , Reel 27 .

40 Johnston, Narrative, pp. 90-91, 99-101.

41 Joseph E. Johnston to Judah P. Benjamin, January 14 , 1862 (with enclosure showing the organization of troops assigned to the Department of Northern Virginia), Joseph E. Johnston to Judah P. Benjamin, January 18, 1862, Judah P. Benjamin, January 25, 1862 , Joseph E. Johnston, February 1, 1862 , in $\mathrm{OR}, \mathrm{V}$ : pp. 1028-1032, 1036-1037, 1045-1046, 10571058; Judah P. Benjamin to Howel1 Cobb, December 14, 1861 (with enclosure "statement of the number of troops now in the service enlisted for the war and of the states from which they have volunteered"), Henry Hill to the Chairman, 
The fact that an army in more than name even existed in February, 1862, was due primarily to the efforts of General Johnston. Contrary to the image with which his memory has been saddled, the General worked diligently to prepare his divisions to face the enemy and bent every resource he possessed toward maintaining their strength and propping up their sagging morale. Unlike the majority of his men and many of his officers, Joseph Johnston allowed himself no vacations from the responsibilities of command: from the day he took charge at Manassas in July 1861, until he travelled to Richmond on Jefferson Davis's direct orders in February, 1862, Johnston remained with the army.42

Recognizing the dangers of his army's dispersal, Johnston instituted a policy of quick response to enemy actions designed to allow his widely separated columns to react without wasting time to refer to headquarters for specific orders. Jackson, in the Valley, and Hill, at Leesburg, were encouraged to communicate with each other directly and authorized to send reinforcements to any point

Committee on Military Affairs, House of Delegates, Virginia, January 20, 1862 (with enclosure "An abstract showing the commencement of the termination of service of the volunteers of Virginia who went into the service in April, May, and June, 1861"), "statement of troops in the service of the Confederate States," March 1, 1862, in OR, Series 4, I: pp. $788-790,859-861,962-964$.

42 Johnson, Johnston, p. 78 . 
of attack without consulting Centreville.43 In the same manner, Johnston instructed Whiting, on the lower Potomac, and Holmes, near Fredericksburg, to coordinate an immediate response to any Federal landing in their areas. 44 Johnston required Major-General Earl Van Dorn, who might have to march his troops on short notice to reinforce any of these positions, to have accurate maps of the roads on his flank, and assure that the bridges along his line of march were kept repaired. 45 In this manner, Johnston hoped that the speed of his reaction to any Union offensive might somewhat offset his inferiority of numbers. In the event that it did not, he ordered entrenchments built on the northern bank of the Rappahannock River to secure key bridges in case of a retreat. 46

Johnston actively employed what would today be called counter-intelligence procedures to deceive McClellan with regard to his weakness. He had logs painted black and discarded locomotive stovepipes mounted in the embrasures of

43 Joseph E. Johnston to Thomas J. Jackson, January 24, 1862, in LR-AIGO, M-474, Reel 27.

44 A. P. Mason to W. H. C. Whiting, February 4, 1862, in LS-ANVA; Joseph E. Johnston to W. H. C. Whiting, December 5, 1861, Joseph E. Johnston to W. H. C. Whiting, December 6, 1861, Joseph E. Johnston to W. H. C. Whiting, December 7, 1861, in $\mathrm{OR}, \mathrm{V}: \mathrm{pp} .982,986-987$.

45 Joseph E. Johnston to W. H. C. Whiting, December 7, 1861, in OR, V: p. 986; Hanson, Bull Run, p. 37.

46 Joseph E. Johnston to Samuel Cooper, February 9 , 1862, in LR-AIGO, M-474, Reel 27; Joseph E. Johnston to $R$. W. Hughes, April 9, 1867, in RMH; Johnston, Narrative, p. 445 . 
his defenses at Centreville to conceal the fact that the few heavy guns whiting deployed along the Potomac were all that the army owned. Scarecrows were even erected to mimic gun crews. 47 Until winter storms rendered major movements impractical, he kept his infantry brigades shuffling across his front as ostentatiously as possible, with the objective of convincing Yankee spies to count the same soldiers two or even three times. 48 Likewise, French's field batteries on the Potomac stayed on the move all winter, digging in and firing a few rounds across the river, then limbering and deploying to a new location so that Federal pickets could never get an accurate count of their numbers. A small passenger steamer, rechristened the C. S. S. George Page, was outfitted with one or two light cannon and "armored" with spare bjts of iron. The vessel was then run back and forth between the Occoquan River and Chopawamsic Creek in a remarkably successful attempt to convince the enemy that the Confederates had managed to place a real ironclad warship on

47 Testimony of J. S. Potter, March 12, 1862; Testimony of Irwin McDowel1, April 1, 1862, in JCCW, pp. 243, 247, 258; Robert T. Bell, llth Virginia Infantry, lst edition, (Lynchburg, VA: H. E. Howard, 1985), p. 18; Davis, Image of War, II: p. 398 .

48 A. M. Barbour to Abraham C. Myers, January 23, 1862, in Letters and Telegrams Received, Quartermaster-General, Confederate States of America, National Archives, M-469, Reel 1 (hereafter cited as $\mathrm{LR}-\mathrm{QMG}$ ); Robert Rodes to Lieutenant Ingraham, December 25, $\overline{1861,}$ in Jubal A. Early papers, Virgin-a Historical Society, Richmond, Virginia. 
the Potomac.49 The fortuitous combination of Johnston's efforts with the incompetence of Mcclellan's intelligence service and the Federal commander's own innate caution resulted in the Northern general's firm conviction that the rebels in the Department of Northern Virginia numbered 150,000 instead of the 47,000 effectives actually present. 50 There was little Johnston could do directly to improve the shortages of weapons, ammunition, equipment, rations, and medicines which plagued his army. He tried to augment his food supply locally, and an officer was sent to the capital to secure anti-scorbutics.5l He also dispatched Brigadier-General William Nelson Pendleton, his Chief of Artillery, to Richmond, staunton, and Lynchburg to scavenge for the harnesses, caissons, and forges necessary to make his field batteries tactically mobile.52 In the meantime, the Chief of Ordnance, Major E. P. Alexander, concentrated

49 W. T. Street to R. H. Wyman, December 11,1861, R. H. Wyman to Gideon Welles, December 12, 1861, R. H. Wyman to Gideon Welles, December 18, 1861, in United States Navy Department, War of the Rebellion: Official Records of the Union and Confederate Navies (Washington, DC: Government Printing Office, 1921), Series 1, V: pp. 4-5, 7-8 (Hereafter cited as NOR; all citations are from Series 1 unless otherwise indicated); Naval History Division Navy Department, Civil War Naval Chronology, 1861-1865, one-volume edition, (Washington, DC: U. S. Government printing office, 1971), VI: p. 237; Samuel French to Samuel Cooper, February 7, 1862, in LR-AIGO, M-474, Reel 18 .

50 "McClellan's Report (I)," in OR, V: p. 53.

$51_{A}$. P. Mason to H. Cole, January 25,1862 , in LS-ANVA.

52 Susan P. Lee, ed., Memoirs of William Nelson Pendleton (Philadelphia: n. p., 1893), pp. 155-156. 
on keeping rigid control over the expenditure of every grain of precious powder that the army had been issued, while carefully organizing his slender reserves into mobile trains to accompany the divisions when active operations commenced. 53

But Johnston reserved his primary efforts for improving the efficiency with which supplies were delivered from the railhead at Manassas to the troops in the field. As noted, he constructed a six-and-one-half-mile rail spur to cut down the hauling distance for his overworked teams. Sawmills which had been set up to cut lumber for the army's winter quarters were kept running to cut planks with which to corduroy the worst roads. 54 He appointed an Inspector of Transportation to initiate a systematic program of caring for the army's draft animals and maintaining its fleet of wagons.55 To assist the department's Chief Quartermaster, Johnston assigned another officer to take over specific responsibility for administering the stockpiles of materials

$53_{\text {Edward Porter Alexander, Military Memoirs of a }}$ Confederate (New York: n. p., 1907), pp. 52-53.

54 Joseph E. Johnston to A. W. Barbour, February 1, 1862, Joseph E. Johnston to Abraham C. Myers, February 1, 1862, Joseph E. Johnston to Abraham C. Myers, February 3, 1862 , in JJWM.

55 Joseph E. Johnston to Samuel Cooper, January 14, 1862 , in LR-AIGO, M-474, Reel 10; General Orders No. 24, Department of Northern Virginia, February 13, 1862, in $\underline{\text { OR, }}$ LI : p. 468 . 
at Manassas. 56 Major Rhett, the Chief of Staff, constantly badgered the division and brigade commanders, pursuant to Johnston's instructions, to submit accurate and timely strength reports, so that only those supplies absolutely necessary would have to be carted forward to their positions.57 Although the fundamental weakness of the entire Confederate war effort could not be offset by his program to increase the efficiency of his own supply services, it is evident that Johnston spared no energy in trying to get the most out of the little his country could provide him. The General's other priority was to shore up the spirits of his soldiers. He believed firmly that his personal example and as rigorous a regimen of drill and discipline as the weather permitted were key ingredients to elevating morale. The sight of Johnston riding around the camps near centreville, became a daily occurrence for the

56 Joseph E. Johnston to P. G. T. Beauregard, Desember 9, 1861, in E. Murray Smith collection, United States Military History Institute, Carlisle Barracks, Pennsylvania.

57 For typical examples of Johnston of his Assistant Adjutant General remonstrating with his subordinates over their paperwork, see A. P. Mason to Thomas J. Jackson, January 4, 1862, A. P. Mason to E. K. Smith, January 6, 1862 , A. P. Mason to P. G. T. Beauregard, January 7, 1862, Thomas G. Rhett to William Nelson Pendelton, January 7 , 1862, "Assistant Adjutant General" to Theophilus Holmes, January 7, 1862, A. P. Mason to J. E. B. Stuart, January 9, 1862, Circular Letter, A. P. Mason to James Longstreet, Jubal Early, and D. H. Hill, February 7, 1862, in LS-ANVA; J. B. Washington to Theophilus Holmes, January 31,1862 , Joseph E. Johnston to Theophilus Holmes, February 13, 1862, Joseph E. Johnston to Thomas J. Jackson, February 13, 1862 , in JJWM. 
soldiers in the main field army. Like McClellan, Johnston held parades and reviews, personally complimenting those regiments that proved they had mastered the evolutions of the company and the battalion. In addition, however, he demanded that his commanders pay attention to tactical training. Exercises were conducted throughout the winter on both brigade and division levels. Idleness on days without formal drill was not tolerated; each morning, in every company, orderly sergeants called off the names of the men detailed to improve the centreville entrenchments, unload supplies from the freight cars, or upgrade the makeshift short line. 58

Johnston understood fully the importance of symbols to his soldiers. After General Beauregard designed a new Confederate battle flag, Johnston wrote to the governors of the states from which he drew his troops, requesting that each chief executive forward flags for his own regiments. Although only Governor John Letcher of Virginia responded, Johnston used the occasion for as much ceremony as possible,

58 Dorsey Pender to Fanny Pender, September 11, 1861, Dorsey Pender to Fanny Pender, November 21,1861 , in William W. Hassler, The General to His Lady, The Civil War Letters of William Dorsey Pender to Fanny Pender (Chapel Hill, NC: University of North Carolina Press, 1962, pp. 59, 96-97; Wise, Seventeenth Virginia, pp. 43-44, 49; Samuel French to Theophilus Holmes, February 13, 1862, in LR-AIGO, M-474, Reel 17; Richard M. McMurry, John Bell Hood and the War for Southern Independence (Lexington, KY: University Press of Kentucky, 1982), pp. 30-31; Donald B. Sanger and Thomas Robson Hay, James Longstreet (Baton Rouge, LA: Louisiana State University Press, 1952), p. 33. 
holding a series of reviews for the governor to present the new banners. 59 Later, he tried unsuccessfully to convince the president to ride up and address the army, hoping that an appeal from Davis would stimulate more reenlistments. 60 On his own, Johnston granted leaves and furloughs to as many of the soldiers as he considered could be safely spared at one time. 61

Johnston also applied the rod. He attempted, throughout most of the winter, to crack down on the drunkenness of his officers, convinced that such was a prerequisite for enforcing abstinence among the rank and file. Officers found intoxicated on duty were court-martialed, and recommendations sent to Richmond that they be drummed out of the service. 62 Resolutely, Johnston signed the first orders ever given in the Department of Northern Virginia for the execution of deserters and others found guilty of heinous

59F'. N. Boney, John Letcher of Virginia (University of Alabama: University of Alabama Press, 1966), p. 149.

60 Joseph E. Johnston to Jefferson Davis, February 5 , 1862 , in OR, V: p. 1062 .

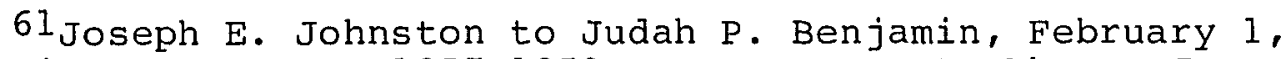
1862, in OR, V: pp. 1057-1058; A. P. Mason to Thomas J. Jackson, January 4, 1862, A. P. Mason to E. K. Smith, January 6, 1862, A. P. Mason to P. G. T. Beauregard, January 7,1862 , in LS-ANVA.

62 Joseph E. Johnston to Samuel Cooper, January 10, 1862 , in LR-AIGO, M-474, Reel 27; W. D. Camp to samuel Cooper, February 13, 1862, in LR-AIGO, M-474, Reel 11; Phillips, Correspondence, p. 592; Terry L. Jones, Lee's Tigers, The Louisiana Infantry in the Army of Northern Virginia (Baton Rouge, LA: Louisiana State University Press, 1987), pp. 35-39. 
crimes.63 Although generally unnoticed, the scope and effectiveness of Johnston's program to support his soldiers' spirits and improve the effectiveness of his army was not surpassed by any other commander under similar conditions at any time during the war. It was only rivalled by his own efforts with the Army of Tennessee and those of Lee with the Army of Northern Virginia in the winter of 1863-1864.

Johnston's quiet accomplishments stand out as all the more remarkable in light of the fact that the civil-military bureaucracy in Richmond seemed consciously determined to undermine him. In nearly every area, either secretary Benjamin, Adjutant General Samuel Cooper, Quartermaster General Abraham Myers, or Commissary General Lucius Northrop directly opposed the field commander. Each official quarreled with Johnston in what amounted to the petty vindictiveness of an administrator insistent on sustaining his own titular authority regardless of the consequences to the cause he served. Taken in sum, the counter-productive measures pursued by the Confederate administration constantly threatened to undo everything Johnston had striven to accomplish.

He clashed constantly with the war Department over the question of weapons. Despite its lack of adequate armaments, Johnston's army was the strongest in the Confederacy.

\footnotetext{
$40-42$.

63 Taylor, Destruction, p. 25; Jones, Lee's Tigers, pp.
} 
For this reason, Secretary Benjamin and General Coopex pressured him incessantly to ship "surplus" muskets--which, in their minds included those of soldiers sent to the hospital--to Richmond for distribution to new regiments. 64 When Johnston demurred, arguing that "this deprives the different regiments of the means of arming their men who return from the hospitals," he found himself subject to a sudden surprise inspection by Cooper himself.65 Finally, in order to retain sufficient muskets to arm his own infantry, Johnston was forced to turn a blind eye while his subordinates illegally concealed guns from the Richmond authorities. 66

Despite the wel1-known numerical and qualitative inferiority of Johnston's cannon, the Confederate war Department actually attempted, in september, 1861, to halt the Tredegar Iron Works' production of field guns in favor

64 Special Orders No. 147, Adjutant and Inspector General's office, October 19, 1861, Judah P. Benjamin to Joseph E. Johnston, October 19, 1861, P. G. T. Beauregard to Samuel Cooper, October 25, 1861, Joseph E. Johnston to Samuel Cooper, January 28, 1862, in OR, V: pp. 897, 905, 921, 1049; Entry of January 17, 1862, Bragg diary, p. 116.

65 Judah P. Benjamin to Joseph E. Johnston, January 24 , 1862, Joseph E. Johnston to Samuel Cooper, January 28, 1862, Joseph E. Johnston to Samuel Cooper, January 29, 1862, Samuel Cooper to Joseph E. Johnston, January 29, 1862, Joseph E. Johnston to Samuel Cooper, February 2, 1862, Joseph E. Johnston to Samuel Cooper, February 3, 1862, in OR, V: pp. 1043, 1049, 1050, 1059 .

66 Joseph E. Johnston to W. H. C. Whiting, February 12, 1862, in OR, V: p. 1069; Thomas J. Jackson to A. R. Boteler, January 24, 1862, in Thomas J. Jackson papers, Virginia Historical Society, Richmond, Virginia. 
of immobile coastal defense artillery.67 Johnston had to dispatch a special representative to Richmond to beg that the policy be changed. Even then, though the casting of field artillery was resumed, seacoast guns remained the government's priority. 68

Both the Quartermaster General and the Secretary of War inhibited Johnston"s initiatives to improve the health of his troops. When Johnston requisitioned additional blankets for his men, Myers peevishly demanded that the General first provide the names of the troops who needed them; he completely ignored the request for anti-scorbutics.69 The war Department failed to require the hospitals in the rear areas to notify commanders when their soldiers died or received discharges, which left Johnston completely ignorant of the fate of soldiers sent to the rear, until they happened to reappear in camp. The few hospital administrators conscientious enough to try on their own to communicate this information to the army, found themselves blocked by the reluctance of the Adjutant and Inspector-General's office to

67 Dew, Ironmaker, p. 114

68 Between Pendleton's July, 1861, mission to Richmond and the end of February, 1862, Tredegar produced 103 pieces of heavy artillery and only forty-nine field guns. See Ibid., p. 111 .

${ }^{69}$ A. P. Mason to R. H. Cole, January 25,1862 , in LSANVA; Abraham C. Myers to William L. Cabell, December $2 \bar{I}$, 1861, in LS-QMG, T-131, Reel 8 . 
provide them with the appropriate forms. 70

Johnston's attempts to improve the efficiency of his supply system were stymied at every turn by Myers and Northrop, and occasionally by Cooper's complicity. By way of answering Johnston's desperate pleas for more forage for his horses, the Quartermaster General observed that "considerable savings would be affected [sic]," if "the animals could be subsisted without hay." He suggested that Johnston substitute a mixture of "corn shucks, wheat straw and wheat chaff, cut into and mixed with corn meal, or corn meal and bran."71 Myers stood on the letter of an obscure technicality to prevent Johnston's subordinates at outlying posts from naming their own chief quartermasters, a response echoed by Northrop with respect to commissaries.72 When William L. Cabell, Johnston's Chief Quartermaster, was transferred, Myers opposed Johnston's choice for a successor, and allowed the eventual nominee to become embroiled in

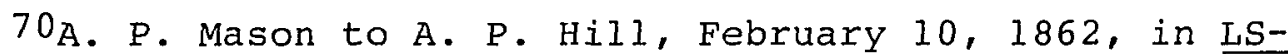
ANVA; Judah P. Benjamin to P. G. T. Beauregard, January 12 , 1862, in LS-SW; Samuel Cooper to P. G. T. Beauregard, January --, 1862, Braxton Bragg to Samuel Cooper, January 8, 1862, in LR-AIGO, M-474, Reel 5; John B. Magruder to Samuel Cooper, January 10,1862 , John B. Magruder to Samuel Cooper, January 16, 1862, in LR-AIGO, M-474, Reel 32; Phillips, Correspondence, p. 586 .

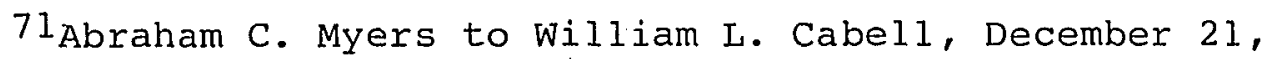
1861 , in LS-QMG.

72 D. H. Hill to Judah P. Benjamin, February 12, 1862, in LR-AIGO, M-474, Reel 23; Nathan Evens to R. H. Chilton, January 3, 1862, A. W. Barbour to A. C. Myers, February 8, 1862 , in LR-AIGO. 
a distracting fight over relative seniority. 73 Northrop contested Johnston's plan to supplement his troops' diet by local purchase, sticking to a centralized system of acquisition that sometimes required food bought in northern Virginia to travel to Richmond on the overtaxed railroad before turning around to return to Johnston's department. 74 When he finally did locate a meat-packing plant in Johnston's area, it was over Johnston's vociferous protests; Thoroughfare Gap, the site of the plant, was a tactically vulnerable location. 75 Cooper refused to sanction Johnston's appointment of an Inspector of Transportation, and delayed action on many other requests by Johnston and his subordinates to increase their logistical staffs. As Longstreet acidly observed in early 1862, it represented a sorry state of affairs when the government reduced a division commander to personally inspecting wagon axles for grease by its reluctance to appoint a captain to do the

73 A. C. Myers to Joseph E. Johnston, December 11, 1862, A. C. Myers to Joseph E. Johnston, January 2, 1862, in LSQMG, T-131, Reel 8: Thomas T. Fisher to Samuel Cooper, January 27, 1862, in LR-AIGO, M-474, Reel 17; Joseph E. Johnston to P. G. T. Beauregard, December 9, 1861, in E. Murray Smith Collection, U. S. Military History Institute.

74 Goff, Confederate Supply, pp. 18-19, Leroy Pope Walker to Lucius B. Northrop, September 7, 1861, Lucius B. Northrop to Leroy Pope Walker, September 9, 1861, in OR, V: pp. $883,835-836$.

75 Johnston, Narrative, p. 104. 
job. 76

But possibly the most egregious outrage with which Johnston had to contend was the unceasing campaign by Benjamin to undermine his command authority. The Louisianian ruled the War Department as if it were a personal fiefdom. He sent orders directly to Johnston's subordinates without consulting or even informing the General.77 He first acknowledged, then arbitrarily repudiated Johnston's organization of the army into two corps. 78 Benjamin fostered a climate in the war office which made it acceptable for everyone, from the lowest private to a general officer, to send him requests without channeling them

76 Joseph E. Johnston to Samuel Cooper, January 14 , 1862, in LR-AIGO, M-474, Reel 10; Joseph E. Johnston to Abraham C. Myers, January 14, 1862, in LR-AIGO, M-474, Reel 27; James Longstreet to Samuel Cooper, April 9, 1862, in LRAIGO, M-474, Reel 30 ; General Orders No. 24, Department of Northern Virginia, February 13, 1862, in OR, LI (part 2): p. 468 .

77 Judah P. Benjamin to Earl Van Dorn, October 31, 1861, Judah P. Benjamin to D. H. Hill, January 18, 1862, Judah P. Benjamin to Thomas J. Jackson, January 30 , 1862, in $\underline{O R}, V$ : pp. $930,1036,1053$.

$78 \mathrm{~V}$. D. Groner to Samuel Cooper, September 30,1861 (with enclosure "List of generals having independent commands; also general officers subordinate to them"), in OR, Series 4, I : pp. 626-633; Judah P. Benjamin to Robert Toombs, September 24, 1861, Jefferson Davis to Gustavus W. Smith, October 10, 1861, Jefferson Davis to P. G. T. Beauregard, October 17, 1861, Judah P. Benjamin to P. G. T. Beauregard, October 17, 1861, Circular Letter, Judah P. Benjamin to P. G. T. Beauregard, Joseph E. Johnston and others, October 19, 1861, Jefferson Davis to P. G. T. Beauregard, October 20, 1861, in OR, V: pp. 877, 894, 904906. 
through the department commander. 79 More often than not, even when official papers passed through Johnston's hands, Benjamin would overrule his decision in what seemed to be a matter of course. Much of Johnston's trouble eradicating alcoholism among his brigades could be traced to Benjamin's refusal to implement the recommendations of Johnston"s courts martial.80 Unsuccessfully, the General remonstrated with the secretary, complaining that "the rules of military correspondence require that letters addressed to you by members of this army should pass through my office." As he wrote, Johnston grew both angrier and more acerbic: "Let me ask, for the sake of discipline, that you have this rule enforced. It will save much time and trouble, and create the belief in the army that I am its commander. . . .81

At the same time, Benjamin undercut Johnston's furlough and reenlistment program by granting authorization to dozens of recruiters to move among Johnston's camps to try to

${ }^{79}$ For typical examples, see Wade Hampton to Judah P. Benjamin, February 1, 1862, George H. Steyart to Judah P. Benjamin, February 22, 1862, in OR, Series 4, I: pp. 902, 946-947; A. T. Rainey to Judah P. Benjamin, February 8, 1862, in LR-SW, M-618, Reel 8 ; D. H. Hill to Judah P. Benjamin, January 22,1862 , D. H. Hill, to Judah P. Benjamin, in LR-AIGO, M-474, Reel 23; Judah P. Benjamin to Joseph E. Johnston, February 12, 1862, in LS-SW, M-522, Reel 3 .

80 Joseph E. Johnston to Samuel Cooper, January 10 , 1862, in LR-AIGO, M-474, Reel 27; "Copy of endorsement on letter of Col. Radford of Feb. 5, 1862, to the Adjt. \& Inptr. Genl.," in J JWM.

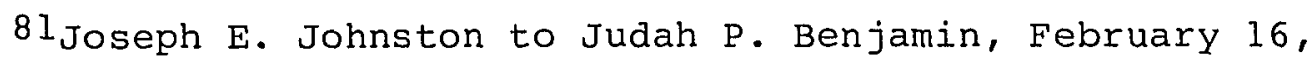
1862 , in OR, $V:$ p. 1075 . 
entice unhappy infantrymen into signing up for new companies of artillery and cavalry. These recruiters arrived armed with furloughs approved by the Secretary of War which Johnston possessed no power to contravene. Johnston also confronted Benjamin on this issue, pointing out: "you will readily perceive that while you are granting furloughs on such a scale at Richmond I cannot safely grant them at all." There should be a system, Johnston insisted. "If the War. Department continues to grant these furloughs without reference to the plans determined on here, confusion and disorganizing collisions must be the result." 82

The secretary denied that he had ever acted so improperly, even though the most superficial glance at the letter books of the War Department would have proven him to be a liar.83 Following this exchange, D. H. Hill forwarded a sheaf of authorizations signed by Benjamin to General Cooper, with the sarcastic request: "will you be kind enough, General[,] to forward this note to the Hon. J. P. Benjamin that he may be advised that there is a forger in his office." 84 In order to keep his army from evaporating, Johnston directed his commanders to stop granting any other

82Joseph E. Johnston to Judah P. Benjamin, February 1, 1862 , in OR, V: p. 1057.

83 Jefferson Davis to Joseph E. Johnston, March 4, 1862, in OR, $V:$ p. 1089. But see literally dozens of Benjaminapproved furloughs in LS-SW, M-522, Reel 3 .

${ }^{84}$ D. H. Hill to Samuel Cooper, March 5, 1862, in LRAIGO, M-474, Reel 23 . 
furloughs, and again looked the other way when some of his subordinates began to toss the ubiquitous recruiters into the guard house.85 As Major-General Richard S. Ewell fumed in a letter to his fiancee, "Had the secretary of War's orders and permits been carried out by General Johnston as regards Artillery and Cavalry, the whole army would have been broken up except those two branches." 86

Eventually, Johnston would bring his complaints about the Secretary's interference in internal army affairs to the attention of Jefferson Davis. Instead of inspecting the evidence, Davis simply asked Benjamin for an explanation. The Secretary's response was a collection of misleading--if technically correct--statements, facile half-truths, and outright falsehoods, all tied together by his lawyer's charisma into a rationalization that a close friend could find perfectly acceptable.87 Johnston, in fact, came out

85 Jubal Early to Jefferson Davis, March 28, 1878, in Rowland, Jefferson Davis, VIII: pp. 139-140; James Longstreet to Samuel Cooper, February --, 1862, in LR-AIGO, M474 , Reel 30 .

${ }^{86}$ Quoted in Percy G. Hamlin, "Old Bald Head" (General R. S. Ewell), The Portrait of a Soldier (Strasburg, VA: Shenandoah Publishing House, 1940), p. 78 .

87 Benjamin told Davis in early March that "he has not granted leaves of absence or furloughs to soldiers for a month past. . . ." This was technically true; the secretary of War himself had stopped granting furloughs, but he had continued to allow recruiters to enter the Department of Northern Virginia armed with documents that empowered them to grant furloughs and leaves of absence in his name. "The authority to re-enlist and change from infantry to artillery," Davis told Johnston, "the Secretary informs me, has been given but in four cases. . . ." This was simply not 
of the exchange with a mild rebuke, Davis observing that

Benjamin "has complained that his orders are not executea,

and I regret that he was able to present to me. . . many

true. Not only had Benjamin permitted twelve rather than four infantry companies to convert into artillery, he continued well into February to authorize ambitious officers to recruit throughout Johnston's command for new companies of heavy artillery and cavalry--at least ten in the six weeks prior to Johnston's protest to Davis. See Judah P. Benjamin to M. P. Dyerle, December 17, 1861, Judah P. Benjamin to J.W. Anderson, December 18, 1861, Judah P. Benjamin to N. Caliborne Wilson, December 19, 1861, Judah P. Benjamin to J. F. Waddell, December 19, 1861, Judah P. Benjamin to T. D. Caliborne, January 4, 1862, Juaah P. Benjamin to J. P. Boyd, January 4, 1862, Judah P. Benjamin to R. Otey, January 6, 1862, Judah P. Benjamin to Joseph E. Johnston, January 4, 1862, Judah P. Benjamin to J. B. McMullen, January 15, 1862, Judah P. Benjamin to H. G. Bowie, January 15, 1862, Judah P. Benjamin to St. George Junkin, January 16, 1862, Judah P. Benjamin to A. B. Rhett, January 28, 1862, Judah P. Benjamin to A. B. Rhett, February 9, 1862, Judah P. Benjamin to Joseph E. Johnston, February 11. 1862, Judah P. Benjamin to Mat. C. Moore, February 12, 1862, Judah P. Benjamin to W. Saunders, February 14, 1862, Judah P. Benjamin to C. S. Peyton, February 14, 1862, Judah P. Benjamin to C. Harwood, February 14, 1862, Judah P. Benjamin to F. J. Reiley, February 14, 1862, Judah P. Benjamin to George W. Clement, February 14, 1862, Judah P. Benjamin to J. L. Wilson, February 14, 1862, Judah P. Benjamin to M. Hewitt, February 17, 1862, in LS-SW, M-522, Reel 3. This list is, if anything, an underestimation of the number of permits that Benjamin issued during the period. Only those permits which give some indication, either by the unit involved, or the address of the recruiter, that they are to be recruited within the limits of Johnston's department have been included. This, for instance, eliminated most of the cavalry transfer and reorganization requests, which are much more ambiguous, and seem to have been sent out either through the War Department or through General Cooper. For an example, see John R. Hart to George W. Randolph, April 26, 1862, in LR-AIGO, which recounts the issue of a permit to a company of Georgians to whom Benjamin issued a permit to go home to acquire horses for a transfer to the cavalry. Benjamin's self-justification is found in Jefferson Davis to Joseph E. Johnston, March 4, 1862 , in $\underline{O R}, \mathrm{~V}:$ p. 1089 . 
instances to justify that complaint. . . " 88

In response to the official roadblocks and Davis's refusal to consider his case, Johnston felt an increasing sense of bitter alienation from his own superiors, a sentiment which had already been growing for months. His letters to Whiting, a close friend as well as a trusted subordinate, began to reveal this mood as early as November, 1861. On November 9, he predicted blackly that "the Secretary of War will probably establish his headquarters within this department soon."89 And three days later, Johnston advised Whiting that "General Cooper replied today that the guns you asked for should be sent without delay. This does not encourage me much as to time. In Richmond their ideas of promptitude are very different from ours."90 Concerned in January that the government was seeking a pretext on which to replace him, Johnston joined Beauregard and G. W. Smith in an effort to begin saving papers and drafting memoranda to prove that they had been doing all they could, despite Richmond's interference, to strengthen

88Jefferson Davis to Joseph E. Johnston, March 4, 1862, in $\underline{O R}, \mathrm{~V}: \mathrm{p} .1089$.

89 Joseph E. Johnston to W. H. C. Whiting, November 9, 1861, in $\underline{O R}, V:$ p. 944 .

90 Joseph E. Johnston to W. H. C. Whiting, November 12 , 1861, in $\mathrm{OR}, \mathrm{V}:$ pp. 949-950. 
the army. 91

By the time he started to the capital in answer to the President's summons, the gulf between Joseph Johnston and Jefferson Davis was, like the distance between Centreville and Richmond, much greater than it first appeared.

91 "Council of War at Centreville," Gustavus W. Smith, October 1, 1861 (countersigned by Joseph E. Johnston and P. G. T. Beauregard on January 31 , 1862); P. G. T. Beauregard to Joseph E. Johnston, December, 1861, in OR, V: pp. 884887,990 . 
Chapter Three

Decision in Richmond

Lead-grey clouds invaded the sky over Richmond on February 19, 1862. Steady rain suited the mood of the city. Despite Davis's pending inauguration as the Confederacy's permanent president, few Richmonders felt either festive or optimistic. In little more than a month, an unbroken string of defeats had destroyed the confidence of the city on the James River. The gloomy atmosphere deepened as the list of catastrophes lengthened: a rout at Fishing Creek; the fall of Fort Henry and Roanoke Island; and now some dire, although still unspecified, disaster at Fort Donelson. An aide to the Governor observed that depression paralyzed the city. Businesses closed, and in the streets, hotels, and bars "people did nothing but collect together in groups and discuss our disasters."l

The uneasy crowds wandering the city grew larger every day. The influx of people associated with the Confederate administration, expanding industries, and the armies defending Virginia had swollen the population of Richmond to more than twice the prewar total of 38,000 . Camps of

1Charles W. Turner, ed., Captain Greenlee Davidson, CSA, Diary and Letters, 1851-1863 (Verona, VA: MCClure, 1975), pp. 34-35; the weather was reported in the entry of February 20, 1862, Bragg Diary, p. 156 . 
instruction and military hospitals had been established throughout the city. Hundreds (possibly thousands, no one kept an accurate tally) of soldiers on furlough loitered in the streets, searching for a place to spend the night. Makeshift prisons housed several thousand Federal prisoners, and Yankee officers who had filed paroles with the Provost Marshal were allowed to walk around freely. Refugees from occupied portions of the state migrated to the capital. Their numbers, too, are impossible to estimate. The inauguration, scheduled to occur in three days, had attracted an additional horde of visitors, making conditions even more overcrowded. 2

These invasions had predictable results. Already inflated prices of food and lodging kept climbing. "Groceries are very high without any fixed price," complained one Richmond newspaper, adding that "it is very difficult to give correct quotations as prices are changing every day."3 Renters bitterly attacked landlords who "run up miserable wooden shells, or . . lease crazy brick tenements, in convenient locations, and ask the most enormous rents for

2 Emory M. Thomas, The Confederate state of Richmond (Austin: University of Texas Press, 1971), pp. 24, 59-62, 78; Virginius Dabney, Richmond, The Story of a City (Garden City, NY: Doubleday, 1976), pp. 166-168; Rudolph Von Abele, Alexander $\mathrm{H}$. Stephens, A Biography (New York: Alfred $\mathrm{K}$. Knopf, 1946), p. 206; Richmond Examiner, February 21, 1862, p. 3 .

3 Richmond Religious Herald, February 20,1862, p. 2 . 
uncomfortable rooms." 4 Visitors who could afford it paid to stay in private homes. Hotels sold space on cots spread around their lobbies at exorbitant prices, but even this expedient could not meet the demand for temporary housing. Those who found no other place to stay frequented the bars and gambling "hells" as late in the evening as possible, and then slept wherever they could.5 The crime rate soared: murder--especially strangling--and highway robbery became particularly prominent, and "disorderly houses" proliferated. The Richmond Examiner observed that "a glance at the police report . . must convince everyone that this city is not a safe place to 'thrash' about in at night." 6 The Dispatch pointedly recalled that the English had only solved their crime problem by resorting to liberal use of the death penalty.7

The gross overcrowding of the city created an atmosphere in which rumors multiplied like mosquitoes on a stagnant pond. Real intelligence about the war was conspicuous by its absence, and the most improbable tales circulated with full credence. Richmond newspapers printed every

${ }^{4}$ Richmond Whig, January 1,1862, p. 1 .

${ }^{5}$ Wilfred Buck Yearns, The Confederate Congress (Athens: University of Georgia Press, 1960), p. 14; Thomas, Richmond, pp. 73-74.

6Richmond Examiner, February 21,1862, p. 3; February $22,1862, \mathrm{p} .3$.

7 Richmond Dispatch, February 21,1862, p. 2 . 
report and hoped for the best. On February 19, the fate of Fort Donelson was still the subject of wild speculation. Neither the President nor the War Department had released any firm news. 8

At 8:00 A. M., Davis and his cabinet secretaries had sequestered themselves on the second floor of the customs House, which had been donated by Virginia to the national government. The meeting continued for hours, the participants apparently oblivious to the curious bystanders in the street below, while clerks and assistants transacted the routine business of government. Questions of grand strategy, it was assumed, were under consideration, and specuiations about potential decisions started circulating. 9

Into this climate of depression, uncertainty, and misinformation, the morning train from Centreville, late as usual, wheezed slowly along the shockoe bottom into Richmond, bearing new grist for the rumor mills. At the Virginia Central Railroad Depot on Broad street, passengers began the normal struggle to exit the ramshackle cars. Couriers carrying official dispatches, soldiers on furlough, commissary officers, recruiting agents, newspaper reporters, and the few private citizens who still held passes to ride

${ }^{8}$ Newspapers published the following day still printed conflicting stories about whether or not a large garrison had surrendered at Donelson. See Richmond Dispatch, February 20, 1862, p. 3; Richmond Whig, February 20, 1862, p. 2; Richmond Examiner, February $\overline{20,} 1862$, pp. 2-3.

9ohnston, Narrative, p. 96; Thomas, Richmond, p. 44 . 
the densely packed train bumped up against each other as they pressed toward the street. The one exception, the man who would have waited until the crowd passed, or for whom it would have instinctively parted, was Joseph Johnston. 10

Johnston had not visited the capital since June, 1861, and his arrival now raised new and much more direct fears for the safety of the city.11 why had Johnston come to Richmond? As he walked up Broad street and turned past Capitol square, the question would have followed him. Had he come in response to a presidential summons, or travelled on his own initiative? Revealing nothing of his purpose, the General strode straight into the Customs House; Jefferson Davis's secretary immediately interrupted the meeting to inform the president of his caller.12 could disaster be imminent in northern Virginia, or were the recent Union advances about to be answered by a counter-invasion across

10 In his memoirs, Johnston made two errors relating to his visit to Richmond. The first was that he stated that it began on February 20, and the second was that he only recounted a single day's meeting with Davis and the cabinet. Bragg's diary, however, makes it clear that the General arrived on February 19, and was present at cabinet sessions on both February 19 and 20. Johnston, Narrative, p. 96; entries of February 19 and February 20, 1862, Bragg diary, pp. 154-157; see also Turner, "Virginia Central," pp. 510-533.

$1 l_{\text {Bradley }} \mathrm{T}$. Johnston does not document his assertion that Johnston had not visited Richmond since the previous year, but a careful study of Johnston's correspondence indicates that he is correct; see Johnson, Johnston, p. 78.

12 Ibid.; Johnston, Narrative, p. 96; Govan and Livingood, Different Valor, p. 93; entry of February 19, 1862, Bragg diary, p. 154 . 
the Potomac? In the hotels and bars the questions flowed along with the drinks. Why had Johnston come to Richmond?

The majority of the cabinet was just as mystified by the General's sudden appearance as the uncertain citizens of Richmond. The expressed purpose of the meeting had been to edit a draft of Davis's inaugural address. 13 Though he certainly did not consider his advisors to be "a cabinet of dummies," as did the Richmond Whig, Davis had limited his confidence in dealing with the military crisis to secretary of War, Judah P. Benjamin. 14 The remaining Eive officers-Secretary of the Treasury Christopher Memminger, Secretary of the Navy Stephen Mallory, Attorney-General Thomas Bragg, Postmaster-General John Reagan, and acting Secretary of State William Browne--though they had access to better military intelligence than the public, had no inkling that the president had chosen this particular day to announce a major shift in Confederate strategy.

To appreciate the significance of Davis's pronouncement, it is necessary to understand his grand strategy for the first year of the war. In the fall of 1861, the President had coolly accepted a desperate but calculated gamble on behalf of his new nation. Without sufficient rifles, cannon, powder, or shot to conduct decisive military operations, he boldly authorized his generals to push their

\footnotetext{
13Entry of February 19, 1862, Bragg diary, p. 154 . 14 Richmond whig, February 22,1862, p. 2.
} 
poorly equipped, severely outnumbered armies as far forward as possible.15 If audacity could disguise abject weakness long enough, he believed that a combination of home production and imports through the blockade would provide them with the weapons to launch real offensives.16

15 The policy initiated by Davis in the fall of 1861 has often been discounted derisively as a cordon defense, adopted as a result of the combination of the president's mediocre strategic insight, demands for local defense on the part of Confederate governors, and an unwillingness on the part of the administration to recognize that there was a substantial Federal threat in the west. This is the argument presented by Thomas Connelly and Archer Jones. They do not see the creation of the Western Department as part of a comprehensive strategic plan, asserting that Davis "merely desired to provide some semblance of command on the western front while it was preoccupied with affairs in Virginia." In making their case for Davis's inability to see beyond departmental administration, Connelly and Jones rely on trying to prove by induction rather than hard evidence (with an assist from some hazy cause-and-effect chronology on the organizational dates of the major departments) that Davis had no grand strategic plan for the conduct of the entire war. They also ignore a considerable amount of material written by the President, either during or after the war, in which he explained his concept. Jefferson Davis to W. M. Brooks, March 15, 1862, in OR, Series 4, I: pp. 998-999; Jefferson Davis to Joseph E. Johnston, November 10, 1861; "Council of War at Centreville," Gustavus W. Smith, October 1, 1862; both in OR, V: pp. 884-887; Davis Rise and Fall, I: pp. 406, 449-452; II: p. 43; Thomas Lawrence Connelly and Archer Jones, The Politics of Command, Factions and Ideas in Confederate Strategy (Baton Rouge, LA: Louisiana State University Press, 1964), pp. 92-101.

16 Even the most hostile recollection of Davis's policy acknowledged that he advocated constant harrying of the enemy across the potomac. At his conference with Generals Johnston, Beauregard, and Smith on september 26, 1861, "the President proposed that, instead of an active offensive campaign, we would attempt certain partial operations--a sudden blow against Sickles or Banks or to break the bridge over the Monocacy." See "Council of War at Centreville," Gustavus W. Smith, October 1, 1861, in OR, V: p. 887; Johnston, Narrative, p. 78. 
It was an outrageous bluff, extending far beyond Johnston's Department of Northern Virginia.17 While part of General Albert Sidney Johnston's army attempted to blockade the Mississippi River from Columbus, Kentucky, the remainder had invaded the central portion of the state, and rattled sabers loudly at Bowling Green. "Create the impression that this force is only an advance guard," he instructed MajorGeneral William J. Hardee. Making noise was the best they could do: most of the troops in the department were either sick or unarmed.18 From southern Missouri, Major-General Sterling Price and his ragtag regiments, many of which had not even been formally sworn into Confederate service, tried their best to maintain a threatening posture, while in west Texas Brigadier-General Henry Hopkins sibley marched his motley 3,700-man "Army of New Mexico" toward Arizona. The rest of the Confederate Army guarded the Atlantic or Gulf

17 MCClellan's "Aggregate present" on October 15 was 143,647; Johnston's, for the month of October, was 52,435. See "MCClellan's Report (I)" and "Abstract from return of the Army of the Potomac, General Joseph E. Johnston, C. S. Army, commanding, for the month of October, 1861," both in OR, V: pp. 12,932 .

18 Albert Sidney Johnston to William J. Hardee, November 9, 1861, in OR, IV: p. 531; Charles Roland, Albert Sidney Johnston: Soldier of Three Republics, Austin, TX: University of Texas, 1964, pp. 261-277; Thomas Lawrence Connelly, Army of the Heartland, The Army of Tennessee, 1861-1862

(Baton Rouge, LA: Louisiana state University Press, 1967), p. 63 . 
coasts against amphibious descent by the united states Navy. 19

For months, following the Confederate victory at Manassas, the strategy worked. Mcclellan believed the intelligence estimates that attributed to Johnston's army more than twice its actual strength. 20 In Kentucky, MajorGeneral William T. Sherman insisted in November, 1861 that Confederate troops at Bowling Green "far outnumber us."2l His successor, Major-General Don Carlos Buell, was more skeptical about Rebel numbers, but still counted almost

19 War Department returns for December 31,1861 indicated that 59.3응 of the Confederate troops "Present for duty" were under the command of either Joseph or Albert Sidney Johnston. Roughly $36.2 \%$ defended the coasts, and 4.5\% were deployed in western Virginia. These percentages were only approximate, as the returns upon which they were based were somewhat fragmentary, omitting, for instance, both Sibley"s brigade in New Mexico and Price"s division in Missouri. Yet adding those forces to the rest would only emphasize more clearly that President Davis had pushed the bulk of his meager armies to the periphery of the Confederacy. "Consolidated abstract from returns of the Confederate forces on or about December 31, 1861," in OR, Series 4, I; p. 822 .

20 As an example of his habitual inflation of Confederate numbers, McClelian thought Johnston's army numbered 115,500 in early March, while the departmental return for the end of February showed him with only 47,306 "Aggregate present for duty." See "McClellan's Report (I)" and "Abstract from return of the Department of Northern Virginia, General Joseph E. Johnston, C. S. Army, commanding, for the month of February, 1862," both in OR, V: pp. 53, 1086.

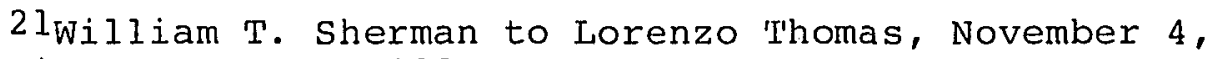
1861, in OR, IV: p. 332 . 
every Confederate soldier twice. 22 Partly as a result of an aggressive southern military policy, the major Union armies remained inactive through the fall and into the winter. When 1861 ended, Jefferson Davis could look out over a national defensive perimeter that was essentially intact.

The necessary weakness of the President's strategy was that by committing his available effective troops to the frontiers of the confederacy he could not maintain a substantial reserve. His expectation that sufficient arms could be obtained to create such a reserve was not realized. Since september, 1861, only 15,000 rifles had slipped through the blockade, nearly half of which arrived on a single vessel. These arms had to be rushed to the front as soon as they were unloaded at the docks.23 Internal production was gearing up, but, when the crisis struck,

22 On January 3, 1862, Buell estimated Albert Sidney Johnston's force between Columbus and Bowling Green at 80,000 men. Johnston's December 31 , 1861 return placed his "Present for duty" strength at those points at 43,661. While that return failed to count two brigades newly arrived at Bowling Green, the omission was roughly offset by counting some of the troops in Polk's district which were west of the line that Buell was considering. See Don Carlos Buell to George B. McClellan, November 27, 1861; Don Carlos Buell to George B. McClellan, December 23, 1861; Don Carlos Buell to George B. McClellan, December 29, 1861; Don Carlos Buell to Henry Halleck, January 3, 1862; "Abstract from return of Western Department, General A. S. Johnston, commanding [Date about December 31, 1861]"; all in OR, VII: pp. $450-452,511,520-521,528-529,813$.

23 The ship was the Fingal, the first ship to brave the blockade solely on the government's account, which landed in Savannah, Georgia in November carrying 7,520 Enfield rifles. Vandiver, Confederate Blockade Running Through Bermuda, pp. xiv, xxxix; Wise, Lifeline, pp. 52-55. 
Colonel Josiah Gorgas's Ordnance Department required an entire month's production of rifles to outfit a single regiment. 24 The situation with regard to powder was equally dismal. Of the 400,000 pounds that Gorgas projected that the Confederacy must import, so little powder had arrived in Southern ports that Davis admitted to the cabinet in late January that there were fewer than twenty-five charges per gun available to the batteries defending the coasts. 25

Thus, when Federal offensives cracked open the eggshell in Kentucky, Tennessee, and North Carolina, almost nothing stood between the Northern armies and the heartland of the Confederacy.

Like many gamblers, Davis had refused to fold his hand and start a new game until his losses were enormous. 26 By

24 Only the Richmond arsenal was dependably turning out weapons on schedule in February, 1862, at the rate of 1,000 rifles a month. See Richard D. Goff, Confederate Supply (Durham, NC: Duke University Press, 1969), p. 31.

25 Entries of January 6,1862 , January 14, 1862, January 16,1862 , in Bragg diary, pp. 99. 110, 112 .

26 In Davis's defense, however, it should be said that while Fishing Creek, Fort Henry, and Roanoke Island were all significant reverses, it was the capitulation of Fort Donelson and the loss of 11,000 soldiers that represented the major disaster, and that defeat was due far more to the incompetence of the political generals in conmand there than to the deficiencies of Davis's strategy. The troops committed there did not face overwhelming odds, were as well armed as any in the confederacy, and acquitted themselves honorably on the field. As William preston Johnston, the son of Albert sidney and later a presidential aide, remarkeä bitterly in his defense of his father's record: "The answer to any criticism as to the loss of the army at Donelson is that it ought not to have been lost. That is all there is of it [italics in original]." William Preston Johnston, "Albert 
February 17, when he learned that Fort Donelson had surrendered, the overall military situation was grave. BrigadierGeneral Ulysses Grant's army, supported by gunboats, stood between the two wings of Albert Sidney Johnston's department, in perfect position to strike the communications of either. Meanwhile, Buell advanced slowly but inexorably through central Kentucky toward Nashville. The success of Major-General Ambrose Burnside's amphibious expedition into Albemarle Sound not only proved the ability of the Federal Navy to land Union troops along almost any stretch of coastIine, but also directly menaced Norfolk and the crucial railroad line between Richmond and wilmington. 27

Only the front in northern and eastern Virginia remained quiet, and it was apparent that this represented the calm before the hurricane. Johnston had pointed out to Davis in his February 16 letter that McClellan "controls the water, however, and can move on the Potomac as easily now as in midsummer. . . " Furthermore, the General cautioned, "We cannot retreat from this point without heavy loss. If we are beaten, this army will be broken up, and Virginia, at

Sidney Johnston at Shiloh," B\&L, I: p. 548 .

27 McClellan's "aggregate present" on February 1, 1862 (which did not include some of the forces in western Virginia opposite Johnston's Valley District) was 208,086, compared to 56,392 in the Department of Northern Virginia. See "McClellan's Report (I)" and "Abstract from return of the Department of Northern Virginia, General Joseph E. Johnston, C. S. Army, commanding, for the month of February, $1862, "$ both in OR, V: pp. 12, 1086. 
least, lost." 28

The President later admitted his miscalculation, though even in his eulogy for the failed strategy, Davis did not repent having accepted the risks. "I acknowledge the error," he wrote on March 15, 1862,

of my attempt to defend all of the frontier, seaboara, and inland; but will say in justification that if we had received the arms and munitions which we had good reason to expect, the attempt would have been successful and the battle-fields would have been on the enemy's soil.29

But belying his reputation for inflexibility, as soon as the surrender of Donelson was confirmed, Davis totally reoriented Confederate grand strategy in less than forty-eight hours.

His deliberations were certainly influenced by the opinions of senior generals throughout the Confederacy, many of whom had recently written concerning ominous increases in Federal strength, often including specific strategic suggestions. General Robert E. Lee, in whose judgment Davis had implicit trust, had advised from South Carolina on January 8 that

The forces of the enemy are accumulating, and apparently increase faster than ours. I have feared, if handled with proportionate ability with his means of speedy transportation and concentration, it would be impossible to gather troops necessarily posted over a long line in sufficient

28 Joseph E. Johnston to Jefferson Davis, February 16 , 1862 , in OR, V: p. 1074 .

29 Jefferson Davis to W. M. Brooks, March 15, 1.862, in OR, Series 4, I: Pp. 998-999. 
strength to oppose sudden movements.

Wherever his fleet can be brought no opposition to his landing can be made except within

range of our fixed batteries. We have nothing to oppose to its heavy guns. . . The farther he can be withdrawn from his floating batteries the weaker he will become. . . 30

Lee reiterated his warning on February 10, admitting that while "I exceedingly dislike to yield an inch of territory to our enemies they are, however, able to bring such large and powerful batteries to whatever point they please, that it becomes necessary for us to concentrate our strength." 31

On February 15, Major-General Braxton Bragg, another officer whose views the President valued, had addressed Secretary of War Judah P. Benjamin with his own suggestions: "Our means and resources are too much scattered. The protection of persons and property, as such, should be abandoned, and all our means applied to the Government and the cause. Important strategic points only should be hela." Bragg advised the removal of Confederate troops from all but the largest ports on the Atlantic and Gulf Coasts, as well as the complete military evacuation of 'Texas, Floriả, and Kentucky. "A small loss of property would result from their occupation by the enemy; but our military strength would not be lessened thereby, whilst the enemy would be weakened by

\footnotetext{
$30_{\text {Robert }} \mathrm{E}$. Lee to Samuel Cooper, January 8,1862 , in OR, VI: p. 367 .

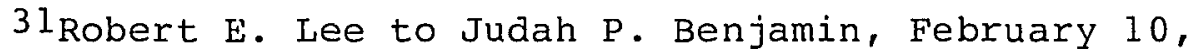
1862 , in OR, VI: p. 380 .
} 
the dispersion." 32

Nor did the President lack the opinions of the two Generals Johnston. Joseph Johnston had, as previously noted, warned on February 16 of the vulnerability of his own extended line. Though Albert Sidney Johnston remained out of contact on February 16 and 17 , almost a month earlier he had posted to Richmond a similar warning of imminent calamity, ending it with a simple, though extreme, suggestion to prevent disaster:

The enemy will probably undertake no active operations in Missouri and may be content to hold our forces fast in their position of the Potomac for the remainder of the winter, but to suppose with the facilities of movement by water which the well filled rivers of the Ohio, Cumberland, and Tennessee give for active operations, that they will suspend them in Tennessee and Kentucky during the winter months is a delusion. All the resources of the confederacy are now needed for the defense of Tennessee. 33

Thus, the consensus among those generals in whom Davis placed the greatest trust--and their opinion was shared by other key figures--was that the survival of the Confederacy depended upon a concentration of its limited resources in defense of a few critical points, even at the risk of losing

32Braxton Bragg to Judah P. Benjamin, February 15 , 1862 , in $\mathrm{OR}, \mathrm{VI}:$ p. 826.

33Albert sidney Johnston to Samuel Cooper, January 22, 1862, quoted in Roland, Albert Sidney Johnston, p. 227; for the inability of Davis and Benjamin to contact Johnston during the two days in question, see Judah $P$. Benjamin to Albert Sidney Johnston, February 18, 1862, and William J. Hardee to Jefferson Davis, February 18, 1862; both in OR, VII: p. 890 . 
large sections of territory with less military value.34 Yet

\begin{abstract}
34 It should be emphasized, however, that the opinions of Lee, Bragg, and the Johnstons carried the bulk of the weight with Jefferson Davis. Others of prominence who counseled a concentration of resources included General P. G. T. Beauregard; Secretary of War Benjamin; and former Secretary of War, and currently Brigadier-General, Leroy Pope Walker. Beauregard had written to Congressman Roger Pryor, his indirect contact with the administration, on February 14 that "we must give up some minor points and concentrate our forces to save the most important lines, or we will lose them all in succession." Connelly and Jones use this quotation--curiously citing the manuscript source rather than the identical printea letter in OR--to buttress their case for Beauregard as the chief architect of the concentration of troops that created Johnston's army at Shiloh. But there is no direct evidence that pryor communicated the essence of Beauregard's letter to Davis, and his February 18 letter to Samuel Cooper dealt only with the specific question of a withdrawal from Columbus, not grand strategy. Even if it could be proven that Davis read Beauregard's earlier letter, his influence on the President at the time would seem to have been minimal. Twice in January, Davis had spoken less than favorably about the Louisiana general in cabinet sessions. Thomas Bragg recorded, on January 8 , that when discussing the merits of the Confederate generals, Davis "never mentions Beauregard. I think, after all, he does not like him or think much of him." And on January 31, when discussing Beauregard's pending assignment to command at Columbus, "the President spoke of his engineering talent as good, but did not seem to entertain a high opinion of his talents as a General." Secretary Benjamin indicated in a February 23 letter to Major-General Mansfield Lovell that he had thought for some time that Davis's commitment to dispersed garrisons along the coasts was a mistake. Referring specifically to Mississippi, he told Lovell that the orders to do so "were issued against my judgment, but the urgency of the members of that state on the president was so great that it was not politic to refuse at the time to gratify their wish." But while Benjamin had the respect and the constant ear of Davis, his biographers agree that he dia not, as secretary of War, push hard to bring the President around to his views on strategic policy. As Robert Douthat Meade put it, Benjamin would "offer suggestions to Davis when he felt he coula do so without causing undue offense, but he would not lay his head on the block." Ex-secretary walker offered unsolicited strategic advice to his successor on February 17, but, given the fact that he had left the war Department partly as the result of a strategic disagreement with Davis,
\end{abstract}


in the end, Davis had to face the situation by himself, directly assisted only by an inewperienced secretary of war. Davis acted both resolutely and quickly in the crisis. By February 18, letters drafted by Benjamin at the President's direction had been dispatched to the department commanders. These instructions represented a dramatic reversal in strategy. Union numerical and naval superiority, combined with the Confederate arms shortage and the arguments of his generals, had convinced Davis that "it may not be possible, with our limited means, to protect every point which the enemy can attack by means of his fleets. - . "35 Benjamin's orders to Bragg stated the case even more frankly: "The heavy blow which has been inflicted on us by the recent operations in Kentucky and Tennessee renders necessary a change in our whole plan of campaign. . . .36

\footnotetext{
any direct effect of his views on the president's eventual decisions is doubtful. Judah $\mathrm{P}$. Benjamin to Mansfield Lovel1, February 23, 1862, in OR, VI: p. 829; P. G. T. Beauregard to Roger A. Pryor, February 14, 1862; Leroy Pope Walker to Judah P. Benjamin, February 17, 1862; P. G. T. Beauregard to Samuel Cooper, February 18, 1862; all in OR, VII: pp. 880, 889, 890; Entries for January 8, 1862, January 31 , 1862, Bragg diary, pp. 104, 130; Connelly and Jones, Politics of Command, pp. 97-100; Patrick, Davis and His Cabinet, p. 176; Robert Douthat Meade, "The Relations Between Judah P. Benjamin and Jefferson Davis: Some New Light on the Working of the Confederate Machine," Journal of

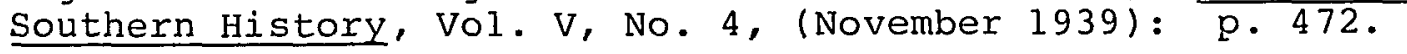
35Jefferson Davis to W. W. Avery, February 18, 1862, in OR, IX: p. 436 .

36 Juãah P. Benjamin to Braxton Bragg, February 18 , 1862 , in $\underline{\text { OR, }}$ VI: p. 828 .
} 
The new strategy subordinated considerations of local defense to a national effort concentrated on preserving the economic vitals of the Confederacy. Garrisons would be ruthlessly stripped away from less important points and transferred to more critical theaters of war. The emphasis of military operations was to be changed from static, linear defense, to the more active "offensive-defensive" with field armies maneuvering and counterpunching the enemy. "We must dismiss all ideas of scattering our forces in defense of unimportant points and concentrate them at vital lines," Benjamin told Major-General Mansfield Lovell.37

Davis contemplated a reduced, but still viable, defensive perimeter. The first priority was to seal off Federal penetrations in Tennessee, safeguarding both the material resources of Mississippi, Alabama, Georgia, and eastern Tennessee, and the Confederacy's only direct rail connection between Virginia and the Mississippi River. "No effort will be spared," Benjamin assured Major-General Leoniajas K. Polk, on February 18, "to save the line of communication between Memphis and Bristol, so vital to our defense." 38

To provide General Albert Sidney Johnston the means to defend his department, troops were withdrawn from almost all

37Judah P. Benjamin to Mansfield Lovell, February 23, 1862 , in OR, VI: p. 829 .

38 Judah P. Benjamin to Leonidas K. Polk, February 18, 1862 , in OR, VII: p. 894 . 
quarters of the country. Along the Atlantic coast, eastern Florida and parts of eastern North Carolina were abandonea outright, as were the small islands off the coast of south Carolina and Georgia. The only ports to be held in strength were Wilmington, Charleston, and Savannah.39 In the Gulf, the Confederates quit Pensacola, removed all but heavy artillerymen from Mobile and the small Texas ports, and severely reduced the forces defending New Orleans. 40 Troops from Missouri were ordered east of the Mississippi, and the garrison at Columbus, Kentucky evacuated its fixed position to join the army in the field. 41

Despite the resistance that Davis knew he would meet both from Congress and the state governments, he saw his decision as a purely military one, and, as such, above the bounds of factional politics. He believed, as he had written to Major-General Leonidas Polk in September, 1861 , that "it is true that the solution of the problem requires the consideration of other than the military elements involved in it; but we cannot permit the indeterminate qualities, the political elements, to control our action in

39 Ibid., Judah P. Benjamin to Robert E. Lee, February

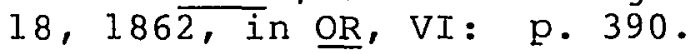

40 Judah P. Benjamin to Leonidas K. Polk, February 18, 1862, in OR, VII: pp. 893-894; Judah P. Benjamin to Braxton Bragg, February 18, 1862 ; Judah $P$. Benjamin to Mansfield Lovel1, February 23, 1862; Judah P. Benjamin to P. O. Hebert, February 23, 1862; al1 in OR, VI: pp. 828-830.

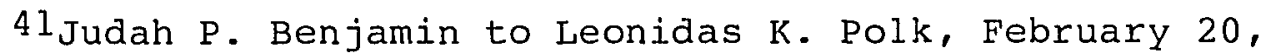
1862 , in OR, VII: p. 893. 
cases of military necessity."42 By January, after months of bickering with governors who seemed to balk at every war measure, no matter how essential, Davis stated himself far more bluntly. General Thomas Bragg recorded, in his diary, that Davis stated in a cabinet meeting, that

if such was to be the course of the states towards the Gov "t the carrying on [of] the war was an impossibility--that we had better make terms as soon as we could, and those of us who had halters around our necks had better get out of the country as speedily as possible. . . 43

Nor was he mistaken in his belief that any strategic decision would provoke a public outcry from his political opponents. As Davis convened his advisors to inform them of his decisions, the House of Representatives was counting the electoral votes to certify his election as President under the permanent Constitution. No sooner had they finished, and the results been confirmed, than Tennessee Congressman Henry S. Foote rose and demanded "that a committee be appointed to enquire into the cause of the recent disasters which have befallen our arms. . ." 44

The cabinet was the first group of civilian politicians, albeit a friendly one, to whom Davis announced the

42 Jefferson Davis to Leonidas K. Polk, September 15, 1861, in OR, IV: p. 188 .

43 Entry of January 17, 1862, Bragg diary, p. 115; see also Boney, Letcher, pp. 132-134; Frank L. Owsley, "Local Defense and the Overthrow of the Confederacy," Mississippi Valley Historical Review, Vol. XI, No. 4 (March 1925): pp. 493-494, 498.

${ }^{44}$ Richmond Examiner, February 20, 1862, p. 2. 
radical shift in policy. Explaining in detail the dismal state of military affairs, "the Pres't said the time had come for diminishing the extent of our lines--that we had not men in the field to hold them and must fall back." 45 The news astounded his audience, and in some way it directly affected each of them. Both Postmaster-General Reagan of Texas and Navy Secretary Mallory of Florida hailed from states Davis had already ordered to be denuded of troops. The weakening of garrisons at key ports was of special concern to Mallory, whose department had ironclads under construction at Norfolk and New Orleans. He was already contemplating dispatching the completed Virginia into the Chesapeake to "make a dashing cruise on the Potomac as far as Washington," and dreamed of using the armored frigate to attack New York. 46 Davis's bombshell meant to him that his bases of construction might no longer be secure. Christopher Memminger, the Treasury Secretary, had to calculate the impact that the withdrawals would have on an already faltering economy and the credibility of $\$ 130,000,000$ worth of Confederate bonds soon to be issued, while acting state Secretary Browne would have to find ways to minimize the

45 Entry of February 19, 1862, Bragg diary, p. 153. $46_{\mathrm{Mall}}$ lory's rather fantastic plans were laid out in letters to the Virginia's commander, who then had the unpleasant job of informing his superior just how unseaworthy the frigate really was. See stephen Mallory to Franklin Buchanan, February 24, 1862, and stephen Mallory to Franklin Buchanan, March 7, 1862; both in NOR, VI: pp. 776$777,780-781$. 
negative diplomatic effects of surrendering large tracts of territory without a contest. For Attolney-General Thomas Bragg, the President's revelations sparked a more personal response: this was the first he had heard of his brother, Major-General Braxton Bragg, being ordered out of the quiet Gulf toward the crumbling front in Tennessee. Already pessimistic about the Confederacy's chances, he found that Davis's news left him too distracted to concentrate on anything else. 47

But the President had not even finished explaining his new strategy. His second priority, after solidifying a line in Tennessee, was the defense of Richmond. Johnston's army, as well as those of Major-Generals John B. Magruder and Benjamin Huger guarding the coastal approaches to the city at Yorktown and Norfolk, had been among the few Confederate organizations not drained of troops in the concentration on Tennessee. 48 But the catastrophes in the west, and the more immediate defeat at Roanoke Island had also brought Davis to the belief that the extended line of defense in Virginia was

47 Entry of February 19, 1862, Bragg diary, pp. 152-154.

48 Johnston had lost three Tennessee regiments in early February from the Army of the Northwest, which was temporarily attached to Jackson in the Valley District. While this transfer was partly motivated by Grant's expedition against Fort Henry, disaffection among those particular regiments over their winter: quarters and the belief that they would not reenlist if stationed in Virginia were the primary motivations for the War Department's orders. Judah P. Benjamin to Joseph E. Johnston, February 7, 1862, in OR, V: pp. 1066-1067. 
equally vulnerable to dismemberment by Federal naval power. "The President was farther of the opinion," wrote Bragg, "that we must fall back from Manassas and in the valley of Va. as far as stanton [sic]."49

Davis's concern for the safety of the capital was not the result of some unbalanced, monophobic refusal to acknowledge threats to the other theaters of war. He was quite aware of the resources and industrial potential of the Mississippi Valley and the interior of Georgia. Those regions held his nation's future--if it was to have one-because only by retaining them and developing their productive capacity could the Confederacy hope to sustain a long war. But what Davis also fully recognized was the fact that the loss of Richmond in the first half of 1862 would have almost immediately ended the war. If the western heartland did represent the Confederacy's future, the eastern capital was its present.

"Richmond," wrote historian Peter Parish, "was in effect the economic as well as the political capital of the Confederacy. . . "50 The city's four largest banks had combined assets exceeding $\$ 10,000,000$, a figure that appeared especially significant to a capital-poor nation

49 Entry of February 19, 1862, Bragg diary, p. 154.

50 peter J. Parish, The American Civil War (New York: Holmes and Meier, 1975), p. 307 . 
like the Confederacy.51 Richmond was the major flourmilling center for the southeast, and an important transportation terminus for the region as well; five railroad lines radiated out like spokes from a wheel, and heavy barge traffic plied the upper James River canal system, while ocean-going vessels could dock just below the city. 52 The only arsenal in the South capable of mass-producing smallarms was located in Richmond. 53

But as important to the survival of the Confederacy as all those attributes were, they were secondary to the city's capability for heavy manufacturing. "Iron was the key to Richmond 's greatest economic advantage to the Confederacy," concluded Emory Thomas.

The city was the center of the industry south of the Potomac. In 1860 she claimed four rolling mills, fourteen foundries and machine shops, a nail works, six works for manufacturing iron railing, two circular-saw works, and fifty iron and metal works. 54

Yet rather than the breadth of Richmond's iron industry what made it critical to the confederacy was the concentration of

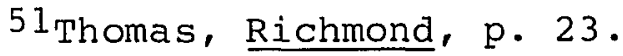

52Thomas, Richmond, p. 21; see also Thomas S. Berry, "The Rise of Flour Milling in Richmond," Virginia Magazine of History and Biography, Vol. LXXVII, No. 4 (October, 1970): pp. 387-408.

53 The arsenals seized by the Confederates at Nashville, Baton Rouge, Montgomery, Mount Vernon, Augusta, Charleston, and Savannah were only capable of making accoutrement and (with a supply of powder) cartridges. Goff, Confederate Supply, pp. 15, 31.

54 Thomas, Richmond, p. 23. 
production capability in a single firm: Joseph R. Anderson's Tredegar Iron Works.

Tredegar's capacity carried the south through the first year of the war. There were eighty-one establishments turning out bar, sheet, or railroad iron in the Confederacy. Tredegar alone accounted for better than $37 \%$ of the total production. By the end of February, 1862, Anderson's firm had delivered sixty-eight field guns and 197 pieces of heavy artillery, while most of the other establishments were either still in the process of tooling up to cast cannon, or had defaulted on their contracts. Mallory's ironclads would have been impossible without Tredegar; the plant cast the metal plates that covered the Virginia as well as her rifled guns, and was forging the main shaft for the Mississippi. 55

Beyond simply supplying the armed forces, Tredegar possessed the unique capability, given enough time, to bring other industrial plants up to its level. Though there were ten rolling mills in the South after secession, only Anderson's company owned the steam hammer so necessary for sustained mass production. This gave Tredegar the ability not only to manufacture ordnance materials, but also to create new manufacturing establishments and supplement existing ones. Tredegar repaired the rifling machinery captured at Harper's Ferry that would soon be sending 500 new weapons a month to the front from the Fayetteville

55 Dew, Ironmaker, pp. 86, 88, $111,119$. 
arsenal. Even as Davis and his cabinet met, the firm had just completed the twelve rolls, six bed circles, and ten shafts necessary to put the huge Augusta Powder Mill into operation. A second steam hammer, cast in Richmond, would eventually allow the Confederate foundry at Selma, Alabama to begin manufacturing heavy guns. Virtually none of the munitions plants or navy yards that would sustain the Confederate military economy in spite of the blockade could have been built without the support of the Tredegar Iron Works. 56

Later, diversification of ordnance production somewhat diminished the critical importance of Tredegar, but in February, 1862--and for some six months thereafter--Joseph Anderson's company represented the single resource without which the Confederacy could not survive. So as politically important as defending northern Virginia might be, and as agriculturally significant as was the Shenandoah Valley, President Davis subordinated both to the defense of Richmond.

With a flourish of real-life dramatic timing, the President had just mentioned his intention to withdraw from the frontiers of Virginia when General Johnston's arrival was announced.57 Davis's February 13 letter to Johnston was

${ }^{56}$ Dew, Ironmaker, pp. 86, 124-125; Kathleen Bruce, Virginia Iron Manufacture in the Slave Era (New York: The Century Co., 1931), pp. 331, 349.

57 Entry of February 19, 1862, Bragg diary, p. 154. 
unknown to most of the cabinet, and because Johnston had been forced to delay his trip due to G. W. Smith's illness, even the President had not known exactly when to expect him. 58

Davis left the room to confer with Johnston for a few minutes before bringing him into the meeting. He first wanted to assure the General that rumors of an impending transfer of G. W. Smith to east Tennessee were false.59 After that, the President brought Johnston up to date on the

58 Freeman, following the Narrative and Davis's February 19 letter to Johnston, mistakenly asserted that Davis summoned Johnston on February 19. Davis's order to Johnston on February 16 has not been found, but the gist of it can be inferred from the General's telegraphic response the same day. There is no extant letter that shows that Johnston ever informed Davis of when he would arrive. Freeman, Lee's Lieutenants, I: p. 134n; Jefferson Davis to Joseph E. Johnston, February 19, 1862, in OR, V: p. 1077; Joseph E. Johnston to Jefferson Davis, February 16, 1862, in Joseph E. Johnston Letterbook, in JJWM.

59 Johnston had raised the question in his February 16 letter. Davis had responded on February 19, in a letter he had presumably mailed prior to the cabinet meeting, but realized that Johnston could not possibly have yet received. This was welcome news to the General, of course, but tempered by the fact that the rumor was mistaken only as to initials: Major-General E. K. Smith, not G.W. Smith was being detached from the Department of Northern Virginia on the request of Albert Sidney Johnston to be sent as commander from the east to take over the mountainous district. Benjamin had already informed Johnston that E. K. Smith was being transferred on February 15, but the fact that Johnston did not actually issue the order until after his trip to Richmond suggests that he may have protested it directly to Davis. Judah P. Benjamin to Joseph E. Johnston, February 15, 1862; Joseph E. Johnston to Jefferson Davis, February 16, 1862; Jefferson Davis to Joseph E. Johnston, February 19, 1862; Special Orders No. 56, Headquarters Department of Northern Virginia, February 21, 1862; all in OR, V: pp. 1073-1074, 1077-1078; Albert Sidney Johnston to Judah P. Benjamin, February 14, 1862, in OR, VI: p. 879. 
latest intelligence from the west, explained his concentration in Tennessee, and told him that he was just in time to help decide the question of withdrawing his own army. 60 Johnston readily admitted that, from a purely military point of view, withdrawal from his exposed lines in northern Virginia to a more concentrated and more defensible position behind the Rappahannock was desirable. But he emphasized the difficulties of such a movement while winter lingered, calling them, "almost insurmountable."61 In his memoirs, Johnston's account of the list of problems he presented to the cabinet is sustained by Thomas Bragg's diary entry that same evening: the General described

the present condition of the roads, the want of means by Rail Road Road [sic] to do it expeditiously, and the great sacarfices [sic] we would have to make, as any movement of the kind would be very soon known to the enemy. He seemed to think that the enemy could and would advance by coming down to Aquia Creek and getting to Fredericksburg. our heavy guns could not be well moved or got away

60 In the published version of the Narrative, Johnston did not mention his conference outside the larger meeting, and implies that he was ushered directly into the room and only informed in front of the secretaries as to the subject of the discussion. But, in his first draft of his memoirs, Johnston stated that "in the office of his A. D. C., he [Davis] informed me that the withdrawal of the army was the subject to be considered." That proposition would not have made sense to Johnston without at least a short explanation of the overall strategic context. Johnston's unpublished version is followed here because it accords with Bragg's contemporary account. Johnston, Narrative, p. 96; Draft of Johnston's Narrative in Box 28, Folder 4, in the Robert Morton Hughes collection, Old Dominion University; entry of February 19, 1862, Bragg diary, p. 154.

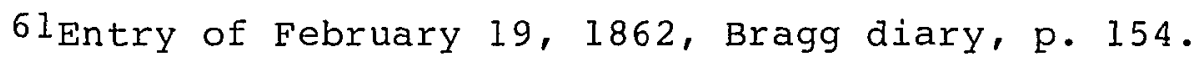


from Evansport. 62

This last comment evidently provoked a lively discussion about the ways and means of retiring Whiting's heavy artillery from the Pctomac. Aside from mentioning the practical difficulties of such a removal, Johnston finally ended the discussion by pointing out that new Federal positions on the Maryland shore made it now impossible to perform any such maneuver in secret. At that, Davis tabled the matter, asked Johnston to consider the issue more fully and return the next day to continue the aebate. 63

Before the cabinet returned to the original business of the day--editing the President's inaugural address--Davis made several more important comments on his strategy in Virginia. According to Bragg, Davis said "that unless something of the kind was done"--referring to a withdrawal by Johnston--"Richmond would be taken, that we must have troops in supporting distance to repel an attack from North or South by Burnside, who he thought would endeavor to advance to Suffolk, isolate Norfolk which must fall \& then advance upon Richmond." He believed that Federal strategists would also divert Commodore Porter's mortar fleet to assist Burnside. Recognizing that the forces deployed in a broad defensive arc around the capital were commanded by

62 Johnston, Narrative, p. 96 ; entry of February 19, 1862, Bragg diary, p. 154 .

.63 Entry of February 19, 1862, Bragg diary, p. 154 . 
five independent generals, the President admitted that he had been recently considering the recall of General Robert E. Lee from Georgia to orchestrate their operations. But Lee, Davis revealed, felt that Savannah was in immediate danger of attack, and did not think he could safely depart the area for at least a week, perhaps more. "It was left undecided," wrote Bragg. 64

After all these revelations, the cabinet abruptly returned to work on the speech. Some of the members were perhaps relieved to get back to politics, a subject they more fully comprehended, and devoted several hours to arguing nuance and syntax. But Thomas Bragg, whose brother was heading into battle, and whose home state of North Carolina seemed to be rapidly disappearing into enemy hands, could not concentrate on the task in front of him. "To me it seemed rather a useless waste of time. My mind was away, and $I$ was thinking of how we were to escape the storm which threatened to overwhelm both Gov't \& people."65

Exactly when Johnston left the meeting is not clear. Bragg's diary can be read as implying that he was dismissed prior to Davis's comments about recalling Lee to Virginia, but the entry is too ambiguous to be offered as definitive evidence. Johnston never stated, then or later, whether he had heard the remarks, although his correspondence with Lee

64 Ibia. , pp. 154-155.

$65_{\text {Ibid. }}$, pp. $155-156$. 
the next month can also be read in such a manner as to indicate that he did. That question notwithstanding, Bragg's notes clearly settle two key issues. First, the idea for withdrawing Johnston's army originated with Davis; it was, in fact, under discussion before Johnston ever entered the room. Secondly, the Attorney General's journal also confirms explicitly that Davis was considering the transfer of Lee back to Virginia to exercise a specific coordinating command function. The context also suggests, though again stopping short of outright assertion, that the President had no intention of turning complete control of the defense of Richmond over to Joseph Johnston. Johnston, for his part, regardless of when he left the Mechanic's Institute, probably had other matters on his mind. Immediately, he wanted to see his wife, then residing at a Richmond hotel. Though she had visited him frequently --his critics said excessively--during the winter at Centreville, he had not seen her in some weeks. On his way to the hotel, his natural reserve and his sense of military security would have served to deflect the inquiries of curious civilians as to his business at the capital. But in the hotel lobby, General Johnston met a man whose questions he could not so easily avoid.

Twenty-eight-year-old Colonel Dorsey Pender of the 6 th North Carolina had just finished a thirty-day leave to see his wife; he had signed into the hotel overnight to await 
the morning train back to Centreville. From the moment he arrived in Richmond that morning, Pender had been hearing rumors that the cabinet was in session to discuss the withdrawal of the army from Centreville and Manassas. The dozens of details such a move would entail for a regimental commander must already have been running through his mind when he saw his commander enter the hotel. Without hesitation, Pender approached Johnston and put the question directly: was the army being withdrawn?

Johnston, horrified at this breach of security, politely brushed off the Colonel's inquiry with a negative answer, but one which did not totally convince the younger officer. 66 The exchange also served to place Johnston into an even more defensive frame of mind with reference to the administration. Davis had ordered him to Richmond with a secret summons, and now he found the subject being bantered openly in the streets. How far could he trust civilian politicians with military secrets?

According to Bragg, the General never broached that subject at the cabinet meeting on the following morning. Johnston did say that he considered a withdrawal from

\footnotetext{
66 Johnston, Narrative, p. 97; Dorsey Pender to Fanny Pender, February 21,1862 , in Hassler, General to His Lady, pp. 113-114. Pender's letter also provides additional confirmation that Johnston was in Richmond for three days instead of the two he claimed in his memoirs. Pender's February 21 letter says that he reached camp "last evening"--February 20--which would have placed his meeting with Johnston in Richmond in the afternoon of February 19.
} 
Manassas "advisable, but every means of doing it and saving our artillery \& stores, especially the heavy guns on the Potomac, seemed to be wanting--it was next to impossible." This was followed by an exchange of opinions--"a prolonged discussion" as Johnston remembered it somewhat derisively-by the cabinet secretaries over various schemes to save Whiting's exposed cannon. 67 Nothing in this conversation would have improved the professional soldier's view of his civilian superiors.

The meeting "terminated without the giving of orders," recalled Johnston, "but with the understanding on my part that the army was to fall back as soon as practicable."68 Bragg's diary supports this statement, and notes with reference to the selection of a new position that Johnston "was directed however to have a reconnaisance [sic] of the country in his rear with reference to another $l$ ine, and it is probable the Rappahannock will be selected."69

Three years later, Jefferson Davis asserted that a reconnaissance had been necessary because Johnston himself

67 Entry of February 20, 1862, Bragg diary, p. 157.

68 Johnston, Narrative, p. 96; Johnston's memory of the event had changed, however, by the time he prepared an article for the Century a few years later. There he contended that "the President directed me to prepare to fall back from Manassas, and to do so as soon as the condition of the country should make the marching of troops practicable. - ." But his first recollection more nearly matched contemporary evidence. Johnston, "Responsibilities," B\&L, I: p. 256 .

${ }^{69}$ Entry of February 20, 1862, Bragg diary, p. 157. 
did not have any idea of the country behind him:

On enquiry into the character of his position at Centreville, he stated that his lines there were untenable; but, when asked what new position he proposed to occupy, declared himself ignorant of the topography of the country in his rear. This confession was a great shock to my confidence in him. That a General should have been for many months in command of an Army, should have selected a line which he himself considered untenable, and should not have ascertained the topography of the country in his rear, was inexplicable on any other theory than that he had neglected the primary duty of a commander. 70

The charge reflected the antipathies of 1865 rather than the realities of 1862 . Johnston was hardly ignorant of the land behind him; he had already ordered a survey of the Rappahannock line when his engineers fortified the bridge crossings. 71

But the question of exactly where Johnston's retreat would cease was left undecided. In the absence of indisputable evidence, one logical reason for this omission suggests itself. The stated object of a withdrawal from northern Virginia was to move Johnston's troops into closer supporting distance of Richmond, should either McClellan or Burnside launch and amphibious attack on the city. Obvious1y, such a movement would also entail a retrograde by Jackson's forces in the Shenandoah, which would, otherwise,

70 Jefferson Davis to James Phelan, February 18, 1865, in Jefferson Davis, Constitutionalist, VI: pp. 493-494.

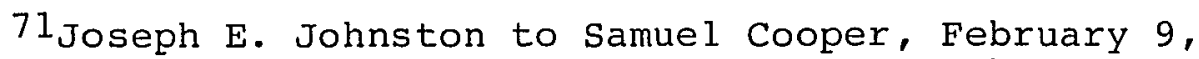
1862, in LR-AIGO, M-474, Reel 27; Joseph E. Johnston to R. W. Hughes, April 9, 1867, in RMH; Johnston, Narrative, p. 445 . 
have been left in a position far too exposed to be safe. Neither Johnston nor Davis wanted to yield an inch of soil unnecessarily, and so both would have favored a position for Johnston's main army close enough to defend Richmond, but far enough north to support Jackson as far down the Valley as possible. The Rappahannock looked like the natural choice for such a deployment, but, as trained soldiers, both men would have known that the final decision was a judgment call based in large measure on the Federal reaction to Johnston's movements. Further, Johnston was aware that the defense of Richmond was now the administration's stated priority, and only someone in Richmond, receiving daily intelligence reports from northern Virginia, eastern Virginia, and North Carolina, could decide exactly how much nearer to the capital he should withdraw. So his destination, while provisionally the Rappahannock River, had not been finally determined.

Leaving the meeting, probably sometime in the early afternoon, Johnston spent the remainder of the day transacting minor administrative affairs with Adjutant-General Cooper. 72 He planned to return to Centreville the following morning, and did not, of course, mention the outcome of the cabinet meeting to anyone not already privy to the decision. But that evening, if the memoirs of an ardent congressional

72 Samuel Cooper to Theophilus Holmes, February 20, 1862 , in LS-AIGO, Vol. 36, Reel 2 . 
foe of the Davis administration are to be believed, the General may have committed an indiscretion of another sort. Just a few days earlier, Henry stuart Foote had arrived in Richmond, newly elected to the permanent Confederate Congress from Nashville, Tennessee. Foote, originally a Mississippi politician who had defeated Davis for governor of that state in a particularly acrimonious race in 1853 , was an avowed opponent of both secession and the current administration. "That Confederate Tennesseans elected proUnion Foote to the Southern Congress," wrote historian Patricia Faust, "is almost as puzzling as their representative's willingness to serve."73 Perhaps it was not love of the Confederacy but hatred for Davis that convinced Foote to accept his election, for he wasted no time pillorying the administration's war policies. Even as Johnston prepared to leave the cabinet meeting on February 20, Foote, "an orator of the fist-pounding Bible-spouting variety," rose on his first day in Congress to attack Jefferson Davis so bitterly that he missed ending up in a duel with Albert Gallatin Jenkins of Virginia by only the narrowest of margins. 74 That night, according to Foote's 1866 memoirs, "I

73 Patricia J. Faust, "Henry stuart Foote," in Patricia J. Faust, ed., Historical Times Illustrated Encyclopedia of the Civil War (New York: Harper \& Row, 1986), p. 266 (hereafter cited as HTIE).

$74 \mathrm{El}$ i N. Evans, Judah P. Benjamin, The Jewish Confederate (New York: Macmillan, 1988), p. 148; Richmond Examiner, February 21,1862, p. 3 . 
chanced to be invited to a dinner-party, where some twenty of the most prominent members of the two houses of the Confederate Congress were congregated, including the speaker of the House of Representatives, Mr. Orr of South Carolina, and others of equal rank." Johnston, Foote asserted, had also been invited, but seems to have taken little part in the conversation, at least until the subject turned to Secretary of War Judah Benjamin. While discussing Benjamin's "gross acts of official misconduct," Foote recorded, one of the company turned to General Johnston, and inquired whether he thought it even possible that the Confederate cause could succeed with Mr. Benjamin as War Minister. To this inquiry, General Johnston, after a little pause, emphatically responded in the negative. This high authority was immediately cited in both houses of Congress against $M r$. Benjamin, and was in the end fatal to his hopes of remaining in the Department of War. 75

No specific corroboration for Foote's anecdote has been found beyond the fact that Arkansas Congressman Thomas B. Hanly called for Johnston's appearance before the House on February 25, to testify during the confirmation debates. But considerable circumstantial evidence suggests that such an act would not have been out of character for Johnston. James orr, the only other individual mentionea by name in the story, had been colonel of the lst South Carolina Rifles before he had resigned to enter Congress; it is not unlikely that he would have invited Johnston to the dinner. Johns-

75 Henry S. Foote, War of the Rebellion; or Scylla and Charbydis (New York: Harper and Brothers, 1866), p. 356. 
ton's alleged comments were certainly in accordance with his personal beliefs, as both his own memoirs and contemporary correspondence testify. The early postwar date at which Foote wrote gives his account more credibility, for most of the controversies over Johnston's defense of Richmond that might have colored his memory had not yet surfaced. 76

If Foote's account is accurate, Jefferson Davis's friends in Congress could hardly have avoided telling him that Johnston's opinions were being quoted in debates in order to discredit Benjamin. Such an indiscretion on the part of the General at the expense of his friend would have only advanced the President's distrust of his field commander. Even if the anecdote was fabricated or exaggerated, it is indicative of a climate of suspicion that already existed between Johnston and Davis in February, 1862, at a time when the need for absolute mutual confidence had become paramount.

That level of trust declined again, in Johnston's mind, the following day. Riding the slow-moving train back to

76 Foote claimed that Johnston's comments torpedoed any chance of Benjamin's reappointment as secretary of war because it was widely quoted in Congressional confirmation hearings. Benjamin biographer Robert Douthat Meade credited this story, though he did not cite any other sources. See. Steward Sifakis, Who Was who in the Civil War (New York: Facts on File, 1988), pp. 479-480; Foote, Scylla and Charbydis, p. 356; Robert Douthat Meade, Judah P. Benjamin, Confederate Statesman (New York: Oxford University Press, 1943), p. 235; "Proceedings of the First Confederate Congress--First Session," in Southern Historical Society Papers, Vol. XLIV (June 1923): p. 50 . 
Centreville, he made profitable use of the hours by discussing details of the upcoming withdrawal with one of his quartermasters, Major B. P. Noland, who chanced to be riding in the same car. 77 They were interrupted by a friend of Johnston's, "an acquaintance from the county of Faquier, too deaf to hear conversation not intended for his ear," who told Johnston that he, like Dorsey Pender, had heard that the army was being withdrawn from Manassas.78 Aghast, the General asked him for the source of his information. It had come, Johnston said later, "from the wife of a member of the Cabinet. " 79

77 Lucius B. Northrop to Jefferson Davis, January 14, 1885, in Rowland, Jefferson Davis, Constitutionalist, IX: p. 326 .

78 Johnston, Narrative, p. 97.

${ }^{79}$ First draft of Narrative, p. 18 , in Box 28 , Folder 1 , $\mathrm{RMH}$. 


\section{Chapter Four \\ Withdrawal from the Frontier}

The rain came down even harder in Richmond on Inauguration day. The deluge "fell in torrents, and the streams and gutters were like the flowing of little rivers."l Jefferson Davis and his Negro footmen approached the wooden platform beside the statue of George Washington attired in somber black. "This, ma' am, is the way we always does in Richmond at funerals and such like," one coachman told an inquisitive spectator. 2 The tall Mississippian bent to kiss the Bible, and then stood bareheaded in the rain and delivered his speech. It was vintage Davis, logical and concise, if not inspiring; Attorney General Bragg remarked that, after all the in camera editing, "it is the best seasoned document surely that ever was issued." Bragg also said that February 22 was "one of the worst days I ever saw." 3 "Very few heard the inaugural address" over the drumming of the rain, recalled one observer, and in the depression gripping the

Isally Putnam, Richmond During the War: Four Years of Personal observation by a Richmond Lady (New York: G. W. Carleton \& Co., 1867), p. 106 .

${ }^{2}$ Quoted in James M. McPherson, Battle Cry of Freedom, the Civil War Era (New York: Oxford University Press, 1988), p. 403 .

3 Entries of February 20, 1862, February 22, 1862, Bragg diary, pp. 156, 160-A. 
crowd there was a common feeling that the war had passed the point where the words of the politicians mattered much anyway. 4

In Centreville that Saturday, it was also raining, but General Johnston met with his staff indoors where they could hear him. He had been back from the capital fewer than twenty-four hours, and he was determined to waste no time in executing the order to withdraw his army. He hoped quietly to remove enough of his supplies and heavy guns in about two weeks to allow himself freedom of maneuver.

It was an optimistic time-table, perhaps excessively so, considering the difficulties that Johnston faced. Neither his subordinate generals nor his staff had much experience in planning the movement of an entire army on so much as a route march, much less a retreat with all baggage over muddy roads. Likewise, his troops, though well-drilled in tactical evolutions, were innocent of real marching experience. Mountains of supplies--from an unwanted 4,000,000 pounds of meat at Thoroughfare Gap to the excess trunks of his gentlemen-officers--had to be removed down the inadequate railroad line. Something had to be done with Whiting's cannons along the Potomac. And it all had to be accomplished in complete secrecy, lest McClellan scent that something was afoot and attack one of the outlying garrisons just as the withdrawal began.

4Putnam, Richmond, p. 107. 
Johnston knew that the command structure of his army was dangerously weak. In a little more than three months, General Beauregard; Major-Generals Edmund Kirby-Smith and Earl Van Dorn; and Brigadier-Generals Milledge Bonham, Charles Clark, Philip st. George Cocke, Nathan G. "Shanks" Evans, W. H. T. Walker, Henry C. Wayne, and Louis T. Wigfall had all left the army due to a variety of causes ranging from transfer, to election to Congress; aggrieved resignation, to suicide. 5 The result, as Johnston wrote Davis, was that

The army is crippled and its discipline greatly impaired by the want of general officers. The four regiments observing the fords of the Lower Occoquan are commanded by a lieutenant-colone1; and, besides a division of five brigades is without generals; and at least half the field officers are absent--generally sick. 6

Nor could Johnston feel absolutely confident in the abilities of those officers left to him. His senior majorgeneral, forty-one-year-old Kentuckian, Gustavus Woodson Smith, was a personal friend from prewar days who had received his commission based primarily on his reputation as an engineer and Johnston's own recommendation: "Smith is a

5 Ezra J. Warner, Generals in Gray, Lives of the Confederate Commanders (Baton Rouge, LA: Louisiana State University Press, 1959), pp. 23, 29, 51, 57, 84, 280, 315, $323,329,337$.

6Joseph E. Johnston to Jefferson Davis, February 25, 1862 , in OR, V: p. 1081 . 
man of high ability, fit to command in chief."7 But Smith had "gone South" later than most, missing the Battle of Manassas, and had, thus far, little chance to prove Johnston correct or live up to his own aura of self-assurance. He had been impressive as an administrator during the winter-even the irascible Robert Toombs admitted that "the army has been a great gainer by his appointment." 8 But Smith suffered from some mysterious nervous malady which, without warning, could send him to bed for days at a time. Such an attack had already caused Johnston to delay his trip to Richmond for three days; would the stress of active operations make his condition worse? 9

A year older and physically Smith's opposite, James Longstreet had the robust constitution of a draft horse. A fighter, rather than a thinker by nature, Longstreet actually benefitted by being slightly deaf, as one cavalry officer remembered: "he impressed me then as a man of limited capacity who acquired reputation for wisdom by never saying anything--the old story of the owl. I do not remember ever hearing him say half a dozen words beyond

7 Joseph E. Johnston to Jefferson Davis, August 19, 1861, in OR, V: p. 797; see also Longstreet, Manassas to Appomattox, p. 103; Warner, Generals in Gray, pp. 280-281.

${ }^{8}$ Phillips, Correspondence, p. 579.

9 Joseph E. Johnston to Jefferson Davis, February 16 , 1862, in JJWM. 
'yes' and 'no,' in a consecutive sentence. . ."10 He owed an early commission as a brigadier-general to an accident of timing, but justified it, and his next promotion, with his performance at Manassas. Like Smith, he proved his worth as an administrator, reputedly paying more attention to drilling his division than any other officer.l1

Yet, as Johnston began to consider his evacuation, he had reason to worry about Longstreet's state of mind. Throughout most of the winter, Longstreet had joined in the rather convivial atmosphere around headquarters, enlarging on prewar notoriety as a skilled poker player.12 But in early February, not long before Davis summoned Johnston to Richmond, tragedy had struck the Georgian. In a single week, three of his children died of a fever in Richmond; by February 25, Longstreet had only just returned from an emergency leave to bury his dead. Now his silence appeared to be the silence of brooding and depression; how would this affect him as a division commander? 13

10W. W. Blackford, War Years with Jeb Stuart (New York: Charles Scribner's Sons, 1945), p. 47.

I. Wise, Seventeenth Virginia, p. 49.

12 Moxley Sorrel, Recollections of a Confederate staff Officer (New York: Neale, 1905), pp. 37-38.

13 Longstreet's children died on January 25, 26, and February 1, 1862; see Sanger and Hay, James Longstreet, pp. 36-37. Sorrel remarked in Ibid. about the great change that appeared in Longstreet after the loss. In his recent revisionist book, Lee's Tarnished Lieutenant, James Longstreet and His Place in Southern History, William Garrett Piston argues that Longstreet was, nonetheless, Johnston's 
The third major-general with Johnston's field army had just received his second star; Richard stoddert Ewell advanced to division command on January 24,1862 , two weeks prior to his forty-fifth birthday.14 "Bald as an eagle," recalled one staff officer, Ewell "looked like one; had a piercing eye and a lisping speech."15 He was a hypochonariac, sometimes an insomniac, and when he grew excited, he swore until "he made the air blue"; in an army of eccentrics, "Dick" Ewell stood out as a genuine character.16 But what of his military capacity? Richard Taylor remembered

most trusted subordinate, and that the army commander wished that the Georgian and not Smith were second in command. He cites the fact that Johnston "constantly gave him greater responsibilities and more difficult assignments than Smith." But Piston's sources do not bear out his contention that in February, 1862, Johnston considered Longstreet superior to Smith. Piston cites only the Sanger and Hay biography and two reports from the Peninsula campaign: Johnston's of Williamsburg and Longstreet's own from seven Pines. In point of fact, it was Smith, not Longstreet, that Johnston considered on February 16, 1862, to be "necessary here as the commander of the main body. . . ." And Longstreet himself admitted that prior to April, 1862, Smith stood higher in Johnston's councils than he himself did. On balance, however, Piston's book provides a much-needed corrective view of Longstreet's performance and place in Confederate historiography. William Garrett Piston, Lee's Tarnished Lieutenant, James Longstreet ana His Place in Southern History (Athens, GA: University of Georgia, 1987), pp. 18, 193; Joseph E. Johnston to Jefferson Davis, February 16,1862 , in OR, V: p. 1074; Longstreet, Manassas to Appomattox, p. 60 .

14 Warner, Generals in Gray, pp. 84-85; the best recent treatment of Ewell is Samuel J. Martin, "The Complex Confederate," Civil War Times Illustrated, Vol. XXV, No. 2 (April, 1986): pp. 26-33.

15 Sorrel, Recollections, p. 53.

16 Douglas, Stonewall, p. 53 . 
that more than once Ewell turned to him and asked, "What do you suppose President Davis made me a major-general for?"l7 His deployment on the Confederate right flank had kept him from winning any great acclaim at Manassas, and the bleak fall and winter had not given him any chance to demonstrate any potential for higher responsibilities. Perhaps the fact that Ewell was a Virginian had helped. Virginia had contributed enough troops to the army to fill one of its four divisions; but, after Jackson's transfer to the Valley District and before Ewell's promotion, there had been no major-generals from the old Dominion, and only three brigadiers. Maintaining a careful, political balance between the number of regiments and the number of generals hailing from each state had always concerned Jefferson Davis, and as the senior Virginian under Johnston's immediate command, Ewell quite possibly benefitted as much from his state affiliation as from any military reputation. 18 Though neither Smith nor Longstreet had proven his ability to handle a division in combat, both must have represented

17 Taylor, Destruction, p. 37.

18Martin, "Complex Confederate," p. 28; for the President's sensitivity to the issue of balancing the regiments, brigades, and generals from the various states, see Jefferson Davis to Joseph E. Johnston, October 7, 1861, Jefferson Davis to Gustavus W. Smith, October 10, 1861, Judah P. Benjamin to Joseph E. Johnston, November 15, 1861, General orders No. 18, Adjutant and Inspector General's Office, November 16, 1861, Gustavus W. Smith to D. H. Hill, December 26, 1861, Judah P. Benjamin to Joseph E. Johnston, January 7,1862 , in $\underline{\text { OR, }} \mathrm{V}: \mathrm{p} .892,893-894,954,960-961$, 1008,1023 . 
less of a question mark in Johnston's mind than Ewell, who had not yet had enough time to prove himself competent at even the administrative level.

The two other major-generals assigned to the Department of Northern Virginia--fifty-seven-year-old North Carolinian, Theophilus H. Holmes, and thirty-eight-year-old Virginian, Thomas J. "Stonewall" Jackson--both held detached commands. Holmes, in charge of the Aquia District, had been a friend of Jefferson Davis and a classmate of Joseph Johnston at West Point (though at the far end of the class--Johnston finished thirteenth and Holmes forty-fourth of forty-six). 19 He had advanced to the rank of major in the infantry in 1861, due more to tenacity and the inexorability of army seniority than any spark of talent; nonetheless, the fact that Holmes was one of only fifteen active, field-grade officers to resign his commission had guaranteed him early promotion. 20 From his relatively quiet headquarters at Fredericksburg, Holmes had had no opportunity to prove himself competent or otherwise, though Johnston had already had at least one occasion to criticize him for dilatory

\footnotetext{
19 Walter F. Fleming, "Jefferson Davis at West Point" Publications of the Mississippi Historical Society, Vol. X (1909): p. 267 .

20 See Official Army Register for 1861 (Washington, DC: Adjutant General's Office, 1861), and compare it to official Army Register for 1862 (Wasinington, DC: Adjutant General's office, 1862).
} 
performance of his duties. 21 But the question of Holmes' abilities would not have weighed too heavily on Johnston's mind, because the withdrawal would necessarily affect the Aquia command least of all.

Jackson, however, held a much more critical and more dangerous post. Wintering his troops at winchester, he already faced growing Federal threats from the north and west; when Johnston withdrew the main army from Centreville, a quick thrust by McClellan from the east could trap Jackson in a very tight sack. Yet both political and military realities demanded that, in avoiding capture or defeat by Union forces, Jackson not relinquish a foot more of Valley soil than was absolutely necessary. It was an assignment that demanded equal portions of boldness, judgment, and skill--all talents which the next few months would reveal that Jackson possessed in abundance.

But it is important to remember that in February, 1862, no one suspected Jackson of harboring the seeds of genius. Jefferson Davis had characterized him in a January 31 cabinet meeting as "utterly incompetent." Both the President and secretary Benjamin thought him a poor administrator who played favorites with his troops when assigning the best

21 Joseph E. Johnston to Jefferson Davis, August 19, 1861 , in OR, V: p. 797 . 
quarters. 22 His own subordinates verged on outright mutiny during the winter, complaining directly to Richmond of mistreatment at the hands of their general.23 His personali.ty, prior to his rise to fame, tended to be seen as arbitrary and querulous, rather than eccentric and endearing, and his appearance did not improve his image. "Above the average height, with a frame angular, muscular, and fleshless," wrote Henry Kyd Douglas, Jackson "was, in all his movements from riding a horse to handing a pen, the most awkward man in the army." 24 Even after his rise to fame, Jackson's peers respected him more than they loved him; A. P. Hill characterized Jackson in November, 1862 as "that crazy old Presbyterian fool," and suggested that "the Almighty will get tired of helping Jackson after a while [sic], and then he'11 get the d--ndest thrashing. . . ."25 Johnston, who had been Jackson's superior since May, 1861 at Harper's Ferry, had his own opinion of the dour

22 Entry of January 31,1862 , Bragg diary, p. 130; Jefferson Davis to Judah P. Benjamin, January 29, 1862, in OR, V: p. 1050 .

23 William B. Taliaferro et al . to W. W. Loring, January 25,1862 , W. W. Loring to Judah P. Benjamin, January 31, 1862 , Joseph E. Johnston to Samuel Cooper, February 7, 1862, in $\mathrm{OR}, \mathrm{V}: \mathrm{pp}$. 1046-1047, 1054-1056, 1065-1066.

24 Douglas, stonewal1, p. 226.

25A. P. Hill to J. E. B. Stuart, November 14, 1862, in James Ewell Brown Stuart papers, Virginia Historical Society, Richmond, Virginia; see also Mark Grimsley, "Jackson: The Wrath of God," Civil War Times Illustrated, vol. XXIII, No. 1 (March 1984): pp. 10-17. 
Virginian, one which seems to have been more favorable than the consensus. Jackson, unlike many other officers, always filed his reports on time, kept Johnston apprised of his position and intentions, and appeared to be capable of critically evaluating intelligence about enemy numbers and intentions. Johnston did believe that Jackson tended to be overly aggressive. Commenting on Jackson's plan for a winter campaign in November, 1861, Johnston observed: "It seems to me that he proposes more than can well be accomplished. . ." But once the government had committed to the operation, Johnston whole-heartedly supported Jackson against all his critics, from private soldiers to the President of the Confederacy. After an embarrassing directive from Benjamin countermanded his own orders, Jackson attempted to resign, and Johnston felt strongly enough about him to delay his letter and press for a reconsideration. To the secretary of War, Johnston wrote pointedly, "I don"t know how the loss of this officer can be supplied."26 Johnston implied after the war--as did almost everyone else--that he had seen early signs of talent for independent command that Jackson later demonstrated, but the evidence does not support this assertion. 27 still, it is

26 Joseph E. Johnston to Samuel Cooper, November 22 , 1861, endorsement on Thomas J. Jackson to Judah P. Benjamin, January 31, 1862, Joseph E. Johnston to Thomas J. Jackson, February 3, 1862, in OR, V: pp. 966, 1053, 1059-1060.

27 Johnston, Narrative, pp. 86-89, 106-107. 
clear that Johnston rated Jackson much higher in February, 1862, than did almost anyone else.

Among Johnston's brigadiers, four woula have figured most significantly in his plans for maneuvering the army: Jubal Sarly, D. H. Hill, J. ت̇. B. Stuart, and W. H. C. Whiting. All were West Point graduates and Johnston recommended at least three of them for promotion. 28 In the absence of government action, the General decided unilaterally to advance them to higher levels of responsibility, in fact, if not in title.

Early was a forty-five-year-olà Virginian who had resigned from the army in 1838 to pursue a legal and political career in his horne state, interrupted only by volunteer service in the Mexican War. He had opposea secession, but quickly devoted himself to the confederacy, accepting the colonelcy of the 24 th Virginia. His conduct at Manassas won him a general's star, and by February, 1862,

28 Warner, Generals in Gray, pp. 79, 136-137, 296-297, 334-335; Johnston's recommendation for Early's promotion may be inferred from the fact that he assigned him to a division command prior to receiving the appointment of Richard $\mathrm{S}$. Ewell, who was senior to Early. See General orders No. 22, Department of Northern Virginia, February 5, 1862, in oR, V: pp. 1061-1062; for Johnston's recommendation of stuart, see Joseph $\mathrm{i}$. Johnston to Jefferson Davis, August 10, 1861, in OR, V: p. 77; Johnston referred to whiting in glowing terins throughout the winter and spring, but Whiting's difficulties with Jefferson Davis over the commana of a Mississippi brigade kept Johnston from actually submitting a recommendation for promotion until April. See Joseph ie. Johnston to George Wythe Randolph, April 20, 1862, in W. H. C. Whiting, Compiled Service Record, Record Group 94, National Archives. 
Johnston had begun using him as a division commander. 29 Stoop-shouldered, addicted to chewing tobacco, argumentative, ambitious, and profane, Early elicited extreme responses from his peers: they either liked him or hated him. Longstreet, in particular, found him distasteful and distrusted his capabilities, but Johnston disagreed, and consistently handed Early critical assignments. 30

Daniel Harvey Hill, as previously noted, commanded the detached garrison at Leesburg, stronger than a brigade but not quite as large as a division. A forty-one-year-old North Carolinian, Hill had resigned from the army in 1849 to become a professional educator. An ardent Southern nationalist who eagerly embraced secession in 1861 , Hill had won, as colonel of the lst North Carolina, the Battle of Big Bethel, the first land engagement in Virginia, securing his promotion to brigadier-general. 31 His coolness under fire was already well-known among his soldiers: at Leesburg,

29 Warner, Generals in Gray, p. 79; General Orders No. 22, Department of Northern Virginia, February 5, 1862, in OR, V: pp. 1061-1062.

30 Longstreet's poor opinion of Early seems to have stemmed from an inability to make the virginian follow orders on outpost at Fairfax Court House in the late summer of 1861. By the Battle of Williamsburg, his assessment had fully crystallized into a belief that Early was incompetent to handle a brigade. See James Longstreet to Thomas Jordan, undated, but by context from August or September, 1861, in James Longstreet, Compiled Service Record, Record Group 94, National Archives; Longstreet, Manassas to Appomattox, p. 78; Sorrel, Recollections, p. 56 .

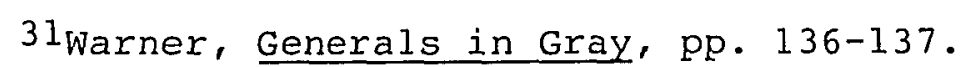


when he wanted to know the range and calibre of enemy guns across the river, Hill paraded up and down the banks with an ostentatious escort until the Federals fired on them. Some rounds fell short and others flew overhead. Before the barrage ended, Hill casually took a pick and began digging up shells embedded in the ground to measure their size. 32 Notoriously moody, his letters and reports read more like newspaper editorials than military correspondence. Sarcastic comments about a forger in the war Department and the incompetence of army surgeons have already been cited; on another occasion, he complained that "it was my hopes [sic] to have been a soldier in this war, but I have only been a passport clerk."33 Hill's competence and nerve were essential components in any withdrawal plans, because for one to two days after the movement began, the Leesburg garrison would be outside its fortifications and too far away from the rest of the army to be reinforced if attacked. Covering the witharawal would be the responsibility of the army's cavalry brigade, commanded by James Ewell Brown "Jeb" Stuart, a Virginian who had just turned twenty-nine. Stuart had been a protege and special favorite of Johnston's when the two men had served as lieutenant and lieutenantcolonel of the lst Cavalry on the Kansas border in the

32 Stiles, Four Years, p. 67.

33 D. H. Hill to George Wythe Randolph, March 22, 1862, in OR, LI (part 2): p. 513; see also D. H. Hill to Joseph E. Johnston, May 25, 1885, in RMH. 
1850 's. The two men were reunited in June, 1861, when Stuart commanded Johnston's cavalry in the Shenandoah Valley and screened the movement to Manassas so successfully that the Federal commander did not even know Johnston's army had departed for several days. 34 He was flamboyant and seemed, at times, not to take the war any more seriously than a jousting tournament; his headquarters' camp rang with music and laughter throughout most nights, and was decorated in front with a captured Blakely rifled cannon, next to which was chained a trained raccoon. 35 But on duty, even his critics admitted that stuart was the consummate professional. Johnston described his cavalry commander to Davis as "a rare man, wonderfully endowed by nature with the qualities

34During the time that Johnston had served in the lst Cavalry in the $1850^{\circ} \mathrm{s}$, he had become embroiled with the regiment's commander, Colonel Edwin Vose sumner, in a feud so divisive that the war Department had been forced ultimately to split the regiment into two sections. Johnston's partisans in the regiment included Major William $\mathrm{H}$. Emory, Captain George B. McClellan, and probably First Lieutenant J. E. B. Stuart. Sumner had relieved stuart of the post of regimental quartermaster, and his promotion to captain was recommended by Johnston protege, Emory. Warner, Generals in Gray, pp. 296-297; Emory M. Thomas, Bold Dragoon, The Life of J. E. B. Stuart (New York: Harper and Row, 1986), pp. 40, 47, 60, 69-73; Robert Ransom to $W$. T. Walthall, March 23, 1879, in Rowland, Jefferson Davis, Constitutionalist, VIII: pp. 370-371; Govan and Livingood, Different Valor, pp. 21-23; Stephen W. Sear, George B. McClellan, The Young Napoleon (New York: Ticknor and Fields, 1988), p. 50; Albert Gallatin Brackett, History of the United States Cavalry (New York: Harper and Brothers, 1865), pp. 141-145, 177; Joseph E. Johnston to Flora Cook Stuart, September 28, 1861, in James Ewell Brown Stuart papers, Virginia Historical Society.

35thomas, Bold Dragoon, pp. 90-93. 
necessary for an officer of light cavalry. Calm, firm, acute, active, and enterprising, I know no one more competent than he to estimate the occurrences before him at their true value." 36

William Henry Chase Whiting commanded the de facto division of three brigades blockading the lower Potomac and guarding Johnston's right flank. The thirty-seven-year-old Mississippian had a well-deserved reputation as one of the best engineers in the army; he had not only graduated first in his class at west point in 1845, he had achieved the highest grades ever recorded. In June, 1861, as a major of engineers, he had been assigned to Johnston's staff as chief engineer of the Army of the Shenandoah, and planned the rail movement of the army to Manassas. Johnston and Whiting had been friends long before the war, and both that acquaintance and Johnston's professional evaluation of Whiting's skills led to his promotion to brigadier-general on July 21 , 1861.37 Johnston's choice of Whiting to supervise the line of the lower Potomac was an example of putting the right man in the right place. Whiting constructed multiple firing positions for each of his few heavy guns and kept them constantly rotating from one to the next, successfully disguising his weakness from the Federals across the river.

36 Joseph E. Johnston to Jefferson Davis, August 10, 1861 , in $\mathrm{OR}, \mathrm{V}:$ p. 777 .

37 Warner, Generals in Gray, pp. 334-335. 
These positions were fortified only from the front, and left in the direct line of sight of concealed field batteries placed further back from the river, so that if a Union raiding party ever seized one of his forward batteries he could drive them off almost immediately. 38 Johnston relied implicitly on Whiting's judgment as a military engineer, and thought highly of his administrative capabilities.

But for all his competence, Whiting could often become a management problem for his commander. Though personally popular with the troops, who dubbed him "Little Billy," he was notoriously pessimistic; Longstreet recalled of Whiting that "though of brilliant, highly cultivated mind, the dark side of the picture was always more imposing with him."39 This trait was aggravated by periodic bouts of severe depression and impulsive outbursts. Johnston occasionally chided him gently about the former, and repeatedly had to protect him from the consequences of the latter. In January, 1862, an intemperate letter from whiting to the war Department concerning the reorganization of Mississippi troops into exclusive brigades had aroused President Davis's wrath, and he had demanded that whiting be stripped of his

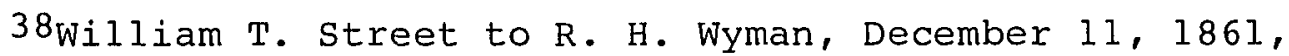
R. H. Wyman to Gideon Welles, December 12, 1861, R. H. Wyman to Gideon Welles, December 18, 1861, R. H. Wyman to Gideon Welles, March 11, 1862, in NOR, V: pp. 4-5, 7-8, 25.

${ }^{39} \mathrm{C}$. B. Denson, "William Henry Chase Whiting," Southern Historical Society Papers, Vol. XXVI (1898): p. 140; Longstreet, Manassas to Appomattox, p. 113. 
general's rank and demoted back to a major of engineers. Only some uncharacteristically diplomatic letter-writing by Johnston, and an abject apology he forced out of whiting, sufficed to save his commission.40 As Johnston sat down to plan his withdrawal on February 25, he was aware that Whiting had become despondent over the news of the fall of Fort Donelson, and the Mississippian's state of mind would have to figure prominently in his calculations. 41 Thus, the state of the senior command structure of the Department of Northern Virginia in late February, 1862 was hardly a cause for optimism. Ten generals had left the army in the past few months. None of Johnston's division commanders had ever marched, let alone fought, their divisions. His second-in-command was in precarious health. Three key commanders--Longstreet, Hill, and Whiting--were,

40 For Johnston remonstrating with whiting over the Mississippian's bouts with depression, see Joseph E. Johnston to W. H. C. Whiting, March 6, 1862, in OR, V: pp. 1091-1092; for the controversy over Whiting and the Mississippi brigade, see Judah P. Benjamin to Joseph E. Johnston, December 27, 1861, Joseph E. Johnston to Judah P. Benjamin, January 1, 1862, Judah P. Benjamin to Joseph E. Johnston, January 5, 1862, Joseph E. Johnston to Judah P. Benjamin, January 14, 1862, Joseph E. Johnston to Judah P. Benjamin, January 16, 1862, in OR, V: pp. 1011-1012, 1015-1016, 1020, 1028, 1035; Joseph E. Johnston to Samuel Cooper, January 12, 1862, Joseph E. Johnston to Samuel Cooper, January 13, 1862 , Joseph E. Johnston to Judah P. Benjamin, January 13, 1862, in LR-SW, M-618, Reel 8 ; W. H. C. Whiting to Samuel Cooper, January 5, 1862, in LR-SW, M-437, Reel 21; Joseph E. Johnston to Samuel Cooper, January 7 , 1862 , in LR-AIGO, M474 , Reel 27, W. H. C. Whiting to Samuel Cooper, January 5 , 1862 , in LR-AIGO, M-474, Reel 52 .

41 Joseph E. Johnston to W. H. C. Whiting, March 6 , 1862, in OR, V: pp. 1091-1092. 
for various reasons, deeply depressed. Jackson, Stuart, and Whiting were all in disfavor with the authorities in Richmond.42 The leadership of Johnston's department looked like that of an army recently defeated in battle, rather than one about to conduct a major movement. Nor could Johnston lean too heavily on his staff. He had written Davis in the letter of February 16 that he had "no competent staff," a condition that existed for three reasons. 43 First, neither west Point nor the prewar United States Army had emphasized staff training. Those officers who had somehow acquired staff experience, with few exceptions, preferred field command to a supporting role, and thus, most staff billets were filled either with untrained civilians, political appointees, or officers of such mediocre talent that they could not manage a higher commission. Finally, Confederate law followed United states precedent and parsimoniously restricted the number of staff officers even an army commander could appoint to ridiculously inadequate figures; Johnston's entire staff for the Department of Northern Virginia numbered just eleven

42 Davis criticized Stuart's performance in a letter erroneously dated February 6, 1862 when printed in OR; a careful. reading of Joseph $E$. Johnston to Jefferson Davis, March 3, 1862, reveals that the letter concerning stuart should carry the date March 6, 1862; Jefferson Davis to Joseph E. Johnston, February [sic] 6, 1862, Joseph E. Johnston to Jefferson Davis, March 3, 1862, in $\underline{\mathrm{OR}}, \mathrm{V}: \mathrm{pp}$. 1063-1064, 1088 .

43 Joseph E. Johnston to Jefferson Davis, February 16, 1862, in OR, V: p. 1074 . 
officers, supplemented by about a half-dozen aides-decamp. 44

As Civil War staffs went, Johnston's was about average. Five of the eleven--Colonel G. W. Lay, Acting InspectorGeneral; Colonel W. N. Pendleton, Chief of Artillery; Lieutenant-Colonel Robert G. Cole, Chief Commissary; Major E. P. Alexander, Chief of Ordnance; and Major Thomas G. Rhett, Assistant Adjutant-General--were West Pointers. Two of the others--Major A. J. Foard, Chief Surgeon and Captain E. J. Harvie, Assistant Adjutant General--were former officers in the regular army, but not Academy graduates. Taking the family connections of several of these officers into consideration, it could be argued, with some justice, that Johnston shared the vice of many other generals in staffing his headquarters: he surrounded himself with the sons of the Confederate elite, sometimes to the detriment of effective operations.

44 Return of the Department of Northern Virginia, December 31, 1861, in JJWM; Russell F. Weigley, History of the United States Army, enlarged edition (Bloomington, IN: Indiana University Press, 1984), pp. 240-241; Testimony of J.H. Simpson, July 26, 1860, Testimony of A. M. McCook, July 26, 1860, Robert C. Buchanan to J. C. Ives, August 3, 1860 , J. G. Barnard to J. C. Ives, August 21, 1860, Edward Otho Cresap ord to J. C. Ives, August 17, 1860, George G. Meade to J. C. Ives, August 30,1860 , in Thirty-sixth Congress, Second Session, Report of the Commission appointed under the eighth section of the act of Congress of June 21, 1860, to examine into the organization, system of discipline, and course of instruction of the United states Military Academy at West Point (Washington, DC: Government Printing office, 1860), pp. 85, 86, 236-237, 330-331, 334, 345; see also J. D. Hittle, The Military Staff, Its History and Development (Harrisburg, LA: Stackpole, 1961), p. 67. 
Lay and Rhett, among the professionals, had the most impressive family pedigrees of anyone on the staff. Yet, despite the fact that they had prewar experience commensurate with their positions in tine Department of Northern Virginia, both men turned out to be something of a disappointment at Johnston's headquarters. Lay was the son-inlaw of Supreme Court Justice and Assistant Confederate Secretary of War, John Archibald Campbell and the former aide of Lieutenant-General, Winfield scott. He was also one of the very few officers to resign from the United states Army as a lieutenant-colonel, and never achieve a general's star during the war. Though experienced, he lacked energy: War Department staff officer, Robert G. H. Kean, thought Lay possessed "sound principles of administration but . . . little vim in the head." He was also, by some reports, an alcoholic. 45 Thomas Rhett had both 1 ineal and marital ties

${ }^{45}$ Lay ended the war working as the Inspector-General of the Bureau of Conscription; even there, General Braxton Bragg criticized him as indolent. J. B. Jones, A Rebel War Clerk's Diary at the Confederate State Capital (New York: old Hickory Bookshop, 1935), II: pp. 249, 278; Mrs. Burton Harrison, Recollections Grave and Gray (New York: Charles Scribner"s Son's, 1911), p. 79; Edward Younger, ed., Inside the Confederate Government, The Diary of Robert Garlick Hill Kean (New York: Oxford, 1957), pp. 84-85; "List of Officers in duty in the Bureau of Conscription, August 29, 1864," endorsement, Braxton Bragg to Jefferson Davis, September 5 , 1864, in OR, Series 4, II: pp. 609-610; Elliot, West Point, pp. 370-371; Joseph H. Crute, Confederate Staff Officers, 1861-1865 (Powhatan, VA: Derwent Books, 1982), pp. 19, 104, 116; Francis Heitman, Historical Register and Dictionary of the United States Army, from Its Organization. . . to 1903 (Washington, DC: Government Printing Office, 1903), I : pp. 620 ; Jon L. Wakelyn, Biographical Dictionary of the Confederacy (Westport, CT: Greenwood Press, 1977), pp. 122-123; 
to the top of Confederate society: his uncle was South Carolina fire-eater, Robert Barnwell Rhett; his father-inlaw, Virginia politician Thomson F. Mason; and his wife's uncle, Confederate diplomat, James M. Mason. In April, 1861, Rhett had been a major and an army paymaster--the same position that James Longstreet resigned for a brigadiergeneralcy--and when he entered Confederate service, he did so at his old rank. Rhett's failure to advance with his peers seems to center around his personality; he was goodnatured company and a fine poker player, but hated paperwork, and only served on the staff as a personal favor to Johnston. There were, of course, persistent rumors that Jefferson Davis discriminated against him because of his uncle's persistent anti-administration stance. 46

C. Vann Woodward and Elisabeth Muhlenfeld, The Private Mary Chesnut, The Unpublished Civil War Diaries (New York: Oxford University Press, 1981), p. 28n; Woodward, Mary Chesnut's Civil War, pp. 28n, $121,125$.

46 Thomas Rhett was twice related to the Mason family: his brother had married his wife's sister. He was the only one of South Carolina's early brigadier-generals not to eventually receive an equivalent commission in the Confederate Army. See Charles E. Cauthen, South Carolina Goes to War, 1860-1865 (Chapel Hill, NC: University of North Carolina Press, 1950), p. 115; Laura A. White, Robert Barnwell Rhett: Father of Secession (New York: Century, 1931), p. 220n; Elliot, West Point, p. 417; Heitman, Historical Register, I: pp. 641, 826; Crute, Staff OffiCers, pp. 104, 178; Sorrel, Recollections, p. $\overline{31 ; \text { Woodward }}$ and Muhlenfeld, Private Mary Chesnut, pp. 65n, 150n; Wakelyn, Biographical Dictionary, pp. 314, 367-368; Burton J. Kendrick, Statesmen of the Lost Cause, Jefferson Davis and His Cabinet (Boston: Little, Brown and Co., 1939), pp. 237-240; Robert $\mathrm{E}$. Lee to Samuel Cooper, June 3, 1862, in LR-AIGO, M-474, Reel 3 . 
Among the rest of the professionals there were men from whom more might be hoped. Harvie was competent as a junior staff officer, possibly because he was doing more or less the same job that he had as a lieutenant in the 9 th U. S. Infantry. Cole had managed the food supplies at Manassas efficiently, but his authority did not extend to the meatpacking plant at Thoroughfare Gap. Only twenty-four medical officers of the United States Army resigned their commissions to enter the Confederate Army; as an assistant regimental surgeon with nearly eight years' experience, A. J. Foard represented a treasure to the new nation. As a testimony to his talents, in the very fine confederate Medical Department, Foard spent the entire war as Chief Surgeon in either the Department of Northern Virginia or the Department of Tennessee. Often, Foard's standard operating procedures were accepted by the surgeon-General for the entire Medical Department. Pendleton and Alexander represented equally bright spots on the professional side; both men were excellent administrators; between them, they would account for two of the four general officers' commissions ever granted to artillerymen in the Army of Northern Virginia. 47

47 Pendleton came under much fire later in the war because he was not a field commander, and was misplaced as a field artillery commander, so much so that Lee's reorganization of the reserve artillery prior to Gettysburg can be viewed as an attempt to limit the scope of his influence. Sorrel called him "a well-meaning man, without qualification for the high post he claimed. . . " But for the first few 
The four non-professionals were Major A. H. Cole, Inspector of Transportation; Major A. P. Mason, Assistant Adjutant General; Major Alfred W. Barbour, Chief Quartermaster; and Major B. P. Noland, the Commissary of Subsistence at Thoroughfare Gap. Cole, a loyal Johnston partisan, was energetic, outspoken, and assertive in carrying out his duties, regardless of any lack of training. He had no formal standing, as the war Department still declined to acknowledge the need for an Inspector of Transportation; so, though competent and active, his authority was seriously limited. 48 Mason was another case of an officer who

months of the war, dealing with the minutiae of organizing the artillery arm, scavenging for material, and setting up the foundation for the army's artillery, Pendleton was, perhaps, the perfect choice. Alexander earned a reputation for thoroughness, precision, and effectiveness at every assignment he ever accepted, from arranging the confederate signal service to Johnston's Chief Ordnance, eventually rising to Chief of Artillery for the First Corps, Army of Northern Virginia, earning the accolade of Lee"s "top tactical artilleryman" from historian Larry J. Daniel, although Jennings $C$. Wise found fault with Alexander's sometimes overly critical nature. See H. H. Cunningham, Doctors in Gray, The Confederate Medical Service (Gloucester, MA: Peter Smith, 1970), pp. 34, 161, 249; Richard B. Stark, "Surgeons and Surgical care of the Confederate states Army," Virginia Medical Monthly, vol. LXXXVIII, No. 10: p. 607; Warner, Generals in Gray, pp. 3-4, 234-235; Elliot, West Point, pp. 271-272, 287, 316-317, 408; Sorrel, Recollections, p. 114 ; Larry J. Daniel, Cannoneers in Gray, The Field Artillery of the Army of Tennessee, 1861-1865 (University, AL: University of Alabama Press, 1984), p. 135; Wise, Long Arm, pp. 76-78, 193-195; Crute, Staff officers, pp. 14, 21, 103, 115, 189; Heitman, Historical Register, I: pp. 426,503 .

48 See the arguments over the appointment of an Inspector of Transportation, cited in chapter Two. Cole eventually rose to become Inspector of Transportation for the Confederate Army. A. H. Cole is sometimes confused with R. 
probably acquired his commission as a result of family

influence. He was the son of Thomson F. Mason and, therefore, Thomas Rhett's brother-in-law. He was the son-in-law of Judge Campbell, which made him G. W. Lay's brother-inlaw, as well. Mason seems to have adapted well, but his assignment was primarily clerical. 49

There is considerable evidence that in February, 1862, Johnston already doubted the competence of both Barbour and Noland, which was an ominous sign, since the Quartermaster and Commissary Departments would be primarily responsible for evacuating the bulk of the goods stored near Centreville, Manassas, and Thoroughfare Gap. Neither man had any formal training for his post, and, in Johnston's opinion, neither showed much natural inclination toward his duties. 50

G. Cole. See Crute, Staff Officers, pp. 68, 103, 115, 125; Elliot, West Point, pp. 84-86, 316; Goff, Confederate Supply, p. 72 .

49 Mason's abilities as a staff officer can be inferred from the fact that he served almost continuously as the $A$. A. G. to army commanders from Johnston to Robert $E$. Lee to Johnston again and then John Bell Hood. Men without talent, no matter their family connections, tended to be relegated eventually to minor posts. Woodward and Muhlenfeld, Private Mary Chesnut, p. 65n; Stewart Sifakis, Who was who in the Civil War (New York: Facts on File, 1988), p. 436; Crute, Staff Officers, pp. 104, 116 ; Wakelyn, Biographical Dictionary, p. 314; Kendrick, statesmen, pp. 2377-240.

50 Johnston had not wanted to lose W. L. Cabell, his former Chief Quartermaster, and did not want Barbour to replace him; see the dispute over the position of Chief Quartermaster for the Department of Northern Virginia in Chapter Two. Whether it was Noland personally, or the Subsistence Department in general that Johnston distrusted, is not clear. What is evident from his correspondence and memoirs was a general belief that the department was riddled 
Unfortunately, it was these two officers of all his staff that Johnston was powerless to replace, because Confederate law gave the right of appointment for those positions to the bureau chiefs in Richmond: Johnston's implacable enemies, Myers and Northrop. 51

Thus, Johnston's staff represented that uneven mixture of talent and mediocrity peculiar to most Civil war era headquarters. Even if the staff could plan the army's movements, and the subordinate generals could direct them, just how well the troops could execute them was another critical question. The rebel soldiers inhabiting the camps in northern Virginia in February, 1862 were not yet the lean, fast-marching infantrymen that would outpace the Federal army time and again in the last two years of the war. Instead, Johnston's brigades, which were composed of men who had fought no more than a single, short battle (and only about half the soldiers present in February had done

with inefficiency, waste, and possibly corruption. That Johnston did not have the highest opinion of Noland can be inferred from the manner in which he limited his assignment during the withdrawal, discussed later in this chapter. There is also the fact that Johnston waxed--for him-eloquent on the merits of the army's first Chief Commissary and bemoaned his loss, and was also complimentary toward $R$. G. Cole, but did not mention Noland by name in his memoirs. Joseph E. Johnston to Jefferson Davis, August 16, 1861, Joseph E. Johnston to Jefferson Davis, August 17, 1861, Leroy Pope Walker to Lucius B. Northrop, September 7, 1861, Lucius B. Northrop to Leroy Pope Walker, September 9, 1861, in OR, V: pp. 789-790, 833, 835-836; Johnston, Narrative, pp. 67-68; Crute, Staff officers, p. 103.

$51_{\text {Goff, }}$ Confederate Supply, p. 21 . 
that), spent a winter drilling in the muddy fields alongside their camps. They naively believed that this experience would make them seasoned veterans. "A trunk had come with each volunteer," Johnston later bemoaned, recalling the extent of his soldiers' baggage.52 After spending four pages detailing the long list of items that Confederate soldiers thought essential to camp life in the first year of the war, Carlton McCarthy of the Richmond Howitzers writes in 1882 that

It is amusing to think of the follies of the early part of the war, as illustrated by the outfits of the volunteers. They were so heavily clad, and so burdened with all manner of things, that a march was torture. - . Subordinate officers thought themselves entitled to transportation for trunks, mattresses, and folding bedsteads, and the privates were as ridiculous in their demands. 53

When Johnston issued an order to reduce the troops' impediments to "light marching order," reluctance to part with the luxuries of camp life combined with an ignorance of military terminology to create tremendous confusion. What exactly was "light marching order"? Captain James Conner of the Hampton Legion recorded that the term meant, in his unit, "nothing but blankets and overcoats, and one day's rations, cooked, in their haversacks. The wagons followed

52Johnston, Narrative, p. 98; see also Jubal A. Early, War Memoirs; Autobiographical Sketch and Narrative of the War Between the states (Bloomington, IN: Indiana University Press, 1960), pp. 53-54.

53Carlton McCarthy, Detailed Minutiae of Soldier Life in the Army of Northern Virginia, 1861-1865 (Richmond: Carlton McCarthy and Co., 1882), pp. 16-20. 
with two days" rations and the cooking utensils."54

Brigadier-General Richard Taylor allowed his men a blanket, an extra shirt, an extra pair of drawers, two pairs of socks, and an extra pair of shoes; officers were allowed to strap a tent "fly" to their saddles. 55 The most tragicomical description of "light marching order" came from Colonel Thomas W. Thomas of the 15th Georgia, who had grappled with the problem a few months earlier:

I have had to decide how much a frying pan weighed, how much a skillet, how much a tin pail, how much a coffee pot--even if a credit was to [be] allowed because the handle was off. We were ordered to put ourselves in "light marching order'--what that was I had to figure out. Now allowing that the officers have theirs, it requires 2 lbs. of cooking utensils to the man, counting noncommissioned officers and privates--this will do--it is light marching order and less will not do. . . Cooking utensils was the most vexed question before me --my ten company commanders were at all points about it. . . Why sir a treaty can be made with England and France, yea with the North itself, with less diplomatic skill and talent than it required to settle that question of skillets. Besides this I settled the officer's clothing question, the knapsack question, the blanket question, the tent question, the mess chest question, the barrel question, and the extra arms question--all in four hours, among ten disputants, when
no two had similar ideas at the beginning. . . . 56 w

Besides troops, the sheer bulk of supplies and equipment possessed by the Department of Northern Virginia represented an almost insurmountable obstacle to rapid movement by Johnston's army. In Richmond, Johnston had

\footnotetext{
54 Moffet, Conner, p. 62.

55 Taylor, Destruction, p. 40.
}

56Phillips, Correspondence, pp. 582-583. 
emphasized to Davis and the cabinet that "saving our artillery \& stores, especially the heavy guns on the Potomac" would be "next to impossible."57 From Aquia to Evansport, Whiting deployed some forty-five heavy cannon, ranging in size from 8-inch rifled guns to 42-pound Naval smoothbores. Some of these guns had limited mobility, and these were the ones that whiting constantly maneuvered from point to point, but most of the heavy cannon were firmly planted on siege carriages which rendered them almost unmovable. Not only did whiting lack enough teams of draft animals to haul the guns off if field carriages could be improvised, but his horses and mules were among the weakest in the department. 58 Plainly, some other method of removing the guns would have to be found.

The question of saving Whiting's guns, as a logistical problem, paled by comparison to the mountains of supplies that had grown in the rear of the army. They collected all winter because Johnston did not have the wagons to distribute the goods. Considering every category of goods--from food and uniforms to ammunition and blankets--3,240,354 pounds of supplies had accumulated at Manassas Junction, despite Johnston's attempts in January and February to have

57 Entry of February 20, 1862, Bragg diary, p. 156.

58 Scharf, Confederate States Navy, pp. 95-99; W. H. C. Whiting to Theophilus Holmes, March 21, 1862, in OR, V: $p$. 529. 
deliveries from Richmond halted.59 on the army's immediate left flank, at Thoroughfare Gap, stood a meat-packing plant erected by the Commissary Department, over Johnston's objections. 60 on the train back from his Richmond conference, the General found in his discussions with Major Noland, that the surplus piled up both in warehouses and sitting in open fields was far greater than he had imagined. There were $1,510,819$ pounds of pork and $1,195,914$ pounds of beef which had to be evacuated out of union reach.6I Without even considering the supplies on hand at the division or brigade level, Johnston had to calculate just how to use his inadequate trains and a dilapidated railroad effectively enough to spirit away nearly 6,000,000 pounds of material!

Johnston's final problem was secrecy. Outnumbered nearly four-to-one, he could not afford to have Mcclellan divine his intentions and attack his columns during the vulnerable days after leaving their old entrenchments and before arriving at their new positions. A variety of threats existed. The Federals might combine an attack out of the Allegheny Mountains with an advance against Winches-

59 Johnston, Narrative, pp. 98-99.

60 Frank G. Ruffin to Lucius B. Northrop, January --, 1862, in OR, Series 4, vol. 2, p. 522; Johnston, Narrative, p. 99 .

$61_{B}$. P. Noland to Lucius B. Northrop, March 27, 1862, in OR, Series 4, I: pp. 1038-1039. 
ter to trap Jackson's division. Likewise, a thrust northwest from Alexandria, simultaneous with one southeast from Harper's Ferry, could potentially pick off D. H. Hill as he retired from Leesburg. Nor was the least of Johnston's fears a sudden amphibious landing on the lower Potomac, within hours of the time whiting deserted his batteries on the river. This would put Brigadier-General Joseph Hooker's division of Yankees in among Whiting's trains before his division had struggled more than a few miles down the muddy roads.

Only an impenetrable cloak of deception could cover Johnston's army through the first, critical hours of the retreat, and, as Johnston reviewed his position, it must have been obvious that such would be difficult, if not impossible, to achieve. He had just experienced the incredible security leaks which prevailed in the Confederate capital; no details confided to the government could be considered safe. Quite probably, Johnston guessed, even as he called his staff together, McClellan already knew that a retreat was being discussed. If not, the Federal commander would become aware almost as soon as the railroads began hauling supplies away from instead of toward Manassas; both Union and Confederate Iines were simply too porous to keep such an operation secret. Worse, still, Hooker's men on the Maryland side of the Potomac had been busily erecting new observation towers, which might spot any withdrawal the 
moment it began. 62 Once the army began to move, its only protection would be the screen provided by stuart's cavalry brigade--1,300 horsemen organized into five-and-one-half regiments--which could find itself opposed by more than 8,000 blue troopers. To make matters worse, no sooner had Johnston begun his preparations, than the Adjutant and Inspector-General attempted to strip him of one of his best regiments. 63 If removing the army from the frontiers of Virginia seemed to be a monumental task, removing it secretly must have seemed impossible.

Johnston met the challenges of mobilizing his department for a withdrawal behind the Rappahannock River with the same systematic efficiency that he had applied to maintaining the strength and morale of his army through the winter. He broke the problem down into its constituent parts, and assigned the best officer available to each particular job. Like a master chef, he stood back from detailed management of the preparations once everyone had been assigned his respective responsibilities, stepping forward only when it

62 Entry of February 20, 1862, Bragg diary, p. 156.

63 The regiment which the Richmond authorities attempted to withdraw was Colonel Robert Ransom's lst North Carolina Cavalry. "Abstract from the return of the Department of Northern, Virginia, General Joseph E. Johnston, C. S. Army, commanding for the month of February, 1862," "Abstract from the return of the Army of the Potomac, commanded by Maj. Gen. George B. McClellan, U.S. Army, for the month of February, 1862," in OR, V: pp. 732, 1086; Joseph E. Johnston to Samuel Cooper, February 27, 1862, Joseph E. Johnston to Samuel Cooper, March 3, 1862, in JJWM. 
was necessary to adjust the overall design. Johnston's administrative skill, assisted by a healthy dose of McClellan's usual timidity, resulted in a well-executed maneuver, unmolested by the Federals and accompanied by a minimal loss of supplies.

Even before his first staff meeting, Johnston tackled the problem of removing more than $6,000,000$ pounds of supplies. He directed Major Noland to proceed immediately to the meat-packing plant at Thoroughfare Gap and shut down the operation. Noland was then to begin removing the bulk of the meat from the store-houses to the loading platforms by the railroad, while shipping off what he could directly to Warrenton in his own few wagons. The empty buildings were to be burnt or disassembled. Agents were to be appointed and dispatched to Mount Jackson and Orange Courthouse to arrange for the reception and storage of the meat. 64 At the same time, Johnston delegated to Major Cole the responsibility for arranging special trains to Thoroughfare to pick up the tons of beef and pork. Noland assured Johnston that if enough trains ran to Thoroughfare, he could empty the facility in little more than a week. 65

To Lieutenant-Colonel Cole and Major Barbour fell the task of emptying the depots at Manassas the Centreville.

$6^{64}$. P. Noland to Lucius B. Northrop, March 27, 1862, in OR, Series 4, I: p. 1039 .

65 Ibid. 
Instead of continuing the system of assigning labor details on a revolving basis from each brigade in turn, they received a permanent working party detached from Ewell's division, to be under their exclusive control for the period of the evacuation. 66 Johnston distrusted both Barbour's competence and energy, so he limited the quartermaster's direct orders to preparing the stocks on hand for removal, and delegated the actual coordination of transportation to the two Coles and Brigadier-General Isaac Trimble. The Coles were to supervise the wagon trains and Trimble, with his brigade, to attend to loading the trains. The appointment of Trimble to that position represented Johnston's attention to detail: the Maryland brigadier had been a railroad engineer and administrator for thirty years. He could be expected to know how to handle any crisis which arose.67 Colonel Pendleton and Major Alexander were assigned complete responsibility for the preparation of their respective commands--the Reserve Artillery and the ordnance train--for the move, but were told that when the time came they would each be subordinated to one of the division commanders for purposes of security and marching

\footnotetext{
$66_{\mathrm{A}}$. P. Mason to Richard S. Ewell, March 2, 1862, in IS-ANVA.

67 Jubal A. Early to Jefferson Davis, September 22, 1877, in Rowland, Jefferson Davis, Constitutionalist, VIII: p. 3; Warner, Generals in Gray, p. 310; Abraham C. Myers to Joseph E. Johnston, March 7, 1862, in LS-QMG, T-131, Reel 8.
} 
orders. 68

The army's remote detachments, Johnston handled differently. Obviously, at his extreme distance from the main body, Jackson could not be closely supervised by Johnston's staff. Instead, Johnston relied on Jackson's already proven administrative competence, entrusting him with the general outlines of the operation and leaving him the details to work out by himself. Jackson was ordered on March 1 to prepare his command to move in case the main army had to fall back. Johnston's letter of instruction has not been found, but Jackson's response two days later made it clear that he understood his assignment to be "keeping between you and the enemy and at the same time opposing his advance along the valley."69 The logistics of preparing the Army of the Valley for eventual retreat were far simpler than those facing Johnston, both because his force was but a fraction of the size of the main army and because Jackson's staff had received some extremely useful--if uncomfortable --training for the conduct of rapid movements in the Romney operation. Without any fuss, Jackson had his sick and wounded gradually shipped back to staunton and Charlottesville, his main depot relocated from winchester to Mount Jackson, and the movable supplies of the army loaded onto

\footnotetext{
68 Special Orders No. 70 , Department of Northern Virginia, March 5, 1862, in OR, V: p. 1091.

${ }^{69}$ Thomas J. Jackson to Joseph E. Johnston, March 3, 1862, in OR, V: pp. 1087-1088.
} 
the wagons. Major John A. Harman, his profane Chief Quartermaster, had the wagon trains ready to move several days before Jackson would actually order the evacuation of Winchester. So effectively did Jackson plan his own withdrawal that no question ever arose in anyone's mind concerning a waste of supplies in the Valley District. 70 Holmes's task in the Aquia District was even simpler, from a logistical point of view. His main depot at Fredericksburg would still be within his lines after the retreat, and the only evacuation of men or supplies that he would have to accomplish was the withdrawal of Brigadier-General John G. Walker's brigade from Aquia and Potomac Creeks, and the destruction of a few miles of railroad. His most pressing task would be to safeguard Johnston's right flank-specifically Whiting's division--Exom a surprise Federal landing during the movements. Johnston decided, almost immediately upon his return from Richmond, to keep communication to Holmes down to an absolute minimum, because the North Carolinian had little more to do than react to direct orders. Besides, there was no telegraphic link between Centreville and Fredericksburg, which meant that any messages the army commander sent had to pass through

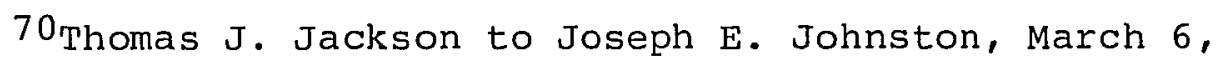
1862, in OR, V: pp. 1092-1093; Joseph E. Johnston to T. H. Williams, February 27, 1862, in JJWM; Robert G. Tanner, Stonewall in the Valley, Thomas J. "Stonewall" Jackson"s Shenandoah Valley Campaign, Spring of 1862 (Garden City, NY: Doubleday, 1976), p. 106 . 
Richmond, which now, more than ever, equated, in Johnston's mind, to an open breach of security. 71

The main question with Hill's Leesburg garrison was not logistical but strategic: to what point should Hill's troops march? Jackson clearly felt that Hill should witharaw into the Valley and join his division, and kept trying to bring Johnston around to this view even after the retreat had begun. He wrote his commander on March 8:

And now, general, that Hill has fallen back, can you not send him over here? I greatly need such an officer; one who can be sent off as occasion may offer against an exposed detachment of the enemy for the purpose of capturing it. But his command is mostly needed for holding the valley, and I believe that if you can spare Hill and let him move here at once, you will never have any occasion to regret it. The very idea of re-enforcements coming to winchester would, I think, be a damper to the enemy, in addition to the fine effect that would be produced on our troops, who are already in fine spirits. 72

There was undeniable logic in Jackson's argument, but in the end, Johnston decided that to dispatch Hill into the Shenandoah would run contrary to the general strategy behind the withdrawal that Davis had ordered: to bring as many troops as possible into supporting distance of Richmonã. Hill would rejoin the main army.

71Jefferson Davis to Joseph E. Johnston, September 5 , 1861, Robert E. Lee to Theophilus H. Holmes, March 14, 1862, in OR, V: pp. 830,1099 ; Theophilus H. Holmes to Samuel Cooper, March 9, 1862, in OR, LI (part 2): p. 497; Archer Anderson to W. H. F. Lee, March 11, 1862, in George Bolling Lee papers, Virginia Historical Society, Richmond, Virginia.

72 Thomas J. Jackson to Joseph E. Johnston, March 8, 1862 , in OR, V: p. 1095. 
In the meantime, his primary requirement was security. The Confederates at Leesburg were too few to quit their post without the advantage of surprise. Johnston advised Hill not to burn any supplies or facilities he might have to abandon not only because he probably could not do a thorough job of destruction, but also because the flames would attract enemy attention hours earlier than necessary. The retreating column was, however, to set fire to every railroad bridge along its line of march. So that Hill's troops could concentrate on swift movement instead of protecting bulky trains, Johnston had provisions for 3,200 men stationed along his route for immediate consumption. 73

Hill kept his own counsel until the last couple of days prior to the move. He even kept the patriotic ladies of Leesburg sewing flannel cloth into powder bags for the cannon until the very day of the evacuation. One sharp artilleryman, however, noticed that the ladies had been instructed to concentrate on producing smaller bags for field guns rather than the larger items, which would have been required for the handful of siege guns that Hill planned to abandon on the banks of the Potomac. 74

Besides the mountains of supplies at Thoroughfare and Manassas, Whiting's heavy artillery along the Potomac was

\footnotetext{
73Joseph E. Johnston to D. H. Hill, March 6, 1862, in OR, V: p. 1091 .

74 Stiles, Four Years, pp. 71-72.
} 
Johnston's other major concern. It was obvious that the understrength teams which had not been able to effectively transport even rations during the winter could not be expected to evacuate the supplies of an entire division, plus forty-five guns that each weighed somewhere between 8,000 and 17,000 pounds.75 The only other option seemed to be building rafts and attempting to float some or all of Whiting's artillery down the Potomac to the railhead at Aquia right under the noses of Federal lookouts. Whiting had been ordered to investigate that possibility as soon as Johnston had returned from Richmond. He consulted French, his chief of artillery, as well as Captain Frederick Chatard of the Confederate Navy and Colonel J. Johnston Pettigrew, commanding a regiment of North Carolina troops supporting many of the guns. Pettigrew believed that it might be physically possible to build rafts to carry the guns, but French and Chatard were adamant that the operation was not safe. "I deem the attempt to get them there [Aquia Creek] by water with our means, in the face of the enemy, impracticable and hazardous," French reported to whiting on February 24. "The steamers guard the river closely and the enemy from the opposite shore see everything at the batteries, and you may rest assured that by the time two-thirds of the guns are dismounted it will be discovered and an attack be made

\footnotetext{
75 Coggins, Arms and Equipment, p. 88 .
} 
by the steamers and from the guns opposite."76 Johnston received this information and passed it on to the President the next day, taking responsibility himself for the decision not to try to haul the guns off by land: "The land transportation would, it seems to me, require too much time and labor, even were the roads tolerable. They are not now practicable for our field artillery with their teams of four horses."77 The only thing that could be done was to try to destroy the guns in place so that, at the very least, the enemy would not benefit from their capture.

Meanwhile, as Johnston dealt with each of the peripheral issues of evacuation, the major impediment to tactical mobility--the $6,000,000$ pounds of supplies at Thoroughfare and Manassas--stubbornly refused to cooperate with the department commander's timetable. The primary reason was the inefficiency of the confederate railroads upon which Johnston was forced to depend. To remove $6,000,000$ pounds of cargo, based on an average carrying capacity of 16,000 pounds per freight car, required at least 375 cars. The Orange and Alexandria, which would have primary responsibility for evacuating everything--at least as far as Gordonsville--had begun the war with only 140 box cars and flat

$76_{\mathrm{W}}$. H. C. Whiting to Samuel G. French, February 24 , 1862, Samuel G. French to W. H. C. Whiting, February 24, 1862, in OR, LI (part 2): pp. 477-478.

77 Joseph E. Johnston to Jefferson Davis, February 25, 1862 , in OR, V: p. 1081 . 
cars. A significant number of these had been seized by the Federals in Alexandria and, since then, the slow, steady drain of wartime service without replacement parts had whittled the fleet down even further. Because the run from Manassas to Gordonsville passed over a single line of track with short and infrequent turn-outs for passing trains in opposite directions, scheduling was of paramount importance. 78

Still, difficult as the operation appeared, it should have been possible in the time Johnston allotted. With the average locomotive pulling fifteen freight cars, the entire stockpile of the Department of Northern Virginia should have required just slightly more than two trains a day during the period Johnston allowed for the evacuation. 79 But because of the reluctance of the confederate government to. assume complete control of railroads, even in an active military theatre, Johnston's staff officers found themselves compelled to negotiate with the civilian superintendents and engineers of the rail lines rather than simply requisitioning what they needed. Johnston himself had little more real control. 80

The result was that while Johnston's subordinates could

78 Johnston, Virginia Railroads, p. N1; Black, Railroads, p. 18; Turner, "Virginia Central Railroad at War," pp. $521-522$.

79 Black, Railroads, p. 18 .

$80^{\text {Ibid. }}$, p. 76 . 
prepare their supplies for timely removal, once that had been accomplished they could do little more than sit beside the loading docks and wait for a train to happen along. At Thoroughfare Gap, Major Noland began disassembling the meatpacking plant on February 22; tons of meat were "taken from the houses and placed on platforms for convenience of loading the cars. The force of hands was increased, and every possible arrangement on our part was made for sending off the property." But no trains came. Agreements made between Commissary Department agents and the superintendent of the railroad were not honored, and even Major cole could only manage to conjure up a total of forty-five usable freight cars in early March. Noland frantically commenced loading as much of the meat--now starting to spoil--as possible into his inadequate fleet of wagons, "although," Noland reported angrily, "many trains passed the point and several of them were entirely empty."81 The process of removing the meat actually delayed Johnston's withdrawal by several days, and continued even after the infantry had marched south. It ended only when Lieutenant Colonel Thomas T. Munford of the 2nd Virginia Cavalry, commanding the last rear guard of stuart's cavalry screen, ordered the remains of the stockpiles burned at noon on March 12, as the last

$81_{B}$. P. Noland to Lucius B. Northrop, March 27, 1862, in OR, Series 4, I: pp. 1039-1040. 
Confederate troops quit northern Virginia. 82

While the aroma of burning meat certainly pervaded the district for many hours, the scale of the waste and destruction has been distorted by participants and historians out of all proportion to reality. Jubal Early contended after the war that so much meat was lost that it "embarrassed us for the rest of the war, as it put us at once on a running stock."83 Johnston himself is often cited for his comment to Jefferson Davis on March 13, 1862 that "more than half of the salt meat at Thoroughfare was left there for want of the means of bringing it away." 84 comparing this ratio to the total amount of meat reported at the plant, Douglas Southall Freeman concluded that "more than 1,000,000 pounds were destroyed or given to farmers in the neighborhood."85 This has become the standard account of the affair, further expanded and exaggerated by later writers, until it reached tragi-comic proportions, exemplified by Robert Tanner's description in his Stonewall in the Valley: "Unable to empty an army packing plant, Johnston consigned a million pounds of beef to the flames, and his ill-fed retreating

\section{Ibid.}

83 Early, War Memoirs, pp. 54-55.

84 Joseph E. Johnston to Jefferson Davis, March 13, 1862, in OR, LI (part 2): pp. 1073-1074.

85 Freeman, Lee's Lieutenants, I: p. 140 . 
columns were tormented by the aroma of sizzling steak."86 Aside from the fact that every one of Johnston's soldiers except a few hundred cavalrymen had already passed Thoroughfare Gap before the fire started, nothing close to a million pounds of meat was burned. According to the official report of Major Noland--filed on March 27, two weeks after Johnston made his off-the-cuff estimate to the President--of the $2,706,733$ pounds of pork and beef at Thoroughfare on February $22,86.3 \%$ of it was successfully evacuated, leaving only 369,819 pounds beside the railway. of that, in the last two days before the burning, Noland estimated that at least 200,000 pounds was given away to neighborhood farmers, leaving only 169,819 pounds to be incinerated--a far cry from $1,000,000$ pounds. 87

Yet, a loss in excess of 389,000 pounds of meat seems, at first, like a very sizable one. But how important was it really? The total stockpile at Thoroughfare Gap represented $2,971,156$ daily rations of meat, figured at the often optimistic official standard of three-quarters of a pound of pork or one-and-a-quarter pounds of beef for one soldier for one day. Against the "Aggregate Present" (ration strength) for the Potomac District at the end of February, 42,860 officers and men, this amounted to a stockpile of 69.3 days

86 Tanner, Stonewall in the Valley, p. 98.

87 B. P. Noland to Lucius B. Northrop, March 27, 1862, in OR, Series 4, I: pp. 1038-1039. 
worth of meat. The total poundage either given away or burned amounted to no more than a 9.8 days' meat ration for Johnston's entire force; the supposed towering mountain of food condemned to the fire represented somewhere between three and five days" rations for the withdrawing soldiers, hardly enough to have seriously "embarrassed" the confederates for the rest of the month, let along the rest of the war. 88

The situation at Manassas Junction was equally, if not more, troublesome. General Trimble, Johnston's designee to handle the loading of supplies on the trains running south, found that no one respected his requests. Conductors complained about him to the Quartermaster General, Myers, and lesser officers from both the Quartermaster and the Commissary Departments felt themselves empowered to contradict him and appropriate space as they chose. Myers's unique solution to these problems was to rebuke Johnston for having given Trimble any authority, and to suggest to Jefferson Davis that Johnston was requiring too many trains! 89

Making the best of a bad situation, Trimble, Barbour,

${ }^{88}$ Ibid.; "Abstract from the return of the Department of Northern Virginia, General Joseph E. Johnston, C. S. Army, commanding, for the month of February, 1862," in OR, V: p. 1086; Goff, Confederate Supply, pp. 17-18n.

89 Joseph E. Johnston to Abraham C. Myers, March 2, 1862, in JJWM; Abraham C. Myers to Joseph E. Johnston, March 7, 1862, in IS-QMG, T-131, Reel 8; Abraham C. Myers to Jefferson Davis, March 7, 1862, in OR, V: p. 1093. 
and the two coles made the tough choices necessary to keep the operation even close to their commander's schedule. Any equipment already damaged, or rations that had spoiled, was shoved to the side; Trimble's men endeavored to load only the best materials on the trains. What they could not load, they passed out to the troops retreating through the town, or attempted to destroy. It is more difficult to pin down just what fraction of the total had to be abandoned, because no report as thorough as Noland's was ever filed respecting the evacuation of Manassas Junction. Only LieutenantColonel R. G. Cole's 1871 letter, cited by Johnston in his Narrative, provides any quantification for the total amount of supplies in the depot, and his account is questionable on two grounds. The first is the normal vagaries of hindsight, which make his ability to recall exact quantities nine years later somewhat suspect. The second problem is that cole's letter is phrased somewhat ambiguously, and it is difficult to tell whether or not his figure of $1,434,316$ pounds of supplies left behind includes the 369,817 pounds of meat at Thoroughfare or not. Cole's account does make clear that at least 443,000 pounds of bread, flour, and vinegar was abandoned because it had already spoiled. 90

Without specific confederate statistics, the best information on just what Johnston's army left behind can be

90Johnston, Narrative, pp. 98-99n; see also, Davis,

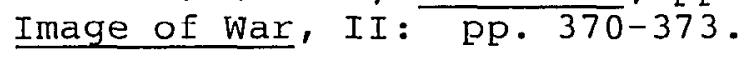


found in Federal reports. Just two days after Johnston evacuated Manassas, J. S. Potter entered the town with the first Union cavalry scouts. On March 12, he testified before the Joint Congressional Committee on the Conduct of the War concerning his observations:

Several hundred bazrels of flour, that they had attempted to destroy by burning lay there in a pile partly consumed. There was also a part of a train of cars there, partially destroyed. Among other things, I found a very complete printing office, with press, type, forms standing, and imposing stone, army blanks, \&C., and I should think a little paper had been printed there. The place was generally in a ruin. The depot was burned, some cars and a locomotive or two destroyed, a bridge blown up, several buildings destroyed, and altogether the most desolate scene, it seemed to me, that the human eye could rest upon. 91

More dispassionately, McClellan, who certainly had the best of motives to exaggerate the booty found in Confederate camps, reported to the secretary of war that he had found "many wagons," but only "some caissons, clothing, ammunition, personal baggage, \&c. [italics added]." In fact, he closed his description by noting that "the country [was] entirely stripped of forage and provisions."92 The context of Federal accounts, supported by numerous Rebel reminiscences, strongly suggests that most of what was abandoned at Manassas fell into one of three categories: spoiled rations, excessive personal gear, or broken down transport. 244 .

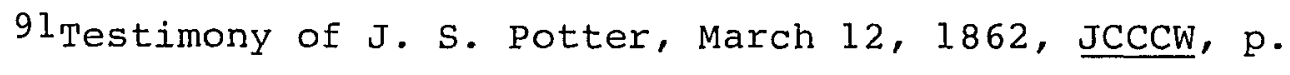

92 George B. MCClellan to E. B. Stanton, March 11,1862 , in $\mathrm{OR}, \mathrm{V}: \mathrm{p}$. 742 . 
From a logistical standpoint, therefore, Johnston's evacuation of Thoroughfare Gap and Manassas Junction deserves to be applauded rather than scorned.

The withdrawal has also been criticized on operational grounds. Freeman again censured Johnston's organization of the movement severely in Lee's Lieutenants:

The orders, which were issued piecemeal, were wretchedly drawn. In some instances, clarity was lacking. Marches were not precisely timed in relation to one another. Gen. T. H. Holmes, commanding at the northern terminus of the R. F. \& P. Railroad, actually was not informed of the withdrawal or told what to do with the troops or heavy guns on his sector. Neither the president nor the secretary of war was advised when the movement would begin or what the 1 ines of retreat would be. 93

Freeman's assessment, which has become the accepted standard account of the withdrawal, neglects many key points, and rests on very slender evidence.

Moving several columns simultaneously over roads that Captain James Conner of the Hampton Legion characterized as "awful; stiff clay, mud, and water; we stalled about every hundred yards," could not have been organized on a precise minute-by-minute timetable.94 Instead, Johnston followed the principal of decentralized authority that he had instituted during the winter. Early's division marched Eirst, followed by G. W. Smith and Longstreet on parallel roads. Smith was assigned to direct the movements of

\footnotetext{
93 Freeman, Lee's Lieutenants, I: p. 140 . 94 Moffet, Conner, pp. 84-85.
} 
Pendleton's Reserve Artillery and D. H. Hill's Leesburg garrison, while Longstreet supervised Colonel Walton's Washington Artillery Battalion, in addition to his own division. Ewell's division formed the infantry rear guard, with the dual assignment of supporting stuart's cavalry screen and scouring the country one last time for provisions and forage. 95

As with his efforts to maintain the strength of the army throughout the winter, the withdrawal from the frontier was marked through with little touches that bespoke Johnston's attention to detail. Extra tents had been ordered to shelter the troops turned out of winter cabins.96 small parties of pioneers were dispatched to improvise temporary crossings over rain-swollen streams.97 Each division had a bridge on the Rappahannock assigned to it, and when the troops arrived at the river, they discovered that the railroad bridges had already been planked over to accommodate wagons.98 They also found Johnston's previously prepared entrenchment and stacks of incendiary material

95 Special orders No. 70, Department of Northern Virginia, March 5, 1862, in OR, V: p. 1091; Taylor, Destruction, p. 38 .

96 Joseph E. Johnston to Abraham C. Myers, February 26 , 1862 , in JJWM; Abraham C. Myers to Joseph E. Johnston, March 2 , 1862, in LS-QMG, T-131, Reel 8 .

97 Taylor, Destruction, p. 36 .

98Abraham C. Myers to Thomas R. Sharpe, March 8, 1862, in LS-QMG, T-131, Reel 8; Dickert, Kershaw's Brigade, p. 93. 
piled neatly beside the right of way, just in case Federal pursuit might be quicker than anyone imagined.99 The entire maneuver, recalled Richard Taylor, "was executed with the quiet precision characteristic of General Johnston, unrivaled as a master of logistics."100 of course, the march was muddy and uncomfortable for the soldiers, who were neither accustomed to long marches nor yet resigned to the reality that active campaigning meant giving up the luxuries of camp life; but, this result was unavoidable and, in Johnston's eyes, probably not a bad thing.101

Whiting's withdrawal from the Potomac was not conducted under Johnston"s direct eye, but Whiting and French both received considerable supervision from Johnston in terms of the manner in which he wanted the evacuation conducted. Johnston spoke at length with each man on at least one occasion during the planning stages, and dispatched at least five letters of instruction to Whiting and three to French during the two weeks prior to the move.102

99McHenry Howard, Recollections of a Maryland Confederate Soldier and Staff Officer under Johnston, Jackson, and Lee (Baltimore: Williams and Wilkins, 1914), p. 68; Gary Gallagher, Fighting for the Confederacy, The Personal Recollections of General Edward Porter Alexander (Chapel Hill, NC: University of North Carolina Press, 1989), p. 72 .

100 Taylor, Destruction, p. 36.

101 Joseph E. Johnston to Jefferson Davis, March 13, 1862, in OR, LI (part 2): p. 1074.

102 French, Two Wars, p. 143; Joseph E. Johnston to $W$. H. C. Whiting, February 27, 1862, Joseph E. Johnston to $W$. H. C. Whiting, February 28, 1862, Joseph E. Johnston to W. 
These letters spelled out Johnston's intentions very clearly. Heavy guns to be abandoned were to be destroyed in place as quickly and quietly as possible. Whiting was instructed to phase his withdrawal from north to south: "If I telegraph 'It is time,' give your orders and move. Hampton should have a start of some hours. How would it do for him to start after dark, leaving pickets, and march to the road leading from Bacon Rice to your camp, bivouac, and march at your hour next morning."103 Johnston later admonished that, since his would be the first brigade in the department to withdraw, "Hampton must move off as cunningly as possible."104 Whiting, as the senior brigadier-general present, would supervise the movement until he reached the Fredericksburg area, where he would automatically come under the authority of Holmes. 105

Holmes, of course, had been intentionally left in the dark by Johnston until March 8 , the day the evacuation began. The decision to do so, while defensible on the

H. C. Whiting, March 5, 1862, Joseph E. Johnston to W. H. C. Whiting, March 6, 1862, in OR, V: pp. 1082-1083, 1085, 1090-1093; Joseph E. Johnston to Samuel G. French, February 27, 1862, Joseph E. Johnston to Samuel G. French, March 6, 1862 , W. H. C. Whiting to Samuel G. French, March 7, 1862, in OR, LI (part 2): pp. $481,487,488$.

103 Joseph E. Johnston to W. H. C. Whiting, March 5, 1862, in OR, V: pp. 1090-1091.

104 Joseph E. Johnston to W. H. C. Whiting, March 6, 1862 , in OR, V: p. 1092 .

105 Ibid. 
grounds of security and the limited participation of the Aquia District in the removal of troops and stores, certainly infuriated Holmes, who felt he had been misused, and complained immediately to the Adjutant and InspectorGeneral. But his very complaint indicated how thorough Johnston's orders, once they arrived, had been:

I was notified yesterday by General Johnston that he had ordered General French to abandon Evansport, and that he and General Whiting with their commands would immediately march on Fredericksburg. He advised me to place these troops beyond the Rappahannock and only to hold the Potomac with strong outposts, breaking up the wharf at Aquia and being ready to destroy the railroad from thence to Fredericksburg. As the outpost for the Potomac, I purpose to keep General Walker's brigade at Aquia as it is. I am at a loss whether to remove the guns from the batteries there, and will be obliged if you will inform me by telegraph. . . I have not been informed of the object of these sudden and, to me, very unexpected movements, and therefore can only strive to be ready for anything. . . . Since writing the above General French has arrived here and reports his brigade en route to Fredericksburg, that all the guns at Evansport have been or will be destroyed there before the rear guard leaves. . . 106

This letter, which is the mainstay of Freeman's contention that Holmes was ill-informed, actually indicates that the commander of the Aquia District received reasonably complete instructions in a timely fashion, although it is obvious that Johnston could have taken a few more pains to assuage his subordinate's ego.

Most likely, Holmes's aggrieved letter to General Cooper was the first formal notice that Richmond received of

106Theophilus H. Holmes to Samuel Cooper, March 9, 1862, in OR, LI (part 2): p. 497. 
the beginning of the movement. Johnston had been purposefully vague about his starting date in all his communications with Davis, because he worried that to be specific might result in further leaks that would cost him the several hours of secrecy he needed to extricate Whiting's and Hill's commands from their exposed positions. Aside from that consideration, since Johnston had been given positive orders to conduct the withdrawal--as opposed to the contingent orders Davis later claimed had been issued--he reckoned that setting the exact date was a decision completely within the army commander's purview.

Johnston always acknowledged that he did not communicate with Richmond until the movement was well under way: "The withdrawal from Centreville was not known in Richmond until after the army had taken its position on the Rappahannock."107 He sent his first official notice of the move four days after it began, on March 12, by which time Smith's, Longstreet's, and Early's divisions had all crossed the river, and both whiting and Hill had reached safe havens.108 In a purely military sense, Johnston's decision seemed justifiable. Whiting's evacuation was reported by Hooker within less than a day, Hill's retreat from Leesburg by Colonel John Geary in about twelve hours. Federal in RMH.

107 Johnston, draft of Narrative, in Box 2\%, Folder 3, 108 Joseph E. Johnston to Jefferson Davis, March 12 , 18662 , in $\mathrm{OR}, \mathrm{V}:$ pp. 526-527. 
cavalry uncertainly probed stuart's cavalry screen in the Manassas area on March 8 and 9.109 The Richmond Examiner published complete reports of the movement on March 11, even correctly inferring that the intent of the operation was to place Johnston's army in better position to participate in the defense of Richmond.110 Attorney-General Bragg's diary indicates that the withdrawal may already have been common knowledge in the confederate capital. 111

What Johnston overlooked, underestimated, or ignored was the very predictable result that his reticence had on the mind of Jefferson Davis.

109Joseph Hooker to Randolph B. Marcy, March 9, 1862, Philip Kearney to E. S. Purdy, March 9, 1862, John W. Geary to R. Morris Copeland, March 9, 1862, in OR, V: pp. 524, 537,549 .

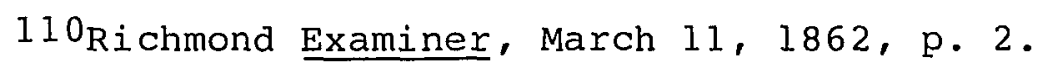

111Entry of March 10, 1862, Bragg diary, p. 178. 


\section{Chapter Five}

Enter Lee

Even as Confederate rear guards at Leesburg and Dumfries spiked the heavy guns and laid powder trails into their magazines, and Major Noland waited impatiently for the trains to cart away his mountains of beef and pork, two events occurred that would have distinct implications for the defense of Richmond. The first was the return of General Robert E. Lee to the capital city, after an absence of several months; the second was the sortie of the ironclad, Virginia, into Hampton Roads. The combination of the two served to confuse an already strained relationship between Joseph Johnston and Jefferson Davis.

General Lee rode the Richmond and Petersburg Railroad into the city, accompanied only by a single aide, twentyfour-year-old Captain walter H. Taylor. Lee's arrival was so unheralded that it is still impossible to determine with absolute certainty whether he entered the capital on Thursday, March 6 or Friday, March 7.1 what is clear is that as the train lumbered over the James River bridge below the smokestacks of the Tredegar Iron Works, Lee himself had

IFreeman, R. E. Lee, I: p. 628; Clifford Dowdey and Louis H. Manarin, ed., The Wartime Papers of Robert E. Lee (New York: Bramhall House, 1961), p. 124 . 
no idea why Jefferson Davis had abruptly summoned him to Richmond.

He was the son of Revolutionary war hero and Virginia Governor, "Light Horse" Henry Lee. He had served on Winfield Scott's personal staff in Mexico, earning three brevet promotions for gallantry; and, twice held the prestigious position of superintendent of the United states Military Acadeny. So when Lee had resigned his commission as colonel of the lst Cavalry, and turned down an offer of command of the Union Army in April, 1861, he went South to great expectations. 2 Virginia immediately conferred upon him command of the state's forces, Governor John Letcher citing his "talent, experience, and devotion to the interests of Virginia."3 "Whether we have the right of secession or revolution," said Jubal Early on the floor of the Virginia State Convention, "I want to see my state triumphant. I do believe that it will be triumphant under the lead of Major-General Lee."4 When Virginia formally entered the Confederate States, Jefferson Davis appointed Lee as third-ranking general officer in the army, behind only Samuel Cooper and Albert Sidney Johnston. 5

2 Warner, Generals in Gray, pp. 179-183.

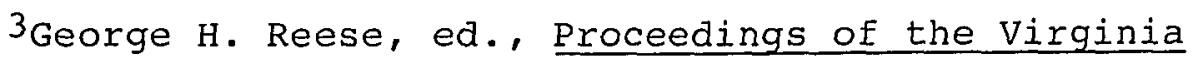
State Convention of 1861, February 13 - May (Richmond: $n$. p., n. d.), IV: p. 363 .

4 Ibid.

5 Warner, Generals in Gray, p. 180. 
But for Lee, who turned fifty-five in January, 1862, the first ten months of the war were filled with personal frustration and public criticism. "There is no place I can expect to be but in the field," he wrote his wife on May 2, 1861, anticipating that his administrative assignment to coordinate the defense of Virginia from Richmond would end with the establishment of the Confederate government. 6 He was mistaken; Davis retained him at his desk throughout the summer. Much to Lee's disappointment, his only contribution to the victory at Manassas was the necessary, but personally unsatisfying, task of forwarding troops and supplies to Johnston and Beauregard.

In August, the President allowed Lee into the field with an ill-defined supervisory command in western Virginia. At first, he was ebullient at the prospect of active duty, and sent his wife optimistic letters filled with descriptions of the country: "The mountains are beautiful, fertile to the tops, covered with the richest sward of blue grass \& white clover. The inclosed fields waving with the natural growth of timothy. . . This is magnificent grazing country. . . "7 But within a month, the realities of his position eroded his confidence and depressed his buoyant spirits. His outnumbered troops had few supplies, and

6 Robert $\mathrm{E}$. Lee to Mary Lee, May 2, 1861, in Dowdey and Manarin, Wartime Papers, p. 18 . p. 63 .

7Robert $\mathrm{E}$. Lee to Mary Lee, August 9, 1861, in Ibid., 
measles raged through their camps. His subordinates, politician-generals untutored in military operations, feuded with each other and ignored his instructions. Even nature seemed to have turned against him: "Rain, rain, rain, there has been nothing but rain," he complained to his son. "So it has appeared to my anxious mind since I approached these mountains." 8

Lee first discovered the biting criticism of the Southern press when the incompetence of Brigadier-Generals John Floyd and Henry Wise combined with Lee's own inexperience in coordinating field operations and resulted in an inglorious failure to drive the enemy off Cheat Mountain in mid-September. Beauregard might be hailed as the Confederacy's Napoleon and Jackson nicknamed "Stonewal1," but the sobriquets reserved for him were "Granny" and "Evacuating Lee."9 At first, he was stoic: "Everybody is slandered, even the good. How should I escape?"10 But, by october, the harshness of the Richmond papers had become so unrelenting that even the reserved Lee could not keep himself from reacting, at least to family and close friends:

I am sorry . . that the movements of the armies cannot keep pace with the expectations of the editors of the papers. I know they can

${ }^{8}$ Robert E. Lee to G. W. C. Lee, September 3, 1861, in Ibid., p. 70 .

9 Freeman, R. E. Lee, I: pp. 602-603.

$10_{\text {Robert }} \mathrm{E}$. Lee to Mary Lee, September 9, 1861, in Dowdey and Mandarin, Wartime Papers, p. 71 . 
regulate matters satisfactorily to themselves on paper. I wish they could do so in the field. No one wishes them more success than I do \& would be happy to see them have full swing. Genl Floyd has the benefit of three editors on his staff, I hope something will be done to please them.11

Jefferson Davis, however, had been fully aware of the handicaps unaer which Lee had attemptea to operate, and never allowed public opinion to shake his faith in those he trusted. In November, he recalled Lee from the rain-soaked mountains and dispatched him to oversee the coastal defenses of South Carolina, Georgia, and Florida. The assigninent did not bring a respite from either politicians or publishers, but did carry the unequivocal authority of a department commander.

He inherited the same dismal conaitions as did Johnston in northern Virginia: "The volunteers dislike work \& there is much sickness among them besides. Guns too are required, ammunition, \& more men."12 Faced with the prospect of defending hundreds of miles of coastline with fewer than 30,000 soldiers and inadequate artillery, Lee instituted a policy of defense in depth at critical points, abandonment of isolated or insignificant islands, and the maintenance of a mobile reserve along the coastal rail line. The key to his defensive system was to avoid direct confrontation with

\footnotetext{
p. 80 .

$11_{\text {Robert }} \mathrm{\Sigma}$. Lee to Mary Lee, October 7,1861 , in Ibid.,

12 Robert $\mathrm{E}$. Lee to G. W. C. Lee, January 19,1862 , in OR, VI: p. 106 .
} 
the "enemy's big boats;" "I am in favor of abandoning all exposed points as far as possible within reach of the enemy's fleet of gunboats \& of taking interior positions, where we can meet on more equal terms."13 several letters that Lee posted to Richmond during this period were critical in providing the President with his rationale for shortening the lines of the Confederacy on a much larger scale. 14

By the end of February, Lee's scanty resources had been seriously depleted by Davis's strategic redeployment of several of his regiments to Tennessee. Unhappily, and in the face of great local opposition, he ordered an almost complete withdrawal of Confederate forces from eastern Florida, and cut his garrisons along the Georgia and South Carolina coasts to the bone. Certain that the Federals would assault Savannah when they learned of his reduction in force, Lee went to that city in order to personally direct its defense. He was there on March 2 when an abrupt and unrevealing telegraph from the President arrived: "If circumstances will, in your judgment, warrant your leaving, I wish to see you here with the least delay."15

His state of mind, by this point, was gloomy, although

13 Robert E. Lee to Roswell s. Ripley, February 19 , 1862, in OR, VI: p. 394 .

14 See Chapter Three.

15 Robert E. Lee to Joseph E. Brown, February 22, 1862, Robert E. Lee to J. H. Trapier, February 24, 1862, Robert E. Lee to John H. Milton, February 24, 1862, Jefferson Davis to Robert E. Lee, March 2, 1862, in OR, VI: pp. 397-400. 
hardly desperate. The same day he received Davis's telegram, Lee had written to his daughter, Annie, that times "look dark at present, \& it is plain we have not suffered enough, labored enough, repented enough, to deserve success. - . Our people have not been earnest enough, have thought too much of themselves \& their ease, \& instead of turning out to a man, have been content to nurse themselves \& their dimes, \& leave the protection of themselves \& families to others." Though he could not dismiss the numerical superiority of the Federals--"against ordinary numbers we are pretty strong, but against the hosts our enemies seem to be able to bring everywhere, there is no calculation"--he was still combative: "if our men will stand to their work, we shall give them trouble \& damage them yet." 16

Lee delayed his departure just long enough to write out detailed instructions for Brigadier-General A. R. Lawton, commanding in Georgia, and to turn over the department to his deputy, Major-General John C. Pemberton. Leaving Savannah on March 3, he arrived in Charleston the next day, and took the train north for Richmond on March 5.17 Whatever speculation the Virginian made on the nature of Davis's orders, it is almost certain that he did not

16 Robert $\mathrm{E}$. Lee to Annie Lee, March 2, 1862, in Dowdey and Manarin, Wartime Papers, pp. 121-122.

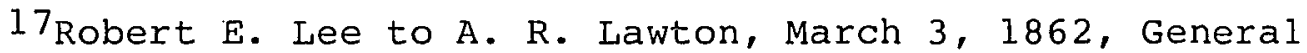
Orders No. 6, Department of South Carolina, Georgia, and Florida, March 4, 1862, in OR, VI: pp. 400-401; Freeman, R. E. Lee, I: p. 628 . 
anticipate that the President wanted to appoint him Commanding General of the Confederate Army .

Even had Lee been publicly expected in Richmond, the events of March 8 would have immediately overshadowed his entrance. Shortly after noon, the Confederacy's first ironclad, the converted frigate Merrimac--rechristened the Virginia--steamed slowly out of the Norfolk Navy Yard, down the Elizabeth River, and into Hampton Roads. The Virginia, recalled Captain John Taylor Wood, who commanded her aft gun,

was an experiment in naval architecture, differing in every respect from any then afloat. The officers and the crew were strangers to the ship and to each other. Up to the hour of her sailing she was crowded with workmen. Not a gun had been fired, hardly a revolution of the engines had been made, when we cast off . . . From the start we saw that she was slow, not over five knots; she steered so badly that, with her great length, it took thirty to forty minutes to turn. She drew twenty-two feet, which confined us to a comparatively narrow channel in the Roads; and, as I have before said, the engines were our weak point. ${ }_{18}$ sine was as unmanageable as a water-logged vessel.18

But she was also nearly invulnerable. In an action lasting four hours, Admiral Franklin Buchanan's ship rammed and sank the thirty-gun sloop Cumberland, pounded the fiftygun Congress into surrender with her rifled cannon, and ran the frigate Minnesota aground. Shot after shot ricocheted harmlessly off her angled iron plating. Watching the unequal fight from Ragged Island on the south bank of the

$18 \mathrm{John}$ Taylor Wood, "The First Fight of Ironclads," B\&L, I: p. 696 . 
James River, Brigadier-General Raleigh Colston found that a freak acoustical effect imparted an air of eerie unreality to the conflict: "to our amazement, not a sound was heard by us from the beginning of the battle. A strong March wind was blowing direct from us toward Newport News. We could see every flash of the guns and the clouds of white smoke, but not a single report was audible."19

The repercussions of the engagement, however, rang loud and clear. The Virginia "made obsolete the navies of the world," observed historian shelby Foote, "between noon and sunset of that one day. . . "20 The clash, editorialized the Richmond Examiner, "opens a new chapter in naval warfare, and marks a new era in the struggle which the south is engaged in."21 The effect of the news on the confederate capital, recalled one Richmonder, "was electrifying. . . . For days, this glorious engagement filled all hearts and minds. Nothing else was talked of. . . "22 The "gunboat fever" which had haunted the city on the James evaporated in hours; one newspaper commented wryly about residents who claimed to have been able to hear the sound of the battle. 23 713.

19R. E. Colston, "Watching the 'Merrimac," B\&L, I: p.

20 Shelby Foote, The Civil War, A Narrative (New York: Random House, 1958), I: p. 255 .

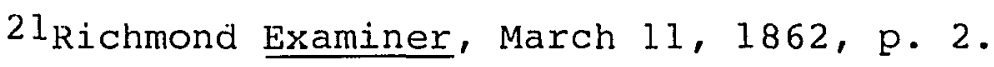

22 putnam, Richmond, pp. 111-112.

23 Richmond Examiner, March 11,1862, p. 2. 
Even the appearance of an opposing ironclad, the Monitor, the next day could not keep the optimistic citizens from visualizing a fleet of Virginias smashing the blockade and securing Southern independence.

Commanders, on the spot, predicted far less grand results. Naval officers knew that "at no time did the Virginia attain the power and capacity of a seagoing vessel or exceed the measure of usefulness originally designed for her--that of harbor defense."24 Major-General Huger, commanding at Norfolk, did not want to keep risking the ironclad in Hampton Roads, and suggested that she be limited to operating inside Norfolk Harbor. 25 writing from Yorktown, Major-General John B. Magruder predicted that "the Merrimac [sic] will make no impression on Newport News, in my opinion, and if she succeeds in sinking the ships lying there it would do us little or no good. . . ."26

But, despite these cautions, the first genuinely good news in months introduced an atmosphere of optimism into the Confederate high command. War Secretary Benjamin admonished Huger that "none of us are of the opinion that it would be

24 "Extracts from a general court-martial convened at the city of Richmond, VA., on the 5 th day of July, 1862, for the trial of Flag-Officer Josiah Tattnall, C. S. Navy," in NOR, VII: p. 793.

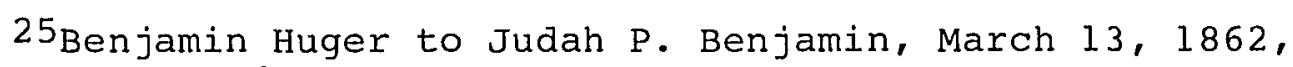
in $\underline{O R}, \mathrm{IX}: \mathrm{p} .65$.

$26 \mathrm{John}$ B. Magruder to Samuel Cooper, March 6, 1862, in OR, IX: p. 57; see also John B. Magruder to Robert E. Lee, March 20, 1862, in OR, XI (part 3): pp. 386-388. 
proper to lose the vast advantage resulting from the enemy's fright at the bare idea of the Virginia reappearing among the wooden ships."27 Naval Secretary Mallory, who fervently believed in the ironclad's ability to "make a dashing cruise on the Potomac as far as Washington" or even New York, where "she could shell and burn the city and the shipping," was extremely reluctant to give up his dreams. He pressed the ship's commander for the next month to make "a dash in York River, or even further. . . "28 General Lee was never optimistic enough to plan raids on Northern cities, but he also subscribed to the idea that the vessel could cruise into the York River and disrupt Federal shipping there.29 An inflated idea of the Virginia's capabilities probably influenced Jefferson Davis to believe that the ship could so effectively protect Norfolk and Yorktown that he could afford to transfer a substantial number of troops from eastern Virginia to the Department of Northern Virginia. He telegraphed Johnston on March 10 that "further assurances given to me this day that you shall be promptly and adequately reinforced, so as to enable you to

27Judah P. Benjamin to Benjamin Huger, March 15, 1862, in $\mathrm{OR}, \mathrm{IX}: \mathrm{p} .68$.

28 Stephen R. Mallory to Franklin Buchanan, February 24, 1862, Stephen R. Mallory to Franklin Buchanan, March 7, 1862, in NOR, VI: pp. 776-777, 780-781; stephen R. Mallory to Josiah Tattnall, April 12, 1862, in NOR, VII: p. 224.

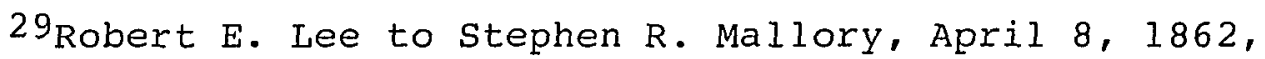
in NOR, VII: p. 761 . 
maintain your position. . ."30

Johnston, of course, had already begun his withdrawal

from the frontier, though Davis would not know that for several more days. The juxtaposition of his decision not to inform Davis of the start of the operation with Lee's appearance in Richmond and the brief elation at the early exploits of the Virginia, led to a further deterioration of relations between Johnston and the President. It also put Lee in a position to begin modifying Davis's plans for the defense of Richnond.

Exactly when Davis knew Johnston had evacuated his position is difficult to determine. He told Johnston that he had received his "first information of your retrograde movement" on March 15, though he later admitted that "I have had many and alarming reports of great destruction of anmunition, camp equipage, and provisions, indicating precipitate retreat; but, having heard no cause for such a sudden movement I was at a loss to believe it."3I yet Thomas Bragg's diary suggests that the cabinet discussed the issue on March 10: "Our Army of the Potomac is moving everything back. I fear it will be a bad business."32 That is consistent with the timing of Davis's telegram to

\footnotetext{
30 Jefferson Davis to Joseph E. Johnston, March 10, 1862 , in OR, $V:$ p. 1096.

31 Jefferson Davis to Joseph E. Johnston, March 15, 1862 , in $\underline{\text { OR, }} \mathrm{V}:$ p. 527.

32 Entry of March 10,1862, Bragg diary, p. 178 .
} 
Johnston the same day concerning reinforcements. And the President could hardly have been unaware of the operation after March 11, when the Richmond newspapers began to report the story.

The most thorough coverage came from the anti-administration Richmond Examiner, which perhaps not coincidentally had close ties to Joseph Johnston. 33 Characterizing the operations as "the judicious movements of our army," the Examiner detailed not only the extent of the retreat but correctly named Johnston's new line and even analyzed the strategic thinking behind Davis's decision to pull back: The grand movement of the army on the Potomac, in withdrawing from its offensive line on the river of that name, and assuming a defensive one on the line of the Rappahannock and Rapidan, places a new complexion on the entire war in Virginia. The policy of this change of position with reference to the intended attack of the enemy is obvious. The Potomac was the proper base for offensive operations ayainst Maryland and Washington city; but as a line of aefense for Richmond, or for general resistance, it is the most dangerous that could be held. . . .34

The paper further asserted that "General Johnston is understood to have the confidence of the administration to

33 Former editor R. W. Hughes had married Johnston's niece Eliza, the adopted daughter of John B. Floyd. The current editor, John M. Daniel, had served the first few months of the war on Floyd's staff. Robert M. Hughes, "Some Letters from the Papers of General Joseph E. Johnston, William and Mary Quarterly, Vol. XI, 2nd Series, No. 4 (October 1931): p. 320; Jedediah Hotchkiss, Virginia, Vol. III of Confederate Military History, expanded edition (Dayton, OH: Morningside Bookshop, 1975), p. 949 .

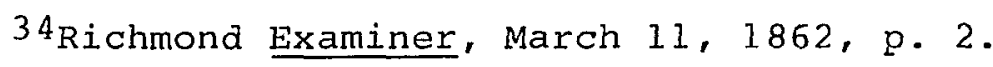


such an extent that, as a singular exception, he has the control and direction of military movements in his department entirely in his own discretion."35 While the paper's antagonistic stance certainly alienated the President, Bragg's diary indicates that topics covered in the Examiner were often discussed in cabinet meetings. It stretches credulity to the breaking point to believe that no one in the cabinet or his own entourage would have brought such an important story to the President's attention. 36

There were other indicators that the move had commenced. Theophilus Holmes's complaint about not having been informed of Johnston's imminent retreat was posted to Cooper on March 9, ana Lee's response, dated March 14, reveals that he already knew for certain that the march was under way. 37 Johnston himself mailed a letter announcing the change of base to Davis on March 12, although the President never acknowledged its receipt. 38

\section{${ }^{35}$ Ibid.}

36 The cabinet even discussed buying the Richmond Enquirer during early February, in order to have a newspaper friendly to the government being printed in the confederate capital. Robert G. Cleland, "Jefferson Davis and the Confederate Cabinet," Southwestern Historical Quarterly, Vol. XIX, No. 3 (January 1916): p. 216; entries for January 3, 1862, January 8, 1862, February 5, 1862, Bragg diary, pp. $94,104-105,135$.

37Theophilus Holmes to Samuel Cooper, March 9, 1862, in OR, LI (part 2): p. 497; Robert E. Lee to Theophilus Holmes, March 14, 1862, in OR, V: po. 1099-1100.

38Joseph E. Johnston to Jefferson Davis, March 12, 1862 , in $\mathrm{OR}, \mathrm{V}: \mathrm{pp} .526-527$. 
Given the evidence that Davis must have been aware of Johnston's action well prior to March 15, why did the President deny any such knowledge? Two possibilities suggest themselves. The first is that Davis had convinced himself that he never issued positive orders for the retreat, that it was only discussed as a contingency plan, and that Johnston had not been authorized to initiate it without further consultation. The preserved correspondence between Davis and Johnston from February 23 through March 6 is unfortunately quite ambiguous. Davis later cited it to prove he had never ordered or authorized the move, and Johnston quoted many of the same letters in his own memoirs to argue the opposite case. 39

Davis's first significant letter of the period, dated February 28, began by admitting that Johnston's appreciations of McClellan's intention to advance very soon "clearly indicate prompt effort to disencumber yourself of everything which would interfere with your rapid movement when necessary. . ." Following a discussion of potential defensive lines and the likelihood of reinforcing Johnston's army, the President returned to the topic of retreat:

In the mean time, and with your present force, you cannot secure your communication from the enemy, and may at any time, when he can pass to your rear, be compelled to retreat at the sacrifice of your siege train and army stores, and

${ }^{39}$ Jefferson Davis to Marcus J. Wright, October 14 , 1980, in Rowland, Jefferson Davis, Constitutionalist, VI: pp. 502-504; Johnston, Narrative, pp. 100-101, 482-483. 
without any preparation on a second line to receive your army as it retired. As heretofore stated in conversation with you, it is needful that the armies on the north, the east, and the proximate south of this capital should be so disposed as to support each other. With their present strength and position the armies under your command are entirely separated from the others.

Threatened as.we are by a large force on the southeast, you must see the hazard of your position, by its liability to isolation and attack in rear, should we be beaten on the lines south and east of Richmond; and that reflection is connected with consideration of the fatal effect which the disaster contemplated would have upon the cause of the confederacy.

Again, Davis commented on the need to save supplies and munitions, and then presented his analysis of Jackson's position in the Valley. 40

To this point, the letter resembled a strategic appreciation; but, in the last few Iines, the President included three sentences rife with the potential to be interpreted in different ways: "As has been my custom, I have only sought to present general purposes and view. I rely on your special knowledge and high ability to effect whatever is practicable in this our hour of need. . . Let me hear from you often and fully."4l

Honorable men could disagree concerning Davis's intentions in crafting those sentences, and be so sure of their reading that they never realized the ambiguity

40 Jefferson Davis to Joseph E. Johnston, February 28, 1862 , in $\mathrm{OR}, \mathrm{V}$ : pp. 1083-1085.

$4 \mathrm{I}_{\text {Ibid. }}$ 
inherent, therein. Obviously, Johnston had been given authority to maneuver his army as he saw fit if directly attacked, but could he order a retreat without enemy action? Johnston firmly believed that he had already been given instructions to conduct the withdrawal, and would have read those sentences as confirmation that the President had left the timing up to him. But, to Davis, the phrase "let me hear from you often and fully" may well have betokened a desire to be consulted prior to any non-emergency action. Unfortunately, each man was so sure of his own interpretation of the words that after February 28 neither bothered to make sure of the other's intentions.

Certainly the letter that Davis dispatched to Johnston on March 6 showed clearly that the President hoped that events would render the evacuation unnecessary: "I am making diligent effort to re-enforce your columns. It may still be that you will have the power to meet and repel the enemy. . . " Yet, Davis remained pessimistic, observing that "it is not to be disguised that your defective position and proximity to the enemy's base of operations do not permit us to be sanguine in that result. It is therefore necessary to make all due preparations for the opposite course of events." 42

42 Jefferson Davis to Joseph E. Johnston, February [March] 6, 1862, in OR, V: p. 1063. The argument concerning the dating of this letter is made in the notes of the preceding chapter. 
Though Davis ended the letter with the admonition to "please keep me fully and frequently advised of your condition," he coupled this with a reiteration of the army commander's latitude of action. "You will be assured that in my instructions to you I did not intend to diminish the discretionary power which is essential to successful operations in the field, and that I fully rely upon your zeal and capacity. . . "43 The letter, which probably arrived after Johnston had already begun the withdrawal, did not decisively clear up potential misunderstandings.

So it is possible that Davis simply did not credit the early reports of Johnston's withdrawal, because he could not believe that even Johnston would disobey what the President evidently considered direct orders. But it is also possible that Davis's response to the retrograde may have been colored by Lee's arrival in Richmond. For Lee, to Davis's great surprise, did not agree with his plans to reduce the length of Confederate lines in Virginia.

As soon as the President had developed his strategic concept of subordinating all operations in Virginia to the defense of Richmond, he had realized that a major command problem existed. The city itself was the logical central point from which to coordinate the movements of Johnston's department with those of Magruder, Huger, and the Richmond defenses. And while Davis undoubtedly believed himself

43 Ibid., pp. 1063-1064. 
competent to direct those armies, he was realist enough to understand that he could not do so while also performing as the country's chief executive. 44

So what were his choices? As much as the President admired Judah Benjamin personally and supported his tenure at the War office, he realized the folly of entrusting an untrained, if brilliant, civilian with what amounted to an operational command. Adjutant General Cooper had evidenced neither the talent nor the inclination to handle such an assignment. Johnston himself, as the ranking commander in the area, would naturally command any combined army; but, for several reasons, he was a poor choice for the overall responsibility. Probably most important to Davis was his belief that Johnston's presence was essential to the morale of the Department of Northern Virginia. "I had no wish," Davis remarked later, and in a slightly different context, "to separate him from the troops with whom he was so intimately acquainted, and whose confidence I believed he deservedly possessed."45 Less significant, but also presumably a consideration, was the friction that Davis recognized existed not only between himself and Johnston, but between the general and the secretary of War, Adjutant General, Quartermaster General, and Commissary General. 45 .

${ }^{44}$ Patrick, Jefferson Davis and His Cabinet, pp. 34, 4445 Davis, Rise and Fall, II: p. 88 . 
This fact argued against bringing him to Richmond, especially when combined with Johnston's apparent willingness to be openly friendly with the administration's political enemies.

In order for Johnston to be retained in command of his own army, yet subordinated to the orders of a supervising commander, Confederate law required that the new officer outrank him. Eliminating Cooper from consideration, only Albert Sidney Johnston and Robert $E$. Lee met that qualification. The other Johnston, deeply involved in the campaign to redeem the disasters in Tennessee, was obviously not a candidate for the post. Almost by default, as soon as Davis settled on his new concept for defending Richmond, to include establishing a theatre command, the choice fell on Lee.

None of the foregoing should be construed to suggest in any way that, to Davis, Lee represented Hobson's Choice. The President had unwavering faith in Lee's capacity as a commander, despite his superficially disappointing Confederate career. As an additional plus, Lee had been the original architect of Virginia's defenses, had planned most of the fortifications now under construction, and had a thorough knowledge of the terrain in northern and eastern Virginia.46 Davis may have also believed that the rank-

46 For the most detailed assessment of Lee's part in designing Virginia's defenses, see Freeman, R. E. Lee, I: pp. 479-486, 497-500. Davis made his opinion of Lee freely 
sensitive Johnston might be more amenable to accepting direction from an old friend.

The position that Davis planned for Lee was originally to be entitled "Commanding General of the Armies of the Confederate states," following the United States practice of depositing that title on the senior general officer in service at the nation's capital. This would allow Lee not only to control operations in Virginia, but also to deal with a variety of military matters throughout the confederacy--matters which were not readily resolved by civilians, as had been proved by the experience of having Leroy Pope Walker and Benjamin in the War office. Davis's friends in Congress introduced a bill to create the appointment. Even the President's opponents supported the measure, because they believed that it would take much of the management of the war out of his hanās. 47

The only problem which resulted was from the wording of the legislation, which Davis considered entirely too strong:

[T] $T$ he said officer shall be appointed by the President by and with the advice and consent of the senate. His usual headquarters shall be at the seat of government, and shall be charged, under the direction of the president, with the general control of military operations, the

known throughout Rise and Fall; see also Arthur Martin Shaw, ed., "Some Post-war Letters from Jefferson Davis to his former Aide-de-camp, William Preston Johnston," Virginia Magazine of History and Biography, Vol. II, No. 2 (April 1943): p. 152 .

47 Richmond Examiner, March 6, 1862, p. 2; Yearns, Confederate Congress, p. 108. 
movement and discipline of the troops, and the distribution of the supplies among the armies of the Confederate states, and may, when he shall deem it advisable, take command in person of our army or armies in the field. 48

It was the last 1 ine that gave Davis pause, for it put the assumption of field command at the general's discretion, not that of the President. Douglas Southall Freeman has suggested that this question of constitutional authority represented Davis's major objection: "strict construction of the organic law was a matter of political conscience, for which he would do battle even if the enemy's divisions were at the doors of the capitol."49

Compelling as this argument seems, Davis's veto message contained a second line of reasoning, which nay have come to him from consultation with Lee, or upon reflection on the personality of Johnston. "[N] general would be content to prepare troops for battle, conduct their movements, and share their privations during a whole campaign if he expected to find himself superseded at the very moment of action."50 Impatient to install Lee officially, Davis resolved his dilemma by using his own executive power on

48 "An Act to create the office of commanding general of the armies of the Confederate States," March 6, 1862, in OR, Series 4, I: pp. 997-998.

49 Freeman, R. E. Lee, II: p. 5.

50 Jefferson Davis to the Speaker of the House of Representatives, March 14, 1862, in OR, Series 4, I: p. 997; see also entry of Narch 14, 1862, Bragg diary, pp. 183184 . 
March 13 to order Lee "assigned to duty at the seat of government" and "under the direction of the President . . charged with the conduct of military operation in the armies of the Confederacy." 51

Lee did not welcome another desk assignment--"I cannot see either advantage or pleasure in my duties"--and the newspapers denigrated it as a reduction "from a commanding general to an orderly sergeant."52 Historians have tended to interpret Lee's distaste and the public derision of the position as supporting the view that Davis had nominated him for an essentially powerless advisory post. Freeman described the assignment thus: "Broadly speaking, Davis entrusted to him the minor vexatious matters of detail and the counseling of commanders in charge of the smaller armies. On the larger strategic issues the President usually consulted him and was often guided by his advice, but in no single instance was Lee given a free hand to initiate and direct to full completion any plan of magnitude. He had to work by suggestion rather than by command. - . .53 "The grandiose official designation was almost meaningless," contended Clifford Dowdey, "and he was advisor

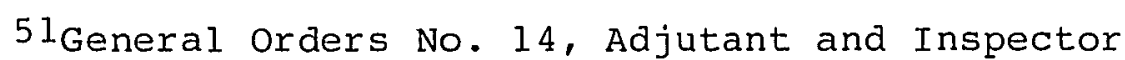
General's Office, March 13, 1862, in OR, V: p. 1099.

52 Robert E. Lee to Mary Lee, March 14, 1862, in Dowdey and Manarin, Wartime Papers, pp. 127-128; Freeman, R. E. Lee, II: p. 6 .

53 Freeman, R. E. Lee, II: pp. 6-7. 
in name only. From the beginning, Davis apparently regarded Lee as something of an executive assistant. . . "54 More recently, historians Herman Hattaway and Archer Jones have argued that "Davis created informally through Lee's appointment a modern chief of staff," an interpretation that credits Lee with more power than previously assumed, but still characterizes him as having no actual command authority. 55

This was not the case. From March 14 until June, 1862, Robert E. Lee styled himself and functioned as the Confederacy's commanding general. Davis referred to him as the "Commanding General" as did the secretary of War.56 walter Taylor described his duties as "military advisor to the President and as commanding general of all the armies in the field."57 Colonel T. A. Washington and Major A. L. Long, both of whom soon joined Lee's staff, habitually referred to him as the commanding general, and phrased letters in his

54 Dowdey and Manarin, Wartime Papers, p. 124.

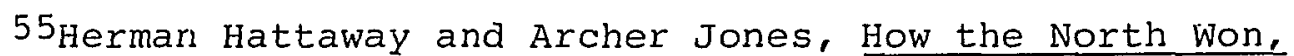
A Military History of the Civil War (Urbaña, IL: University of Illinois Press, 1983), p. 124 .

56 Jefferson Davis to the editor of the Louisville Courier-Journal, May 7, 1887, in Rowland, Jefferson Davis, Constitutionalist, XI: p. 553; George W. Randolph to Robert E. Lee, April 2, 1862, in LS-SW, Vol. 6-7.

57Walter H. Taylor, Four Years with General Lee (New York: D. Appleton, 1877), p. 43; see also walter H. Taylor, General Lee, His Campaigns in Virginia, 1861-1865, with Personal Reminiscences (Norfolk: Nusbaum, 1906), p. 38 . 
behalf as definitive orders and not requests. 58 Lee acted directly, and not at all as if he believed his title to be purely nominal. On his own authority he issued General Orders to the army, transferred troops from one department to another, and directed the Adjutant-General's office to settle organizational questions to his specifications. He signed the majority of his letters to the commanders of departments as "Robert E. Lee, General, Commanding."59 Following United States Army precedent, Lee did not seek to closely control the activities of Albert Sianey Johnston, because Johnston's commission outranked Lee's appointed position. But, in all his dealings with other generals, there is ample evidence that Lee's command authority was acknowledged throughout the army. General Cooper immediately began to forward all operational inquiries from field commanders to "General Lee, Commanding." The list of general officers who directly addressed Lee as the

58For example, see T. A. Washington to samuel Cooper, April 4, 1862, in LR-AIGO, M-474, Reel 30 .

${ }^{59}$ The correspondence preserved in OR is not necessarily representative of Lee's habits in signing his letters or with respect to his personal command authority. Many of the direct orders that he issued during the period under consideration were of a direct technical nature and not chosen for inclusion. See Robert $\mathrm{E}$. Lee to Benjamin Huger, March 18, 1862, Robert E. Lee to Joseph E. Johnston, March 18,1862 , Robert E. Lee to Theophilus Holmes, March 19, 1862, Walter $\mathrm{H}$. Taylor to Benjamin Huger, March 25, 1862 , Robert E. Lee to Gustavus W. Smith, April 1, 1862, in Robert E. Lee Letterbook, National Archives, Washington, DC (hereafter cited as Lee Letterbook); Robert E. Lee to Samuel Cooper, April 17, 1862, Robert E. Lee to George W. Randolph, April 20, 1862, in LR-AIGO, M-474, Reel 30. 
commanding general included P. O. Hebert in Texas, Henry Heth and Humphrey Marshall in western Virginia, Benjamin Huger in Norfolk, John Bankhead Magruder in Yorktown, John Pemberton in South Carolina, and even Joseph Johnston himself. 60

Clearly, Jefferson Davis did not recall Lee from the Atlantic coast to serve as a figurehead. Though Lee commanded "under the direction of the President," this qualification existed in both Davis's appointment orders and the vetoed legislation. In point of fact, the only diminution of power intended by the President was the prohibition against Lee assuming a field command without positive orders. To have emasculated the post would have defeated the intent of Davis to make Lee the direct supervising commander for the defense of Richmond.

The problem that developed in the triangular relationship between Davis, Johnston, and Lee was not, therefore, one of any ambiguity in Lee's authority. It was one of strategic conception: Lee did not agree with the premise upon which Davis and Johnston had agreed to conduct operations. Though necessity had required him to retire inland

60 For the best explanation of United States Army precedent for the conduct of the commanding general, see Robert F. Stohlman, Jr., The Powerless Position, The Commanding General of the Army of the United States, 18641903 (Manhattan, KS: Kansas State University, 1975), pp. 212, in which he discusses the position in the prewar army. For an early situation in which rank distinctions played a part in limiting the Commanding General's authority, see Weigley, History of the United States Army, pp. 170-172. 
to oppose the Federals along the coast, Lee consistently

disapproved of intentionally relinquishing territory in anticipation of an enemy offensive. He outlined his rationale for retaining positions as far forward as possible in a letter to Major-General John C. Breckinridge in March, $1864:$

The enemy generally, in his advances in the country, threatens several sections and rapidly advances against one, and concentration of our troops can only be made on a retired line. The longer, however, he can be held on an advanced line the more certain].y can concentration be made to oppose him in retired positions.61

There was an emotional as well as an intellectual component to Lee's disinclination to yield Virginia soil to the Yankees. Much of his personality was tied up with his identification as a Virginian; during the secession crisis, Freeman represents Lee as "determined from the outset that he would adhere to Virginia and defend her from any foe."62 Though it is probably incorrect to extend this argument as far as have Thomas Connelly and Archer Jones, and to assert that "one might infer that Lee was fighting for Virginia and not the south," there is little room to doubt that Lee felt a special obligation to contest the Federals grudgingly for every piece of the old Dominion's territory. 63

$6 \mathrm{l}_{\text {Robert }} \mathrm{E}$. Lee to John C. Breckinridge, March 23, 1864, in OR, XXXIII: p. 1239.

62 Freeman, R. E. Lee, I: p. 434 .

63 Connelly and Jones, Politics of Command, p. 46. 
Lee had even more personal reasons to reject strategic withdrawals. He had already lost his ancestral home at Arlington to Union occupation in 1861, which concerned Lee for financial as well as emotional reasons: "everything at Arlington will I fear be lost," he had written G. W. C. Lee in January, 1862, "\& it will take all the land at the White House \& Romancoke to pay the legacies to the girls with interest."64 But a Federal advance up York River would threaten White House directly, endangering not only the family's financial stability but also the safety of Lee's invalid wife.65 These were, however, secondary considerations. Lee, like many other Southerners, was willing to risk personal ruin and family disaster to achieve independence.

To Lee, Davis's plan to withdraw Johnston's army--and Jackson's detachment in the Valley--simply made little, if any, military sense, especially in the light of the Virginia's apparent ability to defend the mouth of the James River. After the war, he confided to Colonel John S. Mosby that he believed that Johnston's withdrawal had been a great mistake.66 Attorney-General Bragg noticed on March 10 that,

${ }^{64}$ Robert E. Lee to G. W. C. Lee, January 19, 1862, in Dowdey and Manarin, Wartime Papers, p. 105. p. 142 .

65 Robert $\mathrm{E}$. Lee to Mary Lee, April 4, 1862, in Ibid.,

66Charles Wells, Russell, ed., The Memoirs of Colonel John S. Mosby (Boston: Little, Brown, and Co., 1917), p. 375 . 
with respect to Johnston's withdrawal, Lee "had not been informed of it, I suppose, and to me it seemed he did not approve of the movement." 67

Lee's letter to Holmes on March 16 is also significant with regard to his appreciation of the military situation in Virginia. After observing that the muday condition of the roads would probably prevent a general advance by Mcclellan, he continued:
but that he will advance upon our line as soon as he can, I have no doubt. To retard his movements, cut him up in detail if possible, attack him at disadvantage, and, if practicable, drive him back, will of course be your effort and study. It is not the plan of the Government to abandon any country that can be hela, and it is only the necessity of the case, I presume, that has caused the withdrawal of the troops to the Rappahannock. I trust there will be no necessity of retrograding farther. The position of the main body of the Army of the Potomac seems to have been taken in. reference to the reported advance of the enemy up the Shenandoah Valley. A report from General Johnston of his plans and intentions has not yet been received. His movements are doubtless regulated by those of the enemy. . . [ [emphasis

For Lee, ten days after arriving in Richmond, and three days after his appointment to the army's senior post, to say that "it is not the plan of the Government to abandon any country that can be held," represented a complete reversal of Jefferson Davis's pronouncement to an astonished cabinet on February 19 that "the time had come for diminishing the

67 Entry of March 10, 1862, Bragg diary, p. 178.

$68_{\text {Robert }}$ E. Lee to Theophilus Holmes, March 16, 1862, in OR, V: p. 1103 . 
extent of our lines. . ." Thus, Davis's hard Iine in response to Johnston's withdrawal may well have been a reaction to Lee's strongly held opinion that strategic retreats were not only unnecessary but positively dangerous. If such was the case, then it would explain the next immediate controversy between Davis and Johnston: where to position his army. At the February 20 cabinet meeting, Davis ordered Johnston "to have a reconnaissance of the country in his rear with reference to another 1 ine, and it is probable the Rappahannock will be selected."69 But Johnston had trouble securing sufficient engineers to perform such a survey. 70 Besides, Davis's February 28 letter lead him to think that the position of his forces was a strategic, rather that a tactical, question; he would locate his army however close the President thought it should be to Richmond, and fortify that position as best he could.

Accordingly, on March 13, Johnston informed Davis that as soon as he had emptied the reserve depot at culpeper Court House "I shall cross the Rapidan and take such a position as you may think best in connection with those of other troops."71 The President asserted in 1865 that he

69 Entry of February 20, 1862, Bragg diary, p. 156.

70 Johnston, Narrative, p. 445.

71 Joseph E. Johnston to Jefferson Davis, March 13, 1862, in OR, LI (part 2): p. 1073 . 
took this as a declaration that Johnston was "ignorant of the topography of the country in his rear."72 Yet Johnston's letter itself contains strong evidence that such was not the case, for it included a well-conceived suggestion for the positioning of the army. "By proper management of the railroad it seems to me that, from the neighborhood of Gordonsville 20,000, or even 30,000, men rilight be thrown into Richmond in a single day." Centering his divisions on Gordonsville would also leave Johnston ready to dispatch troops quickly to support Jackson in the Shenandoah. 73

But the Presicient chose to interpret Johnston's letter in the narrowest possible terms, and essentially to repuaiate his own strategic design of the previous month. Instead of acknowledging his intent to bring Johnston's army within supporting distance of the capital, Davis wrote to the General :

I have not the requisite topograpinical knowledge for the selection of your new position. I had intended that you should determine that question. - . The question of throwing troops into Richmond is contingent upon reverses in the west and southeast. The immediate necessity for such a movement is not anticipatea.74

"To further inquiry from General Jonnston as to where

72 Jefferson Davis to James Phelan, February 18, 1865, in Rowland, Jefferson Davis, Constitutionalist, VI: $\mathrm{pp}$. 493-494.

73 Joseph ש̈. Johnston to Jefferson Davis, March 13, 1862 , in OR, II (part 2): p. 1074.

74 Jefferson Davis to Joseph E. Johnston, March 15, 1862 , in OR, $V:$ pp. 527-528. 
he should take position," Davis said in his memoirs, "I replied that I would go to his headquarters in the field, and found him on the south bank of the river, to which he had retired, in a position possessing great natural advantages."75 The narrative of this visit is extremely confusing, and many of the specifics are contradicted by other evidence. Davis implied that the visit began at Rapidan Station and continued to Fredericksburg only when Johnston expressed ignorance of the defensive potential of the lower part of the Rappahannock River. But Johnston and his staff consistently denied throughout the decades following the war that the President had ever visited the main body of the army.76 The dates and locations of the correspondence of Davis and Johnston, as well as casual references to the trip by Lee and Bragg, all suggest that the President took the train to Fredericksburg on March 21 and returned to Richmond in the evening of March 2.2.77 He did, however, travel to Fredericksburg via Gordonsville, but there is no direct

75 Davis, Rise and Fall, I: p. 465.

76 The testimony of Johnston's aides was omitted in the abriogement of his article from the Century Magazine for publication in B\&L; see Johnston, "Responsibilities," B\&L, $I:$ p. 257; Joseph E. Johnston, "Manassas to Seven Pines," Century Magazine, Vol. Xxx, No. 1 (May 1885): pp. 109-110.

$77_{\text {Robert }} \mathrm{E}$. Lee to Mary Lee, March 22, 1862, in Dowdey and Manarin, Wartime Papers, pp. 133-134; entries of March 21, 1862, March 24, 1862, Bragg diary, pp. 190-191. 
evidence that he visited Johnston's lines there.78 Even when he was collecting evidence for his memoirs, all the statements submitted to Davis in 1885 only mentioned a visit to Fredericksburg, not to the Rapidan.79

Specific itinerary aside, why did Jefferson Davis visit Joseph Johnston at all? Davis claimed that he did so to help Johnston select a satisfactory defensive position, a task made necessary because Johnston "had neglected the primary duty of a commander" in determining a safe line of retreat. If this was the case, it is difficult to explain why the President waited a week after receiving Johnston's inquiry to act. By the time Davis met Johnston, the army had already taken a permanent line on the south bank of the Rappahannock, complete with artillery emplacements on commanding hills and entrenchments around the bridges. Nor does it make sense for the Chief Executive of the Confederate states to spend two days surveying a defensive line forty miles north of the capital when he had just appointed a commanding general to supervise the operations of the armies in the field.

Contemporary letters and telegrams suggest that Davis

78 Ann Eliza Gordon to Douglas A. Gordon, March 22, 1862 , provided by Robert K. Krick, to whom I am indebted for the information.

$79 \mathrm{~J}$. T. Doswell to William S. Barton, August 10, 1885, John L. Mayre to William S. Barton, August 11, 1885, statement of Frank T. Forbes, August 15, 1885, in Rowland, Jefferson Davis, Constitutionalist, IX: pp. 377-378, 381383 . 
visited Johnston for another reason entirely. Federal advances in North Carolina and the first landing of troops from the Army of the Potomac at Fortress Monroe had convinced Davis--and Lee--that the main Union effort was to be made against either Richmond or Norfolk from the southeast. 80 The President went to see Johnston in order to gauge personally the feasibility of withdrawing some infantry and artillery from the Department of Northern Virginia to reinforce the other departments defending Richmond. He also needed to find a senior commander to accompany the troops.81 Fully aware of Johnston's sensitivity to having his army raided for general officers, Davis probably decided that it would be better to confront the issue in person.

Davis planned to have two brigades of infantry, each supported by an artillery battery, sent to the capital, from which they could be deployed with about a day's notice to North Carolina, Norfolk, Yorktown, or even back to the Rappahannock.82 Loath as he was to part with any of his soldiers, Johnston recognized that this sort of maneuver was

$80_{\text {Robert }} \mathrm{E}$. Lee to John B. Magruder, March 18, 1862, in OR, XI (part 3): pp. 385-386; Robert E. Lee to Jefferson Davis, March 22, 1862, in OR, LI (part 2): p. 512.

81 Jefferson Davis to Joseph E. Johnston, March 22, 1862 , in OR, V: p. 392; Robert E. Lee to Jefferson Davis, March 22, 1862, in OR, LI (part 2): p. 512.

82 Jefferson Davis to Joseph E. Johnston, March 22, 1862 , in OR, V: p. 392; Joseph E. Johnston to Samuel Cooper, March 24, 1862, in LR-AIGO, M-474, Reel 27. 
precisely why he had been withdrawn closer to Richmond, and he could not have argued against the logic of establishing a centrally located reserve, no matter how small.

Besides, Davis's plan allowed Johnston to rid himself of one general in whom he had little confidence, and advance another for whom he had great plans. Theophilus Holmes had never been a favorite with his commander, and his loud fits of pique at being kept in the dark during the withdrawal had greatly embarrassed Johnston. Since then, even though reinforced by Whiting's 7,000 men, Holmes maintained an incessant barrage to Richmond on the untenability of his position. 83 Unfortunately, his date of rank made him senior to every other Major-General in the Department of Northern Virginia except G. W. Smith. 84 But as a native North Carolinian, Holmes was a politically acceptable choice if a senior officer had to be sent to oppose Burnside. Johnston, therefore, was hardly unhappy about agreeing to let him go. Holmes's departure paved the way to advance Smith from division commander to the semi-independent command of the Aquia District. 85

Johnston and Davis seem to have had only one prolonged

83 Theophilus Holmes to Robert E. Lee, March 14, 1862, Theophilus Holmes to Robert E. Lee, March 15, 1862--Lee's correspondence in reply indicates that Holmes also wrote on March 16 and 17; see OR, V: pp. 1100, 1103, 1104-1105, 1106 .

${ }^{84}$ Warner, Generals in Gray, pp. 84, 141, 151, 192, 281. 85 Johnston, Narrative, p. 109. 
private conversation during the President's stay in Fredericksburg. That occurred around midday on March 22, when the two men rode north across the Rappahannock onto stafford Heights, accompanied only by a few aides, who discreetly fell back out of earshot. 86 What they discussed remains a subject for conjecture; neither man ever alluded to the conversation in letters or memoirs. But, at the end of the ride, President Davis did agree with General Johnston that the north bank of the river, and even the city of Fredericksburg, could not be held against a determined enemy attack. To one of Holmes's aides Davis quipped, "To use a slang phraze [sic], your town of Fredericksburg is right in the wrong place."87 Following this excursion, the president met with several delegations of townspeople; drafted the orders detaching Holmes, two brigades, and two batteries from Johnston's army; and caught the afternoon mail train back to Richmond. 88

Those two weeks, from March 7 to March 22, 1862, represented a definite, if undramatic, turning point in the Confederate defense of Richmond. Davis, once committed to a close defense of Richmond, was now vacillating between his

$86 \mathrm{~J}$. T. Doswell to William S. Barton, August 10, 1885, in Rowland, Jefferson Davis, Constitutionalist, IX: pp. 377-378.

87 Ibid.

88 Jefferson Davis to Joseph E. Johnston, March 22, 1862 , in oR, V: p. 392 . 
own concept and that of Lee, which envisioned keeping the Federals at arm's length for the longest practical time. Eventually, by mid-April, Davis would subscribe totally to Lee's idea of defending as much of Virginia as possible, instead of concentrating on the defense of the capital. But between March 22 and April 17, 1862, neither Davis nor Lee had complete control of Confederate strategy.

From Johnston's perspective, the result was a series of mixed messages from his high command. First, the President seemed to authorize his withdrawal from the frontier, and then he essentially repudiated it. Next, Davis told Johnston on March 15 that there was no immediate need to consider shuttling troops into the capital, and reversed himself a week later. Johnston represented the President during this visit in his Narrative as "uncertain," and his correspondence over the next few weeks indicated that he often wondered just who was in charge of operations in Virginia--Davis or Lee? 89

89 Johnston, Narrative, p. 109. 


\section{Chapter Six \\ Should Yorktown Be Defended?}

Sixty miles south of Norfolk, on March 20, 1862, the Federal transport, Delaware, deposited two companies of Colonel Thomas G. Stevenson's 24 th Massachusetts on the undefended wharves at Washington, North Carolina. The cannon had been removed from the batteries designed to protect the town, and the pilings sunk to obstruct the Tar River were too far under the water to keep back a shallowdraft transport. A drill-master of some repute in the prewar Massachusetts militia, Stevenson formed his men up and marched them smartly into the center of the town. At the court house "we nailed the Stars and stripes to a flagpole" while "the band played national airs and the men cheered." The Bay state soldiers then reshouldered arms, marched to their boats, and steamed back down to Pamlico Sound. The astonished residents of Washington had been "occupied" for about an hour, but the message was clear: the United States Navy could land troops almost anywhere along the unprotected confederate coast. 1

But as disquieting as was the news out of North

I "Report of Col. Thomas G. Stevenson, Twenty-fourth Massachusetts Infantry," March 23, 1862, in OR, IX: pp. 269-270; Sifakis, Who Was Who, p. 624 .

193 
Carolina, a more ominous storm was finally breaking; when Joseph Johnston and Jefferson Davis conferred in Fredericksburg, McClellan had already begun his much-delayed grand offensive. New York Times reporter william Swinton watched in awe as the Army of the Potomac struck its camps around Washington, D. C. and marched down to the docks at Alexandria and Annapolis. Four hundred assorted steamers and schooners, escorted by the North Atlantic Blockading Squadron, had been contracted to shift McClellan's entire army to Fortress Monroe as the prelude to his advance on Richmond. Swinton watched, day after day, as the troops tramped across the wharves and jammed themselves into the transports. The figures went down in his notebook as the Yankee soldiers boarded the boats: "one hundred and twentyone thousand five hundred men, fourteen thousand five hundred and ninety-two animals, forty-four batteries, and the wagons and ambulances, ponton-trains [sic], telegraph materials, and enormous equipage required for an army of such magnitude. . . ." 2

The movement of such a considerable host, spread out over several weeks, could not be concealed. Confederate pickets stationed near Gloucester Point on York River reported "Twenty-eight steamers, four floating batteries, [and] twenty-six sails of different kinds" heading for Fort

2 Swinton, Campaigns, p. 100 . 
Monroe on March 20.3 From Norfolk the same afternoon, a signal officer observed the arrival of "nineteen steamers loaded with troops and nine schooners" in Hampton Roads. 4 The flotilla seemed endless: "sometimes I counted several hundred vessels at the anchorage, and among them twenty or twenty-five large steam transports waiting for their turn to come up to the quay and land the fifteen or twenty thousand men whom they brought," recalled the Prince de Joinville. 5 A civilian reported to Magruder's pickets on March 24 that "the re-enforcements of the enemy that arrived at old point yesterday - . extend as far as the eye can observe toward Hampton. The force is immense--entirely out of my power to estimate." 6 From Yorktown, Magruder had no such qualms about guessing: he placed Federal numbers between Fortress Monroe and Newport News that day at 35,000. "Should he advance now he would carry all the strong points, and reenforcements would be too late," Magruder warned the Secretary of War. 7

The problem for the Confederates was that McClellan's

3 Charles A. Crump to John B. Magruder, March 20, 1862, in $\mathrm{OR}, \mathrm{XI}$ (part 3): p. 388 .

4 James S. Milligan to John B. Magruder, March 20, 1862, in $\underline{O R}, \mathrm{XI}($ part 3$):$ p. 388 .

5 de Joinville, Army of the Potomac, p. 34 .

${ }^{6}$ Charles Collins to John A. Winston, March 24, 1862, in OR, XI (part 3): p. 394 .

7 John B. Magruder to George W. Randolph, March 24, 1862, in OR, XI (part 3): pp. 392-393. 
intentions were far from clear. That the Union commander might be moving his entire army down the Chesapeake Bay was only one of a number of options which Davis and Lee had to consider. McClellan could be planning to deploy one or two corps to Fortress Monroe to attack Yorktown or Norfolk to draw Confederate reserves away from a projected advance from Manassas or Aquia Creek. Hampton Roads might also be just a temporary stopping place for divisions reinforcing MajorGeneral Ambrose Burnside's operations in Pamlico Sound, which threatened Norfolk from the South. Nor could a similar transfer of troops to augment the long-awaited Federal attack on Savannah be ruled out.

Lee had no choice but to entrain Holmes and his two brigades for North Carolina as soon as they arrived in Richmond, to prop up the sagging defenses and morale of the state. 8 Thus, Jefferson Davis's central reserve had been committed at the very start of the campaign. The remaining troops around Richmond were dispatched to Magruder, but this amounted to no more than two Alabama infantry reyiments which had been kept at the capital because they suffered from a high degree of sickness, and the cavalry battalion of the shattered Wise Legion. Lee also alerted Magruder and Huger to be prepared to reinforce each other in an emergen-

8 Robert E. Lee to Theophilus Holmes, March 23, 1862, Special Orders No. 67 , Adjutant and Inspector General's Office, March 24, 1862, in OR, IX: pp. 450-451. 
cy. 9 Once those moves had been made, Confederate forces in a long arc from the lower shenandoah Valley, extending along the line of the Rappahannock to Fredericksburg, down the York River to Gloucester and Yorktown, across the James to Norfolk, along the line of the wilmington and Weldon Railroad through North Carolina, and down the South Carolina and Georgia coasts, had been fully deployed. No point could be materially strengthened without a corresponding weakness at another, and no substantial field army could be collected without denuding some vital position almost completely

Such dispersal bothered the President, in part because it seemed like a return to the fully extended lines which had failed so miserably in Tennessee, and in part because he had become a believer in concentrating larger field armies for offensive blows. Lee, on the other hand, had a distinct propensity for conducting operations with separate columns, and never seems to have doubted his own ability to delay the enemy long enough with detachments to force him to reveal his objective. Once that happened, Lee would marshal his own forces to fight it out on ground of his own choosing. 10

${ }^{9}$ Walter H. Taylor to John B. Magruder, March 24, 1862, George W. Randolph to John B. Magruder, March 25, 1862, Robert E. Lee to Benjamin Huger, March 25, 1862, in OR, XI (part 3): pp. 393-394, 396-397.

10 John Morgan Dederer, "The Origins of Robert E. Lee's Bold Generalship: A Reinterpretation," Military Affairs, Vol. XLVI (1985): pp. 117-123; Connelly and Jones, Politics of Command, pp. 31-33; see also Louis H. Manarin, "Lee in Command: Strategical and Tactical Policies," (Ph.D. dissertation, Duke University, 1965). 
In this case, as soon as Lee became convinced that Mcclellan was intent on advancing up the York-James Peninsula, he commenced shuffling reinforcements to the Yorktown line. Douglas Southall Freeman described his policy as "a most interesting example of provisional reconcentration to meet an undeveloped offensive," and a "daring, piecemeal reconcentration" accomplished with the full support of Jefferson Davis. Freeman also asserted that Lee's concept had to be implemented in spite of the resistance of Johnston: "several days" exchange of correspondence . . convinced Lee that his old friend would not willingly fall in with his plan."ll Freeman's interpretation overstates the concord between Lee and Davis, and exaggerates the apparent friction between Lee and Johnston out of all proportion.

Davis, in fact, favored a proposal made by Magruder as early as March 21 that, given 30,000 reinforcements from Johnston's army, he would attempt to "crush the enemy, and perhaps with the assistance of the Virginia take Fort Monroe. . ."12 The President directed Lee to sound out Johnston on the feasibility of the plan, which the commanding general did on March 25, but in language that carefully disowned responsibility for the idea: "The President

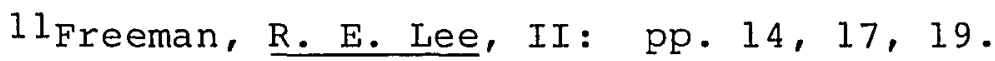

12 John B. Magruder to Robert E. Lee, March 21, 1862, in OR, XI (part 3): pp. 389-390. 
desires to know with what force you could march to reenforce the Army of the Peninsula or Norfolk. . . [F] rom the accounts received nothing less than 20,000 or 30,000 men will be sufficient, with the troops already in position, successfully to oppose them." [emphasis added] ${ }^{13}$ Lee knew that such a number of troops represented the majority of Johnston's force, and that for him "to organize a part of your troops to hold your present line, and to prepare the remainder to move to this city, to be thrown on the point attacked," would be tantamount to exposing central Virginia to the Federals.14 Later correspondence indicated that he had expected Johnston to object to such a proposition, which may have accounted for his repeated emphasis that the plan had been originated by Davis: "The object of the President is to prepare you for a movement which now appears imperative, as no troops are available but those of your army to meet the enemy concentrating on the coast." [emphasis added $]^{15}$

Lee wrote to Johnston concerning a wholesale shift of his army because Davis instructed him to do so. But a subsequent letter to Margurder clearly indicated that he did not think it yet time to begin decisively concentrating the

1.3 Robert E. Lee to Joseph E. Johnston, March 25, 1862, in $\mathrm{OR}, \mathrm{XI}$ (part 3): p. 397.

14 Ibid.

15 Ibid. 
Confederacy's forces. That letter, dated March 26, revealed that his own thinking ran along different lines. He began by observing that it was still impossible to tell whether the Union Army intended to attack Norfolk or advance on Richmond. Thus, he concluded, "until some conclusion can be drawn as to his point of attack it would be manifestly improper to accumulate at either the army to oppose him." [emphasis added] 16

But Johnston had no reason to suspect that Lee and Davis did not completely agree on proper strategy. Besides, Lee's March 25 letter accorded perfectly with what Johnston had understood to be Davis's original strategy for protecting Richmond: utilizing interior lines to tràsfer troops from one threatened point to another. After the departure of Holmes's two brigades, the Department of Northern Virginia deployed about 35,000 men between Fredericksburg and the Rapidan. Johnston, in a response that seems to have confounded Lee, quickly agreed to the premise of a massive transfer of his divisions: "If summoned to Richmond, I shall leave on this frontier only such a force as is now employed on outpost duty, for the mere purpose of masking the movement. This will enable me to take to Richmond at least 25,000 men. . . "17

16 Robert $\mathrm{E}$. Lee to John B. Magruder, March 26, 1862, in OR, p. 398 .

17 Joseph E. Johnston to Robert E. Lee, March 26, 1862, in OR, XI (part 3): pp. 400-401. 
The next day, in support of his belief that a movement away from his line could be successfully covered by a screening force with little risk, Johnston forwarded to Richmond an intelligence report from Ewell's Division. The letter contained several observations which indicated that the Federal forces around Manassas had no intention of advancing. "Soldiers are in good spirits, saying they do not expect another battle will be fought. . . They are working very slowly at Bull Run Bridge, apparently for effect. No other repairs are going on. . . [A]ll the soldiers now at Manassas look to be removed to another point." 18

Much to Johnston's surprise, a telegram arrived from Lee on March 27, ordering him not to move his army to Richmond as previously suggested, but to detach and forward 10,000 men to the Confederate capital.19 The decision made no sense to Johnston: "the division of the troops of this department made by the telegram of this afternoon leaves on this line a force too weak to oppose an invasion, and furnishes to the threatened point a re-enforcement too small to command success." But he obediently ordered 7,500 men from the main body and a brigade of 2,500 from G. W. Smith's

$18 \mathrm{~W}$. Stoddert to Joseph E. Johnston, March 26, 1862, in OR, XI (part 3): p. 401 .

19 The telegram has not been preserved, but Johnston's reponse is Joseph E. Johnston to Robert E. Lee, March 27, 1862, in OR, XI (part 3): p. 405. 
district entrained for Richmond. Johnston's only remonstrance against the order was a request that the authorities in Richmond reconsider their original plan: "I beg leave, with all deference, to suggest to the President the expediency of transferring to the point about to be attacked the whole available force of this department." 20

Again he forwarded intelligence reports that suggested that the Federals had no offensive intentions in northern Virginia or the Valley, beyond movernents designed to distract Confederate attention from the true point of attack. There was activity among the Yankees around Manassas, but Johnston's pickets were quite skeptical about any possibility of a Federal attack. General stuart concluaed from the reports of his cavalry outposts that Major-General Edwin V. Sumner's II Corps "made a great to-do crossing anä recrossing cedar Run, firing artillery at a few vedettes, and the like. . . I begin to think this is a mere demonstration." 21 Jackson reported that, after his abortive attack at Kernstown, "the enemy are still at Strasburg, and I see no indication of an advance."22

Lee responded on March 28 with two very confusing

20 Joseph E. Johnston to Robert E. Lee, March 27, 1862, in $\mathrm{OR}, \mathrm{XI}$ (part 3): p. 405 .

21 J. E. B. Stuart to Joseph E. Johnston, March 27, 1862 , in OR, XI (part 3): pp. 406-407.

22 Thomas J. Jackson to Joseph E. Johnston, March 27, 1862 , in OR, XII (part 3): p. 840. 
letters. The first indicated that when the dispatch ordering Johnston to detach 10,000 troops had been sent, Johnston's own letter agreeing to bring 25,000 had not yet been received in Richmond. The letter then placed upon Johnston the responsibility of deciding how many troops to send, but without giving him any indication of whether northern or eastern Virginia was considered to be the most threatened point. "[I]t is inferred that you apprehend to attack upon your line. If this inference is correct, you can commence the movement of your troops to this place." Next, Lee informed Johnston that President Davis had been responsible for reducing the number of troops to be transferred from 25,000 to 10,000, because he desired "to have a portion in position here to throw where required, while the balance might follow if necessary. . . ." Reiterating that it was still not possible to determine the ultimate objective of the Army of the Potomac, Lee ended by leaving the decision completely up to Johnston: "You can therefore, with this understanding of the case, proceed to forward the desired re-enforcements in part or whole, as in your judgment they can be spared from the defense of your 1 ine." 23

This letter left more questions unresolved than it answered. Having sent Holmes and his two brigades to North

23 Robert E. Lee to Joseph E. Johnston, March 28, 1862, in OR, XI (part 3): p. 408 . 
Carolina, was it the intent of Davis and Lee to reestablish a central reserve at Richmond and attempt to hold everywhere? If so, the idea seemed to contradict the earlier precept of throwing the entire army against one Federal advance. Nor did Lee ever explain why it would not be preferable to have a large force at Richmond, regardless of whether McClellan planned to attack Yorktown or Norfolk. "With this understanding of the case," Lee had said, Johnston could use his discretion in deciding whether to send 10,000 men or himself bring 25,000 to Richmond. But there was no such "understanding" to be derived from the letter--it included no hint of just how high a priority Johnston should assign to the Rappahannock line.

Lee's second letter could only have deepened Johnston's confusion. In it, Lee suggested that the greatest disaster that could happen would be the loss of the upper shenandoah Valley, which he believed would follow if Johnston were forced off his present line. The decision as to whether to detach 10,000 or march with 25,000 men was still to be Johnston's, but now Lee had added an entirely new constraint, protecting the rail line between Richmond and Staunton. "As a mode of expressing to you the limit which it is intended to affix I will cite the remark of the President, that the loss of the Central road and communication with the valley at staunton would be more injurious than the withdrawal from the Peninsula and the evacuation of 
Norfolk."24 This sentence would have stood out in Johnston's view as distinctly as if it had been written in red letters a foot high, because it represented yet another reversal on the part of Jefferson Davis. Just a month prior, the President had informea Johnston anā his cabinet that he planned to withdraw up the Shenandoah Valley as far as staunton as an integral part of his strategy to subordinate the defense of Virginia to the defense of Richmond. Now Johnston was being told that the loss of Norfolk--which necessarily entailed the loss of the shipbuilding capacity at the Navy Yard as well as the probable scutting of the Virginia--and a retreat up the Peninsula which would allow a Federal advance within a dozen miles of Richmond--were both preferable to the loss of his line on the Rappahannock. It almost seemed as if Lee intended to provide Jonnston with reasons not to move his army to Richmond.

In the wake of these letters, Johnston declinea to send any more of his origades to Richmond without specific orders; he was not willing to take the responsibility for denuding a line suddeniy declared critical by his commanding general.25 He possessed no estimates of the strength of the enemy on the Peninsula, or, for that matter, any information concerning the numbers of Magruder's army or the reliability

24 Robert i. Lee to Joseph E. Johnston, March 28, 1862, in $\mathrm{OR}, \mathrm{XI}$ (part 3): p. 409 .

25 phillips, correspondence, p. 593. 
of his defensive line. Nor did he feel that such a decision should be his to make--was the coordination of the several armies defending Richmond not why lee had returned to Virginia? He could only speculate about the reasons for the hesitations and vacillations of his superiors, and their inconsistencies did not relieve him from the responsibility to defend his own 1 ines until directed elsewhere.

Thus, Johnston spent the next few days consolidating his own defenses. Jackson's abortive attack on a Federal division at Kernstown on March 23 revealed the strength of Major-General Nathaniel Banks" Union forces in the lower Shenandoah. Johnston ordered Jackson to avoid further combat unless he could lure the enemy far enough south to make rapid reinforcement from the main army and a surprise attack with superior numbers feasible.26 Ewell's Division and Stuart's Cavalry Brigade, the army's only units north of the Rapidan River, had been left to picket as actively as possible, in order to avoid the Federals launching a surprise attack of their own. But it became daily more evident that no Union advance from Manassas was contemplated, and that the center of Johnston's line--four divisions under Lonstreet, Hill, Early, and D. R. Jones--was by far the most secure portion. Accordingly, Johnston delegated temporary command of

26 The letters from Johnston to Jackson are not in OR, but he briefed Davis on his orders in Joseph $\mathrm{E}$. Johnston to Jefferson Davis, March 26, 1862, in OR, XII (part 3): p. 838 . 
the main body to Longstreet and rode to G. W. Smith's headquarters at Fredericksburg. Smith's post was certainly the most exposed in the Department of Northern Virginia. Though his six brigades contained twice as many men as Jackson's Division in the Valley, his location was susceptible to an amphibious flanking movement from several angles. Union transports could ascend the Rappahannock as far as Fort Lowry; and, if McClellan gained access to York River, he could place a sizeable force on Smith's supply line. Combined with what was, at the time, the universally admitted indefensibility of the city of Fredericksburg from a frontal assault, Smith's men were in a precarious situation. Making matters worse, no direct telegraph line existed between Fredericksburg and Rapidan Station, which meant that any emergency communication had to pass through the hands of the telegraph operators in Richmond; those operators did not work at night.27

Johnston seems to have arrived in Fredericksburg about March 30, and remained there until April 5.28 He and Smith

27 Joseph E. Johnston to Robert E. Lee, April 4, 1862 , in OR, XI (part 3): pp. 419-420.

28 The last indication of Johnston's presence at Rapidan is A. P. Mason to Jubal A. Early, March 30, 1862, in OR, XI (part 3): p. 412. After that, the orders and correspondence indicate that Johnston had left Longstreet in command there. See J. E. B. Stuart to James Longstreet, April 2 , 1862 , G. Moxley Sorrel to D. H. Hill, April 4, 1862, in OR, XI (part 3): pp. 415-416, 420; Thomas J. Jackson to James Longstreet, April 3, 1862, Thomas J. Jackson to James Longstreet, April 5, 1862, Thomas J. Jackson to James Longstreet, April 5, 1862, in OR, XII (part 3): pp. 842- 
certainly spent a good deal of time discussing their ideas of the correct approach to confederate strategy. The army commander conducted several reviews of the troops in order to bolster morale.29 Yet the entire visit was pervaded by a sense that Johnston was simply marking time, waiting for Lee and Davis to decide how to use his army.

Curiously, between March 29 and April 2, Johnston neither sent any communications to Richmond nor received any from Lee. None appear in the Official Records, but that is hardly conclusive evidence; a great many of Johnston's letters and telegrams do not appear, therein. But both of Johnston's letter and books and his telegraph register are devoid of any messages to Richmond. Likewise, Lee's official letter book contains no missives directed to Johnston. Neither the files of the War Department nor those of the Adjutant and Inspector-General reveal any attempt to converse with the commander of the Department of Northern Virginia. The next communication between Lee and Johnston appears to have been a telegram from Lee, dated April 3,

844; G. Moxley Sorrel to Jubal A. Early, April 3, 1862, G. Moxley Sorrel to Jubal A. Early, April 3, 1862, G. Moxley Sorrel to D. H. Hill, April 3, 1862, G. Moxley Sorrel to D. H. Hill, April 3, 1862, G. Moxley Sorrel to Jubal A. Early, April 4, 1862, G. Moxley Sorrel to D. H. Hill, April 4, 1862, G. Moxley Sorrel to D. H. Hill, April 5, 1862, in OR, II (part 2): pp. 527-528; see also Dorsey Pender to Fanny Pender, April 3, 1862, in Hassler, General to His Lady, p. 131; Longstreet, Manassas to Appomattox, p. 65.

29Dorsey Pender to Fanny Pender, April 3, 1862, in Hassler, General to His Lady, p. 131 . 
1862.30 What explains these five days of silence, while every hour saw more Federal transports disgorge troops onto the docks at the tip of the Peninsula?

From Johnston's perspective, the answer is relatively simple: always economical with words, he often went days without writing to Richmond if he had no new information. Lee, confident that Johnston would report any significant developments, concentrated his attention entirely on the Peninsula. McClellan's deliberate caution in refusing to advance from Newport News until more than 50,000 troops had been landed actually kept Lee from figuring out his intent until early April. On April 1, he wrote to Holmes in North Carolina that "while making demonstrations . . on the Peninsula against General Magruder, his real object is to attack Norfolk. . . ."3l Until April 4, Lee's correspondence indicated that he still leaned toward believing Norfolk to be Mcclellan's primary target. Unsure, he waited and watched, delaying the orders which would send a significant number of troops to reinforce Magruder. 32

30 The existence of this telegram is inferred from Joseph E. Johnston to Robert E. Lee, April 4, 1862, in OR, $X I($ part 3): p. 419 .

$3 l_{\text {Robert }} \mathrm{E}$. Lee to Theophilus Holmes, April 1, 1862, in OR, IX: p. 455 .

32 Walter H. Taylor to John B. Magruder, April 3, 1862, Walter H. Taylor to John B. Magruder, April 3, 1862, T. A. Washington to John B. Magruder, April 3, 1862, Robert E. Lee to Joseph E. Johnston, April 4, 1862, in OR, XI (part 3): pp. 418-419, 420; Robert E. Lee to Benjamin Huger, April 3, 1862 , in OR, LI (part 2): p. 528 . 
He almost waited too long. General McClellan himself arrived at Fortress Monroe on April 2. Five divisions of the Army of the Potomac--about 58,000 men--had preceded him. On the morning of April 3, two columns of Federal troops marched toward Yorktown. Mauruder only cieployed about 10,000 Confeäerate soldiers to resist him, and immediately withdrew his most exposed outposts, and retired into nis ines at Yorktown. 33

It was a strong, but not impregnable, position. The Peninsula narrowed there to a width of a little more than six miles, two-thirds of which was blockea by the warwick River. The upper end of the river had been improved as an obstacle by opening several dams and flooding several acres of farmland. Heavy cannon at Yorktown, and Gloucester Point across the river, kept Federal gunboats at bay. Yorktown proper was enclosed in a large eartinwork, designed more to protect the batteries erected to blockade the York River than to hold the town against a Erontal assault. Between the fort and the flooded area were two partially completed redoubts connected by a line of hastily dug rifle pits. Outnumbered nearly six-to-one, with the trenches between the redoubts and the fort still incomplete, and many of the gun embrasures at Yorktown gaping empty, Magruder could not have held the line for more than a day against a determined

33 Swinton, Campaigns, pp. 100-102; "Reports of Maj.Gen. John B. Magruder, C. S. Army, commanding at Yorktown, \&C.," April 5, 1862, in OR, XI (part 1): pp. 403-404. 
$\operatorname{attack} .34$

Fortunately, McClellan did not even probe his lines until April 5. By that time, Lee had satisfied himself as to Federal intent and began rushing reinforcements to the Peninsula. Cadmus Wilcox's Alabama brigade, one of the two sent to North Carolina with Holmes; and Raleigh Colston's Virginia-North Carolina brigade from Norfolk were immediately ordered to the Yorktown line. 35 Also, on April 3, Lee telegraphed Johnston to send 10,000 more troops to Richmond. 36

This order put Johnston back onto the horns of a dilemma. On April 2 and 3, the enemy division at Aquia had begun demonstrating against G. W. Smith's outposts, conceivably as a prelude to an assault on Fredericksburg. 37 The message from Lee neither confirmed nor abrogated Johnston's previous grant of discretion with regard to detaching the troops, and it did nothing to cancel the earlier injunction

34 "Reports of Maj. Gen. John B. Magruder, C. S. Army commanding at Yorktown, \&C.," April 5, 1862, in OR, XI (part 1): pp. 403-404; John B. Magruder to Robert E. Lee, April 5 , 1862, in Or, XI (part 3): p. 422; see also OR Atlas, plates XIV-XIX.

35A. G. Dickinson to B. S. Ewell, April 6, 1862, John B. Magruder to Robert E. Lee, April 7, 1862, A. G. Dickinson to Cadmus Wilcox, April 7, 1862, in OR, XI (part 3): pp. $424-425,426-427$.

36Inferred Erom Joseph E. Johnston to Robert E. Lee, April 4, 1862, in OR, XI (part 3): pp. 419-420.

37Joseph E. Johnston to Robert E. Lee, April 4, 1862, in OR, XI (part 3): pp. 419-420. 
about the necessity of holding the Rappahannock. Johnston decided that his position needed clarification, and he immediately wired Richmond with the latest reports of enemy activity around Fredericksburg, and requested definitive orders. 38 In the meantime, he directed Longstreet to prepare the divisions of Hill, Early, and D. R. Jones for transfer to Richmond, but only authorized the Georgian to load Early's Division on the trains without specific orders. 39

His orders to Longstreet, delivered by courier, arrived promptly. The telegram to Richmond did not; the office there had been shut down for the evening. 40 Frustrated, Johnston dispatched an aide with a letter for Lee on the morning train to Richmond. By this time, he also knew that Jackson had reported the enemy advancing in the Valley, and had called on Longstreet for reinforcements. The question to which Johnston desperately needed an answer was this: did the Rappahannock or the Peninsula now have priority in the eyes of his superiors? If communications with the Shenandoah Valley were still the paramount consideration,

\section{${ }^{38}$ Ibid.}

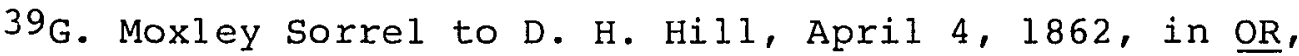
XI (part 3): p. 420; G. Moxley Sorrel to Jubal A. Early, April 4, 1862, G. Moxley Sorrel to D. H. Hill, April 4, 1862, G. Moxley Sorrel to D. H. Hill, April 5, 1862, in OR, LI (part 2): pp. 527-528.

40 Joseph E. Johnston to Robert E. Lee, April 4, 1862, in OR, XI (part 3): pp. 419-420. 
Johnston wanted Lee to know that the ioss of 10,000 more troops "will make us too weak to hold this line if pressed in front and on the left flank at the same time." Again Johnston emphasized that this was a decision that needed to be made in Richmond, not northern Virginia: "The President, however, will always have the means of judging where those troops are most needed." 41

Lee's reply represented the first unequivocal order that Jonnston had received in weeks: "The movement of the troops from your line must immediately be made to this place. E'nemy advancing in force from old point." 42 The transfer of troops was immediatly resumed, and Johnston telegraphed Lee on April 5 with confirmation and, very likely, a repeated suggestion that all of his troops, except a screening force, be employed on the Peninsula. 43 Lee responded by again asking Johnston whether he thought his own line safe from attack, apparently ignoring Johnston's consistent concern over the relative priority of the defense of northern and eastern Virginia. 44 Johnston saw the situation as one that required the Confederates to risk

$41_{\text {Ibiä. }}$

42 Robert E. Lee to Joseph E. Johnston, April 5, 1862, in OR, XI (part 3): p. 420 .

43 Inferred from Joseph $\mathrm{E}$. Johnston to Robert E. Lee, April 6, 1862, in OR, XI (part 3): p. 423.

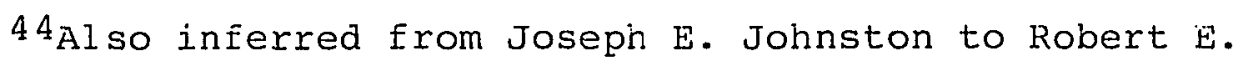
Lee, April 6, 1862, in OR, XI (part 3): p. 423. 
defeat in one area to assure a reasonable chance of victory in the another. "The invading army could not be defeated without. the concentration of the confederate forces; but they were always more divided than the much more numerous army of the enemy," he remarked years later in specific reference to another campaign, but the generalization reflected his thinking on the defense of Richmond as well.45 Lee, it seemed to Johnston, was the man in position to calculate the odds and weigh the risks; it was Lee who should make the critical decision where to concentrate and resist the Federals.

As diplomatically as he could, Johnston tried to prod his friend to a decision. He reported on April 6 that most of Sumner's II Corps seemed to have been withdrawn from Manassas, and that Banks was exerting no pressure on Jackson. He pointed out that the trains carried troops to Richmond so slowly that there remained abundant time for lee to consider a full redeployment of his army. He included a gentle reminder that the responsibliity for such a major strategic decision had to come from Lee: "I cannot here compare the state of affairs in my front with those of others, and cannot, therefore, decide understandingly whether troops are less needed here than elsewhere, which seems to me to be the question. He who directs military

\footnotetext{
45 The statement was made in reference to the Vicksburg campaign. Johnston, Narrative, p. 221.
} 
operations from information from every department can."46 McClellan probed the Yorktown line with two divisions on April 5. Magruder fired every gun he could train on the advancing Yankees, and paraded his outnumbered soldiers as ostentatiously as possible, hoping to bluff the Union commander into believing that he had far more than 11,000 men in his defenses. His imposture succeeded more effectively than he could have dreamed; within two days, Mcclellan had come to the conclusion that Yorktown was so "stongly fortified, armed, and garrisoned, and connected with the defenses of the Warwick by forts and entrenchments, the ground in front of which was swept by the guns of Yorktown," that the Army of the Potomac would have to take it by siege rather than assault. 47

Magruder, of course, was not privy to his opponent's decision, and expected hour by hour that McClellan would punch through his thinly held line. His correspondence with Lee revealed nerves strained to the breaking point. "I have made my arrangements to fight with my small force," he informed Lee on April 5, "but without the slightest hope of

46 Joseph E. Johnston to Robert E. Lee, April 6, 1862, in OR, XI (part 3): p. 423 .

$47 \mathrm{McClel}$ an erroneously believed that Johnston and his army had already arrived in Yorktown by April 7; see George B. McClellan to Edward M. Stanton, April 7, 1862, in OR, XI (part 1): pp. 11-12. 
success." 48 He required a minimum of 10,000 more troops to hold his line. By the evening of April 6, after two days of Federal probing, he reported gloomily that "they discovered a weak point, where numbers must prevail. . . Re-enforcements come very slowly, and will probably be too late."49 But as the succeeding days passed, McClellan showed no signs of aggressive intent. Howell Cobb's brigade from Norfolk arrived, as did those of Jubal Early, Richard Griffith, and Robert Rodes from the Department of Northern Virginia. Newly promoted to Major-General, D. H. Hill appeared and took over supervision of the Yorktown fortifications, freeing Magruder to concentrate on the remainder of his line. 50 Magruder began to recover his composure; by April 8, his letters had ceased to predict calamity. If he received enough field guns to secure Mulberry Island on the Warwick, Magruder informed Lee, "and if the Warwick line can be successfully defended . . Mcclellan is defeated, at least until the iron-clad vessels of the enemy shall be in

48 John B. Magruder to Robert E. Lee, April 5, 1862, in OR, XI (part 3): p. 422 .

49 John B. Magruder to Robert E. Lee, April 6, 1862, in OR, XI (part 3): p. 425 .

50 John B. Magruder to Robert E. Lee, April 6, 1862, Henry Bryan to Cadmus Wilcox, April 7, 1862, John B. Magruder to Gabriel Rains, April 8, 1862, Henry Bryan to Lafayette McLaws, April 8, 1862, John B. Magruder to George W. Randolph, April 11, 1862, in OR, XI (part 3): pp. 425, $426-427,432-433,436$. 
such numbers as to make forts useless." 51

But Magruder's days as an independent commander were numbered. Davis, Lee, and George Wythe Randolph--Benjamin's replacement as secretary of War--all agreed that the concentration of Confederate forces on the Peninsula required a more senior and perhaps less mercurial commander. Lee directed Joseph Johnston on April 8 to report to Richmond, bringing with him all the troops from the Department of Northern Virginia except for a force to mask the maneuver.52 Fourteen days had passed since the idea of transferring Johnston's army to oppose McClellan had first been proposed. During this time, there had been no aggressive enemy movement of any consequence in northern Virginia, while there had been a continuous Federal build-up on the Peninsula. Instead of decisively reinforcing Magruder to withstand the Army of the Potomac, the confederate high command had preferred to augment him in driblets: a regiment here, a brigade there. What saved the confederates was not Lee's "provisional reconcentration," for that came far too late to be effective, but the timidity of the Federal commander. Had McClellan been able to nerve himself for an attack even as late as April 7, he would probably have crashed through the Yorktown line, captured or dis-

51 John B. Magruder to Robert E. Lee, April 10, 1862, in OR, XI (part 3): pp. 435-436.

52Walter H. Taylor to J. H. Claiborne, April 8, 1862, in OR, XI (part 3): p. 430; Johnston, Narrative, p. 110. 
persed the Army of the Peninsula, and begun his march on Richmond.

By the time he received the latest instructions from Lee, Johnston had only two divisions left that could be deployed to the capital, those of Smith and Longstreet, plus Stuart's Cavalry Brigade and Pendleton's Reserve Artillery. Given discretion when called upon to send off earlier detachments, he had purposely withheld his most trusted subordinates and their troops, so that wherever he might be eventually deployed he would have them at hand. Now he instructed each to move his unit to Richmond, by foot as well as rail, in order to save time. 53

Meanwhile, Johnston spent a day or two arranging the forces which would maintain at least the crust of a defense in northern Virginia and the Shenandoah Valley. There was no question of weakening Jackson's three brigades in the Valley; although recruits and soldiers returning from their reenIistment furloughs had raised his strength to about 8,500 , his division was still not much more than a corps of observation.54 The same applied to Ewell's Division-composed of roughly 7,500 men in the three brigades--on the

53 Johnston, Narrative, p. 110; Longstreet, Manassas to Appomattox, p. 66 .

54 Tanner, Stonewall in the Valley, p. 152. 
middle Rappahannock. 55 Brigadier-General Charles W. Field remained at Fredericksburg with about 2,300 men when the other five brigades of G. W. Smith's Division retired, leaving only about 18,000 infantry between that city and the Valley.56 It was obviously not a sufficient number of troops to contest a full-scale invasion.

Yet Johnston did not plan for these three officers to conduct an entirely passive defense. What he had observed of Federal movements in northern Virginia convinced him that there was no coordinated plan of attack among the various Union commanders. Though, in the aggregate, much stronger than his own divisions, the Yankees often marched and countermarched in such haphazard fashion that on more than one occasion it might have been theoretically possible to concentrate equal or possibly superior Confederate numbers against a single Federal unit. 57 such a strategy was risky, but if it worked it promised to confuse and delay any Union advance much more effectively than could 18,000 infantry waiting passively in their rifle pits, strung out over more

55 Jubal A. Early, "Strength of Ewell's Division in the Campaign of 1862--Field Returns," Southern Historical Society Papers, Vol. VIII (1880): pp. 302-303.

${ }^{56}$ Charles W. Field to Robert E. Lee, April 20, 1862, in OR, XII (part 2): p. 434 .

57 Such had been the case when Johnston suggested that while he was in Federicksburg, Longstreet might detach two or more brigades to quickly reinforce Jackson for an attack. See Joseph E. Johnston to Jefferson Davis, March 26, 1862 , in OR, XII (part 3): p. 838; see also Johnston, Narrative, p. $\overline{110}$. 
than 200 miles.

Accordingly, Johnston instructed Jackson to retreat toward Swift Run Gap if the Federals approached, so that he would then be close enough to Ewell's position to call on that division for reinforcements and attack. He ordered Ewell to be ready to march to Jackson's assistance, and to reconnoiter the roads leading from the Rapahannock to the Shenandoah. In the meantime, Johnston also authorized Ewell to make any local attacks on isolated Union forces in his own front that he thought might be successful. Johnston knew that this sort of defense required that his subordinates have the maximum amount of latitude to make their own decisions without wasting the time to request permission for every proposed movement. "The question of attacking the enemy in front of you is one which must be decided on the ground," he told Ewell. "It would be well to arive him away; you would be freer to aid Jackson, and it might make, perhaps, a diversion in his favor." Again he emphasized that each division commander was free to make his own tactical decisions within the overall framework in which he had left him to work: in committing to an offensive move "you have to consider relative forces, the enemy's position, and the facilities for crossing the river. If these are favorable, counted with our confidence in the superiority of our troops--if you feel confident after considering these 
things, attack."58 Accurate intelligence was essential to the success of an attack and would determine the ability to retain central Virginia and the middle Shenandoah Valley, as well as the survival of his two outnumbered divisions. For this reason, Johnston left more than half of his cavalry and some of his finest outpost commanders in northern Virginia. 59

Johnston had probably received his orders from Lee sometime in the evening of April 8. Organizing the transfer of two divisions and the cavalry brigade, and arranging the defense of Jackson, Ewell, and Field, took him about two days. He arrived in Richmond either late on April 11 or

\footnotetext{
58 Thomas J. Jackson to Richard S. Ewell, April 14, 1862, Joseph E. Johnston to Richard S. Ewel1, April 17, 1862, in OR, XII (part 3): pp. 848, 852 .

${ }^{59}$ Stuart took with him to the Peninsula the lst Virginia Cavalry, the 4 th Virginia Cavalry, and the Jerf. Davis (Mississippi) Legion; the Hampton (South Carolina) Legion cavalry accompanied G. W. Smith's Division. Remaining in northern Virginia were the 7 th Virginia Cavalry (Colonel Turner Ashby) in the Valley, about 1,000 strong; the 2nd Virginia Cavalry (Lieutenant-Colonel and then Colonel Thomas T. Munford) and the 6th Virginia Cavalry (Colonel 'Thomas S. Flournoy) with Ewell's Division, about 900 strong in total; and the 9th Virginia Cavalry (Lieutenant-Colonei and then Colonel W. H. F. Lee) with Fiela's Brigade, probably about 400-500 strong. Thus, Johnston left approximately 2,300 cavalrymen in northern Virginia--or about 1,000 more than he took with him to Yorktown. See Tanner, Stonewall in the Valley, $\mathrm{p}$. 152; Jubal A. Early, "Strength of E'well's Division in the Campaign of 1862--Field Returns," Southern Historical Society Papers, Vol. VIII (1880): pp. 302-303; "Organization of the Army of Northern Virginia, commanded by General Joseph E. Johnston, on the Peninsula, about April 30, 1862," in OR, XI (part 3): p. 484. Charles W. Field to Robert E. Lee, April 20, 1862, in OR, XII (part I): p. 434 .
} 
early April 12.60 Davis, Randolph, and Lee brought him up to date on McClellan's inactivity, and strength of Magruder and Huger. Magruder's newfouna confidence in his ability to hold his lines was stressed, and Huger's pessimism concerning his defenses at Norfolk was discounted. The ability of the Virginia to keep the James River closed to Feaeral transports was highlighted. The President then informed Johnston that his command would be extended over the Peninsula and Norfolk, where a concerted attempt to resist or even defeat the Army of the Potomac would be made.61

Johnston may have been skeptical; none of the information possessed by his superiors had been gathered firsthand. Davis had never been to the Peninsula. Lee had helped plan Magruder's second line of defenses at Williamsburc, and had been the one who suggested the flooding of the Warwick River; but, he had not set foot on the Peninsula since the summer of 1861. Randolph had served as Magruder's Chief of Artillery before his appointment to the war office, but even his observations would have been weeks out of date; he could not have known, for instance, how near to completion were the dedoubts connecting Yorktown to the inundations at the

\section{Johnston, Narrative, p. 110 .}

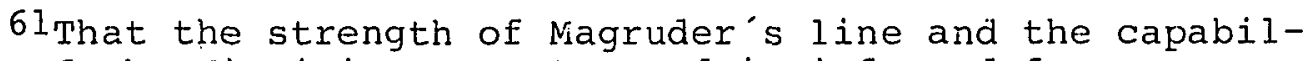
ities of the Virginia were stressed is inferred from previous statements by the principals on the ironclaa's potential (see preceding chapter) and their subsequent positions at the meeting on April 14 (see following chapter); see also, Davis, Rise and Fall, II: p. 86. 


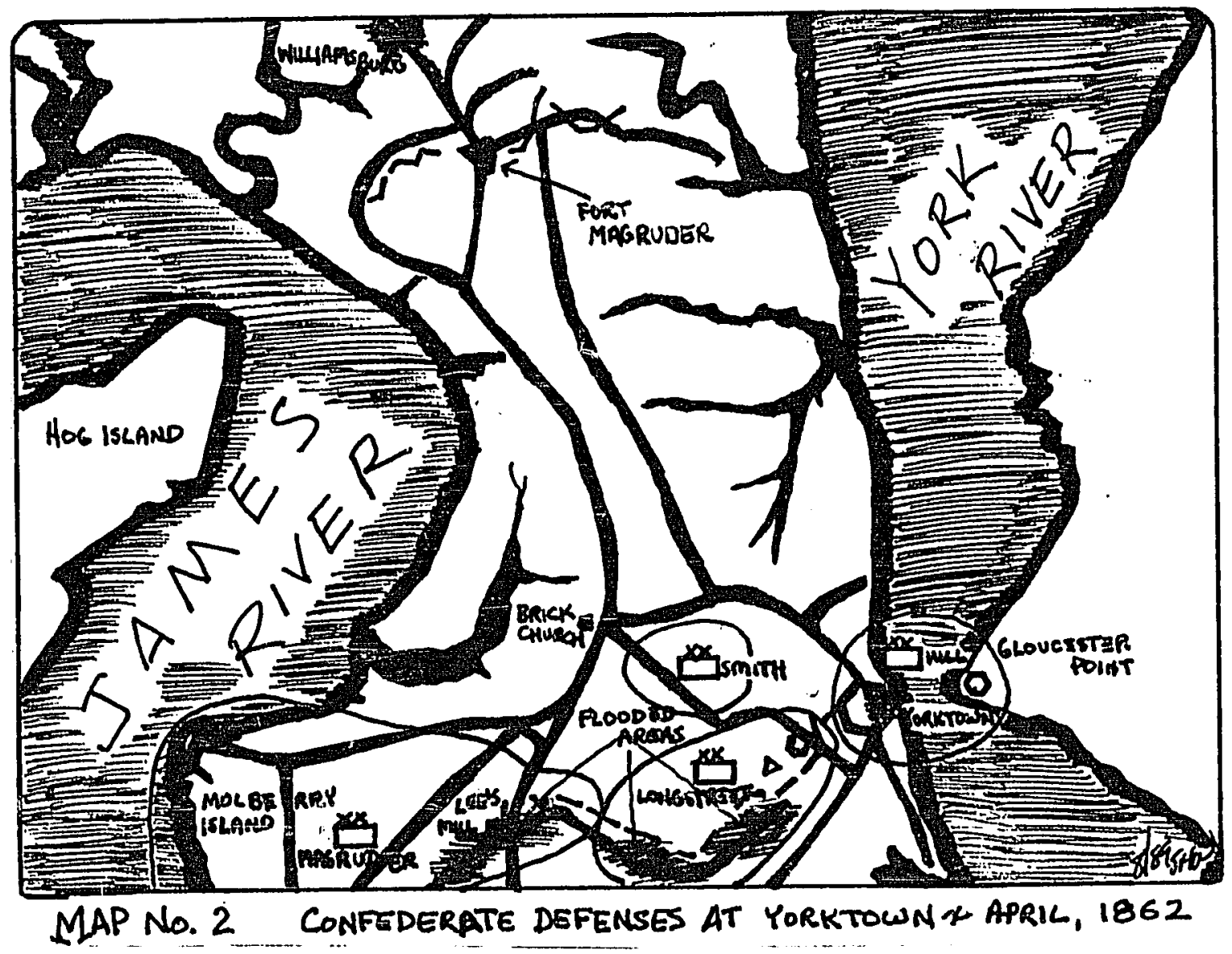


head of the Warwick. With Yorktown less than a day's travel from Richmond, it seemed to Johnston somewhat risky to make major strategic judgments without any officer more senior than Magruder or Huger having personally examined the ground. Davis concurred, and proposed that since Longstreet's and Smith's Divisions were still a ày or two from the capital, Johnston should use the time to conduct an inspection of his expanded department before making any final decisions about the placement of his troops; Johnston quickly agreed. 62

The following morning, Johnston rode the Richmond and York River Railroad to White House, and from there took one of the contract steaners ferrying troops and supplies down the river. Brigadier-General Whiting, who had arrived in Richmond that morning, accompanied him, both as a close friend and as an engineering officer. 63 probably about midmorning, the two arrived on the dock at Yorktown (see Map No. 2). The river at that point was only about a mile wide, and Johnston could have seen the confederate batteries on Gloucester Point on the north shore through the mist. The Federal gunboats swarming just out of range at the river's mouth must have seemed much closer. 64

62 I $\underline{\text { Ibiä. }}$

63 Johnston, Narrative, p. 111.

64 For indications of just how close the Federal gunboats were willing to approach the Yorktown fortifications during early April, see J. Missroon to George B. McClellan, April 6 , 1862, J. Missroon to L. M. Goldsborough, April 9, 1862, in NOR, VII: pp. 208, 209-210, 212-213. 
The fortification around Yorktown consisted of an earthwork seven to ten feet high, fifteen to twenty feet deep, and fronted by a ditch that averaged ten feet deep. In many places, Magruajer's engineers had followed the outlines of General Cornwallis's 1781 ramparts, which resulted in a fort that hugged the perimeter of the town. The work had been originally designed to protect the water batteries commanding the river and hold the town against a siege, not to block the Peninsula to an enemy marching west. As a result, Johnston and Whiting noted several peculiarities that diminishea the fortifications' ability to withstand McClellan's advance. As many of the land batteries faced away from the Federals as toward them. Virtually all of the heaviest rifled cannon had been emplaced to cover the river, and could not be brought to bear on the Union army. The walls of the fort that directly confronted Mcclellan were actually the weakest: three-tofive feet narrower than those in the rear. Few of the batteries or the traversing trenches back to the powder magazines had overhead cover. Most of the bombproof shelters that should have kept the gun crews safe when Mcclellan's artillery opened up were unfinished. 65

These deficiencies Johnston and Whiting could see for

65 "Reports of John G. Barnard, U. S. Army, Chief Engineer Army of the Potomac, of operations during the siege," in OR, XI (part 3): pp. 316, 317, 337; OR Atlas, plates XIV, XV, XIX; D. H. Hill to George W. Randolph, April 13, 1862, D. H. Hill to George W. Randolph, April 15, 1862, in OR, XI (part 3): pp. 439, 441-442. 
themselves. It remained for D. H. Hill to present his commander with more depressing news. He pointed out that labor in the protective works around the batteries proceeded so slowly because his men did not have tents, and sleeping on the open ground in a period of heavy rains had rendered many of them too ill to work. Besides, there were not enough sana bags on hand to build up protective walls around the open embrasures. He had only sixty-five rounds per gun, and just sixteen rounds each for his best riflea pieces. With so little ammunition he could neither respona to the harassment of the gunboats nor prevent McClellan's men from digging siege parallels. Ĺven if he had sufficient ammunition, Hill told Johnston bitterly, it would not have improved matters much. The rifled cannon produced at the Iredegar Iron Works were so undependable that they were equally as likely to explode and kill their own crews as to harm the enemy. Standing upon the parapet of his works, Hill delivered the coup de grace with a gesture toward the enemy lines. About 800 yaras in front of the wall lay a band of trees that broke his gunners' line of sight, behind which the Yankees could hide and constuct their own batteries. He had known about those trees since he had been at yorktown in 1861, but no axes had ever come from Richmond to cut them down.66

66 J. Thomas Goode to George W. Randolph, April 12, 1862 , D. H. Hill to George W. Randolph, April 13, 1862, D. H. Hill to George W. Randolph, April 15, 1862, in OR, XI (part 3): pp. 438,439,441-442; Dew, Ironmaker, pp. 179-180. 
Johnston listened to most of Hill's information in silence. When the North Carolinian had completed his list of the position's inadequacies, Johnston askea him how long he felt he could hold his post after McClellan opened fire.

"About two days," Hill said.

Johnston looked surprised, and replied, "I supposed about two hours." 67

What did Hill think should be done then? D. H. Hill was never slow to express his opinions, and it is certain that he told Johnston exactly what he wrote to the secretary of War the following day. "Would it not be better to let our railroads in North Carolina be cut, our cities in South Carolina and Georgia captured, and have the whole Southern army thrown here and crush McClellan?" The policy of shifting brigades and divisions piecemeal from threatened point to threatened point angered him: "By attempting to hold so many points we have been beaten in detail, and are losing all that we have been trying to hold." While the Confederates could not match the weight of Union ordnance, Hill had confidence in Southern elan. "We must fight on the field and trust to the bayonet. If we had 100,000 men here we could march out of the trenches and capture McClellan, unless he haō a swift-footed horse." 68

67D. H. Hill to Joseph E. Johnston, May 25, 1885, in RMH.

68 D. H. Hill to George W. Randolph, April 15, 1862, in OR, XI (part 3): pp. 441-442; see also D. H. Hill to Joseph E. Johnston, May 25, 1885, in RMH. 
Much of what Hill said appealed to Johnston--he had long been an advocate of concentrating a large Confederate army even if doing so risked capture of the areas stripped of troops. Yet the question he had to ask himself was where to employ it? He did not yet know if there was a place, anywhere along Magruder's line, from which he might profitably take the offensive.

After instructing Hill to begin moving some of his heavy guns from the water batteries to where they could bear on the Union Army, Johnston left to examine the remainder of the defenses.69 Four hunared yards of trenches, fairly well covered by abatis, extended south from the front corner of the Yorktown works. While adequate as an extension of the main work, this row of rifle pits suffered from two major defects. The row dead-ended in a swamp, rather than connecting with the entrenchments around Magruder's secondary redoubts between Yorktown and the Warwick River. As a result, infantry stationed there coula neither reinforce the positions to their right nor be quickly withdrawn if threatened with overwhelming numbers. The secona deficiency was the lack of a drainage system; soldiers standing guard or fighting from those trenches would have to do so in water that varied from

${ }^{69}$ D. H. Hill to George W. Randolph, April 15, 1862, in OR; XI (part 3): pp. 441-442. 
ankle- to knee-deep. 70

Carefully picking their way across the boggy ground that separated those trenches from the lesser redoubts--an open, if swampy, expanse about 300 yards wide--Johnston and Whiting arrived at the larger of the two subordinate fortifications, Fort Magruder. This redoubt had front walls as high and thick as those at Yorktown, and mounted three heavy cannon which could fire toward the Union lines. Unfortunately, however, it had been originally designed to confront an enemy approaching from the south and not the east. Thus, as the two generals stood within the fort, they could easily see at least one hill within McClellan's lines from which cannon could rain shells directly down into the gun emplacements. 71

The second redoubt was about 300 yards farther south. It was smaller and unnamed. Its square shape provided adequate protection for its gun crews, but the same Yankee-occupied hill overlooked it as well as Fort Magruder. The cannon in this work were not long-range guns, but only smoothbore field pieces. They would be absolutely useless until faced

70 "Reports of John G. Barnard, U. S. Army, Chief Engineer Army of the Potornac, of operations during the siege," in OR, XI (part 3): pp. 316, 317; OR Atlas, plates XIV, XV, XIX; Edward P. Alexander, "Sketch of Longstreet's Division, Yorktown and Williamsburg," Southern Historical Society Papers, Vol. X (1882): p. 36 .

71 "Reports of John G. Barnard, U. S. Army, Chief Engineer Army of the Potomac, of operations during the siege," in OR, XI (part 3): pp. 316, 317; H. T. Douglas to Gabriel Rains, April 8, 1862, in OR, XI (part 3): p. 432 . 
with a direct assault by the union infantry. 72

The trenches that extended from Fort Magruder to the smaller redoubt were extensive and somewhat better arained than those immediately around Yorktown. Their layout seemed haphazard, almost as if they had been dug by troops interested in protecting their own camps rather than laid out by engineers seeking to establish effective lines of fire. The entire system spanned about 800 yards of the front, but did not join the works at Yorktown on the left or the Warwick defenses on the right. 73

Only a broken line of rifle pits, crowned with varying heights of parapets and filled to varying depths with water, connecteā the redoubts to Magruder's next defensive point at Wynn's Mill. This did not appear that dangerous from a defensive point of view, because the two generals could see that the area in front of these irregular entrenchments had been flooded by closing the Warwick River dams. Nonetheless, the question remained: how quickly could a brigade be moved laterally from the redoubts across nearly 3,000 yards of broken ground to support Wynn's Mill in case of an emer-

\section{Ibid.}

73 "Reports of John G. Barnard, U. S. Army, Chief Engineer Army of the Potomac, of operations during the siege," in OR, XI (part 3): pp. 316, 317; OR Atlas, plates $\mathrm{XIV}, \mathrm{XV}, \mathrm{XIX}$. 
gency? 74

At Wynn's Mill, Johnston met Brigadier-General Jubal Early, who had assumed command of that part of the line a few days ago. After his own initial inspection of the Yorktown-Warwick defenses, Early had predicted to Magruder that the line "must be inevitably broken, sooner or later, and in that event our whole force gobbled up." He preferred an immediate retreat to the Chickahominy River. Showing Johnston and whiting around his sector, which consisted of nothing more than rifle pits and hastily dug-in field batteries, Early attempted to press this idea on his conmander. But Johnston had seen too much already, and had grown increasingly taciturn: "he did not seem disposed to discuss the matter, and I desisted."75

It is questionable whether Johnston and whiting travelled any farther down the Warwick than Wynn's Mill. It is also not certain just when Magruder joined his new commander; he had not been informed of Johnston's visit in advance. Magruder did not attempt to hide or rationalize the deficiencies of his line, for he had never claimed it to be anything more than a hasty expedient occupied as a last resort. Eventually, thinking perhaps of Hill's plan to gather an army of 100,000

$74_{\mathrm{R}}$. G. Lowe, "Magruder's Defense of the Peninsula," Confederate Veteran, Vol, VIII, No. 3 (March 1900): p. 105; OR Atlas, plates XIV, XV, XIX.

75 Jubal Early to Jefferson Davis, September 22, 1877, in Rowland, Jefferson Davis, Constitutionalist, vol. VIII: p. 3 . 
men and seize McClellan, Johnston asked him just how an army on this line could ever attack the Federals, since Magruder himself had flooded the only likely lines of approach to the enemy's positions? 76

The question would have astounded Magruder, who had never intended the line for anything other than a hasty defense. His suggestion to be reinforced by Johnston's army to conduct an offensive had been made three weeks earlier on March 21, at a time when McClellan's forces had not advanced beyond Big Bethel. Since being invested at Yorktown, he had given up any idea of attacking the enemy. Of 31,500 men, once he subtracted the garrisons at Yorktown, Gloucester Point, Williamsburg, Jamestown Island, and Mulberry Island, he was left with barely 23,000 soldiers to hold a line seventeen miles long. Far from planning to attack Mcclellan, his most recent strategic suggestion to Richmond had been to rapidly evacuate Norfolk and the entire Peninsula except for a small garrison at Yorktown, and to combine his and Huger's armies with Johnston's for a counterinvasion across the Potomac. Nor did Magruder have any illusions about the dangerous position of his army once McClellan managed to open either the York or James Rivers; he lived with the threat of a flotilla of gunboats and transports steaming up

76 Inferred from "Report of Joseph E. Johnston, C.S. Army, commanding Department of Northern Virginia, of operations from April 15, to May 19," in OR, XI (part 1): p. 275 . 
one or the other to land Federal divisions in his rear. 77

Johnston had seen enough. He had intended to tour Magruder's second line of works at williamsburg, then cross the James, examine the Virginia personally, and inspect the harbor defenses of Norfolk.78 The information provided by Magruder and Hill, combined with the evidence before his own eyes, convinced him, however, that while Magruder had performea a miracle of improvisation, no rational general would commit an army to defend such a place. The 31,500 men already there were at grave risk. A week later Johnston put on paper what he must have been thinking on April 14: "No one but McClellan could have hesitated to attack. The defensive line is far better for him than for us."79

As he boarded the steamer for the return trip to Richmond, Johnston realized that he faced an even larger problem at the capital. His superiors all believed that Yorktown was defensible, and were resolved to send his entire army into a cul de sac. How was he to convince them that such a course represented sheer lunacy?

77 John B. Magruder to George W. Randolph, April 4, 1862, John B. Magruder to George W. Randolph, April 11, 1862 , in oR, XI (part 3): pp. 422, 436 .

78 Johnston, Narrative, p. 110; Davis, Rise and Fal1, II: p. 86 .

79 Joseph E. Johnston to Robert E. Lee, April 22, 1862 , in OR, XI (part 3): p. 455 . 


\section{Chapter Seven \\ Decision in Richmond (II)}

A week before Joseph Johnston left Richmond on his inspection tour of the Peninsula, Albert Sidney Johnston had attempted to redeem his own reputation and Confederate fortunes in the west with a surprise attack on Major-General Ulysses S. Grant's army at Shiloh, Tennessee. For nearly two months, since the surrender of Fort Donelson, Johnston had been retreating before the Federal gunboats that roamed freely down the Tennessee and Cumberland Rivers, and avoiding contact with the Yankee armies that followed in their wake. Nashville and Columbus had been evacuated. Desperately, Johnston and his new Iieutenant, General P. G. T. Beauregard, struggled to assemble an army to resist the Union offensive. Slowly, they gathered together the remnants of their demoralized garrisons, to which were added thousands of troops that Jefferson Davis stripped the coastal fortifications to provide. One brigade came at the cost of uncovering New Orleans, another left Pensacola defenseless, a third thinned southern lines on the Georgia coast. In early April, fate finally seemed to smile on Albert Sidney Johnston: Grant's army had encamped without entrenchments on the banks of the Tennessee River, separated by a long day's march from the nearest supporting column. 
"I hope you will be able to close with the enemy before his two columns unite," Davis telegraphed his friend on April 5. "I anticipate victory."1 And Johnston, after several days of trying to forge a motley collection of garrison troops and nearly untrained recruits into something that resembled an army, tried to inspire his men with what he hoped would be a prophetic line: "Tonight we will water our horses in the Tennessee River." 2 on the morning of April 6, 1862, he sent his divisions into what became the largest and bloodiest battle yet fought on American soil. The next message that Jefferson Davis received was a wire from Beauregard on the evening of April 6: "We this morning attacked the enemy . . anā after a severe battle of ten hours, thanks be to the Almighty, gained a complete victory." Beauregard signed himself "General, Commanding," for his telegram also included the news that "General A. S. Johnston. - fell gallantly leaaing his troops into the thickest of the fight." 3 But Beauregard's assurance of

IJefferson Davis to Albert Sidney Johnston, April 5 , 1862, in OR, $X$ (part 2): p. 394. The best accounts of the maneuvering and concentration prior to the battle are found in Stanley F. Horn, The Army of Tennessee (Wilmington, NC: Broadfoot, 1987 , reprint of 1952 edition), pp. 99-121; Thomas L. Connelly, Army of the Heartland, The Army of Tennessee, 1861-1862 (Baton Rouge, LA: Louisiana state University Press, 1967), pp. 126-157; James Lee McDonough, Shiloh--In Hell Before Night (Knoxville, TN: University of Tennessee Press, 1977), pp. 3-26.

2Quoted in McDonough, Shiloh, p. 84.

3P. G. T. Beauregard to Jefferson Davis, April 6, 1862, in $\mathrm{OR}_{\mathrm{R}} \mathrm{X}_{\mathrm{f}}$ (part 1): p. 384 . 
victory faded quickly. Within a few days, having withdrawn to Corinth, he claimed only a partial defeat of the Union Army, admitting that "next day, finding Buell's forces arriving on the field to re-enforce Grant, I withdrew. - . "4 Ominous rumors began to reach Richmona that Beauregard himself had canceled the orders for one last charge at dusk which might have completely annihilated Grant's force. By April 9, he was telling General Cooper that he expected the enemy to attack him "with overwhelming force," predicting the loss of "the Mississippi Valley and probably our cause," if he were not immediately reinforcea. 5 The argument that Beauregard made for receiving massive reinforcements paralleled almost exactly the one which Joseph Johnston would present on his return to Richmond. Beauregard reasoned that "we could even affora to lose for a while Charleston and Savannah for the purpose of defeating Buell's army, which would not only insure us the valley of the Mississippi, but our ināependence." 6

Implicit in Beauregard's letter--at least from Davis's point of view--was a criticism that the President remained unwilling to make tough choices, to take the chance of losing in one region to secure victory in another. Had they

${ }^{4}$ P. G. T. Beauregard to Samuel Jones, April 10, 1862, in OR, $X($ part 2): p. 407 .

5P. G. T. Beauregard to Samuel Cooper, April 10, 1862, in OR, $X$ (part 1): p. 403 .

6 Ibid. 
been on better terms, Davis might have asked the Louisiana general whether he realized that just to give him the chance to defeat Grant, the President had already risked Fort Pulaski, New Orleans, and Pensacola? Granted, by April 14 Davis did not know for sure that those places would fall, one after the other, during the next month, but he certainly knew that such was a likely consequence of having fought, let alone having failed to win, at shiloh. Henceforth, the President would be a great deal more careful before he authorized another massive redeployment of troops on the basis of a general's confidence in victory. Davis had already bet once on the man he considered the confederacy's greatest general, and lost.

Joseph Johnston, of course, lacked this insight into the President's mind. Having rushed back from the Peninsu1a, he confronted Davis the moment the President entered his office. He immediately launched into a criticism of Magruder's dispositions, concluding that "although they were the most judicious that that officer could have adopted when he devised them, they would not enable us to defeat Mcclellan. - . . 7 The best that could be achieved was to delay the Army of the Potomac for a few weeks. Eventually though, Johnston argued with uncharacteristic loquacity, Mcclellan's heavier guns would dismount the confederate cannon, and "that being done, we could not prevent him from turning our

7Johnston, Narrative, pp. 112-113. 
position, by transporting his army up the river and landing in our rear, or by going on to Richmond and taking possession there." 8

Obviously, said Johnston, an alternative plan must be instituted, and on the trip back up the York River he had devised one. It was a combination of his own inclinations with ideas borrowed both from Magruder and Hill, and he proposed it with every certainty that it represented an original and irrefutable strategic vision:

Instead of only delaying the Federal Army in its approach, I proposed that it should be encountered in front of Richmond by one quite as numerous, formed by uniting there all the available forces of the Confederacy in North Carolina, South Carolina, and Georgia, with those at Norfolk, on the Peninsula, and then near Richmond, including Smith's and Longstreet 's divisions, which had arrived. The great army thus formed, surprising that of the United states by an attack when it was expecting to besiege Richmond, would be almost certain to win; and the enemy, defeated a hundred miles from Fort Monroe, their place of refuge, could scarcely escape destruction. Such a victory would decide not only the campaign, but

It never occurred to Johnston that not only was his concept not original, but the president had already tried it once in another theater of the war. The fact that Beauregard had also suggested it during the past week probably only served to make Davis even more cautious.

Yet Johnston had brought firsthand information from the

${ }^{8}$ Ibid. , p. 113.

${ }^{9}$ Ibid. 
Peninsula that could not be discounted. If he was correct, and McClellan's eventual penetration of Magruder's Iine was a foregone conclusion, then the implications of the fact had to be considered. Could Norfolk be held without Yorktown? If both were lost, what would be the fate of the Virginia? On what line could the Federal advance be resisted if the Union Navy controlled the York and James Rivers? Tactfully, Davis told Johnston "that the question was so important that he would hear it fully discussed before making his decision," suggesting that the General return at 11:00 A. M. to meet with him as well as Secretary Randolph and General Lee. 10 Feeling himself somewhat outnumbered, Johnston asked if he could invite Generals smith and Longstreet to join the conference. Davis agreed. II

It took Johnston most of the time before the meeting to track down his two division commanders. Longstreet, he probably found in his camps; Smith, he finally located at the spottswood Hotel only half an hour before the appointed time. There, his second-in-command had nearly collapsed from the exertions of the previous few days and his chronic nervous malady. Smith told Johnston that he felt entirely too ill to attend such an important conference. But Johnston was insistent, and rapidly acquainted the Kentuckian with the dangers inherent in allowing the remainder

\author{
$10_{\text {Ibid. }}$, p. 114 . \\ $11_{\text {Davis, }}$ Rise and Fall, II: pp. 86-87.
}


of the army to be deployed to Yorktown. Convinced by Johnston's arguments, Smith said that he would attend. An inveterate writer of memoranda, the General rose from his sickbed to put Johnston's position on paper.12

The six men gathered first in the President's office, but later adjourned for dinner and reconvened at Davis's house, a site selected because the continuation of the meeting there was unlikely to be noticed or disturbed.13 Davis allowed Johnston, as the person whose concerns had required the conference, to speak first. Johnston was uncomfortable speaking in front of groups--even when he knew everyone present, he often had trouble finding the right words--so he began by handing the President Smith's memorandum.14 The paper called attention to the deficiencies of Magruder's defenses, and proposed essentially the same plan that Johnston had earlier given the President, except that Smith's version specified that a concentrated army at Richmond should also include confederate troops from the Shenandoah Valley. This strategy formed the centerpiece of

12 This account is taken from a report of a conversation that Smith had in 1863 with Johnston's older brother. Beverly R. Johnston to Joseph E. Johnston, September 14, 1867 , in RMH.

13 Johnston, Narrative, p. 115.

14 Johnson, Johnston, p. 313; Gustavus W. Smith, Confederate War Papers; Fairfax Court House, New Orleans, Seven Pines, Richmond and North Carolina (New York: AtIantic, 1884), p. 41. 
the debate that followed. 15

Both Smith and Longstreet had some preference for an alternative which involved using the army thus formed for a counterinvasion across the Potomac, but neither man actually mentioned this option.16 when they spoke, they supported their chief. But neither man contributed very much along any line. Longstreet, due to his deafness, had a difficult time following the conversation. The first time he did open his mouth, to speculate on just how long McClellan might delay the opening of his siege batteries, Davis cut him off abruptly. "From the hasty interruption," the Georgian recalled, "I concluded that my opinion had only been asked through polite recognition of my presence, not that it was

${ }^{15}$ Smith later claimed that his memorandum had called for a counter invasion across the Potomac, and that this option received considerable attention. But the bulk of the evidence points to this as being a postwar addition to the record. Not only did neither Johnston nor Davis, nor Longstreet recall any such discussion, but in several discussions with Beverly Johnston during the war, Smith failed to mention any such plan. As Beverly Johnston wrote to Joseph in 1868: "Nothing was said by him expressing or hinting at any other idea as being proposed or suggested by him. I am perfectly confident that I could not have forgotten so daring and eccentric a scheme as he says (in the passage you quote) he presented to the council." See Smith, Confederate War Papers, pp. 41-42; Davis, Rise and Fal1, II: p. 87; Longstreet, Manassas to Appomattox, p. 66 ; Johnston, Narrative, p. 114; Beverly Johnston to Joseph E. Johnston, September 14, 1867, Beverly Johnston to Joseph E. Johnston, February 23, 1868, Beverly Johnston to Joseph E. Johnston, February 23, 1868, in RMH.

16 It is assumed here that smith may well have favored such an action but not actually have mentioned it. Smith, Confederate War Papers, pp. 41-42; Longstreet, Manassas to Appomattox, p. 66 . 
wanted, and said no more."17

G. W. Smith had been active in the hour immediately after his memorandum had been read, speaking more to the wisdom of a confederate concentration than to conditions on the Peninsula, which he had not seen. But as the discussion eventually grew more spirited, Smith's stamina waned. He became pale and ceased speaking. At length he felt so faint that he had to ask Davis if he might lie down on a couch in the adjoining room. Within a few minutes, he fell asleep, and did not rouse until the very end of the meeting, when all the key decisions had already been made. 18

The lack of participation by his two subordinates left Johnston, as he had feared, arguing his case alone.

Longstreet's silence, he could understand and forgive. The Georgian was never talkative at the best of times, and the depression caused by the death of his family still hung over him. Besides, Johnston had never really included him among the circle of his intimates with whom he discussed strategy and politics.19 As far as military opinions went, Johnston

17Longstreet, Manassas to Appomattox, p. 66; Davis, Rise and Fal1, II: $\mathrm{p} .87$.

18 Beverly Johnston to Joseph E. Johnston, September 14 , 1867, Joseph E. Johnston to [Gustavus W. Smith], January 6, 1868, Beverly Johnston to Joseph E. Johnston, February 23, 1868, Beverly Johnston to Joseph $\mathrm{E}$. Johnston, February 23, 1868, in RMH; Joseph E. Johnston to Gustavus W. Smith, January 21 , 1868, in JJWM.

${ }^{19}$ Longstreet himself admitted that "It was the first time that I had been called to such august presence, to deliberate on momentous matters. . . "; see Longstreet, 
would probably have preferred to bring whiting to the meeting, both because he had also seen Magruder's line and was one of the army's most respected military engineers. But Johnston knew that Whiting was still persona non grata with the President for his refusal to accept command of a brigade of Mississippians in December. 20 Longstreet's assessment was correct: he had been brought to the meeting more because the solidity of his physical presence would even the odds than due to any intel lectual contribution he was expected to make.

On the other hand, Smith's withdrawal angered Johnston. The Kentuckian had secured his commission on the strength of Johnston's recommendation, and had always been privy to the most secret counsels of the army. After the transfers of Van Dorn and Beauregard, Smith became Johnston's primary confidante. Now, "on the most important occasion of the kind in my life," Johnston had almost been forced to beg his second-in-command to attend.21 In his urgency, Johnston perhaps underestimated the extent of his subordinate's illness, and interpreted Smith's later silence as reticence, his departure from the room as desertion. Rumors floating around the upper levels of the army during the next week

Manassas to Appomattox, p. 66 .

20 see the references to that feud in Chapter Four. 21 Joseph E. Johnston to Gustavus W. Smith, January 21 , 1868, in JJWM. 
confirmed just how upset Johnston had been: it was reputed that he told whiting not long after the meeting adjourned that if Smith had not fallen asleep, the army would never have been sent to Yorktown. 22

For his part, Jefferson Davis did not take an active role in the discussion either. He had convened the group to explore the consequences of Johnston's revelations about Confederate weakness on the Peninsula. While immediate reaction to Johnston's strategy was negative, he wanted to consider the General's arguments thoroughly. He respected Johnston's opinions even when he did not agree with them, and if he had to decide against the General he wanted Johnston to believe that his ideas had received a fair hearing. Circumstantial evidence suggests, however, that Davis did not come to the meeting with his mind already made up. Johnston's proposal did not differ in theory from the strategy that the President himself had initiated prior to Shiloh; he remained willing to risk territory if he could be convinced that the potential gains were commensurate with the probable losses. He saw his proper part as the ultimate

22 Johnston denied the rumor after the war, but in language that was singularly unconvincing: "You say that I told Genl. Whiting that if you had not gone to sleep the army would not have been sent to that position (of Yorktown). I cannot pretend to remember what I may have said in casual conversation at that time. But such an opinion seems to me now so unreasonable that I cannot imagine that it was ever entertained by me. I hope, therefore--indeed think that Genl. Whiting must have misunderstood me." See Joseph E. Johnston to Gustavus W. Smith, January 21 , 1868, in JJWM. 
decision-maker, not as an active participant. 23

This left the debate to Johnston, Randolph, and Lee. Randolph, like Longstreet, came to the conference still relatively new to such critical policy deliberations. The gaunt, forty-four-year-old Virginian, however, had a personal assurance that Longstreet lacked. In a society where family ties assisted access to power and augmented personal credibility, Randolph's pedigree was as good, if not better, than that of anyone else in the room. Johnston and Lee might be descended from Revolutionary war heroes and Virginia politicians, but the secretary of war was the grandson of Thomas Jefferson. Though participation in such a meeting was still a novelty, unlike Longstreet, Randolph never doubted his right to be there. 24

The secretary of war brought with him three particular pieces of personal expertise that had bearing on the questions at hand. He was the only man in the room with any significant naval experience, having served six years at sea before his nineteenth birthday, and an additional two in land assignments before ill health forced him to resign his

23 Johnston, Narrative, p. 115.

24 Rembert Patrick suggested that Randolph's appointment owed more to his family name than any personal stature. But Thomas Bragg was clearly impressed by the new secretary. See Patrick, Jefferson Davis and his Cabinet, p. 122; J. B. Jones, Rebel War Clerk's Diary, I: p. 117; H. J. Eckenrode, The Randolphs, the Story of a Virginia Family (New York: Bobbs-Merril1, 1946), pp. 257-258; entry of March 24, 1862, Bragg diary, p. 192 . 
midshipman's commission. He qualified, in general, as an artillery expert, having raised the Richmond Howitzers, and, in specific, as being knowledgeable about Magruder's guns, having been the Chief of Artillery for the Army of the Peninsula until mid-February. Finally, along with Lee, he was thoroughly acquainted with the disorganization of the army caused by the Bounty and Furlough Act, and the tricky, behind-the-scenes negotiations underway to write the Confederacy's first conscription act. 25

Naturally reserved in his demeanor, Randolph, like Smith, also suffered from a chronic illness--in his case pulmonary tuberculosis. The disease had necessitated his resignation from field service, and active debate would have tired him almost as quickly as it did the Kentuckian. He would have measured his responses, conserved his energy, and attempted to contribute to the conversation as dispassionately as possible. 26

Thus, the meeting included three men--Longstreet, Smith, and Davis--who said very little for differing reasons; and Randolph, who participated, but did so in a

25 Though both Patrick and Freeman gave Randolph negligible credit for the passage of the conscription act, historian Archer Jones has presented a very convincing case that Randolph was instrumental in its adoption. See Patrick, Jefferson Davis and his Cabinet, p. 124; Freemen, R. E. Lee, II: pp. 28-29; Archer Jones, Confederate Strategy from Shiloh to Vicksburg (Baton Rouge, LA: Louisiana State University Press, 1961), pp.42-49; Sifakis, Who was Who, pp. 530-531.

26 sifakis, who was who, pp. 530-531. 
restrained and intellectual manner, leaving the brunt of the disagreement between Joseph Johnston and Robert E. Lee. G. W. Smith remembered that the debate became, even before he left, "very heated."27 Yet Johnston and Lee were not only old friends since their cadet days at West Point, but men of great emotional restraint, at least in public display. What explains a meeting at which, with the fate of their country at stake, tempers flared, and neither man was willing to budge an inch from his position?

First, it must be understood that their relationship of nearly forty years contained as many elements of rivalry as camaraderie. Tension and competitiveness had existed between the Johnstons and the Lees since their fathers' day. Peter Johnston and Henry Lee had fought together in the Revolution, but in the decades after their paths had diverged. Johnston became a Republican, Lee a Federalist; in the General Assembly they argued opposing views on the Alien and Sedition Acts. Both men were politically successful--Peter Johnston becoming a circuit court judge, Henry Lee attaining the governor's chair. But their two families represented one of the basic political divisions within Virginia. The Lees came from the old Tidewater tobacco elite, connected by blood and marriage to the Byrds, Randolphs, and Carters. The Johnstons hailed from the rougher southwestern portion of the state, and their ties

27 Smith, Confederate War Papers, p. 42. 
were to a newer, more widespread breed of Southern aristocrats: not only the Floyds of Abingdon, but the Breckinridges of Kentucky and the Prestons of South Carolina, as well. In the middle decades of the Nineteenth Century, the political and financial fortunes of families like the Johnstons were on the rise, those of the Arlington-Tidewater clans to which the Lees belonged in decline. 28

When Joseph Johnston first met Robert $E$. Lee at the United States Military Academy, the two did not become instant best friends. Academic attrition among the other Virginians in their class, however, slowly brought them together. Their personalities seemed agreeably matched. 29 Both were serious about their studies, although Johnston concerned himself, perhaps, a fraction less with his grades to the exclusion of all else than did Lee. He occasionally slipped off to go ice-skating, infrequently visited the infamous Benny Havens tavern, and was rumored to have embroiled himself in at least one fist-fight over the charms

28Lewis Preston Summers, History of Southwest Virginia, 1746-1786, washington County, $1777-1870$ (Richmond: J. L. Hil1, 1903), pp. 768-769; Edgar Erskine Hume, Peter Johnston, Junior, Virginia Soldier and Jurist (Charlottesville, $\mathrm{VA}$ : Historical Publishing Co., 1935), pp. 7-10; Armistead Churchill Gordon, "Peter Johnston," Dictionary of American Biography (New York: Charles Scribner's Sons, 1955 edition), V: pp. 147-148; Connelly and Jones, Politics of Command, pp. 54-60.

$$
29 \text { Freeman, R. E. Lee, I: p. } 74 .
$$


of a barmaid. 30

Yet the seeds of a life-long friendship were certainly sown. It was Lee who comforted Johnston when he received the news that his mother had died. Years later, Johnston recalled Cadet Lee as "full of sympathy and kindness, genial and fond of gay conversation, and even of fun, that made him the most agreeable of companions. . ." 31 In the first few years after receiving their commissions, the young lieutenants were often stationed together, and their friendship deepened. It was Lee, again, who laughed at Johnston's romantic escapades, and it was also Lee who crossed a battlefield in Mexico to bring personally to Johnston the news that his nephew Preston had been killed. For the rest of his life, Joseph Johnston always remembered that when his friend broke the news, Lee had tears in his eyes. 32

They were both young officers on the rise in an essentially peacetime army where promotion was so slow that it sometimes involved waiting for a senior officer to die of ola age so that everyone below could step up. In the race for advancement, a basic difference emerged between the

30 James A. Bethune to Robert Morton Hughes, February 25, 1910, George B. Johnston to Robert Morton Hughes, December 12, 1912, Robert Morton Hughes to Gamaliel Bradford, December 16, 1912, in RMH; Fleming, "Jefferson Davis at West Point," p. 266. 14.

${ }^{31}$ Quoted in Govan and Livingood, A Different Valor, p. ${ }^{32}$ guoted in Ibid., p. 20. 
personalities of the two Virginians. Lee had aspirations to higher rank, but overt ambition arove Johnston almost relentlessly. He resigned from the army in 1837, he told his brother Beverly, "principally because, from the rules of our service, of promotion by regiments, many of my juniors who had the luck to be assigned to regiments in which promotion was less slow than in that to which I belonged had got before me. . . . "33 Johnston accepted a new commission when the Corps of Topographical Engineers was formed, promising better chances for promotion, only after being assured that his break in service would not be counted against his seniority. 34

Johnston never saw rising in rank as anything but a

33 Joseph E. Johnston to Beverly Johnston, June 13, 1837, in JJWM; his regiment, the 4th Artillery, had been nicknamed the "Immortal Fourth," by junior officers waiting for their superannuated superiors to die. See Edward M. Coffman, The old Army, A portrait of the American Army in Peacetime, 1784-1898 (New York: Oxford University Press, 1985), p. 49.

${ }^{34}$ Govan and Livingood assert that "although gratified by his promotion to first lieutenant in July 1836, Johnston felt that with the end of the war he should resign. . . . In september, though, hostilities again broke out in Florida, and he immediately volunteered his services." But Johnston's correspondence and discussions with his brothers, Edward and Beverly, made it clear that the issue was promotion. It is also no coincidence that Johnston resigned in the midst of the three years prior to the Civil War that saw more resignations due to frustration over promotion than at any other time, and that, like may others, he could only be tempted back by the formation of the Corps of Topographical Engineers and a guarantee that he would not lose his previous seniority. Govan and Livingood, Different Valor, p. 16; Joseph E. Johnston to Beverly Johnston, June 13, 1837, in JJWM; Edward Johnston to John Warfield Johnston, January 2, 1848, in $\mathrm{RMH}$; Coffman, old Army, pp. 52, 56. 
contest, for there were too many junior officers and too few senior positions. A series of letters he wrote to his nephew while Preston was a Cadet are particularly revealing of this facet of Johnston's personality. "Determine to beat your competitors \& you will never fail to do it," he admonished the younger man. "Endeavor. . to be foremost --\& remember that such efforts are never thrown away; for tho' your competitor should be before you, the benefits of your very exertions in the contest will be felt thro' life."35 At another point, he advised Preston to avoid some of the mistakes he had made: "in selecting your regt. or corps you must consider which is worth most--agreeable present position, in a staff corps, or better promotion in the infantry, rifles, or arty. I am inclined to the rifles."36 Promotion, Joseph Johnston admitted to his brother Edward in 1851, was "a thing I desire more than any man in the army."37

He pursued it with a vengeance. Johnston assiduously cultivated the good opinion of any senior officer who might help him advance his cause, from Brigadier-General William

35 Joseph E. Johnston to J. Preston Johnston, August 31 , 1839; the original is in JJWM; a slightly edited version appears in Robert Morton Hughes, "Some Letters from the Papers of General Joseph E. Johnston," William and Mary Quarterly, 2nd Series, Vol. XI, No. 4 (October 1931): p. 320 .

36Joseph E. Johnston to J. Preston Johnston, May 25, 1843 , in JJWM.

37Joseph E. Johnston to Edward Johnston, January 6 , 1851 , in JJWM. 
J. Worth to Lieutenant-General Winfield Scott. In the

Mexican War, Johnston accepted the lieutenant-colonelcy of a temporary regiment in the hopes that his two-rank promotion might eventually become permanent. 38 His rank expired with the regiment, but Johnston carried on an eight-year fight with the War Department and three successive Secretaries of War to gain legal recognition for a brevet promotion based on his temporary rank. 39 Twice he applied directly for commissions in newly forming regiments, and in 1860 Johnston transferred from the cavalry to staff duty to receive a promotion to brigadier-general as Quartermaster-General of the Army. 40

"No other officer of the United States Army of equal rank, that of brigadier-general, relinquished his position

38 Joseph E. Johnston to J. Preston Johnston, November 27, 1842, in JJWM; Govan and Livingood, Different Valor, pp. 16-25; K. Jack Bauer, The Mexican War, 1846-1848 (New York: Macmilian, 1974), p. 276 .

39 Joseph E. Johnston to Edward Johnston, January 6 , 1851, undated opinions of Secretary of War John B. Floyd and Adjutant General Samuel Cooper, in JJWM; Samuel Cooper to Jefferson Davis, July 13, 1855, endorsement of Joseph $E$. Johnston to Jefferson Davis, July 11 , 1855, in SW-MS, M-567, Reel 58I; abstracted in Haskell Monroe Jr., James T. McIntosh, Linda Lasswell Crist, et al., ed., The Papers of Jefferson Davis (Baton Rouge, LA: Louisiana State University Press, 1985), V: pp. 440-441.

40 The first time was in January, 1851, when there was a rumor that two new regiments would soon be formed. That did not happen, but four new regiments were created in March, 1855. See Joseph E. Johnston to Edward Johnston, January 6, 1851, in JJWM; Joseph E. Johnston to Samuel Cooper, February 24, 1855, in the Joseph E. Johnston papers, Duke University, Durham, North Carolina. 
in it to join the Southern Confederacy," he proclaimed in his Narrative. 41 This distinction was important to Joseph Johnston because his two major rivals for advancement throughout his career had been Robert $\mathrm{E}$. Lee and Albert Sidney Johnston. Lee had placed ahead of Johnston at West Point, outranked him as a captain on entering Mexico, and had been placed by then-Secretary of War Jefferson Davis one notch above him in the corps of cavalry when it was organized in 1855. The other Johnston had been a colonel of volunteers in Mexico when Joseph was a temporary lieutenantcolonel, had also ranked above him in the cavalry, and had received a brevet promotion to Brigadier-General in 1858 for commanding the Utah Expedition. 42

Thus the matter of relative seniority between the three was a critical issue to Johnston, explaining his angry reaction to Jefferson Davis's decision to rank him behind the other two among the generals of the Confederate Army . Now, still unconvinced of the legality of that ranking, Johnston found himself once again in a position where Lee was his superior. Friends or not, Johnston may have resented Lee's seniority.

For the most part, Lee had always managed to be detached and philosophical about Johnston's passion for

41 Johnston, Narrative, p. 10.

42 Alfred P. James, "Joseph E. Johnston, Storm Center of the Confederacy," Mississippi Valley Historical Review, Vol. XIV, No. 3 (December 1927): p. 345 . 
advancement--but he could afford to be, since he had almost always remained just one step ahead of his friend until Johnston's appointment as Quartermaster General. His 1846 comment on Johnston's maneuvering to gain a staff post is typical of Lee's attitude about the issue: "Joe Johnston is playing $A[d] j[$ utant]t Gen'l in Florida to his heart's content. His plan is good, he is working for promotion. I hope he will succeed."43 But in 1860, when Johnston, not Lee, received the promotion from lieutenant-colonel to brigadier-general, Lee did not manage to remain quite so detached. He did write his old friend a letter of hearty congratulations, opening with "My dear General: I am delighted at accosting you by your present title, and feel my heart exult within me at your high position."44 Three months earlier, however, his heart had not exulted so strenuously when he wrote his son Custis of Johnston that "in proportion to his services he has been advanced beyond anyone in the army and has thrown more discredit than ever on the system of favoritism and making brevets." 45

Even though both Virginia and the Confederacy had

43 Robert E. Lee to John Mackay, February 3, 1846, quoted in Freeman, R. E. Lee, I: P. 411.

44 Robert E. Lee to Joseph E. Johnston, July 30, 1860, in JJWM; also quoted in Govan and Livingood, Different Valor, pp. 24-25.

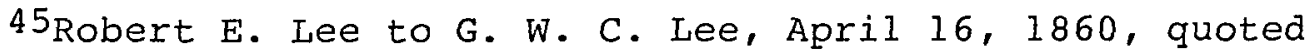
in J. William Jones, Life and Letters of Robert Edward Lee, Soldier and Man (New York: Neale, 1906), p. 114 . 
promoted him atop Johnston again, from Lee's perspective his old friend had, so far, enjoyed a much better war. To this point, the war for Lee had been primarily a desk job; his only true field service in western Virginia had brought him nothing but public criticism and personal frustration. Johnston shared the laurels for winning at Manassas, and had spent the intervening months in command of the South's largest and best equipped field army. Lee's own military secretary, Armistead Long, admittea years later that "at this time General J. E. Johnston bore the highest reputation in the Confederacy, since by his manoeuvring [sic] with Patterson in the Valley, his splendid success at Manassas, and his masterly retreat from Centreville he had acquired a world-wide renown."46 Though outranking his friend and invested with the position of commanding general, Lee saw Johnston as having the two things that he desired in war: reputation and a field command.

These were the tensions, submerged behind the masks of friendship and professional courtesy, that existed between the two Virginia generals on April 14, 1862. Each man would have denied that his objectivity or his decisions could be swayed by such personal resentments, and each undoubtedly would have thought he was telling the truth. But each man also eventually discovered that the stress of conducting a

$46 \mathrm{~A}$. L. Long, Memoirs of Robert E. Lee (New York: J. M. Stoddart \& Co., 1886), p. 151. 
war at long odds could produce extreme emotional responses in him, decades of professional soldiering, notwithstanding. The chances of judgment being affected were increased when those tensions underlay profound intellectual disagreements. Four questions dominated the dispute, and a fifth critical one never seems to have been asked by anyone at the meeting. Could Norfolk be held if McClellan gained the Peninsula? How long could the Yorktown-Warwick line be maintained against the Federals? Did the loss of that line necessarily equate with the loss of the entire Peninsula and a retreat to the environs of Richmond? Was the concentration of troops from Georgia and the Carolinas which Johnston proposed desirable or even possible? The unasked question was whether or not there was any possible compromise between the strategic stances of Johnston and Lee?

"I don't think there was any difference of opinion as to the necessity of evacuating Norfolk if the Peninsula was evacuated," Randolph testified before a Congressional committee ten months later. 47 Even with the Virginia blocking direct approaches to the harbor, all that Mcclellan had to do was march far enough up the Peninsula to reach a point on the James River at which the channels were too shallow for the ironclad to operate effectively. A pontoon bridge thrown across the river would then allow him to land

47 Testimony of George W. Randolph, February 5, 1863, "Investigation of the Navy Department," NOR Series 2 (part 4): p. 716 . 
on Huger's supply, link up with Burnside's force in North Carolina, and completely isolate the Norfolk garrison.48

Retaining Norfolk--or more precisely the Gosport Naval Yard--was a key strategic question for the Confederates. Randolph, representing the interests of the navy, pointed out that its capture would entail the loss of "our best if not our only opportunity to construct in any short time gunboats for coastwise and harbor defense." 49 He did not overestimate the importance of the facility. Nearly 1,200 heavy guns had been seized there in the first days of the war, providing the scaffolding upon which most of the Confederacy's coastal defenses had been erected; several hundred still remained, protecting the harbor.50 Removing them quickly would be no more practical than saving whiting's cannon on the Potomac had been.

But even irreplaceable heavy ordnance was secondary to the significance of the Gosport Navy Yard. Even though the last Union garrison had attempted to burn it to the water's edge, the shipyard was the best facility of its kind available to the south. The conversion of the Merrimac into

48 Ibid., pp. 716-717; Robert E. Lee to Stephen Mallory, April 8, 1862, in OR, XI (part 3): pp. 429-430.

49 Davis, Rise and Fall, II: p. 87.

50 William H. Parker, Recollections of a Naval officer, 1841-1865 (New York: Charles Scribner's Sons, 1883), p. 247; "Report of the armament of batteries around Norfolk, October 29, 1861," in NOR, VI: pp. 740-741; Stephen Mallory to Jefferson Davis, July 18, 1861, in NOR, Series 2 II: p. 77. 
the Virginia had been its most heralded project so far, iut not its only one. Workers had begun construction in March on the Richmond, a second ironclad designed along the same 1 ines as her predecessor. 51 The presence of two such vessels in Hampton Roads would secure the mouth of the James River beyond any doubt. During 1861, the navy yard had also partly armored the converted merchant steamer Patrick Henry which, with her ten guns, was the second most powerful Confederate warship operating in the James River.52 Two scuttled sailing sloops of war, the Plymouth and the Germantown, had been raised and converted into floating batteries, each mounting twenty-two heavy guns. 53 Two small but agile wooden gunboats, christened the Hampton and the Nansemond, had been completed in the first months of 1862 ; two more were under construction, and Naval Secretary Mallory envisioned a fleet of the pesky little vessels with which to harass Federal blockaders. 54 Not only the ships currently under construction would be lost if Norfolk fell, but the capability to produce many more would also be sacrificed.

Johnston, who had cut his inspection trip short before

51 "Statistical Data of Confederate Ships," in NOR, Series II (part 2): p. 265 .

52 Ibid., p. 262.

53 Ibid. , pp. $254,263$.

54 Ibid. , pp. 255,261 . 
visiting Norfolk, found himself hard-pressed to refute any of these arguments. Had he travelled to the port, an interview with General Huger would have provided him with a counterargument. Norfolk's strategic importance could not be disputed, but McClellan's army on the Peninsula hardly represented the only threat to its safety. In mid-February the "mosquito fleet" of gunboats protecting Elizabeth City, North Carolina, had been destroyed by the Federal vessels attached to Burnside's expedition. Elizabeth City guarded the southern entrance to the Dismal Swamp Canal, a waterway which could be traversed by light-draft gunboats all the way to suffolk. Although the Union troops had then turned their attention farther south to New Berne, the right flank to Huger's position lay wide open. Only a thin screen of wretchedly armed Confederates stood between Burnside and the one railroad connecting Norfolk to the rest of Virginia. Even if the Peninsula could be held indefinitely, Johnston could have argued, that alone would not guarantee the longterm safety of Norfolk. 55 But he did not know that, and so Randolph's point stood unassailed.

But Johnston scored heavily in return on the question of Yorktown's ultimate defensibility. He admitted that, although Magruder's line could not stand a heavy bombard-

55L. M. Goldsborough to Gideon Welles, February 10 , 1862, in NOR, VI: pp. 604-605; OR Atlas, plates CXXXVII, CXXXVIII; Benjamin Huger to Robert E. Lee, Apri1 29, 1862, in OR, XI (part 3): p. 474 . 
ment, it could probably hold out against a frontal assault by McClellan's army, even if his 31,500 men received no further reinforcements. 56 However, he maintained that the cautious Federal commander would never order such an attack; if he had ever had such an inclination, Mcclellan would have tried to force the line weeks ago when Magruder could field fewer than 10,000 soldiers to oppose him. Johnston probably used words very similar to those which he wrote to Lee two weeks later: "It is plain that General McClellan will adhere to the system adopted by him last summer, and depend for success upon artillery and engineering. We can compete with him in neither." 57

The argument made sense to everyone. Randolph recalled that there was unanimity of opinion "that if the enemy assaulted our army at the Warwick River line we should defeat them. . . ." Johnston also successfully convinced them--possibly with Randolph's help--that if "they made regular approaches - . and took advantage of their great superiority of heavy artillery, the probability would be that one flank, or both, of the army would be uncovered. - ." Randolph concluded that "thus the enemy, ascending York and James Rivers in transports, could turn the flank of

56Johnston, "Manassas to Seven Pines," B\&L, II: p. 209.

57 Joseph E. Johnston to Robert E. Lee, April 30, 1862, in $\underline{O R}, X I$ (part 3): p. 477 . 
the army and compel it to retreat." 58

Sensing his advantage, Johnston pressed two more points which he thought argued effectively against deploying any more troops into the Peninsula. First, he portrayed the climate as being so unhealthy that many of Magruder's men had already become too ill to be of any use; should Smith's and Longstreet's Divisions be sent there, a similar depletion of their strength could be expected. 59 Even if this did not occur, the increased number of troops to support on the Peninsula could bring the Confederacy no material benefit. The two divisions would not give Johnston numbers close enough to McClellan's to justify an attack on the open field, and Magruder's flooding had insured that no matter how numerous an army was transferred to the Peninsula, it could not reach the Army of the Potomac to attack it. 60

This indictment of the policy of damming and flooding the Warwick River probably stung Lee, who had at the least approved it, and may actually have been the first to suggest

58Testimony of George w. Randolph, February 5, 1863, "Investigation of the Navy Department," NOR, Series 2 (part 4): pp. $716-717$.

59 John B. Magruder to Samuel Cooper, May 3, 1862, in OR, XI (part 3): pp. 408-411.

60 "Report of General Joseph E. Johnston, C. S. Army, commanding Department of Northern Virginia, of operations from April 15 to May 19," May 19, 1862, in OR, XI (part 1): p. 275 . 
it. 61 Instead of responding directly to Johnston's assertion that the Yorktown line was inevitably untenable, he raised a new objection. The loss of that line did not necessarily mean the loss of the entire Peninsula. Davis remembered that Lee "insisted that the Peninsula offered great advantages to a smaller force in resisting a numerically superior assailant." 62

Specifically, Lee argued that where the Peninsula narrowed to four miles wide at williamsburg, and then along the banks of the Chickahominy River, there were secondary positions from which Johnston's army might delay the enemy or even inflict defeat upon him. He recalled that the previous year he had devised the plans for a continuous line of works at williamsburg from which to rally against the Federals. This line should be much easier to hold than the Yorktown line. Magruder had several times reported progress in constructing the Fortifications. Cannon in place on Jamestown Island could probably blockade tine James River. 63 If that line had to be evacuated, the few bridges over the Chickahominy and the tangled swamps around its banks

61Freeman, R. E. Lee, II: p. 18; Robert E. Lee to John B. Magruder, March 26, 1862, in OR, XI (part 3): p. 399.

62 Davis, Rise and Fall, II: p. 87.

63 Alfred Rives to Judah P. Benjamin, March 12, 1862 , Robert $\mathrm{E}$. Lee to John B. Magruder, March 15, 1862, in OR, IX: pp. 61-62, 68; Robert E. Lee to John B. Magruder, March 26, 1862, Robert E. Lee to John B. Magruder, April 9, 1862, in OR, XI (part 3): pp. 398-399, 433-434; Catesby Ap R. Jones to S. Barron, May 5, 1861, in NOR, VI: p. 699. 
would provide Johnston yet another chance to confront McClellan from a favorable position. Forced to fight for one or more of the crossings, the Army of the Potomac would have a difficult time bringing its superior numbers to bear, and the marshy ground would not be favorable to heavy artillery. Lee apparently envisioned a protracted fight before the Yankees could force the river. The Federals could be deterred from any attempt to land behind Johnston"s line by burning all the wharves on the York and the James, and by making "such display of force in front of the landings which the enemy may approach as will retard their advance from the rivers to the interior of the country. . . $" 64$

The image of a deliberate, step-by-step retreat, with the possibility of inflicting a series of sharp repulses-or even a major defeat--on the Union Army appealed to the President. This was especially true because of what he knew of the state of Richmond's defenses; the city was in no way prepared to stand a siege. Excavation had not begun on four of the eighteen batteries in the ring of fortifications around the capital, and those which had been constructed did not inspire confidence. Most of the powder magazines contained two or three feet of standing water, and large tracts of woods obscured the field of fire from many of the

64 Robert E. Lee to John B. Magruder, March 26, 1862, Robert E. Lee to John B. Magruder, April 9, 1862, in OR, XI $($ part 3): pp. 398-399, 433-434. 
batteries. Yet these were not even the worst defects of the positions. Colonel Charles Dimmock, Chief of ordnance for the state of Virginia, had reported at the end of February that the Batteries had been sited too near the city: "so near can the enemy come that the city can be shelled and burned before our works are captured. . . " of course, Dimmock admitted that his question was somewhat academic, since only twenty-five of the 218 cannon needed to arm the batteries had been mounted. Dimmock, like Lee, felt that "the Iine of defense should be near the banks of the Chickahominy. . . ."65

Again the brevity of Johnston's tour of the Peninsula prevented him from countering Lee's arguments. He did not know that the line of fortifications at Williamsburg had not been completed to Lee's specifications. Instead, they had been modified into a series of detached forts without Lee's knowledge or consent. Alfred Rives, Chief of the Confederate Engineer Bureau, had supervised this change, and even he recognized that they were fatally flawed. "I would take occasion here to condemn, as a general system, small detached redoubts, although you might infer from what you see near Williamsburg that I am in favor of them," Rives told

65 Robert Tansill to John H. Winder, February 27, 1862, Charles Dimmock to the Speaker of the Virginia House of Delegates, February 28, 1862, Alfred Rives to Judah P. Benjamin, March 12, 1862, in OR, IX: pp. 45-48, 61-62; John H. Winder to Samuel Cooper, February 28, 1862, in LR-AIGO, M-474, Reel 52; John H. Winder to Samuel Cooper, February 28 , 1862, in LR-SW, M-437, Reel 76 . 
Magruder's Chief Engineer on March 20. "I was, when they were commenced, completely inexperienced. . . I now know and have known for some months past that the system is most defective, making a line equally strong it is true, but equally weak at the same time."66 Nor did Johnston know that the James River was more than a mile and a half wide at Jamestown Island, and that it was questionable whether the thirteen poorly entrenched guns there could keep the river closed. Beyond the island, the next and only point below Richmond from which the James River could be effectively blocked was Drewry's Bluff, a point at which construction of entrenched batteries had barely been begun. 67

No one in the room really knew much about just how practical it would be to defend behind the Chickahominy River. The necessity of sending out most of the Engineer Bureau's officers either to Johnston or Magruder had delayed a survey of the river. Even Lee, who advocated the river as a third line of defense, did not know the condition or even the number of bridges spanning the stream. Most of the arguments seem to have been made by examining a blue line on

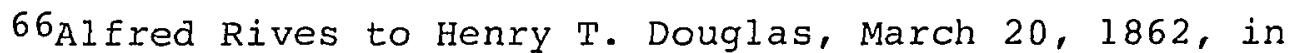
OR, XI (part 3): pp. 388-389; undated manuscript for speech by Benjamin Stoddert Ewell before the Magruder-Ewell Camp, United Confederate Veterans, in Benjamin Stoddert Ewell papers, College of William and Mary, Williamsburg, Virginia.

67 Alfred Rives to Judah P. Benjamin, March 12, 1862, in OR, IX: pp. 61-62; Robert E. Lee to Joseph E. Johnston, May 1, 1862, Robert E. Lee to Joseph E. Johnston, May 8, 1862, in OR, IX, (part 3): pp. 485, 500-501. 
some map. 68

Yet even such a cursory examination should have revealed that a Union Army that drew its supplies from the York River rather than the James could sidestep uncomfortably close to Richmond without ever contesting the river crossings. This would force Johnston to keep more than twenty miles of the winding river under observation--a line significantly longer than Magruder's at Yorktown. But on the Chickahominy, no entrenchments or batteries had ever been erected, and the river itself was navigable to Federal gunboats more than a dozen miles inland.69 Nor did any Confederate batteries exist to keep the Union Navy from landing troops west of the river's moutin. Finally, the climate around the swamps was, if possible, even more malarial than that in the vicinity of Yorktown. 70 Johnston's shock at seeing the condition of the Yorktown-Warwick River defenses, and the understandable urgency he felt in returning to explain their defects to the President, had again deprived him of vital details. Lee's contentions about the practicality of defending the peninsula, even after Magruder's line was evacuated, won the day in the mind of Jefferson Davis. At this point in the debate

\footnotetext{
$68 \mathrm{Nichols,} \mathrm{Confederate} \mathrm{Engineers,} \mathrm{p.} 84$.

${ }^{69}$ W. Smith to L. M. Goldsborough, May 29,1862 , in NOR, VII : p. 435 .

$70_{A 1}$ fred Rives to Judah P. Benjamin, March 12, 1862, in OR, IX: pp. 61-62; Davis, Rise and Fall, II: p. 103 .
} 
then, Lee was far ahead on points. The ultimate fall of Yorktown had been the only point he had conceded. Against this, he had successfully argued that its defense should be protracted as long as possible to preserve Norfolk, and that the remainder of the Peninsula was defensible. Now he proceeded to attack Johnston's suggestion to bring troops from the Carolinas and Georgia to Virginia.

The numbers themselves seem to support Johnston. His two divisions in Richmond, plus Magruder's army, totaled in excess of 55,000 men. Even discounting the cavalry screen and Field's tiny command, Jackson and Ewell could contribute 16,000 infantry. Despite reinforcing the Peninsula, Huger still retained 12,000 troops at Norfolk. In the Department of North Carolina there were 20,000 Confederate soldiers, and another 29,000 in the Department of South Carolina and Georgia. Most of these troop strengths had been underreported by their commanders, and more regiments were in the process of organization. With at least 83,000 men already present in the old Dominion, Johnston presented a convincing numerical argument that by reducing the coastal defenses to minimal garrisons at Wilmington, Charleston, and Savannah, the Confederacy could raise his numbers to parity with the Army of the Potomac, which was accurately believed to have between 100,000 to 120,000 soldiers. 71

$7 l_{\text {For }}$ the argument that such numbers were usually understated, see the section on the numbers of Johnston's army on the Peninsula in the next chapter. See "Abstract 
But there were practical objections to Johnston's plan, and Lee made the most of each one. He objected to Johnston's premise that risking the loss of Charleston and Savannah against the chance to defeat McClellan was an acceptable gamble. The Atlantic ports currently represented the major pipeline through which the South was receiving weapons from abroad. 72 These weapons were particularly critical at just that moment because most of the new regiments in Confederate camps of instruction had none. Lee was well aware that he could not yet arm all the troops that had volunteered for the war within the last month. 73

Yet if losing Charleston and Savannah represented a fair trade for MCClellan's army in purely military terms, the same was not true in a political sense. As Jefferson Davis was well aware, the ardor of most governors and many Confederate soldiers was limited to the defense of their home states. Governors had already grudgingly resisted every transfer of troops from their coasts, and regiments serving far from home continually petitioned the government

from return of Department of South Carolina and Georgia, Maj. Gen. John C. Pemberton, commanding, for March 1862," in OR, VI: p. 422; "Abstract from the return of the Department of Norfolk, Maj. Gen. Benjamin Huger, commanding, for January, 1862," "Abstract from statement of the troops serving in the Department of North Carolina, commanded by Maj. Gen. T. H. Holmes, April 19, 1862, in OR, IX: pp. 38 , 459 .

72 Davis, Rise and Fall, II: p. 87.

73 Judah P. Benjamin to Jefferson Davis, March 12, 1862,

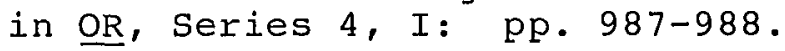


to send them back. With the army undergoing the reorganization of all the one-year troops, Lee, Randolph, and Davis all feared that thousands of soldiers would allow their enlistments to expire if they felt that the government had no commitment to protecting their homes while they served elsewhere. 74

Severe logistical problems also existed. Just how rapidly the rickety network of Confederate railroads could deliver tens of thousands of soldiers to Virginia was more than questionable, and the inability to do so might well be critical. If the massive redeployment Johnston suggested-unprecedented in scale even by the pre-Shiloh concentration --were set in motion, a slow performance by the railroads could spell disaster. A moment of vulnerability would exist while the troops were in transit. During this time, neither the Atlantic ports nor Johnston's army would be at full strength; if the trains rolled too slowly, this moment of weakness might stretch out for several weeks. A coordinated Federal attack on Charleston and Savannah simultaneous with a penetration of Magruder's line might rapidly end the war, it was true--but with a Confederate surrender.

Celerity of motion, even willing cooperation, was something that everyone in the room knew the railroads could not be depended upon to provide. It is unlikely that Davis

74 Davis, Rise and Fall, II: p. 87; Patrick, Jefferson Davis and his Cabinet, p. 124; Freeman, R. E. Lee, II: pp. 28-29; Archer Jones, Confederate Strategy: pp. 42-49. 
or Lee could have resisted the urge to point out to Johnston that he had blamed all the difficulties in his withdrawal from northern Virginia on the railroads. 75 The type of maneuver that Johnston had proposed would require a far greater level of coordination between a minimum of six different railroad companies. 76 How did Johnston expect this to be accomplished?

The General's answer would have been the response that any number of Confederate officers made at various critical points in the war: government control of the rails. This was a proposition to which Davis and Randolph were not hostile; but the Confederate Congress disagreed. Even as the President, the Secretary, and the four generals met, the House Committee on Military Affairs was in the process of first emasculating and then killing a bill to provide for emergency military control of the railroads. In just three days, Augustus R. Wright of Georgia and Thomas J. Foster of Alabama would successfully attack any such idea as "subversive of, and in direct contravention to, the great and fundamental principle of state sovereignty." Even had he agreed with Johnston, Davis did not possess the power necessary to implement his plan. 77

75 Joseph E. Johnston to Jefferson Davis, February 28, 1862 , in OR, V: p. 1083 .

$76 \mathrm{Black}$, Railroads, inset map.

77 Ibid. , p. 98. 
Again, there were counterarguments to most of these objections, but Johnston did not--in fact could not--have known them. Confederate intelligence on the coast was so bad that the conferees did not know that their army in the Carolinas and Georgia substantially outnumbered the Union forces there. Holmes deployed 20,000 men in North Carolina; Burnside opposed him with 14,000. Pemberton reported 29,000 "Present for Duty" along the lower coast, while Federal Major-General David Hunter listed only 17,000 soldiers in the same category.78 Johnston was more correct than he knew. By attempting to defend everything, the Confederacy had dispersed a larger number of men so widely that the Union Navy could almost always deliver enough Yankees to any given point to guarantee local superiority. Careful concentration at critical points would have allowed the Southern army to defend the coastline with no more than the number of troops the Federals were using to attack it. This would have freed at least 18,000 men to reinforce Virginia, which could have given Johnston more than 100,000 men, the minimum number he needed to confront McClellan on the open fiela. 79

78 David Hunter to Edward M. Stanton, April 3, 1862, in OR, VI: p. 263; "Abstract from return of the Department of North Carolina, Maj. Gen. Ambrose Burnside commanding, for April, 1862," in OR, IX: p. 381 .

79 This assumes a reduction in North Carolina from 20,000 to 12,000 troops, and along the lower coast from 29,000 to 19,000 men. Neither diminution of troops would have rendered the Confederates incapable of defending the 
Removing just over one third of the soldiers on the coasts would have been politically touchy, but not impossible for the Davis administration. The transportation objections to concentration could have been overcome by using a concept that General Braxton Bragg would prove to be effective in a few months: that of operating the railroad as if it were a strategic pipeline, shuttling a few troops from each garrison a few miles north to "bump" the next garrison farther along the route. Confederate experience in moving troops in this manner suggests that 18,000 troops could have been brought to Virginia in less than three weeks without unduly exposing any critical point on the coast. 80

As concerned the question of reorganization, Johnston could have argued the fact that he intended to use those troops for an offensive; thus offsetting any decline in morale resulting from a partial evacuation of the coast. An opportunity to strike a blow at the invading Federals had to be more satisfying to the minds of Confederate soldiers than merely sitting and waiting for the fearsome gunboats to appear. 81

Johnston, however, could make most of these contentions in theory, only, without citing specific details. He did

major ports.

80 Hattaway and Jones, How the North Won, p. 218.

81 Joseph E. Johnston to Robert E. Lee, April 30, 1862, in OR, XI (part 3): p. 477. 
not know the realities of Confederate and Union troop strengths on the coast--he had only the assertions of Lee and Randolph that the Yankees deployed far more men. He had never been thoroughly informed of the extent of the scarcity of weapons. Nor had he researched the technical details of actually moving thousands of Confederate soldiers to Virginia. Lee, on the other hand, seemed to possess every answer necessary to support his case, and those answers, even if incorrect, stood unchallenged by the end of the evening.

By midnight, in Davis's mind, the debate had narrowed down to a choice between two radically different options. Johnston proposed an almost immediate withdrawal from the Peninsula, Norfolk, and much of the coast, luring McClellan inland where he could be assaulted by an army of at least equal, if not superior, numbers. Lee advocated committing as many troops as were currently available--Johnston's two divisions--to reinforce McClellan's advance inch by inch, preserving Norfolk for as long as possible, and hoping that an opportunity to strike a blow might present itself even to an outnumbered army. Johnston's plan required immediate massive risks, offering an eventual chance for a strategic victory. Lee's plan deferred the risks, in the hopes that time might provide a better solution.

To Davis, leery of repeating the mistakes of the past few months, Johnston's proposal entailed an unacceptable 
level of risk. He finally announced his decision: he would follow Lee's line of reasoning. Johnston's army would be committed to the defense of the Peninsula. 82

Before examining Johnston's reaction to the President's declaration, it is important to realize that the chief failure of all of Davis's advisors was in allowing the question to be narrowed down to two mutually exclusive choices. The Confederacy"s two senior field generals had an obligation, in a council call for the purpose of determining grand strategy, to lay out for their chief executive all the possible solutions to the problem facing him. But Johnston and Lee became so enmeshed in their own arguments that they did not present their president with a full range of options. A third, possibly very much sounder, strategy for defending Richmond existed.

Assuming the correctness of Johnston's view that Magruder, with 31,500 men, could hold out just as long at Yorktown against McClellan as could Johnston with an army of 55,000 , the question actually boiled down to the most effective use that could be made of the 23,500 men in Smith's and Longstreet's Divisions, Stuart's Cavalry Brigade, and the fifty-six guns of Pendleton's Artillery Reserve. Sending them to the Peninsula was one option, but so was retaining them in Richmond as the nucleus of Johnston's Grand Armee. Even discarding the more or less

$$
82 \text { Davis, Rise and Fall, II: p. } 87 .
$$


fantastical schemes of Smith and Longstreet to join Jackson and Ewell to cross the Potomac, there was another option. The remainder of Johnston's army could have been kept in the immediate Richmond area to facilitate the very delaying strategy which Lee advocated. Those 23,500 men represented a labor force capable of completing the Richmond defenses, and erecting the vital batteries at Drewry's Bluff. Obstructions and delaying positions could have been prepared at the Chickahominy bridges. White House and Eltham's Landing on the upper York River and those below Harrison's Landing on the James could have been strongly enough garrisoned to discourage Federal landing even after the Yorktown-Warwick line crumbled. His flanks secure, Magruder could have dropped back from Yorktown to Williamsburg where, despite the shortcomings of the fortifications, he would have been able to stall Mcclellan on a 1 ine not seventeen but four miles long.

In many ways, such a plan would have satisfied the wishes of both Lee and Johnston. Two divisions holding the retired flanks of the Peninsula would have maximized the time to be gained in a delaying action, and would have materially increased the chances of successfully combatting the enemy at the Chickahominy. The time gained, if it was as much as two or three months, would mean more riflemuskets produced in the factories and landed in the ports, leading to a substantial reinforcement of Johnston's army. 
If he could not have met the Army of the Potomac with exact numerical parity, he could certainly have fielded 85,00090,000 men--no worse disadvantage than he had faced at Manassas.83 Furthermore, his army would have the advantage of awaiting the Yankees behind a third or fourth successive defensive line, the final one of which would necessarily have drawn McClellan away from his naval support.

But while such a plan might well have been workable, it could never arise while Johnston and Lee discussed the problem as adversaries, because it would have required each man to compromise on at least one of his most dearly held strategic precepts. Johnston would have had to accepted an operational concept that seemed at odds with his own belief in the need to concentrate the Confederacy's outnumbered troops. While maneuvering with detached--even isolated-columns never bothered Lee, he always advised meeting the enemy as far forward as practical with as many troops as possible. Keeping better than two divisions in the Richmond area violated his natural urge to close with the Federals and strike a blow. The two men could only have arrived at such a plan in a spirit of collaboration, a feeling sadly lacking between good friends that night.

Jefferson Davis, choosing from the plate set before him, decided to follow the arguments and instinct of Robert E. Lee. He told Johnston that the next morning the General

\section{${ }^{83}$ Livermore, Numbers and Losses, p. 77 .}


should start his army for the Peninsula. The President acknowledged years later that he had known that Joseph Johnston "did not agree with this decision," but that "he did not ask to be relieved," which Davis evidently interpreted as Johnston's acquiescence to his verdict. 84 Johnston's own postwar comment in the Narrative has often been cited as evidence that he secretly planned to disobey Davis's orders and pursue his own strategy of withdrawal without reference to the wishes of the government: "The belief that events on the Peninsula would soon compel the Confederate government to adopt my method of opposing the Federal army, reconciled me somewhat to the necessity of obeying the President's order."85 Douglas Southall Freeman contended that this ex post facto "comment curiously and not creditably revealed the man," while clifford Dowdey took it as evidence that "when Johnston left the meeting to return to Yorktown, he had no intention of obeying the intent of the order." 86

It cannot be inferred from his later statement that Johnston engaged in willful deception of the government, unless he kept this view to himself; the only evidence of that fact is Johnston's own words. The published phrasing

\footnotetext{
${ }^{84}$ Davis, Rise and Fall, II: p. 88.

85 Johnston, Narrative, p. 116.

86 Freeman, Lee's Lieutenants, I: p. 151; Dowdey, Seven Days, p. 55 .
} 
is ambiguous, and does not conclusively settle the question of whether the General voiced this opinion--this prediction, actually--or whether he left the meeting in a taciturn, sulky mood. The original draft of Johnston's memoirs is, however, much more definitive. Upon receiving Davis's instruction, Johnston wrote, "I replied that nothing reconciled me to obedience to this order but confidence that the cautious character of the Federal General would permit me to extricate my troops, after their flank was uncovered by the destruction of Yorktown. [emphasis added]"87 He had not been at all reticent about arguing his case with vehemence for several hours; there was no reason for him to stop giving the President his opinions just because he had lost the debate.

Discouraged but determined to follow his orders and buy as much time as he could and still save the army from a trap of his own government's creation, Johnston and Longstreet left the room. In the parlor, Johnston roused the unconscious Smith and informed him of the outcome of the discussion.88 There was quiet talk of the next day's preparations, and the three men departed to begin their campaign.

${ }^{87}$ Draft of Narrative, p. 18, in Box 28, Folder 3 , in RMH; see also Joseph E. Johnston to Gustavus W. Smith, January 21,1868 , in JJWM.

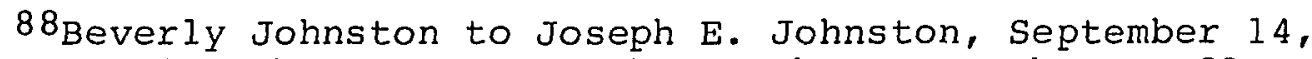
1867, Beverly Johnston to Joseph E. Johnston, February 23, 1868, Beverly Johnston to Joseph E. Johnston, February 23, 1868 , in $\mathrm{RMH}$. 
Chapter Eight

Isolated on the Peninsula

A year earlier in Charleston Harbor, Major Robert Anderson had formally surrendered Fort sumter. The next week Abraham Lincoln called for 75,000 volunteers, and Virginia seceded. Tents arose on the fringes of Richmond as General Lee struggled to organize the state's volunteers. In a short time, regiments from the rest of the Confederacy began to arrive, some of the earliest being the 1 st and 2nd South Carolina, "veterans" of the bombardment of Fort Sumter. A crowd gathered at the railroad station to meet them; and, as Richmonder Sally Putnam recalled, "they bore the appearance of guests at a holiday festival, rather than the stern features of the soldier." Hundreds of the city's citizens flocked to their camps to hear the story of all the war there had thus far been: "The evening dress-parade attracted admiring crowds of ladies, to whom every soldier seemed a hero." 1

By April 15, 1862, however, both the city and the soldiers knew a great deal more about war. When Thomas Bragg looked out his window at the troops marching through Richmond to the Peninsula, he thought that they appeared

lputnam, Richmond, p. 29. 
"rough but hardy . . . very muddy \& . . anything but neat and trim." The horses pulling field pieces and caissons down Broad street he thought "much reduced in flesh and all looked woebegone. . . "2 These were not the polished young dandies who had marched so gaily off to battle a year ago; these were gaunt men who had spent a winter under canvas, subsisting on short rations, and pulling guard duty in the mud. Some of them were veterans in the true sense now, having seen combat at Manassas, Ball's Bluff, Dranesville, or a dozen other nameless skirmishes.

In most cases, the trip to Richmond had not been easy or even safe. The train conveying Colonel John B. Gordon's 6th Alabama suffered a head-on collision with a locomotive returning up the same track. "Nearly every car on the densely packed train," Gordon remembered, "was telescoped and torn into pieces; and men, knapsacks, arms, and shivered seats were hurled to the front and piled in horrid mass against the crushed timbers and ironwork." Several soldiers died in the wreck, and dozens more were seriously wounded. 3 But even walking to Richmond did not guarantee a safe trip. The Hampton (South Carolina) Legion marched to the capital from Fredericksburg through rain, hail, and sleet. In makeshift shanties of poles and pine brush, the men in

\section{Entries of April 6, 1862, April 8, 1862, Bragg diary,} pp. 201-202, 205 .

3 John B. Gordon, Reminiscences of the Civil War (New York: Charles Scribner's Sons, 1903), p. 52. 
Captain James Conner's company slept wet and shivering cold, their blankets lagging behind on supply wagons. Fires would only reluctantly ignite to cook their biscuits or their bacon. Conner sourly describes the latter as having just "one streak of lean and five inches of fat." Of sixteen new recruits his company had received in the previous month, Conner reported that three died of exposure on the march.4

But wet and bedraggled as Johnston's regiments were, to the citizens of the city they represented the army that would hold McClellan at bay. So Richinonders turned out en masse to welcome them. Bands played, women waved handkerchiefs from second-floor windows, and the streets were lined with families, friends, and well-wishers. 'The day broke bright and clear for a change; and, soon after dawn, the streets filled with the sound of the tramping feet of Longstreet's Division. They had walked from Centreville to the Rapidan; and, when the call caine to pull back to Richmond, Longstreet's men marched, while other troops took the trains. Sarcastically, the soldiers dubbed themselves "Longstreet's Walking Division," and opined that if Jefferson Davis ever planned for them to reinforce New Orleans, he would probably tell them to walk. 5

They made a show of their passage through Richmond,

\footnotetext{
4 Moffett, Conner, p. 88 .

5putnam, Richmond, pp. 119-120; Foote, Civil War, I: p. 403 .
} 
nonetheless. At the division's head rode its phlegmatic commander, James Longstreet, whose mule-like stamina allowed his appearance to belie the fact that, since the meeting the previous evening, he could not have gotten any sleep. Most of the band music was lost on the nearly deaf Georgian, but his staff cantered about on their best mounts, raised their hats and saluted the crowds. Behind them came the infantry, in columns of half-companies "with music, banners, mounted officers, artillery, etc.," one soldier recalled. 6 "Soldiers left the ranks to grasp the hands of friends in passing," wrote one Richmonder, "to receive some grateful refreshment, a small bouquet, or a whispered congratulations."7 Ten thousand troops took a long time to march past a given point, and the cheering went on for hours before the last Confederate soldier passed down to the wharf at Rocketts to board the boats for Yorktown. Some were heartened by the turn-out; others barely noticed. A private in Brigadier-General George Pickett's Virginia brigade ignored all the demonstrations and "sadly gazed at the shop windows where loaf-bread, and clean clothing, and books, and other needed articles so tantalized my eyes, and empty pockets." 8

6Putnam, Richmond, pp. 119-120; J. G. de Roulhac Hamilton, The papers of Randolph Abbot Shotwell (Raleigh, NC: North Carolina Historical Commission, 1929), I: p. 175. ${ }^{7}$ Putnam, Richmond, p. 119-120. 8Hamilton, Shotwell, I: p. 176 . 
"Jeb" Stuart's cavalry paralleled Longstreet's Division, flowing down the side-streets to equally enthusiastic applause. "They swept through our streets on that beautiful morning, with their horses in good order, their own spirits buoyant and cheerfull [sic], many of them wearing in their caps bouquets of the golden daffodils of early spring," said Sally Putnam.9 Stuart camped his brigade just outside the city limits, and allowed his men one last night on the town before trotting toward Yorktown.10

But for all the showmanship and pageantry of the horse soldiers, Longstreet's Assistant Adjutant-General, Moxley Sorrel, believed that the finest spectacle of the day had been staged by Brigadier-General Robert Toombs. Always more politician than general, Toombs led his troops "past the crowds at spottswood Hotel, with childlike delight." His brigade was composed of one Virginia and four Georgia regiments. Toombs "put himself at the head of one regiment and moved it out of sight amid hurrahs, then galloping back he brought on another, ready himself for cheers, until the brigade was down the street. . . .11

But the procession through the Richmond streets was to be the last moment of glory for some time to come. Gustavus W. Smith's Division, which had marched directly to white

\footnotetext{
${ }^{9}$ Putnam, Richmond, p. 120 .

10 Thomas, Bold Dragoon, p. 103.

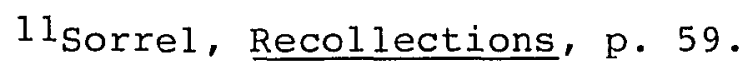


House on the York River, boarded a motley collection of schooners and small steamers for the trip to Yorktown. Longstreet's men crowded on flatboats at Rocketts, which lurched slowly down the James River toward Jamestown. Conditions on the boats were horrible: there was no food, no water, no provision for sanitation, and, in most cases, no place either covered or ventilated to sleep.12 Brigadier-General Joseph Kershaw's South Carolinians found themselves forced, on an earlier trip, to rotate between the holds of their small sailboats and the deck: it was a choice between freezing or suffocating.13 Pickett's men used the hours that the tug pulling their flatboat needed to clear the obstructions at Drewry's Bluff in order to cut tethers to keep sleeping soldiers from being washed overboard.14 It was a miserable experience for the infantry, and the cavalry and artillery saw little more comfort as they trooped down the muddy roads that crossed the chickahominy.

Nor did the conditions that Johnston's men found around Yorktown make up for the poor conditions on the trip. The

\footnotetext{
12 River transportation was strained to the breaking point in the transfer of Johnston's army to the Peninsula. on the James River, for example, even packing the men and their baggage in as tightly as possible, the QuartermasterGeneral could only send about 4,000 troops down the river at one time. See Larkin Smith to Walter H. Taylor, March 26, 1862, in OR, XI (part 3): p. 400 .

13 Dickert, Kershaw's Brigade, p. 93.

14 Hamilton, shotwell, I: p. 177 .
} 
trenches in the lines were flooded, the ground for the camps boggy, the rain unceasing, the food bad, and the Federal artillery and sharpshooters annoying--sometimes fatally so. 15 Soldiers assigned to the redoubts or the rifle pits spent theix days digging in deeper, often in direct sight of the enemy. Pickett's men erected one earthwork only by the expedient of posting a lookout to shout, "Lie down!," when he saw the smoke issue from the mouths of far-off Yankee cannon.16 Kershaw's troops scoured the area for scraps of wood to maintain bonfires around the clock. During the day, soldiers not on duty huddled around them; at night they competed for sleeping positions near the flames.17 Chief of Ordnance E. P. Alexander echoed the sentiments of most Confederate soldiers when he claimed that "in the whole course of the war there was little service as trying as that in the Yorktown lines."18

Joseph Johnston did not immediately accompany his soldiers to Yorktown on April 15. Instead, he spent the day working out administrative details with Lee and Cooper. He had two major worries: the forces left in northern Virgin-

15Alexander, "Sketch," p. 36; Joel Cook, The Siege of Richmond: A Narrative of the Military operations of MajorGeneral George B. McClellan during May and June, 1862 (Philadelpina: G. W. Childs, 1862), pp. 144-145.

16 Hamilton, Shotwel1, I: pp. 180-181.

17 Dickert, Kershaw's Brigade, p. 95.

18 Edward P. Alexander, Military Memoirs of a Confederate (New York: n. p., 1907), p. 64 . 
ia, and his wagon trains.

Johnston's primary concern about Jackson, Ewell, and Field was not that they might be overwhelmed, for he believed each of the Confederate columns to be much more mobile than the Yankees who opposed them. He worried, for the most part, about any coordinated actions. With the department commander on the Peninsula, the time lag for correspondence between Johnston and Jackson coulä easily exceed a week. Johnston reiteratea to Ewell that all questions of attack and retreat "must be decided on the ground"--in the time necessary for letters and telegrams to find him, precious opportunities might be lost.19

He instructed Jackson and Ewell to forward their correspondence to him through Cooper's office. 20 This was proper military procedure in the strictest sense, but it is difficult to escape the suspicion that Johnston may have preferred to keep internal departmental letters out of Lee's hands. The April 14 meeting marked a low point in the Eriendship of the two men. Not only did Johnston know that Lee differed from him on strategy, he may have suspected that the other virginian planned to use his power as Commanding General to put some of them into practice while Johnston was isolated on the Peninsula.

19Joseph E. Johnston to Richard 3. Ewell, April 17, 1862, in OR, XII (part 3): p. 852 .

20 Ibia. 
The question of the Department of Northern Virginia's wagon trains was one of disposition and security. While the Confederates held the James and York Rivers, sufficient, if not overly ample, supplies could reach Yorktown by water, saving the necessity of committing the rickety wagons and worn-out horses to the muddy Tidewater roads and malarial atmosphere. In the event of a retreat, however, the threat of Federal gunboats prowling up the rivers would close that route of supply. Within a few days Johnston's army would need to be rnet by wagon trains of food and ammunition, or else disaster might result.

The solution to this problem was to keep Johnston's wagons in Richmond, loaded and ready to meet the army with only a few hours' notice. But hundreds of wagons could not be left in the capital without a guard. Eventually, the decision was reached that, until Johnston called for them, the wagon trains would become the security responsibility of Brigadier-General John H. Winder, Provost-Marshal of Richmond, and commander of the newly expanded Department of Henrico. 21

Johnston was pleased to be relieved of the necessity of guarding the wagons, but hardly happy about the status of Winder's department. The Department of Henrico had been established in December, 1861, to put Richmond under

${ }^{21}$ Robert E. Lee to John H. Winder, April 27, 1862, in Lee Letterbook. 
military control. Winder, a Marylander, was willing to suffer personal unpopularity to ride herd on Union prisoners, guard various military facilities, discipline soldiers on furlough, and smell out anti-Confederate conspiracies. He never had enough men assigned to him to do more than a minimally adequate job, and his enemies periodically accused him of favoritism, terrorism, and even treason. But Winder, with Jefferson Davis's full support, persevered at his task. 22

On March 26, Davis and Lee extended Winder's authority to include Petersburg and all the territory within ten miles of both cities. Ostensibly, the President and Commanding General made this decision in order to organize better the rail transfer points that would also have to be used to shift troops in an emergency. It would also place responsibility for the completion of the Richmond fortifications and the batteries at Drewry's and Chaffin's Bluffs in the hands of a single officer. 23 From Johnston's perspective, however, this left a dangerous pocket of someone else's authority at the central point between all the wings of his widespread army. Messages, troops, and supplies all had to

22 General Orders No. 8, Adjutant and Inspector-General's office, March 1, 1862, in NOR, Series 2, III: pp. 122123; Robert G. Cleland, "Jefferson Davis and the Confederate Cabinet," Southwestern Historical Quarterly, Vol. XIX, No. 3 (January 1916): p. 216 .

23 special orders No. 69, Adjutant and InspectorGeneral's office, March 26, 1862, in OR, XI (part 3): p. 403. 
pass back and forth through a bottleneck that he did not control; Johnston could not even send his own provost marshals into the city to round up stragglers.24 Johnston protested this state of affairs, but Davis and Lee refused to give him authority over winder. 25

Disheartened at this outcome, Johnston boarded a steamer on York River the morning of April 17, and arrived at Yorktown again that evening, just four days after his inspection tour. The next morning he officially assumed command of the army. 26

McClellan had been uncharacteristically aggressive in the past few days. On April 16, concerned that Confederate batteries at Dam No. I could harass the construction of some of his siege batteries, the Union commander ordered Brigadier-General William F. "Baldy" Smith to "reconnoiter" the Rebel position. Smith moved up a Vermont brigade, with a pair of field batteries, and opened fired across the creek separating the two lines. The confederate counterfire, from a single cannon, was silenced in about an hour, with the crew driven from their gun. Smith ordered the 3rd Vermont, along with several companies of the 4 th, to wade the creek

24 A. P. Hill to Samuel Cooper, April 27, 1862, LR-AIGO, M-474, Reel 24; Robert E. Lee to John H. Winder, May 3 , 1862 , in Lee Letterbook.

25 Inferred from the tone of Joseph E. Johnston to Robert E. Lee, MaY 8, 1862, in OR, XI (part 3): p. 499.

26 General orders No. 1, Department of Northern Virginia, April 18, 1862, in OR, XI (part 3): p. 448 . 
and probe the now-quiet rifle pits in front of his position. 27

The ease with which the Confederate artillery had been quieted encouraged McClellan, who had ridden to Smith's headquarters sometime after the beginning of the action. He told Smith to move up his other two brigades. If circumstances permitted, he should attempt to take and hold the dam, not just examine it. 28

The only forces from the Army of the Peninsula which had actually been in the trenches to oppose the Federal probe were a single six-pounder from a Georgia battery and a company of pickets from the 15th North Carolina of Brigadier-General Howell Cobb's brigade. The rest of the Confederate outwork was filled with "Quaker guns"--blackened logs between wagon wheels--and most of the North Carolinians were several hundred yards to the rear, draining and improving their camps. Colonel Robert McKinney, a Virginia Military Institute graduate, ordered his men to arms as soon as word came back that the enemy had crossed the creek. 29

McKinney did not wait for reinforcements, a proper

27 "Reports of Brig. Gen. William F. Smith, U. S. Army, commanding Second Division, Fourth Corps, of engagement at Lee's Mill, or Burnt Chimneys," April 17, 1862, in OR, XI $($ part l): p. 364 .

28 Ibid. , April 18, 1862, p. 365.

29 "Report of Lieut. Col. Ross R. Ihrie, Fifteenth North Carolina Infantry, of the engagement at Dam No. 1 (Lee's Mill)," April 19, 1862, in OR, XI (part 1): pp. 421-422. 
military but personally fatal decision. He could see more Yankees gathering across the water, and would have known that if he did not clear the Vermonters out of his rifle pits quickly, Smith's Division would soon wade the creek in force. Mckinney double-timed his Tarheels toward the enemy, who opened fire as soon as the North Carolinians came into range. Out in front of his men, the colonel lined them up to return fire, and the two sides traded volleys until a Federal minie ball caught Mckinney in the forehead and killed him instantly. Though his lieutenant-colonel later denied it, the 15th North Carolina fell back in some confusion amid cries from the ranks that it had been ordered to retreat. 30

But McKinney's prompt response had brought other Confederate units to the field. A second regiment from Cobb's brigade, the 16 th Georgia; and two companies of a third, the 2nd Louisiana, rushed without orders to the sound of the firing, where they met the 7 th and 8 th Georgia of Brigadier-General D. R. Jones's brigade marching up from the other direction. These regiments joined the rallied 15 th North Carolina to form a force the size of a brigade,

30 Ibid., p. 422; but see "Report of Brig. Gen. Howell Cobb, C.S. Army, commanding Second Brigade, Second Division, of engagement at Dam No. I (Lee's Mill)," April 22,

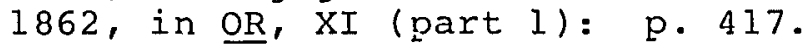


probably numbering over 2,000 men. 31

Less than half an hour had passed since the 3rd Vermont had first occupied the rifle pits, and the regiment's position was growing precarious. Reinforcements did not appear to be moving up as ordered, and, after the first skirmish with the North Carolinians, Colonel Breed N. Hyde discovered that few of his men had any dry ammunition left. He dispatched a runner to Smith's headquarters with this information, and settled in to hold the rifle pits as long as he could. 32

No Confederate general had yet arrived to coordinate the activities of the North Carolinians, Georgians, and Louisianians who had converged at the point of attack. Precious minutes ticked by, until Colonel George 'T. Anderson, commander of the lith Georgia and senior field officer of Jones's brigade, rode up and assumed command. Quickly, he deployed the troops into line, and gave the order to fix bayonets. Unlike McKinney, he did not intend to halt and

\footnotetext{
${ }^{31}$ Ibid.; if these regiments were no stronger than they were two weeks later, then they probably numbered:

15th North Carolina: 532 effectives

l6th Georgia: 488 effectives

2nd Louisiana ( 2 cos.) 156 effectives

7 th Georgia 611 effectives

8th Georgia: 251 effectives

Total: 2,028 effectives

See "Organization of the Army of Northern Virginia, commanded by General Joseph E. Johnston, on the Peninsula, about April 30, 1862," in OR, XI (part 3): p. 480.

32 "Report of Col. Breed N. Hyde, Third Vermont Infantry, of engagement at Lee's Mill, or Burnt Chimneys," April 17, 1862, in $\underline{\text { OR, }} \mathrm{XI}$ (part 1): p. 375 .
} 
return the fire of the Vermonters; he would accept initial casualties in order to close with his superior numbers and regain the trenches before any more Yankees could cross the creek.33 Colonel Hyde, finding himself greatly outnumbered, and having received neither reinforcements nor dry powder, shouted for a retreat, losing about ninety-five men killed, wounded, or captured, before he got his regiment back across the dam. 34

Both sides concentrated more troops on opposite sides of the creek throughout the afternoon, waiting expectantly for the action to resume. 35 But Mcclellan had found out what he came to learn: the confederates had little artillery capable of impeding his build-up, but reacted quickly to any probes. 36 Magruder, who believed that the Federals had made "a serious effort to break through," turned in to Johnston the next day another pessimistic report on the

33 "Report of Brig. Gen. Howell Cobb, C. S. Army, commanding Second Brigade, Second Division, of engagement at Dam No. 1 (Lee's Mill)," April 22, 1862, in OR, XI (part 1): p. 417 .

34 "Report of Col. Breed N. Hyde, Third Vermont Infantry, of engagement at Lee's Mill, or Burnt Chimneys," April 17,1862 , in OR, XI (part 1): p. 375 .

35 "Reports of Brig. Gen. William F. Smith, U. S. Army, commanding Second Division, Fourth Corps, of engagement at Lee's Mil1, or Burnt Chimneys," April 17, 1862, in OR, XI $($ part 1): p. 364 .

36 "McClellan's Report (I)," in $\underline{\mathrm{OR}}, \mathrm{XI}$ (part 1): p. 18 . 
strength of his lines. 37

Johnston had earlier seen the rifle pits as the weakest links in Magruder's extended line. The unwelcome news that the enemy was also aware of this deficiency caused him to examine carefully his options for defending his positions. Counting detached forces at Gloucester Point, Williamsburg, and Jamestown Island, Johnston's army containea twenty-four brigades of infantry, one of cavalry, and two battalions of reserve artillery--at least 70,000 men "present for duty."38

37 "Reports of Maj. Gen. John B. Magruder, C. S. Army, commanding at Yorktown, \&C.," May 3, 1862, in OR, XI (part $1)$ : p. 406 .

${ }^{38}$ The only relatively complete return for Johnston's army on the Peninsula is "Organization of the Army of Northern Virginia, commanded by General Joseph $\mathrm{E}$. Johnston, on the Peninsula, about April 30, 1862," in OR, XI (part 3): pp. 479-484. This lists Johnston's army as having 55,633 "effectives," and is the figure usually accepted for tine army at Yorktown. It is defective, however, in several respects which render it far too low. First, it does not include any numbers for the 3rd Virginia Cavalry or the Reserve Artillery. Second, being "effective" returns, as the Confederates figured them, this represented only the enlisted men actualiy available for the battle line, and excluded the officers and detailed men normally carried under the heading "present for duty." "Present for duty" gives a much more accurate estimation of the army's strength, and a consistent one by which to measure Johnston's strength relative to McClellan, who did not use the term "effectives" in his returns. Finally, these figures do not allow for the fact that the memorandum was compiled about April 30, 1862, or two weeks after the balance of Johnston's army had arrived at Yorktown. Hundreds, if not thousands, of men had been returned to the Richmond hospitals or had wandered off in the interim.

In order to reconstruct Johnston's actual strength on the Peninsula, it is necessary to account in some way for each of these factors. The strength of the 3rd Virginia Cavalry can be determined from Magruder's April 23, 1862 return, which gives it, and two other independent companies of cavalry 923 enlisted men. Jennings Wise used the average 
The army roster contained four major-generals: Smith,

Longstreet, Magruder, and D. H. Hill, each of whom Johnston

strength of Johnston's other field batteries to calculate that there were 1,050 enlisted men in the Reserve Artillery. Thomas Livermore argued quite convincingly that the "effective" force of confederate units represented between $85 \%$ (cavalry) and $93 \%$ (infantry and artillery) of the enlisted men "present for duty." Thus 54,344 "effective" infantry and artillery equate with 58,434 enlisted men "present for duty." Likewise, 2,221 "effective" cavalry equate with 2,613 enlisted men "present for duty," giving a total enlisted strength of 61,047 men. Allowing the lowest percentage that Livermore cites for officers in the Confederate army $(6.5 \%)$, these men were probably accompanied by 3,968 officers, for a total "present for duty" strength on April 30, 1862, of 65,015.

But this still does not account for two weeks of debilitating sickness and desertions. What percentage should be assigned to that? From Magruder's report on April 23, only two units--the heavy artillery battalion and the artillery from McLaws' division--can be determined with relative certainty to have the same composition as they had a week later. The heavy artillerymen suffered a 10\% decline in strength, the field gunners, who presumably saw more service in the trenches, lost $20 \%$ of their numbers. The lower of the two would correlate closely with the rate of illness and absence in the Department of Northern Virginia during the winter, and seems therefore an acceptable percentage. Taking the lower figure, $10 \%$, as a working figure, this means that Johnston had 72,239 officers and men "present for duty" when he assumed command.

Obviously the figure is an approximation, and each of the precise calculations could be challenged, but the methodology is that which is most widely accepted, and indicates that Johnston's army on the Peninsula was, in fact, much stronger than has heretofore been suggested. See "Abstract from Memorandum Return of the Right Wing, Army of the Peninsula, Maj. Gen. John B. Magruder commanding, for April 23, 1862," in OR, XI (part 3): p. 460; Wise, Long Arm, p. 186; Livermore, Numbers and Losses, pp. 67-70; Robert E. Lee to Abraham C. Myers, April 29, 1862, Robert E. Lee to Samuel P. Moore, April 29, 1862, Robert E. Lee to John H. Winder, May 3, 1862, in wee Letterbook; Returns of the Department of Northern Virginia, October, November, and December, 1861, in JJWM. 
assigned to command a division of six brigades. 39 That he thought such divisions overly large is evidenced by the fact that he allowed his four subordinates to sub-divide their own commands, and requested the promotion of W. H. C.

Whiting. 40 Johnston moved to improve the overall quality of his brigade commanders, recommending promotion for colonel Wade Hampton, permitting the elderly S. R. Anderson to resign, and campaigning to avoid the assignment of politician-general Henry $A$. Wise to the army. 41

He decided to leave Hill in command of the Yorktown fortifications, because the North Carolinian was familiar with the strengths and weaknesses of the positions, and because he had already begun to implement Johnston's orders to move a substantial number of heavy cannon from the river to the land side of the fort. 42 chief of Artillery Pendleton was dispatched to assist him.43 Johnston 1 imited

${ }^{39}$ General Orders No. 1, Department of Northern Virginia, April 18, 1862, in OR, XI (part 3): p. 448.

40 Joseph E. Johnston to George W. Ranỏolph, April 20, 1862, in W. H. C. Whiting, Compiled Service Record.

$41_{\text {Louis T. Wigfall to Joseph E. Johnston, May [April] }}$ 21, 1862, in JJWM; S. R. Anderson to Samuel Cooper, March 5, 1862 , S. R. Anderson to Jefferson Davis, March 8, 1862, in LR-AIGO, M-474, Reel 3; Theophilus H. Holmes, March 6, 1862, in LR-AIGO, M-474, Reel 23; Warner, Generals in Gray, p. 10; Joseph E. Johnston to Robert E. Lee, April 28, 1862, in OR, XI (part 3): p. 471 .

42D. H. Hill to George W. Randolph, April 15, 1862, in OR, XI (part 3): p. 442 .

43 Lee, Memoirs, pp. 180-181. 
Magruder's command to the far right side of the line-overlooking the Warwick River all the way to the James. He assignea Longstreet the center segment; and G. W. Smith the reserve. 44

Moving Magruder, who had designed the entire defensive system, to the least critical point in the line appears to have been a tacit editcrial comment by Johnston on "Prince John's" initial conduct of operations. Despite having commanded on the Peninsula for nearly a year, and having held this line for several weeks, Magruder had allowed much necessary work to remain undone. He retained too many guns facing York River. The critical rifle pits in the center of the line had never been connected, improved, or drainea. No telegraph 1 ines had been run behind his front, and even locally no provisions seemed to have been made for commanders to react to a Federal attack. McClellan's probe of April 16, had it not been met by troops instinctively marching to the sound of the guns, and the initiative of two colonels, might well have shattered the key point in the Yorktown line. "Labor enough has been expended here to make a very strong position," Johnston advised Lee on April 22, "but it has been wretchedly misapplied by the young engineer officers."45 He did not need to mention who had supervised

${ }^{44}$ General Orders No. 1, Department of Northern Virginia, April 18, 1862, in OR, XI (part 3): p. 448.

45 Joseph Ë. Johnston to Robert E. Lee, April 22, 1862, in OR, XI (part 3): pp. 455-456. 
the engineers.

The methodical Longstreet received the assignment to shore up the middle of the line. Unlike Magruder, who had often halted labor on his fortifications when he could not find slaves to impress, the Georgian put his own troops to work. Shacks and other buildings behind the lines were dismantled, not to be fed into bonfires, but to plank over the muddy bottoms of the trenches. 46 His regiments worked in relays connecting and extending the rifle pits, and erecting small redoubts every few hundred feet along the line. The rear walls of the two detached redoubts were filled in with a combination of earth, sand bags, and bales of cotton. 47 Longstreet's men already knew how to walk-now he taught them to dig.

The six brigades of G. W. Smith's Division remained in reserve throughout the entire period of the army's stay in the trenches. The fact that his troops never had to rotate into the water-logged front lines caused some resentment among the rest of the soldiers of Johnston's army, but the deployment represented sound military logic. Smith was Johnston's most trusted subordinate, the man he wanted

\footnotetext{
$46 \mathrm{G}$. Moxley Sorrel to A. P. Hill, April 20, 1862, in OR, LI (part 2): p. 543 .

47David F. Riggs, 7th Virginia Infantry (Lynchburg, VA: H. E. Howard, 1982), p. 22 ; Robert T. Bell, 1 th Virginia Infantry (Lynchburg, VA: H. E. Howard, 1985), p. 19; Hamilton, Shotwell, I: pp. 180-181; Alexander, "Sketch," p. 36; Alexander, Military Memoirs, p. 64 .
} 
instantly available to protect the army's flanks if Mcclellan's gunboats succeeded in opening either the James or York Rivers. Kept in their camps about a mile to the rear of the main Iine, Smith's brigades could be ready to march hours sooner than regiments which would have to be relieved in the trenches first. True, Johnston could have rotated the troops, brigade by brigade, to give the rest of his men more respite from disagreeable duty. But while such an action might have improved morale, it could also have left him with the fragments of two or more divisions as his reserve, not a single concentrated force of 10,000-15,000 men accustomed to working together. As usual, Johnston's dispositions were governed by military necessity; if he had a failing it was that he never saw a need to explain to anyone else that which he believed to be patently obvious. 48

Under ordinary circumstances, the perceived disparity in duties assigned might have passed with minor discontent. But during the months of March, April, and May, 1862, the situation inside every Confederate army, including Johnston's, was hardly ordinary. In a desperate attempt to keep Southern brigades from melting away when the enlistments of

\footnotetext{
48 There is also evidence that Johnston himself was a little distant from the problem of the living and working conditions of the troops in the trenches. On April 25 he wrote to D. H. Hill: "Do I understand you to say that your men already require relief? I suppose not, as there had [been] no occasion yet for fatiguing service." Joseph $\mathrm{E}$. Johnston to D. H. Hill, April 25, 1862, in OR, XI (part 3): p. 464 .
} 
the one-year regiments expired, the Confederate congress had passed legislation requiring those units to reorganize for three years, but granting each company, battery, battalion, and regiment the right to re-elect its officers. 49

It was a most peculiar exercise in denocracy: men who could not vote for their own Senators, or even in some cases for President, had demanded and won the right to select by popular vote the officers who would lead them into battle. For years after the war, veterans recalled the elections with reactions that ranged from wry humor to thinly veiled disgust. In the 18th Mississippi, Captains A. G. Brown (exGovernor and senator) and O. R. Singleton (ex-Congressman), both standing for higher office, "told us that if we would reorganize immediately they would 'wager their heads to brass pins the war would end in sixty days." 50 An orderly sergeant campaigning for election to lieutenant in the lst Virginia Cavalry performed the morning roll call while the men of his company lay in their bedrolls. He promised them that if they elected him he could get the company reorganized as artillery and sent on detached service to more favorable climes.51. "It was a comical sight," wrote a

49patrick, Jefferson Davis and his Cabinet, p. 124 ; Freeman, R. E. Lee, II: pp. 28-29; Jones, Confederate Strategy, pp. 42-49.

$50 \mathrm{~W}$. Gart Johnson, "The Barksdale-Humphrey Brigade," Confederate Veteran, April 1894 supplemental issue, p. 25 .

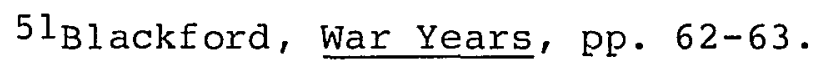


member of the Richmond Howitzers, "to see the officers of an army 'elected' by the people in ranks," but Colonel John Brockenbrough of the 40 th Virginia found nothing humorous in the situation: "we find worthless, intriguing, politicians, and those who have been defeated in company elections, taking advantage of all these conflicting bills and unsatisfactory constructions . - using bribery, a great deal of flash plausibility, and arguments which any worthless demagogue is capable of making." 52

But the situation was hardly amusing to Joseph Johnston or his generals. The elections seriously disrupted discipline, and consumed his senior officers' time supervising contests or puzzling out the finer points of byzantine Confederate election laws. More detrimental yet, the upheaval cost the army the service of hundreds of experienced officers in the midst of an active campaign, men often replaced by ciphers, demagogues, and aspirants with true potential but no training.

No statistical study has ever quantified the precise effect of the elections on either the Department of Northern Virginia or the southern forces as" a" whole, but rough approximations can be made. Over half of the army on the Peninsula was affected by the reorganization: fifty of

52 Carleton McCarthy, Richmond Howitzers in the war, Four Years Campaigning with the Army of Northern Virginia, By a Member of the Company (Richmond: n. p., 1891), p. 55; John M. Brockenbrough to Theophilus Holmes, March 21, 1862, in OR, XII (part 3): pp. 832-833. 
eighty-eight and one-half infantry regiments, three of four cavalry regiments, and probably twenty of thirty-eight field batteries. 53 This represented roughly 35,600 officers and men, with about 2,175 officers forced to fight for reelection. 54 spot samples, and research by historian Robert K. Krick, suggest that about thirty-seven percent of the company officers and nearly fifty-three percent of the field officers were defeated, sending home more than 800 experi-

\footnotetext{
53 These numbers result from a comparison of "Organization of the Army of Northern Virginia, commanded by General Joseph E. Johnston, on the Peninsula, about April 30, 1862," in OR, XI (part 3): pp. 479-484, with "Statement of the number of troops now in the service enlisted for the war and of the states from which they have volunteered," December 13, 1861, in OR, Series 4, I: pp. 788-790. The artillery batteries are not broken out in the second document, ana have been assigned the same percentage as the infantry, which does not seem unlikely, since many of them were Virginia companies, which had to reorganize almost without exception. The following regiments were therefore affected by the reorganization (with battalions and regiments split between war companies and twelve-month companies counted as half a regiment): Gracie's Battalion, 4, 5 (1/2), 6, 26 Alabama; Arkansas Battalion; 2 Florida, 7 Georgia; 1 Kentucky; 2 Louisiana; 2, 11, 12, 13, 17, 18 Mississippi; $13,14,15,16,22,23$ North Carolina; Hampton Legion, 2, 3, $4,5,6,7,8,9$ South Carolina; 1, 7, 14 Tennessee, 1 (1/2) Texas; Noland's Battalion, 1, 1 Cavalry, 3, 3 Cavalry, 4 Cavalry, 7, 8, 11, 17, 18, 19, 24, 26, 28, 32, 46, 47, 49 Virginia. In the other components of the Department of Northern Virginia the percentage of units affected was even higher. In Jackson's and Ewell's Divisions, twenty-three of thirty-two regiments had to reorganize; in Huger's Division, eleven of twelve; and among the units gathered around Fredericksburg, eleven out of twenty-one. In total, at least ninety-eight out of 152 1/2 infantry and cavalry regiments, or more than sixty-two percent, underwent the throes of reorganization.
}

54 Taken from the April 30 "effective" strengths, allowing for officers by using Livermore's multiplier of $6.5 \%$. 
enced officers during March, April, and May.55 Certainly some of the defeated candidates had been overage, political appointees, or deadwood better pruned from the army rosters, but dozens, if not hundreds, of competent men lost their positions. Among the able officers who left the army as a result of the elections were West Pointers Benjamin Stoddert Ewell, Robert Johnston, William E. "Grumble" Jones, Edward Murray, Stephen Dodson Ramseur, Beverly Robertson, and Armistead Rust; along with Virginia Military Institute graduates Charles Crump and Charles Lightfoot.56 Most of these men eventually returned to the army in other capacities, but for the moment they were as lost to Johnston as if

55 The figure of $37 \%$ of company officers is from Robert K. Krick, 30th Virginia Infantry (Lynchburg, VA: H. E. Howard, 1983), p. 13, and is confirmed by spot-checking other entries in the $\mathrm{H}$. E. Howard regimental series. Krick's biographical dictionary--Robert K. Krick, Lee's Colonels, A Biographical Register of the Field officers of the Army of Northern Virginia, 2nd edition (Dayton, $\mathrm{OH}$ : Morningside, 1984)--makes it possible to determine the number, of field officers ousted with some precision. Eliminating Gracie's Alabama Battalion, Noland's Virginia Battalion, and the lst Kentucky, which Krick does not cover, eighty field officers lost their positions out of 152 required to stand the elections.

56 Ramseur did not leave the army because he had lost an election, but because he had won one. He had been serving as the captain of the Ellis (North Carolina) Light Artillery, when he learned of his election to the colonelcy of the 49 th North Carolina, and left the army to go back to his home state and finish the regiment's training. See Gary $w$. Gallagher, Stephen Dodson Ramseur, Lee's Gallant General (Chapel Hill, NC: University of North Carolina Press, 1985), p. 37; the other cases are drawn from Krick or Warner; see Krick, Lee's Colonels, pp. 90-3i, 114-115, 181, 205, 245-246, 283-284; Warner, Generals in Gray, pp. 167, 260 . 
Federal bullets had struck them in combat.

It would be difficult to overstate the confusion caused by the elections. Several units, like Dreux's Louisiana Battalion and the 9 th south Carolina, simply ceased to exist when their companies attached to other regiments. 57 The 4 th South Carolina lost so many men that it was barely saved by the expedient of reorganizing it as a battalion rather than a regiment. 58 Enough regiments to fill two brigades, petitioned Johnston directly for discharge; he dutifully transmitted their request to the secretary of War. 59

Meanwhile, aspiring officers probed for every favorable technicality in the poorly written rules, and drove their brigadiers to distraction trying to adjudicate their claims. Captain David G. Houston of Company D, llth Virginia, asserted that because his company had reorganized several days earlier than the remainder of the regiment, he was now, by law, the senior captain of the regiment, and due for an automatic promotion to a vacant majority. When BrigadierGeneral A. P. Hill forwarded this contention to Richmond, Adjutant-General Cooper ruled that Houston was correct:

57 Krick, Lee's Colonels, p. 48; R. G. Lowe, "The Dreux Battalion," Confederate Veteran, Vol. V, No. 2 (February $1897):$ p. 55 .

58 Krick, Lee's Colonels, p. 452; Thomas G. Rhett to James Longstreet, April 27, 1862, Thomas G. Rhett to James Longstreet, April 28, 1862, in LS-ANVA.

59 Joseph E. Johnston to George W. Randolph, April 28, 1862, Joseph E. Johnston to George W. Randolph, April 29, 1862, in LR-SW, M-618, Reel 9. 
"Officers take rank from the date of their election. It was the intention of the law to give this advantage to companies first organized."60 Later, this precedent was seized by Captain Reuben Cleary of the 7th Virginia--another of Hill's regiments--to claim likewise an open majority. The War Department upheld his right to the post, even though the company which elected him had disbanded! 61

But Hill's were among the more simple problems facing Confederate officers during the reorganization. In the 9 th Virginia, stationed at Norfolk, Company $C$ held a disputed election for the captaincy. Ten of the seventy-seven men abstained, leaving one candidate with thirty-five votes, the other with thirty-two. But thirty-five votes, Major Mark Hardin pointed out, was only a majority of the sixty-seven men who actually voted, not of the entire company. Should the election stand? An anonymous endorsement from Cooper's office ratified the election. 62 Colonel Wade Hampton faced an even knottier problem in his brigade with the 16 th North Carolina, whose Company D entered the election season with 141 men. On April 22, Hampton presented Secretary Randolph with the following conunarum: "Seventy four men of Company

60 David G. Houston Jr. to Samuel Cooper, May 24, 1862, in LR-AIGO, M-474, Reel 25 .

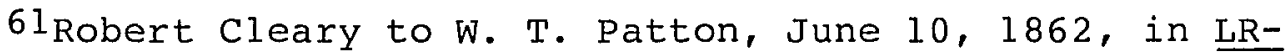
AIGO, M-474, Reel 29.

62 Mark Hardin to Samuel Cooper, March 25, 1862, in LRAIGO, M-474, Reel 24 . 
D $16 \mathrm{NC}$ regt. re-enlisted \& chose their officers under the bounty act leaving sixty-seven men in old company which is now Company D. What äisposition shall be made of the residue?" He needed a quick answer, because the election-in whichever company the War Department decided really was Company D--was scheduled for the following day. Almost plaintively, he closed the telegram: "Do answer." There is no indication in the files that anyone ever did.63

The situation was even more mudaled in regiments like the lst Texas and the 5th Alabama, both of which had been so hastily assembled in the fall of 1861 that each contained five companies enlisted for one year and five that had signed on for three. "Does the Ilth section of the Act of Congress require a new election of officers if the war companies and field officer," queried Brigadier-General Early, whose brigade incluảed the Alabamians, "or merely an election of officers of the 12 months companies?"64 Again, there is no reply extant; by mid-April, 1862, it seerned as if the Secretary of War and the Adjutant-General had quietly given up, and decided to ratify whatever the senior officer in the field decided fit the rules.

The confusion was not confined to the infantry. Colonel Pendleton's effort to achieve consistent calibers in

63 Wade Hampton to George W. Randolph, April 22, 1862 , in LR-SW, M-618, Reel 9 .

64 Jubal Early to George W. Randolph, April 21, 1862, in LR-AIGO, M-474, Reel 13 . 
each company, not only resulted in the constant transfer of guns between different batteries, but left the gunners with perplexing electoral questions, as well. The Jeff Davis (Alabama) Artillery had originally boasted eight cannon, but had been reduced by transfer to six. The problem was that the War Department had authorized the overstrength battery several additional lieutenants. Did their commissions expire with the loss of their guns? Nobody, including the Secretary of War, seemed to be certain. 65

Competition in the cavalry was even more keen than in the infantry or artillery. Of the seven Virginia regiments required to undergo reorganization, five voted out their colonels, all of whom had been professional soldiers before the war. This included the colonels of all three of Stuart's regiments on the Peninsula.66 Jubal Early protested that "the bad effects of the election system has - - been shown in the case of a Virginia Cavalry Regiment [the 3rd], in which, in my opinion by a mistaken [exception] of the law, the election of field officers was held by the men, and the Colonel, an efficient officer from the old army, was beaten." 67 But following its system of ratifying

65 There is no endorsement on the letter and no reply in the letterbooks. Jubal Early to George W. Randolph, April 21, 1862, in LR-AIGO, M-474, Reel 17 .

66 Krick, Lee's Colonels, p. 181; Warner, Generals in Gray, pp. 167,260 .

67 Jubal Early to George W. Randolph, April 21, 1862, in IR-AIGO, M-474, Reel 13 . 
almost any outcome that did not result in the dissolution of the regiment in question, the war Department declined to overturn the election.

Johnston, like Lee and almost every other professionally educated officer in the army, viewed the elections with quiet apprehension. Even in his memoirs, he remained mostly silent on the subject, noting only that the law "had the effect of weakening the army. . . "68 But despite their other differences, it is nearly certain that Johnston wholeheartedly agreed with the position stated by Lee, several months earlier:

The best troops are ineffectual without good officers. Our volunteers, more than any other, require officers whom they can respect and trust. The best men for that position should be selected, and it is important to consider how it can be effected. It would be safe to trust men of the intelligence and character of our volunteers to elect their officers, could they at the time of the election realize their dependent condition in the day of battle. But this they cannot do, and I have known them in the hour of danger to repudiate and disown officers of their choice and beg for others. Is it right then, for a state to throw upon its citizens a responsibility which they do not feel and cannot properly exercise?69

Yet regardless of his personal feelings, Johnston could do little to ameliorate the ill effects of the elections. He prevented disgruntled soldiers from simply leaving the army when they thought their legal enlistments had expired, employing stuart's cavalry to round them up and return them

\footnotetext{
68 Johnston, Narrative, p. 90.

${ }^{69}$ Robert E. Lee to A. G. Magrath, December 29,1861 , in OR, VI: p. 350 .
} 
to the ranks.70 He punctually forwarded the questions of his commanders to the appropriate departments in Richmond and enforced the ensuing decisions. He sanctioned the creation of boards of examination, which would hopefully remove the most blatant incompetents before they could do severe harm to their own men. 71 Beyond these measures, there was little for the army commander to do but keep himself firmly focused on the military problem at hand: resisting McClellan.

There were certainly enough other issues at hand with which Johnston had to deal, for at least one of which nothing in his entire military career had prepared him. In assuming command of the Peninsula and Norfolk, he had also acquired a navy. The Virginia and the other vessels under construction at Gosport were not really his concern. The talented if temperamental Flag-officer, Josiah Tattnall, had assumed command of the ironclad, whose mission was fairly simple: to cruise in the vicinity of Hampton Roads as often and as ostentatiously as possible. The Richmond and the other incomplete craft remained under the control of Captain Sidney Smith Lee, the commandant of the navy yard. But the remainder of the James River squadron had been ordered out of Hampton Roads and up the James to support the far right

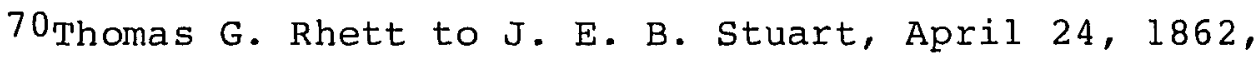
in LS-ANVA.

71 Lewis Armistead to Samuel Cooper, May 24, 1862, in LR-AIGO, M-474, Reel 3 . 
of the Yorktown line. 72

Compared to the massive flotilla with which Admiral Goldsborough supported the Army of the Potomac, Commander John R. Tucker's five vessels seemed almost inconsequential. Only the partially armored Patrick Henry, mounting ten guns, could be considered a threat to anything other than an undefended transport. Her sister ship, the Jamestown, sported no armor at all, ana carried but two cannon, winjch left her no more powerful than the smaller Teazer, which also carried two guns. The Raleigh and the Beaufort belonged to Mallory's envisioneä fleet of pesky little gunboats--converted tugs whicn, although light of draft and manueverable, were essentially impotent, having only a single riflea field piece placed in each bow.73 As Tattnall informed the secretary of the Navy on April 21: "I can not prevent the enemy's gunboats or light draft transports from entering and ascending the James River, or their army crossing it, except so far as the force of steamers I have placed in the river may prevent it. "On this, however," he remarked gloomily, "I have little reliance, as the enemy at any time can sena a force so superior as to compel them to

72Entry of April 5, 1862, Bragg diary, p. 201; Stephen Mallory to Josiah Tattnall, March 21, 1862, Stephen Mallory to Sidney Smith Lee, March 24, 1862, Josiah Tattnall, April 20,1862 , in NOR, VII: pp. 748, 749, 768 .

73"Report of Flag-Officer Buchanan, C. S. Navy," March 27, 1862, in OR, IX: p. 8; Stephen Mallory to Jefferson Davis, July $1 \overline{8}, 1861$, in NOR, Series 2 , II: p. 77. 
retire upon the river behind our forts."74

Helpless or not against the Federal Navy, Johnston did not realize that, until it actually was overwhelmed, Tucker's squadron could provide him with intelligence concerning operations on McClellan's left flank. The five vessels could also inhibit, if not prevent, any crossing of the lower Warwick River by unsupported Yankee infantry. Aside from that, Johnston instructed Tucker that "it would be well for your boats to do the enemy harm whenever they can." He also included the caution that "it is hardly worth while to fire, however, merely to annoy them." As with his most trusted subordinates, Johnston left the final decision up to the man in the field--or in this case, in the water-"You in the neighborhood can always judge when it is worth while to open fire."75

His trust proved to be well placed. A fifty-year-old Virginian, with thirty-five years experience afloat, including duty in the Mexican War, Tucker was cool under fire, meticulous about details, and a talented tactical improvisor. Within a week of his first assignment to Johnston's command, the General praised Tucker's abilities to Tattnall: "I am much pleased with his intelligence and

74Josiah Tattnall to Stephen Mallory, April 21, 1862, in NOR, VII: pp. 769-770.

75Joseph E. Johnston to John R. Tucker, April 28, 1862, in NOR, VII: pp. 775-776. 
zeal."76 Both Johnston and the Confederate authorities in Richmond would soon find even more reasons to appreciate his imagination and nerve.

The normal details of army administration consumed much of the rest of Johnston's time. He ordered the few decent roads through Williamsburg kept clear of miscellaneous wagon traffic in order to ensure that they would be open if Smith's Division had to move out quickly. 77 Likewise, he insisted that the Engineer Bureau inspect and, if necessary, repair the major bridges over the Chickahominy. 78 Johnston also had telegraph lines strung along the length of the army's rear. 79 He badgered both the secretary of war, requesting better cannon; and General Lee, asking him to inspect hospital accommodations for his sick men in Richmond, and to push General winder to sweep the city for soldiers absent without leave. 80

76 Sifakis, Who was Who, p. 662; Joseph E. Johnston to Josiah Tattnali, April 28, 1862, in NOR, Series 2, II: p. 633 .

77 Thomas G. Rhett to Benjamin S. Ewell, April 21, 1862, in LS-ANVA.

78 Joseph E. Johnston to Robert E. Lee, April 22, 1862, in $\underline{\mathrm{OR}}, \mathrm{XI}($ part 3): p. 456 .

${ }^{79}$ Indicated in T. G. Hunt to John R. Tucker, April 27, 1862 , in NOR, VII: p. 775 .

80 Joseph E. Johnston to George W. Randolph, April 25, 1862 , in LR-AIGO, M-474, Reel 27; Robert E. Lee to Samuel P. Moore, April 29, 1862, Robert E. Lee to Abraham C. Myers, April 29, 1862, Robert E. Lee to John H. Winder, May 3, 1862, in Lee Letterbook. 
For a man normally economical with words, the army commander almost barraged his superiors with updates and requests: during his sixteen-day tenure at Yorktown, Johnston wrote Lee or Randolph at least fourteen times, and quite possibly more.81 He also attempted to maintain contact with his other subordinates. Several telegraphic messages and letters, some delivered by staff officers authorized to expand on their content, arrived at Norfolk for General Huger, Flag-Officer Tatnall, and Captain Lee. 82 Messages requiring Generals Jackson and Ewell to communicate through Cooper's office in Richmond had been dispatched before Johnston left the capital; Field received similar instructions during the following week. 83 But despite his

81 This covers the number of letters preserved in $\mathrm{OR}$ and LS-ANVA, those found so far in LR-AIGO and LR-SW, as well as those alluded to in OR and Lee Letterbook, but not actually found. The list certainly omits many telegrams and dozens of endorsements on correspondence by his juniors, but as it stands now, letters or telegrams from Johnston to Lee or Randolph can be listed for the following dates (an asterisk indicates that the letter in question is mentioned but has not been found: Joseph E. Johnston to Robert E. Lee, April 20*, April 22 (two letters), April 24, April 27, April 28, April 29, April 30, May 1*; Joseph E. Johnston to George W. Randolph, April 20, April 24, April 25, April 28 (two letters).

82 Joseph E. Johnston to Benjamin Huger, April 27, 1862, Benjamin Huger to Robert $E$. Lee, April 29, 1862, Robert E. Lee to Benjamin Huger, April 29, 1862, in OR, XI (part 3): pp. 469-470, 474-475; Joseph E. Johnston to Josiah Tattnall, April 28, 1862, Joseph E. Johnston to Josiah Tattnall, May 1, 1862, Testimony of Sidney Smith Lee, January 31, 1863, Investigation of Navy Department, in NOR, Series 2, II: pp. $633-634$.

83 Thomas G. Rhett to Charles W. Field, April 24, 1862, in LS-ANVA. 
best efforts, Johnston soon found himself receiving less and less information from the rest of Virginia. By April 26, he would certainly have agreed with Colonel Dorsey Pender of the 6th North Carolina, who wrote his wife: "We are about as near cut off from all communication with the world as we could well be. Our mail all seems to come by chance and I have not yet been able to find out from what post office it came. " 84

But in Johnston's case, the culprit was not the Confederate Post office--it was his superiors in Richmond, specifically Generals Cooper (though probably unintentionally) and Lee. Though Johnston had left instructions for his mail from Jackson, Ewell, and Field to be forwarded to him through the Adjutant-General's Office, Cooper sent them all, instead, to Lee. Neither the originals nor copies were ever posted to Johnston who, unknowingly, found himself forced to rely upon letters from Lee, letters that subtly distorted not only the situation among Johnston's subordinates, but also his own role in directing them. 85 That Lee

84 Dorsey Pender to Fanny Pender, April 26, 1862, in Hassler, General to his Lady, p. 137.

85 While a few of the letters in the oR show endorsements of Lee forwarding them to Johnston, most of the letters were never forwarded to Johnston, and several, when they were copied for $\mathrm{OR}$, had their endorsements omitted. See Richard S. Ewell to Samuel Cooper, May 9, 1862, in LRAIGO, M-474, Reel 17, for an example of a letter forwarded by Cooper to Lee and not Johnston. Compare the version of Richard S. Ewell to Robert E. Lee on May 14, 1862, in OR, XII (part 3): p. 890, with the version in LR-AIGO, M-474, Reel 17, which contains an endorsement forwarding it for the 
had the authority to intercept Johnston's correspondence and issue orders directly to his subordinates was indisputable; it was, however, his methods that were questionable. Many historians have assumed that Johnston simply neglected his detached subordinates, leaving a command vacuum into which Lee, Jefferson Davis's "Military Advisor," quietly inserted himself, guiding by suggestion in order to avoid rumpling Johnston's sensibilities. Clifford Dowdey entitled his chapter on the subject "Lee plays at Machiavelli," and Douglas Southall Freeman asserted, without sources, that President Davis had instructed a reluctant Lee to intercept Johnston's correspondence and "supervi.se the movements of these two officers as long as Johnston was at a distance from Richmond"86 Robert G. Tanner, in Stonewall in the Valley, characterized Lee's intervention as being conducted "with great skill and little authority." 87

But as has already been demonstrated, Lee's position as Commanding General was far less than nominal. Ana he seems

information of Cooper, but not sending it to Johnston. That this process did not begin after Johnston's withdrawal from Yorktown is evident from an examination of $\mathrm{A}$. Blanchard to Samuel Cooper, April 28, 1862, in LR-AIGO, M-474, Reel 6 . Blanchard commanded a brigade in the Department of Norfolk, and was, therefore, Johnston's subordinate, but the letter was forwarded to lee instead. See also arguments on communications from Ewell and Jackson for the rest of this chapter. p. 131 .

86Dowdey, Seven Days, p. 63; Freeman, R. E. Lee, I I :

87 Tanner, Stonewall in the Valley, p. 156. 
to have hardly blinked at asserting his authority. Two letters from Ewell to Cooper, dated April 20 and intended fcr Johnston, announced that Jackson had called him from his frost on the Rapidan toward the Shenandoah because the Federals were advancing. Johnstoul levf saw the letters, which were diverted to Lee, who answered them most authoritatively: "If it is practicable to strike a speedy blow at General Banks and drive him back it will tend to relieve the pressure on Fredericksburg." 88

The same day, Lee mailed a letter to Jackson, advising him that "if you can use General Ewell's division in an attack on General Banks, and to drive him back, it will prove a great relief to the pressure on Fredericksburg. - ." If this was impracticable, Lee strongly suggested that Jackson return Ewell to supporting distance of Field's brigade south of the Rappahannock. Most importantly, Lee essentially cut Johnston out of the line of communication by telling Jackson to "please communicate with me on this subject. [emphasis added]"89

Nor did Lee inform Johnston, in a letter to the department commander on the same day, that he had written to both of Johnston's subordinates. Besides ignoring his own

$88_{\mathrm{Ri}}$ chard S. Ewell to Samuel Cooper, April 20, 1862, Richard S. Ewell to Samuel Cooper, April 20, 1862, Robert E. Lee to Richard S. Ewell, April 21, 1862, in OR, XII (part 3): $\mathrm{Pp}$. 857-859.

${ }^{89}$ Robert E. Lee to Thomas J. Jackson, April 21, 1862, in OR, XII (part 3): pp. 859-860. 
correspondence with Jackson and Ewell, Lee did not advise Johnston that Field had abandoned Fredericksburg, and that he, standing on his authority as Commanding General, had sent the young brigadier-general explicit orders that were a far cry from the deferential suggestions of a military adviser. "I desire that you shall do everything in your power to prevent the enemy from advancing from Fredericksburg," Lee instructed Field on April 19, continuing: "You will use every exertion to ascertain the strength and movements of the enemy and keep me informed of the same. You will also communicate with General Ewell. . . " These were positive directives, directives of which Lee did not advise Johnston. 90

Lee did not even inform Johnston until April 23--six days after the fact--that the Confederates no longer held Fredericksburg. He vaguely detailed the reinforcements being dispatched to Field's position, but in such a way that Johnston could not have estimated their numbers, even though Lee had an accurate count of the soldiers being sent north. Nor did he advise Johnston whether or not either of the brigade commanders, Maxcy Gregg or Joseph R. Anderson, ranked Field, and would, therefore, take over his command. In the same pair of letters, Lee finally informed Johnston that Jackson had called Ewell into the Valley, but omitted

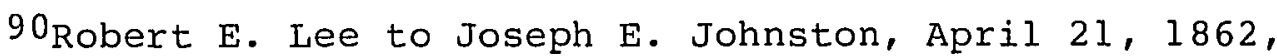
in OR, XI (part 3): p. 452; Robert E. Lee to Charles W. Field, April 19, 1862, in OR, XII (part 1): p. 433. 
the date on which Jackson had done so, and continued to ignore his own correspondence with the two generals.91 Lee's actions in regard to the Fredericksburg front became even more misleading on April 26. Brigadier-General Joseph R. Anderson did indeed outrank Field, and received his formal instructions from Lee when he passed through Richmond from North Carolina. "You will proceed with your brigade to the vicinity of Fredericksburg," Lee told Anderson, "where Brig. C. W. Field is now with the troops which have preceded you, and assume command of the operations of our army in that quarter, being the senior general officer." No mention was made by Lee that Field had been subordinate to Johnston, nor that Anderson's command was a district in someone else's department. The appointment to command having been made, Lee continued with detailed strategic orders: "If it be impossible to drive the enemy from his present position, I desire you to lose no effort to keep him confined to the smallest possible margin."92 Anderson obviously considered himself the commander of

$91_{\text {Lee }}$ did not give Johnston the numbers of either Gregg's or Anderson's brigades, both of which he would have had at least a rough idea from departmental returns in Cooper's office. The strength of the regiments sent from Richmond he knew exactly, because he had the muster rolls. See Robert E. Lee to Joseph E. Johnston, April 23, 1862, Robert E. Lee to Joseph E. Johnston, April 23, 1862, in OR, XI (part 3): pp. 458-459; Robert E. Lee to Samuel Cooper, April 24, 1862, in LR-AIGO, M-474, Reel 30 .

92 Robert E. Lee to Joseph R. Anderson, April 25, 1862, in $\mathrm{OR}, \mathrm{XII}($ part 3): p. 867 . 
one of the Confederacy's many small independent armies, answerable only to the Commanding General. Lee neither corrected him when he styled his division the "Army of the Rappahannock," nor ever informed him that Johnston was his official superior.93 Johnston did not receive news of Anderson's assumption of command until May 8, when Lee responded to a direct question. On the other hand, Lee informed both Jackson and Ewell of Anderson's appointment in advance, and ordered all three generals to communicate with each other. 94

Lee's methods plainly discomfited both Jackson and Ewell. Jackson pointed out to him on April 23 that the options that they had been discussing "would be departing from General Johnston's instructions. . ."95 Three days later, Jackson, still uneasy about the lack of any word from his official superior, queried Ewell: "Do you make regular reports to General Johnston? The General directed me to send communications for him to you. Please acknowledge receipt of the accompanying one and let me know to what

93Joseph R. Anderson to Robert E Lee, April 29, 1862, in OR, XII (part 3): p. 873; See also J.R. Anderson Order Book, Virginia Historical Society, Richmond, Virginia.

94 Robert E. Lee to Joseph E. Johnston, May 8, 1862, in OR, XI (part 3): pp. 500-501; Robert E. Lee to Thomas J. Jackson, April 25, 1862, Robert E. Lee to Richard S. Ewell, April 25, 1862, in OR, XII (part 3): pp. 865-866.

95Robert E. Lee to Thomas J. Jackson, April 23, 1862, in OR, XII (part 3): p. 863 . 
point you send it." 96

Jackson's April 26 letter to Johnston did not survive to be included in either the official Records or the files of the Adjutant and Inspector-General's office. But its timing suggests that Jackson, who had always kept Johnston carefully apprised of his movement, probably explained that he intended, on Lee's orders, to leave Ewell's Division to observe Banks while he united with Brigadier-General Edward Johnson west of Staunton, to attack the Federals debouching from the mountains of western Virginia. As aggressive as he was, it would have been in character for Jackson to tell his superior that he intended to use the discretion granted him to pursue his plan unless he was overruled within a few days.97 Four days later, having received no response, Jackson began the deceptive maneuvering which inaugurated the later-famous "Valley Campaign." It is impossible to determine whether or not Johnston would have sanctioned Jackson's offensive, because he never received the letter. Lee's disregard for the formal command structure also distressed Ewell. "Dick" Ewell's personality was such that his performance depended upon the receipt of explicit

96 Thomas J. Jackson to Richard S. Ewell, April 26, 1862, in OR, XII (part 3): p. 868 .

97Jackson had, for instance, always kept Johnston wellinformed during his Romney campaign in the previous winter. Nor would the content have been much different than in Thomas J. Jackson to Robert E. Lee, April 29, 1862, in OR, XII (part 3): p. 872; Tanner, Stonewall in the Valley, pp. 161-162. 
orders; ambiguity, or even an excess of personal discretion, unnerved him.98 And nobody, during April, May, and June, 1862, ever seemed to want to explain to him where he was to march, why he was headed there, or who was in charge. He confided in one of his brigade commanders that "he never saw one of Jackson's couriers approach without expecting an order to assault the north pole."99 Lee's letters suited him little better; on April 26 he complained to the Commanding General that "I have the honor to state that I don't clearly understand your letter of the 25th. . . " This was followed by an extract and a series of detailed questions aimed at pinning down Lee's intent.100 Lee responded briefly on April 27 that the information had been more intended for Jackson than Ewell, and that Ewell had been informed almost as an afterthought.101 Three days later, still disgruntled by the fact that he could not determine just who was in control of operations, Ewell shot back to Lee a rejoinder:

I beg leave to say that it seems important to me that the whole line, including the forces south of Fredericksburg (Generals Field and Anderson), should be under one general, authorized to combine them against any point deemed advisable. This

98Freeman, Lee's Lieutenants, I: pp. 350-352.

99 Taylor, Destruction, p. 36 .

100 Richard S. Ewell to Robert E. Lee, April 26, 1862, in OR, XII (part 3): p. 367 .

$101_{\text {Robert }} \mathrm{E}$. Lee to Richard S. Ewell, April 27, 1862, in $\underline{O R}, \mathrm{XII}($ part 3): p. 869 . 
does not seem to be the case at present, and the enemy are exhausting the country at free cost.102

Johnston's continued ignorance of this, however, raises two significant questions. First, why did Lee keep Johnston in the dark? Second, what efforts did or should Johnston have made to find out what was occurring in northern Virginia?

There is no evidence extant to support Freeman's contention that Jefferson Davis ordered Lee to take over coordination of the movements of Johnston's detached subordinates. Nor did there need to be such a directive-the correspondence of Jackson, Ewell, Anderson, and Field all reveal the fact that each officer took Lee's title of "Commanding General" quite seriously, and assumed that he could legally issue them orders. But if he had legal authority to command Johnston's subordinates, why did Lee not openly advise Johnston that he was doing so?

The correspondence between Johnston and Lee suggests a possible answer. Johnston had always been reluctant to commit his army to the Peninsula, and when Lee had written on April 21 that it might be necessary to detach units from Johnston's army to reinforce Field in order to protect the Fredericksburg line, Johnston had reacted very negatively: "I think it anything but expedient to divide these forces." Further, said Johnston on April 22:

102 Richard S. Ewell to Robert E. Lee, April 30, 1862, in OR, XII (part 3): p. 876 . 
Should McDowell advance upon the capital, which is certainly probable, the only course for us, in my opinion, is . . to assemble near Richmond as many troops as possible, those from Norfolk, North Carolina, and South Carolina to be joined by this army, then to endeavor to fight the enemy before all his forces are united. To detach troops from this position would be ruin to those left. 103

This reaction caused Lee to tread very lightly around the subject of a threat from Fredericksburg, primarily because his own preferred strategy involved holding the Peninsula as long as possible. This would also have given Lee cause to believe that Johnston would respond negatively to any suggestion that Jackson and Ewell might actually march theix divisions farther away from Richmond for any reason.

But even allowing for the fact that Lee controlled much of Johnston's access to information about other fronts, why was there not a greater effort by Johnston to communicate directly with his own subordinates? Did his preoccupation with McClellan's army and growing siege train make him "lose touch" with the rest of his department, as Freeman believed?

The question of timing is critically important to resolving this issue. Johnston had last written to Jackson and Ewell on April 17, before leaving Richmond. Letters travelling from Richmond to the Rappahannock, Johnston knew

103 Joseph E. Johnston to Robert E. Lee, April 22, 1862, in $\underline{\text { OR, } X I ~(p a r t ~ 3): ~ p . ~} 456$. 
from his own experience, usually required two or three days for delivery. A letter forwarded through Ewell to Jackson would take at least another day to reach the commander in the Shenandoah. Assuming that Jackson responded on the same day he received the letter, a minimum of three days could be expected in its return trip to the capital. Soon after arriving at Yorktown, Johnston discovered that the mail between Richmond and the Peninsula normally spent the better part of two additional days in transit. Therefore, even under the best of circumstances, Johnston woula not have expected any reply from Jackson until April 24 or 25 . A single missed connection or significant delay somewhere in the postal chain could have reasonably extended this period by two days; Johnston should not have had any cause to be anxious until after April 27.104

But by that time, Johnston had already received Lee's letter of April 23, which seemed to update him on the positions of his subordinates. Jackson, he inferred incorrectly, had ordered Ewell toward the Valley on April 21, pursuant to Johnston's original orders to try to engage Banks near swift Run Gap. Given the fact that it should take Ewell at least two days to join Jackson, and that Lee had "heard nothing . . of the junction of Jackson and Ewell," Johnston had no real reason to expect either of his

104 These times are derived from a study of the transmittal and reception dates of earlier correspondence. 
commanders to write until some sort of action commenced.105 Even if a battle took place immediately upon Ewell's reinforcement of Jackson--which Johnston believed would happen about April 24 or April 25--then a letter from Jackson could not reasonably be expected until April 29 or April 30. The only problem with this series of assumptions was that it rested upon the mistaken belief that Jackson had ordered Ewell to march on April 21, when he had, in fact, done so on April 17. Had he known that events were progressing so rapidly in the Valley, it is unlikely Johnston would have remained so sanguine about the lack of correspondence. Only by the last few days of April would Johnston have begun to realize that something was dreadfully amiss with his lines of communication to his subordinates. Unfortunately, it was just then that another event occurred which rightfully rivetted the army commander's eyes to the Yankee army directly in front of him: MCClellan's siege artillery opened fire.

$105_{\text {Robert }} \mathrm{E}$. Lee to Joseph E. Johnston, April 23, 1862, in OR, XI, (part 3): pp. 458-459. 
Chapter Nine

The Retreat from Yorktown

The Farinholt House stood on a bluff overlooking Wormley's Creek, roughly 4,200 yards south of Yorktown. It was a large, colonial-style frame house with four white pillars on the front porch, chimneys at either end, and third-floor dormer windows. From the roof, an observer with a telescope could see over the ramparts protecting Yorktown, discern details of the water battery, and even watch the unloading of the schooners that glided down the upper York River to provide Johnston's army with provisions and ammunition. It had been a key observation point for McClellan's engineers and artillery officers throughout the siege. 1

Shortly after noon, on Wednesday, April 30, 1862, the roof would have been packed with far more men than usual. Battery No. 1--often informally known as the "Farinholt Battery"--was scheduled to open fire on the Confederates at 2:00 P. M.2 Brigadier-General William F. Barry, Chief of Artillery of the Army of the Potomac, would have been there,

lDavis, Image of War, II: p. 45.

2 "Reports of Brig. Gen. William F. Barry, U. S. Army, Chief of Artillery, Army of the Potomac, of the siege," May 5,1862 , in $\mathrm{OR}, \mathrm{XI}$ (part 1): p. 345 . 
as well as Colonel Robert 0 . Tyler, organizer of the 1st Connecticut Heavy Artillery and commander of McClellan's siege train. Other officers from the lst Connecticut, serving at batteries still incomplete, might have slipped away to watch the effect of the first heavy shells to drop into Yorktown, and beside them might well have been officers from the 5th New York. The New Yorkers had a special interest in the guns in Battery No. 1: they had hauled them off the ships across paths so muddy that the monstrous cannon sunk in to their axles. Then they had dug them out and manhandled them at the direction of the artillerymen into the battery they helped to excavate. 3 Possibly McClellan himself, attended by his retinue of staff officers and foreign military observers, climbed onto the roof to watch what he hoped was the systematic destruction of Johnston's fortifications.

Major Elisha F. Kellogg, also from the lst Connecticut Artillery, did not have such a good view of Yorktown, even though what he saw counted most of all. Kellogg commanded Battery No. 1 , and thus he was down inside the carefully dug traverses, calculating trajectories for his guns. His battery boasted five 100-pound Parrotts and one monster 200pounder. The smaller guns weighed 9,700 pounds, and required ten pounds of powder to throw a shell as far as 6,800 yards; the larger one weighed 16,500 pounds, and

3 Ibid., p. 348. 
lobbed its projectiles 8,000 yards on a charge of sixteen pounds. The shells themselves weighed between seventy and 175 pounds. To hit the wharves or the batteries at Yorktown was well within their capability, but called for careful ranging; missed shots were significant because the big guns took nearly an hour to reload. 4

Kellogg's targets that Wednesday afternoon were the Yorktown wharves, where detailed soldiers struggled to unload half a dozen supply vessels. As the first shells plunged in, D. H. Hill's soldiers fled the docks in confusion, and the skippers of the schooners cast off and sailed behind Gloucester Point, a position which had, heretofore, represented safe haven from Yankee shells. But not today. Kellogg's 200-pound Parrott slowly pivoted and the gunners cranked it almost up to its thirty-five degree maximum elevation. They loaded a shell, and sent it crashing down among the anchored vessels some 6,200 yards up the river. 5

Hill fired back. His men could sight Battery No. 1 quite easily, but McClellan's engineers had measured very carefully. An 8-inch Columbiad smoothbore was the largest piece that the confederates could bring to bear, and the

4 Ibid., p. 339, 345-346; Coggins, Arms and Equipment, p. 86; David G. Martin, "Civil War Artillery," Strategy \& Tactics, No. 81 (July-August 1980): pp. 18-19.

5 "Reports of Brig. Gen. William F. Barry, U. S. Army, Chief of Artillery, Army of the Potomac, of the siege," May 5, 1862, in OR, XI (part 1): p. 345; Martin, "Artillery," p. 18 . 
Yankee guns had been dug in just on the fringes of its most extreme range. Hill's gunners got close enough to rattle the teeth of the New Englanders inside the battery, but not close enough to hurt them; General Barry reported several days later: "The enemy's fire was well directed, but the protection afforded by the battery effective, and their fire caused us no casualties." 6

Lowering the barrels of two of the 100-pounders slightly, Kellogg's men returned the favor. They could only fire once for every three times the Confederates did, but the greater range and shell weight of the Parrott rifles soon told; Hill's gun was quickly silenced. The firing continued throughout the afternoon and evening, thirty-nine heavy shells in all landing inside Hill's perimeter. 7

The cannonade ceased with darkness. Gunnery with such heavy weapons in the mid-nineteenth century still required much direct sighting for accuracy, and Mcclellan hated to waste shells. Dense fog the next morning provided the Confederates something of a reprieve. Since no one could see where the shells were landing, Kellogg was ordered to limit himself to one shot an hour in the direction of the wharves, simply to discourage the unloading of supplies. 8

\section{${ }^{6}$ Ibid.}

7"Reports of Brig. Gen. William F. Barry, U. S. Army, Chief of Artillery, Army of the Potomac, of the siege," May 5,1862 , in OR, XI (part 1): pp. 345-346.

${ }^{8}$ Ibid. , p. 346 . 
But Johnston knew that the fog could not last forever, and his own observers confirmed that other heavy batteries across the warwick were only days away from opening fire, as well. Nothing in his own artillery park could seriously harm McClellan's batteries as they demolished his own positions piece by piece. In a classic siege, this would have been the moment for a sally against the enemy guns, but the inundations of the river to his front made this impossible.

Johnston had dreaded this moment. The day before Battery No. 1 opened fire, he had written to Lee that "should the attack upon Yorktown be made earnestly, we cannot prevent its fall; nor can it hold out more than a few hours." He believed that McClellan would combine his bombardment with a rush up the James River by Federal ironclads which, unlike the Virginia, had shallow enough drafts to follow the main channels. This "would enable him to reach Richmond three days before these troops, setting out at the same time. Should such a move be made, the fall of Richmond would be inevitable, unless we anticipate it." 9 Anticipation meant withdrawal: "As two or three days, more or less, can signify little, I think it best for the safety of the capital to do it now, to put the army in position to defend Richmond." Yet he intended to move

9Joseph E. Johnston to Robert E. Lee, April 29, 1862, in $\underline{O R}, X I$ (part 3): p. 473 . 
deliberately, "as soon as can be done conveniently, looking to the condition of the roads and the time necessary for the corresponding movement from Norfolk." And, perhaps remembering Davis's earlier disavowal of approving his withdrawal from Manassas, Johnston made sure that Lee understood the intent of his communication: "As this is an important movement, I think it necessary that the intention to make it be reported to the Government."10

The opening of Battery No. 1 forced Johnston's hand much more quickly than even he had expected. If the Federals could deny him the Yorktown docks, then the army became almost completely dependent on the trickle of supplies which could be landed at Jamestown Island. Further, he was faced with the prospect that this one battery could, within days, dismount all the Confederate cannon in the Yorktown water battery, and across the river at Gloucester Point. He called his senior officers at Longstreet's headquarters on May 1: Smith, Longstreet, Magruder, Hill, Stuart, Pendleton, and Alexander. Not one of them believed that the Yorktown line could or should be held longer than another forty-eight hours.ll Johnston had already ordered Huger to prepare Norfolk for evacuation; now he told his subordinates that the withdrawal would occur on the evening of May 2, and telegraphed Jefferson Davis to the

\author{
10 Ibid.

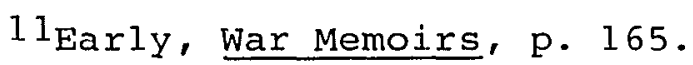


same effect. 12

Though aware that "the wretched condition of the roads may cause us heavy losses of materials on the march," Johnston determined to avoid leaving anything behind for McClellan that could be hauled away.13 As in northern Virginia, this did not include his heavy artillery which, besides being nearly immobile, would have to cover the retirement of his divisions. He ordered Alexander to ship to Richmond all the extra ammunition and ordnance stores in depot beginning April 30.14 Pendleton's artillery was assigned the best of several poor roads, and scheduled to march several hours ahead of the main body.15 He ordered Colonel Fitzhugh Lee's lst Virginia Cavalry to precede the army to the vicinity of Eltham's Landing and West Point, in order that the army would be immediately alerted to the expected Federal amphibious landing once Yorktown and

12 Joseph E. Johnston to Benjamin Huger, April 27, 1862 ; the telegram to Davis has not been preserved, but may be inferred from Jefferson Davis to Joseph E. Johnston, May 1 , 1862; see also Joseph E. Johnston to D. H. Hill, May 1, 1862, all in OR, XI (part 3): pp. 469-470, 484-485.

13Joseph E. Johnston to Robert E. Lee, April 29, 1862, in $\underline{O R}, X I$ (part 3): p. 473 .

14 E. P. Alexander to Edwin Taliaferro, April 30, 1862, in Beverly Randolph Wellford papers, Virginia Historical Society, Richmond, Virginia.

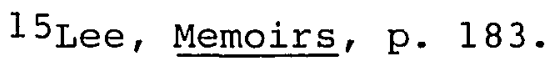


Gloucester were evacuated. 16

A Federal landing on the banks of the York River to his rear was Johnston's greatest concern. He believed that the Virginia could hold Admiral Goldsborough's flotilla at bay on the James, at least for a few days.17 But even though he had ordered the batteries at Gloucester Point to be manned for several hours after the retreat of the bulk of the army, he harbored few illusions that this would keep the Federals from ascending the York River.18 So he took what few precautionary measures he could. He ordered the supply vessels on the York River sailed upstream to critical points and sunk in the river as obstructions; fifty-three schooners were thus scuttled as Yorktown fell.19 The railroad bridge over the York River near West Point was burned, as were the docks at key points along the river. 20 But Johnston knew that such measures could at best delay, not prevent, an amphibious descent on his rear; he could count on having to

$16_{\mathrm{H}}$. B. McClellan, The Life and Campaigns of MajorGeneral J. E. B. Stuart (Boston: Houghton Mifflin, 1885), pp. 47-48.

17 Joseph E. Johnston to Robert E. Lee, April 29, 1862, in OR, XI (part 3): p. 473 .

18 Joseph E. Johnston to D. H. Hill, May 2, 1862, in JJWM.

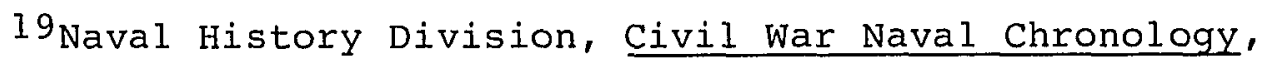
VI: pp. 331-333; Thomas S. Phelps to William Smith, May 5, 1862, in NOR, VII: p. 313.

20 William Smith to L. M. Goldsborough, May 5, 1862, T. H. Patterson to William Smith, May 4, 1862, william Smith to I. M. Goldsborough, May 12, 1862, in NOR, VII: pp. 310-311, 316 . 
fight MCCleIlan's troops with part of his army before the rest haà even cleared the vicinity of williansburg. Johnston wanted G. W. Smith's Division available to oppose any Federal landing on the York River. The troops were the freshest in the army, and among Smith's brigade commanders were Whiting and Harnpton, two men whom he trusted implicitly. So he arranged that, once the army passed through Williamsburg, Smith's Division would be in the lead. Whiting's three brigades were scheduled to be among the first troops to march away from Yorktown on May 2.21 He also gave Smith control of the lst Virginia Cavalry, as well as Magruder's Division, and part of the Reserve Artillery as soon as those units cleared Williamsburg. 22 with half the army available to him, Smith should be able, Joinston hoped, to contain, if not repulse, a Yankee landing, while Johnston supervised the rear guard and the evacuation of the army's guns and supplies.

The pounding of heavy shells from battery No. 1 resumed in earnest on the morning of May 2: Kellogg's men droppea sixty rounds on the Yorktown aocks and the water battery; Hill's 8-inch columbiad burst returning the fire.23 how

21 Joseph E. Johnston to D. H. hill, May 1, 1862, in OR, XI (part 3): p. 486 .

22 Smith, Confederate war Papers, pp. 45-48.

23 "Reports of Brig. Gen. Williain F. Barry, U. S. Army, Chief of Artillery, Army of the Potomac, of the siege," May 5,1862 , in $\mathrm{OR}, \mathrm{XI}$ (part 1): p. 347 . 
many more days could the Yorktown fortifications withstand the shells of the Parrott guns? How long before more of McClellan's heavy artillery commenced battering the other sections of his line? Once the other Union batteries opened, the Confederate withdrawal could potentially become a bloody disaster. Johnston's timetable was tight--much tighter than the one attempted in northern Virginia--because no movements near the front could be attempted until nightfall, lest they be observed. The orders for the retreat were carefully drawn and circulated to all the division commanders on the morning of May 2.24

Delays and confusion among the trains of Longstreet's and Magruder's Divisions forced Johnston to postpone the movement for twenty-four hours. It was a tense day: the lst Connecticut Artillery poured another thirty-four rounds into Hill's fortifications at Yorktown, which now had no guns capable of reaching Battery No. 1 with return fire. Meanwhile, General Barry reported to McClellan that the next morning the ten 13 -inch seacoast mortars of Battery No. 4, four more in Battery No. 11, five 10-inch siege mortars in Battery No. 12, six 30-pound Parrotts in Battery No. 13, and three 100-pound Parrotts in Battery No. 14 would all be ready to open fire at dawn on May 4. Major Charles 5 . Wainwright of the lst New York Light Artillery, who had

24 General Orders no. --, Department of Northern Virginia, May 2, 1862, in OR, XI (part 3): pp. 489-490; see also the copy in LS-ANVA for distribution notes. 
dropped by Barry's headquarters, confided to his diary that evening that "it will be a splendid sight when all our guns and mortars open, especially if the rebs reply lively; one worth half a lifetime to see. . . "25 Johnston had only hours left before the conflagration began.

A heavy rain started to fall in the evening of May 3, as the first brigades slipped quietly out of their rifle pits.26 It was a decidedly mixed blessing, for while it would disguise the movement to some extent, the downpour ruined the roads over which the army had to travel. Alexander wrote: "I recall that night's march as particularly disagreeable. The whole soil of that section seemed to have no bottom and no supporting power."27 The soil had been so soaked with the rain of previous weeks that the water could not even sink in; a private in Pickett's Brigade remembered that "the clay and sand of the roads was now worked into a liquid mortar, which overspread their entire surface, hiding the deep holes cut by heavy gun wheels, until man or beast discovered them by stumbling therein." 28

25"Reports of Brig. Gen. William F. Barry, U. S. Army, Chief of Artillery, Army of the Potomac, of the siege," May

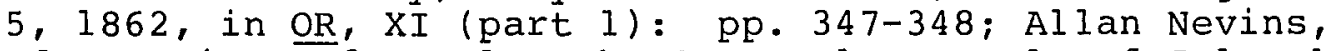
ed., A Diary of Battle, the Personal Journals of Colonel Charles S. Wainwright, 1861-1865 (New York: Harcourt, Brace, and World, 1962), p. 44 .

26 Smith, Confederate War Papers, p. 46.

27 Al exander, Military Memoirs, p. 66.

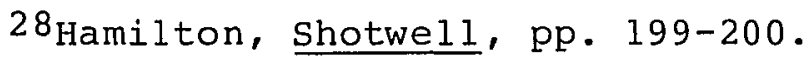


The columns waded and struggled along at a pace that never exceeded one mile an hour, and that with exhausting effort. "The roads," said Alexander, "were but long strings of guns, wagons, and ambulances, mixed in with infantry, artillery, and cavalry, splashing and bogging through the darkness in a river of mud. . . " 29

At best, Johnston knew that his men might make seven or eight miles by sunrise. It was barely enough to give him a head start on the Federals, and even that was threatened by the constant stalling of wagons, caissons, and guns in the mud. Horses sank up to their bellies and wagons to their axles. Each time this happened, ropes had to be tied to the floundering teams and their wagons, and the already jaded horses of other wagons brought back to assist in their rescue. Often this was not enough, and the infantry and gunners swarmed into the mud to manhandle wheels loose from the mire. 30 Johnston himself dived into the muck to help pry loose a 12-pounder of Snowden's (Georgia) Battery. 31 Some of the horses drowned, while others had their hearts simply give out. Wagons were abandoned and guns spiked. One private wrote later, "sometimes I caught myself stumb-

\section{Al exander, Military Memoirs, p. 66.}

30stiles, Four Years, p. 83; Edgar Warfield, A Confederate Soldier's Memoirs (Richmond: Masonic Home Press, 1936), p. 84; Hamilton, Shotwell, pp. 199-200.

$3 l_{F}$. Y. Dabney, "General Johnston to the Rescue," B\&L, II : pp. 275-276. 
ling over a dead horse and sometimes upon a half-living man."32 Yet, somehow, the army kept moving, if only at a snail's pace, even though everyone was as tired as colonel Pender, who told his wife, "I have seldom been more sleepy, hungry or tired than I am just now." 33

The army kept moving, but many individual soldiers did not. The backbreaking work, combined with lack of sleep and the absence of rations for two days, caused many of Johnston's troops to collapse in an apathetic stupor. D. H. Hill counted more than 1,500 stragglers along his route of march through williamsburg, and told his wife, "there are thousands also scattered over the country engaged in plundering." When Hill attempted to encourage or intimidate them into rejoining the ranks, "some answered by my entreaties with curses, some with 'I don't care if the Yankees do take me. I am starving to death and freezing with cold." "34 Well aware of the condition of his troops, Johnston knew that he could only retreat so far before he halted to give the men a rest. If not molested by federal pursuit, he intended to halt between the Pamunkey and Chickahominy

32 Hamilton, Shotwell, p. 200; Stiles, Four Years, p. 83.

${ }^{33}$ Dorsey Pender to Fanny Pender, May 8 , 1862, in Hassler, General to His Lady, p. 140 .

${ }^{34}$ D. H. Hill to "My Dear Wife," May 11, 1862, in D. H. Hill papers, College of William and Mary, Williamsburg, Virginia. 
Rivers, and there await McClellan. 35

But that depended on just how long Mcclellan would remain in front of empty entrenchments, and how determined his pursuit would be. As most of the infantry evacuated the fort at Yorktown, Hill's cannoneers inaugurated their heaviest bombardment of the Yankee lines during the entire siege, firing off their stocks of powder and shot as if there were no tomorrow, because there was not, one. By mianight, or soon thereafter, the fire began to slacken, as the gunners spiked their pieces one by one, and laid powder trails into their magazines. Major Bryan Grimes of the 4 th North Carolina commanded the last few companies of the infantry rear guard, which picked its way back from the picket line around 4:00 A. M. Grimes had to balance the speed necessary to clear the town before the fuses burned down against the need to avoid "torpedoes [that] had been planted on all the roads and streets leading into Yorktown. . . . " 36

The torpedoes--mostly 10-pounder shells rigged with pressure fuses and buried as mines--were the work of

\section{Smith, Confederate War Papers, p. 48.}

36 "Report of Brig. Gen. Charles D. Jameson, U. S. Army, as General of the Trenches, May 3-4, with indorsement, "May 4, 1862, in OR, XI (part 1): P. 398; Pulaski Cowper, ed., Extracts of Letters of Major-General Bryan Grimes to his Wife, written while in Active Service in the Army of Northern Virginia, together with some personal recollections of the war written by him after its close, etc. (Raleigh, NC: Alfred Williams, 1884), p. 12 . 
Brigadier-General Gabriel J. Rains. Enraged by Federal shelling of New Berne, North Carolina, his hometown, Rains considered land mines a fair response. Almost everyone else--from Johnston to McClellan--disagreed, but after the fact, for Rains had never informed his superiors of his intentions. Despite the fact that Johnston would later disown the tactic, Rains' explosives killed enough unwary Union soldiers to slow down the Federal penetration of Yorktown. 37

For several hours after sunrise on May 4, as Johnston's infantry and artillery struggled up muddy roads, stuart's depleted cavalry brigade was the only force actually facing the Army of the Potomac. Having detached the lst Virginia Cavalry to cover Eltham's Landing, stuart was left with only 1,500 sabers to slow down the pursuit. He deployed Lieutenant-Colonel William Wickham and the 4 th Virginia Cavalry, as well as part of Colonel Thomas F. Goode's 3rd Virginia Cavalry, to cover the williamsburg road. A few miles south of Wickham and Goode, on the Telegraph Road, Stuart himself took charge of the Jeff. Davis (Mississippi) Legion and several companies of the Wise (Virginia) Legion. There was

37 "Reports of Brig. Gen. William F. Barry, U. S. Army, Chief of Artillery, Army of the Potomac, of the siege," August 25, 1862, "Report of Col. Jesse A. Gove, Twentysecond Massachusetts Infantry, of occupation of Yorktown, May 4," May 4, 1862, in OR, XI (part 1): pp. 349-350, 399400; G. Moxley Sorrel to Gabriel J. Rains, May 11, 1862, A. P. Mason to D. H. Hill, May 12, 1862, Gabriel J. Rains to D. H. Hill, May 14, 1862, in OR (part 3): pp. 509-510, 511, 516-517. 
little or no communication between the two wings of stuart's Brigade, because the heavily wooded country "was exceedingly unfavorable for cavalry operations. . . ."38

Stuart was careful throughout the morning to keep Johnston informed of the advance of Federal cavalry on the Telegraph Road under Brigadier-Generals George Stoneman and William H. Emory. What he did not know was that, on his left flank, Wickham and Goode were being pushed back steadily, until the blue-clad horsemen had actually gotten between stuart and Johnston. This he only found out when a courier returned with the news that he colld not thread his way through Union lines with a message for the army commander. Resourceful in every extremity, stuart trotted his men farther south, and detoured around the enemy by way of the beaches near Jamestown. 39

Johnston, however, did not know that stuart was extricating himself. About noon, he realized that the courier was overdue. This was at roughly the same time the lst and 4 th Virginia Cavalry found themselves pushed back to the outskirts of Williamsburg. In the densely forested terrain, there was no way to be certain that there was not a division of infantry on the heels of the Federal cavalry. So assuming the worst, at 1:00 P. M., Johnston himself rode

38 "Report of Brig. Gen. J. E. B. Stuart, commanding Cavalry Brigade," May 13, 1862, in OR, XI (part 1): p. 444.

${ }^{39}$ Ibid.; Thomas, Bold Dragoon, pp. 104-105. 
to the rearmost unit in the line of march, Brigadier-General Paul J. Semmes" Georgia-Kentucky Brigade, and ordered it into the forts around Williamsburg.40 About an hour later, Johnston located Brigadier-General Lafayette McLaws, who commanded part of Magruder's Division. He instructed him to send another brigade back to support semmes, and to go himself to supervise the line.41

Mclaws, a Georgian who had graduated from West Point in Longstreet's class, picked the South Carolina brigade of lawyer-turned-soldier Joseph B. Kershaw for the assignment. Both arrived at semmes' position about 3:00 P. M. MCLaws was vaguely aware that the fortifications in front of Williamsburg were centered on a large earthwork--Fort Magruder--with minor works extending toward the rivers north and south at intervals of several hundred yards. Semmes had already occupied some of the redoubts to the right of the road, but neither he nor McLaws knew the exact location of all the forts. Fortunately, Colonel Benjamin S. Ewell of the 32 nd Virginia was at hand. Ewell had commanded the post of williamsburg for months, and was thoroughly familiar with the terrain. He quickly guided Kershaw's Brigade into the

40 "Reports of Brig. Gen. Paul J. Semmes, C. S. Army, commanding brigade," May 17, 1862, in OR, XI (part 1): p. 445 .

41 "Report of Brig. Gen. Lafayette McLaws, C. S. Army, commanding division," May 16, 1862, in OR, XI (part 1): pp. 441-442. 
correct positions. 42

Yet even before the Confederates had deployed their second brigade, stoneman's advance guard arrived. The Federal cavalry, apparently unaware that it was probing a line now held by infantry, rode forward so boldly, Mclaws reported, that "at first they were supposed to be our own men, so close were they and so confident in their advance. - ." He soon realized his error, as Union horse artillery opened up in support of the horsemen. About this time, Colonel J. Lucius Davis, commanding the Wise Legion cavalry, and the first of stuart's detachment to rejoin the army, arrived on the scene. McLaws ordered counter-battery fire against the Union artillery and a charge by Davis's men on the suddenly confused Federal cavalry. The charge routed the bluecoats with little loss to either side, and Kershaw's men finished occupying the forts along the road. No more probes were made against Mclaws" positions for the rest of

42 "Report of Brig. Gen. Lafayette McLaws, C. S. Army, commanding division," May 16, 1862, "Report of General Joseph E. Johnston, C. S. Army, commanding Department of Northern Virginia, of operations from April 15 to May 19, May 19, 1862, in OR, XI (part 1): pp. 275, 441-442. The information about Ewell conducting McLaws" troops into the line is from interlineal notes by Benjamin $S$. Ewell in the original of Johnston's report, which is in JJWM. Ewell habitually wrote notes inside Johnston's reports when he served on the General's staff later in the war; see Joseph E. Johnston to Benjamin S. Ewell, October 12, 1868, in Benjamin S. Ewell papers, College of William and Mary, Williamsburg, Virginia. 
the afternoon. 43

Johnston, who had been looking over McLaw's shoulder during the skirmish, knew that the Federal infantry could be, at best, a few hours behind the cavalry. When he thought of the condition of the roads and the torturous progress of his army, he realized that he probably could not escape without fighting to slow down the pursuit. Inade- . quate as Magruder's line of redoubts may have been, it represented the only prepared fortification between Yorktown and Richmond, and he knew that he should make use of it. At sunset, he ordered McLaws to pull out his brigades, and to be replaced by two from Longstreet's Division. 44 If he could get the army marching at the crack of dawn, he might yet elude McClelian without combat; if not, the action would be supervised by one of his most trusted subordinates. This arrangement evidently calmed any fears Johnston had that night, for he treated two of his staff officers to an impromptu, bare-chested display of saber-handling before retiring for the evening. 45

Longstreet sent back Brigadier-General Richard $\mathrm{H}$.

43 "Report of Brig. Gen. Lafayette McLaws, C. S. Army, commanding division," May 16, 1862, in OR, XI (part 1): pp. 441-442; Thomas, Bold Dragoon, p. 105.

44 Johnston actually ordered Longstreet to send one brigade, but, thinking his brigades too small, the Georgian dispatched two. Johnston, Narrative, p. 120 ; Longstreet, Manassas to Appomattox, p. 72 .

$$
45 \mathrm{Gallagher,} \mathrm{Fighting}, \mathrm{pp} .49,80-81 \text {. }
$$


Anderson's South Carolinians and Colonel Roger Pryor's mixed brigade of Alabamians, Virginians, and Louisianians. Anderson, a South Carolinian himself, and a classmate of McLaws and Longstreet at West Point, met McLaws just after dark. The Georgian had already withdrawn his men from the line of redoubts in preparation to resume his march. Heavy rain was falling again. 46

In the cold, wet darkness, the South Carolinian made an error of judgment that the next day would threaten the safety of Johnston's retreat. Richard Anderson, who had been followed by suspicions of alcoholism throughout his Regular Army career, was a talented tactician and a brave leader of troops in battle, but he was not a man who paid a great deal of attention to detail. "He was indolent," admitted Moxley Sorrel. "His capacity and intelligence [were] excellent, but it was hard to get him to use them."47 That night, he took the easiest course. Expecting that his men would be pulled out soon after sunrise, he occupied the forts to the right of the road, but only two of the redoubts on the left. He did not send out scouts to find out how far the 1 ine extended; if he had done so, he would have discovered that there were at least four more fortifications around the boggy ground bordering the road to Allen's wharf. If seized by the Federals, possession of these works would

46 Longstreet, Manassas to Appomattox, pp. 72-73. 47 Sorrel, Recollections, p. 128 . 
allow them to enfilade Fort Magruder (see Map 3).48

Neither Longstreet nor Johnston knew that this had happened. The division commander, having delegated the rear guard to Anderson, spent the night preparing his trains and the rest of his troops to move. He did authorize Anderson to call in other brigades from the division for reinforcements, if pressed, but did not check on his subordinate's deployment or personally examine the line of redoubts until several hours after dawn. In fact, Longstreet did not even arrive on the field until a few minutes after noon. 49 Anderson, his two brigades now reinforced by the brigades of A. P. Hill, George Pickett, and Raleigh Colston --the remainder of Longstreet's Division--had been fighting Brigadier-General Joseph Hooker's 2nd Division, III Corps, of the Army of the Potomac, since sunrise. "Being in pursuit of a retreating army," Hooker wrote five days later, "I deemed it my duty to lose no time in making disposition of my forces to attack, regardless of their number and position. - . By doing so my division, if it did not capture the army before me, would at least hold them, in

\section{Longstreet, Manassas to Appomattox, pp. 72-73;} Freeman, Lee's Lieutenants, I: pp. 177-178; "Report of Maj. Gen. James Longstreet, C. S. Army, commanding Second Corps, with congratulatory order from General Joseph E. Johnston, C. S. Army," May 16, 1862, in OR, XI (part 1): pp. 564-565.

${ }^{49}$ Longstreet, Manassas to Appomattox, p. 72; "Report of Maj. Gen. James Longstreet, C. S. Army, commanding Second Corps, with congratulatory order from General Joseph E. Johnston, C. S. Army," May 16, 1862, in OR, XI (part 1): pp. 564-565. 


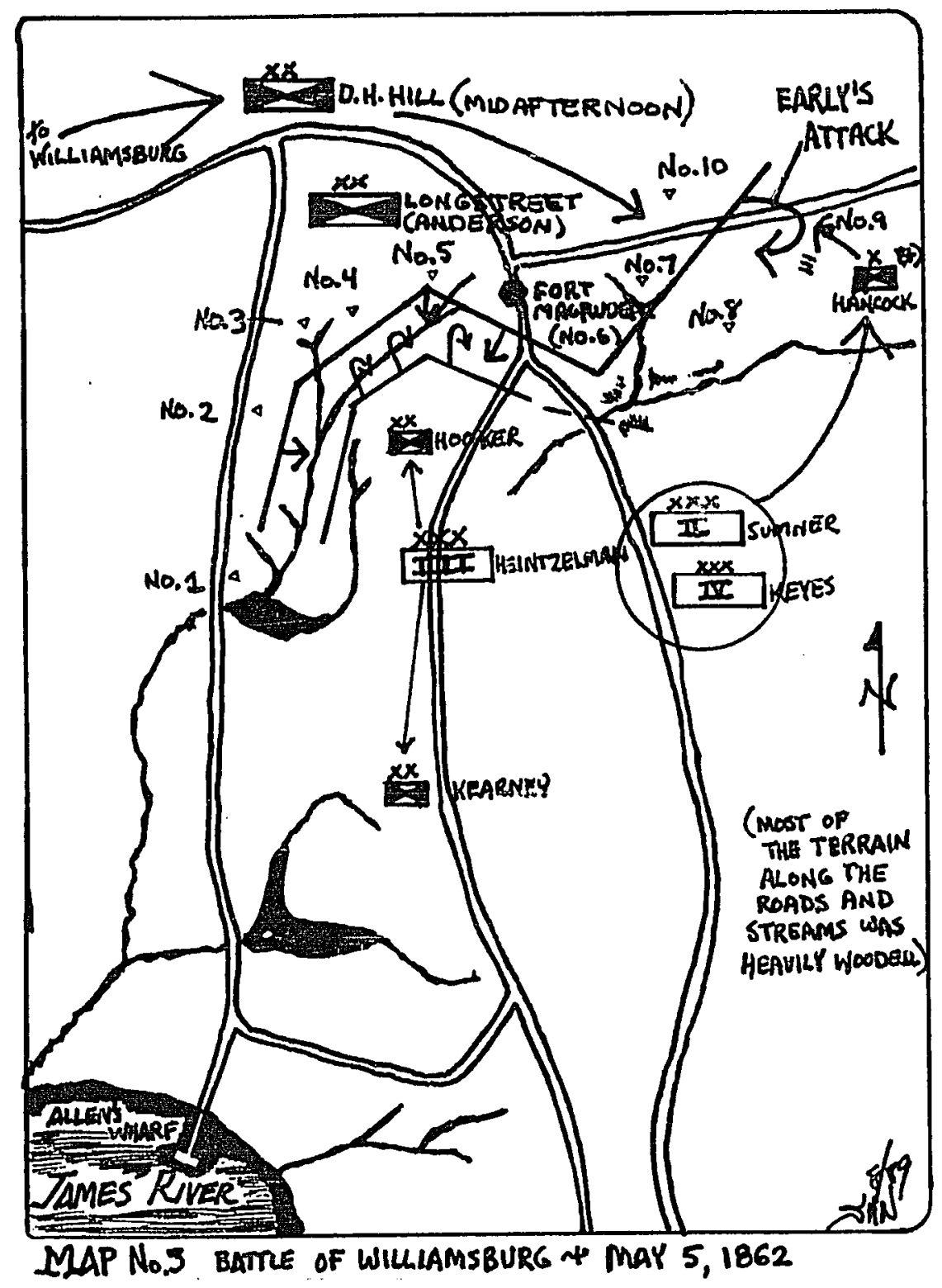


order that others might."50 "Hooker," observed historian Bruce Catton, "was an army politician and a devious man - . but as a fighter he was direct and straightforward. - ."51 without waiting to reconnoiter the strength of the Confederate defenses or to acquire authorization from his corps commander, Hooker waded in, attacking the fortifications which Anderson had already garrisoned. 52 He drove in the Conference skirmishers, but foundered against Fort Magruder, and began probing farther down Anderson's right flank. 53

This only succeeded in attracting the attention of Confederate reinforcements. Discounting his own brigade, which held Fort Magruder and the two redoubts on the far left, and Colston's, which was still marching up, by 10:00 A. M. Anderson had four brigades, numbering about 8,000 men, available for a counterattack. He also had Longstreet's permission. 54

50 "Report of Brig. Gen. Joseph Hooker, U. S. Army, commanding Second Division," May 10, 1862, in OR, XI (part 1): p. 465 .

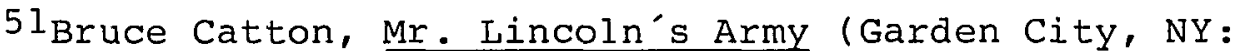
Doubleday, 1951), p. 266 .

52 Mark Grimsley, "Rear Guard at Williamsburg," Civil

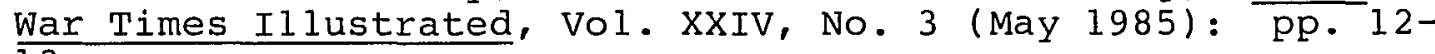
13 .

53 "Report of Brig. Gen. R. H. Anderson, commanding Second Brigade," May 10, 1862, in OR, XI (part 1): p. 580.

54 "Report of Maj. Gen. James Longstreet, C. S. Army, commanding Second Corps, with congratulatory order from General Joseph E. Johnston, C. S. Army," May 16, 1862, in 
Anderson left Fort Magruder to assume personal command of the attack, which was quite successful, despite being launched piecemeal. Wilcox advanced first, against Hooker's left, and became involved in a confusing fight in dense woods. Soon realizing that he was engaging a brigade against a division, Wilcox sent for assistance. Since he did not know that Anderson was riding to that part of the field to take command, he dispatched couriers directly to Pryor and A. P. Hill for support. Pryor, in the absence of orders from Anderson, and still under obligation to hold two of the redoubts, could only reinforce wilcox's attack with two of his three regiments. Hill, who had never received adequate orders from anybody, did not know exactly who was in command or what he should do. Consequently, he sent a courier to find Longstreet and waited. About half an hour later, Anderson arrived at his headquarters and ordered him to support wilcox. Pickett's men, meanwhile, waited behind Fort Magruder until Anderson remembered to call them forward still later in the morning. 55 with Anderson busy bringing

OR, XI (part 1): pp. 564-565.

55 "Report of Brig. Gen. Ambrose P. Hill, C. S. Army, commanding First Brigade, Second Division," May 10, 1862, "Report of Brig. Gen. Richard H. Anderson, C. S. Army, commanding Second Brigade," May 10, 1862, "Report of Brig. Gen. George E. Pickett, C. S. Army, commanding Third Brigade," May --, 1862, "Report of Brigadier-General Roger A. Pryor, C. S. Army, commanding Brigade," May 10, 1862, "Report of Brig. Gen. Cadmus M. Wilcox, C. S. Army, commanding Brigade," May 25, 1862, in OR, XI (part 1): pp. 576, $580-581,584-585,587-588,591$. 
up reinforcements, no one effectively assumed command of anything larger than a brigade for several hours.

The consequences of such disorganization could have been disastrous, for there were probably 40,000 Federal troops within an hour's march of Hooker's now-beleaguered division. That morning, however, there was no one in effective command of the Union Army, either. Mcclellan was back in Yorktown, loading Brigadier-General William Franklin's division on transports for an amphibious landing farther up the York River. The senior Federal officer at Williamsburg was the commander of the II Corps, MajorGeneral Edwin Vose Sumner, who sat in his headquarters at the nearby Adams House, "slightly befuddled." Because Sumner ranked the IV Corps commander, Major-General Erasmus Keyes, he could do nothing, despite having two divisions-William F. Smith's and Darius Couch's--nearby. Hooker's own commander, Major-General samuel P. Heintzleman of the III Corps, had been delayed, bringing forward his other division.56 Neither army, it seemed, had yet learned how to coordinate a battle. It was a perfect example of what the Prince de Joinville ruefully characterized as "the American system of 'every man for himself.' . . ."57

Numbers and Rebel enthusiasm seemed to be prevailing in the chaotic melee. After several hours of confused battle,

\footnotetext{
56Grimsley, "Rear Guard," p. 27.

57 de Joinville, Army of the Potomac, p. 52.
} 
Hill's lst Virginia finally supplied the weight that forced Hooker's line back several hundred yards, capturing a battery of eight guns that the Yankees had time neither to spike nor to withdraw.58 Yet though the decision to the right of Fort Magruder went to the Confederates, they were too disorganized to profit by it. The regiments involved in the fighting had become intermingled and difficult to maneuver. Most of the soldiers were low on ammunition, and the brigade commanders soon discovered that the reserve ammunition trains were heading in the other direction as rapidly as possible. A. P. Hill could not round up either enough horses to haul off all his captured guns or axes to destroy their carriages. 59

Meanwhile, the attention of the senior officers of both armies had turned to the opposite flank, toward the redoubts north of Fort Magruder which Anderson had failed to occupy. Brigadier-General William F. Smith finally prevailed on Sumner to let him attempt a flanking maneuver. Sumner agreed to let Smith send a brigade to probe the Confederate left. Smith selected Brigadier-General Winfield scott Hancock to command the troops, and quietly expanded both Hancock's strength and mission when the two were out of

58 "Report of Brig. Gen. Ambrose P. Hill, C. S. Army, commanding First Brigade, Second Division," May 10, 1862, in OR, XI (part l): p. 577 .

${ }^{59}$ Ibid. , pp. 577-578; Longstreet, Manassas to Appomattox, pp. $74-77$. 
Sumner's earshot. Smith gave Hancock two additional regiments from an adjoining brigade, plus a battery of artillery. He then, Hancock reported, "authorized me to advance farther if I thought advantage could be obtained, and if I required them to send to him for re-enforcements." 60 Hancock started at 11:00 A. M.; by noon his force had already outflanked Fort Magruder, taken two of the ungarrisoned redoubts, and was advancing toward one held by Anderson's men. Smith, sensing a decisive breakthrough, promised to order forward another four regiments and an additional battery. From his position, Hancock's artillery could actually bombard Fort Magruder from the rear.61 If decisively reinforced, the attack could possibly succeed in cutting off Longstreet's entire division.

Shortly after 12:00 P. M., with Anderson's attention completely absorbed in the battle with Hooker on the right, and Hancock creeping up on the left, Longstreet finally rode back to the field. In his official report, the Georgian contended that he did so because "it became evident that the trains would not be out of my way before night, and that I could, therefore, make battle without delaying the movement of the army." He asserted that he arrived on the field in time to see "the successful issue of the first grand

60 "Report of Brig. Gen. Winfield S. Hancock, U. S. Army, commanding First Brigade," May 11, 1862, in $\underline{\mathrm{OR}}, \mathrm{XI}$ (part 1): p. 535 .

$61_{\text {Ibid. }}$ pp. 535-537. 
assault" by Anderson's four brigades, which he complimented as having been "well arranged. . . ." It was the victory over Hooker's division, Longstreet claimed, that caused him to seek reinforcements: "The advanced positions so extended my Iines that I found it necessary to bring other forces upon the field." 62

Neither Longstreet's own memoirs, nor the reports of his own subordinates bear out this account. Anderson's attack was hardly well-organized, nor was there any indication in any of the brigadiers' reports that Longstreet made it to their part of the field that early. The division commander admitted in his memoirs that it was "the swelling noise of battle," from which he "concluded that it would be well to ride to the front. . ." When Hancock's artillery opened from several hundred yards in his rear, he quickly became aware that "viewing the ground on the left, I thought it not so well protected as Anderson conceived. . . " "63

62 "Report of Maj. Gen. James Longstreet, C. S. Army, commanding second Corps, with congratulatory order from General Joseph E. Johnston, C. S. Army," May 16, 1862, in OR, XI (part I): pp. 564-565.

63The question of when Hancock's artillery opened fire is critical to understanding how concerned Longstreet would have been about his left flank. It has usually been assumed that the Federals did not begin firing until late in the afternoon, when Early's Brigade had already been deployed on the left. Hancock says that he took the first unoccupied redoubt about noon, and fired his first shots with his guns while advancing on the second. This would have placed the action probably between noon and 1:00 P. M. Micah Jenkins, left in command at Fort Magruder mentions Hancock opening on the rear of Fort Magruder between 3:00 and 4:00 P. M., but does not specifically rule out earlier fire from that 
Even this was quite an understatement. With more than two-thirds of his division engaged with Hooker, and the rest tied down holding the remaining redoubts, Longstreet suddenly realized that he had no troops of his own available to deal with Hancock. He sent an aide galloping back up the Williamsburg Road with orders for D. H. Hill's Division to march back to support him. Longstreet sent this order directly to Hill because the North Carolinian had been subordinated to him during the retreat. For whatever reasons, either haste or embarrassment at having been caught in the flank, Longstreet did not send any messages to Johnston. 64

direction. If, as Johnston later suggested, the Confederates did not even know that Hancock had gotten into their left and rear, there is little to explain Longstreet's examination of the ground to his left on first arriving on the field (while an active battle was in progress on the right) nor his deployment of the bulk of Hill's Division on the left. See Longstreet, Manassas to Appomattox, p. 74; "Report of Brig. Gen. Winfield S. Hancock, U. S. Army, commanding First Brigade," May 11, 1862, "Report of Col. M. Jenkins, Palmetto Sharpshooters, commanding brigade," -- --, 1862, "Report of Maj. Gen. D. H. Hill, commanding division, of operations April 6 to May 9," January 11, 1863, "Report of Brig. Gen. Jubal A. Early, commanding brigade," June 9, 1862, in OR, XI (part 1): pp. 536-537, 580, 602-603, 606607; Johnston, Narrative, pp. 124-125.

64 Longstreet claimed in his memoirs that he first sent for a single brigade from Hill's Division, but Hill's report makes it clear that his entire division was ordered back. That Johnston had not received any messages from Longstreet is inferred from Longstreet's memoirs and report, and Johnston's own report, none of which mention sending any dispatches to his commander. In his report, Johnston only said that he returned to the area of Fort Magruder after hearing Hill's Division ordered back, and the timing of his arrival supports this. In his own memoirs, Johnston claimed that "at noon the fighting was reported by Longstreet and 
The first brigade of Hill's Division to arrive was that of Jubal Early, at about 3:30 P. M. Along with his four regiments and company of artillery, Early had in tow Colonel George T. Ward's detachment, consisting of the 2nd Florida and the 2nd Mississippi Battalions.65 That Early's troops were the first to arrive added to Longstreet's unease at the situation, for he neither liked nor trusted the Virginia brigadier.

Longstreet was heading toward Anderson's battle as Early marched up, probably to find out if he could detach some of those regiments to safeguard his left flank. What he found instead was that most of the regiments in the four

Stuart to be so sharp, that D. H. Hill's division, which had marched several miles, was ordered back to williamsburg, and I returned myself; for at ten o'clock, when the action had lasted more than four hours, there seemed to be so little vigor in the enemy's conduct, that I became convinced that it was a mere demonstration, intended to delay our march - . and had ridden forward to join the leading troops." But by 10:00 A. M. no one was making any reports from which Johnston could have concluded this, and read literally, Johnston's paragraph only implies but does not emphatically state that he had received messages from Longstreet and Stuart. See "Report of General Joseph E. Johnston, C. S. Army, commanding Department of Northern Virginia, of operations from April 15 to May 19," May 19, 1862, "Report of Maj. Gen. James Longstreet, C. S. Army, commanding Second Corps, with congratulatory order from General Joseph E. Johnston, C. S. Army," May 16, 1862, "Report of Maj. Gen. D. H. Hill, commanding division, of operations April 6 to May 8," January 11, 1863, in OR, XI (part 1): pp. 275, 564565, 602; Longstreet, Manassas to Appomattox, p. 74; Johnston, Narrative, p. 120 .

65 "Report of Maj. Gen. D. H. Hill, commanding division, of operations April 6 to May 9," January 11, 1863, "Report of Brig. Gen. Jubal A. Early, commanding brigade," June 9, 1862, in OR, XI (part 1): pp. 602-603, 606-607. 
brigades were nearly out of ammunition. Since he could not replenish their cartridge boxes from the retreating ordnance trains, Longstreet was forced to commit more troops to hold the ground gained on his right, even though his left was in danger. Colston's Brigade, which had arrived a few minutes before Early and Ward's detachment, was ordered to report to Anderson.

He reluctantly left Early in charge of the left of the line. "I proceeded as near as practicable to the position designated by General Longstreet on the left and rear of Fort Magruder" Early reported, "and formed my regiments in line of battle on the crest of a ridge in a wheat field, and near a barn and some houses, with a woods some 200 or 300 yards in front. . . " In that position, "we were not in view of any body of the enemy, though we were soon informed by the firing from a battery in or beyond the woods toward Fort Magruder that a portion of the enemy were in our front." 66

The battery firing at Early's men from beyond the woods was Company E, lst New York Light Artillery, which had been attached to Hancock's force. Unable to grasp the opportunity that Hancock's advance against the unoccupied redoubts had given him, and believing that he was about to face another major Confederate attack, Sumner overruled Smith,

66 "Report of Brig. Gen. Jubal A. Early, commanding brigade," June 9, 1862, in OR, XI (part 1): pp. 606-607. 
and refused to allow him to reinforce Hancock. Hancock sent one of his own aides to explain the importance of his position and to plead for more troops, but sumner remained adamant. All that had been left for Hancock to do, since his augmentea brigade was too small to risk a further advance on its own, was to open fire with his field artillery, in hopes of aiverting the attention of some of the Rebels from the other side of the line. The gambit was far more successful than he ever could have expected. 67 Somenow, Jubal Early came to the conclusion that a lone Federal battery hać located itself on the confecierate flank, and he decided that several Yankee cannon had situated themselves in just the right place for him to capture them. 68 Hill and the remaining brigaảes of nis division haỏ marched up by this time, and varly brought the idea to his

67 "Report of Brig. Gen. Winfield S. Hancock, U. S. Arrny, commanding First Brigade," Nay 11, 1862, in $\underline{O R}, X I$ (part 1): p. 535; Grimsley, "Rear Guarä," p. 28.

68varly denied in his report that this was his idea, attributing it instead to D. H. Fill. But Hill, Longstreet, and Johnston all agreed--though their accounts did differ on other particulars--that the original iaea to capture tine battery was Early"s. See "Report of General Joseph ï. Joinston, C. S. Army, commanding Department of Northern Virginia, of operations from April 15 to May 19," May 19, 1862, "Report of Maj. Gen. James Longstreet, C. S. Ariny, commanding Second Corps, with congratulatory order from General Joseph E. Johnston, C. S. Army," May 16, 1862, "Report of Maj. Gen. D. H. Hill, commanding division of operations April 6 to May 9," January 11, 1863, "Report of Brig. Gen. Jubal A. Early, commanding brigade," June 9, 1862 , in OR, XI (part 1): pp. 275, 564-565, 602, 607; Longstreet, Manassas to Appomattox, p. 78 ; Johnston, Narrative, p. 121 . 
superior. What he did not tell the North Carolinian--and what Hill forgot to ask--was that he had done no reconnaissance to ascertain that the Federal battery was indeed unsupported. In fact, Early still did not know exactly where it was when he proposed the attack.69 After spending several weeks in Yorktown, impotently unable to strike back at enemy artillery, Hill was quickly caught up in Early's enthusiasm, and set out to find Longstreet to get permission to launch the attack.

It was at this point that Johnston himself finally showed up. He had been urging the rest of the army up the road all morning and afternoon, more concerned with a possible landing on the York River than about the Federals immediately to his rear. 70 when he realized that a second division had become embroiled east of williamsburg, the army commander spurred his horse in search of Longstreet and a report on the battle. Johnston, Longstreet, and Hill all converged somewhere in the rear of Fort Magruder. Longstreet was feeling more confident by this time. With Colston's and Ward's regiments in line, supported by the reorganizing brigades that had made Anderson's attack, he felt that his right flank was secure, at least for the rest of the day. Hill reported that the brigades of Jubal Early, Winfield Scott Featherston, Gabriel Rains, and Robert

69Grimsley, "Rear Guard," p. 29. 70 Johnston, Narrative, p. 120. 
Rodes were now emplaced on the left. Thus, even if the redoubts on the far end of the line were in enemy hands, Longstreet's Division no longer seemed to be in danger of being cut off.71 Always unwilling to admit that events ever got out of his control, Longstreet told Johnston that the battle had thus far proceeded exactly as he had planned it: a successful, limited rear guard action to discourage pursuit. 72

Hill's proposal then, came at what seemed an opportune moment. Success in the form of eight captured guns had already been achieved on the right. Why not attempt the same on the left, especially as the Yankees there now appeared to have no idea what a potentially commanding position they held? Johnston deferred to Longstreet's opinion, and the Georgian was willing to sanction the attack--with one condition. He did not have faith in Early

71 "Report of Maj. Gen. D. H. Hill, commanding division, of operations April 6 to May 9," January 11, 1863, in OR, XI (part 1): pp. 602-603.

72 The tenor of Longstreet's report may be inferred from Johnston's comments on the Georgian's conduct of the battle. "I rode upon the field, but found myself compelled to be a mere spectator, for General Longstreet's clear head and brave heart left me no apology for interference," Johnston wrote in his official report. He rewrote himself a much larger part in the Narrative, but one which was not completely borne out by contemporary reports. See also Longstreet's account in his memoirs, which played down the threat of Hancock on the Confederate left. "Report of General Joseph E. Johnston, C. S. Army, commanding Department of Northern Virginia, of operations from April 15 to May 19," May 19, 1862, in OR, XI (part 1): p. 275; Johnston, Narrative, pp. 122-12 $\overline{5 ;}$ Longstreet, Manassas to Appomattox, p. 77. 
to carry out the assault competently; later he claimed to have announced to the other generals that "the brigade you propose to use is not in safe hands." He consented to the movement only if Hill directed it personally. Hill agreed. 73

With remarkable candor, Hill admitted the next year that "neither Longstreet nor myself knew the precise location of the battery, and both were entirely ignorant of the ground." Despite this, the two "agreed in the general plan of getting in rear of the battery by passing through the woods to the left of its supposed position." Though he "could not distinctly locate the battery by the sound," Hill split Early's Brigade into two detachments and, commanding one of them himself, marched the 5 th and $23 \mathrm{rd}$ North Carolina, and the 24th and 38th Virginia, into the woods in search of enerny guns. 74

The ill-considered venture reaped exactly the kind of harvest which, in hindsight, might have been expected. Early's regiments came out of the woods one at a time, not facing, but flanked by, the New York guns which were supported by five regiments of Federal infantry. Neither Hill nor Early could regain any semblance of control over his regiment. Early went down with a wound trying to lead

73 Longstreet, Manassas to Appomattox, p. 78 .

74 "Report of Maj. Gen. D. H. Hill, commanding division, of operations April 6 to May 9," January 11, 1863, in OR, XI (part 1): p. 603 . 
the 24th Virginia and the 5th North Carolina in a desperate charge against Hancock's line. Hill remained in the woods trying, without success, to organize the other two regiments to support him. The 24 th Virginia took 190 casualties, the 5 th North Carolina more than 300. Watching the Tarheels mowed down, Hill always remembered that "the regiment was shot down like beeves, the yankees cheering and laughing as they fired at the poor fellows."75

Ironically, the only circumstance that saved Early's men from even higher casualties was the fact that Hancock thought the confederate regiments lost in the woods were about to envelop his own flank. He initially intended to charge and capture the entire 5th North Carolina:

The whole line advanced cheering, and on arriving . . delivered two volleys, doing great execution. The order was then given to charge down the slope, and with reiterated cheers the whole command advanced in line of battle. A few of the leading spirits of the enemy were bayoneted; the remainder then broke and fled. The want of protection in my rear, and expecting an assault from that quarter every moment, I ordered a halt at the floor of the slope, and delivered a terrible fire along the whole line, expending 15 to 20 rounds. The plunging fire from the redoubt, the direct fire from the right, and the oblique fire from the left were so destructive that after it had been ordered to cease and the smoke arose it seemed that no man had left the ground unhurt

75 "Report of Maj. Gen. D. H. Hill, commanding division, of operations April 6 to May 9," January 11, 1863, "Report of Brig. Gen. Jubal A. Early, commanding brigade," June 9, 1862, in OR, XI (part 1): pp. 602-603, 606-607; Freeman, Lee's Lieutenants, I: pp. 182-189; Grimsley, "Rear Guard," pp. 29-30. 
who had advanced within 500 yards of our 1 ine. 76

Satisfied that the battle was well in hand, Johnston had ridden off the field prior to Early's debacle, leaving Longstreet to close operations. Longstreet claimed that "this mishap could have been remedied by an extreme flank movement and complete victory won; but. . . we were not in a condition to increase our responsibilities, and a great delay might have endangered other operations of the army."77 D. H. Hill agreed, but for different reasons: "the turning of the Yankee position was still deemed practicable, but I soon found that the confusion was so great, arising mainly from the want of drill and discipline, that all idea of further advance was abandoned." Since Hill's Division still had three fresh brigades, he was designated to take over rear guard responsibilities for the following day. 78 The Battle of Williamsburg had cost the Army of the Potomac 2,233 casualties, while Johnston's army lost 1,70379 Johnston and his subordinates asserted that they had won a

76 "Report of Brig. Gen. Winfield S. Hancock, U. S. Army, commanding First Brigade," May 11, 1862, in OR, XI $(\operatorname{part} 1):$ p. 540 .

77 "Report of Maj. Gen. James Longstreet, commanding Second Corps, with congratulatory order from General Joseph E. Johnston, C. S. Army," May 16, 1862, in OR, XI (part 1): pp. 565-566.

78 "Report of Maj. Gen. D. H. Hill, commanding division, of operations April 6 to May 9," January 11, 1863, in OR, XI $(\operatorname{part} 1)$ : p. 604 .

${ }^{79} \mathrm{Livermore,} \mathrm{Numbers} \mathrm{and} \mathrm{Losses,} \mathrm{pp.} \mathrm{80-81.}$ 
victory because they had held the field at the end of the day, had captured eight guns and several hundred prisoners, and because the Federals did not contest the army's withdrawal the next morning. 80 Both Johnston and Longstreet were in high spirits that evening. They spent the night together at the Bowden House, several miles west of Williamsburg. Johnston described the battle as merely a "pretty severe skirmish," and laughed off the lady of the house who "said she had no room for retreating Generals."81 Yet had Johnston taken the time to evaluate the engagement critically, he would have learned some disquieting facts. Longstreet, in whom he reposed great confidence, had allowed five of his six brigades to become committed to combat before he had even reached the field, leaving himself with few reserves and a left flank hanging in the air. Hill had shown himself to be aggressive to the point of rashness. Elections and service in the Yorktown trenches had taken their toll on drill and discipline; regiments from both divisions became entangled with each other and the woods around them. In fact, Confederate success at Williamsburg was more a matter of Union miscues than anything that Johnston, Longstreet, or Hill did right.

\footnotetext{
80 Johnston, Narrative, pp. 124-125; Longstreet, Manassas to Appomattox, p. 79 .

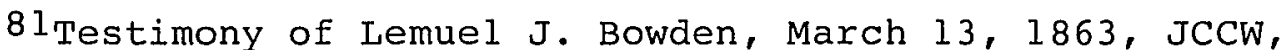
I: p. 583; undated notes for a speech by Benjamin S. Ewell before the Magruder-Ewell Camp, United Confederate Veterans, Benjamin Stoddert Ewell papers, College of William and Mary.
} 
Johnston had four reasons for not evaluating the performance of his army at williamsburg. The first reason was victory--claiming to have won the battle, he hardly had much to stimulate him to seek out shortcomings. Longstreet was quick to reinforce this idea, effusively praising his subordinates, and recommending promotions for Anderson, Hill, and Pryor. 82

Secondly, Johnston's style of supervision on the battlefield, it turned out, was not nearly as close as his supervision of administrative matters. Both on May 4 and 5 , the army commander had felt comfortable delegating the entire responsibility for tactics on the field to a subordinate--first McLaws, then Longstreet. On May 5 in particular, Johnston had not bothered to be present until many hours after the battle had begun, and accepted the judgments of Longstreet and Hill uncritically. Thus he did not know the details of the blunders which had marked the conduct of the battle. Was his behavior anomalous, caused by excessive concern about amphibious landings and the slow progress of the trains, or was it to be a consistent characteristic of Joseph Johnston as an army commander? There was no one nearby to ask the question.

82 Longstreet had an ulterior motive in these requests. He wanted Anderson and Hill promoted to command divisions of three brigades each under a permanently established army corps that he would control. See James Longstreet to Samuel Cooper, May 9, 1862, in LR-AIGO, M-474, Reel 30; Robert E. Lee to James Longstreet, May 28, 1862, in Lee Letterbook. 
Even had Johnston been motivated to examine the army's performance more closely, he would have had difficulty in doing so, at least for several days. Most of the brigadiers were tied up immediately in moving their exhausted commands through the torrential rain; few reports of the battle were written before May 10. Early did not complete his until June, and D. H. Hill's was not submitted until January of the following year. When Johnston wrote his official account of the battle, he had primarily Longstreet's account, which Freeman correctly labeled "casual, almost complacent," upon which to base his own narrative. 83

The final reason that Johnston turned his attention away from williamsburg was probably the most influential. While he and Longstreet celebrated that night, an aide arrived at the Bowden House with unwelcome news. Johnston's worst fear had been realized: Federal transports had reached the mouth of the Pamunkey River, between his army and Richmond. 84

Union gunboats, as Johnston predicted, had wasted no time ascending the York River after the confederates evacuated Yorktown. Lee wrote Johnston on May 5, even as Longstreet and Hill struggled with the Yankees outside Williamsburg, that gunboats had been spotted at the mouth of

\footnotetext{
83 Freeman, Lee's Lieutenants, I: p. 189.

84 Testimony of Lemuel J. Bowden, March 13, 1863, JCCW, I : pp. 583-584.
} 
the Pamunkey River.85 When that letter reached Johnston, probably on May 6 , it confirmed what his cavalry pickets had already discovered: his line of communication was no longer clear. But the question of McClellan's intentions remained. Was the main weight of his pursuit following overland, as the battle at Williamburg seemed to indicate; or, had those Federal attacks been designed purely to delay Johnston long enough to envelop and isolate his army?

The commander on the spot was G. W. Smith, whose division reached Barnamsville early on May 6 . With the remainder of the army strung out all the way back to Williamsburg, it was Smith's responsibility to determine the Yankee's intent. That evening, Smith and Whiting rode to Fitzhugh Lee's forward cavalry pickets in the woods above Eltham's Landing, where they had a clear view of the disembarking Federals. Blue-clad soldiers, in at least division strength, had already landed.86

The troops were the regiments of Brigadier-General Willjam B. Franklin's division, the first of four divisions that McClellan planned to advance by water to cut off

$85_{\text {Robert }} \mathrm{E}$. Lee to Joseph E. Johnston, May 5, 1862, in Lee Letterbook. This letter does appear in OR, but was incorrectly dated March 5, 1862, and therefore published in the wrong volume. See OR, V: p. 1090.

86 "Report of Maj. Gen. Gustavus W. Smith, C. S. Army, commanding Reserve," May 12, 1862, "Report of Brig. Gen. William H. C. Whiting, commanding First Division," May 8, 1862, in OR, XI (part 1): pp. 627, 629; Smith, Confederate War Papers, p. 47. 
Johnston's retreat. Fortunately for the Confederates, a shortage of transports forced Mcclellan to ship the divisions up the York River sequentially rather than simultaneously.87 Even more fortuitously, the lead division was commanded by the least aggressive of the four Union generals. 88

Though he began landing troops at 3:00 P. M. on May 6, Franklin was oppressed by "my ignorance of the topography of the place of landing, and the fact that the enemy's cavalry and infantry were seen in the woods surrounding the plain upon which we landed as soon as the landing began. . . ." As a result of his apprehension, the division commander sent out no scouts of his own, and concentrated instead on "extraordinary precautions . . to prevent the success of an attack."89 Thus he had no idea that the confederate pickets he saw from the plain were virtually the only force available to oppose him during the first few hours after his 1 anding.

Such was not long to remain the case, however. Smith had immediately ordered up Whiting's three brigades from Barnamsville, though his object was not initially the attack

87 "MCClellan's Report (1)," in OR, XI (part 1): p. 23.

88 The others were Fitz-John Porter, Israel B. Richardson, and John Sedgewick, all of whom would later earn reputations for more combativeness than Franklin; see Ibid.

89 "Reports of Brig. Gen. William B. Franklin, U. S. Army, commanding division," May 17, 1862, in OR, V: p. 615. 
that Franklin supposed. The Kentuckian hoped that the absence of any appreciable force to his front would lure Franklin into striking inland, away from the artillery support provided by his gunboats, and allowing whiting to engage him at advantage.90 when it became obvious on the morning of May 7 that the Yankees were entrenching and not moving forward, Smith had to change his plans; he ordered Whiting to attack Franklin's right flank and drive it back close enough to the river for his own artillery to fire on the gunboats. 91

Whiting selected Brigadier-General John Bell Hood's brigade to lead the attack. Though it also contained the 18th Georgia during the Peninsular Campaign, Hood's command earned its fame as the "Texas Brigade." Eltham's Landing was the baptism of fire for the $1 \mathrm{st}, 4 \mathrm{th}$, and 5 th Texas, as well as Hood's first battle. It was not much of a battle. The action was little more than a skirmish between Hood's brigade, supported by a single battery, and that of Brigadier-General John Newton, likewise four regiments attended by one company of artillery. Between 9:00 and 11:00 A. M., Hood drove in Newton's skirmishers, and the two lines traded vollies in the woods for another three or four

90 Smith, Confederate war Papers, p. 47.

91 "Report of Maj. Gen. Gustavus W. Smith, C. S. Army, commanding Reserve," May 12, 1862, "Report of Brig. Gen. William $\mathrm{H}$. C. Whiting, commanding First Division," May 8, 1862 , in $\underline{O R}, \mathrm{XI}(\operatorname{part} 1): \mathrm{pp} .627,629$. 
hours, while Hood's artillerymen determined that they could not hit the gunboats from an extended range, after which Hood was ordered to withdraw. He had taken thirty-seven casualties and inflicted 186, a tactical victory to be sure, but hardly a devastating defeat for Franklin's division, which was reinforced by the first brigade of sedgwick's division that afternoon.92

Victory or defeat is often as much the commander's perception as it is reality. Within another twelve to twenty-four hours, approximately 25,000 Union soldiers hāō been concentrated near Eltham's, more than enough to engage Johnston and attempt to delay his retreat.93 But Franklin, the senior division commander, credited reports from Newton that he had been attacked by a full division, supported by 20,000 additional troops, and wrote McClellan's Chief of Staff, "I congratulate myself that we have maintained our

$92 \mathrm{~A}$ few supporting troops were engaged on both sides, beyond the two brigades--the 5th Maine and lst New Jersey for the Federals and Hampton's Legion and two regiments of Anderson "s Tennessee brigade for the Confederates--but these units had little to do with the actual contest. "Reports of Brig. Gen. William B. Franklin, U. S. Army, commanding division," May 17, 1862, "Report of Brig. Gen. John Newton, U. S. Army, commanding Third Brigade," May 8, 1862, "Report of Maj. Gen. Gustavus w. Smith, C. S. Army, commanding Reserve," May 12, 1862, "Report of Brig. Gen. John B. Hood, C. S. Army, commanding First Brigade," May 7, 1862 in $\mathrm{OR}, \mathrm{V}$ : pp. 615-617, 623-625, 627, 631-632; McMurry, Hood, pp. 3839 ; Hood, Advance and Retreat, pp. 21-22.

93 Derived from "Abstract from return of the Army of the Potomac, Maj. Gen. George B. McClellan, U. S. Army, commanding, for MaY 20, 1862," in OR, XI (part 3): p. 184 . 
position."94 He soon convinced McClellan that Johnston already had 80,000 to 120,000 men in the area, and cautiously awaited the arrival of the main body of the Army of the Potomac, while Johnston's weary legions plodded unmolested past his position. 95

Johnston himself breathed a sigh of relief when he halted his divisions near Baltimore Cross Roads on May 10. He had originally desired to halt at New Kent Court House, six miles farther east, but the distance from the Richmond and York River Railroad, his line of supply, had forced the army to keep moving.96 To Johnston's weary and bedraggled soldiers, the halt represented the first chance for a hot meal and sleep in several days. Many of them, like D. H. Hill, were too exhausted to do more than collapse; "I slept nearly all day yesterday," Hill wrote to his wife on May ll, "just lying on the ground. . . ."97

Johnston could finally afford to rest his army because he had reached the position in which he intended to await

94"Reports of Brig. Gen. William B. Franklin, U. S. Army, commanding division," May 7, 1862, "Report of Brig. Gen. John Newton, U. S. Army, commanding Third Brigade," May 8,1862 , in $\mathrm{OR}, \mathrm{XI}(\operatorname{part} 1):$ pp. 614, 625.

95 George B. MCClellan to Edwin M. Stanton (received May $8,1862)$, in OR, XI (part 3): p. 151 .

96Joseph E. Johnston to Robert E. Lee, May 8, 1862, Joseph E. Johnston to Robert E. Lee, MaY 9, 1862, in OR, XI $($ part 3): pp. 499-500, 502-503.

97D. H. Hill to "My Dear Wife," May 11,1862 , in D. H. Hill papers, College of William and Mary. 
McClellan and give battle.98 The area had many advantages for a smaller army, fighting on the defensive. Johnston's left flank rested on the Pamunkey River which, though navigable, was narrow enough to be blockaded by field artillery. His right was anchored by the Chickahominy, above the head of navigation, but below all the bridges which McClellan could have used for a rapid crossing. The Richmond and York River Railroad ran directly behind the Confederate lines, providing for relative ease of supply. Finally, the terrain between the two rivers was heavily wooded; limited visibility would help to offset the Federal superiority in artillery.99 The only apparent weakness of the position was that it could be flanked by a waterborne advance up the James River, though this could not seriously endanger Johnston's army as long as the fortifications at Drewry's Bluff held out.

As he waited for the Army of the Potomac to arrive, Johnston now found the time to resume normal communications with the authorities in Richmond. He had not, as Freeman and other critics have asserted, ceased to keep his superiors informed of his movements between the withdrawal from Yorktown and the skirmish at Eltham's Landing.100 The published correspondence in the Official Records does

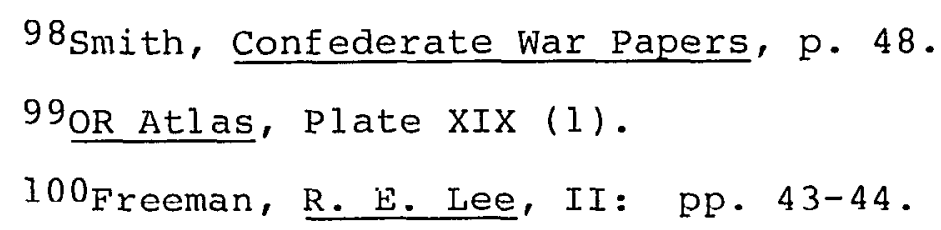


portray Johnston as silent between May 1 and May 7, but this is misleading. Numerous notes and endorsements signed by Johnston concerning routine administrative matters appear in the records of the Adjutant and Inspector-General. Especially significant are the endorsements by Johnston on two letters by Longstreet to Cooper, dated May 7 and May 9, which indicate that he filed a preliminary report on the battles at Williamsburg.101 Though this document has not been found, its existence is further suggested by Johnston 's immediate reports of the much smaller engagement at Eltham "s Landing.102 Contextual evidence in Lee's letterbook also indicates that Johnston wrote him on May 6, with reference to provisions for the army.103 The longest period during which Johnston remained incommunicado definitely did not exceed four days (May 2-5) and may well have been shorter. 104

101 James Longstreet to Samuel Cooper, May 7, 1862, James Longstreet to Samuel Cooper, May 9, 1862, in LR-AIGO, M-474, Reel 30 .

102 Joseph E. Johnston to Robert E. Lee, May 8, 1862, in OR, XI (part 3): pp. 499-500; Joseph E. Johnston to Robert E. Lee, May 7, 1862, in OR, LI (part 2): pp. 552-553.

103 Robert $\mathrm{E}$. Lee to Joseph E. Johnston, May 7, 1862, Robert E. Lee to Lucius B. Northrop, May 7, 1862, in Lee Letterbook.

104 Johnston announced his intention to evacuate Yorktown to Lee on May I (not preserved, but mentioned by Lee the following day). He evidently attempted to communicate his plan to delay the withdrawal by one day on May 2 or 3 , but discovered that the Williamsburg telegraph office had been broken up. If Johnston then attempted to post a letter on the same subject to Richmond, is has been lost. During 
Johnston notified Lee on May 7 that he could not provision the army near West point, but indicated that Federal naval power concerned him more. "The sight of the iron-clad boats makes me apprehensive for Richmond, too, so I move on in two columns, one by the New Kent Road under Major-General Smith, the other by that of the chickahominy under Major-General Longstreet."l05 By the next day, when a brief halt at New Kent Court House left him time for reflection, Johnston realized that events in his front had distracted his attention from the remainder of his command. He received three letters from Lee which had, unfortunately, been signed for the general by walter Taylor. This particu-

May 3-5, the retreat from Yorktown and the two engagements in front of Williamsburg, Johnston apparently found no time to write, but by May 7 his endorsement on Longstreet's letter indicates that he had already filed his williamsburg report, as does the context of his May 7 letter to Lee. This was probably a different letter from his May 6 letter to Lee concerning provisions, which had been posted twelve miles west of Williamsburg, and would have been written either on the evening of May 5 or the morning of May 6 . Thus, a tentative reconstruction of Johnston"s correspondence during the withdrawal period looks like this:

May 1: Johnston to Lee (mentioned by Lee)

May 3: Johnston to Lee (telegram that could not be sent; inferred from Johnston to D. H. Hill, May 3) May 3: Johnston to Lee (conjectural; letter sent in. place of telegram?)

May 5 or 6: Johnston to Lee or Cooper (inferred from endorsements on Longstreet's letters)

May 6: Johnston to Lee (mentioned in Lee Letterbook)

See Robert E. Lee to Joseph E. Johnston, May 2, 1862, Joseph E. Johnston to D. H. Hill, May 3, 1862, John B. Magruder to George W. Randolph, MaY 6, 1862, in OR, XI (part 3): pp. $488,491,496$.

105Joseph E. Johnston to Robert E. Lee, May 7, 1862, in OR, LI $(\operatorname{part} 2)$ : pp. 552-553. 
larly upset Johnston because one of the letters gave him specific orders concerning his wagon trains, and another countermanded a portion of his orders to Huger for the transfer of certain troops from the south side of the James. None of the letters provided him with any intelligence concerning affairs in the Valley, central Virginia, or around Fredericksburg. 106

"My authority does not extend beyond the troops immediately around me," Johnston complained. "I request therefore to be relieved of a merely nominal geographical command. The service will gain thereby unity of command, which is essential in war."107 Clifford Dowdey misconstrued this paragraph as a "Threatening gesture of "resignation'" which "revealed an infantilism in Johnston's relations with the war officers."108 But the remainder of Johnston's letter, and Lee's response, makes it clear that he was only asking--albeit quite brusquely--to either have his orders to Huger obeyed or to have the Department of Norfolk removed from the Department of Northern Virginia. Intemperate language aside, Johnston had a reasonable case against the

106 only one of these letters is printed in OR--Robert $\mathrm{E}$. Lee to Joseph E. Johnston, May 7, 1862, in OR, XI (part 3): p. 497. A second is in the Lee Letterbook. The third has not been found, but it may be inferred from Johnston's response that it did not provide information on the activities of Jackson, Ewel1, or Anderson.

107Joseph E. Johnston to Robert E. Lee, May 8, 1862, in OR, XI (part 3): p. 499 .

108Dowdey, Seven Days, p. 66. 
Richmond authorities. Without ever informing him, they had delayed Huger's withdrawal from Norfolk, ordered a brigade from his command to central Virginia, and changed the objective of his eventual retreat from Richmond to Petersburg. 109 While each of these actions may have been defensible in terms of the overall strategic situation, ignoring Johnston's authority over Huger was a serious infraction against proper military procedure.

That Johnston did not intend to relinquish command of the Department of Northern Virginia was made clear in his next paragraph: "I have had in the Peninsula no means of obtaining direct information from the other departments of my command nor has the Government furnished it." He was especially worried about the forces south of Fredericksburg: "I wish to place them so that they may not be cut off by an army landing at west Point."110

This letter sparked a confusing exchange of letters between the two generals that lasted for nearly a week, and can only be satisfactorily explained if one assumes, as Lee finally did, that some of the correspondence miscarried and arrived out of order. The exchange centered around the

109 George $W$. Randolph to Benjamin Huger, May 3, 1862, Robert E. Lee to Benjamin Huger, May 7, 1862, Robert E. Lee to Joseph E. Johnston, May 7, 1862, Robert E. Lee to Benjamin Huger, May 8,1862 , Robert E. Lee to Joseph E. Johnston, May 8, 1862, in OR, XI (part 3): pp. 490, 497, 499, 500-501.

$110_{\text {Joseph }} \mathrm{E}$. Johnston to Robert E. Lee, May 8,1862 , in OR, XI (part 3): pp. 499-500. 
question that had been deferred but not settled weeks earliex in Richmond: by what strategy should the Federal offensive be countered? Subsidiary issues included the control and positioning of Anderson's division near Fredericksburg and the proper thrust of operations in the Valley. The tone of the letters became steadily more antagonistic-particularly on Johnston's part--which ironically disguised the fact that, by mid-May, both Johnston and Lee had drawn a good deal closer in terms of their view on proper conduct of operations.

Lee attempted to mollify Johnston on May 8 , by assuring him, "I consider your authority to extend over the troops on both sides of the James River. . ." But he also cooly denied having become Johnston's only conduit of information from the outlying districts. "I do not recollect your having requested information relating to the other departments of your command to be forwarded by any other means than the usual course of the mails, and supposed the commanders were in direct correspondence with you."lll This sentence ignored exactly such a request, made on April 22, which had alerted Lee to the fact that Johnston had no direct communication with either Jackson or Ewell, and expected to depend on Lee to forward information.112 The

$11 l_{\text {Robert }} \mathrm{E}$. Lee to Joseph E. Johnston, May 8, 1862, in OR, XI (part 3): p. 500 .

112 Joseph E. Johnston to Robert E. Lee, April 22, 1862, in $\mathrm{OR}, \mathrm{XI}$ (part 3): p. 455 . 
letter also slid quietly by the fact that only in this letter did Lee tell Johnston that J. R. Anderson was in command below the Rappahannock, that Jackson had marched to attack the Federals west of Staunton, or that a brigade from Huger's department had been ordered to central Virginia. Nor did Lee explain that he himself had been the authority by which all these movements had been made. 113

By May 10, based on the intelligence provided by Lee, Johnston had the following picture of events in Virginia. On the Federal side, McClellan was cautiously advancing up the Peninsula with something more than 100,000 men. From Fredericksburg, Major-General Irvin McDowell's corps, estimated accurately as containing nearly 40,000 soldiers, was threatening to march south.114 Banks, who had last been reported to Johnston as having 34,000 troops, was apparently leaving the Valley to unite with McDowell.115 Thus, the strategic picture that confronted Johnston was one of at least 175,000 Yankees converging on Richmond from the north and east.

113 Robert E. Lee to Joseph E. Johnston, May 8, 1862, in OR, XI (part 3): pp. 500-501.

$114_{\text {Robert }} \mathrm{E}$. Lee to Joseph E. Johnston, May 10, 1862, in $\mathrm{OR}, \mathrm{XI}($ part 3): p. 505 .

115 The last intelligence from Jackson to Johnston on Bank's strength came on March 27, and was, though Johnston had no way of knowing it, quite out of date by May 10. See Robert E. Lee to Joseph E. Johnston, May 8, 1862, in OR, XI (part 3): p. 501; Thomas J. Jackson to Joseph E. Johnston, March 27, 1862, in OR, XII (part 3): pp. 840-841. 
How were the Confederates disposed to receive them? Jackson had led a division of 8,000 off into the mountains away from the main theater of war. Ewell's Division, numbering 8,500 men, was positioned in Swift Run Gap, ostensibly outnumbered by four-to-one. At least one brigade was located at Gordonsville, observing nothing. Anderson's 12,000 soldiers south of Fredericksburg faced more than three times their own numbers. Huger's Division had concentrated at Petersburg, where no enemy forces seemed to be. In front of McClelian, Johnston now mustered only about 50,000 men, in an army reduced by battle casualties and straggling. 116 So, even though the Confederates deployed over 90,000 troops across the old Dominion, and still held a central position with interior lines, they had spread their forces too thin to hope for a victory without concentrating somewhere.

Not knowing that Lee and Jackson had been considering the question since late April, Johnston saw three possible strategies for foiling the Federal offensive. United, the forces of Jackson, Ewell, Branch, and Edward Johnson (stationed at Monterey) might be able to attack Banks in the Valley, prevent Banks from reinforcing McDowell, and allow Jackson to march about 20,000 men to reinforce Anderson. This would allow the force below Fredericksburg to meet

\footnotetext{
116 Joseph $\mathrm{E}$. Johnston to Robert E. Lee, May 9, 1862, in OR, XI (part 3$):$ p. 503 .
} 
McDowell's corps on equal terms, removing the specter of a combination of the two Federal columns in eastern Virginia. Johnston dispatched orders to Jackson and Ewell on May 13 to pursue this course. 117

If Jackson's force could not detain Banks in the Valley, then Johnston believed the proper course was to have him march directly "to join either the army near Fredericksburg, commanded by Brig. Gen. J. R. Anderson, or this one."118 If Huger were brought to Richmond at the same time, this would create a situation in which Johnston would be able to deploy his 90,000 men in one army between enemy wings of roughly 75,000 and 100,000 , separated by forty miles. He could then maneuver to engage either McDowell or McClellan in succession, with relative parity of numbers. The third option available to the Confederates was a simple concentration of all available troops to defend Richmond, including brigades from North Carolina and points farther south. "If the president will direct the concentration of all the troops of North Carolina and Eastern Virginia," Johnston told Lee on May 10, "we may be able to hold Middle Virginia at least. If we permit ourselves to be driven beyond Richmond we lose the means of maintaining this army." He concluded with a contention that only "a concen-

117 Joseph E. Johnston to Richard S. Ewell, May 13, 1862, in OR (part 3): p. 888 .

118 Ibid. 
tration of all our available forces may enable us to fight successfully."119 This has traditionally been cited as Johnston's preferred strategy, but a close reading of his correspondence from May" 8 to May 13 suggests that he advocated it as much from frustration as preference. 120

Either of Johnston's other strategic choices depended upon a single variable that he had not yet been able to master: the control of the detachments of his army at long distances. How could he expect to control the operations of as many as six separate columns when he could not even reliably communicate with five of them? "I must be informed of your movements and progress, that your instructions may be modified as circumstances change," Johnston told Ewell on May 13.121 By this time, the sentence had almost a plaintive ring to it, for since May 8 Johnston had been unable to reach Huger or Anderson.122 It must have seemed to Johnston that the only way he would ever be able to exert his authority over his widely spread divisions would be to gather them all in one place, where he could depend for

119 Joseph E. Johnston to Robert E. Lee, May 10, 1862, in OR, XI (part 3): p. 506.

120 For the traditional interpretation of Johnston's intention to concentrate, see Freeman, Lee's Lieutenants, I: p. 202 .

121 Joseph E. Johnston to Richard S. Ewell, May 13, 1862, in OR (part 3): p. 888 .

122 Joseph E. Johnston to Robert E. Lee, May 10, 1862, in $\mathrm{OR}, \mathrm{XI}$ (part 3): p. 506 . 
success on the fighting qualities of his soldiers and not have to rely on a nonfunctional command system to orchestrate intricate maneuvers.

Though Lee, like Johnston, never outlined his strategy for the defense of Richmond in a single sentence or paragraph, a sampling of his letters indicates that his intentions were now far less at odds with those of Johnston than they had been a month earlier. He suggested to Jackson on May 8 that at least Ewell's Division should pursue Banks out of the valley, attacking him en route if possible, and eventually joining Anderson's force.123 on May 14, Lee was contemplating almost exactly the same strategy for Valley operations that Johnston had ordered the day before, authorizing walter Taylor to write to Jackson that "if you can form a junction with General Ewell with your combined forces you should be able to drive Banks from the Valley." 124

Lee was also in agreement with Johnston that the 12,000 Confederates near Fredericksburg should be united with Johnston's main army for the purpose of striking either McDowell or McClellan. He advised Johnston on May 10 that even President Davis now held the "view that operations of its [Johnston's army] several divisions might be combined to

123 Robert E. Lee to Thomas J. Jackson, May 8,1862 , in OR, XII (part 3): pp. 883-884.

124 Walter H. Taylor to Thomas J. Jackson, May 14, 1862, in OR, XII (part 3): p. 889 . 
attack the enemy, who seemed to have exposed himself and his line of communication, and to prevent any movement that might threaten your rear."125 on May 11, for the first time, Lee directed J. R. Anderson to "conform all your movements to the direction of General Johnston."l26 The next day Lee asked Johnston, "toward what point in the vicinity or Richmond do you desire them [outlying troops] to concentrate?" The letter specified only Anderson's force, but also implied that Lee now understood that Johnston might need to draw in the divisions of Jackson and Ewel1.127 Lee had even apparently accepted Johnston's premise that more troops must be drawn from the coast to reinforce Johnston's army. In the last month, he had transferred Maxcey Gregg's Brigade from South Carolina, and those of Anderson and L. O'Bryan Branch from North Carolina. Now he wrote the North Carolina Governor, Henry Clark, and Major-General John C. Pemberton, commanding Lee's old Department of South Carolina and Georgia, that more brigades would have to be released to Virginia. 128

$125_{\text {Robert }} \mathrm{E}$. Lee to Joseph E. Johnston, May 10, 1862, in $\mathrm{OR}, \mathrm{XI}$ (part 3): p. 505 .

$126_{\text {Robert }} \mathrm{E}$. Lee to John R. Anderson, May 11,1862 , in OR, XI (part 3): p. 887 .

127 Robert $E$. Lee to Joseph E. Johnston, May 12, 1862, in OR, XI (part 3): p. 511 .

128 Walter H. Taylor to John C. Pemberton, May 12, 1862, Robert $E$. Lee to Henry T. Clark, May 13, 1862, in OR, XI $($ part 3): pp. 512-513. 
Thus, when Davis and Lee rode out unannounced to Johnston's headquarters on May 14, there was more concord among the senior members of the confederate command structure than had existed for months.129 Davis contended in his memoirs that the conversation was "so inconclusive" that he and Lee were "unable to draw from it any more definite purpose than that the policy was to improve his position as far as practicable, and wait for the enemy to leave his gunboats, so that the opportunity might be offered to meet him on land."130 But the contemporary record reveals that the President's memory had become colored with the passage of two decades. It is doubtful that any discussion of operations would have excluded Johnston's instructions to Jackson and Ewell, posted the previous day. With respect to Johnston's appreciation of the fact that McClellan would eventually have to leave his naval support to advance either

129 Freeman suggested that the date of the Davis-Lee visit to Johnston's army cannot be fixed with absolute certainty on May 14, but all available circumstantial evidence supports that date. Lee addressed a letter to Johnston on May 13 that responded to one hand-carried to Richmond by $A$. $H$. Cole; had he been visiting Johnston that afternoon, he would have had no reason to write the letter. All of Lee's May 14 correspondence was actually written and signed by Walter Taylor, and on the morning of May 15 Taylor placed Lee at Drewry's Bluff. See Freeman, Lee's Lieutenants, I: p. 210; Robert E. Lee to Joseph E. Johnston, May 13, 1862, Walter H. Taylor to Joseph E. Johnston, May 15, 1862, in $\mathrm{OR}, \mathrm{XI}$ (part 3): pp. 512-513, 518; Walter $H$. Taylor to Thomas J. Jackson, May 14, 1862, in OR, XII (part 3): p. 889; Walter H. Taylor to [J. B. Walton], May 14, 1862, in OR, LI (part 2): p. 556 .

$130_{\text {Davis, }}$ Rise and Fall, II: pp. 101-102. 
north or south of the Chickahominy, Lee acknowledged on May 17 that "I think there can be little doubt as to the correctness of your views. . . "131 Davis himself informed Johnston the same day that "if the enemy proceed as heretofore indicated, your position and policy, as you stated it in our last interview, seems to me to require no modification. . ."132 The President, Johnston later correctly asserted, left with "no cause to complain" about the conference, "especially as he suggested nothing better."133 Whatever fragile harmony had been established among the three men soon disappeared, for the next day everyone's calculations were upset again. The much dreaded Federal ironclads had finally arrived at Drewry's Bluff.

$131_{\text {Robert }} \mathrm{E}$. Lee to Joseph E. Johnston, May 17, 1862, in $\mathrm{OR}, \mathrm{XI}(\operatorname{part} 3):$ p. 523 .

132Jefferson Davis to Joseph E. Johnston, May 17, 1862, in $\mathrm{OR}, \mathrm{XI}$ (part 3): p. 524 .

133 Johnston, "Manassas to Seven Pines," B\&L, II: p. 206. 
Chapter Ten

Defending Richmond

While the army retreated toward the Chickahominy, critical events were also transpiring on the James River. When he determined to evacuate Yorktown, Joseph Johnston had also dispatched orders to Commander Tucker's James River Squadron. Initially, while the Virginia still closed the mouth of the James to the Union Navy, Tucker was instructed to transport what he could save of the heavy guns at Jamestown Island back to Richmond. But eventually, Johnston knew, the Virginia would either have to be scuttled, lightened to run upriver, or undertake a final, suicidal dash into Hampton Roads to try to sell herself as dearly as possible among the Federal transports at anchor there. When that happened, Tucker and his command were to "continue to observe and control the upper James River as long as practicable, in order to prevent the enemy from crossing and attempting to cut off our forces retiring from Norfolk."l It was an incredibly tall order: against Tucker's five vessels--only one of which was partially armored--mounting just sixteen guns, Admiral Goldsborough would send Commander John Rodgers with nine vessels--including the ironclads

1 Joseph E. Johnston to John R. Tucker, May 2, 1862, in OR, XI (part 3): pp. 488-489. 
Monitor and Galena--boasting forty-five cannon, five of which were the monstrous 100-pound siege rifles.2 "When hard pressed," Johnston advised Tucker on May 2, "you will retire upon Richmond." 3

But after completing one trip hauling the artillery and ordnance stores from Jamestown Island to Richmond, Tucker received new orders, this time from secretary of the Navy Stephen Mallory. McClellan's troops held Yorktown, and Longstreet was fighting his rear guard action in front of Williamsburg; the Confederates on the Peninsula were in full retreat. Yet Mallory's orders read: "Proceed to navy yard, Norfolk, with Patrick Henry and Jamestown and await orders." 4

The operation could only be attempted at night, because it involved running past the heavy batteries at Newport News and avoiding detection by the Federal ships prowling Hampton Roads. As silently as possible, drifting more than steaming, Tucker steered the two vessels under the Yankee guns

2See L. M. Goldsborough to Gideon Welles, May 21,1862 , in NOR, VII: p. 406. The Federal vessels were the Monitor (two guns), the Galena (six guns), the Wachusett (10 guns), the E.A. Stevens (one gun), the Aroostook (three guns), the Port Royal (eight guns), the Maratanza (six guns), the Mahaska (six guns), and the Dragon (two guns); for detailed descriptions, see NOR, Series 2, II: pp. 39, 62, 90, 132, $134,148,182,215,235$.

3 Joseph E. Johnston to John R. Tucker, May 2, 1862, in OR, XI (part 3): pp. 488-489.

${ }^{4}$ Quoted in J. N. Barney to John R. Tucker, May 4, 1862, in NOR, VII: p. 784 . 
and picked his way around the obstructions in the Elizabeth River on the night of May 5.5

What Tucker found in Norfolk was chaos. Major-General Benjamin Huger's Department of Norfolk had always been a source of problems for the War Department. The army and navy constantly quarreled over spheres of authority, a disagreement still unsettled after the subordination of the naval forces in the department to Johnston in mid-April. 6 The original commandant of Gosport Navy Yard had been replaced in March, primarily because of a perceived lack of energy in meeting construction deadines. 7 Huger himself had survived calls for his resignation by his own officers, members of Congress, and even the Vice-President, who labeled him "inefficient--indeed [an] imbecile. . . " President Davis had sustained him, not from any great confidence, but for lack of any better candidates to replace him. When the subject came up in a March cabinet meeting, with members calling for Huger to be superseded, Davis responded that "it was easy to say so, but the question was

5John R. Tucker to Stephen R. Mallory, May 8, 1862, in NOR, VII: p. 786 .

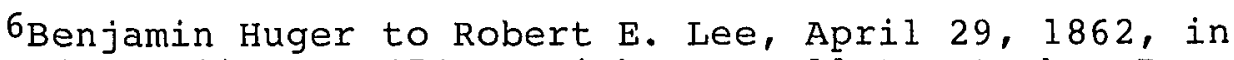
OR, XI (part 3): p. 474; Josiah Tattnall to Stephen R. Mallory, April 29, 1862, in NOR, VII: p. 776.

7Stephen R. Mallory to F. Forrest, March 19, 1862, Stephen Mallory to F. Forrest, March 20, 1862, Stephen R. Mallory to Sidney Smith Lee, March 24, 1862, in NOR, VII: pp. 747-749. 
where to get one to take his place." 8 Benjamin, Randolph, and Lee all found it necessary constantly to send Huger detailed orders to accomplish even the simplest of tasks. 9 When Johnston directed Huger on April 28 to "be prepared for a prompt movement, and if compelled to move, as little public property as possible should be left for the enemy," the fifty-seven-year-old South Carolinian panicked. He wrote back to Lee, not Johnston, that he could not remove or damage his guns, destroy his ammunition, relinquish any outlying parts of his garrison, or assist in the destruction of property in the navy yard. "It seems to me the best I can do is to be prepared to repel promptly any attack and defend the position as long as I can."l0 As the time for the withdrawal from Yorktown grew closer, Johnston sent more detailed orders to Huger, Tattnall, and Sidney Smith Lee. The orders were hand-carried by Colonel Lay, who was

8 Entries of March 4, 1862, March 7, 1862, Bragg diary, pp. 171, 175; see also Jefferson Davis to Benjamin Huger,

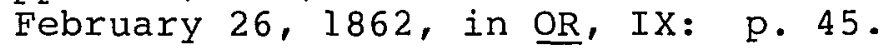

9 Judah P. Benjamin to Benjamin Huger, March 5, 1862 (two letters), Judah P. Benjamin to Benjamin Huger, March 15, 1862, in $\underline{\mathrm{OR}}$, IX: pp. 55-56, 68; Robert E. Lee to Benjamin Huger, March 18, 1862, walter $\mathrm{H}$. Taylor to Benjamin Huger, March 29, 1862, Walter H. Taylor to Benjamin Huger, March 31, 1862, George W. Randolph to Benjamin Huger, April 1,1862 , Robert E. Lee to Benjamin Huger, April 7, 1862, in $\underline{\mathrm{OR}}, \mathrm{XI}$ (part 3): pp. 384-385,411,412-413,414,425-426; see also George W. Randolph to T. M. R. Talcott, April 4, 1862, in Talcott Family papers, Virginia Historical Society, Richmond, Virginia.

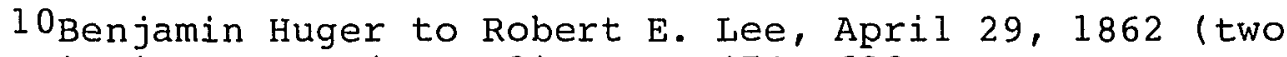
letters), in $\underline{\mathrm{OR}}, \mathrm{XI}$ (part 3): pp. 474, 682. 
empowered to explain more fully his commander's intentions.11 When word of Johnston's instructions reached Richmond, Davis ordered Secretaries Mallory and Kandolph to Norfolk to delay the evacuation long enough to ship out such supplies as could be saved and destroy those that could not. 12

Thus occurred the confusea situation in Norfolk on the night of May 5, when Commander Tucker quietly passed the obstructions neax Craney Island. Two cabinet secretaries were personally supervising the shipment of supplies.13 Flag officer Tattnall was trying to convince them that the Virginia could not possibly execute his orders to "protect Norfolk as well as James River, and if possible prevent the enemy from ascending it." At the same time, he was desperately attempting to find a pilot who could navigate the ironclad upriver if her draft was lightened.14 Captain Lee was dismantling the navy yard, and General Huger, by all

$11_{\text {Robert }} \mathrm{E}$. Lee to Joseph E. Johnston, May 2, 1862, in OR, XI (part 3): p. 488; Joseph E. Johnston to John R. Tucker, May 2, 1862, in NOR, VII: p. 782 .

12 'Pestimony of George $W$. Randolph before the Confederate states Congress Naval Committee, February 5, 1863, in NOR, Series 2, I: pp. 716-717.

\section{Ibiä.}

14 Testimony of Josiah Tattnall at his court-martial, July 19, 1862, in NOR, VII: p. 796. 
reports, was hardly capable of doing anything.15

He discovered that Tucker's two steamers had been ordered to Norfolk to attempt to haul off the Richmond ordnance supplies and as many gunboats as possible before Gosport fell back into Yankee hands. If sneaking into Norfolk had been difficult, steaming back upriver with several other vessels in tow was even more dangerous. Tucker did not hesitate; the next night he re-entered Hampton Roads. The Patrick Henry towed the unfinished ironclad and a partially completed gunboat. The Jamestown had in tow another gunboat and the brig loaded down with the cannon and ammunition for the Richmond. The two gunboats, recalled Lieutenant Commander William H. Parker of the Beaufort, "had sawmill engines, and when they got underweigh [sic] there was such a wheezing and blowing that one would have supposed all hands had suddenly been attacked with the asthma or heaves." Miraculously, "they ran by the batteries at Newport News however without waking the sentinels up." The following morning, May 7, while Hood and Newton traded volley at Eltham's Landing, Tucker handed the vessels over to his smaller ships to be conveyed to Richmond, and

15Wood, "First Fight," B\&L, I: p. 709; testimony of George W. Randolph before the Confederate States Congress Naval Committee, February 5, 1863, in NOR, Series 2, I: pp. 716-717; testimony of Josiah Tattnall at his court-martial, July 19, 1862, in NOR, VII: p. 797. 
stationed himself to run the gauntlet again that night.16 By the night of May 7, however, the Federals had more securely closed Hampton Roads; and Tucker's vessels were spotted and forced to retreat soon after midnight.

The next morning, Tucker watched impotently as the Galena, the Port Royal, and the Aroostook, having themselves bypassed the Virginia, pounded the Confederate battery at Day's Bluff into submission. 17 The Federal gunboats, Tucker wrote from his vantage point upriver, "silenced it in one hour." As he retreated slowly ahead of the Yankee vessels, Tucker warned Commander Ebenezer Farrand, commanding at Drewry's Bluff, that "the iron vessel the 'Galena' is one of them and can ascend the river to Richmond if she desires. I feel anxious for the fate of Richmond. . . "18

But Fort Huger, sitting atop Harden's BIuff with thirteen guns, several of which were rifled, proved too well entrenched to be silenced. Under orders from Admiral Goldsborough to ascend the James as rapidly as possible "to harass the retreat of the rebels wherever they can be reached," Commander Rodgers decided to bypass the second

16 William H. Parker, Recollections of a Naval officer, 1841-1865 (New York: Char les Scribner's Sons, 1883), p. 278 ; John R. Tucker to Stephen R. Mallory, May 8, 1862, in NOR, VII: p. 786 .

17 Ibid.

18John R. Tucker to Ebenezer Farrand, May 8, 1862, in Charles T. Mason papers, Virginia Historical Society, Richmond, Virginia. 
fort.19 The Galena capitalized upon her relative invulnerability to the battery's ordnance, passing and repassing the Confederate position seven times to draw fire and distract attention from the two wooden vessels. Rodgers hoped that he could then quickly engage Tucker's squadron, guaranteeing Federal control of the lower James. But the Confederates had moved the channel markers, and managed to decoy the Galena into a sandbar near Hog Island. Her pipes filled with sand and water, choking the engines so effectively that she remained aground for thirty-six hours. Rodgers realized that without the ironclad the Port Royal and the Aroostook alone could not force the river against Tucker's five vessels, so he settled in to await repairs and reinforcements. 20 While his engineers pumped out the Galena's fouled plumbing, the Confederates finished the evacuation of Norfolk and, on May 10 , a disconsolate Flag-officer Tattnall ordered the destruction of the Virginia. 21

So far, Confederate operations on the James River had bought precious time to improve the fortifications at Drewry's Bluff. Rodgers did not move up the river from Hog Island until the evening of May 12, more than a week after

${ }^{19}$ L. M. Goldsborough to John R. Rodgers, May 7, 1862, in NOR, VII: p. 327 .

20 John Rodgers to I. M. Goldsborough, May 9, 1862, John Rodgers to L. M. Goldsborough, May 11, 1862, in NOR, VII: pp. 328-329.

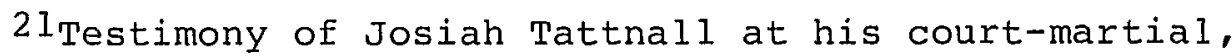
July 19, 1862, in NOR, VII: p. 797. 
Johnston's army had left the trenches at Yorktown. 22 The time would not have been half so critical had Joseph Johnston's suspicions not been well founded: despite having had nearly eight weeks available to perfect the fortifications at Drewry's Bluff, the Richmond authorities had allowed the work to proceed in a desultory and haphazard manner. Even as Commander Rodgers weighed anchor, it was questionable whether or not enough guns had been planted there to resist his passage.

Captain Augustus H. Drewry's Southside Heavy Artillery (Company C, 2nd Virginia Artillery) had been organized from overage volunteers in January, 1862. Drewry believed that his company's first position, in Battery Nineteen on the turnpike between Richmond and Drewry's Bluff, "was unimportant, and that we would likely be called to field duty, for which I did not think my men were well suited. . . 23 He requested an interview with General Lee in early March, and sold the Commanding General on the idea of erecting a battery on the James River below Richmond. Already conscious of the long-term weakness of Norfolk, Lee quickly agreed, sending Major Alfred Rives and Lieutenant Charles T.

\footnotetext{
22 John Rodgers to L. M. Goldsborough, May 12, 1862, in NOR, VII: p. 345 .

23 Quoted in William Izard Clopton, "New Light on the Great Drewry"s Bluff Fight," Southern Historical Society Papers, Vol. XXXIV (1906): p. 83; see also A. H. Drewry, "Drewry"s Bluff Fight," Southern Historical Society Papers, Vol. XXIX (1901): pp. 284-285.
} 
Mason of the Engineer Bureau down the river with Drewry to select a suitable location. The three men settled on the bluffs on Drewry's own farm, which bore his family name. The James River narrowed enough there to be obstructed, and the cliffs were high enough to allow for plunging fire into enemy vessels below. The Southside Artillery marched to its new post on March 17.24

Improving Drewry's Bluff, like the rest of the defenses of Richmond, turned out be a low priority for Confederate authorities. The Tredegar Iron Works provided the iron bolts and shoes for the pilings to reduce the channel in the river, but only as a secondary effort. 25 Lee did not get around to requesting cannon for the battery until early April.26 Drewry could requisition neither wagons and teams, nor supplementary labor; he quickly concluded that the government had no real interest in his project and set his men to building cabins for themselves instead of digging firing positions. There was a brief flicker of activity in mid-April when three guns, an additional company of artillery, and the commander of the 2nd Virginia Artillery, Colonel Robert Tansill, all showed up at about the same time. But Tansill and the extra company were soon ordered

\section{Ibid.}

25 Dew, Ironmaker, p. 182.

26 Robert E. Lee to Josiah Gorgas, April 4, 1862, in OR, $X I$ (part 3): p. 421 . 
away to Fredericksburg, and Drewry recalled that after that "the work went on pretty much after the order of a private enterprise until a short while before Norfolk was evacuated. . . $" 27$

By the time Johnston began to speak of withdrawing from Yorktown, Lee and Naval Secretary Mallory began to take renewed interest in the project. Starting in late April, one or both would usually ride out to the bluffs to check the progress of the work. 28 But it was not until early May and the urgency caused by Johnston's withdrawal from Yorktown that Drewry's Bluff was granted any sort of priority. It was almost too late.

on May 2, Lee ordered a company of "sappers and miners" to augment Drewry's company. 29 The day that the Federal gunboats reduced Fort Huger, May 8, secretary Mallory ordered Commander Farrand to take a detail of beached seamen to the position and take command of the works. 30 The next day he ordered the crews of the James River Squadron to the

27Clopton, "New Light," pp. 83-84.

28 Joseph T. Durkin, Stephen R. Mallory, Confederate Naval Chief (Chapel Hill, NC: University of North Carolina Press, 1954), p. 194 ; Robert E. Lee to Joseph E. Johnston, April 30, 1862, Robert E. Lee to Joseph E. Johnston, May 10 , 1862, Walter H. Taylor to Joseph E. Johnston, May 15, 1862, in $\mathrm{OR}, \mathrm{XI}($ part 3$)$ : pp. 476, 505, 518 .

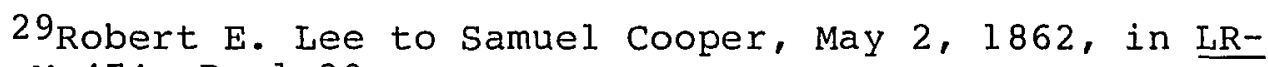
AIGO, M-474, Reel 30 .

30 Stephen R. Maliory to Ebenezer Farrand, May 8, 1862, in NOR, Series 2, I: pp. 635-636. 
bluff to emplace cannon from the Jamestown and the Patrick Henry. 31 on May 11, as Commander Rodgers' crew struggled to complete the repairs on the Galena and free her from the Hoy Island sandbar, Lee ordered six more companies of heavy artillery to Chaffin's Bluff, just across the river from the original position, to begin aigging in a new battery.32 The following morning, Mallory dispatched Lieutenant Catesby ap R. Jones and the crew of the scuttled Virginia (minus only engineering officers) to the same location, followed a day or two later by Captain John D. Simms and two companies of Confederate Marines. 33 A company of the Washington (Louisiana) Artillery was also transferred to Chaffin's Bluff on May 13.34 While Lee and Davis conferred with Johnston on May 14, Secretary Ranäolph ordered Huger--now in Petersburg --to send Brigadier-General William A. Mahone's Virginia Brigade to the bluffs to support the artillery, in case transports carrying infantry followed the Yankee gunboats. 35

By May 15, nearly 1,800 sailors and soldiers gathered at Drewry's and Chaffin's Bluffs, and General Manone was

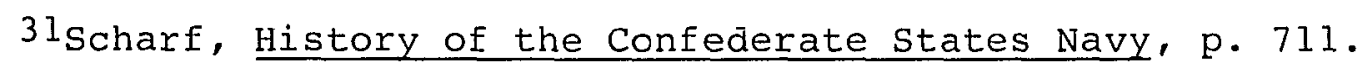

32 These six companies constituted 668 men. W. H. Fry to Samuel Cooper, May 14, 1862, in LR-AIGO, M-474, Reel 18 .

33 Stephen R. Mallory to Catesby ap R. Jones, May 12 , 1862, in NOR, VII: p. 799; Scharf, History of the Confederate States Navy, p. 717.

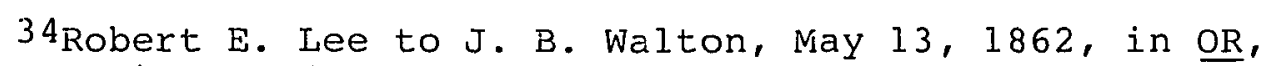
LI (part 2): p. 555 .

${ }^{35}$ Scharf, History of the Confederate States Navy, p. 717. 
marching up with nearly 4,000 more.36 Twelve guns had been placed in hastily dug embrasures; the heaviest were a 10inch Columbiad and a 9-inch Dahlgren Rifle.37 After the Patrick Henry and the smaller gunboats had passed upriver, the Jamestown was sunk in the channel to completely close it to anything but boats with the lightest of drafts. 38

In material terms there were enough men and guns and obstructions at Drewry's and Chaffin's Bluffs to keep Rodgers' squadron from threatening Richmond. But there was no one really in command. Farrand had been superseded by Sidney Smith Lee, who only arrived on the morning of May 15.39 But Mahone was also coming to take command, while

${ }^{36}$ Drewry's company, the company of sappers and miners, and the company from the Washington Artillery probably numbered something less than 300 men. The six companies of heavy artillery added 668 more (see note 32 above), and the muster rolls of the Virginia, the Patrick Henry and the Jamestown numbered over 700 men, to which should be added at least another 150 men for the two companies of marines and Farrand's original work party. For the muster rolls of the three vessels, see NOR, Series 2, I : pp. 289-290, 299-301, 308-311; for the closest estimate of Mahone's Brigade, see "Abstract from return of the Department of Norfolk, Maj. Gen. Benjamin Huger, commanding, for January, 1862," in OR, IX: p. 38 .

37 Scharf, History of the Confederate states Navy, p. 711; Clopton, "New Light," p. 88; Drewry, "Drewry's Bluff Fight, " pp. 285-286.

38Midshipman D. M. Lee, brother of Fitzhugh Lee and nephew of Robert $E$. Lee, was one of the crewmen of the Jamestown who bored the holes in her hull to sink her. See Robert Wright, "Sinking of the Jamestown," Southern Historical Society Papers, Vol. XXIX (1901): pp. 372 . 717.

${ }^{39}$ Scharf, History of the Confederate States Navy, p. 
Captain Drewry and the other army officers studiously

ignored Commander Tucker, who had taken effective control of the navy work parties. It was almost as if the army and navy were preparing to fight two separate battles.

General Johnston only discovered the true nature of the confusion at Drewry's Bluff on May 15, when Federal ironclads had already tested the strength of the position. On May 13, from his headquarters near Baltimore Crossroads, he sent three staff officers to the Richmond area. Major A. H. Cole went to evaluate the logistical situation near the capital; Major walter $H$. Stevens, an engineering officer, and Major Jasper Whiting, Smith's Assistant AdjutantGeneral, made the trip to examine the terrain of the upper Chickahominy and the preparations made to defend Drewry's Bluff. The responses from stevens and Whiting were immediate and depressing: "There is nothing," reported Stevens on May 14, "to prevent their [the Federals'] lanaing at City Point or above, up to Drewry's Bluff, in force." From Drewry's Bluff itself, Major Whiting wrote on the same day: "Stevens and I have done all we could to stir up the imbeciles. It is perfectly discouraging to see how absolutely nothing has been done." He followed this the next morning with an even more gloomy assessment:

It won $t$ do to trust these people in any way. We can't get anything done. . . If not too late, a good brigade under an energetic officer might perhaps save the city. A few more vessels sunk; a gun or two well placed, with bornb-proofs; some sharpshooters intelligently located--all with 


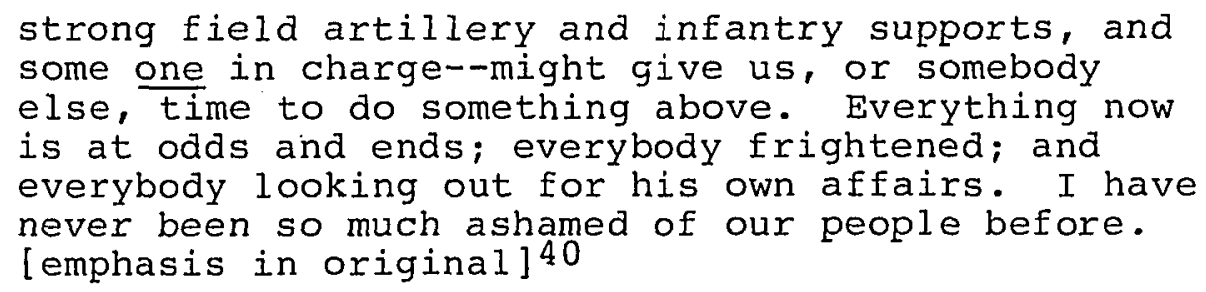

By the time Johnston read this report, the artillerymen at Drewry's Bluff had fought their first disjointed action. While President Davis, General Lee, and his brother, Captain Lee, all watched, the Galena, now reinforced by both the Monitor and the Naugatuck, steamed toward the obstructions in the river. Commander Rodgers, believing from past experience that his ironclads were invulnerable to Confederate fire, planned to remove the pilings in the river and then bypass the batteries. 41

No one on the Confederate side coordinated the defense. Two separate parties of sharpshooters, one under Marine Captain Simms, the other led by Lt. John Taylor Wood of the Virginia, harassed Rodgers ' working parties from the banks of the James, apparently without any reference to each other. 42 The army batteries fought under Captain Drewry's command; the navy guns were directed by Commander Farrand, Commander Tucker, and Lt. Jones. Nobody ordered any particular concentration of fire. Instead, the cannoneers

$40_{A l} 1$ quoted in Smith, Confederate War Papers, pp. 48-49. 41 John Rodgers to L. M. Goldsborough, May 16, 1862, in NOR, VII: pp. 357-358.

42 scharf, History of the Confederate States Navy, pp. 716-717. 
simply blazed away at whatever targets they could hit. 43

The battle opened at 7:45 A. M. on May 15 and lasted just over three hours. The Monitor approached within 400 yards of the obstructions in the river, where it sat despite the fire of the batteries on the bluffs, prevented by the sharpshooters from sending out working parties. The Naugatuck, shrugging off the rebel shells, retired only after the 100-pounder in its bow burst. Standing 600 yards out from the bluffs, however, the Galena finally showed that, under the right conditions, land batteries could stand against ironclads. Plunging fire from the Columbiad and the Dahlgren Rifle struck her forty-three times. Contrary to earlier opinion, Rodgers admitted the next day, the Galena "is not shot-proof; balls came through, and many men were killed with fragments of her own iron." At 11:05 A. M., Rodgers signaled his vessels to retreat. Yet he had not been convinced that the fortifications could not be taken; with infantry support to clear the banks of the river, he still thought that his ironclads could eventually steam past them to the confederate capital. At any rate, he wrote to Admiral Goldsborough, "on James River an army can be landed within 10 miles of Richmond on either bank."44

43 Ibid.; Clopton, "New Light," pp. 88-89; Drewry, "Drewry"s Bluff Fight," pp. 285-286.

44 John Rodgers to L. M. Goldsborough, May 16, 1862, L. $\mathrm{H}$. Newman to John Rodgers, May 16, 1862, Ebenezer Farrand to Stephen R. Mallory, May 15, 1862, in NOR, VII: pp. 357-358, 359-360, 369-370. 
That was the thought that had haunted Johnston since late April, and had kept reappearing in his correspondence over the past two weeks.45 Now it seemed that his worst fear was to be realized. Major Stevens reported on May 14 that "the danger is on the south side of James River."46 Unaware that Randolph had done so, Johnston immediately "wrote to General Huger . . desiring him to send a body of good riflemen . . . to shoot the crews of the enemy's gunboats near the 'obstruction' in James River. . . ." He also urged Lee to have any deployable forces in the Department of Henrico "placed near the battery. . . "47 No sooner than he had posted those letters, Johnston began receiving even more disturbing news from Drewry's Bluff. First came the warning from Major whiting, and then, from Walter Taylor, the first notice of the battle. "The report given me by Captain Zimmer, who is connected with the Ordnance Department, and who was present," Taylor wrote, "is to the effect that the fire of the enemy was very bad. - . "48 Lee sent him a more restrained report later in the

45 Joseph E. Johnston to Robert E. Lee, April 29, 1862, Joseph E. Johnston to Robert E. Lee, May 8, 1862, Joseph E. Johnston to Robert E. Lee, May 9, 1862, in OR, XI (part 3): pp. 473, 499-500, 503-504.

46 Quoted in Smith, Confederate war Papers, p. 48.

47 Joseph E. Johnston to Robert E. Lee, May 15, 1862, in Beverly Randolph Wellford papers, Virginia Historical Society, Richmond, Virginia.

48 Walter Taylor to Joseph E. Johnston, May 15, 1862, in OR, XI (part 3): p. 518 . 
day, which emphasized that "only the two iron boats engaged. No one exposed and no chance for sharpshooters. No signs of landing." 49 But Lee admitted to Huger that he expected McClellan to "avail himself of the river as far up as possible. He may come beyond City Point. . . ."50

This settled the matter for Johnston; he could not afford to wait north of the Chickahominy while the Federals possessed the ability to land in his rear and approach Richmond before he could react, especially when Lee informed him that "there is no force in this city" which could be rushed to oppose a landing.51 He called in Smith and Longstreet. The failure of the government, he told them, to finish the fortifications at Drewry's Bluff invalidated the premise under which they had been deployed to give battle between the Pamunkey and the Chickahominy; the army could not afford to become engaged with a superior force without secure flanks. Johnston ordered a withdrawal behind the river: Longstreet would move his own division to Drewry's Bluff and take over responsibility for the defense there, while Smith assumed responsibility for defending the

49 Robert E. Lee to Joseph E. Johnston, May 15, 1862, in OR, XI (part 3): p. 519 .

$50_{\text {Robert }} \mathrm{E}$. Lee to Benjamin Huger, May 16, 1862, in OR, XI (part 3): p. 520 .

$5 I_{\text {Robert }} \mathrm{E}$. Lee to Joseph E. Johnston, May 16,1862 , in OR, XI (part 3): p. 520 . 
crossings of the upper Chickahominy. 52

Johnston promptly advised Lee of his apprehensions, his intention to move, and his general plan of action. He believed that Mcclellan would try to shift his base from the York to the James, which would require the Federal commander to order his troops across the chickahominy. If so, there would come a moment of vulnerability for the larger Yankee army, when it would be split in two sections by the river, and the smaller Confederate army might engage one portion of it with parity or numerical superiority if it could maneuver swiftly enough. 53

Both Lee and Davis accepted this strategy as valid, despite contentions to the contrary made by the president much later. Lee admitted that work at Drewry's Bluff was "progressing, but not satisfactorily." The heavy guns were "well posted, but not as perfectly protected as designed, for want of time." He hoped that Johnston, when he retired

52 James Longstreet to D. H. Hill, May 16, 1862, in OR, XI (part 3): pp. 521-522; Jongstreet, Manassas to Appomattox, pp. 81-82; Smith, Confederate war Papers, p. 49.

53 Johnston's second May 15 letter has not been found, but its substance can easily be inferred from Robert $E$. Lee to Joseph E. Johnston, May 16, 1862, Robert E. Lee to Joseph E. Johnston, May 17, 1862, and Jefferson Davis to Joseph E. Johnston, May 17, 1862, in OR, XI (part 3): pp. 521, 523524. Lee's remark that "I have supposed that if your army took a position so near this city its right would rest in that vicinity [Drewry's Bluff]," implies that Johnston had advised him of the position he intended to take near Richmond. Lee's second letter agrees with Johnston that Mcclellan would probably try to cross the Chickahominy, and the Davis letter reiterates the same point. 
nearer Richmond, would rest the flank of his army there on the James to assist with the labor and protect the batteries.54 "It is fair for us to conclude," Lee continued in another letter,.."that his operations in front of Yorktown will be re-enacted in front of the obstructions on James River, unless you can prevent it." As for Johnston's plan to strike McClellan when the Army of the Potomac moved toward the James, Lee wrote: "Should his course to James River be below the mouth of the Chickahominy this will be difficult, but should his march be across the cinickahominy his passage between that river and the James may furnish you the opportunity." 55

Davis agreed with his generals. On May 17, he sent an aide, Colonel G. W. C. Lee, to report to Johnston on the state of the defenses at Drewry's Bluff.56 In the letter that colonel Lee hand-carried, the President told the

\footnotetext{
54 Robert E. Lee to Joseph E. Johnston, May 16, 1862, in OR, XI (part 3): p. 521 .

55 Robert E. Lee to Joseph E. Joinnston, May 17,1862 , in OR, XI (part 3): p. 523 .

56 Davis implied in his memoirs that he had sent Lee primarily to confer upon strategy, rather than as a courier instructed to present and receive information. This interpretation strains the wording in Davis's letter to the breaking point. He also stated that Johnston did not ever inform either colonel Lee or himself as to an intention to cross the Chickahominy. Not only, however, had Johnston already informed Lee of the impending move, he had already begun it when colonel Lee arrived, and in fact received Davis's aide on the near bank of the river. See Davis, Rise and Fall, II: P. 103; Johnston, "Manassas to Seven Pines," p. 207; Jefferson Davis to Joseph E. Johnston, May 17, 1862, in OR, XI (part 3): pp. 523-524.
} 
General that if McClellan continued to advance with York River as his base, then meeting the Federals between the Pamunkey and the Chickahominy was still a good plan. "But if, as reported here, he should change direction, and, leaving his boats on the Pamunkey, would cross the Peninsula to join those [boats] on the James River, the opportunity desired by you to meet him on the land will then be afforded." Like Lee, Davis suspected that the cautious "Little Napoleon" would sidestep down the east bank of the river until he came into contact with the Federal fleet on the James: "This diminishes the space within which his march will be exposed to your attack, unless he should cross the Chickahominy, which we can hardly hope."57 As late as May 17, the views of Johnston, Lee, and Davis were still in harmony with each other.

Events in the Shenandoah Valley had not ceased while Yankee ironclads pounded the Rebel batteries at Drewry's Bluff. Following his victory at McDowell, Jackson headed back for the Valley to unite with Ewell and attack Banks--a project endorsed by both Johnston and Lee. But Banks had split his forces in such a way as to confound the orders sent by the two confederate generals. One division of 7,000 men, under Brigadier-General James Shields, was marching out of the Valley to reinforce General McDowell at Fredericks-

57 Jefferson Davis to Joseph E. Johnston, May 17, 1862, in OR, XI (part 3): pp. 523-524. 
burg. The remainder of Banks" army had retreated to Strasburg--whether to fortify a position or to transfer troops by the Manassas Gap Railroad was not certain. Lee, who believed that Banks' ultimate objective was indeed to leave the Valley, still favored an attack on him by Jackson and Ewel1. "Whatever movement you make against Banks do it speedily, and if successful drive him back toward the Potomac, and create the impression, as far as practicable, that you design threatening that line," Lee instructed Jackson. But he also reminded "stonewall" "not, in any demonstration you may make in that airection, [to] lose sight of the fact that it may become necessary for you to come to the support of General Johnston, and nold yourself in readiness to do so if required." 58

Johnston was far less certain that the bulk of Banks forces were intended to quit the Valley. To retreat to Strasburg, entrench, and essentially take himself out of the war would not, based on previous performance, be out of character for the political general from Massachusetts. "If Banks is fortifying near strasburg the attack would be too hazardous," Johnston advised Ewell on May 17. "In such an event we must leave him in his works." Instead, Johnston proposed that Jackson and Ewell unite and strike Shields' detached division as it marched toward Fredericksburg, then

58 Robert $\mathrm{E}$. Lee to Thomas J. Jackson, May 16,1862 , in OR, XII (part 3): pp. 892-893. 
for Ewell "to move on, while General Jackson should keep Banks away from McDowell." The letter concluded with several sentences that have remained the source of controversy for well over a century:

We want troops here; none, therefore, must keep away, unless employing a greatly superior force of the enemy. In your march communicate with Brigadier-General Anderson, near Fredericksburg; he may require your assistance. My general idea is to gather here all the troops who do not keep away from Mcclellan's greatly superior forces. General Branch is ordered to Hanover Court-House. . . After reading this send it to General Jackson, for whom it is intended as well as for yourself. 59

Douglas Southall Freeman contended that "Johnston could hardly have given more dangerous orders," which sprang from his "conservatism and his concern for his own army in front of Richmond. . . ." He portrayed Lee, on the other hand, as following a natural "inclination. . to take the lesser risks for the sake of the greater gain that would follow a defeat of Banks."60 Clifford Dowdey quoted only the portion of Johnston"s letter that said "we want troops here; none, therefore, must be kept away unless employing a greatly superior force of the enemy," and asserted that Johnston had posted the order, "knowing nothing of the conditions in the Valley. . . " Later, Dowdey condemned Johnston for issuing "sporadic orders" which "had been contradictory, sometimes discretionary and sometimes arbitrary, with a day-to-day

59 Joseph E. Johnston to Richard S. Ewell, May 17, 1862, in OR, XII (part 3): pp. 896-897.

$$
60 \text { Freeman, R. E. Lee, II: pp. 55-56. }
$$


type of thinking that could not direct subordinates with a singleness of purpose."61 Also citing only a portion of Johnston's orders, Robert G. Tanner accused Johnston of trying to enforce upon Jackson "his fundamental strategic preference for massing strength by giving up territory and fighting only when there was nowhere else to retreat and no other friendly forces to muster." His letter, opined Tanner, "abandoned everything the Valley Army had striven for since the evacuation of winchester." 62

These criticisms share the central assumption that Johnston preferred a simplistic strategy of concentration of forces at Richmond, and that he was unable to relate operations elsewhere to those of his own army. Such a case could be made if Johnston were shown to have advocated a purely passive course in the Valley and central Virginia, and to have subordinated all other designs to the strengthening of his own army. Yet this was far from true.

Johnston's suggestion of a combined attack by Jackson and Ewell on Shields' division had been overlooked as a viable strategic option by his contemporaries and historians as well, because the attack upon Banks and Jackson's raid down the Valley turned out to be such signal successes (see Map No. 4). Yet an attack on the lone Federal division had much to recommend it. Jackson and Ewell would have fought

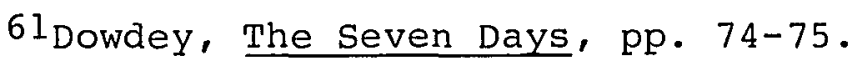

62 Tanner, Stonewall in the Valley, p. 199.
} 


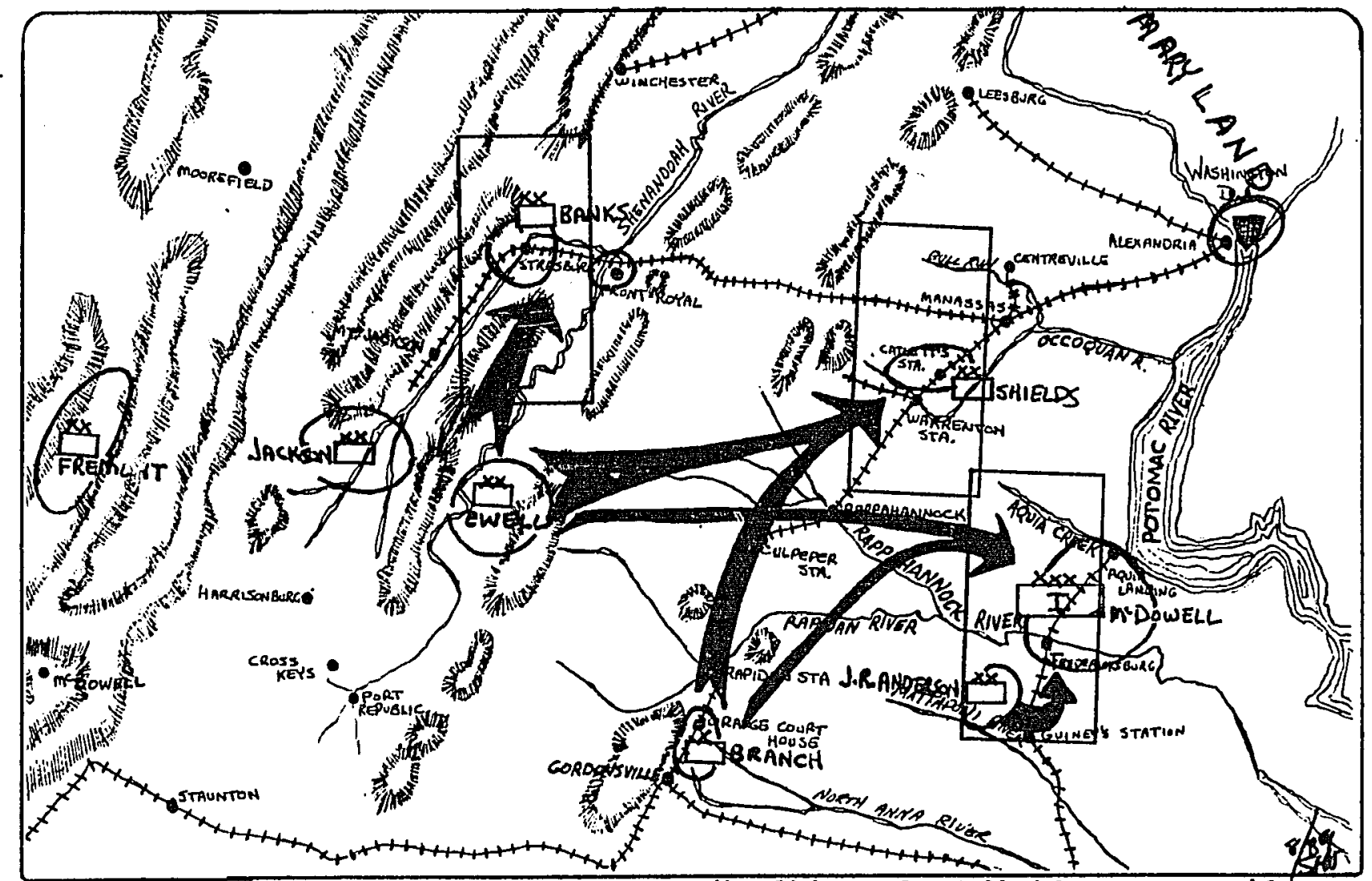

MAP NO.4 STRATEGIC OPTIONS N SHENANDOAN VALLEY GENTRAL VIRGINIA $x$ MID-MAY, 1862 
at favorable odds against an enemy caught on the march. Success would not only have prevented either shields or Banks from reinforcing McDowell, but would have placed the Army of the Valley roughly at Thoroughfare Gap, threatening at once Banks' rear, McDowell's rear, and Washington.63 It was a position that would have allowed as aggressive a commander as Jackson to create fully as much panic north of the Potomac as his actual dash toward Harper's Ferry. Even had Johnston chosen, upon a defeat of Shields, to pursue the most conservative of choices--to return Jackson to the Valley, where he would now meet Banks with relatively even numbers, while Ewell cooperated with Anderson against McDowel1--the victory would have borne substantial strategic fruit. McDowell, with 30,000 men and orders that included the protection of the capital, would have faced an uncomfortable situation at best. To his front would have been Anderson's 12,000 men, with 4,000 more under Branch in easy supporting distance at Hanover Court House. In his rear, between his main body and the capital, would have been Ewell with 6,000-8,000 troops. At the very least, Johnston's proposed maneuver would have prevented him from marching south and blithely brushing past Anderson with better than

\footnotetext{
63 Vincent J. Esposito, ed., The West Point Atlas of American Wars (New York: Praeger, 1959), I: map 51.
} 
two-to-one odds. 64

But Johnston, as well as Lee and Jackson, could read a map, and had plenty of reasons to realize that communication lags could make what appeared to be a good plan in Richmond one that was seriously out-of-date in staunton. He had, after all, been the one who originally ordered Jackson and Ewell to work together and decide tactical questions on their own. So the very next day, May 18, before he could possibly have received the famous protest from Jackson which begged to be allowed to attack Banks, Johnston dispatched two more letters to the Valley District. In the first, Johnston reiterated that the mission of Jackson's army was to keep Banks' forces from uniting with McDowell. If he was too late to successfully attack Banks, then he must pursue the course that led east of the Valley. But Johnston emphasized that he had full confidence in Jackson and Ewell themselves to choose whichever option held greater promise; he would not attempt to dictate a rigid course of action from the suburbs of Richmond. In the second letter, the army commander was even more explicit: "The whole question is, whether or not General Jackson and yourself are too late to attack Banks. If so the march eastward should be made.

${ }^{64}$ For evidence that such a plan can be inferred from existing documents, see Joseph R. Anderson to Richard S. Ewel1, May 17, 1862, in which Anderson, who was now in contact with Johnston, suggests something very similar, in OR, XII (part 3): p. 896 . 
If not (supposing your strength sufficient) then attack."65 Did Johnston, like Lee, anticipate Jackson following up the attack with an exploitation toward the Potomac? on May 18 it is difficult to say, for though he had already advocated threatening that line in April (albeit in quite different terms), Johnston did not actually authorize Jackson to strike north rather than east. 66 But at least by May 27 there was no question in Johnston's mind that Jackson should continue to pursue the most aggressive course possible: "If you can threaten Baltimore and Washington, do so. It may produce an important diversion. . . Your movements depend, of course, upon the strength remaining in your neighborhood. Upon that depends the practicability of your advancing to the Potomac and crossing it. I know of no hostile Force to prevent either."67 If Johnston and Lee sometimes differed on the exact operations to be pursued in the Valley and central Virginia, they never disagreed on the methods--striking exposed Federal forces as opportunity

${ }^{65}$ Quoted in Freeman, Lee's Lieutenants, I: p. $371 \mathrm{n}$.

${ }^{66}$ The suggestion for crossing the Potomac came in Joseph E. Johnston to Robert E. Lee, April 30, 1862, in OR, XI (part 3): p. 477. There Johnston suggested that the Confederates should "take the offensive, collect all the troops we have in the East and cross the Potomac with them. - ." Admittedly, the letter was in a much different context than the Valley campaign, but it does suggest that Johnston had begun to think about the advantages of distracting the enemy with a march north.

67 Joseph E. Johnston to Thomas J. Jackson, May 27, 1862, in Douglas, Stonewall, p. 72 . 
a].lowed--or the objective. In point of fact, when Johnston wrote "we want troops here; none, therefore, must keep away, unless employing a greatly superior force of the enemy," he captured in a single sentence the essence of both men's strategy in May, 1862 .

Federal operations over the next several days sustained the strategic insights of Johnston and Lee. McClellan said later that after Drewry's Bluff "the question now arose as to the line of operations to be followed: that of the James on one hand, and, on the other, the 1 ine from white House as a base, crossing the upper Chickahominy." He personally preferred the James, because he thought it would give him an invulnerable supply line and because advancing on Richmond would be easier from the south. But the condition under which the Federal government was willing to reinforce him with McDowell's corps was that McDowell would join the Army of the Potomac by marching rather than by boat. Thus, reasoned President Lincoln and Secretary of War Stanton, McDowell could still continue to safeguard Washington, by pushing Anderson before him. McClellan was ordered to supply McDowell's corps from White House and to keep one wing extended north of the Chickahominy to meet him.68 Unwisely, the Federal commander attempted simultaneously to prepare to change his base to the James and spread his right

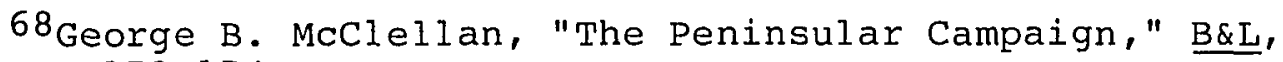
II: $\mathrm{pp} \cdot 173-174$. 
flank north to receive McDowell. He ordered the first troops across Bottom's Bridge on May 20, and within five days had divided his army into two unequal parts, precisely as the Confederates had wished but hardly dared to hope. The III and IV Corps were south of the Chickahominy, while the II, V, and, VI Corps remained on the north bank. 69

But McClellan still had not crossed the Chickahominy on May 18 or 19 when Jefferson Davis rode again to Johnston's headquarters, this time without General Lee. He was, as usual, interested in knowing exactly what course Johnston intended to pursue, and just how close he intended to bring his troops to Richmond.70 Johnston explained that he had pulled his lines in very close to the city in order to assure a good water supply, ease of provision, and to put his troops into place to work on improving the battery at

69 "McClellan's Report (1)," in OR, XI (part 1): pp. 25-26; Swinton, Campaigns, p. 129.

70 Davis's later contention, that he was surprised to find the army on the south bank of the Chickahominy and that the topic of why Johnston had crossed the river dominated the conversation, was even dismissed by Freeman, who charitably credited the President with confusing his dates. The only support for that account came from the gossipy and undependable memoirs of Postmaster-General John Reagan, who claimed to have accompanied the president that day, and to have seen a "look of surprise" sweep over his face, revealing "a trace of pain." The actual topics of discussion can be inferred from Reagan, however, when read in conjunction with later accounts by Johnston and Robert E. Lee to Joseph E. Johnston, May 18, 1862, in OR, XI (part 3): p. 526. See Davis, Rise and Fal1, II: pp. 103-104; Freeman, Lee's Lieutenants, I: p. 210n; John H. Reagan, Memoirs, with Special Reference to Secession and the Civil War (New York: n. p., 1906), pp. 138-139; Johnston, "Manassas to Seven Pines," p. 208 . 
Drewry's Bluff and the Richmond defenses.71 He could not, however, have satisfied the President's curiosity about forthcoming operations, since McClellan had not yet revealed whether he would cross the Chickahominy.

But by May 21 there was no question that the Federal commander intended to accept the bait. Word of the Yankees south of the river reached Richmond, and almost immediately Davis had Lee write Johnston for details: "The President desires to know the number of troops around Richmond, how they are posted, and the organization of tine divisions and brigades; also the programme of operations which you propose." Acknowledging that "your plan of operations, dependent upon circumstances perhaps yet to be developed, may not be so easily explained, nor may it be prudent to commit it to paper," Lee suggested that Johnston visit Richmond and communicate it in person.72 Johnston immediately replied 'with a memorandum showing the approximate strength of each of his brigades, and the next day posted one letter and had another hand-carried to Lee by Major Whiting. Unfortunately, neither of these communications seems to have survived. It is not possible to tell by Lee's responses whether or not Johnston addressed any questions of

\footnotetext{
71 Johnston, "Manassas to Seven Pines," B\&L, II: p. 208; Reagan, Memoirs, p. 139; Longstreet, Manassas to Appomattox, p. 82; Lee, Pendleton, p. 184.

72 Robert $E$. Lee to Joseph E. Johnston, May 21, 1862, in OR, XI (part 3): p. 530 .
} 
strategy. 73

His concern for the safety of the capital, however, did not allow Davis time to sit and wait for a reply. On the morning of May 22, before Johnston's answers--if indeed his letters answered Lee's inquiries--could have reached him, Davis again rode out to the army at Mechanicsville, this time with Lee alongside. He found neither Johnston nor a situation calculated to instill in him confidence in his army commander: "I saw General stuart and General Cobb," he wrote Johnston on his return,

but as neither of them communicated to me any plan of operations, or appeared to know what troops were in front as we approached, I suppose neither of them could have been commanding in chief at that locality. My conclusion was, that if, as reported to be probable, General Franklin, with a division, was in that vicinity, he might easily have advanced over the turnpike toward if not to Richmond.

He was upset enough with this appearance to order Lee back to the army on May 23, for a more thorough discussion of Johnston's plans. 74

By chance, Davis had ridden into the consequences of a

73 Johnston himself admitted that the return was approximate--to the low side--and a superficial examination reveals that the numbers must have been taken directly from his return of effectives on April 30, before the Battle of Williamsburg; see "Strength of the several brigades of the Army of Northern Virginia near Richmond, as shown by General Johnston's memorandum of May 21, 1862." That Johnston wrote twice to Lee on May 22 can be determined from Robert E. Lee to Joseph E. Johnston, May 22, 1862 (two letters), in OR, XI $($ part 3): pp. 530-534.

74 Jefferson Davis to Joseph E. Johnston, May 23, 1862, in $\underline{O R}, \mathrm{XI}$ (part 3): p. 536 . 
dispute between Major-Generals Smith and Magruder. Magruder, who had rejoined the army after a brief illness, was irritated by the arrangement that subordinated his troops-temporarily, he contended--to Smith. As a result, every time Smith ordered regiments here or there, Magruder cooperated grudgingly, if at all. On May 22 and 23, their relationship had deteriorated to the point that, when Smith ordered two regiments from McLaws' Brigade to hold Mechanicsville, Magruder refused and insisted on using two regiments from Brigadier-General D. R. Jones' Brigade. Magruder's motivation seems to have come from a desire to be contentious, rather than from any sound military reason. The two Major-Generals also issued a series of conflicting orders to the cavalry commanders in the area--not just Stuart, but also Colonels Fitzhugh Lee and Beverly $\mathrm{H}$. Robertson. The result was confusion around Mechanicsville at the most inopportune of moments. Not only were the Yankees threatening to advance with at least a division, but Davis was present to witness a part of the army at loose ends.75 Johnston settled the internal dispute within a few days, but Davis's visit had definitely hurt his credibility

75 "Report of Col. Beverly H. Robertson, Fourth Virginia Cavalry," May 24, 1862, in OR, XI (part 1): pp. 663-664; John B. Magruder to Thomas Rhett, May 23, 1862, John B. Magruder to Samuel W. Melton, May 23, 1862 (two letters), in OR, XI (part 3): pp. 537-539. 
with the Chief Executive. 76

Possibly sensitive to the President's criticism, Johnston was a good deal more communicative than usual when Lee arrived at his headquarters on May 23. He definitely intended to strike one of the wings of the Army of the Potomac, but had not yet decided which. Johnston himself seems to have consistently favored attacking south of the river, in the vicinity of Seven Pines. 77 But three considerations made him lean on May 23 toward hitting the Federals on the north bank, in the vicinity of Beaver Dam Creek and Mechanicsville. First and foremost was the necessity for keeping McClelian and McDowell separated; an attack at Seven Pines might only have the effect of driving them together. Also in favor of a northern attack was the fact that the ground had already been thoroughly reconnoitered by Majors Stevens and Whiting a week earlier. 78 Finally, Longstreet, in whose tactical judgment Johnston was inclined to have greater and greater confidence, had conducted a "careful study of the works and armaments at Drury's [sic] Bluff,"

76 Johnston resolved the situation by an almost cosmetic expedient, "elevating" Magruder on May 28 to command of the "Centre" wing of the army, which nominally made him the equal of Smith and Longstreet. But in fact Magruder still only commanded six brigades, divided formally into two "divisions," while each of the other wing commanders controlled eleven or twelve brigades. See Smith, The Battle of Seven Pines, p. 8 .

77 Johnston, Narrative, p. 130; Smith, The Battle of Seven Pines, p. 12 .

78 Smith, Confederate war Papers, pp. 48-49. 
and "ventured the suggestion that we recross the Chickahominy at Mechanicsville and stand behind Beaver Dam Creek. - ."79 Johnston planned to wait a few more days, to find out just how much distance McClellan would voluntarily put between the sundered halves of his army, but he knew that he could not afford to delay too long. He told Lee that he intended to strike somewhere--probably but not definitely north of the river--by May 29.80

Lee evidently made two responses to Johnston's plan. First, he reiterated his suggestion that Johnston visit Richmond and communicate his strategy to the President directly. This Johnston did on May 24.81 In addition, Lee gave Johnston the welcome news that he would try, between then and the time of Johnston's attack, to reinforce the army with whatever troops could be scraped up in the Richmond area. Specifically, there were at least seven batteries of field artillery around the capital, which could

79 Longstreet, Manassas to Appomattox, p. 82.

80 That Johnston planned to attack by May 29 and that he favored an assault north of the river can be determined from Davis's memoirs, although, as G. W. Smith later pointed out, Davis apparently confused the elements of several different plans. Far more likely is that Johnston was still waiting for the Federals to make themselves more vulnerable in one locale or the other. See Davis, Rise and Fall, II: pp. 120-121; Smith, The Battle of Seven Pines, pp. 10-11.

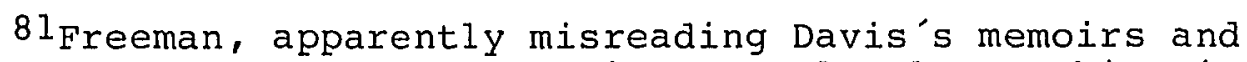
letter to Johnston on May 23, incorrectly places this visit by Lee on May 26. See Joseph E. Johnston to James Longstreet, May 24, 1862, in OR, XI (part 3): pp. 541-542; see also Freeman, Lee's Lieutenants, I: p. 213. 
be used to augment Pendleton's Artillery Reserve.82 The 4 th Virginia Heavy Artillery Regiment and Lieutenant-Colonel Nicholas C. Harris's heavy artillery battalion where both assigned as infantry to Johnston's army.83 Likewise, Johnston was to receive Brigadier-General Henry A. Wise's brigade, still in the process of rebuilding from its defeat at Roanoke Island. Aside from a complete regiment of cavalry, Wise's brigade had roughly the strength of two infantry regiments. 84 But most significantly, Lee promised Johnston that he would try to stretch troops from Holmes's Department of North Carolina to cover Petersburg, releasing the bulk of Huger's Division for the offensive.85

The strategic situation began to change more and more rapidly after McClellan crossed the Chickahominy. On May 23, Jackson had initiated his attack on Banks by gobbling up a detached regiment at Front Royal, and swung around the Federal commander's left flank. By May 25, Banks was in full flight and Jackson's brigades entered Winchester; within four days they had reached Harper's Ferry and the

82 There may have been as many as nine--the statements of A. L. Long and Pendleton disagree. See A. L. Long to John H. Winder, May 23, 1862, in OR, XI, (part 3): p. 539; Lee, Pendleton, p. 185 .

83 Special Orders No. 118, Adjutant and InspectorGeneral's Office, May 23, 1862, in OR, XI (part 3): p. 540.

84 Henry A. Wise to D. H. Hill, May 24,1862 , in $\underline{\mathrm{OR}}, \mathrm{XI}$ (part 3): p. 542 .

85 Robert $E$. Lee to Joseph E. Johnston, May 27, 1862, in OR, XI (part 3): p. 552 . 
banks of the Potomac. 86 It was not, however, the defeat of Banks that most affected events around Richmond. Jackson's raid had a much more profound consequence: at 5:00 P. M. on May 24, in a vain attempt to cut off the Confederate divisions in the lower Valley, President Lincoln ordered McDowell's corps to change front. Instead of marching south to 1 ink up with the Army of the Potomac, Lincoln instructed McDowell to head west in pursuit of Jackson. "At that moment," observed Robert G. Tanner, "the Valley Army won its Valley Campaign." 87

This shift was not immediately evident in Richmond, because all eyes were rooted firmly on McClellan. The same day that Lincoln authorized the diversion of McDowell, Brigadier-General Erasmus Keyes advanced units of his IV Corps into the village of Seven Pines, and McClellan's cavalry finally pushed into Mechanicsville. 88 other Federal horsemen probed the swampland between Bottom's Bridge and the James on May 25 and 26, and Branch's position at Hanover Court House on May 26.89

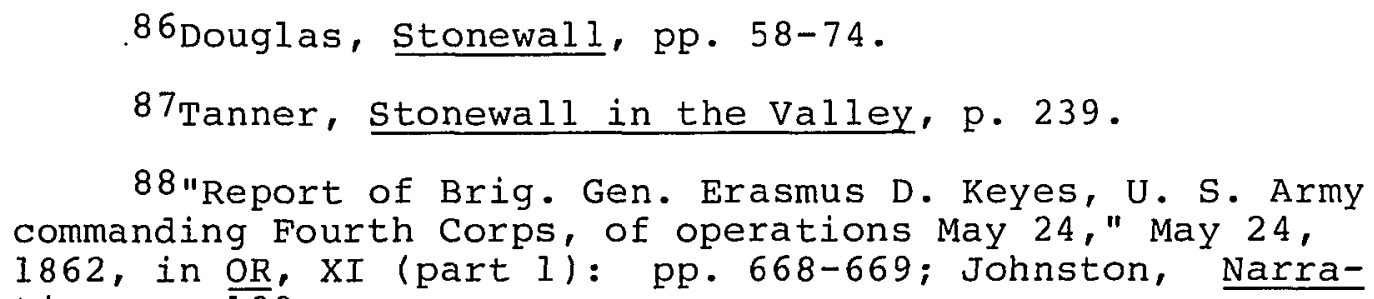
commanding Fourth Corps, of operations May 24," May 24, 1862, in OR, XI (part 1): pp. 668-669; Johnston, Narrative, p. 130 .

89 "Report of Lieut. Frank C. Davis, Third Pennsylvania Cavalry," May 26, 1862, "Report of Lieut. Col. William N. Grier, First U. S. Cavalry," May 26, 1862, in OR, XI (part $1)$ : pp. 675-677. 
Johnston had begun pulling Anderson and Branch closer to the Chickahominy as early as May 23. Anderson sent the 45 th Georgia to Ashland Station on May 23, and issued four days" rations to the rest of his troops.90 Johnston instructed Branch the same day to reconnoiter positions nearer to the chickahominy (and the main body of the army), and advised him that "in a few days General J. R. Anderson will probably be near you."91 The following morning, Anderson issued marching orders to his regiments, culminating in the exhortation: "This Army after having waited long for an opportunity to meet the enemy who has sheltered himself behind the town of Fredericksburg and the river, now moves in pursuance of orders from higher authority to unite in the great battle on the issue of which depends the fate of the capital of our Country."92 Johnston told Branch to expect Anderson by May 27.93

Anderson was late, almost disastrously so for Branch. Brigadier-General Fitz John Porter's V Corps, supported by Brigadier-General William H. Emory's Cavalry Reserve--better

90 Special Orders No. 26, Army of the Rappahannock, May 23, 1862, Joseph R. Anderson Order Book, Virginia Historical Society.

91 Joseph E. Johnston to L. O'Brien Branch, May 23, 1862 , in OR, XI (part 3): p. 537 .

92 General Orders No. 13, Army of the Rappahannock, May 24,1862 , J. R. Anderson Order Book, Virginia Historical Society.

93Joseph E. Johnston to L. O'Brien Branch, May 25, 1862, in OR, XI (part 3): p. 543 . 
than 16,000 troops--hit Branch's six regiments at noon on May 27.94 Branch held his position near slash Church for several hours, until he determined that he was heavily outnumbered and that he had recovered all of his detached units. Then, after suffering several hundred casualties, he withdrew in good order toward Johnston's lines.95 That same day his bloodied brigade, along with Anderson' command, was consolidated into a new division under just-promoted MajorGeneral A. P. Hill.96

Still without reliable intelligence concerning McDowell's movements, Johnston reached an erroneous but understandable conclusion when Porter brushed Branch out of Hanover Court House. MCClellan was extending his flank because he expected McDowell to march south within hours. This assumption was buttressed in Johnston's mind by an equally incorrect report on May 27 from Anderson that represented the Federals in Fredericksburg as having commenced their march to Richmond. "We must get ready to

94 "Abstract from return of the Army of the Potomac, Maj. Gen. George B. McClellan, U. S. Army, commanding, for May 20, 1862," in OR, XI (part 3): p. 184.

95 Branch reported 243 casualties, excluding those in the 28th North Carolina and the 4th Virginia Cavalry. Porter claimed to have found 200 dead and taken more than 700 prisoners. For a discussion of this discrepancy, see Freeman, Lee's Lieutenants, I: p. 220n.

$96_{\text {Robert }}$ E. Lee to Samuel Cooper, May 25 , 1862 , in LRAIGO, M-474, Reel 25; Robert E. Lee to James Longstreet, May 28, 1862, in Lee Letterbook; Jefferson Davis to Joseph E. Johnston, May 26, 1862, A. P. Hill to L. O'Brien Branch, May 27, 1862, in OR, XI (part 3): pp. 546-547, 554. 
fight," Johnston told G. W. Smith, and summoned his senior generals to conference. 97

The moment of combat seemed to have been forced upon the Confederate army, but McClellan's dispositions invited attack. Three of his corps had been arrayed in a ten-mile line running southeast along the northern bank of the Chickahominy from Beaver Dam Creek to the Lower Bridge. Though Beaver Dam Creek was a formidable obstacle, if it could be breached quickly the opportunity existed to roll up the Federal corps in succession. The two corps south of the river were separated from each other by nearly five miles, and would have to march several miles to reinforce the troops to the north.

Johnston proposed that his army would slide suddenly to the left and that G. W. Smith would lead eleven brigades-his own division under whiting, D. R. Jones's Division, and A. P. Hill's Division--across the Chickahominy above Mechanicsville, assault Beaver Dam Creek, and drive down the river. The remainder of Magruder's "wing" would hold the Chickahominy. D. H. Hill would be posted in front of Keyes's IV Corps on the Williamsburg Road, to pin him in position, while Longstreet would move northeast of Richmond to Nine Mile Road, available as a reserve on either flank of

97 Smith, The Battle of Seven Pines, pp. 12-13. 
the army. 98

Despite being forced into an offensive, Johnston's spirits were high. D. H. Hill told one of his brigadiers that "I saw Genls. Johnston \& Smith this afternoon. They think that tomorrow will be a great day in our history."99 It was the same day that Johnston learned that Jackson had routed Banks at Winchester, and optimistically suggested that the Army of the valley might attempt to cross the Potomac. 100 He advised Lee that a battle probably would be fought on May 29, that he had ordered Huger to Drewry's Bluff to replace Longstreet, and requested that Holmes's Division be brought to Richmond.101

The same day, President Davis and one of his aides, Colonel William Browne (formerly the acting Secretary of State), visited Johnston at his headquarters. Johnston was out riding his lines when the President called, and a courier was dispatched to find him. The General sent back a

98 Johnston mistakenly recalled that Huger's Division and not that of $D$. R. Jones would be brought to reinforce Smith's attack. Otherwise, the accounts of Johnston, Smith, and Longstreet are remarkably consistent to this point. See Johnston, Narrative, p. 131 ; Smith, The Battle of Seven Pines, p. 15, Longstreet, Manassas to Appomattox, p. 85.

${ }^{99}$ D. H. Hill to Winfield scott Featherston, May 27, 1862, D. H. Hill letter, Virginia Historical Society, Richmond, Virginia.

100 Joseph E. Johnston to Thomas J. Jackson, May 27, 1862 , in Douglas, Stonewall, p. 72 .

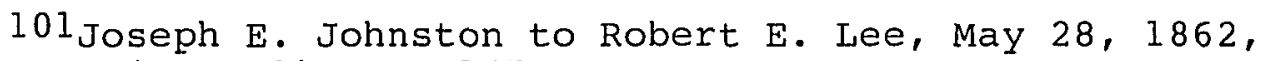
in $\underline{O R}, \mathrm{XI}$ (part 3): p. 555. 
polite note requesting that Davis return later in the afternoon, when he would have the time to acquaint the chief Executive with his plans. Davis was then informed that an attack would take place on May 29.102

But when the President rode out of the capital on May 29 expecting to witness a battle, he found consternation and confusion that recalled his May 22 visit to the front. As had been the case a week earlier, Brigadier-General Howell Cobb had little idea what were the army commander's plans-nor did Brigadier-General Hood. He could find neither Johnston, nor G. W. Smith who was supposed to be conducting the attack. Only Longstreet was where Davis thought he would be, and the massive Georgian was "walking to and fro in an impatient, it might be said fretful, manner."103

Longstreet was incensed because, when it came to the point of contact, Smith had balked at attacking. Sinith claimed that "I reported to General Johnston that I was satisfied the three divisions could carry the works at Beaver Dam Creek by open assault in front; but that it would be a bloody business. . . ." He did not think that

102 No record of the conference has survived, though the fact that it happened is established by Joseph E. Johnston to William Browne, May 27, 1862, in Jefferson Davis papers, Chicago Historical Society, Chicago, Illinois. It may be inferred that Davis was informed of the proposed date of the attack from the fact that he rode out again on May 29, for which his erroneous chronology of the last half of May in his memoirs fails to account satisfactorily. See Davis, Rise and Fall, II: p. 121 .

103 Davis, Rise and Fall, II: p. 121. 
ordering a wide flanking march by A. P. Hill's Division was practical, suggesting as an alternative the rather fantastic idea that Jackson's divisions--then somewhere north of Winchester--be marched back to eastern Virginia for such a purpose. 104 Rumors circulated that Smith had once again fallen ill with his mysterious neurological malady. The President returned to Richmond, his confidence in Johnston eroded once again. 105

That evening the General called together his subordinates once more: Smith, Longstreet, Magruder, and stuart. He announced that stuart's outposts to the north now reported that McDowell had turned back, which meant that there was no longer a pressing necessity for the attack. This satisfied Smith, who continued to express a negative opinion of the original plan. Longstreet, supported by Magruder and stuart, demurred, believing that the concept of rolling up McClellan's right wing "was made stronger by the change of direction of McDowell's column, and should," in Longstreet's words, "suggest more prompt and vigorous action." 106

According to Longstreet's recollection, the council of

104 Smith, The Battle of Seven Pines, p. 14.

105Davis, Rise and Fall, II: p. 121.

106 Curiously, the postwar accounts of both Smith and Longstreet agree fairly closely regarding the conference to this point. See Longstreet, Manassas to Appomattox, pp. 8586; Smith, The Battle of Seven Pines, p. 15. 
war continued for several hours, until, at last, Johnston grew disgusted and walked away. His fighting blood aroused by the prospect of action, Longstreet followed and suggested again the turning movement that Smith felt so impractical. With McClellan's inherent caution, there was little chance that the Federal commander would strike any detached Confederate divisions before they landed on his own flank. "General Johnston replied that he was aware of all that, but found that he had selected the wrong officer for the work," Longstreet asserted in his memoirs, adding that "this ended the talk. . ." 107

Longstreet's account is somewhat suspect, as his memoirs were originally started as a refutation to charges made by Smith after the war. 108 But Johnston's opinion of Smith might well have already begun to decline by the evening of May 29, 1862. Several times Smith's health had forced him to alter plans. The Kentuckian quarreled with other generals, and twice within the past week Smith had caused Johnston to look less than capable in the President's eyes. And what had Smith done so far to justify Johnston's earlier high regard? The only action to his credit was the skirmish at Eltham's Landing, an engagement that, Johnston would have recalled, was directed entirely by Smith's

\section{${ }^{107}$ Longstreet, Manassas to Appomattox, p. 86. \\ 108 James Longstreet to Osmun Latrobe, February 10 ,} 1886, in Osmun Latrobe papers, Virginia Historical Society, Richmond, Virginia. 
subordinates.

Longstreet, by contrast, had a fighting record that began at Manassas and had been extended by victory--at least in his own and Johnston's eyes--at Williamsburg. Now it was Longstreet who argued for the aggressive course. More and more during May, 1862, Johnston came to depend on Longstreet rather than Smith. He had always preferred striking Mcclellan's two isolated corps south of the river; suddenly in Johnston's mind, such an operation would have an extra benefit. Longstreet, not Smith, would be conducting the attack. 109

109 Johnston, Narrative, p. 130. 
Chapter Eleven

Seven Pines

Rain threatened Richmond again on May 30 , 1862, but the ominous grey thunderheads seemed only slightly closer than the Yankee army. After the repulse of the ironclads at Drewry's Bluff, there had been a momentary rise in the city's morale. The Richmond Examiner opined that "when the history of this war is reviewed, it will be found that the chief service the enemy has gotten from his gunboats had been to frighten bad officers and worse troops into surrendering positions which they might have continued to hold."l Then had come the news of Jackson's success at Winchester, and the hope that his dash toward the Potomac might force the recall of the Army of the Potomac to defend Washington. But by that overcast Friday the citizens of Richmond knew that no such reprieve was in their future. Mcclellan inched ever closer; and, if he were to be driven away, it would be by Johnston's outnumbered army, fighting from the outskirts of Richmond.

Hundreds, if not thousands, fled the city. The cabinet debated where to locate the next line of defense if Johnston

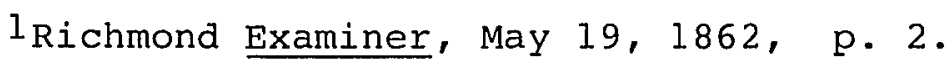


had to relinquish the city. 2 Secretary Randolph ordered the City Council to conduct experiments to find the quickest and safest method of destroying tons of tobacco stored in Richmond warehouses, in order to prevent its falling into enemy hands. ${ }^{3}$ The specters of Nashville, New Orleans, Memphis, and Norfolk hung over the city.

Yet there was a distinct difference between the feeling that gripped Richmond and the terror which had clutched at the hearts of the inhabitants of other southern cities. "After the Confederate command's decision to evacuate their city without a fight, the people of Nashville had been panic-stricken," wrote historian Walter T. Durham. "Citizens shared mixed emotions about the defense of the city. Certainly most wanted to be shielded from the Union Army; however, few wanted to be protected at the expense of the destruction of Nashville. The prevailing desire was to stop

2 The only record extant of the cabinet meeting in which this topic was discussed is that of John H. Reagan, who painted the picture of an emotional Robert E. Lee declaring that "Richmond must not be given up. . . ." Even ignoring the fact that Lee knew that Johnston had no intention of giving up the capital and that such an outburst would have been totally out of character for Lee, it should be sufficient to note that the anecdote is sandwiched between two others of doubtful credibility. Without any supporting evidence, Reagan's description of the scene is best relegated to the status of colorful apocrypha. Reagan, Memoirs, p. 139.

3 Manarin, Richmond at War, pp. 176-177. 
the Yankees--but not in the streets of the city."4 In New Orleans, when Flag-Officer David G. Farragut's fleet had run the batteries and Major-General Mansfield Lovell's troops had withdrawn from the city, the mayor announced to the city Council that "it would be proper to say that the withdrawal. of troops rendering resistance impossible, no obstruction could be offered to the occupation of the place by the enemy. . . "5 The citizens of Memphis watched from the banks of the Mississippi as their River Defense Fleet was destroyed, and then surrendered their city without further resistance. 6 Norfolk had also surrendered without a fight, once the army and navy left town.

In Richmond the prevailing attitude was equally pessimistic, but the gloom was underlain with a grim determination, in President Davis's words, "that the ancient and honored capital of Virginia, now the seat of the Confederate Government, shall not fall into the hands of the enemy. Many say rather let it be a heap of rubbish."7 Already Governor John Letcher and Mayor Joseph Mayo had declared

${ }^{4}$ walter T. Durham, Nashville, The Occupied City, The First Eighteen Months, February 16, 1862, to June 30, 1863 (Nashville: Tennessee Historical Society, 1985), pp. 1, 14.

5 Marion A. Baker, "Farragut's Demands for the surrender of New Orleans," B\&L, II: p. 95.

${ }^{6}$ Samuel Carter III, The Final Fortress: The Campaign for Vicksburg, 1862-1863 (New York: St. Martin's Press, 1980), pp. 51-52.

7 Jefferson Davis to Joseph E. Johnston, May 17, 1862, in OR, XI (part 3): p. 524 . 
their determination to defend the city regardless of what the Confederacy did. Letcher visited Johnston's army on May 30, to spread his resolve to the Virginia regiments within its divisions. 8 The Mayor repeatedly stirred crowds by declaring that "rather than . . surrender the city founded by his own ancestors, he would resign the office of the mayoralty, and though bending under the approach of three score years and ten, he would shoulder the musket himself in defense of the capital." "Some of the most wealthy of our population," recalled Sally Putnam, "declared they would fire their own beautiful residences, in preference to delivering up the city to our foes. . . " "9

The ultimate fate of Richmond, however, still lay with Joseph Johnston's army. When that army had halted between the Pamunkey and Chickahominy Rivers, it was plain that the retreat had taken its toll. "The army is very much demoralized," D. H. Hill told his wife. "Some five thousand threw away their guns and fled to Richmond to avoid a battle." 10 There were other reasons for leaving the ranks besides cowardice. No rations had been issued since Williamsburg, reducing the Richmond Howitzers to stealing feed corn from their own starving horses. Even General officers roamed the

\footnotetext{
8Boney, John Letcher, p. 163.

${ }^{9}$ putnam, Richmond, p. 131 .

10D. H. Hill to "My Dear Wife," May 11, 1862, in D. H. Hill papers, College of William and Mary.
} 
countryside foraging: Brigadier-General Richard Griffith rode into the artillerymen's camp one night to beg an ear of corn for himself and several for his horse.ll Well-drilled soldiers might have been held in the ranks by veteran officers, but Hill pointed out that "the reorganization of the army at Yorktown, under the elective system, had thrown out of service many of our best officers. . . "12 Once again, Joseph Johnston found himself faced with an army on the verge of melting away.

Once again Johnston took immediate steps to improve the morale and efficiency of that army. With Lee, he coordinated the delivery of rations and the return of the army's wagon trains.13 Armed with reports from his regimental and brigade commanders, Johnston finally managed to convince the Richmond authorities to allow his own provost marshals into the city to recover his absentees. 14 The army commander also began a

Ilstiles, Four Years, pp. 85-86.

12 "Report of Maj. Gen. D. H. Hill, C. S. Army, commanding division, of operations April 6 to May 9," January 11 , 1863 , in $\mathrm{OR}, \mathrm{XI}$ (part 1): p. 605 .

13 Robert $\mathrm{E}$. Lee to Joseph $\mathrm{E}$. Johnston, May 7, 1862, Robert E. Lee to Abraham C. Myers, May 7, 1862, Robert E. Lee to Lucius B. Northrop, May 7, 1862, Robert E. Lee to Abraham C. Myers, May 8, 1862 , Robert E. Lee to Lucius B. Northrop, May 8, 1862, in Lee Letterbook; Robert E. Lee to Joseph E. Johnston, May 13, 1862, A. H. Cole to Joseph E. Johnston, May 13, 1862, in OR, XI (part 3): pp. 512-513.

14 Walter Taylor to John H. Winder, May 14, 1862, in Lee Letterbook; George T. Anderson to George W. Randolph, May $\overline{16}$, 1862, in LR-AIGO, M-474, Reel 3; John B. Gordon to George W. Randolph, May 13, 1862, in LR-AIGO, M-474, Reel 21; A. P. Hill to Samuel Cooper, May $\overline{13,1862}$, A. P. Hill to Samuel 
thorough reorganization of both the artillery and cavalry serving under him, a reorganization that was to greatly strengthen those branches throughout the summer and fall.15

Between May 13 and May 30, Johnston's efforts, combined with those of Lee to reinforce him, caused the army to bounce back in terms of fighting spirit, organization, and numbers. Longstreet, who had never ceased his own efforts to buttress morale, wrote that when his men "have their bellies full, also their cartridge boxes," then "I don't fear McClellan or anyone in Yankeedom." By the end of May he felt that his troops "were never so resolved" to fight as they were then; they "even asserted that they would dig bayous, to reach the enerny's trenches, if not allowed some other means of getting to him."16 The Artillery Reserve had

Cooper, May 22, 1862, in LR-AIGO, M-474, Reel 24.

15 Johnston inaugurated the practice of consolidating understrength batteries, and, from contextual evidence, seems to have envisioned separate artillery battalions supporting each division. His calls for the independent companies of cavalry around the state to be gathered together into regiments led the Confederate authorities, during May, June, and July, 1862, to issue orders creating the 5th, 10th, 12 th, and 13 th Virginia Cavalry Regiments, and the 14th, 15th, and 17th Virginia Cavalry Battalions. See Lee, Pendleton, p. 185; Wise, Long Arm, pp. 186-187; D. H. Hill to John Trapier, May 28, 1862, in LR-AIGO, M-474, Reel 25; Joseph E. Johnston to Robert $\mathrm{E}$. Lee, May 14, 1862, Robert $\mathrm{E}$. Lee to Benjamin Huger, May 16, 1862, Special orders No. 120, Department of Northern Virginia, May 28, 1862, in $\underline{O R}, \mathrm{XI}$ (part 3): $\mathrm{pp}$. $515,519,558$.

16 James Longstreet to Gustavus W. Smith, May 8, 1862, in Smith, Confederate War Papers, p. 145; James Longstreet to Jefferson Davis, September 2, 1887 , in Rowland, Jefferson Davis Constitutionalist, IX: pp. 594-595. 
been increased from fifty-six to nearly ninety guns; the Cavalry Brigade enlarged by the addition of several regiments.17 With the addition of Huger's and A. P. Hill's Divisions, by May 31 Johnston's army attained the greatest strength it had yet known: nearly 88,000 officers and men present for duty. Counting the brigades of Brigadier-General Roswell S. Ripley and John G. Walker, both of which were approaching Richmond on May 31, and adding in the garrison troops in the city itself, the Confederacy had managed, both through the administrative efficiency of General Johnston and a herculean effort to secure reinforcements by General Lee, to gather more than 97,000 men for the defense of the capital.18 on the same day, Mcclellan reported the Army of

17Lee, Pendleton, p. 185; A. L. Long to John H. Winder, May 23, 1862, Special orders No. 120, Department of Northern Virginia, May 28, 1862, in OR, XI (part 3): pp. 539, 558; special orders No. 121, Adjutant and Inspector-General's Office, May 27, 1862, Special Orders No. 122, Adjutant and Inspector-General's office, May 28, 1862, in OR, II (part 2): p. 564 .

18 This calculation begins with Johnston's May 21 memorandum. Deficient as that paper is, it is the only starting point available for deducing the army's strength prior to Seven Pines. As previously mentioned, many of the figures had been drawn directly from the April 30 return of the army, before the retreat and before williamsburg. So it is certain that the army had lost several thousand men from those figures between April 30 and May 21. But it is also certain that many of the stragglers returned to the ranks, and many more were dragooned in Richmond by Johnston"s or Winder's provosts, so the figures for the four divisions, Pendleton"s Artillery Reserve, and the Cavalry Brigade still offer good approximations of the "effective" strength of the army on May 21 . This figure is 53,688 .

But significant reinforcements joined the army during the next ten days. Nine artillery batteries left Richmond to join the army, which, calculated at the average "effec- 
tive" strength of artillery companies at that time, would have fielded 560 men. The 4th Virginia Heavy Artillery and four more companies of heavy artillery were also assigned to the army as infantry. The $4 \mathrm{th}$, with ten coinpanies, had a strength of 466 men in late June, after the Battle of Seven Pines; it is not disproportionate to credit the other four companies with at least 200 men. Seventeen infantry companies of the wise Legion also joined the arrny. Fifteen of them reported their strength in late June; adding in the other two at the same average strength gives an "effective" number of 942 infantry. The 3rd Virginia Cavalry, which numbered at least 300 men, the Wise Legion Cavalry (later the loth Virginia), mustering at least 400 , and several other miscellaneous companies of cavalry around Richmond-probably at least 240 men--are not accounted for in Johnston's memorandum, which would increase the size of his cavalry force by 940 "effectives."

Huger's Division at Seven Pines has been estimated everywhere from 5,008 "effectives" by G. W. Smith ana Jefferson Davis, to 7,000 by Johnston himself. A more likely strength seems to be 6,257 , calculated by Thomas Livermore in his Numbers and Losses. But this excludes four regiments, the 6th, 16th, 56th, and 57th Virginia, left at Drewry's and Chaffin"s Bluffs. Allowing these regiments 300 "effectives" each, that would add 1,200 more troops to Huger's roster.

A. P. Hill's Division has long been underestimated by almost ali authorities, since $G$. W. Smith placed its numbers at a ludicrously low 4,000 men. This is haraly possible, considering the four brigades and other miscellaneous troops that composed the division. Field's Brigade (augmented by the 9th Virginia Cavalry) reported 2,200 men. Anaerson's Brigade came to Virginia with 2,873 "effectives," and had seen no combat to reduce its numbers. Lee had sent more than 3,000 men from Richmond to the Rappahannock in midApril, and Gregg's Brigade, by subtraction in one of Lee's letters, should be creaited at least 2,127 men. From these figures should be subtracted about 900 casualties--the highest estimate--incurred at Hanover Court House.

All of these figures, however, are for "effectives." As noted earlier, in the calculations on the army at Williamsburg, "effective" numbers have to be transformed into "present for duty," and officers have to be added to the tabulation before a meaningful comparison with Federal numbers can be reached. Using Livermore"s stanajard percentages for conversion--93\% for infantry and artillery, 86\% for cavalry, and a $6.5 \%$ allowance for officers-the total number of troops in the Department of Northern Virginia on ivay 31 totals 87,890 .

In Richmond, there were between 2,600 and 4,800 more 
the Potomac as 103,382 strong. 19 The overwhelming numerical

officers and men. The lower figure allows 700 for the heavy artillery, 500 for the militia, 400 for the Tredegar Battalion, and 1,000 for the miscellaneous troops. The higher number counts the heavy artillery at 1,400, the militia at 1,000, the Tredegar Battalion still at 400, and the miscel1 aneous troops at 2,000. From contemporary evidence, it is very difficult to hone thuse estimates any closer. Ripley's Brigade, estimated by Livermore at 2,356 "effectives," and Walker's, reported in mid-April as having 3,693 "effectives," were both approaching Richmond that afternoon. Following the same conversion process for these two brigades, and adding in the troops at Richmond, this would be an additional 6,923--even excluding the heavy artillerymen, marines, and naval troops still at Drewry's Bluff. This gives a total number of Confederates--officers and men "present for duty"--in the vicinity of Richmond as at least 94,813 men.

The objection can be made that Johnston certainly could not use all these men in his field army, that it is only fair to count the muskets of men actually in the line of battle. But that is precisely the sort of logic that Mcclellan attempted to employ, and which his own superiors and historians have rejected, arguing that for a true interpretation of his strength all the soldiers even theoretically available in the area should be counted.

See "Abstract from statement of troops serving in the Department of North Carolina, commanded by Maj. Gen. T. H. Holmes, April 19, 1862, in OR, IX: p. 459; Robert E. Lee to Joseph E. Johnston, April 23, 1862, Robert E. Lee to Joseph E. Johnston, May 17, 1862 (two letters), Orders No.--, D. H. Hill's Division, May 17, 1862, "Strength of the several brigades of the Army of Northern Virginia near Richmond, as shown by General Johnston's memorandum of May 21, 1862," A. L. Long to John H. Winder, May 23, 1862, Special orders No. 118, Adjutant and Inspector-General's Office, May 23, 1862, Henry A. Wise to D. H. Hill, May 24, 1862, Special Orders No. 120, Department of Northern Virginia, May 28, 1862, Special Orders No. 21, Headquarters, May 30, 1862, "Strength of the Virginia forces in the Right Wing, Army before Richmond," June 23, 1862, in $\mathrm{OR}, \mathrm{XI}$ (part 3): pp. 458, 523, $525,530-533,539,540,5 \overline{42}, 558,563,615$; "Reports of Brig. Gen. Charles W. Field, C. S. Army, with instructions from General Lee," April 20, 1862, in OR, XII (part 1): p. 434; Livermore, Numbers and Losses, pp. 81-86, Smith, The Battle of Seven Pines, pp. 172-173; Davis, Rise and Fall, II: P. 153; Johnston, "Manassas to Seven Pines," B\&L, II : pp. 208-209; Sears, McClellan, p. 187; Archer Anderson to Joseph E. Johnston, September 14,1887 , in RMH.

$19 \mathrm{McClellan}$ only reported 98,008 "present for duty," but 
advantage enjoyed by the Yankees in February had been almost completely neutralized.

Given McClellan's normal caution, Johnston could have safely awaited Ripley's and Walker's Brigades before attacking. He could have aropped upon Lee the responsibility for supporting Drewry's Bluff instead of leaving four of Huger's regiments there. To have done either would have been consistent with the stereotypical image of him as always postponing battle to gather more strength. But by May 30, Johnston had finally been presented with the opportunity he had been seeking--Keyes' IV Corps at Seven Pines was separated from the rest of the Federal army by several miles--and he was not about to delay in striking a moment longer. "If nothing prevents we will fall upon the enemy in front of Major-General [D. H.] Hill," Johnston told Smith on May 30, "early in the morning--as early as practicable."20

Johnston's plan was simple (see Map No. 5). Three roads extended east from Richmond toward Keyes' position. Most of D. H. Hill's Division was on the center route, the Williamsburg Road, which led directly to Seven Pines. He was to bring his flanking brigade up from Charles City Road to the south, and attack toward seven Pines. The brigade on

in a spurious bookkeeping maneuver omitted from this total 5,374 officers and men actually present and available to him. See "Number of men composing the Army of the Potomac on the 3lst day of May, 1862," in OR, XI (part 3): p. 204.

20 Joseph E. Johnston to G. W. Smith, May 30,1862 , in OR, XI (part 3): p. 563 . 


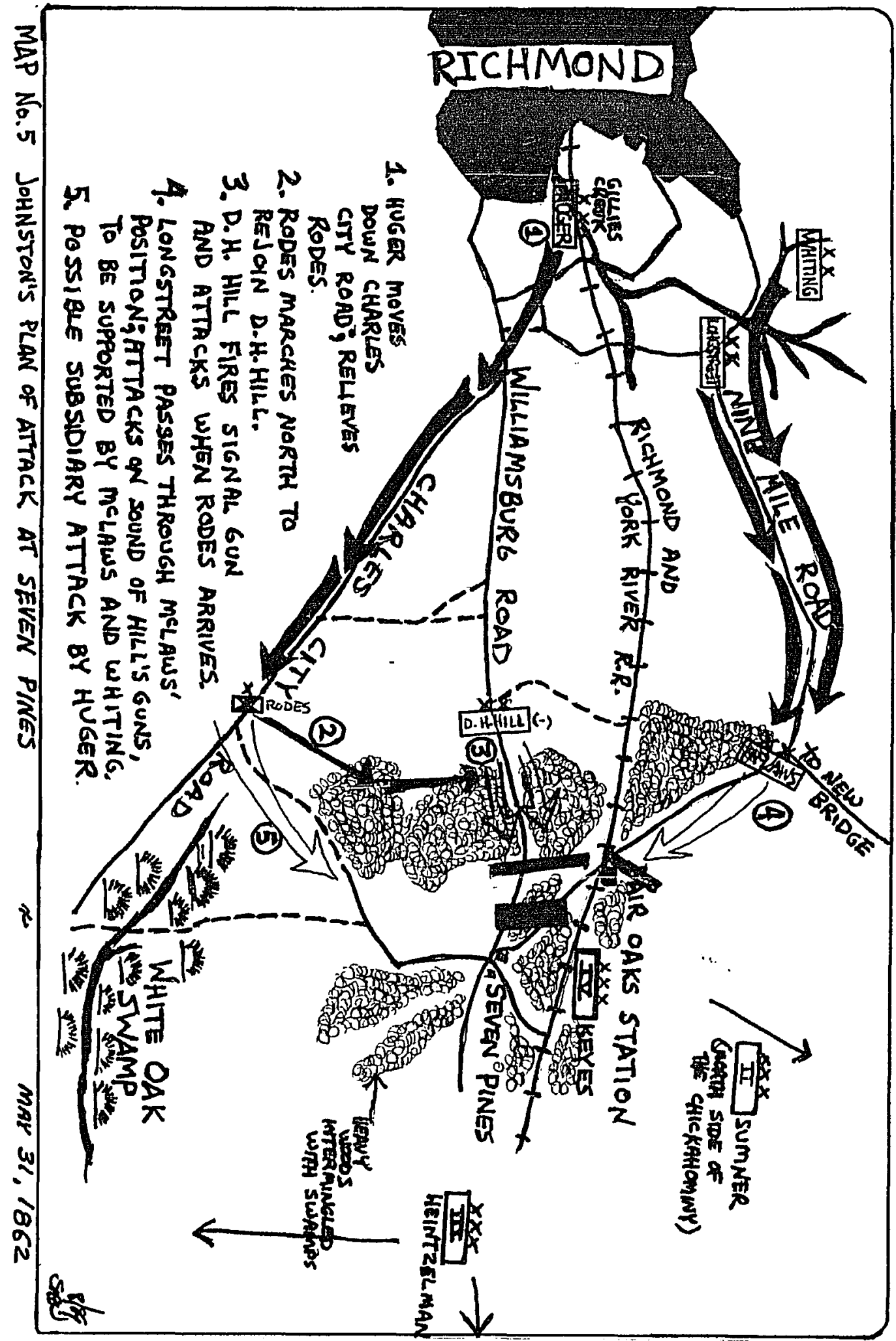


Charles City Road would be replaced by Huger's Division, marching up from Drewry's Bluff. Huger's first task was to secure Hill's right flank, but if he found no opposition he was authorized to attack northeast to support Hill. Longstreet would march his own division down Nine Mile Road, which first paralleled and then intersected the williamsburg Road, running through Fair Oaks station to Seven Pines, and attack on Hill's left. Longstreet was to supervise the combined movements of these three divisions. Meanwhile, part of Magruder's command and A. P. Hill's Division would defend the upper bridges of the Chickahominy, while Whiting's and Mclaws "Divisions would be held in reserve either to support Longstreet or engage any reinforcements McClellan attempted to send across the river. 21

The sequence of events which lead to the development of

$21_{\text {This interpretation follows the account of } G . W .}$ Smith, rather than that of Johnston himself or Longstreet, who maintained in official reports and postwar memoirs that Longstreet was to support Hill on the Williamsburg Road rather than to move down Nine Mile Road. This is accepted for purposes of establishing Johnston's original intentions because of Joseph E. Johnston to Gustavus W. Smith, June 28, 1862 in which Johnston referred to "the misunderstanding between Longstreet and myself in regard to the direction of his division," and asked that Smith omit several paragraphs from his official report. See G. W. Smith, The Battle of Seven Pines, pp. 19-22; "Report of General Joseph E. Johnston, C. S. Army, commanding Army of Northern Virginia, and resulting correspondence," June 24, 1862, "Reports of Maj. Gen. James Longstreet, C. S. Army, commanding Right Wing," June 10, 1862, in OR, XI (part 1): pp. 933-941; Johnston, Narrative, pp. 132-133; Longstreet, Manassas to Appomattox, pp. 87-88; Johnston, "Manassas to Seven Pines," B\&L, II: pp. 211-212; Gustavus w. Smith, "Two Days of Battle at Seven Pines," B\&L, II: pp. 225-226, 228 . 
this plan, and the methods by which the orders were distributed, are critical to any understanding of what happened on May 31. About noon on May 30, D. H. Hill advised Johnston that Keyes" entire IV Corps was concentrated near seven Pines, and that there were apparently no Federal troops on the Charles City Road. "I received a prompt answer from him," Hill stated, "saying that, being satisfied by my report of the presence of the enemy in force in my immediate front, he had resolved to attack him, and directed me to serve with Major-General Longstreet and under his orders." 22 Longstreet arrived at Johnston's headquarters soon after his commander had received Hill's intelligence, and the two generals began to discuss details of the upcoming attack.23

Not only by choosing Longstreet to command the attack, but also by failing to call Smith into the conference about its direction and coordination, Johnston sent a clear signal just how far the Kentuckian had fallen in his estimation. There were other signs of Longstreet's rise and Smith's demise in the eyes of the army commander. Johnston's plan broke up Smith's "wing," leaving A. P. Hill on the upper Chickahominy and bringing Whiting up the Nine Mile Road as a reserve, with McLaws actually scheduled to be committed to battle first. This effectively reduced Smith to a division

22 "Report of Maj. Gen. D. H. Hill, C. S. Army, command-

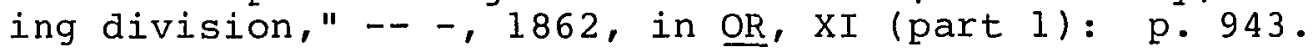

23 Longstreet, Manassas to Appomattox, p. 87 . 
commander or a spectator, depending on whether or not he chose to supersede Whiting. Johnston obviously did not intend him to do so, sending Smith a not-so-subtle message by transmitting movement orders directly to Whiting. 24 Whether Johnston now suspected that his nominal second-incommand lacked nerve--as Longstreet would later imply--or whether he simply feared a physical breakdown at a critical moment, is impossible to determine. In either case, the effect was the same: Johnston deliberately cut Smith out of the attack.

Johnston and Longstreet would have discussed a variety of options for executing the attack. Any map of the Richmond area, of course, suggested the possibility of attacking Keyes simultaneously in front and flank by sending one division down the Williamsburg Road and another down the Nine Mile Road. Yet this raised a serious question about the weight of Hill's frontal assault. At the moment, Hill had only three brigades on the Williamsburg Road; BrigadierGeneral Robert Rodes' Mississippi-Alabama Brigade was stationed on the Charles city Road to protect his right flank.25 Three brigades without reinforcements--fewer than 10,000 men--alone could hardly be expected to spearhead the crushing attack Johnston envisioned. How could the frontal attack be

24 Joseph E. Johnston to Gustavus W. Smith, May 30, 1862, in OR, XI (part 3): p. 563 .

25 "Report of Maj. Gen. D. H. Hill, C. S. Army, commanding division," -- -, 1862, in OR, XI (part l): p. 943. 
strengthened?

Three possible answers suggested themselves. First, Huger's Division could be brought up from Drewry's Bluff along Charles City Road to relieve Rodes to participate in the attack. This would give Hill his full division for the attack, secure his right flank, and even hold out the possibility that Huger's three brigades might assist in enveloping the Federal left. The advantages of this approach were so clear that Johnston dispatched orders to Huger that evening. 26

But this still left Hill attacking Keyes' front with only a single division. A second option for reinforcing his attack would be to bring some of Longstreet's brigades over to the Williamsburg Road to support the attack. If three of his six brigades marched across to support Hill, then the balance of forces in the attack would be seven brigades on the Williamsburg Road (Hill's Division and half of Longstreet's) and seven on the Nine Mile Road (McLaws' Division and the other half of Longstreet's).27 Yet against this plan there were two objections, one of command coordination and the other of Longstreet's ambition. With which column would Longstreet ride, and how would he coordinate the

\footnotetext{
26 Joseph E. Johnston to Benjamin Huger, May 30,1862 , in OR, XI (part 1): p. 938 .

27 That this option was discussed can be inferred from Smith, "Two Days," p. 242; see also Freeman, Lee' Lieutenants, I: P. $232 \mathrm{n}$.
} 
attack on the other road? If he chose the Williamsburg Road, the entire left prong of the attack would be left in the hands of McLaws, one of the most junior-major-generals in the army. Mclaws had just received his commission a week earlier and had not, with the exception of the skirmish at Williamsburg on May 4, maneuvered even a single brigade in combat. 28 on the other hand, if Longstreet personally commanded operations on the Nine Mile Road, there remained a question of delegating the responsibility for opening the action entirely to Hill. In the light of Hill's performance at williamsburg, which his critics could well have characterized as rash, how safe would it be to leave to him the command of half the forces involved in the attack?

There was, however, a third possibility. Hill could be reinforced on the Williamsburg Road with Longstreet's entire division. This would put ten brigades in the main attack under Longstreet's direct supervision. The assault of McLaws' four brigades on the Nine Mile Road would then be relegated to the status of a supporting attack. Should greater weight be needed there, Johnston could always draw on Whiting's five brigades. The advantages of this plan, from an operational perspective, were the added weight to the attack on the center of the IV Corps' 1 ine and Longstreet's personal supervision of the attack. As a disadvantage, however, there was the fact that such a maneuver

28 Warner, Generals in Gray, pp. 204-205. 
required six of Longstreet's and three of Huger's brigades to share one constricted stretch of the williamsburg Road, upon which both divisions would have to travel until Huger's men turned off on the Charles City Road. Without careful coordination, confusion could delay the opening of the attack.

When Longstreet left Johnston's headquarters, the army commander had decided to follow the simplest of the plans discussed: Longstreet would follow the Nine Mile Road, Hill the Williamsburg Road. Huger would relieve Rodes' Brigade, and, when Rodes reported to Hill, the North Carolinian would fire a signal gun to start the attack. The noise was to alert Longstreet's Division on the Nine Mile Road to begin its advance. The sequence of events was to begin as early as possible after dawn. 29

With the advantage of hindsight, it is easy to fault Johnston's faith in the ability of his army to perform such a complex maneuver with clockwork efficiency with the division separated by several miles of dense woodland and murky swamps. Yet such convoluted arrangements for opening battles by an intricate succession of attacks were a regular feature of Civil War combat. Lee attempted to start the battles of Cheat Mountain and Mechanicsville with just such maneuvers. 30

\footnotetext{
29 "Report of Maj. Gen. D. H. Hill, C. S. Army, commanding division," -- -, 1862, in $\mathrm{OR}, \mathrm{XI}$ (part 1): p. 943. 30 Freeman, R. E. Lee, I: p. 562, II: pp. 111-112.
} 
General Braxton Bragg routinely employed complicated echelon movements to begin battles: he did so at Perryville, stone's River, and on the second day at Chickamauga. 31 Upon his promotion to command of the Army of Tennessee, John Bell Hood did the same at Peachtree Creek and the Battle of Atlanta. 32 Nor was faith in their divisions' abilities to conduct flawlessly in battle maneuvers that would have taxed their skilis on the parade ground a strictly confederate delusion. McClellan at Antietam, Hooker at Chancellorsville, and George G. Meade at Mine Run provide only three of a great number of examples of an equal Yankee fascination with overly complex opening gambits. 33

But Johnston committed two far greater mistakes in planning his battle. Though he wrote Huger two letters--one on the evening of May 30 and one very early in the morning of May 31--he neglected to make clear either the scope of the battle or the fact that Huger would be responsible for starting it. Instead of telling Huger on May 30 that an attack was planned, Johnston merely informed him that "the reports of Maj. Gen. D. H. Hill give me the impression that the enemy is in considerable strength in his front. It

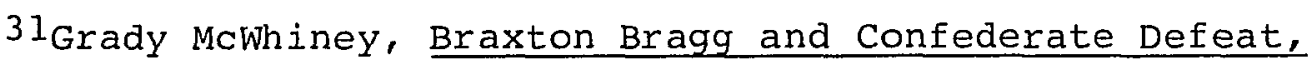
Volume I: Field Command (New York: Columbia University Press, 1969), pp. 315, 350-352; Horn, Army of Tennessee, p. 260 .

32 McMurry, Hood, pp. 127-128, 130-131.

33sears, McClellan, pp. 297-299; Swinton, Campaigns, pp. $271-273,391$. 
seems to me necessary that we should increase our force also." Even when he assigned Huger his post, Johnston did not specify that an attack by Hill's Division was contemplated: "For that object I wish to concentrate the troops of your division on the charles City road and concentrate the troops of Major-General Hill on that to Williamsburg." After providing Huger with directions, Johnston ended the letter with the only sentence, ambiguous as it was, that even hinted at his plans for attack. "Be ready, if an action should be begun on your left, to fall upon the enemy's left flank."34 There was no doubt in Johnston's mind that he intended to attack the next morning; thirty-five minutes after he wrote Huger, he sent much more explicit orders to Smith and Whiting. "If nothing prevents we will fall upon the enemy in front of Major-General Hill," he told them. 35 Why did he fail to reveal his intentions to Huger?

And why, in the predawn hours of May 31, did Joseph Johnston suddenly decide to limit Huger's actions even more strictly? The following confused note would have found Huger as he put his brigades into motion:

GENERAL: I fear that in my note of last evening, of which there is no copy, I was too positive on the subject of your attacking the enemy's left flank. It will, of course, be necessary for you to know what force is before you first. I hope to

34 Joseph E. Johnston to Benjamin Huger, May 30, 1862, in OR, XI (part 1): p. 938 .

35 Joseph E. Johnston to Gustavus W. Smith, May 30, 1862, in OR, XI (part 3): p. 563. 
be able to have that ascertained for you by cavalry. As our main force will be on your left, it will be necessary for your progress to conform at first to that of General Hill. If you find no strong body in your front, it will be well to aid General Hill; but then a strong reserve should be retained to cover our right. 36

This letter more clearly implied an attack, but disregarded several points. Huger was not informed that his relief of Rodes would signal the beginning of the battle; he was not even told which brigade he would replace in Hill's division. Cavalry was to scout the area in front of him, but what cavalry, and when would it report to him? Most critically, the message did not make Huger aware that a major attack by fourteen brigades had been ordered, or that Longstreet was in overall command. Johnston, it almost seemed, expected Huger to divine his intentions by telepathy. Johnston, anxious over the impending battle, may well have dashed off the first note without thinking it through. By the time he dispatched the second letter, he admitted that he could no longer quite remember what he had written, and revealed that he had not had a copy entered in his letterbooks. 37 It was a failure of both the individual and of his mediocre staff; everyone simply assumed that the correct information had been disseminated, and no one both-

36 Joseph E. Johnston to Benjamin Huger, May 31, 1862, in OR, XI (part 1): p. 938 .

37 Nor does the letter appear in any of the extant Johnston letterbooks, either at the college of William and Mary or in the National Archives. The copy published in oR was provided by Huger. 
ered to check.

Yet, as Freeman pointed out, Huger's orders, "while not models of their kind," could reasonably be expected to put him in approximately the right place at roughly the correct hour. If he commenced his march early enough, if the roads were clear and the bridges intact, and if D. H. Hill had guides awaiting him as instructed, then Johnston's plan might not be irrevocably injured. 38

But Johnston's second significant miscue on the day before the battle had the potential for far worse consequences. He had discussed with Longstreet several variations of his original plan, and though he had finally decided on his original concept, he failed to make sure that his division commander left the meeting with the same understanding. 39 Longstreet returned to his own camps and ordered his brigadiers to issue ammunition, have rations cooked, and prepare for an early march.40 Yet along what route?

As Longstreet pondered the attack, more and more he

38Freeman, Lee's Lieutenants, I: p. 228 ; Joseph E. Johnston to Benjamin Huger, May 30 , 1862, in OR, XI (part 1): p. 938 .

${ }^{39}$ In addition to G. W. Smith's evidence that Johnston had decided on deploying Longstreet's Division on the Nine Mile Road and not the Williamsburg Road, his second letter to Huger may be cited. If Johnston had intended Longstreet to be on the Williamsburg Road, he would not have 1 isted Hill as commanding the attack. See Joseph E. Johnston to Benjamin Huger, May 31, 1862, in OR, XI (part 1): p. 938 .

40 "Report of Brig. Gen. Cadmus M. Wilcox, C. S. Army, commanding brigade," June 12,1862 , in OR, XI (part 1): $p$. 986 . 
thought of the personal and strategic advantages which would accrue from sending his division down the williamsburg Road and supervising the combined attack of his and Hill's brigades. There could be no question of credit for a victory if Longstreet commanded both divisions. Combined with his defensive success at Williamsburg, an offensive triumph at Seven Pines would secure his own reputation as the army's chief fighting general and cement his place as Johnston's most trusted subordinate. Rationalizations come easily to an ambitious man: unity of command, weight of attack, and the possible need to restrain the sometimes overly aggressive Hill would all have offered themselves to the Georgian that night. 41

But by what authority could he modify the plan upon which Johnston had settled? At some point in the night, Longstreet convinced himself that as commander of the "right wing" he had been given the assignment to attack the enemy in front of Hill, and that he and the army commander had

4 l'Longstreet's ambitions toward promotion and independent command later in the war have been argued by historians for years. It is evident upon reading the barrage of correspondence with General Cooper during the three weeks following May 5, that Longstreet's designs for carving from Johnston's army a permanent command which would be larger than a single division began with the Battle of Williamsburg. See James Longstreet to Samuel Cooper, May 7, 1862, James Longstreet to Samuel Cooper, May 9, 1862, James Longstreet to Samuel Cooper, May 27, 1862, in LR-AIGO, M-474, Reel 30; James Longstreet to Samuel Cooper, May 12, 1862, in Richard H. Anderson, Compiled Service Record, National Archives, Washington, D. C. It was no slip of the pen that Longstreet cited himself in all these letters as commanding the "second corps" of the army. 
discussed alternatives for that attack without ever firmly deciding on one. It would have been in character for Johnston to have told Longstreet at some point in the discussion that he depended on him to use his own best judgment in controlling the attack. From such an expression of confidence, Longstreet could easily have derived the idea that Johnston had entrusted to him the authority to change plans as circumstances might dictate. 42 without notifying Johnston, Longstreet sent a message to Hill informing the other division commander that his six brigades would march to the Williamsburg Road in the morning to support the attack.43 The only other possible explanations of Longstreet's conduct are that either he completely misunderstood Johnston's instructions, or he coolly and consciously disobeyed orders. Neither seems satisfactory. As poorly conceived as was his correspondence with Huger, the idea that, in a conversation which must have consumed hours, Johnston could not make clear to Longstreet on which of two roads he wished his division to march, stretches plausibility beyond the

42 As has already been shown, this was exactly the sort of authority that Johnston delegated to detached commanders such as Jackson and Ewell in the Valley or Whiting along the Potomac.

$43 \mathrm{Hill}$ stated in his report that "I was directed by General Longstreet to move with my whole division at dawn on the Williamsburg Road and to lead the attack on the Yankees." [emphasis added] That Hill would "lead" the attack on the Williamsburg Road implies that he had been informed that there would be other troops following his. See "Report of Maj. Gen. D. H. Hill, C. S. Army, commanding division," -- , 1862, in OR, XI (part 1): p. 943. 
breaking point. Nor did Longstreet ever adinit that he altered Johnston's original design. In both his official report of the battle and his memoirs, he steadfastly maintained that his dispositions were preciseiy those directed by the army commander. 44 The account of the conference with Joinston and the outline of the plan of attack tinat Longstreet published in his memoirs demonstrate, however, a striking similarity to those passages in which he depicted Lee as firmly agreeing to fight only defensive battles auring the Gettysburg Campaign.45 Throughout his career, the Georgian repeatedly proved that he was quite capable, upon reflection, of hearing what he wished to have heard. Unfortunately, the army commander had an inkling that such was the case. To paraphrase Freeman on Lee and Longstreet in Pennsylvania, Johnston never had intended to commit himself to any changes that Longstreet might introduce to his plan of battle and he did not know that Longstreet considered him so pledged. 46

In his ignorance that the general to whom he haỏ assigned responsibility for the next day"s attack had decided to change the plan, Joinston founä several omens that apparently augured for resounding success. The primary one was

44 "Reports of Maj. Gen. James Longstreet, C. S. Army, commanding Right Wing," June 10, 1862, in OR, XI (part 1): p. 939; Longstreet, Manassas to Appomattox, pp. 87-88.

45 Longstreet, Manassas to Appomattox, p. 331 . 46 Freeman, Lee's Lieutenants, III: p. 50. 
rain--a hard, driving, arenching rain accompanied by pounding thunder. The downpour began within hours of the time Johnston decided to take the offensive, and raised the prospect that the Chickahominy would overflow its banks, rendering communication between the two parts of McClellan's army not difficult but impossible. 47 It did not occur to him that the same deluge might also swell the streams to his rear and slow the approach of Huger's Division or flood the low lying countryside to such an extent that troop movements would be hindered.

More news that Johnston considered good came to headquarters in the person of Colonel Armistead L. Long, Lee's military secretary, who rode out from Richmond with two messages from the Commanding General. First, Long informed the army commander that Ripley's South Carolina Brigade had been ordered to report to him when it arrived in Richmond, probably the next day. 48 The other communication that Long carried with him was a personal message from Lee, "to tell

47 Joseph E. Johnston to Gustavus W. Smith, May 30, 1862, in OR, XI (part 3): p. 563; Smith, The Battle of Seven Pines, p. 146; Longstreet, Manassas to Appomattox, p. 87.

48 That Long brought this news may be inferred from three facts. First, Lee did not include it in the letter he sent later in the day. Second, the order had just been issued at headquarters that morning, and it would have been natural for Long to carry it out with him. Third, Long and Johnston eventually got around to discussing reinforcements, at which point it would have occured to Long to mention Ripley's force even if he did not bring along a copy of the order. See Robert E. Lee to Joseph E. Johnston, May 30, 1862, Special Orders No. 21, May 30, 1862, Headquarters, in $\underline{\mathrm{OR}}$, XI (part 3 ): pp. 560, 563; Long, Personal Memoirs, pp. 158-159. 
him that he would be glad to participate in the battle. He had no desire to interfere with his [Johnston's] command, but simply wished to aid him on the field to the best of his ability and in any manner in which his services would be of most value."49 The offer both pleased and embarrassed Johnston. For two weeks, the two generals had been growing closer together in their strategic appreciation of the military situation. Lee's request to serve under Johnston was a heartening vote of confidence; but, at the same time, it was an awkward proposition. Lee could be relied upon to keep his word not to interfere, but his presence would raise a thorny issue of credit if a victory were gained. Johnston could scarcely have forgotten that the public awarded Beauregard the lion's share of the praise for Manassas; would it be said that Lee had been forced to ride out to Johnston's army to save Richmond? To Long, none of this internal struggle was apparent. He recorded that "General Johnston expressed gratification at this message, and the hope that General Lee would ride out to the field, with the desire that he would send him all the reinforcements he could." Johnston then informed Long that the battle would open the following day, though he did not elaborate on his plans. 50

49 Long, Personal Memoirs, pp. 158-159.

$50_{\text {Both }}$ Freeman and Dowdey find much in Long's account for which to castigate Johnston. Freeman described Long as returning to Richmond with "a polite but indefinite answer to his message: Johnston would be happy to have him ride out to the field, and, meantime, would Lee send him all the rein- 
Few soldiers and even fewer officers in the divisions of Longstreet, D. H. Hill, Huger, or Whiting got much sleep that night; a morning attack required preparations that consumed the hours of darkness. Huger, whose men had the longest distance to travel, was on the march soon after 3:00

forcements he could collect?" Thus far, Freeman was well inside the bounds of legitimate if arguable interpretation of Long's statement, which he cited as his authority for the sentence. But in the next pair of sentences--unsupported by any references--Freeman asserts that "Johnston did not tell Long, nor did Long learn from any other source, when the battle for Richmond would open. Still uncertainty; still suspense!" Dowdey went further afield, distorting the entire exchange: "To Lee's offer of his services, Johnston answered civilly enough that Lee would be welcome at headquarters, but that the only service he could perform would be to send reinforcements. For what purpose he did not tell colonel Long." [emphasis added]

Johnston could not have revealed the full details of his plans, even had he been willing to do so, because when Long approached him, the army commander had not yet held his conference with Longstreet to iron out the essentials of the attack. This may be inferred by the fact that Long did not mention Longstreet's presence and Longstreet did not mention Long. For Long to have arrived after Longstreet left Johnston's headquarters would have placed the visit into the early evening, far later than Long's memoirs suggest. So Johnston could not have confided specifics of his operation to Long.

But it again stretches credibility to suggest that Johnston told Long nothing about his intentions. Lee already knew that Johnston planned to attack McClellan, and that he preferred to strike south of the River. That Lee knew some sort of attack was impending is implied by Long"s statement that Lee "would be glad to participate in the battle." [emphasis added] It also makes little sense to believe that Johnston, who wanted Ripley's Brigade and any other reinforcements he could get, did not tell Lee when he expected to need them, particularly when the two men had been in daily contact since the first week of May, and Johnston had always advised Lee in advance of major movements, from the evacuation of Williamsburg to the aborted attack on May 29. See Freeman, R. E. Lee, II: p. 67; Dowdey, The Seven Days, p. 86. 
A. M.51 Longstreet's men started toward the Williamsburg Road prior to 6:30 A. M.52 on the Williamsburg and Charles City Roads, D. H. Hill had already roused his own troops, and awaited the arrival of Huger's lead brigade to relieve Rodes and allow him to open the attack.53 whiting, who had been cast in the role of reserve on the Nine Mile Road, began his own march at first light. 54

Nor had the sun risen when G. W. Smith met Joseph Johnston just outside the city limits at his headquarters on the Nine Mile Road. Smith's arrival was an event that Johnston knew must eventually occur, but had not anticipatea with pleasure. The previous day, he had essentially removed the Kentuckian--the man he once described as fit to lead the army by himself--from the command structure of the army. Yet since Smith remained legally his second-in-command, Johnston felt constrainea to explain to him the aetails of the attack. 55

Johnston's evident expectation was that Smith would

51 rhomas Pinckney to D. H. Hill, May 31,1862 , in OR, XI $(\operatorname{part} 3)$ : p. 563 .

52 "Report of Brig. Gen. Cadmus M. Wilcox, C. S. Army, commanding brigade," June 12, 1862, in OR, XI (part 1): p. 986.

53"Report of Maj. Gen. Daniel H. Hill, C. S. Army, commanaing division," -- -, 1862, in OR, XI (part 1): p. 943.

${ }^{54}$ Smith, The Battle of Seven Pines, p. 23.

55 Smith, Confederate war papers, p. 162. 
take the hint of his de facto demotion, and avail himself of one of two face-saving alternatives. Either he would personally resume command of Whiting's Division, or he would return to the upper Chickahominy and supervise the four brigades of A. P. Hill's Division guarding the bridges. If he chose to supersede Whiting, Johnston was willing to allow him a part, albeit a very small one, in the battle; the army commander could do so without fear, for, if Smith lost his taste for attacking, or suffered an attack of his illness, there was always whiting there to replace him. Should smith decide to retire to the far left of the army, he would be out of the way entirely.

But Smith confounded Johnston before the first light had streaked across the Virginia sky. Calmly ignoring the choices that his superior had tacitly laid before him, Smith told Johnston that he had left A. P. Hill in charge of observing bridges, and that he "did not propose relieving General Whiting of the command of the division;" instead, he "would accompany it to the designated point, and take whatever part circumstances might require of him in the coming contest." 56

Whiting was scheduled to march down the Nine Mile Road to the point where it split: the left fork heading toward New Bridge, the right to Fair Oaks Station. Since it was from this location Johnston intended to oversee the battle,

$$
{ }^{56} \text { Ibid. , pp. 162-163. }
$$


Smith's announcement meant that he planned to remain at Johnston's shoulder all day. This was not a prospect that pleased Johnston, and he cast about quickly for an assignnent for Smith. Smith recalls that Johnston decided that if the Federals "attempted to cross anywhere above New Bridge, he would place ne in command of all our troops on that siāe, and that I must repel any attack they might make on Richmond, whilst the mass of our army was engaged with McClellan's left wing." 57

The next news that Johnston received was far more welcome. Major-General Theophilus Holmes, whom Johnston had not seen since he aeparted to command in North Carolina, rode up to headquarters, accompanied by Lieutenant colonel Archer Anderson, his chief of staff. Holmes advised Johnston that he had received definitive orders from the secretary of War to reinforce the army in front of Richmond with three of his brigades--more than 8,000 men. The leading troops, 3,000 solaiers of Walker's Brigade, would reach Drewry's Bluff sometime that day, which would allow Johnston to immediately call up the four regiments which he had been forced to leave there. 58 Not only would there be reinforcements available the next day to follow up a successful battle, but it must have seemea to Johnston that the admini-

\footnotetext{
57 Smith, The Battle of Seven Pines, p. 23.

58 Arciner Anderson to Joseph E. Johnston, September 14, 1887, in RiMH; G. W. Randolph to John G. Walker, June I, 1862, in $\mathrm{OR}, \mathrm{XI}$ (part 3 ): p. 565 .
} 
stration had finally decided to strip its coastal garrisons in order to defeat Mcclellan.

His satisfaction, however, was short-lived. Only minutes after Holmes and Anderson had departed, a frustrated inquiry from Whiting arrived by courier. Whiting had attempted to start his division down the Nine Mile Road at daybreak, but found Longstreet's brigades blocking his march. Quickly becoming impatient, he directed his complaint to Smith. Unfortunately, not knowing the entire battle plan, Whiting omitted one key detail from his message: he did not tell Smith that Longstreet was marching south across his 1 ines, instead of east down the Nine Mile Road.59 Johnston was standing beside Smith when the latter received the message. For Johnston, it was the first notice that something had gone awry with his plan. Whiting had sent his letter after 6:00 A. M. and his courier had consumed the better part of an hour in finding Johnston and Smith. The chances for a near-dawn attack were diminishing rapidly. He directed Smith to send an aide to Longstreet to find out what had caused the delay. Lieutenant Robert F. Beckham was chosen for the mission. When Beckham asked Smith where Longstreet's headquarters could be found, Smith referred him back to the army commander. Johnston's answer was abrupt: Longstreet's Division was assigned to the Nine Mile Road, and General Longstreet, "in all probability," was at its

\footnotetext{
${ }^{59}$ Smith, Confederate War Papers, p. 164.
} 
head. Beckham was to hurry Longstreet along and reassure Whiting that Longstreet was to precede him. 60

A tense hour passed before word came back from Beckham. It was not good news. He had ridden as far up the Nine Mile Road as Whiting's Division and could find no sign of the Georgian or his six brigades. But, either from an interview with Whiting, or from his own observations, Beckham realized what had happened; Longstreet was marching toward the Williamsburg Road. On his own initiative, he set off crosscountry in search of the missing division. 61

Even after the receipt of Beckham's intelligence, Johnston resisted the idea that Longstreet had ignored his plan of attack. Perhaps the troops that had delayed whiting were other brigades--in all events, Longstreet should have marched hours earlier--and the Georgian's division had passed down the Nine Mile Road in the dark, and was already east of the position where Johnston and Smith were standing. The lack of any noise from in front was not conclusive, because Longstreet would have kept troops in position as quiet as possible until Hill's attack began. Having convinced himself that Beckham could well be mistaken, Johnston dispatched one of his own aides east down the Nine Mile Road, toward the Federal position at seven Pines. If Lieu-

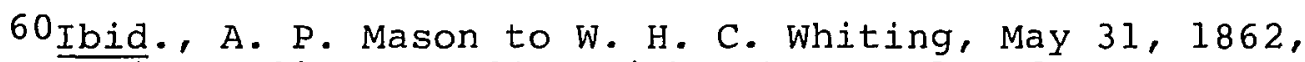
in OR, XI (part 3): p. 564 ; Smith, The Battle of Seven Pines, p. 24.

${ }^{6} 1_{\text {Smith, }}$ The Battle of Seven Pines, p. 24. 
tenant J. B. Washington could not find Longstreet on that part of the road either, the army commander instructed him to cut across to the Williamsburg Road. There he was to order Longstreet, if he found him, to send at least three brigades back to the Nine Mile Road if the attack had not yet opened. 62

That he would order three of Longstreet's brigades to countermarch back to the Nine Mile Road when the attack was already several hours late in opening revealed much about Johnston's state of mind on May 31 . Either he forgot that he still had four brigades under McLaws and five under Whiting available for the left wing of his attack, or he had become fixed upon the idea of keeping Smith from having an active role in the battle. But it is also possible that, in the moment of his first offensive battle, Joseph Johnston proved unable to impose his will upon events. He had proven his ability to direct strategy, administer a department, maneuver his troops, and supervise (if loosely) a defensive battle; but, attacking--turning a plan into reality, despite the fact that troops took the wrong roads and generals misunderstood their orders--was a much more strenuous exercise. So far his reactions could be excused as those of a novice commanding his first attack; but, with his orders to Lieutenant Washington, legitimate suspicions about Johnston's

${ }^{62}$ Smith, Confederate war Papers, p. 169; Smith, The Battle of Seven Pines, p. 25 . 
capacity to command an attack begin to surface.

Three hours had already passed since Whiting's initial complaint, when washington spurred his horse toward seven Pines just after 9:00 A. M. No one at headquarters saw him again that day. Washington became so absorbed in looking for Longstreet's brigades that he completely overshot the Confederate lines and delivered himself as a prisoner into the hands of the lo0th New York, the regiment picketing the far right of Brigadier-General Silas Casey's Second Division of the IV Corps. Although Washington said nothing of his mission or the impending attack to his captors, the capture of an army commander's aide could not help but make the Yankees suspicious. "This circumstance," reported Casey, "in connection with the fact that Colonel Hunt, my general officer of the day, had reported to me that his outer pickets had heard cars running nearly all night on the Richmond end of the railroad, led me to exercise increased vigilance."63

All Johnston knew, of course, was that Washington simply disappeared. In the meantime, Lieutenant Beckham rode back to the army commander's field headquarters with the news that he had found not only General Longstreet but his entire division and all its trains on the williamsburg Road. Since Beckham had pursued Longstreet on his own initiative, however, he had had no orders to pass on to the

63"Reports of Brig. Gen. Silas Casey, U. S. Army, commanding Second Division," June -, 1862, in $\underline{\mathrm{OR}}$, XI (part 1): p. 914 . 
commander of the right wing. It was now nearly 10:00 A. M. To send a courier back to Longstreet with orders to transfer three brigades back to the Nine Mile Road would consume at least another hour, by which time the frontal attack by Hill's and Huger's Divisions should have commenced; and risked even more confusion. In Johnston's mind there would have been only two viable options at this point: either to call off the attack entirely and regroup, or follow Longstreet's lead.

Johnston vacillated. As he told Major S. B. French, Smith's Chief Commissary, to post himself outside his advanced headquarters and listen for the sound of musketry from the south, he made a remark that revealed an inclination to cancel the attack. "He said that he wished the troops were back in their camps," recalled French.64 Left to himself, Johnston might well have called off the offensive, but within a few minutes another event occurred, an event that rendered such a course impossible in Johnston's mind: Robert E. Lee appeared on the field.

Lee could not bring himself to remain in Richmond, doing nothing but shifting papers while the army battled for the city. He made sure that the orders forwarding Walker's and Ripley's troops had gone out, and ordered Pemberton to send an additional pair of regiments from South Carolina. Sometime during the morning, his patience exhausted, the

${ }^{64}$ Smith, The Battle of Seven Pines, p. 26. 
Commanding General mounted Traveller and rode out toward Johnston's headquarters. Eventually, probably about 11:00 A. M., Lee arrived at Johnston's forward command post in a house just off to the right of the Nine Mile Road, where the road to New Bridge turned off. 65

There is little doubt that Lee approached Johnston on May 31 with exactly the same intentions in mind that he had sent Colonel Long to communicate the previous day. He wanted to help. He needed, for his own peace of mind, to be involved in the defense of Richmond. He had told Johnston he would be happy to serve in any capacity; and, he did not seek to usurp command. The remainder of Lee's military career provides mute testimony to his sincerity: he rarely interfered directly in the tactical conduct of his corps, division, or brigade commanders. He would have been far less likely to do so in the case of a general--whom he considered a peer and a friend--commanding an army.

But Johnston, growing more anxious each moment for the success of his plan, was hardly in a state to appreciate this fact. His design had already begun to go awry with Gustavus Smith as an unwelcome witness. As he waited for the guns that would herald the belated attack on the williamsburg Road, his confidence further unraveled. Johnston could not see Lee in any other light than as a threat to his reputation and his command. Would Lee take some sort of

65 Freeman, R. E. Lee, II: p. 68. 
action if he found out about the morning's miscues? If the attack commenced after Lee's arrival, would he somehow be accorded the credit?

"There was a tenseness in the air" between the two men at that moment, wrote Douglas Southall Freeman. It was obvious that an attack was brewing, although not yet underway; but, Johnston was hardly in a mood to confide his plans or his problems to Lee. Lee was caught in the prison of his own "hands-off" attitude; he would not ask until Johnston seemed willing to answer. 66 The net result was that Johnston now found himself with two pairs of eyes gazing directly over his shoulders.

He waited. Longstreet had nearly 30,000 soldiers between his own and the divisions of Hill and Huger. There was no reason that even an attack delayed into midday might not crush Keyes. He "still had full faith," he told Smith, possibly with more bravura apparent than he actually felt as noon approached, that Longstreet's attack would destroy the IV Corps. 67 smith, who had the luxury of being very nearly an uninvolved bystander, was not so sure.

The minutes dragged silently past, until sometime in the early afternoon when Johnston finally decided that he needed another update on Longstreet's position and progress. 236 .

${ }^{66}$ Ibid.; see also Freeman, Lee's Lieutenants, I: $p$. 67 Smith, Confederate War Papers, p. 171. 
He directed Smith to send Major Whiting across country to check on the Georgian. About 2:00 P. M., the staff officer spurred his mount south through the woods toward the williamsburg Road.68 Everyone else--Johnston and his staff, Smith and his, and Robert E. Lee--waited nervously as their apprehension grew. Something must have gone horribly wrong.

A dull roar sounded in the woods to the south shortly before 4:00 P. M. Johnston listened, but heard only cannon. An artillery duel, he concluded. To Lee's ear the noise contained the faint echo of musketry, and he said as much. Johnston could not discern it. 69 More than two-thirds of the day had lapsed without combat. With only a few hours of daylight left, it almost sounded as if the army commander was hoping that Longstreet had the sense to postpone an assault which would be made too late to be decisive.

But Lee was correct: a bloody battle was rolling down the Williamsburg Road. Major Whiting confirmed this at 4:00 P. M. when he galloped back to headquarters with an urgent message from Longstreet. The full text has been lost, but Smith's report summarized its substance:

[H]e had attacked and beaten the enemy after several hours, severe fighting; that he had been disappointed in not receiving assistance upon his

$68 \mathrm{Smith}$ did not specify a time for Whiting's departure in his memoirs. Freeman guessed at 2:00 P. M., which seems logical enough, since the trip should have consumed about an hour each way, and the Major returned at 4:00 P. M. See Ibid., p. 167; Freeman, Lee's Lieutenants, I: p. 236.

69 Davis, Rise and Fal1, II: p. 122. 
left; and, although it was now nearly too late, that an attack, by the Nine Mile road, upon the right flank and rear of the enemy would probably yet enable him to arive them into the chickahominy before dark. 70

Johnston was taken aback. Longstreet's attack had been launched several hours earlier. How was it possible that neither the report of a signal gun, nor sounds beyond the barely audible noise heard-half an hour ago had penetrated to the Nine Mile Road? After reading the Georgian's note, Johnston concluded that perhaps, with swift action, he rnight yet achieve nis goal that afternoon. Three of Whiting's brigades; those of Hood, J. J. Pettigrew, and Whiting's own under its senior colonel had halted in the vicinity of headquarters. The need for haste drove all thoughts of proper chain of command from Johnston's mind. Without pausing to locate Whiting, he began to order those units into Iine. He dispatched Smith back up the road to bring forward the remainder of the division: the brigades of wade Hampton and Robert Hatton. 71

What had happened on the Williamsburg Road?

Longstreet's impromptu change of the attack plan had required three divisions to share at least a part of that

70 This sentence is from the version of Smith's report printed in his memoirs, not that which he submitted to the Adjutant General after Johnston later requested several omissions. Smith, Confederate War Papers, p. 170.

71 Johnston never later admitted that he personally assumed command of Whiting's Division, but on this point Smith and Davis agreed convincingly. See Ibid., p. 174; Davis, Rise and Fall, II: pp. 122-123. 
road as they deployed for battle. When Huger's lead brigade arrived at rain-swollen Gillies Creek, it discovered Longstreet's troops had beaten it to the ford which they were crossing single file on a plank laid across a wagon bed. 72 There was ample reason for Huger to be surprised. He had never even been informed that Longstreet's Division was involved in the attack, and could claim precedence at the crossing--his troops had the assignment of relieving Rodes on the Charles city Road so that the battle could commence. But Longstreet's men refused: they had built the bridge and intended to cross it first. 73

Impatient at this delay, Huger asked for the location of Longstreet's command post and urged his horse across the creek to the Poe House, farther down the Williamsburg Road. There he found Longstreet and D. H. Hill.74 Huger voiced his complaint, and probably demanded to know which other parts of the plan had been kept from him. Hill, by far the most junior of the three generals, would have had little to say. Longstreet, as he often did when challenged, fell back on his authority as commander of the right wing to justify his division passing the creek first. Huger then played

72 Longstreet, Manassas to Appomattox, p. 91; Smith, Two Days," p. 229 .

73 Endorsement by Benjamin Huger, August 10, 1862, appended to "Reports of Maj Gen. James Longstreet, C. S.

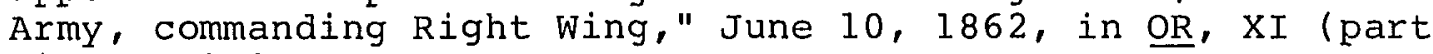
$1)$ : p. 942 .

74 Freeman, Lee's Lieutenants, I: p. 235. 
what he considered to be his trump card. He asked Longstreet his date of commission which, if junior to his own, would give Huger the overall command despite any of Johnston's intentions. Both men had the same date of rank as majorgenerals, which put the issue back to either their respective standings in the skeletal Confederate Regular Army or the prewar United States Army. Longstreet was suspiciously vague on the dates of his own commissions. Huger, with oldarmy rank-consciousness had no trouble providing his first, at which point--without citing specifics--Longstreet flatly asserted his own seniority. Huger was personally unconvinced, but found himself maneuvered into a position where it seemed necessary to drop the issue. Longstreet retained command, and Huger's troops continued to cool their heels as his men inched across the precarious bridge. 75

Longstreet now decided to further modify Johnston"s simple plan of attack. As wing commander, controlling three

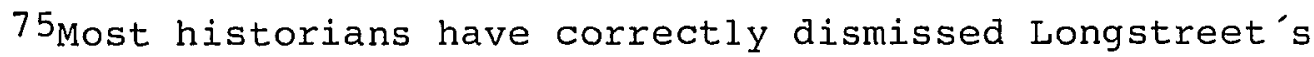
contention in his memoirs that he had admitted to Huger that he was the junior officer and that Huger had declined to take command, citing Endorsement by Benjamin Huger, August 10 , 1862, appended to "Reports of Maj. Gen. James Longstreet, $C$. S. Army, commanding Right Wing," June 10, 1862, in $\underline{\mathrm{OR}}, \mathrm{XI}$ (part 1): p. 942. There is, however, even more compelling evidence to support Huger's position, a letter he addressed to Lee the next week concerning Longstreet's rank and the reponse from the Adjutant General's Office, which reveals that the discussion had extended to dates of rank in the Confederate Regular Army. It may also be inferred from this document that Longstreet did not give Huger specific dates for his own commissions, or else Huger would have phrased his letter to confirm them rather than to ascertain them. Benjamin Huger to Robert $E$. Lee, June 7, 1862, Samuel Cooper to Benjamin Huger, June 8, 1862, in LR-AIGO, M-474, Reel 27. 
divisions, he evidently did not feel that his proper place was the direct tactical supervision of a single division. So he divided his six brigades into two demi-divisions, under Brigadier-Generals Richard Anderson and Cadmus Wilcox. Wilcox would take his own troops, plus those of Colston and Pryor, down the Charles City Road and support Huger on the extreme right of the attack, operating under the now-disgruntled major-general's orders. Anderson, with his own brigade as well as James Kemper's (A. P. Hill's old brigade), would support Hill's attack. George Pickett was deployed independently along the line of the York River Railroad in a half-hearted attempt to connect Hill's left with the right flank of the troops on the Nine Mile Road.

Longstreet's revised dispositions eradicated any possible advantage of increased weight of numbers gained by sending his division down the Williamsburg Road. Pickett's brigade was wasted. Rodes had not yet rejoined Hill, which left his main attack with only five brigades--three of his own and two of Longstreet's. The possibility of the six brigades under Huger achieving anything decisive on the Charles City Road was questionable: the ground there was exceedingly swampy, and Hill had reported on May 30 that he did not believe that there was any significant body of Federal troops within reach. 76 worse, the new attack plan

76 The best reconstruction of these orders is in Freeman, Lee's Lieutenants, I: p. 239. But see also "Reports of Maj. Gen. James Longstreet, C. S. Army, commanding Right Wing," 
entailed even more delays. Longstreet, Huger, and Hill met sometime around 10:00 A. M.77 When the meeting adjourned, Longstreet's Division--including Wilcox's detachment which had been designated to move down the charles City Road-pulled off to the side of the road and watched Huger's Division march past. 78 This pointless "leapfrog" arrangement consumed still more precious time.

The continuing delays weighed more heavily in the mind of D. H. Hill than they apparently did to Longstreet or Huger. The aggressive North Carolinian had been waiting all morning to strike his blow, and following the meeting of the three generals he decided to take some actions of his own. He correctly reasoned that his right flank would be secured by Huger's six brigades quickly enough to risk recalling his own detached brigade to strengthen his attack. Either he asked Longstreet for permission or, on his own authority as division commander, Hill sent orders to Rodes not to wait for Huger's Division to relieve him before rejoining the main body of the division. Even so, Rodes" Alabama and one Mississippi regiment took a great deal of time struggling

June 10, 1862, in OR, XI (part 1): pp. 939-942; Longstreet, Manassas to Appomattox, p. 92; Smith, "I'wo Days," p. 229 ; Smith, The Battle of Seven Pines, p. 77.

77 "Report of Maj. Gen. D. H. Hill, C. S. Army, Commanding division," - - 1862, in OR, XI (part 1): p. 943 .

78 "Report of Brig. Gen. Cadmus M. Wilcox, C. S. Army, commanding brigade," June 12, 1862, in OR, XI (part 1): p. 986 . 
north through White Oak Swamp. "The men had to wade in water waist-deep and a large number were entirely submerged," Hill reported. "It was absolutely necessary to proceed with great caution to prevent the loss of both ammunition and Iife." 79

Longstreet had not relieved Hill of the necessity of awaiting Huger's deployment on the right to initiate the attack. But by 1:00 P. M., the North Carolinian could not wait any longer. He lined his division up in a two-brigade front: Rodes' Brigade south of the Williamsburg Road, Samuel Garland's to the north, supported respectively by the brigades of Gabriel Rains and George B. Anderson. There was still no word from Huger, and only Rodes' skirmishers had arrived. Nonetheless, apparently on his own initiative, D. H. Hill fired his signal guns and sent his division forward. 80

Advancing at the sound of the signal guns, BrigadierGeneral Samuel Garland was unaware that, across the road, only Rodes' skirmishers were present, and that for the first fifteen minutes his brigade would be attacking the Federal

79 "Report of Brig. Gen. R. E. Rodes, C. S. Army, commanding brigade," June 7, 1862, in OR, XI (part 1): p. 971.

80 "Report of Maj. Gen. D. H. Hill, C. S. Army, commanding division," -- -, 1862, "Report of Brig. Gen. R. E. Rodes, C. S. Army, commanding brigade," June 7, 1862, in $\underline{\text { R, }}$ XI (part 1): pp. 943, 971 . 
IV Corps all by itself.81 But the woods were too dense for Garland's regiments to keep their alignment with each other, much less to discover that the brigade on their right had not moved. "The difficulties of the ground were almost insurmountable," Garland stated four days later:

The recent rains had formed ponds of water throughout the woods with mud at the bottom, through which the men waded forward knee-deep, and occasionally sinking to the hips in boggy places, almost beyond the point of extrication. The forest was so thick and the undergrowth so tangled that it was impracticable to see the heads of the several regiments as they moved forward, and the deploying intervals were consequently very imperfectly preserved. 82

Nonetheless, Garland's 2,200 men, unaware that for the first half hour they constituted the entire attacking force of Johnston's army in the Battle of Seven Pines, moved out aggressively.83 The 2nd Mississippi Battalion had been ordered out as skirmishers, with directions to remain at least 150 yards ahead of the main body of the brigade. But in the confusion caused by the limited visibility, when the Mississippians became engaged with the first line of Yankee pickets, the remaining five regiments under Garland's command closed the distance and moved up through them. The 2nd

81 "Report of Maj. Gen. D. H. Hill, C. S. Army, commanding division," -- -, 1862, in OR, XI (part l): p. 943.

82 "Report of Brig. Gen. Samuel Garland, Jr., C. S. Army, commanding Third Brigade, Third Division," June 3, 1862, in OR, XI (part 1): p. 961 .

$83 \mathrm{Garland}$, in Ibid., reported his strength at 2,065 effectives. Allowing 6.5\% for officers, this would have given him about 2,199 soldiers carried into action. 
Mississippi Battalion ceased to exist as a separate fighting force, even though it had taken as yet few casualties; individual companies and squads attached themselves to the nearest regiment and fought on their own for the remainder of the afternoon. 84

This was only the beginning of the disintegration of the formal command structure of Garland's Brigade and Hill's Division. Within minutes, as his brigade hit the first line of Federal abatis, Garland began to lose control of events. His senior colonel, Duncan McRae of the 5 th North Carolina, who had been entrusted with the supervision of the brigade's right flank, had not completely recovered from his wound at Williamsburg. Physical exhaustion caused him to leave the field, and forced Garland to personally move to the far right of his lines. It only required a few minutes for the brigade commander to restore order to the Tarheels; but, while he did so, Colonel Daniel H. Christie's $23 r$ d North Carolina had halted, believing it had heard an order to retreat. Simultaneously, the only field officer in the 24 th Virginia, Major Richard L. Maury, was hit by Federal fire, leaving the brigade's largest regiment in confusion. 85

His troops now heavily engaged with the enemy and somewhat out of control, Garland began to wonder where his supporting brigade was. He wanted to send a courier back to

84 Ibid. , p. 962 .

$85^{\text {Ibia. }}$ 
speed Anderson's march to the battle, but discovered that his entire staff was busy just trying to straighten out his own line of battle. "I trusted to Colonel Anderson's intuition as an accomplished soldier to perceive that we were hotly engaged," wrote Garland--trusting Anderson's instincts more likely from necessity than choice. But he was not disappointed: "as I anticipated, he arrived upon the scene just at the proper time." 86

Colonel Anderson brought up his own 1,835 men, reinforced by two regiments from Brigadier-General Richard Anderson's Brigade of Longstreet's Division, adding weight to Garland's attack just as it stalled. Yet the addition of six more regiments to the fight was only a mixed blessing. The impenetrability of the woods caused Anderson's regiments, like Garland's before them, to march forward in a somewhat haphazard fashion. The 28th Georgia, for example, ended up on the right of the 49th Virginia when it entered the battle, after beginning the approach march on the Virginian's left.87 When Anderson's augmented brigade arrived at the forward Iine of the battle, the ability of Confederate commanders to control the attack diminished even further. Garland explained in his official report that "the passage of lines being a feat in tactics which had never been practiced by

\section{Ibid.}

87 "Report of Colonel George B. Anderson, Fourth North Carolina Infantry, commanding Special Brigade," June 5, 1862, in OR, XI (part 1): pp. 951, 953. 
any of us, large fragments of those regiments who were left without fielā or company officers were joined in and continued forward with that brigade." 88

Much the same thing occurred on the north side of the Williamsburg Road as had happened with Longstreet's Division at the Battle of Williamsburg several weeks earlier. Inadequate reconnaissance left regimental commanders blind. The attacking brigades became so intermingled that no one retained effective control. Brigade commanders scurried about the field rallying and reorganizing individual companies and regiments. The senior generals, in this case D. H. Hill and Richard Anderson, found themselves able to do little more than continue to pour reinforcements into the battle.

The brigades on the left of Hill's Division, however, continued to make headway throughout the afternoon, because Federal reactions were equally disjointed. 'hough he claimed that the capture of Lieutenant washington alerted him to the possibility of an attack, the only action that BrigadierGeneral Silas Casey took to prepare the troops in front of Garland to receive it was to support his picket line with a single regiment, the 430-man-strong l03rád Pennsylvania.89

88"Report of Brig. Gen. Samuel Garland, Jr., C. S. Army, commanding Third Brigade, Third Division," June 3, 1862, in OR, XI (part 1): p. 963 .

89 "Reports of Brig. Gen. Silas Casey, U. S. Army, commanảing Secona Division," June -, 1862, "Report of Maj. Audley W. Gazzam. One hundred and third Pennsylvania Infantry," June 2, 1862, in OR, XI (part 1): pp. 914, 928 . 
Casey did not order his division under arms until two Confederate artillery shells "were thrown over my camp," by which time the lo3rd Pennsylvania was trying to resist five times its own numbers. It held for about fifteen minutes. As Casey began to order his division into line--still in piecemeal fashion--the Pennsylvanians "came down the road in some confusion, having suffered considerable loss. . . ."90

Nonetheless, with more than 4,200 men in his own three brigades, reinforced by as many men as IV Corps commander Erasmus Keyes could spare while organizing a second line of defense, Casey might have succeeded in holding his own against the Confederates attacking north of the Williamsburg Road. But fifteen minutes after Samuel Garland's men assaulted the lo3rd Pennsylvania, Robert Rodes finally brought his own brigade into the battle.

In his haste to open the battle, D. H. Hill committed an error very similar to that of Richard Anderson at williamsburg: he did not pay enough attention to one of his flanks. By the time Garland's Brigade had deployed in the line of battle, Hill could see elements of two regiments from Rodes" Brigade on the south side of the Williamsburg Road. Colonel John B. Gordon's 6th Alabama had spread out in front as skirmishers, and Colonel William H. Taylor's 12 th Mississippi had fallen in about 150 yards behind them.

90 "Reports of Brig. Gen. Silas Casey, U. S. Army, commanding Seconci Division," June -, 1862, in OR, XI (part 1): pp. 914 . 
Rodes warned Hill that he could not possibly have the remainder of the brigade in place for at least another fifteen minutes and possibly as much as half an hour. Nonetheless, Hill had resolved to order the attack.9I

This decision presented Rodes with the difficult tactical problem of just how to get his brigade, arriving unit by unit and already exhausted by its passage through the swamps, into the battle as quickly as possible. He could already hear the sound of musketry on his left to indicate that Garland was engaged. In an instant, Rodes reacted with the type of decisiveness that would begin, this day, to mark him as one of the premier, small-unit tacticians of the army; he determined to attack almost immediately en echelon, bringing each regiment through the dense woods into the battle in successive lines. As he closed with the Yankees--literally under their guns--Rodes intended to redeploy his units from parallel lines into a brigade front with all five regiments abreast. 92

The maneuver was more than audacious, it was downright dangerous. Garland's Brigade to his left had already proven unable to perform a passage of the lines of its own skirmishers, and had been thrown into total disorder by its reinforcements. What Rodes prepared to do was more complicated

91 "Reports of Brig. Gen. R. E. Rodes, C. S. Army, commanding brigade," June 7, 1862, in OR, XI (part 1): p. 971 .

\section{Ibid.}


by several orders of magnitude.

Yet despite appalling casualties, Rodes' Brigade managed to implement its commander's plan. Gordon's 6th Alabama capitalized on the fact that the Federal pickets to the north of the road were distracted by the firing there, and advanced without pause over the first line of abatis, and threatened Casey's main line of rifle pits almost before anyone knew they had attacked. Colonel Gordon himself was the first man through Casey's line of outposts, leaping his horse over the abatis, and shouting for his men to follow him through. Though a cry of "Shoot that man on horseback" echoed through the Federal line, the Colonel miraculously continued to press home his attack unscathed.93

Union resistance stiffened beyond the first pickets, however, and the 6 th Alabama and 12th Mississippi stalled in front of Casey's main line of defense. Rodes placed himself at the head of the 5th Alabama as it struggled up from its trek from the Charles City Road and led it to support the Mississippians. His remaining two infantry units--a heavy artillery battalion, under Captain C. C. Otey; and the 12th Alabama--had been instructed to enter the line of battle at predesignated points as they marched up. If everything proceeded as planned, all 2,200 men of the brigade would be

93"Report of Col. John B. Gordon, Sixth Alabama Infantry," June 7, 1862, in OR, XI (part 1): p. 979; Gordon, Reminiscences, p. 56 . 
in action within half an hour. 94

Of course the conditions under which Rodes operated were no better than those which bedeviled Garland on the far side of the road. The woods were so thick that Rodes himself lost track of half of the 5 th Alabama, ending up on the flank of the 12th Mississippi with only five companies. The heavy artillery battalion, new to the army and composed primarily or older men who had never intended to be infantry in the first place, decided that it had been given orders to halt short of the battle. The 12th Alabama, ordered to the far right flank, had discovered easier ground and advanced out of step with the rest of the brigade, to the point of crowding Gordon's skirmishers.95

Rodes" Brigade was poised, at that moment, on the point of the same degenerating confusion that had already made a shambles of the command structure on the left of the division. That did not happen here, however, due to Rodes' skill, the high standard of training in his brigade, the movements of his supporting brigade, and a healthy dose of luck. The lost companies of the 5 th Alabama, under their field officers, reoriented themselves, and arrived as a unit on the opposite side of the 12th Mississippi, allowing Rodes to quickly reunite the entire regiment during a momentary

94 "Reports of Brig. Gen. R. E. Rodes, C. S. Army, commanding brigade," June 7, 1862, in OR, XI (part 1): pp. 971-972.

95 Ibid. 
break in the firing. He personally bullied the heavy artillery battalion into the fight. Colonel Robert $T$. Jones of the 12th Alabama joined Gordon's 6th Alabama on the far right of the brigade and, without orders, provided enfilading fire against the Federal line. 96

At this juncture, Rodes' original orders called for him to sidestep his entire brigade to the right, allowing Rains' Brigade to attack through his lines. But Rains had perceptively noticed that Rodes had his hands full just forming his brigade under fire, and was certainly not prepared to perform a right oblique march. So the commander of the supporting brigade swung his own regiments around the right of Rodes' units. The maneuver proved decisive despite the considerable amount of time it took Rains" men to pick their way through the swamps, and Rodes" later complaints that Rains had left his men without support for too long a period. Rains' attack, when it came, rolled up Casey's left flank and levered his entire division out of its line.97

It had taken about two hours to drive the Federals from their first defensive line, and the fact that the Confederate attack continued to roll forward was due far more to momentum than planning or organization. Hill's main role after 3:00 P. M. was to try to keep his brigades separate and moving

\section{Ibid.}

97 Ibid.; "Report of Brig. Gen. Gabriel J. Rains, C. S. Army, commanding brigade," June 8,1862 , in OR, XI (part 1): pp. $969-970$. 
forward at roughly the same pace. He fed reinforcements into the battle more cautiously now, paying close attention to avoiding the kind of snafu that had threatened to paralyze his left in the early going. 98

Longstreet's role in the battle after it opened was far less significant than Hill's. He had released Anderson and Kemper to the division commander before the opening of the attack, so when the North Carolinian committed their troops it was on his own initiative. The Georgian never appeared anywhere near the front line of the battle.99 His sole contribution to Hill's attack seems to have been to order Wilcox's Brigade to countermarch yet again, back from Charles City Road to the Williamsburg Road, where Wilcox arrived too late to make any real contribution to the battle.100 By the time Longstreet penned his 4:00 P. M. note to Johnston that his men were driving the enemy, Hill had supervised--if loosely--all the fighting. And all the fighting had been done, thanks to Longstreet's orders, by six of thirteen available brigades.

Yet there was more than a kernel of truth in Longstreet's contention that he had defeated the Yankees and

98 "Report of Maj. Gen. D. H. Hill, C. S. Army, commanding division," -- -, 1862, in OR, XI (part 1): p. 944.

${ }^{99}$ D. H. Hill to Gustavus W. Smith, May 22, 1885, quoted in Smith, The Battle of Seven Pines, p. 66 .

100 "Report of Brig. Gen. Cadmus M. Wilcox, C. S. Army, commanding brigade," June 12, 1862, in OR, XI (part 1): pp. 986-987. 
that they needed only one more sharp push to disintegrate the IV Corps, if not also the III. Despite the substantial reinforcements from Samuel Heinztelman's III Corp which had arrived to bolster his position, and the fact that he had enjoyed several hours to deploy Couch's division as Casey's men slowly crumbled, Erasmus Keyes could not hold his second line. Hill's men, admittedly at the cost of murderous casualties, sent the Yankees reeling back again. By this point Hill's reinforced division had captured ten cannon and held a field scattered with "6,700 muskets and rifles in fine condition, ordnance, commissary, and medical stores."101 A flank attack down the Nine Mile Road might well have delivered the coup de grace, at least to the extent of routing two Federal corps back to the chickahominy.

But by the time that Johnston received Longstreet's message, the conditions under which such an attack would have been possible had changed. Even as Johnston frantically prepared to attack with Whiting's Division, another Federal corps commander took decisive action to save the day for the Army of the Potomac. Edwin Vose Sumner's II Corps, deployed along the north bank of the Chickahominy between the Upper and Lower Bridges, was the portion of McClellan's army closest to the fighting. But the bridges were under water, and Sumner was the commander who had vacillated so long at

101 "Report of Maj. Gen. D. H. Hill, C. S. Army, commanding division," -- -, 1862, in OR, XI (part 1): p. 945. 
Williamsburg that he allowed Hancock's flanking action to accomplish nothing. It should have been a recipe for disaster.

Yet when the moment came on May 31, Sumner did not hesitate. At 1:00 P. M., McClellan advised him that an attack had commenced south of the river and ordered sumner "to be in readiness to move at a moment's warning." At 2:30 P. M., the call came to cross the bridges and march to support Keyes and Heintzelman.102 Perhaps the difference from Williamsburg was that sumner was not in overall command; he merely had to react to orders. His division commanders, Israel B. Richardson and John Sedgwick, were instructed to cross the Chickahominy, regardless of the condition of the bridges. "Our men," reported Richardson, "were obliged to wade (part of the bridge having been swept away) nearly up to their middles in water, and of course could follow but slowly.103 By 4:00 P. M., Sedgwick's division was marching into position on the Federal right at Seven Pines, and the advance by Whiting's Division would not hit the flank of a defeated enemy, but would encounter three fresh brigades of unbloodied Yankees.

Johnston ordered Hood's Brigade into the woods and

102 "Report of Brig. Gen. Edwin V. Sumner, U. S. Army, commanding Second Corps," June 9, 1862, in OR, XI (part 1): p. 763 .

103 "Report of Brig. Gen. Israel B. Richardson, U. S.

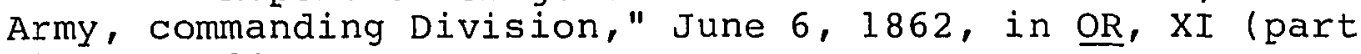
1): p. 764 . 
swamps between the Nine Mile and Williamsburg Roads, in an attempt to link Whiting's right flank with Hill's left. The Texans obligingly angled off into the forest and promptly got lost, removing themselves from the remainder of the battle.104 The army commander planned to send Pettigrew's and Whiting's Brigades abreast in line of battle down the Nine Mile Road. When Smith brought up Hampton and Hatton, the former would extend the line, and the latter would become the division reserve.105 It was a relatively orthodox deployment for those four brigades, marred only by two facts: there were three different generals supervising the move and nobody knew that sedgwick's division was in the woods.

By taking personal command of the division, Johnston had, in his anxiety, both abdicated his role as army commander and also reduced Smith and Whiting to high-ranking supernumeraries. He sent Smith dashing back and forth--first to bring up Hampton and Hatton; again to modify their marching orders; and finally, when contact was made at Fair Oaks Station, to detach brigades from Magruder farther down the river. These were errands that any competent lieutenant serving as an aide de camp should have been able to handle. Johnston kept Whiting at his side; but while he issued his p. 174 .

104 McMurry, Hood, p. 41; Smith, Confederate war Papers, 105Smith, Confederate War Papers, pp. 174-175. 
own orders through the division commander, Johnston did not allow him to function as a commanding general. In the case of Smith, whom Johnston already distrusted, his actions were understandable, if not laudable. In the case of Whiting, who was one of Johnston's most trusted subordinates, his usurpation of the Brigadier-General's command revealed just how badly he was feeling the strain of battle.

As a result of these unwieldy command arrangements, Whiting's Division took far longer than it should have to deploy for battle. Hood, as already noted, simply disappeared. Hampton's Brigade, blundering around in the woods, almost engaged in a fire fight with Pettigrew's men.106 As the sun began to sink, the division finally moved forward, only to run into the unexpected fire of Sedgwick's division. Two batteries of Federal artillery, supported by two of Sedgwick's brigades: the First under Brigadier-General Willis A. Gorman and the Third under Brigadier-General Napoleon J. T. Dana, had arrived in the vicinity of Fair Oaks station. Sedgwick himself was farther down the line, supervising the movement of his other brigade as it connected with the right flank of the hard-pressed III and IV Corps at Seven Pines. This left the immediate direction of the bulk of his division in sumner's hands.107

106 Ibid. , p. 175 .

107 "Report of Brig. Gen. John Sedgwick, U. S. Army, commanding Second Division," June 4, 1862, in OR, XI (part 1): p. 792 . 
Whiting, ever pessimistic, had warned Johnston that the Federals might have crossed the river. But suddenly sensing a chance to win a victory regardless of all the day's miscues, Johnston ignored him. "Oh!" one of Whiting's staff officers recalled the army commander exclaiming, "General Whiting, you are too cautious."108 when the Union artillery opened on the unsuspecting Confederates, the response of the leading brigades was an immediate, uncoordinated attack. This assault failed in short order. Since it had occurred more or less spontaneously, and had not involved all the personnel of the three brigades, the troops rallied very quickly. They were ordered in again. 109

This attack involved all four of the available brigades, and was pressed with a great deal more vigor. BrigadierGeneral Gorman, whose troops supported one of the batteries, reported the contest "as severe a fire of musketry as ever was witnessed or heard, perhaps, by the oldest officers of the army. . ."1l0 practically invisible in the woods and supported by twelve cannon, the Federal troops at Fair Oaks made up for the ignominious retreat of their comrades at Seven Pines. Neither Gorman's nor Dana's brigades suffered

108B. W. Frobel to Gustavus W. Smith, February -, 1868, quoted in Smith, Confederate War Papers, p. 179.

109 Ibid.

110 "Report of Brig. Gen. Willis A. Gorman, U. S. Army, commanding First Brigade," June 3, 1862, in OR, XI (part 1): p. 800 . 
more than 200 casualties; the four brigades of whiting's Division took nearly 1,300. Three of his four engaged brigadiers went down: Hatton killed, Pettigrew seriously wounded and captured, Hampton shot in the foot. As dusk began to fall, it was no longer a question of whether or not Whiting's men could break through the enemy, but whether they could hold their ground.111

The abortive attack of Whiting's Division highlighted the tactical mismanagement of the Battle of seven Pines. Johnston started his brigades forward without any attempt to reconnoiter for Yankees along their route of march. BY accompanying the division personally, the army commander not only confused its chain of command, but also removed himself from the best location on the field from which to coordinate reinforcements. There was no one left at his former headquarters with either complete knowledge of the battle plan or authority to shift troops in Johnston's absence; if McClellan had been industrious enough to counterattack Johnston's far left flank, there would have been no way for A. P. Hill to request reinforcements quickly. Given all of this, why did Johnston decide to supervise Whiting's attack in person?

Three answers suggest themselves, all of which may have

111 "Return of Casualties in the Army of the Potomac at the Battle of Fair Oaks, of Seven Pines, Va., May 31 -June 1 , 1862 ," in OR, XI (part I): p. 758; Smith, Confederate War Papers, pp. 176-177. 
affected the army commander's choice, and rest upon a clear understanding of the mental strain Johnston felt in the late afternoon hours of May 31 .

Johnston had been conscious of his growing cadre of observers since before dawn. Smith, who had every reason now to be a critical witness, had been with him since first light, accompanied by his entire staff. Whiting, who had ridden up as his division approached at midmorning, had hovered around headquarters all day as well; though Johnston accounted him as a friend, Whiting represented another officer whose opinion of the army commander's capabilities might suffer as the result of a botched battle. To these two, Lee's presence was added sometime around noon--his rank and his position both made his presence discomforting to Johnston as he waited for the battle to open. And finally, at just about 4:00 P. M., as Johnston received Longstreet's note, President Davis himself cantered down the Nine Mile Road to join the impromptu entourage that had conglomerated around him. 112

The President's arrival may have been the last straw for Johnston. He knew that Davis's opinion of his administrative ability had been marred by the President's recent excursions to the front when the Chief Executive had been greeted by disorganization and nonexistent attacks. He could also be sure that Davis, unlike Lee, would immediately

$$
112 \text { Davis, Rise and Fall, II: p. } 122 \text {. }
$$


open any conversation with direct inquiries into the progress of the battle. With Smith around and fully aware of the original design, Johnston would be forced to admit that nothing had thus far transpired in accordance with his wishes. He would have to tell Davis that Longstreet had taken the wrong road, that the attack had opened six to eight hours late, and that no one on the Nine Mile Road had been sure enough that the fight had begun to launch the left wing into action promptly.

on the other hand, if Johnston rode off with Whiting's Division, he would escape such a painful situation, at least for the moment. If Whiting's attack succeeded, and he could bring back tidings that included the destruction of at least one Federal corps, then he could reasonably expect that embarrassing post mortems would be delayed for a much longer time, and might be avoided forever in the flush of a desperately needed victory.

It is also possible that Johnston, whose ambitious strain always made him consider the question of personal reputation and ultimate credit for battles won, rode with Whiting's Division not because he feared the President's inquisition, but because he scented victory. Johnston never forgot that at Manassas he had dispatched Beauregard to the threatened flank rather than going there himself; in his Narrative he wrote: "After assigning Beauregard to the command of the troops immediately engaged, which he properly 
suggested belonged to the second in rank, not to the commanaer of the army, I returned to the supervision of the whole field."113 After that battle, noted Freeman, "there was praise for Johnston, to be sure," yet "the concentration of the two armies, not less than the victory itself, was assumed to be the work of Beauregard."1l4 Nothing that Johnston said or wrote, then or later, ever managed to dispel this impression. If Whiting or Longstreet delivered the knockout blow at Seven Pines while Johnston remained again at headquarters, it must have occurrea to him that nistory might well repeat itself.

Both of the foregoing explanations reflect less than favorably on Johnston's personal integrity. They imply that the army commander might base his actions on personal motives--and not purely military considerations--even under the strain of a battle that had gotten out of his control. There is also the possibility that the overriding concern in Johnston's mind was one of conmand. His two most trusted lieutenants had each botched a major operation: Smith by declining to attack on May 28, and Longstreet that mornincj by following the wrong road. The Kentuckian and the Georgian were the two generals whom Johnston had always considered not only competent but absolutely indispensable. If he could not safely assign missions to them, how could he rely

\footnotetext{
113 Johnston, Narrative, pp. 48-49. 114 Freeman, Lee's Lieutenant's, I: p. 80 .
} 
on their juniors? When the instant came in which Johnston expected to strike the decisive blow, he may well have acted out of a belief that the only way to assure an immediate and aggressive movement was to lead it himself.

It should be emphasized, however, that Johnston's choice to accompany Whiting's Division was made in minutes if not seconds. All of the considerations detailed above may have influenced him to a greater or lesser degree; but, in the necessity for haste that he would have felt upon the receipt of Longstreet's note, Johnston had precious little time to think the options through. He did not have the luxury of hours to brood and rationalize like Longstreet the previous night; he had to determine his course as immediately as did Rocles when be brought his brigade into the fighting south of the Williamsburg Road. It is quite possible that all of these considerations passed so rapidly through the army commander's mind that later, upon reflection, he could not reconstruct his reasons even to himself.115

There would be no occasion for such reflection that evening, however, for Joseph Johnston. As it became obvious

115 The manner in which Johnston rewrote his role at the key moment in the battle during the postwar years gives a very strong indication of just how uncomfortable the General was with his rather rash decision to lead Whiting's Division himself. In both the Narrative and his article for Battles and Leaders, Johnston related that he had directed that the division be sent forward, omitting the fact that he accompanied it and issued orders directly to its brigadiers. See Johnston, Narrative, pp. 136-137; Johnston, "Manassas to Seven Pines," B\&L, II: p. 214. 
that Whiting's Division had been stalemated and the evening shadows grew longer and longer, he realized that his army could not follow up the blow that had sent two Federal corps reeling, at least not that day. Yet despite the result at Fair Oaks Station, Longstreet's apparent partial victory might be completed with another attack the next day. "So I announced to my staff officers," Johnston recailed, "that each regiment must sleep where it might be standing when the contest ceased for the night, to be ready to renew it at dawn next morning."ll6

But the battle, if it was to continue on June 1, would have to do so in his absence. Johnston had hardly given those last orders when a stray musket ball hit him in the right shoulder. Though this inflicted little more than a superficial wound, the effects of the random fragment of a Federal artillery shell which then slammed into his chest were far more serious. The impact unseated him from his saddle, and though he never lost consciousness it was a dazed and severely wounded Johnston that his aides carried off the field.117

Though he did not yet realize it, Joseph E. Johnston's campaign in the defense of Richmond had abruptly ended.

116 Johnston, Narrative, p. 138. 117 Ibid. 


\section{Chapter Twelve \\ Johnston's Campaign: An Assessment}

As cynical as the proposition appears, dying in battle at the proper moment can do great things for a general's reputation, while surviving even a great victory can be a dreadful mistake. The American Civil War was full of examples that proved both cases. For almost a century following the death of Albert Sidney Johnston, the fatal wound he received on the first day of the Battle of Shiloh deflected from his memory criticism of his conduct of operations in the months preceding the battle. From the standpoint of his entrance into the pantheon of Confederate legends, no novelist or scriptwriter could have imagined a more dramatic end for "Stonewall" Jackson than to be shot down by his own men at Chancellorsville, in the hour of one of his most audacious and successful maneuvers.

On the opposite side of the coin, by surviving Gettysburg, both George Meade and George Pickett found themselves forced to endure the decline of their reputations from glory into mediocrity. Meade lived to be castigated for failing to pursue Lee's beaten army, raked over the coals by an unsympathic Congressional committee, superseded by Grant, and eventually denied the post of Commanding General of the United States Army in favor of a man who had been his junior 495 
throughout the war. Pickett faced humiliation and defeat at Five Forks and questions after the war about just how he, among all the generals and all but one of the field officers in his three brigades, had avoided Yankee fire in the charge that destroyed his division. Ironically, the verdict of their peers and historians on both men would probably have been much more favorable if Meade had fallen defending Cemetery Ridge and Pickett had died assaulting it.

Johnston's eventual recuperation from the wounds he received at Seven Pines landed him in the company of Meade and Pickett rather than Jackson or the other Johnston. By the time Johnston had recovered sufficiently to return to active duty, Robert E. Lee had an undisputable claim to command of the Army of Northern Virginia. He had driven McClellan away from Richmond in the Seven Days Battles, routed John Pope at Second Manassas, invaded Maryland, and fought the Army of the Potomac to a bloody standstill at Antietam Creek. When Lee's accomplishments were compared to Johnston's record--partial credit for victory at First Manassas, a minor defensive success at williamsburg, and the disjointed stalemate at Seven Pines--it was obvious that no one could expect Jefferson Davis to remove Lee from command in order to reinstate Johnston.

But the President could hardly be accused of injustice to the man who had become the confederacy's second ranking field general. Johnston was assigned in November, 1862, to 
command Department No. 2 , a vast theater that included both Braxton Bragg's Army of Tennessee and John C. Pemberton's army defending vicksburg. It was not a fortunate assignment. Johnston, who would have preferred to lead any single field army, saw his authority as "little more than nominal." He quarreled with the President over strategy, complained that he could never get Pemberton to follow his orders, and presided over the Confederate debacle at Vicksburg. With defeat came frenzied rounds of mutual recriminations that extended to generals and politicians alike; Johnston did not escape unscathed.

Yet Vicksburg did not end his career as it did Pemberton's. After Bragg's defeat at Missionary Ridge in November, 1863, the President set personal rancor aside and appointed Johnston to succeed Bragg in command of the Army of Tennessee. His administrative abilities paid immediate dividends in the restoration of morale and efficiency to his dispirited divisions, and when the campaign of 1864 opened he was back in the spotlight again: defending Atlanta against Sherman while Lee resisted Grant before Richmond. But Johnston's fabian policy of retreating, with the avowed intent of drawing Sherman deeply enough into Confederate territory to assure his army's destruction, did not suit Jefferson Davis at all. By mid-July, Johnston had backed up to the suburbs of Atlanta, and when he could not get from the army commander

1 Johnston, Narrative, p. 154 . 
what he considered to be sufficient guarantees of offensive action, the President sacked Johnston in favor of John Bell Hood.' Hood attacked and lost thousands of men and the city. Johnston claimed that he had been on the verge of launching a successful offensive when relieved; Davis countered that the General had, in fact, been on the verge of abandoning Atlanta without a fight.

The final postscript to Johnston's career was his recall in February, 1865, this time at the insistence of Lee, to undertake the hopeless task of trying to halt sherman's rampage through the Carolinas. Johnston scored a small tactical victory at the Battle of Bentonville on March 19, attacking an isolated wing of Sherman's army; but, it was far too late to have any effect on the course of the war.

When the war ended it was followed in remarkably short order by a war of words among ex-Confederate politicians and military officers, scrambling to avoid being assessed the responsibility for the South's defeat. Men who had fought and bled together now divided into new camps and attacked each other with a petty vindictiveness that often served more to diminish their reputations than to protect them. Carefully worded statements of fact--as misleading as they were true-along with innuendo, edited documents, artfully doctored reminiscences, and outright lies were the weapons in this second, far less honorable conflict.

None of the principals in Johnston's defense of Richmond 
managed to remain above the mud-slinging. The memoirs and articles of Joseph Johnston, Jefferson Davis, Gustavus Smith, and James Longstreet were colored by self-justification and marred by inaccuracies, as were those of lower ranking officers from Jubal Early to John Gordon, Armistead Long to John Bell Hood. For anyone determined to pick his way through the literary charges and countercharges in order to reconcile all the discrepancies, it represents an assignment as hazardous as that handed to the Yankee pickets who had to enter Yorktown after Gabriel Rains had booby-trapped the town with explosives.

The campaign to defend Richmond represents a particular problem for the historian intent upon assessing Johnston's performance as a general, for the course of events leading up to seven Pines has received relatively little attention, even among the writers of memoirs. This is due, in part, to the fact that, while the defense of Richmond in 1862 ended successfully under the direction of Lee and not Jackson, those of Vicksburg and Atlanta did not. Generals rarely feel the need to defend victorious campaigns. When the question of Johnston's Peninsular Campaign did arise in his own memoirs, it was often merely as a blind for some argument about Vicksburg or Atlanta. Hood, for example, voiced the contention that Johnston had supposedly contemplated the evacuation in 1862 as a rationale for believing that he 
would have deserted Atlanta in 1864.2

To evaluate Johnston's performance in 1862 fairly then, it is necessary to approach that campaign as much as possible without reference to later battles or subsequent controversies. In one sense, it is almost necessary to pretend that Johnston's wound at Seven Pines indeed proved fatal in order to reach a judgment on his capacity as a general at that time. Johnston quickly convinced himself that his injuries had snatched victory from his grasp. In his initial report, filed June 24, 1862, Johnston ignored Longstreet's mistake in following the Williamsburg Road (he also asked Gustavus Smith to purge a reference to it from his own report) and relied heavily on the Georgian's recounting of the fighting in front of Seven Pines. Longstreet, anxious to find a scapegoat for his delay in opening the attack, blamed Huger for not marching into position in time. Johnston picked this up and asserted that "had Major-General Huger's Division been in position and ready for action when those of Smith, Longstreet, and Hill moved, I am satisfied that Keyes' corps would have been destroyed instead of being merely defeated." 3

Eventually, due primarily to the efforts of Gustavus

2Hood, Advance and Retreat, pp. 23, 154-156.

3 "Report of General Joseph E. Johnston, C. S. Army, commanding Army of Northern Virginia, and resulting correspondence," June 24, 1862, "Reports of Maj. Gen. James Longstreet, C. S. Army, commanding Right Wing," June 10, 1862, in OR, XI (part 1): pp. 935, 939-941; Smith, Confederate War Papers, pp. 165-171. 
Smith, Huger would be exonerated of the charge that he did not arrive at his designated objective on time.4 Johnston, still convinced that a decisive success had only narrowly eluded him, shifted the ground of his argument, and laid the blame on Smith. "Darkness only," halted the battle on May 31 , Johnston contended, but after the army was turned over to Smith there was "no serious fighting" on June 1, despite the fact that "advantage of position and superiority of numbers would have enabled them to defeat that [Keyes'] corps had the engagement been renewed on Sunday morning. . . . 5 Though Smith spent thirty years presenting evidence to disprove this assertion, arguing that he had attempted to attack on the second day, only to be frustrated by Longstreet's inaction, he never managed to escape the image of a general who folded up under the strain of combat. Freeman, the first historian to examine the evidence closely, seriously condemned the Kentuckian for "vacillation, overcaution and conflicting orders" on June 1.6 Though his rationalizations

${ }^{4}$ Smith dealt with Huger's "alleged "slow movements" in everything he wrote about the battle, more out of an interest in smearing Longstreet's name than from any regard or friendship for Huger. The best case is made in Smith, The Battle of Seven Pines, pp. 64-82.

5 That Johnston did not initially blame Smith for the failure to gain a victory on June 1 is evident from the tone of his June 24, 1862 report. "Report of General Joseph E. Johnston, C. S. Army, commanding Army of Northern Virginia, and resulting correspondence," June 24, 1862, in OR, XI (part 1): pp. 933-935; Johnston, Narrative, pp. $139,1 \overline{41}$.

$$
6 \text { Freeman, Lee's Lieutenants, I: p. } 243 .
$$


changed, Johnston enjoyed great success for many years in advancing the idea that, as Beauregard was almost universally blamed for not pressing home the attack on Grant after Albert Sidney Johnston fell at Shiloh, Smith was the culprit for not delivering the coup de grace at Seven Pines.

Though there was in truth very little to praise in Smith's conduct of the battle on June 1, Johnston's accusation that he had forfeited the fruits of a hard-won victory was without any factual basis. By Sunday morning, there were an equal number of Federal and Confederate soldiers on the field south of the Chickahominy, including fresh troops on both sides that had not participated in the previous days' fighting. Of the Union units which had been bloodied in Hill's attack, onl $\ddot{y}$ a portion of Casey's division had not been sufficiently reorganized to go into combat again. The Confederate advantage of surprise had certainly been lost. Casualties among general officers had been severe for a battle of no more than five hours and included the army commander and four of the ten brigade commanders who were actually engaged. Yankee confidence, far from being shattered, remained solid enough that almost all the actions of June 1 were Federal and not Confederate attacks. 7

But the opportunity to smash at least Keyes' IV Corps on May 31 had been very real. Had Johnston's original plan been 42 .

7"McClellan's Report (2)," in OR, XI (part 1): pp. 41- 
executed, Keyes' six brigades would have been assaulted by thirteen Confederate brigades: three under Huger, four under Hil1, and six under Longstreet. Union reinforcements available in the first two hours would only have been Heintzelman's six brigades, while Johnston had four under McLaws and five under Whiting in reserve. But Johnston's relatively simple plan went hopelessly awry from the very beginning.

It is questionable to what extent Johnston may be faulted for Longstreet's carefully rationalized disobedience. Both Robert $\mathrm{E}$. Lee and Braxton Bragg discovered in their turn that Longstreet, while undeniably talented, was incredibly willful, and his cooperation with operations of which he did not approve was notoriously poor. Nonetheless, given the vague nature of the orders Johnston dispatched to Huger, it is possible to suspect that Johnston may well have employed somewhat ambiguous language in his final oral orders to his wing commander.

It is a military truism that no plan survives contact with the enemy. It is the army commander's responsibility to adapt to unexpected events; therefore, the delegation of an important mission such as Longstreet's supervisory authority over the attack of the right wing does not relieve the commanding general from the responsibility to maintain control of the various detachments of his army. In these terms, at the Battle of Seven Pines, Joseph Johnston failed miserably. 
Johnston made no provisions for couriers or staff officers to move on a regular basis between the separated wings of his army in order to keep him updated on the progress of each division. When the first reports arrived that Longstreet had taken the wrong road, Johnston wasted precious hours without deciding on a modified plan or a cancellation of the attack. In the event the signal guns did not carry, there was no back-up for alerting units on the Nine Mile Road that the attack to the south had begun. Finally, Johnston totally abdicated his responsibility for the overall conduct of the battle when he led Whiting's Division down the Nine Mile Road to Fair Oaks station.

Yet it must be noted that similar failings bedeviled almost every commanding general, Confederate or Union, in his first offensive battle. Civil war battles were almost all planned and fought by generals who had never commanded more than a single regiment under fire prior to 1861 . Lee at Mechanicsville, Bragg at Stone's River, Hood at Peachtree Creek, and Beauregard at Drewry's Bluff all committed the same or comparable mistakes, as did McClellan at Antietam, Hooker at Chancellorsville, Meade at Mine Run, Sherman at Chicksaw Bluffs, and Grant at Belmont. The good generals learned from their mistakes, and slowly, painfully, improved their performances in subsequent battles. It was, however, as Bruce Catton pointed out with regard to ulysses Grant, "at a prodigious cost to himself and to some thousands of young men 
who, without quite realizing it, had joined the Union Army in order to pay for his education." 8 In almost every case, it was very difficult to render a valid judgment on the basis of the first offensive battle, because almost no one ever performed well. The value of a general could best be determined by observing whether or not he was able to improve upon this performance.

If Johnston had botched Seven Pines, he had not done so in a disastrous manner: he had not won, but he had not been defeated either; and, his army certainly survived to fight again. A man as realistic as Jefferson Davis would have known that the proof would come the next time. And that, of course, would eventually be the rub. Robert $E$. Lee handled the Battle of Mechanicsville on June 26, 1862, little, if any, better than Johnston managed the Battle of Seven Pines. But Lee's second attack, the Battle of Gaines' Mill, came on the following day and proved that if he had not become perfect overnight he was capable of learning something from his own mistakes. Johnston may well have been just as able to learn from his own mistakes as Lee, and might have proved that on June I had he not been wounded. Through choice or circumstance, however, Joseph Johnston did not fight another offensive battle until nearly three years later, at Bentonville on March 19, 1865.

\footnotetext{
8Bruce Catton, Grant Moves South (Boston: Little, Brown and Company, 1960), Pp. 216-217.
} 
This, of course, was hardly knowable on the evening of May 31, 1862. Based on his performance at Seven Pines, a verdict on Johnston as a battlefield commander would have been a provisional one: if he had not proved to be an immediate savant, he had not been an unmitigated disaster. His conduct rated another opportunity, and throughout the war Jefferson Davis made good-faith efforts to give him that chance.

Johnston claimed that, even allowing for his failure to totally crush Keyes' corps, the Battle of Seven Pines resulted in two very favorable advantages for his successor. The attack had rocked McClellan enough to freeze him in his tracks for about three weeks, and this period of inaction provided enough time for Lee to receive substantial reinforcements: "General Lee did not attack the enemy until June $26 t h$, because he was engaged from June lst until then in forming a great army. . . . 9

The first of these contentions was valid: the first thing McClellan did in the battle's aftermath was demand that more troops be sent to him before he could advance. 10 But Johnston's insistence that Lee benefited from the time to build a great army that he had been denied was inaccurate. Johnston cited the Army of Northern Virginia as having been augmented between June 1 and 26 with the divisions of Holmes,

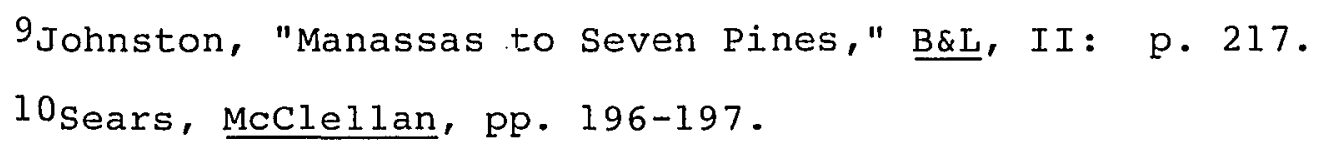


Jackson, and Ewell, as well as the brigades of Ripley and Alexander Lawton and miscellaneous troops.ll But Johnston's argument here was spurious. Holmes and Ripley were in the Richmond area on May 31 and already subject to his orders. If he had considered their participation critical to success, it required but a single day's delay in his battle plan. Jackson and Ewell were also under Johnston's command; they were not available at the end of May because Johnston himself had approved the operations in the Shenandoah Valley which detained them. As has already been shown, in May, 1862, Johnston definitely considered the absence of those two divisions to be completely compensated for by the corresponding absence of the armies of Banks and McDowell on his flanks. Thus, in Johnston's catalogue of units sent to Lee during June, only Lawton's Georgia Brigade had not actually been near his army or under his control on May 31, and Lawton's regiments did not quite muster enough men--even by Johnston's own optimistic estimate--to do more than replace the battle losses of Seven Pines.12 The time won at Seven Pines benefitted Lee by allowing Jackson to finish the Valley Campaign (the troops already in transit to arrive), and to dig substantial entrenchments in front of Richmond.

The successes and failures of Seven Pines, however, were hardly the whole measure of Johnston's defense of Richmond up

11Johnston, "Manassas to Seven Pines," B\&L, II: p. 217. 12 Ibid. 
to May 31, 1862. Between the February conference in Richmond and Johnston's fall from his horse beside the Nine Mile Road, the Confederates had gained several important strategic advantages. First and foremost, the campaign had bought for Jefferson Davis three months of valuable time--time to produce or import weapons, time to muster and train new troops, and time to reorganize the army onto a wartime footing. The second material result of Johnston's campaign was that by the end of May the overwhelming numerical advantage of Union numbers--nearly a four-to-one superiority in February--had been reduced so far at the point of contact that Johnston's inferiority to the Army of the Potomac was roughly 10,000 men. In armies of 80,000-100,000 troops, this hardly represented any decisive disadvantage. And Lee fared even better the next month, entering the Seven Days' Battles with a slight numerical superiority, and fielding the largest army the Confederacy ever sent into battle. This had been achieved by a combination of strategic juggling in Virginia and along the Atlantic Coast, where garrisons were stripped to bare essentials; and the operational maneuvers of Confederate forces in Virginia which led to the immobilization of Banks and McDowel1. Finally, from the nucleus of detached garrisons, strung out across the Potomac frontier throughout the winter of 1861-1862, a solid, well-organized, maneuverable army had been formed: the Army of Northern Virginia. It was not, and it never became, a perfect organization, but 
the army that Joseph Johnston unknowingly and unwillingly bequeathed to Robert $\mathrm{E}$. Lee stood upon a very firm foundation. But these accomplishments cannot be ascribed to Joseph Johnston simply because he commanded the Department of Northern Virginia. Other key leaders, from Davis to Lee and from Jackson to Magruder, played essential roles in the defense of Virginia. To what extent did Joseph Johnston contribute to the successes of early 1862?

The breathing spell won for the Confederacy in this campaign was chiefly the result of three events: the Valley Campaign, the siege of Yorktown, and the retreat up the Peninsula. Johnston's role in the Valley Campaign was supportive but not seminal. He clearly envisioned the potential for combined operations between Jackson and Ewell when the rest of the army left northern virginia for the Yorktown line, though he did not map out a specific strategy. He expected Jackson and Ewell to react opportunistically to Federal miscues. It was the correspondence of Lee and Jackson in late April that developed the original premises of the campaign which would paralyze several Federal armies and terrorize Washington. Nonetheless, Johnston supported the general thrust of the operation when he found out about it, and though his mid-May strategic concepts were slightly at variance with those of Lee and Jackson, they were equally workable. Johnston certainly never lost sight of the important contribution that active forces in the valley and 
central Virginia could make to the defense of Richmond, and he never pursued a myopic strategy of concentration of all the troops in Virginia under his immediate control as a panacea to overcome his own manpower deficiencies.

Initial credit for the delay of McClellan at Yorktown has to be accorded without question to John B. Magruder. In the critical two weeks between March 17 and 31 , he held his line with bravado and a paltry number of troops while Lee wrestled with the problems of determining McClellan's intentions and reinforced him with agonizing slowness. From April 1 through Johnston's evacuation on May 3, 35,000 soldiers on the Peninsula would probably have bought the Confederacy as much time as the 70,000 eventually committed there. All that was required of a commanding general throughout most of the month was a stolid resolution to defend the trenches and redoubts. Magruder himself, Longstreet, Smith, or even D. H. Hill had the skill and tenacity to maintain that line during April, 1862. What Johnston provided was twofold: the only realistic evaluation of just how long Yorktown could be held, and the insight to know exactly when it must be abandoned. The first, even though Johnston's views did not prevail during the April conference in Richmond, alerted both Lee and Davis to the amount of time that they could continue to defer making some very tough choices. The second, if Mcclellan's own engineers are to be believed, at least saved the army thousands of casualties, and possibly avoided its capture. Had 
Johnston's army remained in the Yorktown entrenchments when the Confederate batteries at Gloucester Point were dismounted, there would have been no troops far enough up the Peninsula to resist Franklin's landing at west Point: the army would have been cut off from Richmond and assailed from both front and rear. Johnston's was the key decision that kept the seige of Yorktown from turning into an irredeemable disaster.

The month that the Army of the Potomac required to creep from Yorktown to Seven Pines must be equally attributed to Joseph Johnston and George MCClelian. It is arguable that had Johnston merely decamped from Yorktown and never looked back, the Federal commander could have taken, in his own timidity, almost as long to approach Richmond as he did with Johnston retreating slowly and stopping periodically to offer battle. But that fact does not diminish Johnston's efficiency--only extremely incompetent generals depend upon their enemies to do the wrong thing.

Despite his failure to closely supervise the Battle of Williamsburg, Johnston's retreat was marked by skillful maneuver and strategic insight under difficult conditions. Clear thinking and careful supervision of the army's movements were needed to overcome the muddy roads and general scarcity of transportation. Johnston was able to overcome these hindrances and to balance the deployment of his four divisions so that two would be present to handle the rear guard contest at williamsburg and two would be close enough to 
oppose an amphibious landing near west point. The point between the Pamunkey and Chickahominy River at which Johnston chose to end his retreat and await McClellan was selected based on a sound appreciation of his strategic position. His lines were clear of navigable water, logistically convenient to Richmond, and heavily enough wooded to partially negate McClellan's stili prevalent numerical advantage. It was also a line that, for as long as he held it, kept Johnston's army solidly between McClellan and McDowell. If the failure of the Richmond authorities to press the completion of the fortifications at Drewry's Bluff had not compelled him to retreat across the Chickahominy, McClellan would have been faced with a serious operational dilemma. He would either have to attack Johnston on ground of Johnston's own choice in which his soldiers had been digging entrenchments and laying out abatis for three to five days, forfeiting the advantages of his naval and heavy artillery, or he would have to risk crossing the Chickahominy with the Confederates on his flank. In the end, fear of Federal ironclads and not McClellan forced Johnston out of this position.

Thus, from an operational standpoint, Johnston performed quite well. He contributed to the Valley Campaign, made the key decision at Yorktown, and handled the retreat up the Peninsula with efficiency and aplomb. If his initial conception of strategy in the valley was somewhat hazy, he knew how to exploit the opportunities presented him. Confronted 
with multiple threats, his instincts were consistently sound, and, as in the case of his timing of the Yorktown evacuation, sometimes inspired.

As the Commanding General of the Confederate Army, it was Lee and not Johnston who found the steady stream of troops who reinforced the army between March and June. Lee made the best possible use of the time won by Johnston, Jackson, and Magruder to muster new troops and cajole governors and generals alike into accepting smaller forces in Georgia and the Carolinas. Lee took pains to see that when new regiments were organized they went to the static garrisons to replace more seasoned troops to reinforce the army in Virginia. Thus Johnston consistently received the best-trained brigades available in the eastern Confederacy. Yet Johnston had been the one participant in the April conference who insisted that it was feasible to reduce the coastal garrison. He had argued his point adamantly; as an army commander there was really nothing else he could do.

Johnston consistently used his administrative skills to maintain the army assembled under him at the highest possible strength. From the winter through the spring, Joseph Johnston proved himself an exceptionally capable administrator, managing his limited supplies as efficiently as possible, and combatting desertion, malingering, sickness, malnutrition, and disaffection every day. Johnston conducted both the retreat from the Potomac and the retreat from Yorktown with 
minimal losses of critical supplies, and supervised the transitional elections required by the Conscription Act in a manner that minimized their damage to the army's efficiency. His instincts for command organization were sound, but continually thwarted by Confederate law. He did not ever favor operating his army as separate divisions, realizing that such an arrangement was terminally unwieldy for an army in battle or on the march. His original organization of the army in northern Virginia had been in two corps of two divisions each, with a strong reserve division, which he maintained until the President ruled that the law did not recognize the position of corps commander. This glaring defect in Confederate military organization was not remedied until october, 1862, with the creation of the rank of Lieutenant General, but Johnston--like Lee after him--circumvented the statutes by creating unofficial "wing" commands under his senior division commanders. Gustavus Smith and James Longstreet commanded wings of two divisions each in the Manassas and Yorktown withdrawals. As his army grew when stationed on the Chickahominy by the subdivision of Magruder's command into two divisions and the addition of A. P. Hill and Huger, Johnston reorganized his army into three unofficial corps with an army artillery reserve and an independent cavalry force--an organization strikingly similar to the one employed by Lee from Chancellorsville onward. Johnston's choices for command of wings and divisions 
proved that he had a keen, if occasionally myopic, eye for picking talented commanders. Discounting Magruder, who was incorporated into his army by virtue of his former departmental command, of all Johnston's choices for senior positions, only Gustavus Smith failed in the rest of the war to justify his confidence. Longstreet, Jackson, Stuart, Ewell, A. P. Hill, Richard Anderson, Early, and Hampton rose to corps command under Lee; D. H. Hill achieved the same position in the Army of Tennessee. Though he never advanced beyond division command, Whiting competently carried out the thankless task of defending the critical port city of wilmington until the last months of the war. All these men owed their initial recommendations for promotion to Joseph Johnston.

Yet the allegation that Johnston turned over a demoralized and disorganized body of troops to Lee, who had to quickly whip it into shape has persisted to the present day. Colonel Robert H. Chilton, who served faithfully on Lee's staff, contended after the war that the condition of the Army of Northern Virginia on June 1, 1862

appeared to me to be in a very disorganized condition. Large unauthorized absences of officers and men greatly weakened its force, exhausting wastefulness pervaded all departments, especially apparent with each change of camp, in the abandonment of supplies of different kinds, and a laxity of discipline prevailed, which greatly impaired the efficiency of this Army. . . . 13

13 Robert $H$. Chilton to Jefferson Davis, December 14 , 1877, in Rowland, Jefferson Davis, Constitutionalist, VIII: p. 60 . 
But two facts should be noted about Chilton's statement, which is typical of the assertions made about the army's state in early June. First, Chilton himself later attributed these conditions not to any lack on the part of Johnston, but to the deleterious effects of the recent elections and the necessity for fighting two battles in the same month. Secondly, Chilton's accusation conveniently ignored the fact that several of the staff officers whose departments he castigated, notably Pendleton and Alexander, were the same men who rapidly gained reputations for administrative excellence under Lee.

Douglas Southall Freeman made a point of emphasizing Lee's administrative ability by exaggerating the condition of Johnston's army at the end of May:

In some of its aspects discipline had been lax under Johnston; drunkenness had been frequent; many things were at loose ends. Some of the regiments reported a third of the troops sick. Lee worked as fast as he could to improve the condition of the men. The commissary and the quartermaster's service were improved. Favoritism in granting details for service in the rear was ended.14

But Freeman's own footnotes reveal just how misleading this paragraph was. The allegation concerning drunkenness was supported only by a passage from gossipy war office clerk J. B. Jones and a Confederate Army regulation on stern penalties for drunkenness that was only issued on May 22. It neither referred specifically to the Army of Northern Virginia nor was it available to support Johnston's own efforts to combat

$$
14 \text { Freeman, R. E. Lee, II: pp. 87-88. }
$$


intoxication throughout his tenure in command. His statement of excessive sickness is buttressed not by army returns but by a single regimental history. Nothing is cited to support Freeman's contention that Lee made immediate improvements in the army's logistical services. The praise given Lee for ending "favoritism" in details comes from several documents that Lee submitted to the war office complaining that the Richmond authorities had been the offenders, not Johnston and his officers, as Freeman's passage subtly implied. In fact, Lee's missives to Randolph and Cooper merely echoed complaints that Johnston had been making since the fall of 1861 .

In one aspect and one aspect only did the status of the army immediately improve under Lee: relations with his civil superiors. Johnston and Davis both suffered from the same kind of stiff neck; neither could admit a fault gracefully. Nor could either man readily forgive transgressions. As the friction slowly built between army commander and chief executive over the spring of 1862 , the necessary trust for a desperate campaign quietly eroded. Although Davis did not lose his respect for Johnston as a general, and Johnston never ceased to be formally respectful in his dealings with the President, from March through May, Lee constantly had to intervene between them. Johnston was a prickly subordinate and Davis was not an easy master to serve. In the necessary aspects of civil diplomacy required of a senior military officer in a republic, Johnston was plainly deficient where 
Lee was patently gifted. It was a failing that haunted Johnston for the rest of his career.

But on balance, Johnston's performance as an army commander in Virginia should be rated as a success. He was far from perfect, and his two greatest lacks--the ability to closely control a battlefield and the knack for getting along with his superiors-would eventually develop into fatal flaws. But they were not such during the Peninsular Campaign. Three years later, in a report drafted with the intention of humiliating Joseph Johnston, an embittered John Bell Hood said that "the results of a campaign do not always show how the General in command has discharged his duty. Their enquiry [sic] should be not what he has done, but what he should have accomplished with the means under his control."15 Hood's standard was one that governments cannot always afford but historians usually employ. By either standard, concrete results or credible performance, Joseph Eggleston Johnston's defense of Richmond fares quite well.

15 John Bell Hood to Samuel Cooper, February 15, 1865, in Hood, Advance and Retreat, p. 317. 


\author{
APPENDIX A \\ The deleted paragraph from \\ Joseph E. Johnston to Jefferson Davis, \\ September 12, 1862 \\ (original in the Robert Morton Hughes papers, \\ old Dominion University, Norfolk, Virginia)
}

The spectacle which is presented in the conduct of the Governments on the two sides of the Potomac towards their Commanding Generals cannot fail to arrest our attention. The Commanding General of the Northern army, a veteran of more than fifty years is superseded by his junior of half his years, of scarcely one-fourth of his period of service, because defeated. He is merely removed, however, from the direct command. His superior rank is left him. When we look to the South of the same line, what do we see? The greatest and most important battle ever fought in America has been won. It has been won by a general [holding] the highest rank in his republic. It has been won by his leaving the District in which he commanded, making a forced march (of miles), forming a junction with an army too weak to maintain its ground, and by their united force, against immense odds, winning a victory, which in the minds of all men and nations establishes the glory and independence of the confederate states, and crowns the army and its generals with the highest honor to which they could aspire: the applauding acclamation of the country, the Thanks of Congress, voted unanimously. Such is the first result presented to our view. What is the next reaped by the victorious General? What next? The General was already first in the highest grade known to the service--He could not be advanced. Something should be done--so he was degraded. Three officers, his inferiors in grade, and in service, for neither of them had fought or won a battle for the Republic, were placed above him. Besides all this, a study in aignity is offered him. His noble compeer in the battle has his preferment connected with the victory won by their common toils and dangers. His commission bears the date of the 2lst of July. But care is taken to exclude the idea that the general commanding had any part in winning our triumph. His commission is made to bear such a date that his once inferiors in the service of the United States, and of the Confederate states, shall be above him. But it must not be dated as of the 21 st July. It shall (must) not suggest the victory of Manassas. 
APPENDIX B

The Department of Northern Virginia,

March 1,1862
(compiled from the official Records)

General Joseph E. Johnston, commanding

Potomac District

lst Division: Brigadier-General Jubal A. Early

Early's Brigade--Colonel Duncan K. McRae 20 th Georgia

5 th North Carolina

$23 r d$ North Carolina

24 th Virginia

Jeff. Davis (Alabama) Artillery

Kershaw's Brigade--Brigadier-General Joseph B. Kershaw 2nd South Carolina

3rd South Carolina

7 th South Carolina

8 th South Carolina

Boykin's Rangers (South Carolina) Cavalry Company

Alexandria (Virginia) Artillery

Rodes' Brigade--Brigadier-General Robert E. Rodes

5 th Alabama

6 th Alabama

12 th Alabama

12 th Mississippi

King William (Virginia) Artillery

2nd Division: Major-General Gustavus W. Smith

Jones' Brigade--Brigadier-General David R. Jones

7 th Georgia

8 th Georgia

9 th Georgia

lith Georgia

Wise (Virginia) Artillery

Wilcox's Brigade--Brigadier-General Cadmus M. Wilcox 


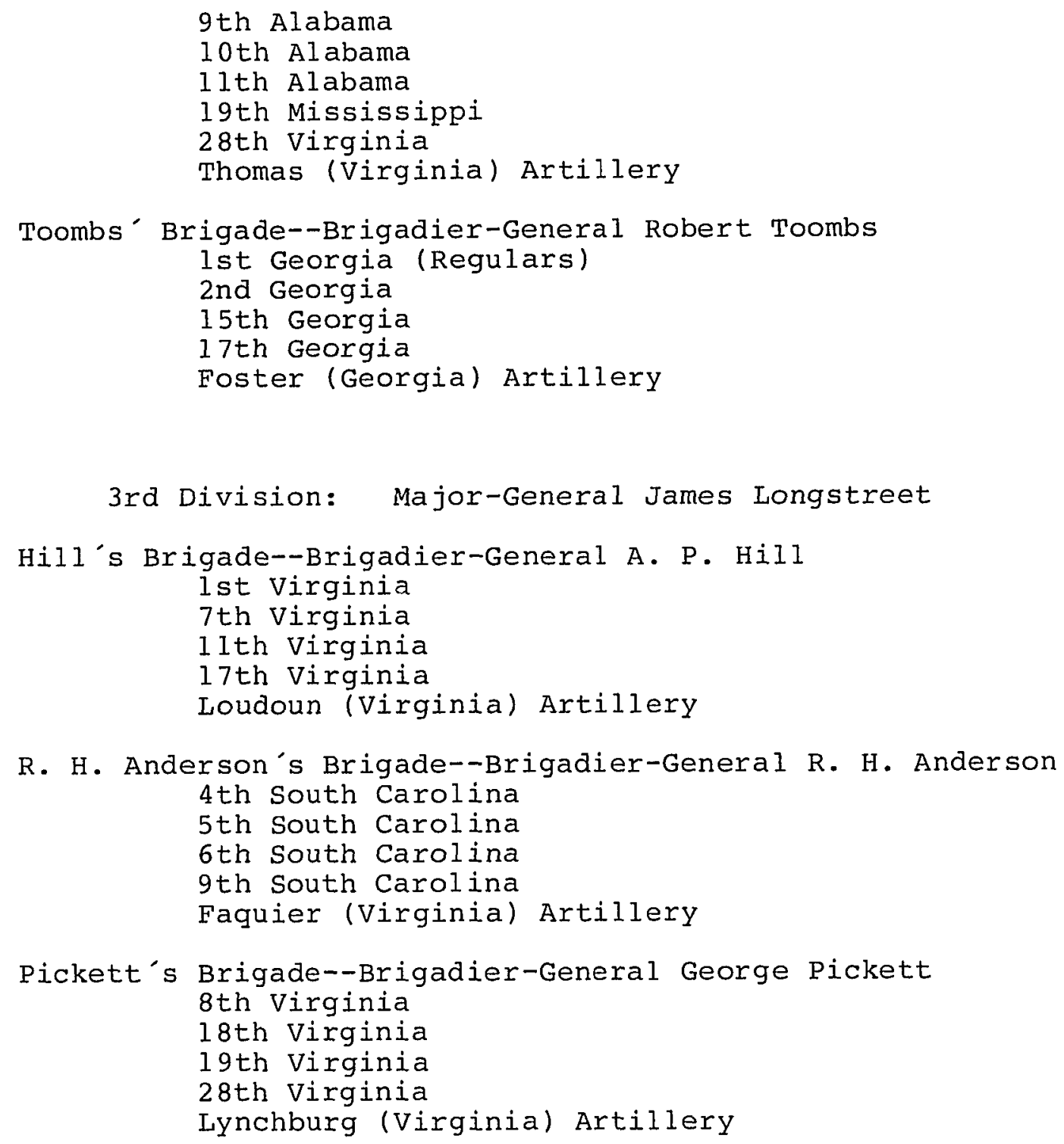

3rd Division: Major-General James Longstreet

Hill's Brigade--Brigadier-General A. P. Hill

lst Virginia

7 th Virginia

1 th Virginia

17 th Virginia

Loudoun (Virginia) Artillery

R. H. Anderson's Brigade--Brigadier-General R. H. Anderson 4 th South Carolina

5 th South Carolina

6 th South Carolina

9 th South Carolina

Faquier (Virginia) Artillery

Pickett's Brigade--Brigadier-General George Pickett

8th Virginia

18th Virginia

19 th Virginia

28 th Virginia

Lynchburg (Virginia) Artillery

4th Division: Major-General Richard S. Ewell

Elzey's Brigade--Brigadier-General Arnold Elzey

lst Maryland

3rd Tennessee

13 th Virginia

l6th Virginia

Baltimore Light (Maryland) Artillery

Trimble"s Brigade--Brigadier-General Isaac R. Trimble 15 th Al abama 


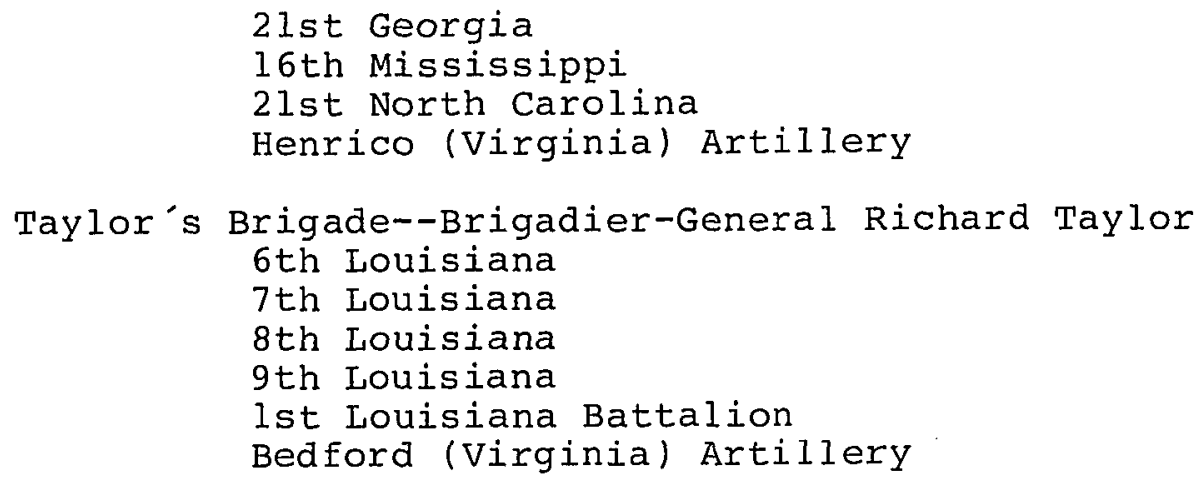

Forces near Dumfries: Brigadier-General W. H. C.

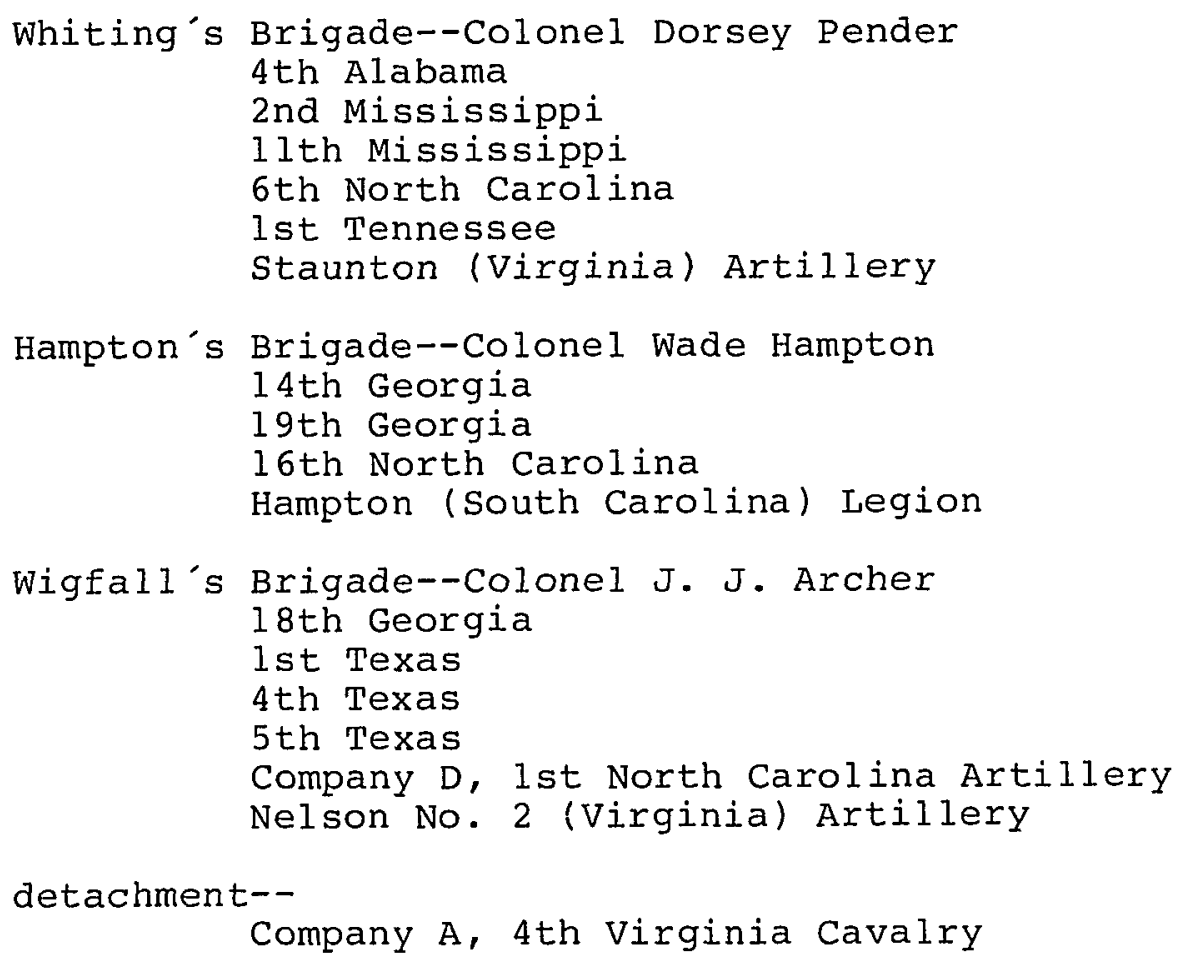

Forces at Leesburg: Brigadier-General D. H. Hill Griffith's Brigade--Brigadier-General Richard Griffith 13 th Mississippi

17th Mississippi

18th Mississippi

2 lst Mizsissippi 


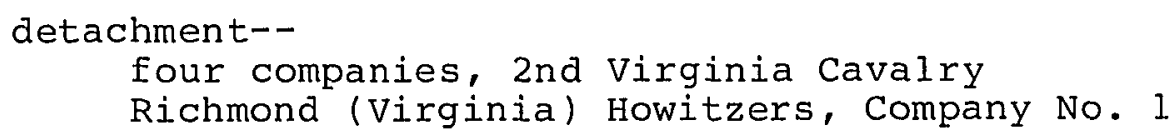

Cavalry Brigade: Brigadier-General J. E. B. Stuart lst North Carolina Cavalry

lst Virginia Cavalry

2nd Virginia Cavalry (minus four companies)

4 th Virginia Cavalry

6th Virginia Cavalry

Jeff. Davis (Mississippi) Legion

Reserve Artillery: Colonel William Nelson Pendleton

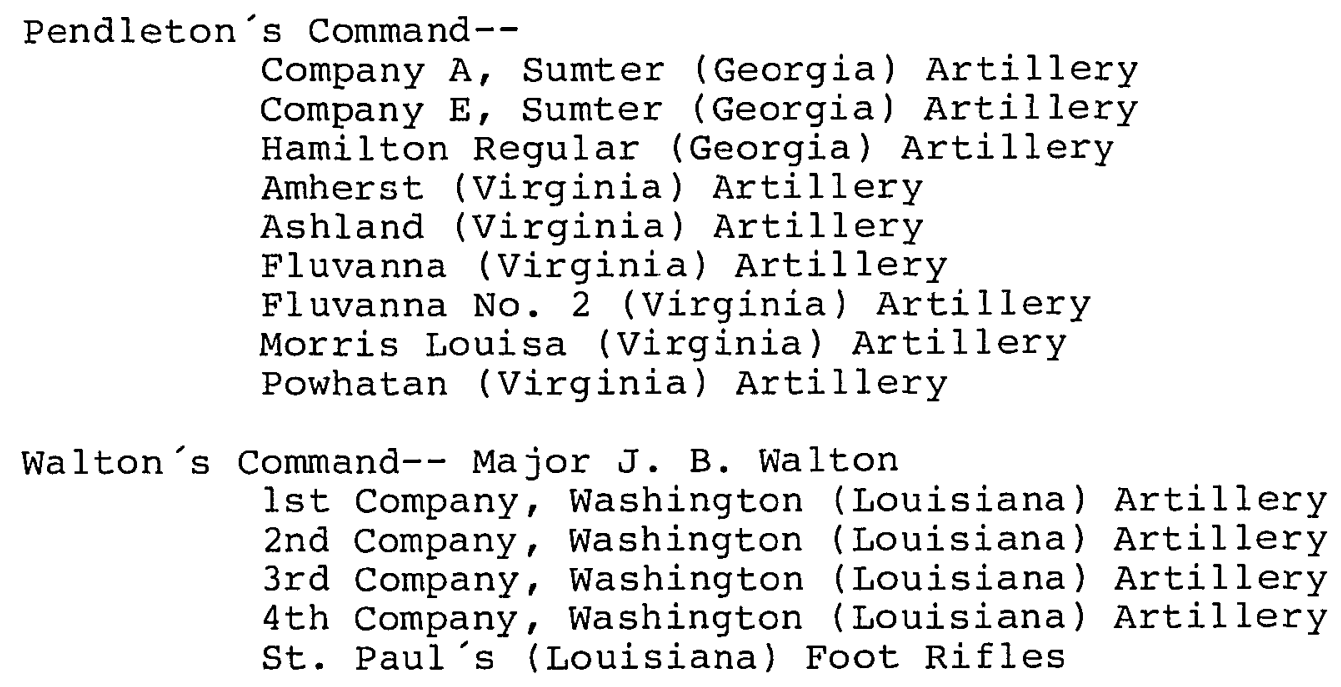

\section{Aquia District}

Major-General Theophilus Holmes, commanding

French's Brigade--Brigadier-General Samuel French 2nd Arkansas Battalion 


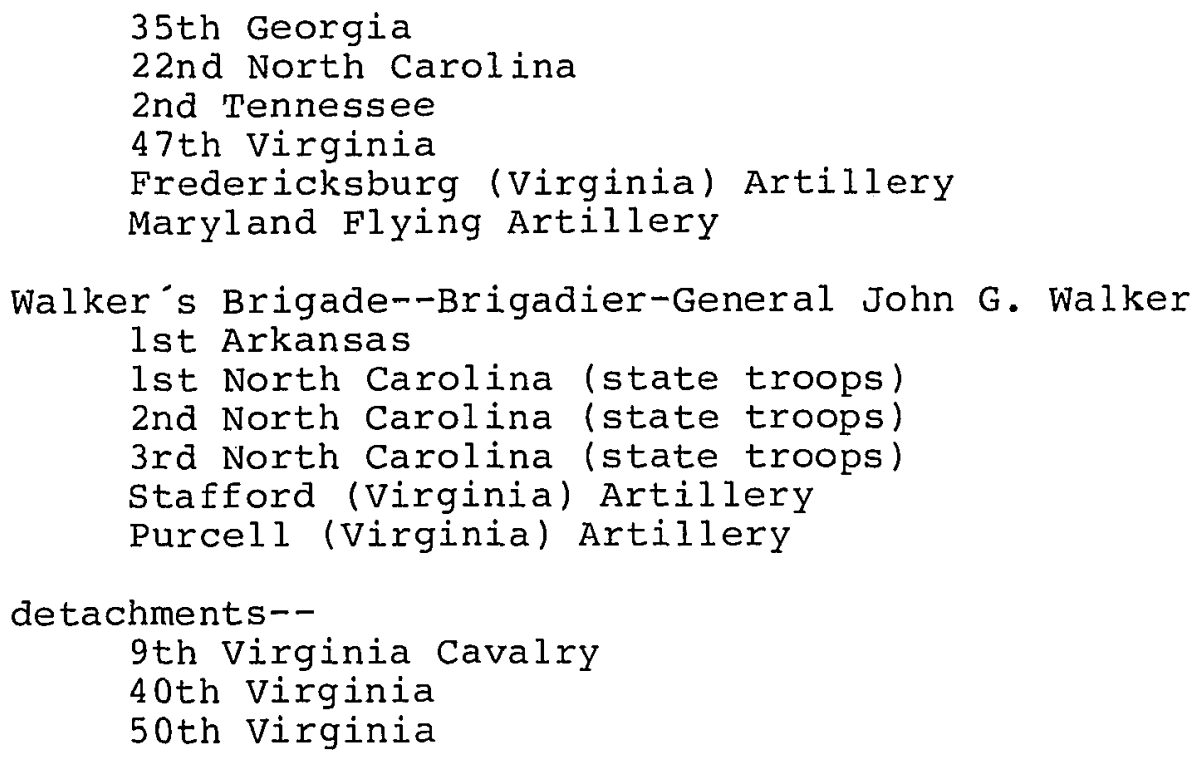

\section{Valley District}

Major-General Thomas J. Jackson, commanding

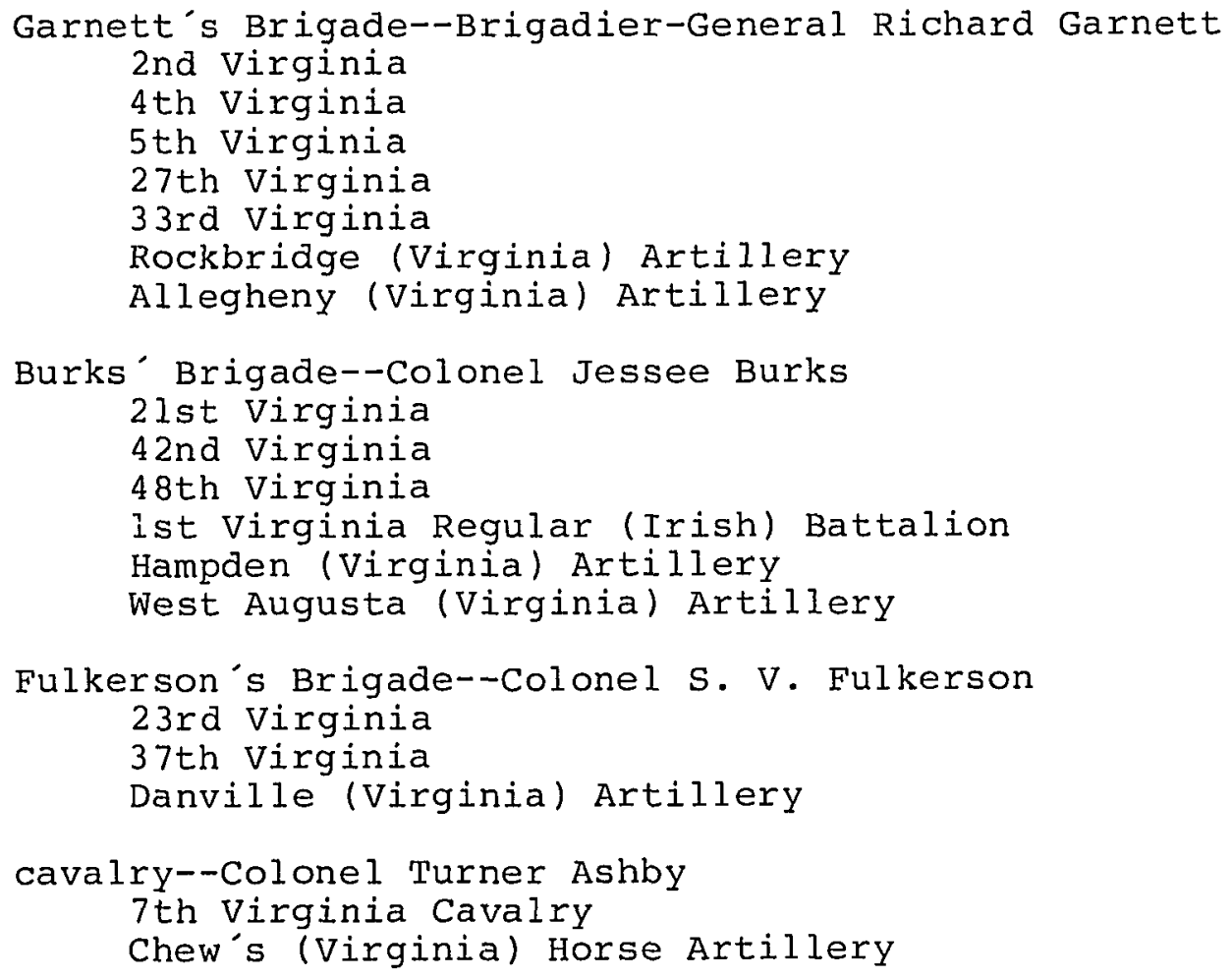


In transit between the Valley and the Aquia Districts:

S. R. Anderson's Brigade--Brigadier-General S. R. Anderson

7 th Tennessee

14 th Tennessee

3rd Arkansas 


\begin{abstract}
APPENDIX C
The Army of Northern Virginia on the Peninsula, May 1, 1862

(compiled from the official Records)
\end{abstract}

General Joseph E. Johnston, commanding

Right of Position: Major-General John B. Magruder McLaws' Division: Brigadier-General Lafayette McLaws

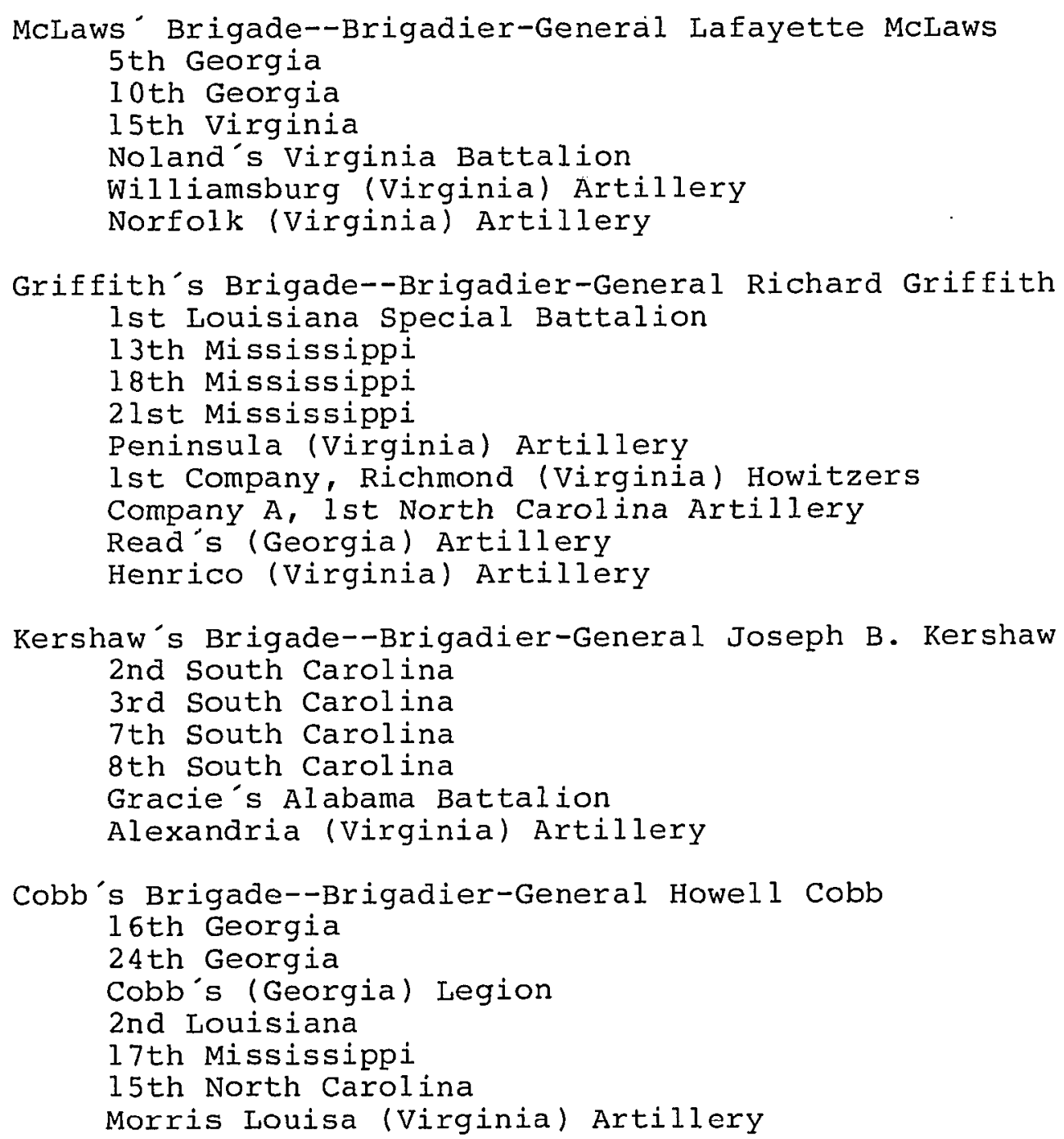


detachment--

10th Georgia

Jones' Division: Brigadier-General David R. Jones

Jones" Brigade--Brigadier-General Paul J. Semmes

7 th Georgia

8th Georgia

9th Georgia

llth Georgia

lst Kentucky

Toombs' Brigade--Brigadier-General Robert Toombs lst Georgia (Regulars)

2nd Georgia

15th Georgia

17 th Georgia

38 th Virginia

Forces at Williamsburg: Colonel Benjamin S. Ewell
32nd Virginia
52nd Virginia Militia
68th Virginia Militia
ll5th Virginia Militia
Old Dominion (Virginia) Rifles
loth Virginia Heavy Artillery Battalion

Center of Position: Major-General James Longstreet

Hill's Brigade--Brigadier-General A. P. Hill

lst Virginia

7 th Virginia

llth Virginia

17th Virginia

Loudoun (Virginia) Artillery

R. H. Anderson's Brigade--Brigadier-General R. H.

Anderson

4 th South Carolina Battalion

5 th South Carolina

6 th South Carolina

9 th South Carolina

Faquier (Virginia) Artillery

Colston's Brigade--Brigadier-General Raleigh Colston 3rd Virginia 
13 th Virginia

l4th Virginia

Pickett's Brigade--Brigadier-General George Pickett

8th Virginia

18 th Virginia

19 th Virginia

28 th Virginia

Lynchburg (Virginia) Artillery

Wilcox's Brigade--Brigadier-General Cadmus M. Wilcox 9 th Alabama

loth Alabama

lith Alabama

19 th Mississippi

3rd Company, Richmond (Virginia) Howitzers

Pryor's Brigade--Colonel Roger Pryor

8 th Alabama

14 th Alabama

l4th Louisiana

Richmond Fayette (Virginia) Artillery

Left of Position: Major-General D. H. Hill

Early's Division--Brigadier-General Jubal A. Early

Early's Brigade--Colonel Duncan K. McRae

20 th Georgia

5 th North Carolina

23 rd North Carolina

24 th Virginia

Jeff. Davis (Alabama) Artillery

Rodes' Brigade--Brigadier-General Robert E. Rodes 5 th Alabama

6 th Alabama

12 th Al abama

12 th Mississippi

King William (Virginia) Artillery

Ward's command--Colonel George Ward

2nd Florida

2nd Mississippi

Rains' Division: Brigadier-General Gabriel J. Rains

Rains' Brigade--Brigadier-General Gabriel J. Rains 13 th Al abama 
26 th Alabama

6 th Georgia

$23 r d$ Georgia

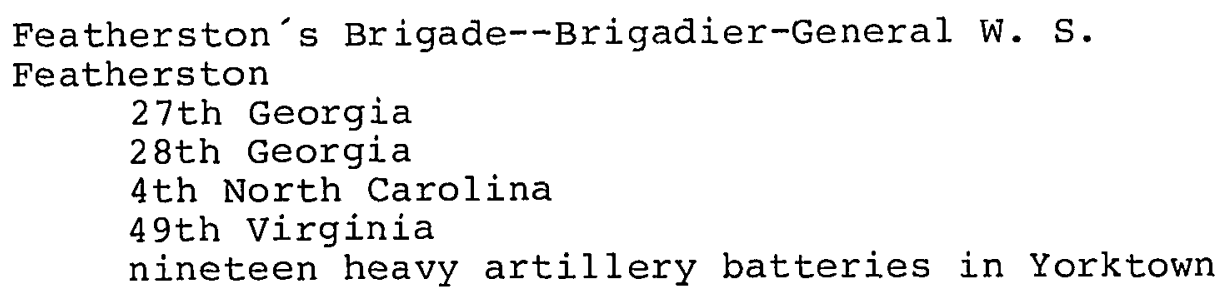

forces at Gloucester Point--Colonel Charles Crump 46 th Virginia

9 th Virginia Militia

2lst Virginia Militia

6lst Virginia Militia

Mathews (Virginia) Light Dragoons Cavalry Company

Mathews (Virginia) Artillery

Virginia heavy artillery battalion

Reserve: Major-General Gustavus W. Smith

S. R. Anderson's Brigade--Brigadier-General S. R. Anderson

lst Tennessee

7 th Tennessee

14 th Tennessee

Fredericksburg (Virginia) Artillery

Pettigrew's Brigade--Brigadier-General J. J. Pettigrew 2nd Arkansas Battalion

35 th Georgia

22nd North Carolina

47 th Virginia

lst Maryland Battery

Whiting's Division: Brigadier-General W. H. C. Whiting

Whiting's Brigade--Colonel Dorsey Pender

4 th Alabama

2nd Mississippi

lith Mississippi

6th North Carolisa

Staunton (Virginia) Artillery

Company D, lst North Carolina Artillery

Hood's Brigade--Brigadier-General John B. Hood 
18 th Georgia

lst Texas

4 th Texas

5 th Texas

Hampton's Brigade--Colonel Wade Hampton

14 th Georgia

19 th Georgia

16 th North Carolina

Hampton (South Carolina) Legion

Madison (Louisiana) Artillery

Cavalry Brigade: Brigadier-General J. E. B. Stuart lst Virginia Cavalry

3rd Virginia Cavalry

4th Virginia Cavalry

Wise (Virginia) Legion Cavalry

Jeff. Davis (Mississippi) Legion

Studar (Virginia) Horst Artillery

Reserve Artillery: Brigadier-General William N. Pendleton

Pendleton's Command--

Company A, Sumter (Georgia) Artillery

Company E, Sumter (Georgia) Artillery

Hamilton Regular (Georgia) Artillery

Amherst (Virginia) Artillery

Ashland (Virginia) Artillery

Fluvanna (Virginia) Artillery

Fluvanna No. 2 (Virginia) Artillery

Powahatan (Virginia) Artillery

Walton's Command--Major J. B. Walton

lst Company, Washington (Louisiana) Artillery

2nd Company, Washington (Louisiana) Artillery

3rd Company, Washington (Louisiana) Artillery

4th Company, Washington (Louisiana) Artillery

st. Paul's (Louisiana) Foot Rifles 


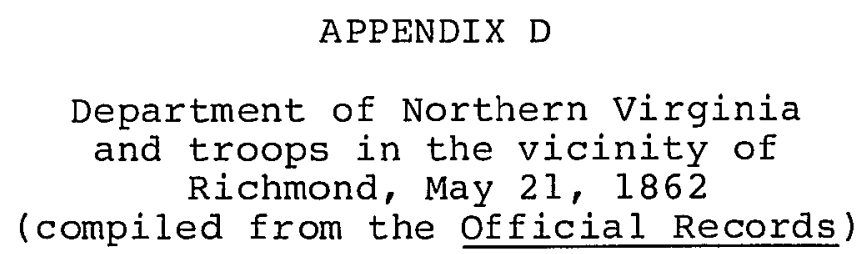

General Joseph E. Johnston, commanding

\section{Left wing}

Major-General Gustavus W. Smith, commanding

Smith's Division: Brigadier-General W. H. C. Whiting

Whiting's Brigade--Colonel Dorsey Pender

4 th Alabama

2nd Mississippi

llth Mississippi

6 th North Carolina

Staunton (Virginia) Artillery

Company D, lst North Carolina Artillery

Hood's Brigade--Brigadier-General John B. Hood

18 th Georgia

lst Texas

4 th Texas

5 th Texas

Hampton's Brigade--Brigadier-General Wade Hampton

14 th Georgia

19 th Georgia

16th North Carolina

Hampton (South Carolina) Legion (minus cavalry)

Madison (Louisiana) Artillery

Hatton's Brigade--Brigadier-General Robert Hatton

lst Tennessee

7 th Tennessee

14 th Tennessee

Fredericksburg (Virginia) Artillery

Pettigrew's Brigade--Brigadier-General J. J. Pettigrew 2nd Arkansas Battalion

35 th Georgia

22nd North Carolina 
47 th Virginia

lst Maryland Battery

A. P. Hill's Division: Major-General A. P. Hill

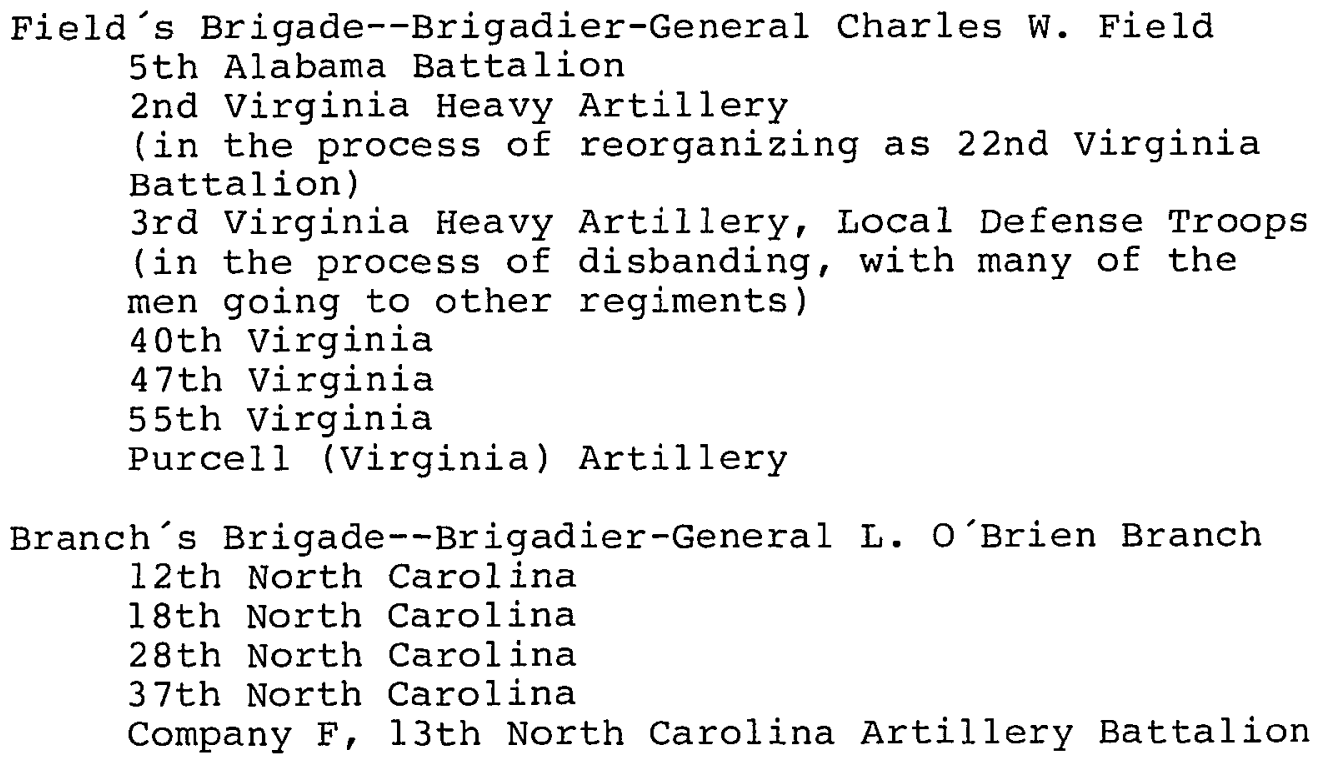

\section{Center}

Major-General John B. Magruder, commanding

Magruder's Division: Major-General Lafayette McLaws

McLaws' Brigade--Brigadier-General Paul J. Semmes 5 th Louisiana 
10 th Louisiana

15th Virginia

Noland's Virginia Battalion

Williamsburg (Virginia) Artillery

Norfolk (Virginia) Artillery

Kershaw's Brigade--Brigadier-General Joseph B. Kershaw

2nd South Carolina

3rd South Carolina

7 th South Carolina

8th South Carolina

Gracie's Alabama Battalion

Alexandria (Virginia) Artillery

Cobb's Brigade--Brigadier-General Howell Cobb

16 th Georgia

24 th Georgia

Cobb's (Georgia) Legion (minus cavalry)

2nd Louisiana

17 th Mississippi

l5th North Carolina

Morris Louisa (Virginia) Artillery

Griffith's Brigade--Brigadier-General Richard Griffith

lst Louisiana Spèial Battalion

13 th Mississippi

18th Mississippi

2 lst Mississippi

lst Company, Richmond (Virginia) Howitzers

D. R. Jones' Division: Major-General David R. Jones

D. R. Jones' Brigade--Colonel George T. Anderson

7 th Georgia

8 th Georgia

9 th Georgia

lith Georgia

list Kentucky

Toombs' Brigade--Brigadier-General Robert Toombs lst Georgia

2nd Georgia

15 th Georgia

17 th Georgia

Reserve Artillery: Lieutenant Colonel Henry C. Cabell

Pulaski (Georgia) Artillery

Company A, lst North Carolina

Peninsula (Virginia) Artillery

Henrico (Virginia) Artillery 


\section{Left Wing}

Major-General James Longstreet, commanding

Longstreet's Division: Brigadier-General R. H. Anderson

R. H. Anderson's Brigade--Colonel Micah Jenkins

4 th South Carolina Battalion

5 th South Carolina

6 th South Carolina

9 th South Carolina

Faquier (Virginia) Artillery

Kemper's Brigade--Colonel James Kemper

lst Virginia

7th Virginia

lith Virginia

l7th Virginia

Loudoun (Virginia) Artillery

Pickett's Brigade--Brigadier-General George Pickett 8 th Virginia

18th Virginia

19th Virginia

28 th Virginia

Lynchburg (Virginia) Artillery

Colston's Brigade--Brigadier-General Raleigh Colston 3rd Virginia

13 th North Carolina

l4th North Carolina

Donaldson (Louisiana) Artillery

Wilcox's Brigade--Brigadier-General Cadmus M. Wilcox 9 th Alabama

10 th Al abama

11 th Alabama

19 th Mississippi

3rd Company, Richmond (Virginia) Howitzers

Pryor's Brigade--Brigadier-General Roger Pryor

8 th Alabama

14 th Alabama

14 th Louisiana

Richmond Fayette (Virginia) Artillery

D. H. Hill's Division: Major-General D. H. Hill 
Featherston's Brigade--Colonel George B. Anderson

27th Georgia

28 th Georgia

4 th North Carolina

49 th Virginia

Garland's Brigade--Brigadier-General Samuel Garland 2nd Florida

2nd Mississippi Battalion

5 th North Carolina

$23 r d$ North Carolina

24 th Virginia

38 th Virginia

Jeff. Davis (Alabama) Artillery

Rains' Brigade--Brigadier-General Gabriel J. Rains

13 th Al abama

26 th Alabama

6 th Georgia

23 rd Georgia

Rodes' Brigade--Brigadier-General Robert E. Rodes

5 th Alabama

6th Alabama

12 th Alabama

12th Mississippi

4 th Virginia Heavy Artillery Battalion

(serving as infantry)

King William (Virginia) Artillery

Wise's Brigade--Brigadier-General Henry Wise

(this brigade probably still in the process of

moving up from Richmond)

4 th Virginia Heavy Artillery (serving as infantry)

20 th Virginia

26 th Virginia

46 th Virginia

Mathews (Virginia) Artillery

Artillery--Major Scipio F. Pierson

Hardaway (Alabama) Artillery

Hanover (Virginia) Artillery

Huger's Division: Major-General Benjamin Huger

Armistead's Brigade--Brigadier-General Lewis Armistead

5 th Virginia Battalion (minus one company)

9 th Virginia

14th Virginia

$53 r d$ Virginia 
Goochland (Virginia) Artillery

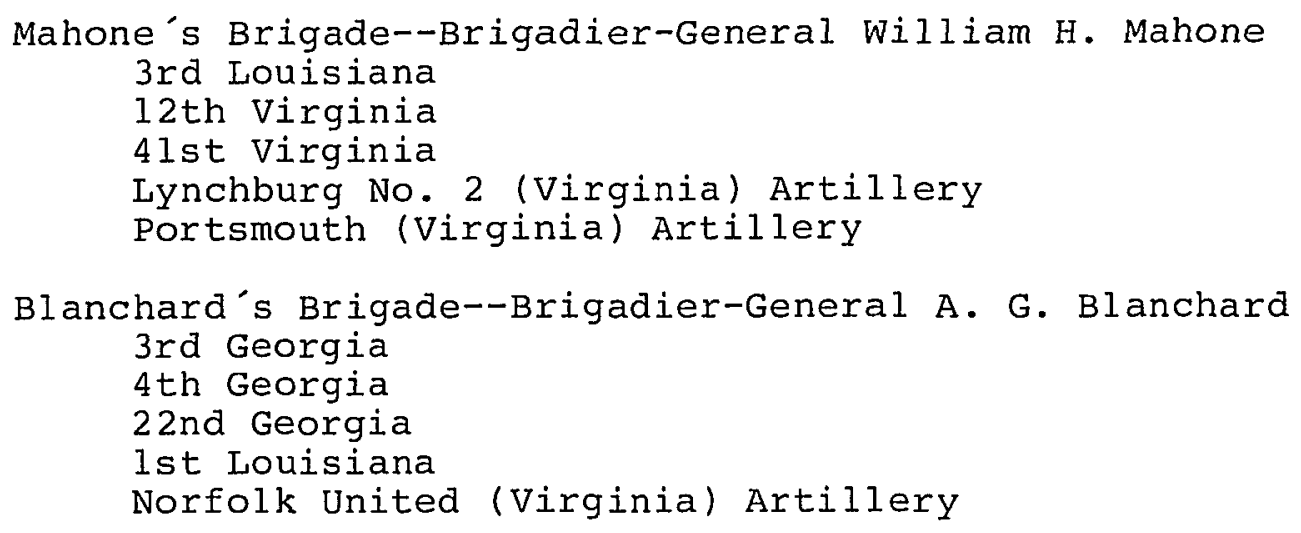

Cavalry Brigade: Brigadier-General J. E. B. Stuart lst Virginia Cavalry 3rd Virginia Cavalry 4 th Virginia Cavalry 9th Virginia Cavalry loth Virginia Cavalry (formerly Wise Legion) Cobb (Georgia) Legion Cavalry Jeff. Davis (Mississippi) Legion Hampton (South Carolina) Legion Cavalry Stuart (Virginia) Horse Artillery

Artillery Reserve: Brigadier-General William N. Pendleton

Pendleton's Command--

(in the process of being broken into battalions)

Company A, Sumter (Georgia) Artillery

Company E, Sumter (Georgia) Artillery

Hamilton Regular (Georgia) Artillery

Chesapeake (Maryland) Artillery

Lloyd's (North Carolina) Artillery

Rhett's (South Carolina) Artillery

Amherst (Virginia) Artillery

Ashland (Virginia) Artillery

Fluvanna (Virginia) Artillery

Fluvanna No. 2 (Virginia) Artillery

Hupp "s (Virginia) Artillery

Long Island (Virginia) Artillery

Mosely's (Virginia) Artillery

Orange (Virginia) Artillery

Parker's (Virginia) Artillery

Powhatan (Virginia) Artillery

Ringgold (Virginia) Artillery 

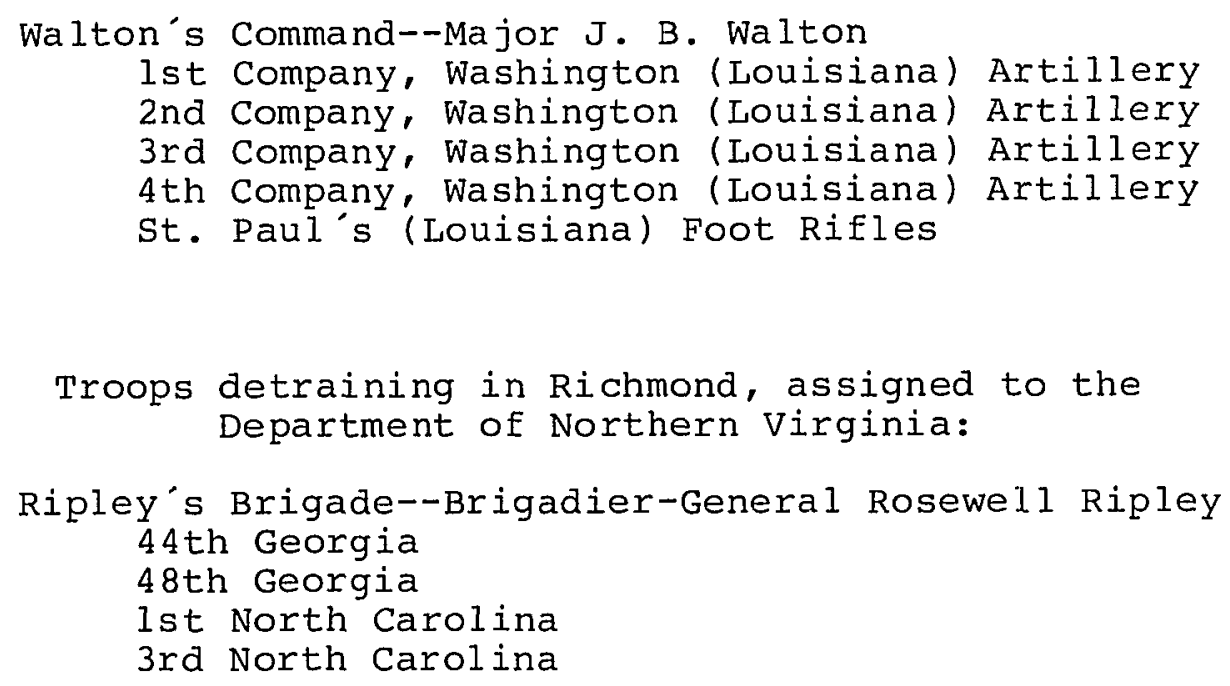

Troops from the Department of North Carolina marching toward Drewry's Bluff and Richmond, already assigned to the Department of Northern Virginia:

Holmes' Division: Major-General Theophilus H. Holmes

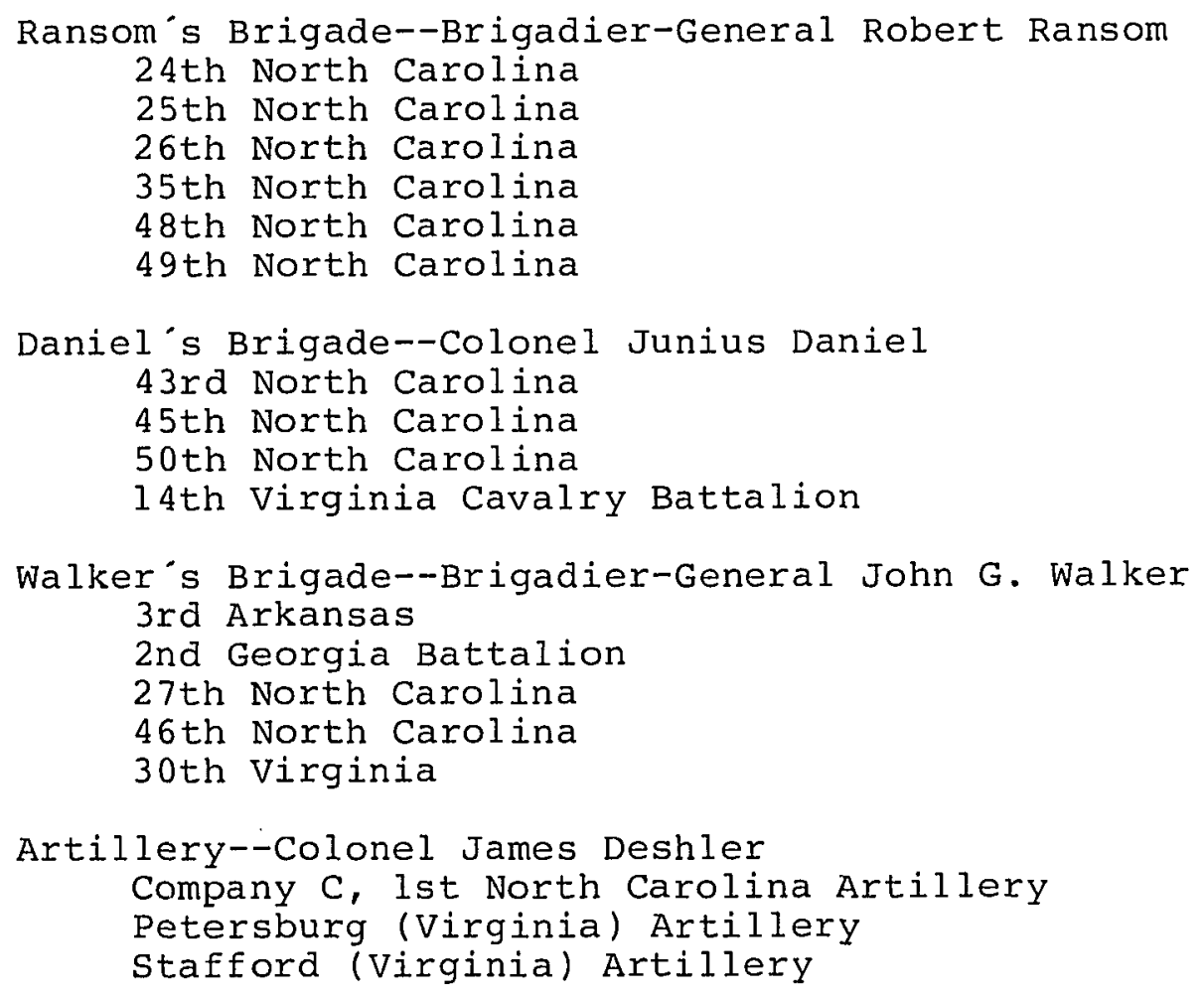


Troops stationed at Drewry's and Chaffin's Bluffs:

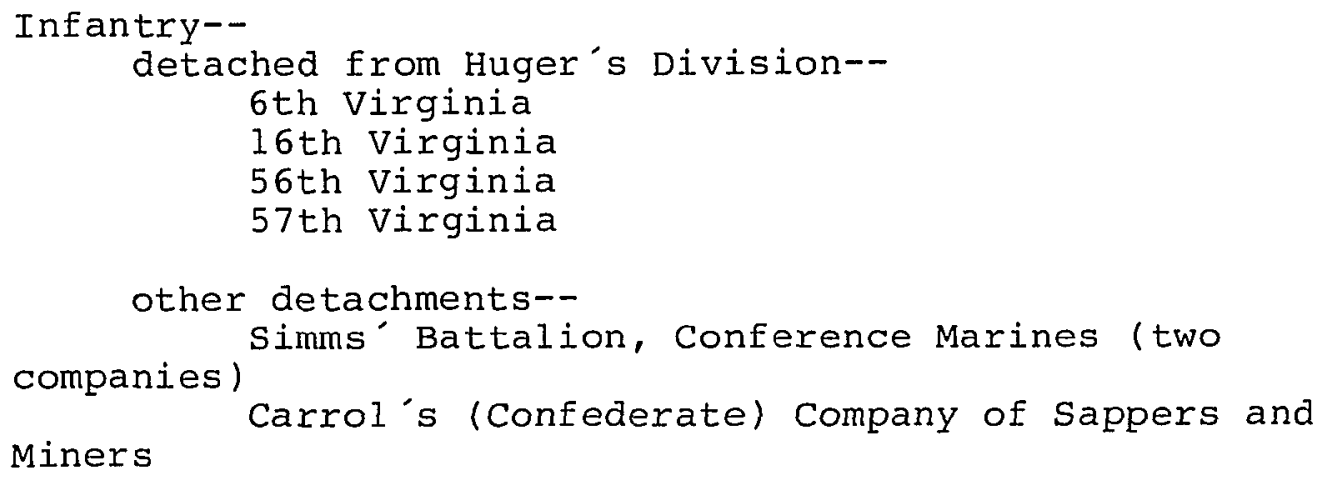

Naval crews serving as artillery--Captain S. S. Lee Jamestown

Patrick Henry Virginia

Troops in and around the Richmond area:

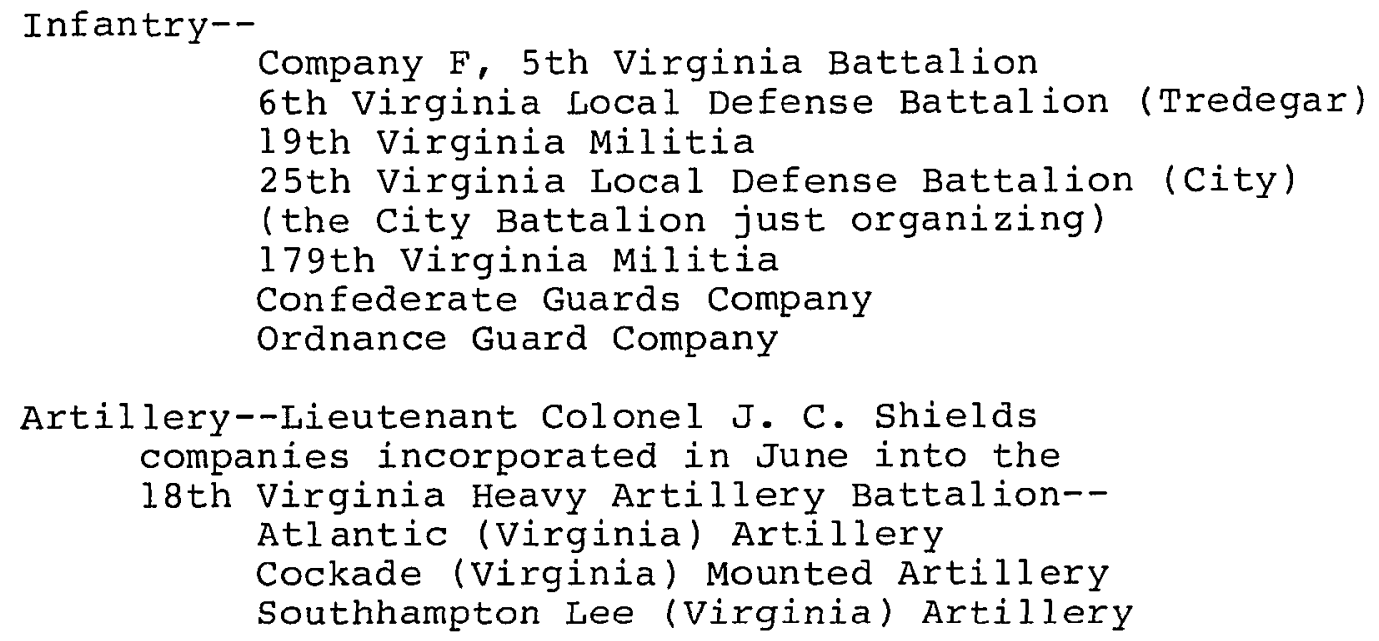




\author{
companies incorporated in June into the \\ 19 th Virginia Heavy Artillery Battalion-- \\ Bossieux (Virginia) Guards \\ Campbell's (Virginia) Company, Heavy Artillery \\ Chalmer's (Virginia) Company, Heavy Artillery \\ United (Virginia) Artillery \\ companies incorporated in June into the \\ 20 th Virginia Heavy Artillery Battalion-- \\ Robertson's (Virginia) Company, Heavy Artillery \\ St. Brides" (Virginia) Artillery

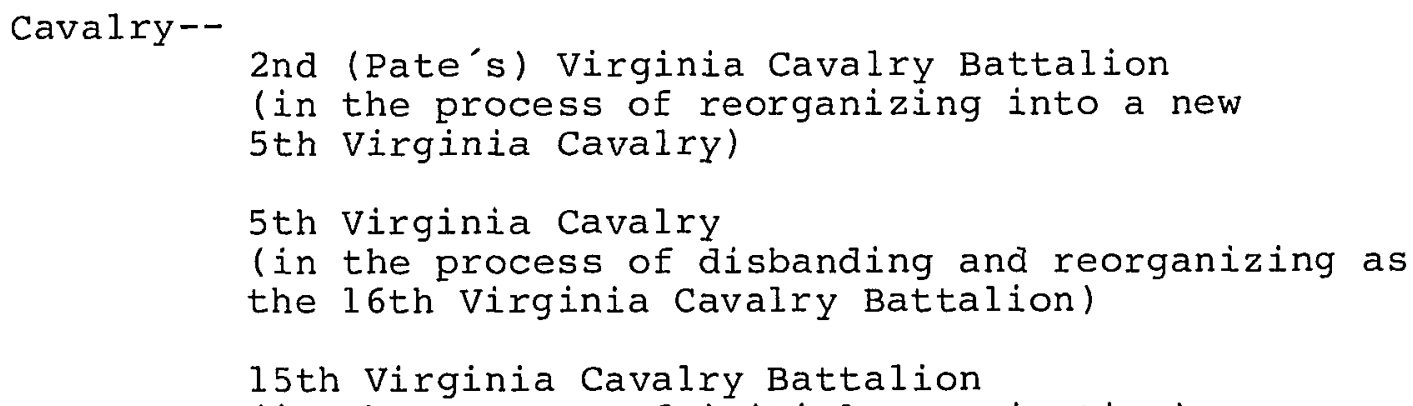

\title{
Valley District
}

Major-General Thomas J. Jackson, commanding

Jackson's Division: Major-General Thomas J. Jackson

Winder's Brigade--Brigadier-General Charles winder

2nd Virginia

4 th Virginia

5 th Virginia

27 th Virginia

$33 r d$ Virginia

Allegheny (Virginia) Artillery

Rockbridge (Virginia) Artillery

Patton's Brigade--Colonel John M. Patton

2 lst Virginia

4 2nd Virginia

48 th Virginia

lst Virginia Regular (Irish) Battalion

Hampden (Virginia) Artillery

West Augusta (Virginia) Artillery

Taliaferro's Brigade--Brigadier-General W. B. Taliaferro 


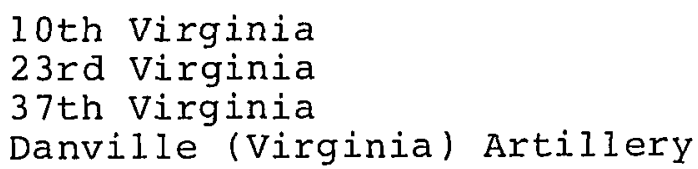

Ewell's Division: Major-General Richard S. Ewell

Elzey's Brigade--Brigadier-General Arnold Elzey

12 th Georgia

13 th Virginia

25 th Virginia

31 st Virginia

Scott's Brigade--Colonel W. C. Scott 44 th Virginia

52 nd Virginia

58 th Virginia

Taylor's Brigade--Brigadier-General Richard Taylor lst Louisiana Battalion

6 th Louisiana

7 th Louisiana

8 th Louisiana

9th Louisiana

Trimble's Brigade--Brigadier-General Isaac Trimble

I5th Alabama

21 st Georgia

16th Mississippi

2 lst North Carolina

Maryland Line--Colonel Bradley Johnson

lst Maryland

Baltimore (Maryland) Light Artillery

Artillery--

Richmond (Virginia) Artillery

Rockbridge No. 2 (Virginia) Artillery

Lynchburg Lee (Virginia) Artillery

8 th Star (Virginia) Artillery

Cavalry--Brigadier-General Turner Ashby

7th Virginia Cavalry

Steuart's Command--Brigadier-General George H. Steuart 2nd Virginia Cavalry

6th Virginia Cavalry 


\section{APPENDIX E \\ Seniority of General officers in the \\ Department of Northern Virginia, \\ March 1, 1862}

This list has been drawn from LS-AIGO, Ezra Warner's Generals in Gray, and Francis Heitman's Biographical Register. When it has been impossible to determine definitely relative seniority between generals (i.e., two generals without previous military records appointed on the same day), the assumption has been made that the order in which the Adjutant and Inspector General received their names was the intended precedence of rank.

\section{General}

1. J. E. Johnston; July 4, 1861; commanding department.

Major-Generals

2. G. W. Smith; September 19, 1861; commanding 2nd Division.

3. T. H. Holmes; October 7, 1861; commanding Aquia District.

4. J. Longstreet; October 7, 1861; commanding 3rd Division.

5. T. J. Jackson; October 7, 1861; commanding Valley District.

6. R. S. Ewell; January 23, 1862; commanding 4 th Division.

Brigadier-Generals

7. D. R. Jones; June 17, 1861; commanding brigade.

8. S. R. Anderson; July 9, 1861; " "

9. D. H. Hill; July 10, 1861; commanding forces at Leesburg.

10. R. H. Anderson; July 19, 1861 ; commanding brigade.

11. R. Toombs; July 19, 1861 ;

12. A. Elzey; July 21,1861 ;

13. J. A. Early; July 21, 1861; commanding lst Division.

14. I. R. Trimble; August 9, 1861; commanding brigade.

15. W. H. C. Whiting; August 28, 1861; commanding forces at Dumfries.

16. J. E. B. Stuart; September 24, 1861; commanding 
cavalry brigade.

17. C. M. Wilcox; October 21, 1861; commanding brigade.

18. R. E. Taylor; October 21, 1861; commanding brigade.

19. R. Taylor; October 21, 1861; commanding brigade.

20. S. French; October 23, 1861 ;

21. R. Griffith; November 2, 1861 ;

22. Richard Garnett; November 14, 1861; commanding brigade.

23. J. G. Walker; January 9, 1862; commanding brigade.

24. G. E. Pickett; February 13, 1862;

25. J. B. Kershaw; February 13, 1862;

26. A. P. Hil1; February 26, 1862;

Even a superficial examination of this list reveals that seniority was not always the determining factor when Johnston decided on the men to handle key assignments. There were seven brigadiers senior to Jubal Early, who remained in command of brigades while he headed a division. Likewise Whiting, the commander of Johnston's de facto division on the Potomac, was also junior to seven other men who still commanded only brigades. 


\author{
APPENDIX F \\ Seniority of General officers in the \\ Department of Northern Virginia, \\ May 31,1862
}

This list has been drawn from LS-AIGO, Ezra Warner's Generals in Gray, and Francis Heitman's Biographical Register. When it has been impossible to determine definitely relative seniority between generals (i.e., two generals without previous military records appointed on the same day), the assumption has been made that the order in which the Adjutant and Inspector General received their names was the intended precedence of rank.

\title{
General
}

1. J. E. Johnston; July 4, 1861; commanding department.

Major-Generals

2. G. W. Smith; September 19, 1861; commanding Left Wing .

3. T. H. Holmes; October 7, 1861; commanding division.

4. B. Huger; October 7, 1861; commanding division.

5. J. Longstreet; October 7, 1861; commanding Right Wing.

6. J. B. Magruder; October 7, 1861 ; commanding Center.

7. T. J. Jackson; October 7, 1861; commanding Valley District.

8. R. S. Ewell; January 23, 1862; commanding division.

9. D. H. Hill; March 26, 1862;

10. D. R. Jones; April 5, 1862;

11. L. McLaws; May 23, 1862;

12. A. P. Hill; May 26, 1862 ;

Brigadier-Generals

13. H. A. Wise; June 5, 1861; commanding brigade.

14. R. H. Anderson; July 19; 1861; commanding division.

15. R. Toombs; July 19, 1861; commanding brigade.

16. A. Elzey; July 21, 1861;

17. I. R. Trimble; August 9, 1861;"

18. R. S. Ripley; August 21 , 1861; "

19. W. H. C. Whiting; August 28, 1861; commanding division.

20. J. R. Anderson; September 3, 1861; commanding brigade. 
21. A. G. Blanchard; September 21, 1861; commanding brigade.

22. G. J. Rains; September 23, 1861; commanding brigade.

23. J. E. B. Stuart; September 24, 1861; commanding cavalry brigade.

24. C. M. Wilcox; October 21, 1861; commanding brigade.

25. R. E. Rodes; October 21,1861 ; commanding brigade.

26. R. Taylor; October 21, 1861;

27. R. Griffith; November 2, 1861;

28. W. Mahone; November 16, 1861;

29. L. O'B. Branch; November 16, 1861;

30. M. Gregg; December 14, 1861;

31. R. E. Colston; December 24, 1861;

32. J. G. Walker; January 9, 1862;

33. R. Ranson; February 12, 1862;

34. G. E. Pickett; February 13, 1862;

35. J. B. Kershaw; February 13, 1862;

36. H. Cobb; February 13, 1862;

37. J. J. Fettigrew; February 26, 1862;

38. J. B. Hood; March 3, 1862;

39. W. B. Taliaferro; March 4, 1862;

40. G. H. Steuart; March 6, 1862; commanding cavalry detachment in Valley District.

41. C. Winder; March 7, 1862; Commanding brigade.

42. C. W. Field; March 9, 1862;

43. W. N. Pendleton; March 26, 1862; commanding Artillery Reserve.

44. L. A. Armistead; April 1, 1862; commanding brigade.

45. R. Pryor; April 16, 1862;

46. W. Hampton; May 23, 1862;

47. T. Ashby; May 23, 1862; Commanding cavalry, Valley District.

48. R. Hatton; May 23, 1862; commanding brigade.

49. S. Garland; May 23, 1862;

The much expanded officer corps of the Department of Northern Virginia on May 31, 1862, reveals one of the major reasons that the confederacy would eventually enact legislation creating the rank of Lieutenant-General for corps commanders. Johnston's three wing commanders held unofficial commands; technically Smith, Magruder, and Longstreet were all division commanders who led their wings by virtue of being the senior division commander. But the return of Holmes and the addition of Huger would have quickly upset Johnston's organizational scheme, because both officers were senior to Magruder and Longstreet. A quick glance at the list will also explain why Johnston resisted the addition of Henry Wise to his army for as long as possible; the political general, whose record included non-cooperation in western Virginia and disaster at Roanoke Island, would have immediately become the senior brigadier-general in the department, and very likely an early candidate for a division 
command.

Reproduced with permission of the copyright owner. Further reproduction prohibited without permission. 


\section{BIBLIOGRAPHY}

\section{Manuscript Sources}

Chicago Historical Society, Chicago, IL

Jefferson Davis papers

College of William and Mary, Williamsburg, VA

Civil War collection

Benjamin Stoddert Ewell papers

John Buchanan Floyd papers

Daniel Harvey Hill papers

Robert Morton Hughes papers

Joseph Eggleston Johnston papers

Stephen Russell Mallory papers

\section{Library of Congress, Washington, DC Manuscript Division}

Judah P. Benjamin diary

Alexander Hugh Holmes Stuart papers

Louis T. Wigfall papers

National Archives, Washington, DC

Richard Stoddert Ewell, Compiled Service Record

Daniel Harvey Hill, Compiled Service Record

Thomas Jonathan Jackson, Compiled Service Record

Joseph Eggleston Johnston, Compiled Service Record

Robert Edward Lee, Compiled Service Record

Robert Edward Lee, Letterbook, 1862-1864

Letters and Telegrams Received, Confederate Quartermaster General

Letters and Telegrams Received, Office of the Adjutant and

Inspector General, Confederate States of America

Letters and Telegrams Received, Secretary of War, Confederate States of America

Letters and Telegrams Sent, Confederate Quartermaster General

Letters and Telegrams Sent, Office of the Adjutant and

Inspector General, Confederate States of America

Letters and Telegrams Sent, Army of Northern Virginia, January, 1862-March, 1863

Letters and Telegrams Sent, Secretary of War, Confederate States of America

Letters Received, Secretary of War, Main Series, 1801-1870 
Letters Sent, Secretary of War, Main Series, 1801-1870

Letters Sent, W. H. C. Whiting, March-July, 1862

James Longstreet, Compiled Service Record

John Bankhead Magruder, Compiled Service Record

Gustavus Woodson Smith, Compiled Service Record

William Henry Chase Whiting, Compiled Service Record

$$
\text { Old Dominion University, Norfolk, VA }
$$

Robert Morton Hughes papers

$$
\begin{gathered}
\text { United States Military History Institute, } \\
\text { Carlisle Barracks, PA }
\end{gathered}
$$

Murray J. Smith collection

University of North Carolina, Chapel Hill, NC

Southern Historical Collection

Thomas Bragg, diary

Stephen R. Mallory, diary

University of Alabama, University, AL

W. Stanley Hoole Special Collections

Jefferson Davis papers

University of Michigan, Ann Arbor, MI

William L. Clements Library

Joseph Eggleston Johnston papers

University of Virginia, Charlottesville, VA Aldermann Library

Robert Mercer Taliaferro Hunter papers

Virginia Historical Society, Richmond, Va

J. R. Anderson, Brigade order Book, 1862

Carter Family papers

Early Family papers

Harwood Family papers

Daniel Harvey Hill letter

Thomas Jonathan Jackson papers

Osmun Latrobe diary 1862-1865 (typescript)

George Bolling Lee papers

Charles T. Mason papers

James Ewell Brown Stuart papers

Talcott Family papers

Beverly Randolph Wellford papers 


\section{Primary Sources}

Adjutant General. Official Army Register For 1843-1862. Washington, DC: Adjutant General's Office, January of appropriate year, except for additional August 1855 edition.

Alexander, E. P. Military Memoirs of a Confederate. New York: 1907 .

Armistead, Drury. "The Battle in Which General Johnston was Wounded." Southern Historical Society Papers. Vol. XVIII $(1890)$.

Blackford, W. W. War Years with Jeb Stuart. New York: Charles Scribner's Sons, 1945.

Clopton, William Izard. "New Light on the Great Drewry's Bluff Fight." Southern Historical Society Papers. Vol. XXXIV $(1906)$.

Cook, Joel. The Siege of Richmond: A Narrative of the military operations of Major-General George B. McClellan during May and June, 1862. Philadelphia: G.W. Childs, 1862 .

Cowper, Pulaski, ed. Extracts of Letters of Major-General Bryan Grimes to his wife, written while in Active Service in the Army of Northern Virginia, together with some personal recollections of the war written by him after its close, etc. Raleigh, NC: Alfred Williams, 1884 .

Davis, Jefferson $F$. The Rise and Fall of the Confederate Government. 2 volumes. New York: Thomas Yoseloff, 1958; reprint of 1881 edition.

Douglas, Henry Kyd. I Rode with Stonewall. Chapel Hill, NC: University of North Carolina Press, 1940.

Dowdey, Clifford, and Louis H. Manarin, ed. The Wartime Papers of R. E. Lee. New York: Bramhal1 House, 1961.

Drewry, A. H. "Drewry's Bluff Fight." Southern Historical Society Papers. Vol. XXIX (1901).

Early, Jubal A. War Memoirs; Autobiograhical Sketch and Narrative of the War Between the states. Bloomington, IN: Indiana University Press, 1960.

Foote, Henry S. War of the Rebellion; or Scylla and Charbydis. New York: Harper and Brothers, 1866 . 
Freeman, Douglas Southal1, ed. Lee's Dispatches to Jefferson Davis, 1862-1865. New edition, enlarged, with foreward by Grady McWhiney. New York: G. P. Putnam's Sons, 1957.

French, Samuel G. Two Wars: An Autobiography of Gen. Samuel G. French. Nashville: Confederate Veteran, 1901.

Gallagher, Gary W., ed. Fighting for the Confederacy, The Personal Recollections of General Edward Porter Alexander. Chapel Hill, NC: University of North Carolina Press, 1989.

-...-..., Gary W., ed. "We are our own Trumpeters,' Robert E. Lee Describes Windfield Scott's Campaign to Mexico City." Virginia Magazine of History and Biography. Vol. XCV (July 1987), No. 3 .

Gordon, John B. Reminiscences of the Civil War. New York, 1928 .

Gorgas, Josiah. "Ordnance Department of the Confederate Government." The Confederate Soldier in the Civil War. New York: Fairfax Press, n.d.

Grimsley, Mark, ed. "We Prepare to Receive the Enemy Where We Stand," The Journal of the Comte de Paris," translated by Bernatello Glod. Civil War Times Illustrated. Vol. XXIV (May 1985), No. 3 .

Hamilton, J. G. de Roulhac, ed. The Papers of Randolph Abbot Shotwell. 3 volumes. Raleigh, NC: North Carolina Historical Commission, 1929.

Harrison, Mrs. Burton. Recollections Grave and Gray. New York: Charles Scribner's Sons, 1911.

Hassler, William W., ed. The General to His Lady, The Civil War Letters of William Dorsey Pender to Fanny Pender. Chapel Hill, NC: University of North Carolina Press, 1962 .

Hill, Daniel Harvey. "The Haversack." Land We Love. Vol. I (May 1866), No. 1 .

-.-----. "The Haversack." Land We Love. Vol. I (June $1866)$, No. 2 .

Hood, John Bell. Advance and Retreat. Secaucus, NJ: BIue and Grey, 1985; reprint of 1880 edition. 
Howard, McHenry. Recollections of a Maryland Confederate Soldier and staff officer under Johnston, Jackson, and Lee. Baltimore: Williams and Wilkins; 1914 .

Hughes, Robert M., ed. "Some Letters from the Papers of General Joseph E. Johnston." William and Mary

Quarterly. 2nd series, Vol. XI (October 1931), No. 4.

Jennings, T. D. "Incidents in the Battle of Williamsburg." Confederate Veteran. Vol. V (September 1897), No. 9.

Johnson, Robert U., and Clarence C. Buell, eds. Battles and Leaders of the Civil War. Secaucus, NJ: Castle, 1980; reprint of 1887 edition.

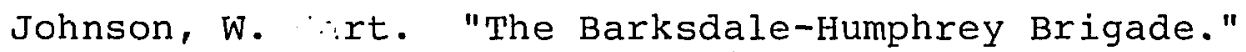
Confederate Veteran. April 1894 Supplemental Issue.

Johnston, Joseph E. "Manassas to Seven Pines." Century Magazine. Vol. XXX (May 1885), No. 1. (A slightly abridged version of this article was published under the same title in Battles and Leaders of the Civil War, Vol. II.)

--- Narrative of Military Operations Directed During the Late War Between the states. Bloomington, IN: Indiana University Press, 1959.

- Responsibilities of the First Bull Run." Battles and Leaders of the Civil War. Vol. I.

Jones, John B. A Rebel War Clerk's Diary at the Confederate States Capital. Edited by Howard Swiggett. 2 volumes. New York: Old Hickory Bookshop, 1935.

Laswell, Mary, ed. Rags and Hope, The Recollections of Val C. Giles, Four Years with Hood's Brigade, Fourth Texas Infantry, 1861-1865. New York: Coward-McCann, 1961 .

Lee, Susan P., ed. Memoirs of William Nelson Pendleton. Philadelphia: n.p., 1893.

Longstreet, James. From Manassas to Appomattox. Secaucus, NJ: Blue and Grey Press, 1984; reprint of 1887 edition.

Lord, Walter, ed. The Fremantle Diary. Boston: Little, Brown and Company, 1954.

Lowe, R. G. "The Dreux Battalion." Confederate Veteran. Vol. V (February 1897), No. 2 . 
-..-.-. "Magruder's Defense of the Peninsula." Confederate Veteran. Vol. VIII (March 1900), No. 3.

McClelian, H. B. The Life and Campaigns of Major-General J. E. B. Stuart. Boston: Houghton Mifflin, 1885 .

McKinney, J. W. "My First Experience at the Front." Confederate Veteran. Vol. III (January 1895), No. 1 .

Manarin, Louis H., ed. Richmond at War, the Minutes of the City Council, 1861-1865. Chapel Hill, NC: University of North Carolina Press, 1966.

Maury, Dabney H. "Interesting Reminiscences of General Johnston." Southern Historical Society Papers. Vol. XVIII $(1890)$.

-------. Recollections of a Virginian in the Mexican, Indian, and Civil Wars. New York: Charles Scribner's Sons, 1894 .

Moffett, Mary Conner, ed. Letters of General James Conner, C. S. A. Columbia, SC: R. L. Bryan, 1950 .

Monroe, Haskell et al., ed. The Papers of Jefferson Davis. 5 volumes to date. Baton Rouge, LA: Louisiana State University Press, 1971-1985.

Northrop, Lucius B. "A Statement from the Confederate Commissary General." Century Magazine. Vol. XXXI (March 1886), No. 5 .

Oates, William $c$. The War Between the Union and the Confederacy and its Lost Opportunities. (No publication information in volume).

Parker, William H. Recollections of a Naval officer, 1841 1865. New York: Charles Scribner's Son, 1883.

Pendleton, S. H. "Seven Pines, or Fair Oaks." Confederate Veteran, April 1894 Supplemental Issue.

Phillips, U. B., ed. The Correspondence of Robert Toombs, Al exander H. Stephens, and Howell Cobb.... WashingEon, DC: n.p., 1913 .

Reagan, John H. Memoirs, with special reference to Secession and the Civil War. New York, 1906.

Report of the Commission Appointed Under the eighth section of the Act of Congress of June 21 , 1860 , to examine 
into the organization, system of discipline, and course in instruction of the united States Miliary Academy at West Point. Washington, DC: n.p., 1860 .

Report of the Joint Committee on the Conduct of the War. 37 th Congress, 3rd Session; House of Representatives. 3 volumes. Washington, DC: Government Printing office, 1863 .

Richmond Howitzers in the War; Four years campaigning with the Army of Northern Virginia, By a member of the Company. Richmond: n.p., 1891 .

Rowland, Dunbar, ed. Jefferson Davis, Constitutionalist: His Letters, Papers and Speeches. 10 volumes. Jackson, MS: n.p., 1923.

Scott, Winfield. Memoirs of Lieut.-General Scott, LL.D., Written by Himself. New York: Sheldon and Company, 1864 .

Shaw, Arthur Marvin, ed. "Some Post-War Letters from Jefferson Davis to His Former Aide-de-Camp William Preston Johnston." Virginia Magazine of History and Biography. Vol. LI (April 1943), No. 2.

Smith, Gustavus Woodson. The Battle of Seven Pines. New York: C. C. Crawford, 1891 .

- Confederate War Papers: Fairfax Court House, New Orleans, Seven Pines, Richmond, and North Carolina. 2nd edition. New York: Atlantic Publishing and Engraving, 1884 .

Sorrel, G. Moxley. Recollections of a Confederate staff officer. New York: Neale, 1905.

Stiles, Robert. Four Years under Marse Robert. Washington DC, n.p., 1903 .

Tapscott, J. B. "Early War Incidents on the James." Confederate Veteran. Vol. VII, No. 1 (January 1898).

Taylor, Richard. Destruction and Reconstruction. New York, n.p., 1889 .

Taylor, Walter H. Four Years with General Lee. New York: D. Appleton, 1877. 
Turner, Charles W., ed. Captain Greenlee Davidson, CSA, Diary and Letters, 1851-1861. Verona, VA: MCClure, 1975 .

Vandiver, Frank, ed. Confederate Blockade Running Through Bermuda, 1861-1865, Letters and Cargo Manifests. Austin, TX: University of Texas, 1947.

Warfield, Edgar. A Confederate Soldier's Memoirs. Richmond: Masonic Home Press, 1936.

Woodward, C. Vann, and Elisabeth Muhlenfeld, ed. The Private Mary Chesnut, the Unpublished Civil war Diaries. New York: Oxford University Press, 1984.

Wright, Robert. "Sinking of the Jamestown." Southern Historical Society Papers. Vol. XXXIX (1901).

Younger, Edward, ed. Inside the confederate Government, The Diary of Robert Garlick Hill Kean. New York: Oxford, 1957 .

\section{Secondary Sources}

Alexander, P. W. "Confederate Chieftains." Southern Literary Messenger. Vol. XXXV (January 1863), No. I.

Allan, William. History of the Campaign of Gen. T. J. (Stonewal1) Jackson in the Shenandoah Valley of Virginia. Dayton, $\mathrm{OH}$ : Morningside, 1974; reprint of 1880 edition.

Bell, Robert T. llth Virginia Infantry. Lynchburg, VA: $H$. E. Howard, 1985 .

Berry, Thomas S. "The Rise of Flour Milling in Richmond." Virginia Magazine of History and Biography. Vol. LXXVIII, (October 1970), No. 4 .

Black, Robert C., III. The Railroads of the Confederacy. Chapel Hill, NC: University of North Carolina Press, 1952.

Boatner, Mark Mayo III. The Civil War Dictionary. New York: David McKay, 1959 .

Boney, F. N. John Letcher of Virginia. University, AL: University of Alabama Press, 1966.

Bradford, Gameliel. Confederate Portraits. Boston: 
Houghton Mifflin, 1912 .

Bruce, Kathleen. Virginia Iron Manufacture in the Slave Era. New York: The Century Company, 1931.

Bryan, Charles F., Jr. "Stalemate at Seven Pines." Civil War Times Iliustrated. Vol. XII, No. 5 (August 1973).

Cauthen, Charles E. South Carolina Goes to War, 1860-1865. Chapel Hill, NC: University of North Carolina Press, 1950 .

Chapla, John D. 42nd Virginia Infantry. Lynchburg, VA: H. E. Howard, 1983 .

Cleland, Robert G. "Jefferson Davis and the Confederate Cabinet." Southwestern Historical Quarterly. Vol. XIX, (January 1916), No. 3 .

Connelly, Thomas Lawrence. Army of the Heartland; The Army of Tennessee, 1861-1862. Baton Rouge, LA: Louisiana State University Press, 1967.

tions and Ideas in Confederate Strategy. Baton Rouge, LA: Louisiana University Press, 1964.

Crute, Joseph H., Jr. Confederate Staff Officers, 18611865. Powhatan, VA: Derwent Books, 1982 .

H. H. Cunningham, Doctors in Gray, the Confederate Medical Service. Gloucester, MA: Peter Smith, 1970 .

Daniel, Larry J. "Manufacturing Cannon in the Confederacy." Civil war Times Illustrated. Vol. XII, No. 7 (November 1973).

Davis, William C. Duel Between the First Ironclads. Baton Rouge, LA: Louisiana State University Press, 1975.

Dederer, John Morgan. "The Origins of Robert E. Lee's Bold Generalship: A Reinterpretation." Military Affairs. Vol. XLVI (1985).

Denson, C. B. "William Henry Chase Whiting." Southern Historical Society Papers. Vol. XXVI, $189 \overline{8 .}$

Dew, Charles B. Ironmaker to the Confederacy, Joseph R. Anderson and the Tredegar Iron Works. Wilmington, NC: Broadfoot, 1987; reprint of 1966 edition.

Dickert, Augustus P. History of Kershaw's Brigade. 
Newberry, SC: Elber H. Aull, 1899.

Dictionary of American Biography. 11 volumes. Dumas Malone et al., ed. New York: Charles Scribner's Sons, 1955.

Divine, John E. 8th Virginia Infantry. 1st edition. Lynchburg, VA; H. E. Howard, 1983.

Dowdey, Clifford. The Seven Days, the Emergence of Robert E. Lee. New York: Fairfax, 1978 .

Driver, Robert J., Jr. 52nd Virginia Infantry. Lynchburg, $\mathrm{VA}:$ H. E. Howard, 1986 .

Durkin, Joseph T. Stephen R. Mallory, Confederate Naval Chief. Chapel Hill, NC: University of North Carolina Press, 1954.

Eckenrode, J. J., and Bryan Conrad. James Longstreet, Lee's War Horse. Chapel Hill, NC: University of North Carolina Press, 1936.

------. The Randolphs, The story of a Virginia Family. New York: Bobbs-Merrill, 1946.

Evans, Eli N. Judah P. Benjamin, The Jewish Confederate. New York: Macmillan, 1988.

Faust, Patricia, ed. Historical Times Illustrated Encyclopedia of the Civil War. New York: Harper and Row, 1986 .

Fields, Frank E., Jr. 28th Virginia Infantry. 1st edition. Lynchburg, VA: H. E. Howard, 1985 .

Flemming, Walter L. "Jefferson Davis at West Point." Publications of the Mississippi Historical Society. Vol. X (1909).

Freeman, Douglas Southall. Lee's Lieutenants, A Study in Command. 3 volumes. New York: Charles Scribner's Sons, 1942-1944.

- R. E. Lee, A Biography. 4 volumes. New York: Charles Scribler's Sons, 1935.

Frye, Dennis E. 2nd Virginia Infantry. Lynchburg, VA: H. E. Howard, 1984 .

Gallagher, Gary W. Stephen Dodson Ramseur, Lee's Gallant General. Chapel Hill, NC: University of North Carolina Press, 1985. 
Goff, Richard D. Confederate Supply. Durham, NC: Duke University Press, 1969.

Govan, Gilbert, and James W. Livingood. A Different Valor, The Story of General Joseph E. Johnston, C. S. A. New York: Bobbs-Merrill, 1956.

Grimsley, Mark. "Jackson: The Wrath of God." Civil War Times Illustrated, Vol. XXIII, No. 1 (March 1984).

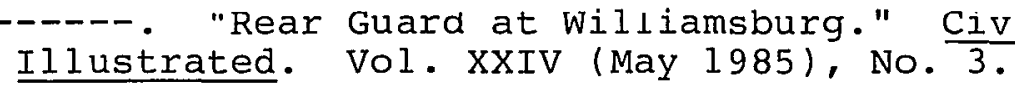

Hanson, Joseph Mills. Bull Run Remembers... The History Traditions and Landmarks of the Manassas (Bull Run) Campaigns Before Washington, 1861-1862. Manassas, VA: National Capitol Publishers, 1953.

Hamlin, Percy Gatling. "Old Bald Head" (General R. S. Ewel1) The Protrait of a Soldier. Strasburg, VA: Shenandoah Publishing House, 1940.

Hay, Thomas Robson. "The Davis-Hood-Johnston Controversy of 1864." Mississippi Valley Historical Review. Vol. XI (June 1924).

Heitman, Francis B. Historical Register and Dictionary of the United States Army. 2 volumes. Washington, DC: Government Printing Office, 1903.

Hittle, J. D. The Military Staff, Its History and Development. Harrisburg, PA: Stackpole, 1961 .

Hotchkiss, Jedediah. Virqinia. (Vol. III of Confederate Military History). Expanded edition. Dayton, OH: Morningside, 1975; reprint.

Hughes, Robert M. General Johnston. New York: D. Appleton, 1893 .

Hume, Edgar Erskine. Peter Johnston, Junior, Virginia Soldier and Jurist. Charlottesville, VA: Historical Publishing Company, 1935.

James, Alfred P. "General Joseph Egqleston Johnston, Storm Center of The Confederacy." Mississippi Valley Historical Review. Vol. XIV (December 1927), No. 3 .

Johnson, Bradley T. A Memoir of the Life and Public Service of Joseph E. Johnston. Baltimore: R. H. Woodward and Company, 1891 . 
Johnston, Angus James II. Virginia Railroads in the Civil War. Chapel Hill, NC: University of North Carolina Press, 1961.

Jones, Archer. Confederate Strategy from Shiloh to Vicksburg. Baton Rouge, LA: Louisiana State University Press, 1961.

Jones, J. William. Life and Letters of Robert Edward Lee, Soldier and Man. New York: Neale, 1906.

Jones, Terry L. Lee's Tigers, the Louisiana Infantry in the Army of Northern Virginia. Baton Rouge, LA: Louisiana State University Press, 1987.

Kendrick, Burton J. Statesmen of the Lost Cause, Jefferson Davis and His cabinet. Boston: Little, Brown, and Co., 1939.

Klein, Maury. Edward Porter Alexander. Athens, GA: University of Georgia Press, 1971.

Krick, Robert E. I. 40th Virginia Infantry. Lynchburg, VA: H. E. Howard, 1985 .

Krick, Robert $K$. Lee's Colonels, A Biographical Reqister of the Field officers of the Army of Northern Virqinia. 2nd edition, revised. Dayton, OH: Morninqside, 1984.

9th Virginia Cavalry. Lynchburg, VA: H. E. Howard, 1982 .

- 30th Virginia Infantry. Lynchburg, VA: H. E. Howard, 1983 .

Livermore, Thomas I. Numbers and Losses in the Civil War in America, 1861-1865. Dayton, OH: Morninqside, 1986.

Long, Armistead L. Memoirs of Robert E. Lee. New York: J. M. Stoddart and Company, 1886 .

Luvaas, Jay. "An Appraisal of Joseph E. Johnston." Civil War Times Illustrated. Vol. IV (January 1966), No. 9.

McMurry, Richard M. John Bell Hood and the War for Southern Independence. Lexington, KY: University Press of Kentucky, 1982 .

-.--.-. Two Great Rebel Armies, An Essay in Confederate Military History. Chapel Hill, NC: University of North Carolina Press, 1989. 
Manarın, Louıs H. "Lee in Command: Strategical and Tactical Policies." Ph.D. dissertation, Duke University, 1965.

Martin, Samuel J. "The Complex Confederate." Civil War Times Illustrated. Vol. XXV, No. 2 (April 1986).

Maurice, Frederick. Robert E. Lee the Soldier. Boston: Houghton Mifflin, 1925 .

Meade, Robert Douthat. Judah P. Benjamin, Confederate Statesman. New York: Oxford University Press, 1943.

-.--ne-.-. "The Relations Between Judah P. Benjamin and Jefferson Davis: Some New Light on the Working of the Confederate Machine." Journal of Southern History. Vol. V (November 1939), No. 4 .

Melvin, Philip. "Stephen Russell Mallory, Southern Naval Statesman." Journal of Southern History. Vol. X (May 1944 ), No. 2 .

Naval History Division, Naval Department, compilers. Civil War Naval Chronology, 1861-1865. Six volumes. Washington, DC: U.S. Government Printing office, 1971 .

Nichols, James L. Confederate Engineers. Tuscaloosa, AL: Confederate Publishing Company, 1937.

Owsley, Frank L. "Local Defense and the Overthrow of the Confederacy." Mississippi Valley Historical Review. Vol. XI (March 1925), No. 4 .

State Rights in the confederacy . Chicaqo: University of Chicago, 1925 .

Parish, Peter J. The American Civil War. New York: Holmes and Meier, 1975.

Patrick, Rembert. Jefferson Davis and His Cabinet. Baton Rouge, IA: Louisiana State University Press, 1944.

Piston, William Garrett. Lee's Tarnished Lieutenant, James Lonastreet and His Place in Southern History. Athens. GA: University of Georgia Press, 1987.

Rankin, Thomas M. 23rd Virginia Infantry. Lynchbura, VA: H. E. Howard, 1985 .

Riags, David F. 7th Virginia Infantry. Lynchbura, VA: H. 
E. Howard, 1982 .

Robertson, James I. 18th Virginia Infantry. Lynchburg, VA: H. E. Howard, $19 \overline{84}$.

Howard, $\frac{4 \text { th }}{1982}$.

-...-... General A. P. Hill, the Story of a Confederate Warrior. New York: Random House, 1987 .

Roland, Charles. Albert Sidney Johnston: Soldier of Three Republics. Austin, TX: University of Texas, 1964 .

Sanger, Donald B., and Thomas Robson Hay. James Longstreet. Baton Rouge, LA: Louisiana State University Press, 1952 .

Scharf, J. Thomas. History of the Confederate States Navy From its Organization to the Surrender of its Last Vessel. New York: Rogers and Sherwood, 1887.

Schwab, John C. The Confederate States of America, 18611865, A Financial and Industrial History of the South During the Civil War. New Haven, CT: Yale, 1913.

Sears, Stephen W. George B. MCClellan, The Young Napoleon. New York: Ticknor \& Fields, 1988.

Sifakis, Stewart. Who was who in the Civil War. New York: Facts on File, 1988 .

Stark, Richard B. "Surgeons and Surgical Care of the Confederate States Army." Virginia Medical Monthly. Vol. IXXXVIII, No. 10.

Stiles, Kenneth I. 4th Virginia Cavalry. Lynchburg, VA: H. E. Howard, 1985 .

Sublett, Charles w. 57th Virginia Infantry. Lynchburg, VA: H. E. Howard, $19 \overline{85 .}$

Thomas, Emory. Bold Dragoon, The Life of J.E. B. Stuart. New York: Harper and Row, 1986.

Trask, Benjamin $\mathrm{H}$. 9th Virginia Infantry. Lynchburg, VA: H. E. Howard, 1984 .

Turner, Charles $w$. "The Virginia Central Railroad at War, 1861-1865." Journal of Southern History. Vol. XII (November 1946), No. 4 . 
United States Navy Department. Official Records of the Union and Confederate Navies in the war of the Rebellion. 30 volumes. Washington, DC: Government Printing office, 1896-1922.

United States War Department. The War of the Rebellion: Compilation of the Official Records of the Union and Confederate Armies. 128 volumes. Washington, DC: Government Printing office, 1880-1901.

Wakelyn, Jon I. Biographical Dictionary of the Confederacy. Westport, CT: Greenwood Press, 1977.

Wallace, Lee A., Jr. Ist Virginia Infantry. Lynchburg, VA: H. E. Howard, 1985 . Howard, 1986 .

-- A Guide to Virginia Military Organizations, 1861-1865. 2nd edition, revised. Lynchburg, VA: H. E. Howard, 1986 .

Warner, Ezra. Generals in Gray, Lives of the Confederate Commanders. Baton Rouge, LA: Louisiana University Press, 1959.

Wellman, Manly wade. Giant in Gray, A Biography of Wade Hampton of South Carolina. New York: Charles Scribner's Sons, 1949 .

Wert, Jeffrey. "I am so Unlike Other Folks." Civil War Times Illustrated. Vol. XXVIII, No. 2 (April 1989).

- "Lee's First Year of the War." Civil War Times Illustrated. Vol. XII, No. 8 (December 1974).

White, Laura. Robert Barnwell Rhett: Father of Secession. New York: Century, 1931 .

Wiatt, Alex L. 26th Virginia Infantry, Lynchburg, VA: H. E. Howard, 1984 .

Williams, T. Harry. "Freeman, Historian of the Civil War: An Appraisal." Journal of Southern History. Vol. XXI, February, 1955, No. I.

Wise, George. History of the Seventeenth Virginia Infantry C. S. A. Baltimore: Kelly Piet \& Co., 1870.

Wise, Jennings $C$. The Long Arm of Lee, or the History of the Artillery of the Army of Northern Virginia. 2 
volumes. Lynchburg, VA: Bell, 1915.

Wise, Stephen R. Lifeline of the Confederacy, Blockade Running During the Civil War. Columbia, SC:

University of South Carolina Press, 1988.

Wright, Marcus J. List of Staff officers of the Confederate Army, 1861-1865. Washington, DC: Government Printing Office, 1891 . 
VITA

\section{STEVEN HARVEY NEWTON}

Born in Dillwyn, Virginia, November 1, 1956. Graduated from Wilson Memorial High School, Fishersville, Virginia, June, 1975. B. A., St. Andrews Presbyterian College, 1979. M. A., History, James Madison University, 1986, with a concentration in American Military History. In September, 1986, the author entered the college of William and Mary as a graduate assistant in the Department of History. Employed as instructor in the Department of History at James Madison University, 1988-1989, and currently employed as Assistant Professor of History at Clarion University of Pennsylvania. 